The San Andreas Fault System, California

U.S. GEOLOGICAL SURVEY PROFESSIONAL PAPER 1515 


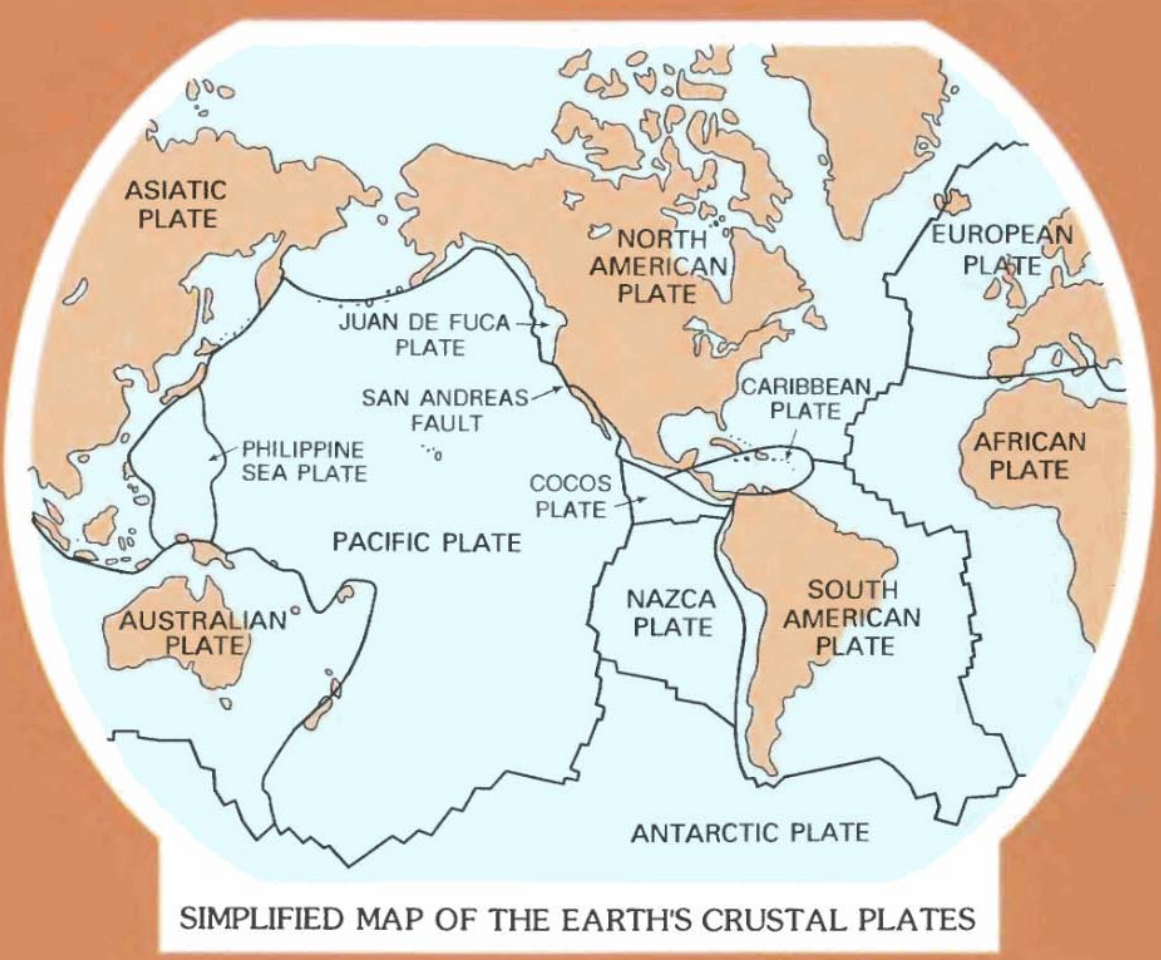

FRONT COVER: On the Carrizo Plain in central California, the San Andreas fault appears as a conspicuous gash across the terrain. Streams are offset and deflected at the fault. View northwestward. 


\section{MAP OF THE SAN ANDREAS FAULT SYSTEM, CALIFORNIA}

Maps of northern and southern California printed on flyleaf inside front cover and on adjacent pages show faults that have had displacement within the past 2 million years. Those that have had displacement within historical time are shown in red. Bands of red tint emphasize zones of historical displacement; bands of orange tint emphasize major faults that have had Quaternary displacement before historical time. Faults are dashed where uncertain, dotted where covered by sedimentary deposits, and queried where doubtful. Arrows indicate direction of relative movement; sawteeth on upper plate of thrust fault.

These maps are reproductions, in major part, of selected plates from the "Fault Map of California," published in 1975 by the California Division of Mines and Geology at a scale of 1:750,000; the State map was compiled and data interpreted by Charles W. Jennings. New data about faults, not shown on the 1975 edition, required modest revisions, primarily additions; however, most of the map was left unchanged because the California Division of Mines and Geology is currently engaged in a major revision and update of the 1975 edition. Because of the reduced scale here, names of faults and places were redrafted or omitted. Faults added to the reduced map are not as precise as on the original State map, and the editor of this volume selected certain faults and omitted others. Principal regions for which new information was added are the region north of the San Francisco Bay area and the offshore regions.

Many people have contributed to the present map, but the editor is solely responsible for any errors and omissions. Among those contributing informally, but extensively, and the regions to which each contributed were G.A. Carver, onland region north of lat $40^{\circ} \mathrm{N}$.; S.H. Clarke, offshore region north of Cape Mendocino; R.J. McLaughlin, onland region between lat $40^{\circ} 00^{\prime}$ and $40^{\circ} 30^{\prime} \mathrm{N}$. and long $123^{\circ} 30^{\prime}$ and $124^{\circ} 30^{\prime}$ W.; D.S. McCulloch, offshore region between lat $35^{\circ}$ and $40^{\circ} \mathrm{N}$.; J.G. Vedder, offshore region south of lat $35^{\circ}$ N.; and D.G. Herd, southern San Francisco Bay region. The Fault Evaluation Program of the California Division of Mines and Geology, under the direction of E.W. Hart, provided much data about many faults. Unpublished material about the Bartlett Springs fault zone that was gathered by Geomatrix Consultants for the Pacific Gas and Electric Co. was very useful. In addition, selected publications that provided invaluable data include Bortugno (1982), Herd (1977), Herd and Helley (1977), Pampeyan and others (1981), and Yerkes and others (1980). Full references for these publications are listed at the end of chapter 2.

To all of the above, and to numerous others, the editor expresses his great appreciation. 


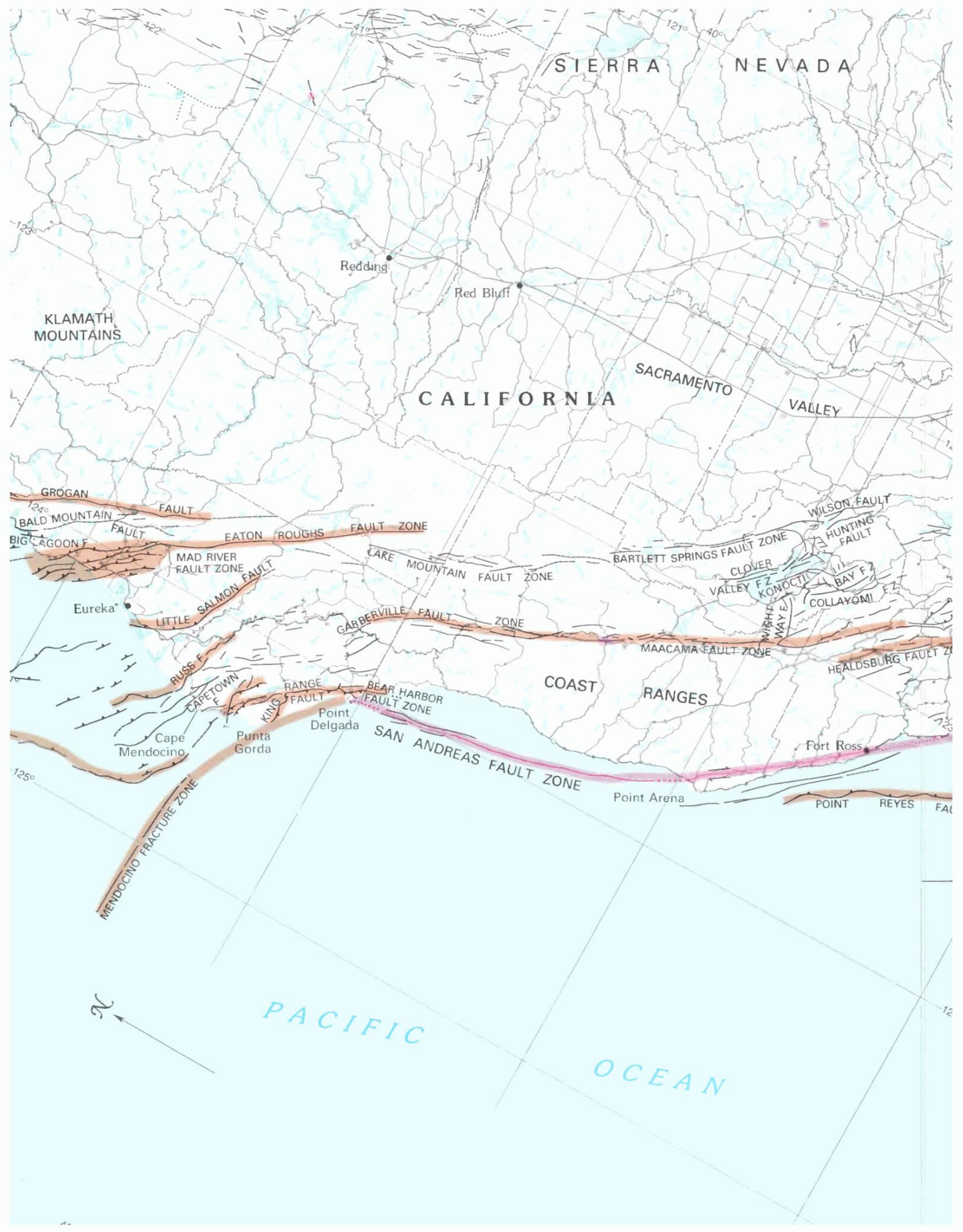




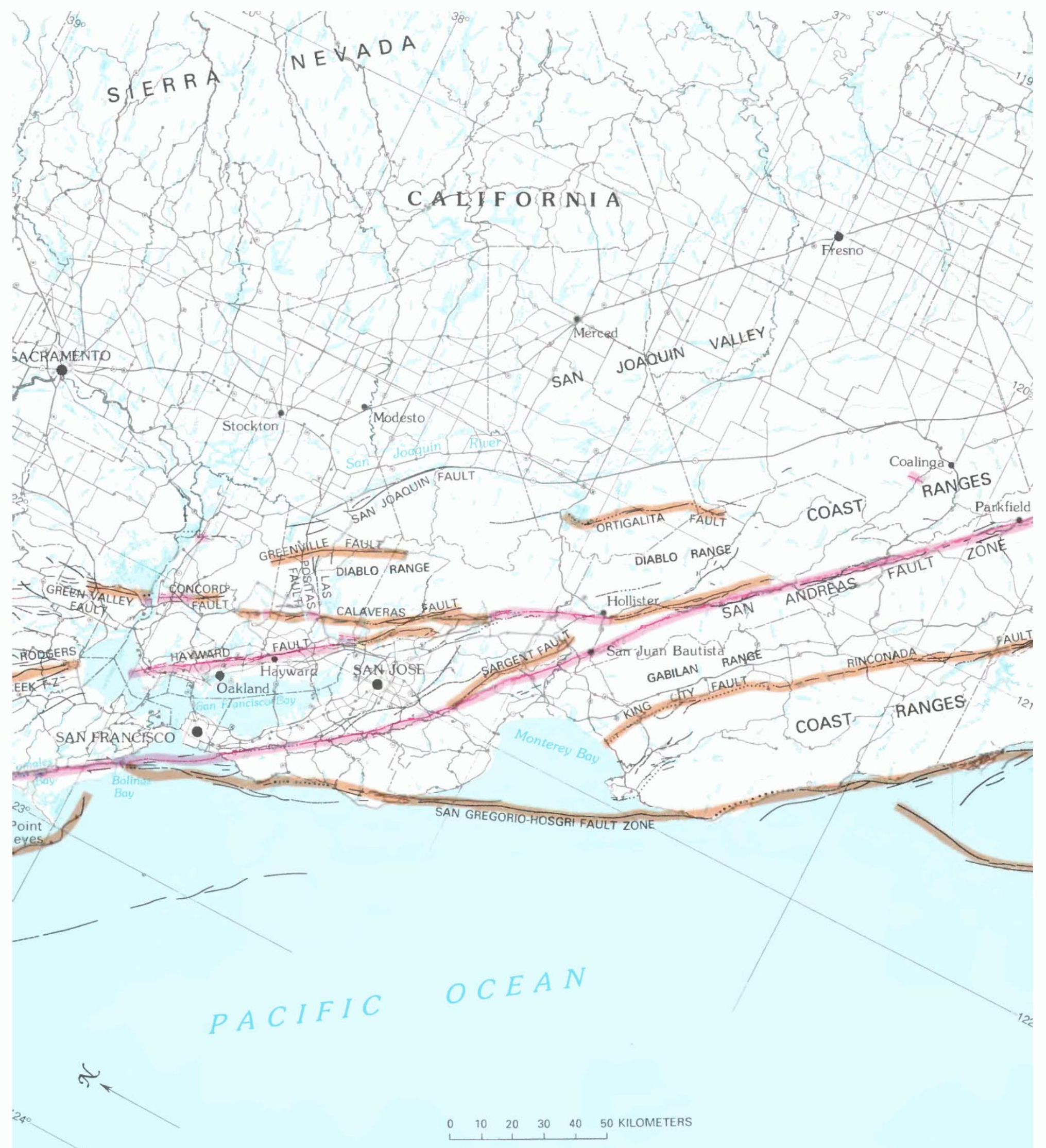




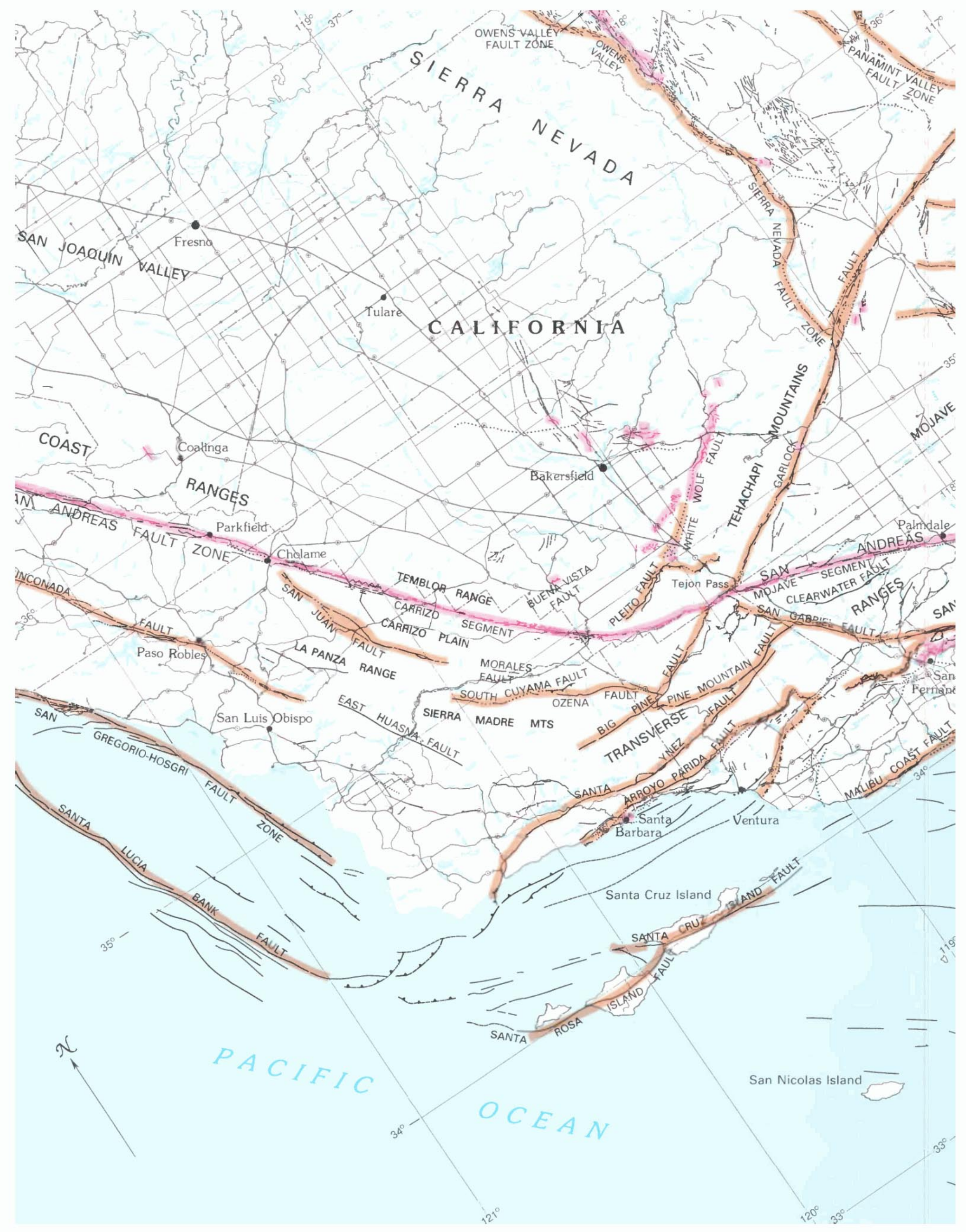




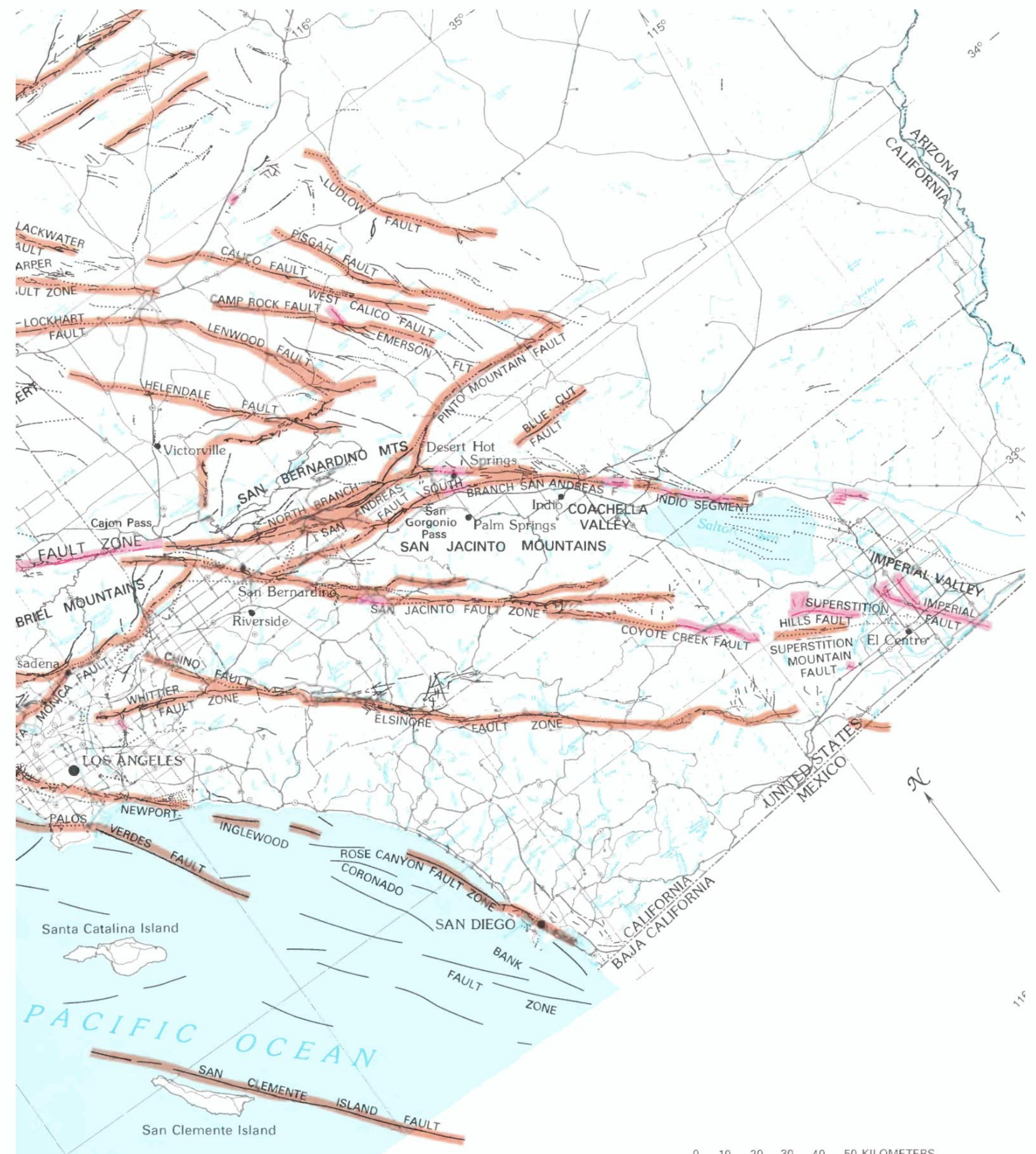



THE SAN ANDREAS FAULT SYSTEM, CALIFORNIA 


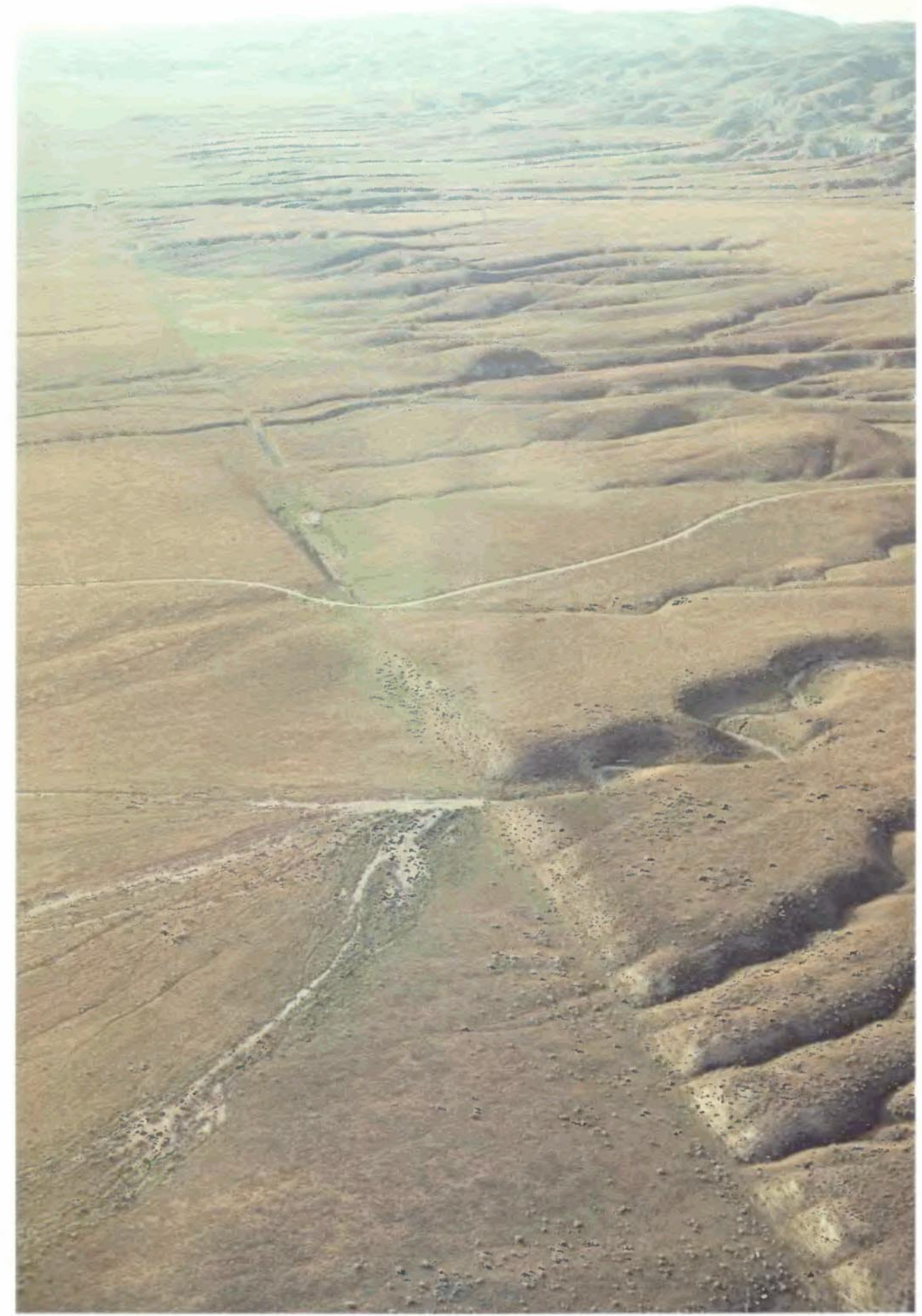

The San Andreas fault in central California. Striking linearity of the trace of the fault is characteristic of strike-slip faults. Carrizo Plain to left; Temblor Range to right. View northwest. 


\title{
The San Andreas Fault System, California
}

\author{
ROBERT E. WALLACE, Editor
}

U.S. GEOLOGICAL SURVEY PROFESIONAL PAPER 1515

An overview of the history, geology, geomorphology, geophysics, and seismology of the most well known plate-tectonic boundary in the world 


\title{
U.S. DEPARTMENT OF THE INTERIOR
}

\author{
MANUEL LUJAN, JR., Secretary
}

\section{U.S. GEOLOGICAL SURVEY}

DALLAS L. PECK, Director

Any use of trade, product, or firm names in this publication is for descriptive purposes only and does not imply endorsement by the U.S. Government

First printing: 1990

Second printing: 1991

Library of Congress Catalog in Publication Data

The San Andreas fault system, California / Robert E. Wallace, editor.

p. $\quad$ cm. - (U.S. Geological Survey professional paper : 1515)

Includes bibliographical references ( $p$.

Supt. of Docs. no.: I 19.16:1515

1. San Andreas Fault (Calif.). I. Wallace, R.E. (Robert Earl), 1916- . Series.

QE606.5.U6S26 1990

$551.8^{\prime} 7^{\prime} 09794-\mathrm{dc} 20$

$90-13874$

For sale by the Books and Open-File Reports Section, U.S. Geological Survey,

Federal Center, Box 25425, Denver, CO 80225 


\section{PREFACE}

With the increasing public concern about the potential for destructive earthquakes in California since the great Alaska earthquake of 1964, and the general acceptance of the concept of plate tectonics and sea-floor spreading by earth scientists in the late 1960's, the San Andreas fault has gained wide attention. The fault has long been recognized as the source of the destructive San Francisco earthquake of 1906 and of the similarly large Fort Tejon earthquake of 1857 , as well as the smaller $(M=7.1)$, but also destructive, Loma Prieta earthquake of 1989. Many textbooks in recent decades have included photographs, maps, and descriptions of the San Andreas fault, and so among earth scientists around the world, few geologic features have greater identity than the San Andreas fault. The fault-better designated a "fault system" because of its complexities - represents an exceptional example of a plate margin that can be seen and studied on land; many other plate margins are covered by the oceans.

This volume is addressed to a varied audience, but especially to earth scientists who wish to gain a brief overview of the San Andreas fault system. We hope that the nontechnical reader also will find the volume interesting and useful. Each chapter has its own references that direct the investigator more to specific literature; suggestions for additional reading and sources of information are included at the end of the volume.

The public-safety issues of earthquake-hazard mitigation and earthquake prediction are not covered in this volume except by implication. Fundamental concepts and understanding of how the solid Earth works are essential to the development of realistic and effective procedures for hazard mitigation. Without such understanding, mitigation measures may be ineffective and wasteful of resources. Earthquake prediction requires geologic and geophysical models and data that constitute valid bases for extrapolation into the future. We believe that these concerns are well served by the reviews in this volume.

The 10 chapters that follow review geologic, geomorphic, geophysical, geodetic, and seismologic information about the San Andreas fault system. Although the material is intended to represent our current state of knowledge and understanding, many investigators will find their own specialities inadequately treated. A full discussion of the more rapidly changing and controversial ideas currently in play is impossible, given the constraints of this volume.

Manuscript approved for publication, May 4, 1990.
The need for such a volume has been recognized since the 1960 's, but until recent years, data about the San Andreas fault system was so incomplete that a significant review seemed premature. Now, a general overview of many significant elements seems possible, but even so, the questions far outnumber the answers, and if history is any guide, many of the concepts put forth here will have changed markedly within the next few years. Indeed, one of the purposes of this volume is to assist and hasten the evolution of our understanding through the consolidation, under a single cover, of some of the current ideas and models.

Reference to a few of the more outstanding problems concerning the San Andreas fault system may serve to suggest how little is yet known about the fault system and how much remains to be learned. In studying the San Andreas fault system, opportunities abound for learning how the Earth works in a general sense.

A group of particularly significant problems can be collectively expressed under the question: "How does a fault system that has primarily strike slip terminate at its northwest and southeast ends, and how does it bottom out at depth?"

At the northwest end of the fault system, the Mendocino triple junction represents an intriguing structural knot where the North American, Pacific, and Gorda plates join. A fourth block at depth, made up of material below the North American plate but east of the San Andreas fault and south of the Gorda plate, also is juxtaposed with these three named plates. How are the diverse motions of these four plates or blocks accommodated where they join? Clearly, severe space problems must occur at detailed scales, even though the gross theoretical geometry of triple junctions has been fairly well described. How do these four structural blocks interact to influence the energetics of the fault system (see chap. 10)? How did the triple junction migrate over time, and how are the consequences of that migration recorded geologically?

Crustal convergence also strongly influences the fault system. Where major bends occur, as in the Transverse Ranges region, structural complexities arise. There, major left-lateral faults splay from the main San Andreas fault, and dense clusters of earthquakes extend to depths of $20 \mathrm{~km}$. Elsewhere, as in the Santa Cruz Mountains, some segments of the fault dip at steep, but not vertical, angles.

Adjacent to the San Andreas fault on its east side lies the North American plate, at least in the upper few tens of kilometers; but below this plate, as indicated above, is 
a block of almost unknown characteristics left in the wake of the eastward-moving and subducting plate now represented by its remnants, the Gorda and Juan de Fuca plates. After pulling away from the Pacific plate in its eastward passage, did this plate leave remnants here and there under the North American plate? Did the spreading center spread continuously, or did it move eastward in one or more leaps? What sort of mantle material rose to fill in behind the stern of the eastward-moving plate? Was this newly emplaced material similar to that being generated at modern spreading centers, and to what extent did the overlying blanket of continental material alter both the geometry and thermal histories of the emplaced rocks?

Some of the models mentioned above imply decoupling between the subducting plate and the North American plate, as well as a rather significant discontinuity between the North American plate and the underlying backfill behind the stern of the eastward-moving plate. Some of the problems of this "window" behind the subducting plate are discussed in chapter 3 . The San Andreas fault, indeed, may bottom in a zone of decoupling, either within the crust or below, possibly a low-angle thrust fault, as described in chapter 1 , or perhaps involving gravitationally driven detachments. The characteristics of this decoupling are almost unknown. Much needs to be learned before the style of stress and strain propagation across such discontinuities can be addressed adequately.

Present-day strain is demonstrable by geodetic techniques (see chap. 7), and longer-term strain is represented geologically by the pattern of folds, faults, and magmatic intrusion into the upper crust (see chaps. 3, 4). Release of elastic strain, its timing and spatial distribution, is nicely displayed by seismicity, especially microseismicity (see chap. 5). Heat-flow measurements provide an important insight into the energetics of the San Andreas fault system (see chap. 10). Integration and comparison of these data sets, however, reveal numerous unresolved problems and apparent paradoxes. As reported in chapter 10, no sharp increase in heat flow is found directly over the San Andreas fault, even though heat would be expected to be generated in the narrow fault zone by the annual slip of several centimeters on the fault. Instead, the heat flow is distributed across a broad zone, further suggesting distributed slip on a subhorizontal plane that decouples the upper-crustal materials from those below.

The detailed characteristics of the fault zone itself are far from fully understood. Low values of stress drop that occur during seismic events have long been known (see chaps. 5, 10). The dominance of right-lateral slip along the fault, despite evidence for fault-normal compression, together with the absence of a pronounced heat-flow anomaly, attests to general weakness of the fault. How the fault zone has grown to its present 0.5 - to l-km width, given this weakness, is also a puzzle. Furthermore, at many places along the fault, as in central California, the width of the fault zone is appropriately considered to be $10 \mathrm{~km}$ or more wide; that is the width of highly sheared and deformed rocks which lie between relatively undeformed terrane to the northeast and southwest. What is the nature of asperities, or strong points, on the fault, and how do its stronger and weaker parts interact? To what extent does plastic-behaving fault gouge move within the fault zone to change the overall geometry?

The role of water in the kinematics and dynamics of the fault system can scarcely be overemphasized, and yet almost nothing is known about the actual hydrotectonic relations. To what extent does elevated or reduced pore pressure modify the properties of the lithologic packages of rocks at different places along and across the fault? What geochemical changes in the fault zone are enhanced by the movement of fluids along the fault and through rocks adjacent to the fault? What mineralogic changes take place as a result of thermal changes related to friction, possibly accompanied by exsolution of water from minerals? Can localized, tectonically elevated pore pressure initiate slip, and once slip acceleration occurs, what role does friction play in the dynamics of slip? Why are so few volcanic rocks associated with the fault except for those related to the passing triple junction?

What are the rates of fault slip, folding, and the overall budget of deformation among various forms of strain? How do erosional rates compare with tectonic rates in changing the landscape, and to what extent do these processes deviate from linearity? How do complex geomorphic processes interact among themselves, as well as with the tectonic processes? How can the ubiquitous landforms be interpreted to illuminate the younger history of the San Andreas fault?

Strands and branches of the San Andreas fault system bound numerous exotic terranes, those aggregates of rocks which are so dissimilar that they could not have been born in their present relation to one another. The patterns of movement and distances traveled by these terranes may constitute the most significant characteristic and role of the San Andreas fault in the overall scheme of global tectonics. By whatever mechanisms these exotic blocks or terranes were transported, the western part of North America has been enlarged by the accretion of these "strangers," while at the same time other pieces of older continental material have been plucked away, eventually to join land somewhere to the northwest.

This volume represents but a small punctuation mark in the early stage of our understanding of the San Andreas fault system and the tectonics that it highlights. Most of the story has yet to be learned. 


\section{CONTENTS}

[Numbers indicate chapters]

Preface--_-_-_-_-_-_-_-_-_-_-_-_-_-_-_-_-_-_- V

1. General features-_-_-_-_-_-_-_-_-_-_-_-_-_-_-_- 3

Robert E. Wallace

2. Geomorphic expression-_-_-_-_-_-_-_-_-_-_-_-_-_- 15

Robert E. Wallace

3. Geology and plate-tectonic development-_-_-_-_-_-_-_ 61 William P. Irwin

4. Quaternary deformation-_-_-_-_-_-_-_-_-_-_-- 83 Robert D. Brown, Jr.

5. Seismicity, 1980-86 -__-_ 115

David P. Hill, Jerry P. Eaton, and Lucile M. Jones

6. Earthquake history, 1769-1989-_-_-_-_-_-_-_-_-_-_- 153 William L. Ellsworth

7. Present-day crustal movements and the mechanics of cyclic deformation-_-_-_-_-_-_-_-_-_-_-_-_-_-_-_ 189 Wayne Thatcher

8. Lithospheric structure and tectonics from seismicrefraction and other data Gary S. Fuis and Walter D. Mooney

9. Crustal and lithospheric structure from gravity and magnetic studies Andrew Griscom and Robert C. Jachens

10. Stress and heat flow Arthur Lachenbruch and A. McGarr

Supplement: Additional reading and source material 279 Robert E. Wallace, compiler 



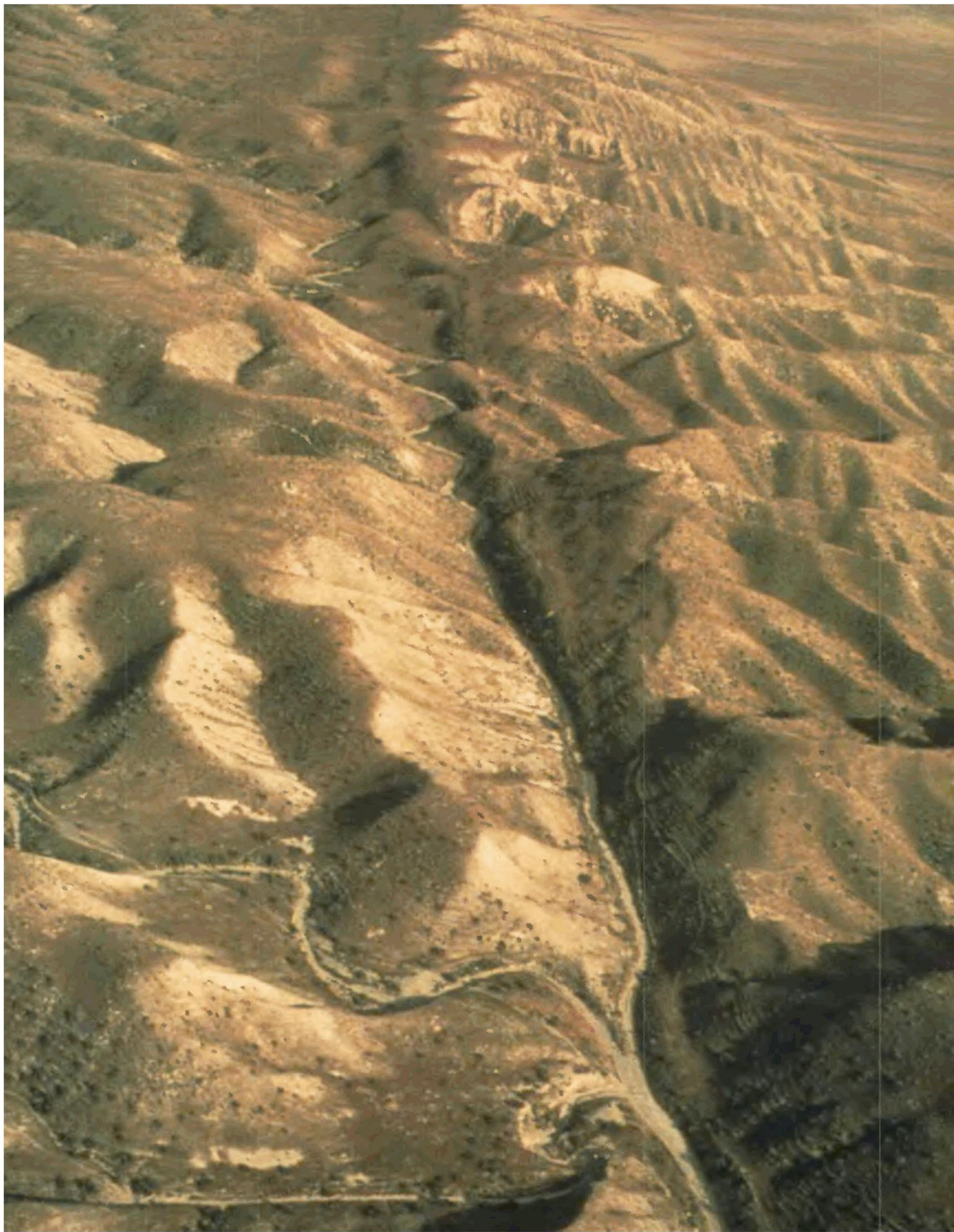



$T$ he San Andreas fault system, a complex of faults that display

1 predominantly large-scale strike slip, is part of an even more complex system of faults, isolated segments of the East Pacific Rise, and scraps of plates lying east of the East Pacific Rise that collectively separate the North American plate from the Pacific plate.

\title{
1. GENERAL FEATURES
}

\author{
By Robert E. WaLlace
}

\section{CONTENTS}

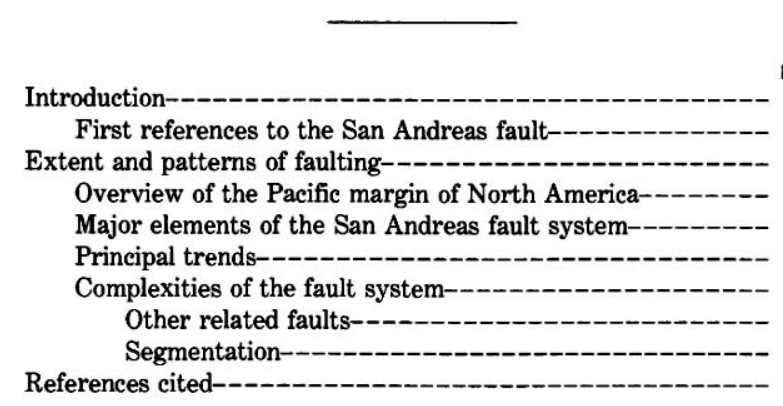

INTRODUCTION

This chapter briefly describes the San Andreas fault system, its setting along the Pacific Ocean margin of North America, its extent, and the patterns of faulting. Only selected characteristics are described, and many features are left for depictions on maps and figures. The other chapters in this volume elaborate on the history and evolution of the fault system, and the behavior of the Earth's crust and upper mantle within the fault system.

Because of the extent and complexity of the San Andreas fault system, it is helpful to distinguish between the broad, complex feature as seen on a map of the Western United States and the individual faults on which displacements occur to produce single earthquakes.
From larger to smaller features, the terms "fault system," "fault zone," "fault," and "fault branches, splays, strands, and segments" are useful.

The term "San Andreas fault system" refers to the network of faults with predominantly right-lateral strike slip that collectively accommodate most of the relative motion between the North American and Pacific plates. The boundaries of this fault system are poorly defined, but to separate the San Andreas fault system from other tectonic provinces and systems, it is useful to limit the term to the set of faults along the Pacific rim of North America, both on land and off shore. Accordingly, at the latitude of San Francisco, the system is approximately 80 $\mathrm{km}$ wide, and at the latitude of San Diego approximately $150 \mathrm{~km}$ wide (see fig. 1 and maps at front of book).

The term "fault zone" refers to the complex zone of sheared rock that may be from 0.5 to more than $1 \mathrm{~km}$ wide and hundreds of kilometers long. The fault zone has developed over a period of millions of years while growing in width and complexity. The terms "fault," "fault branches," and "fault strands" refer to smaller elements and can be applied as needed. For example, surface rupture accompanying an earthquake commonly produces a complex pattern of fractures, and detailed elements can be discussed more effectively by using such terms as "fault branch, splay, or strand." The term "fault segment" recognizes that the fault is not completely continuous but is in sections or parts with poorly defined boundaries, as discussed below in the subsection entitled "Segmentation."

FIGURE 1.1. - The San Andreas fault zone appears as a gash across the terrain in the Carrizo Plain area of south-central California. Streams are deflected or offset, as in foreground. Note that strata of Pleistocene age are tilted to steep angles on right (west) side of fault. View southeastward. 


\section{FIRST REFERENCES TO THE SAN ANDREAS FAULT}

The San Andreas fault first came into prominence only after it was fully understood by geologists as the cause of the great San Francisco earthquake of 1906 . The name had been first used only 9 years previously by A.C. Lawson (1895) for a small segment of the fault on the San Francisco peninsula, where he reported that "a remarkably straight fault $* * *$ has conditioned the San Andreas and Crystal Springs Valley" (p. 439). Lawson applied the name "San Andreas fault" almost incidentally in a discussion of "subsequent streams that flowed in the valleys." He suggested vertical displacement on the fault but apparently was not convinced of that, inasmuch as he failed to show the fault or, with one exception, displaced strata on several cross sections in his report (for example, pl. 7). Clearly, neither the amount of displacement on the fault nor its great regional and tectonic significance was appreciated at the time of Lawson's work.

In one of the first reports about the 1906 earthquake, G.K. Gilbert (1907) accurately described the fault and its characteristic displacement, but he did not use the name "San Andreas fault." In his field notes for April 28, 1906, just 10 days after the great earthquake, Gilbert described $20 \mathrm{ft}$ of right-lateral displacement of a road where it crosses the fault at the head of Tomales Bay. He had been following the surface rupture for several days, and on April 26 he recorded in his notes that along the west side of Bolinas Bay "some of the cracks were clearly secondary; others may have been primary." By the time the final report of the State Earthquake Investigation Commission was published (Lawson, 1908), the name "San Andreas" had been adopted, and its characteristics and role in causing the earthquake were clear. That report, which contains a remarkably extensive and accurate account, constitutes a major milestone in our understanding of the San Andreas fault and of strike-slip faults as a class.

\section{EXTENT AND PATTERNS OF FAULTING}

\section{OVERVIEW OF THE PACIFIC MARGIN OF NORTH AMERICA}

The San Andreas fault system is part of a complex system of faults, isolated segments of the East Pacific Rise, and scraps of plates lying east of the East Pacific Rise that collectively separate the North American plate from the Pacific plate (fig. 1.2). On a more generalized or global scale, the North American plate can be thought of as lying across and partly covering the northern part of the Pacific system of plates. In simplified terms, the Pacific system of plates includes three elements: a westward expanding plate (the Pacific plate), an eastward-expanding plate (the Juan de Fuca plate), and a spreading center (the East Pacific Rise) from which the plates expand as new material is added. To the north, the Pacific plate is underriding, or being subducted under, the North American plate along the Aleutian thrust.

Some investigators (Atwater, 1970; Atwater and Molnar, 1973) suggested that the North American plate has converged with and, indeed, slid over the Pacific system of plates, leaving only segments of the East Pacific Rise exposed, to which such names as "Juan de Fuca and Gorda Ridges" are applied. Similarly, related scraps of the eastward-expanding plate are the Juan de Fuca and Gorda plates (fig. 1.2). Absolute plate motions derived by Minster and Jordan (1980), and Jordan and Minster (1988) are shown in figure 1.2, along with the platemotion vectors derived from the relative migration of mantle plumes or hotspots responsible for volcanic activity in Yellowstone National Park and the Hawaiian Islands.

At its north end, the San Andreas fault joins the Mendocino Fracture Zone at a high angle, and there three plates are juxtaposed: one moving relatively northwestward, the second southeastward, and the third eastward and northeastward, to form a triple junction. At its southeast end, the San Andreas fault system merges more gradually with the set of transform faults underlying the Gulf of California. Just northwest of the area of merging, however, the trend of the San Andreas fault system changes to much more westerly, whereas a set of echelon faults accompanied by volcanism less than a million years old form a north-south-trending zone that extends northward across the Mojave Desert into Owens Valley of eastern California (Hill and others, 1985). This zone may be considered the East Pacific Rise overridden, and thus modified in pattern, by the North American plate.

The San Andreas fault system may be viewed as forming the hypotenuse of a right triangle of which the northward extension of the East Pacific Rise and the eastward extension of the Mendocino Fracture Zone are the legs. The model of an overridden, subducted oceanic plate within this triangle and underlying the North American plate (Dickinson and Snyder, 1979) presents significant tectonic problems (see chap. 3).

The San Andreas fault system has rearranged an assemblage of microplates, or terranes, some of which originated tens of degrees of longitude apart. During the fault's approximately 29-m.y. existence, an extremely complex pattern of rock distribution, has thus has been created (see chap. 3).

\section{MAJOR ELEMENTS OF THE SAN ANDREAS FAULT SYSTEM}

The San Andreas fault system consists primarily of the San Andreas fault and several major branches, such as 


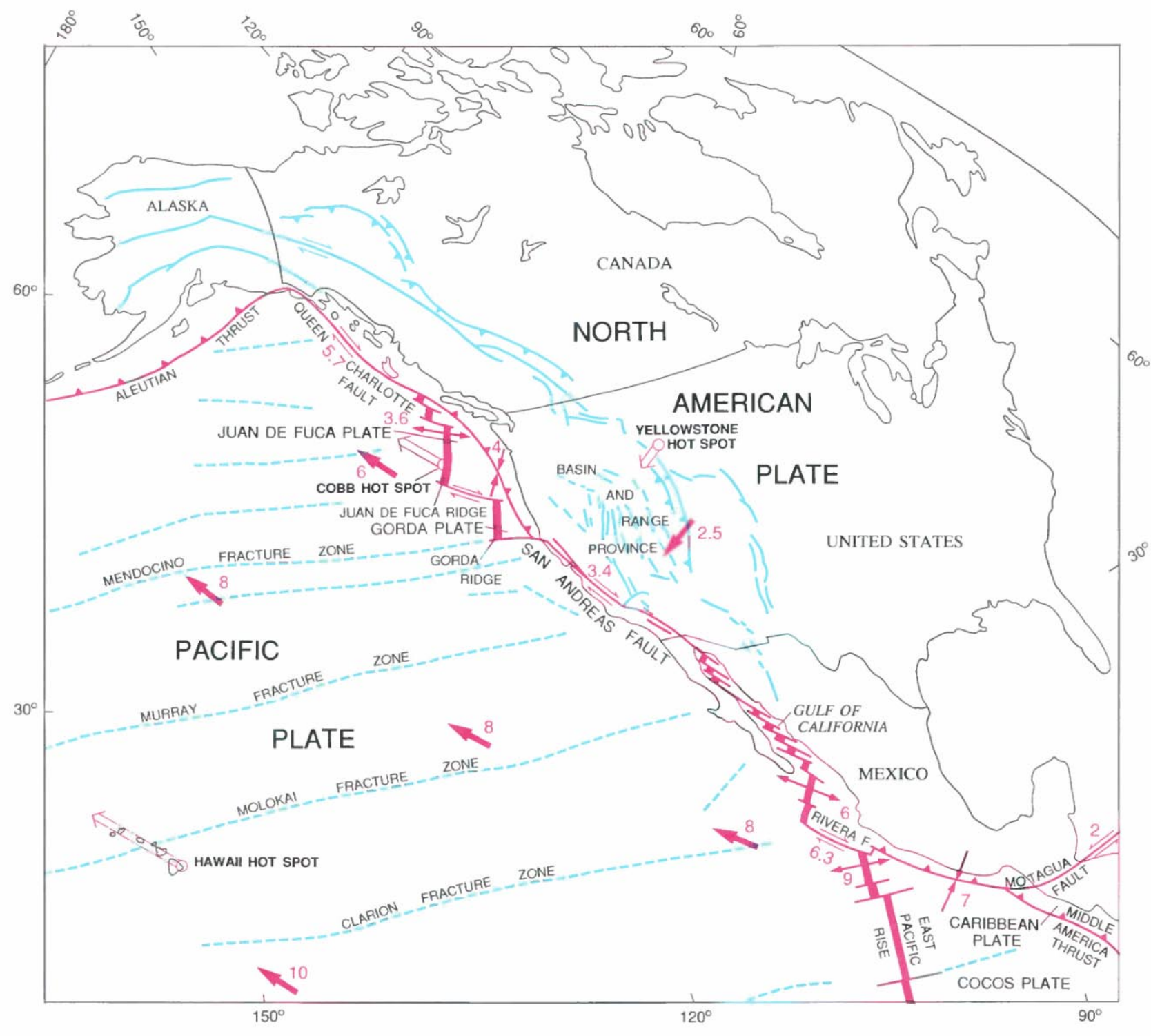

EXPLANATION

$\underline{5.7}$ Strike-slip fault-Showing slip vectors and rate $(\mathrm{cm} / \mathrm{yr})$

ـ Subduction zone-Showing slip vectors and rate $(\mathrm{cm} / \mathrm{yr})$ of convergence: sawteeth on upper plate

$\stackrel{6}{\longrightarrow}$ Spreading center-Showing vectors and rate $(\mathrm{cm} / \mathrm{yr})$ of spreading

8 Vector and rate $(\mathrm{cm} / \mathrm{yr})$ of absolute plate motion

$\longleftarrow \quad$ Hot spot and vector of plate motion relative to it

Fracture zone in Pacific plate

Fault in North American plate-Sawteeth on upper plate of thrust fault

Figure 1.2.-Northeastern Pacific Basin, showing relation of the San Andreas fault as one element in the complex boundary between the North American and Pacific plates. Modified from Drummond (1981). 
the Hayward and Calaveras faults in central California and the San Jacinto and Elsinore faults in southern California (fig. 1.3). In addition, in southern California the San Andreas fault splits into northern and southern branches in the eastern Transverse Ranges east of Los Angeles. These major faults accommodate about twothirds of the right-slip motion between the North American and Pacific plates.

Numerous smaller branches, and extensions of segments of the fault, include in northern California such faults as the Rodgers Creek and Maacama faults, which may be considered northward extensions of the Hayward fault. The Green Valley and Bartlett Springs fault zones extend the Calaveras fault northward in a complex way (see maps at front of book). At the south end of the system, the Imperial fault represents a transition from the more continuous San Andreas fault to a more nearly echelon pattern characteristic of the faults under the Gulf of California. The Superstition Hills and Coyote Creek faults similarly represent a transition from the San Jacinto fault to a more segmented pattern to the south in Mexico.

In this volume, the San Andreas fault system is considered to lie principally within a belt about $100 \mathrm{~km}$ wide by $1,300 \mathrm{~km}$ long, but this boundary is arbitrary. Indeed, part of the relative strike-slip motion between the North American and Pacific plates seems to be taken up as far as 1,000 km east of the coastline throughout the Great Basin province (Jordan and Minster, 1988). The name "San Andreas fault system," however, should be confined to the more limited belt with the highest concentration of right-lateral strike slip.

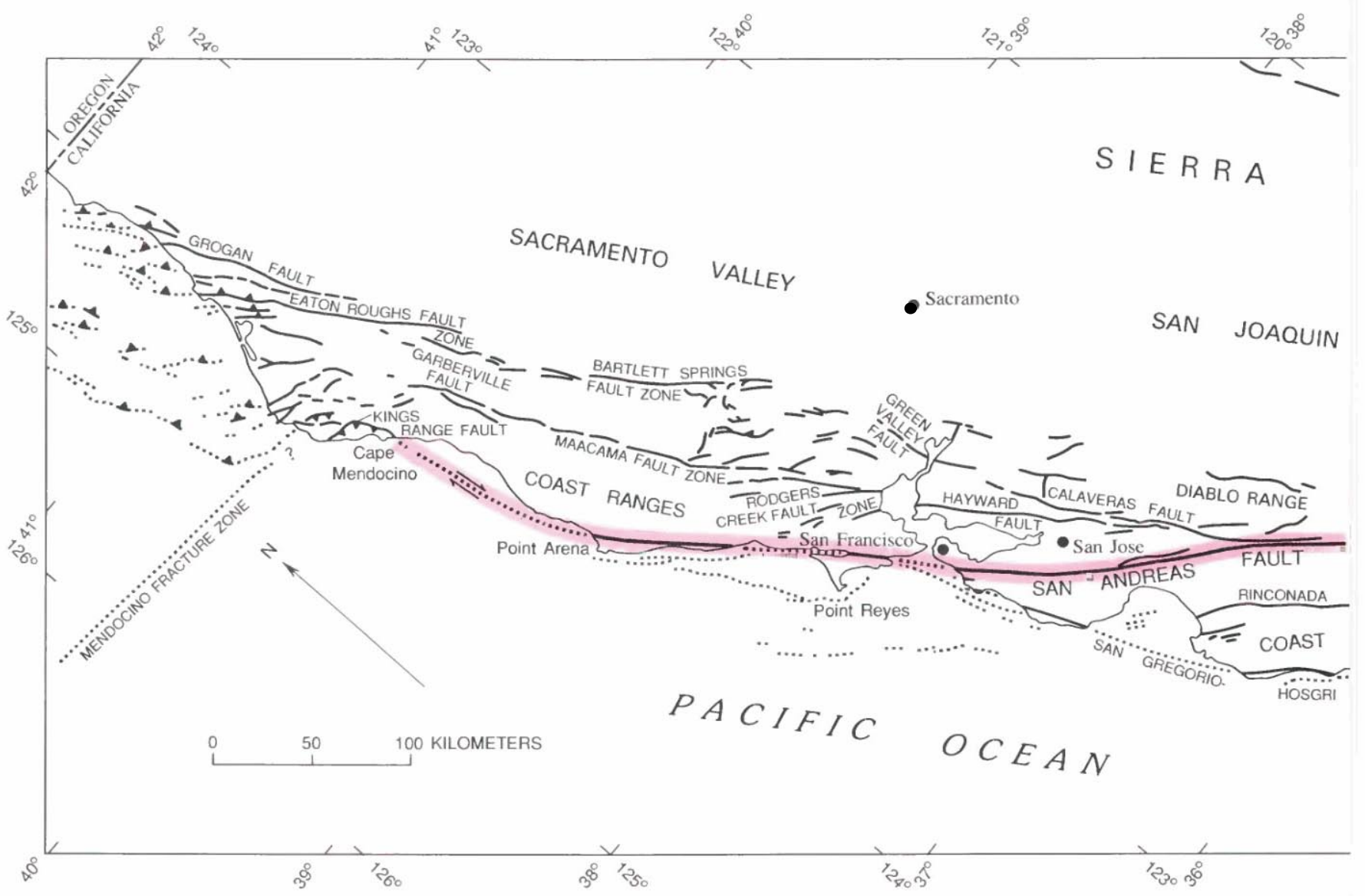

Figure 1.3.- The San Andreas fault system in California. Arrows on San Andreas fault (red) indicate direction of relative movement. 


\section{PRINCIPAL TRENDS}

With some notable exceptions, the fault trends about N. $35^{\circ}-40^{\circ} \mathrm{W}$. (fig. 1.3). In its central section between the latitudes of San Jose and Bakersfield, the fault is relatively simple and straight, but farther to the south and north several branches splay from the main active trace. Near San Jose, where the fault bends about N. $50^{\circ}$ W., the Calaveras and Hayward faults splay to the east and trend between N. $20^{\circ}$ and $35^{\circ} \mathrm{W}$. South of the latitude of Bakersfield, the main fault changes most sharply in strike, in what commonly is referred to as the Big Bend reach of the fault. For $120 \mathrm{~km}$ or more the fault strikes about N. $60^{\circ} \mathrm{W}$., where it bounds the Mojave block on the south. This bend has significant tectonic implications (see chaps. 2 and 3, and maps at front of book).
South of the latitude of Los Angeles, the Elsinore and San Jacinto faults splay to the southeast, forming, in a general way, a reversed image of the splays in the San Francisco Bay region, although both faults trend about N. $50 \mathrm{~W}$.

\section{COMPLEXITIES OF THE FAULT SYSTEM}

\section{OTHER RELATED FALLTS}

In addition to the right-lateral strike-slip faults that characterize the San Andreas fault system, faults displaying left-lateral strike slip, as well as thrust faults and reverse faults of many sizes, are present (see maps at front of book). Normal faults are less common but are present in some places, for example, in zones of extension

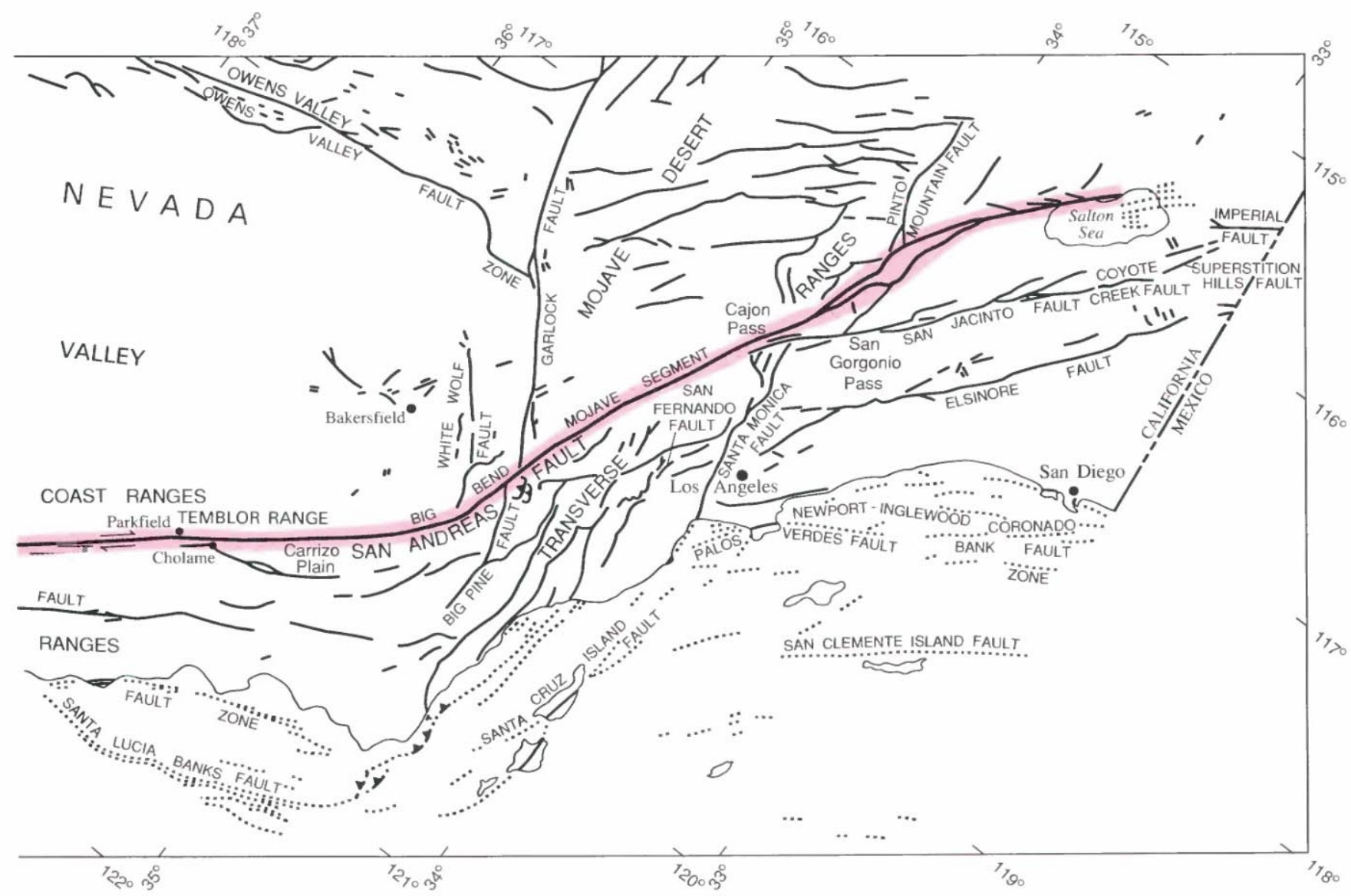

Faults dotted where concealed; sawteeth on upper plate of thrusts. Mendocino Fracture Zone queried where uncertain. 
at the crest of folds associated with the major faults, in the bordering ranges, and at jogs in the fault where local extension is to be found.

Most conspicuous of the faults displaying left-lateral slip is the Garlock fault which intersects the San Andreas fault at about lat $35^{\circ} \mathrm{N}$. and extends northeastward and eastward from there for $240 \mathrm{~km}$ (fig. 1.3; see maps at front of book). On the west side of the San Andreas fault, the southwest- and east-west-trending Big Pine fault joins the San Andreas fault a few kilometers northwest of the point where the Garlock fault joins the San Andreas fault.

The left-lateral Pinto Mountain fault zone joins the San Andreas fault on its east side at about lat $34^{\circ} \mathrm{N}$. and extends northeastward, in a pattern not unlike that of the Garlock fault. The Blue Cut fault is another left-lateral fault in the same general area.

On a broad regional scale, thrust faults and detachments that accommodate subduction of the lower crust are significant, and various interpretations and speculations have been offered (fig. 1.4; Weldon and Humphreys, 1986; Namson and Davis, 1988). Intermediatescale thrust faults that border the Transverse Ranges on the south side are characterized by such faults as the San Fernando fault zone (Grantz, 1971) and the Cucamonga fault zone (fig. 1.5). At the north end of the San Andreas fault system, where it joins the Mendocino Fracture Zone, such thrust faults as the Kings Range fault

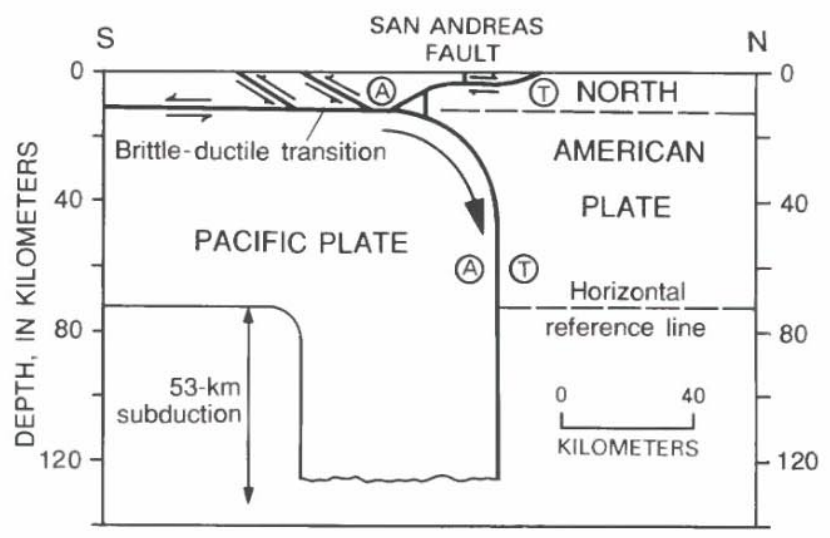

Figure 1.4. - Some interpretations suggest that the San Andreas fault bottoms at a detachment fault and that numerous thrust faults, as well as the San Andreas fault itself, are important elements which accommodate the relative displacements between the North American and Pacific plates (from Namson and Davis, 1988). Heavy lines, faults; arrows indicate direction of relative movement: A, away from observer; $\mathrm{T}$, toward observer. similarly accommodate crustal shortening. Smaller thrust faults that flank the San Andreas fault and dip toward it are common along many parts of the fault zone. A range of fault types, and the complexities that typify much of the fault zone, are well illustrated near Cajon Pass and southeast of there (fig. 1.5), where the San Andreas fault zone splits into a northern and a southern branch. The strike of the, San Gorgonio Pass fault zone in the east-central part of figure 1.5 changes in several places, and depending on the trend of a given segment, strike or dip slip may predominate. In this same area, the San Andreas fault, which to the northwest is relatively continuous and linear, ends as a surface feature, and the style of deformation changes from strike slip to primarily dip slip at the surface. Left-lateral slip characterizes the Pinto Mountain fault in the eastern part of figure 1.5, and small normal faults can be found throughout this area.

\section{SEGMENTATION}

Different behavior patterns along different parts of the fault began to be recognized when Steinbrugge and Zacher (1960) found that continuous slip or "creep" occurred along the fault in central California. Allen (1968) delineated five different regions along the San Andreas fault, three displaying seismic activity and two displaying little or no current activity. Wallace (1970) described in more detail major differences in behavior along different segments.

Large segments of the fault system that are believed to produce damaging earthquakes are illustrated in figure 1.6, which also shows an evaluation of the probabilities of earthquakes of different magnitude along these major segments of the San Andreas fault and three of its branches, the Hayward, San Jacinto, and Imperial faults. Both historical seismicity and paleoseismic evidence of large earthquakes and slip rates that characterize these different segments have been used in this assessment (Working Group on California Earthquake Probabilities, 1988).

Segmentation at a scale of a few to several kilometers is shown in figure 1.7, and a cumulative plot of the segment lengths in figure 1.8. The maximum length of these segments is about $18 \mathrm{~km}$, but a more significant upper range appears to be near $10 \mathrm{~km}$. These mappable segments are based on relatively fresh geomorphic features considered to be "young," that is, probably less than several thousand years old.

Both left (fig. 1.7)- and right-stepping echelon patterns are displayed, and combinations or transition zones are also present. Complex patterns are common. 


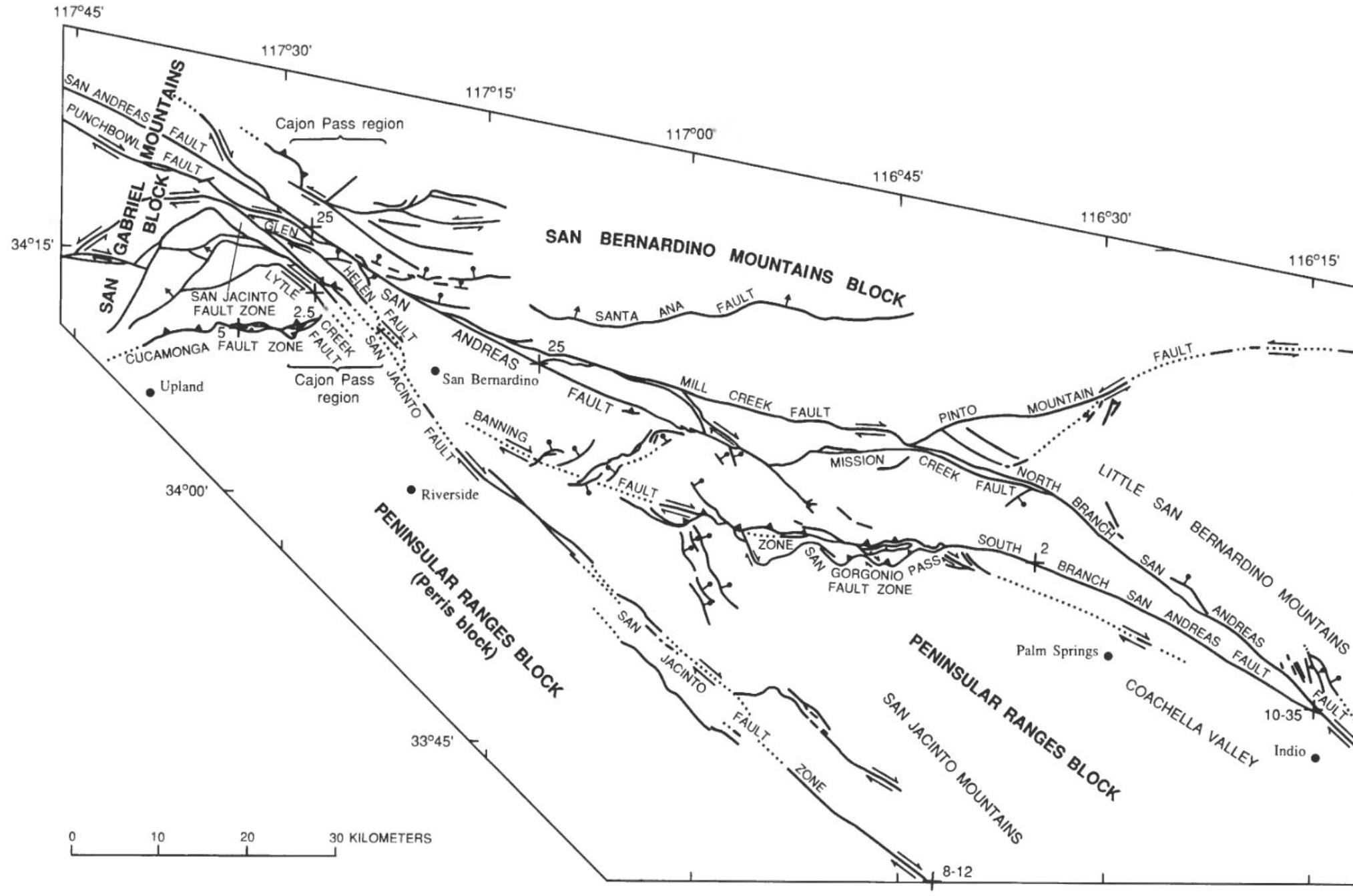

$\rightleftharpoons \mathcal{1}$.. Fault-Dotted where concealed; queried where uncertain. Paired arrows show relative strike

EXPLANATION

teeth on upper plate

FIGURE 1.5. - Complex branching and changes in the style of faulting characterize the eastern branch of the San Andreas fault system in southern California. Although right-lateral strike slip characterizes the main San Andreas fault and its major branches, thrust faults, normal faults, and left-lateral faults are also present (modified from Matti and others, 1985) 


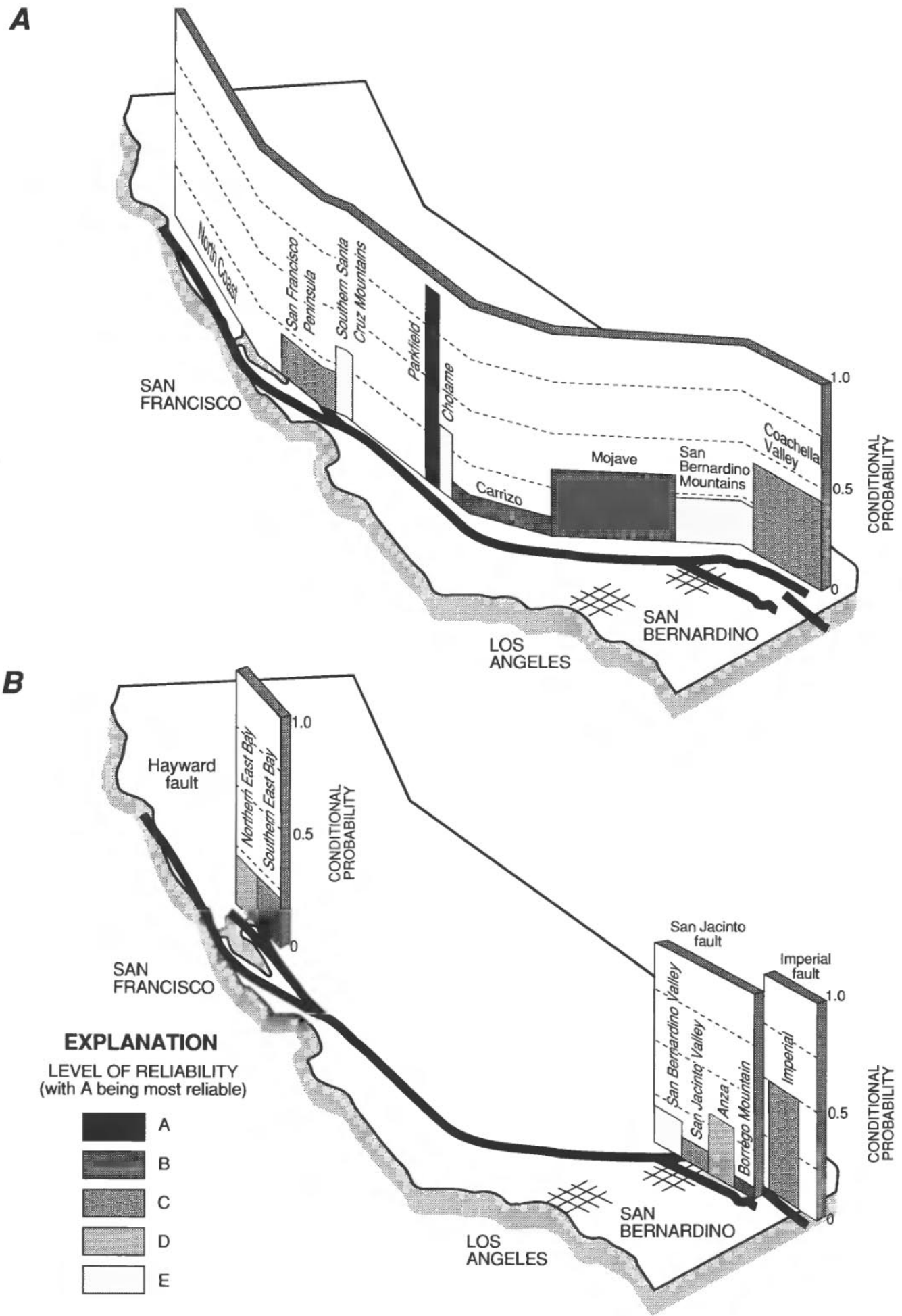

FIGURE 1.6.-Segments of the San Andreas fault system display different behavior. Here are shown conditional probabilities for the occurrence of major earthquakes along segments of the San Andreas $(A)$ and the Hayward, San Jacinto, and Imperial faults $(B)$ for the 30-year interval from 1988 to 2018. From Working Group on California Earthquake Probabilities (1988). 


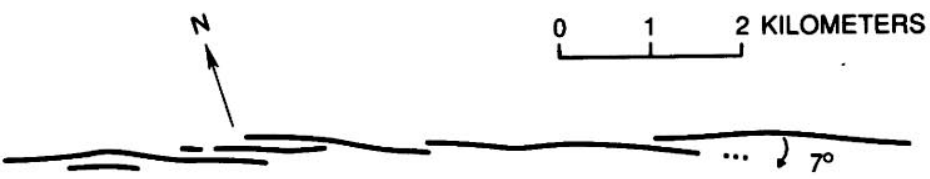

A. Quail Lake

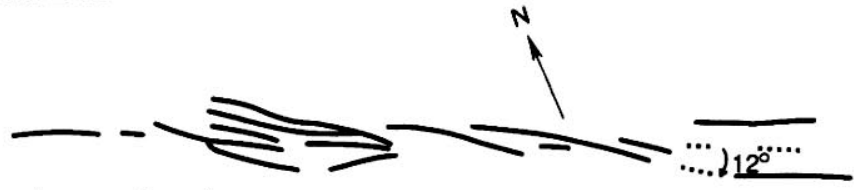

B. Yucaipa quadrangle

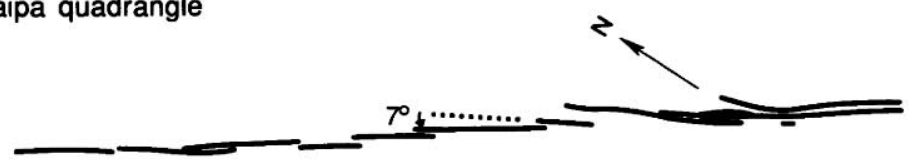

C. Gualala River

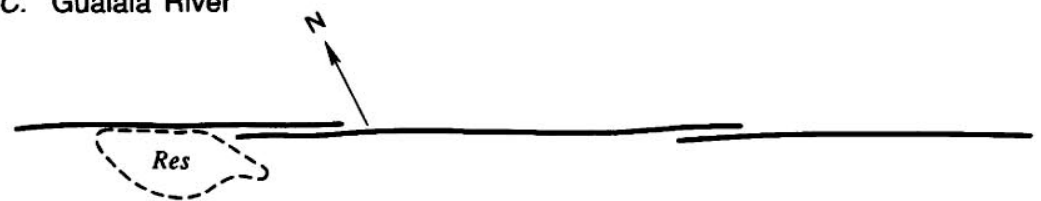

D. Palmdale Reservoir
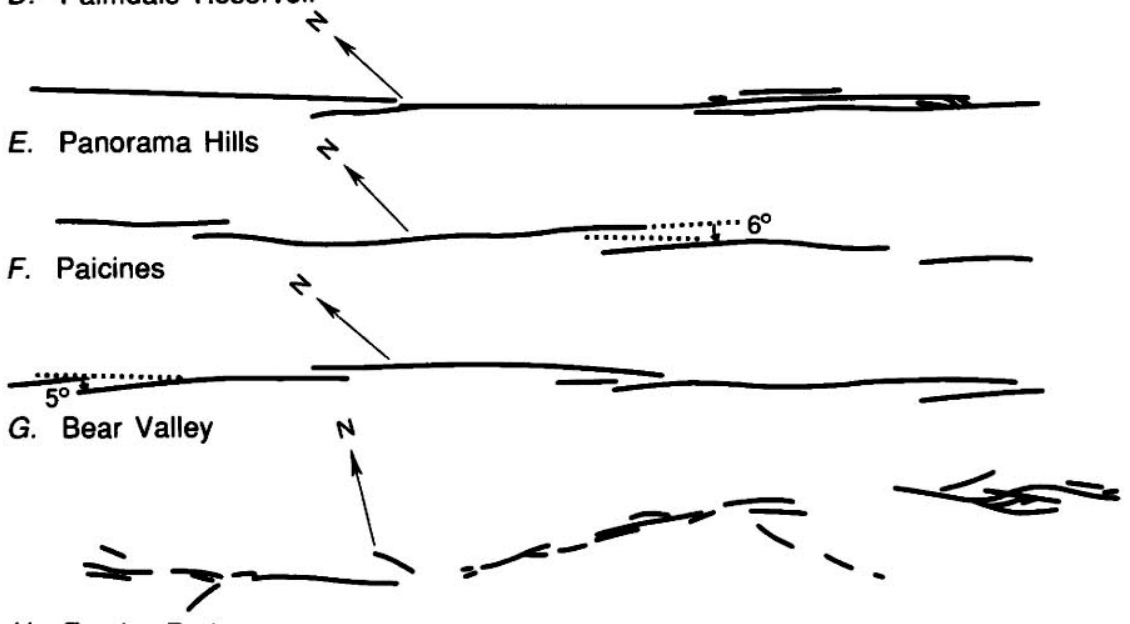

FIGURE 1.7.-Individual branches and

H. Frazier Park

strands of surface trace of the San Andreas fault are arranged in various patterns: $A-C$, left-stepping echelon arrangement; $D-F$, right-stepping echelon arrangement; $G$, both left- and right-stepping arrangements; $H-J$, complex arrangements of individual strands. Note that individual strands may be at an angle of as much as $12^{\circ}$ to general trend of fault zone. Sources: $A, D$ (Ross, 1969); $B$ (Hope, 1969; see references in this chapter); $C, J$ (Brown and Wolfe, 1972); $E, H, I$ (Vedder and Wallace, 1970); $F, G$ (Brown, 1970; see references in chap. 2).

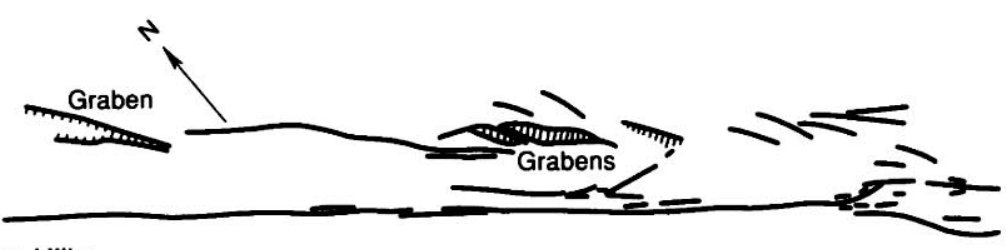

I. Elkhorn Hills

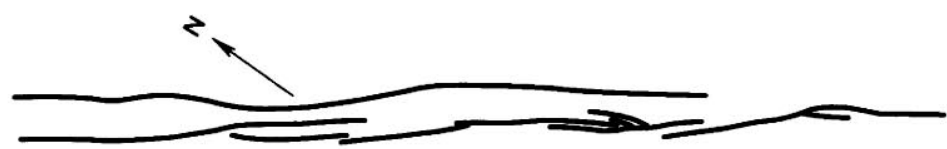

J. Point Reyes peninsula 


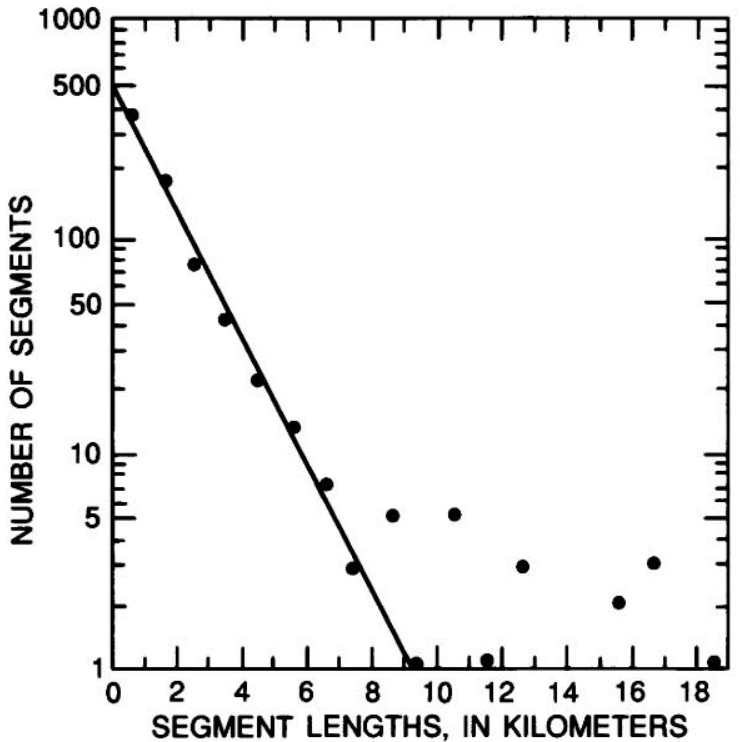

Figure 1.8. - Census of lengths of individual segments of the San Andreas fault. Maximum lengths are in the range 10-18 $\mathrm{km}$. Line is fitted by eye to show trend of values. From Wallace (1973).

\section{REFERENCES CITED}

Allen, C.R., 1968, The tectonic environment of seismically active and inactive areas along the San Andreas fault system, in Dickinson, W.R., and Grantz, Arthur, eds., Proceedings of conference on geologic problems of San Andreas fault system: Stanford, Calif., Stanford University Publications in the Geological Sciences, v. 11, p. $70-80$.

Atwater, Tanya, 1970, Implications of plate tectonics for the Cenozoic tectonic evolution of western North America: Geological Society of America Bulletin, v. 81, no. 12, p. 3513-3535.

Atwater, Tanya, and Molnar, Peter, 1973, Relative motion of the Pacific and North American plates deduced from sea-floor spreading in the Atlantic, Indian and South Pacific Oceans, in Kovach, R.L., and Nur, Amos, eds., Proceedings of the conference on tectonic problems of the San Andreas fault system: Stanford, Calif., Stanford University Publications in the Geological Sciences, v. 13, p. 136-148.

Drummond, K.J., chairman, 1981, Pacific Basin sheet of Plate-tectonic map of the circum-Pacific region: Tulsa, Okla., American Association of Petroleum Geologists, scale 1:10,000,000.

Dickinson, W.R., and Snyder, W.S., 1979, Geometry of triple junction related to the San Andreas transform: Journal of Geophysical Research, v. 84, no. B2, p. 561-572.

- 1979, Geometry of subducted slabs related to the San Andreas transform: Journal of Geology, v. 87, no. 6, p. 609-627.
Gilbert, G.K., 1907, The earthquake as a natural phenomenon, in The San Francisco earthquake and fire of April 18, 1906, and their effects on structures and structural materials: U.S. Geological Survey Bulletin 324, p. 1-13.

Grantz, Arthur, 1971, The San Fernando, California, earthquake of February 9, 1971, Introduction, in Grantz, Arthur, ed., The San Fernando, California, earthquake of February 9, 1971: U.S. Geological Survey Professional Paper 733, p. 1-4.

Hill, D.P., Wallace, R.E., and Cockerham, R.S., 1985, Review of evidence on the potential for major earthquakes and volcanism in the Long Valley-Mono Craters-White Mountains regions of Eastern California: Earthquake Prediction Research, v. 3, no. 3-4, p. 571-594.

Hope, R.A., 1969, Map showing recently active breaks along the San Andreas and related faults between Cajon Pass and Salton Sea, California: U.S. Geological Survey open-file map, scale 1:24,000, 2 sheets.

Jordan, T.H., and Minster, J.B., 1988, Measuring crustal deformation in the American West: Scientific American, v. 259, no. 2, p. 48-58.

Lawson, A.C., 1895, Sketch of the geology of the San Francisco peninsula: U.S. Geological Survey Annual Report 15, p. 439-473.

- chairman, 1908, The California earthquake of April 18, 1906: Report of the State Earthquake Investigation Commission: Carnegie Institution of Washington Publication 87, $2 \mathrm{v}$.

Matti, J.C., Morton, D.M., and Cox, B.F, 1985, Distribution and geologic relations of fault systems in the vicinity of the central Transverse Ranges, southern California: U.S. Geological Survey Open-File Report 85-365, 27 p., scale 1:250,000, 2 sheets.

Minster, J.B., and Jordan, T.H., 1980, Present-day plate motions: A summary, in Source mechanism and earthquake prediction (Coulomb volume): Paris, Centre National de la Recherche Scientifique, p. 109-124.

Namson, J.S., and Davis, T.L., 1988, Structural transect of the western Transverse Ranges, California: Implications for lithospheric kinematics and seismic risk evaluation: Geology, v. 16, no. 8, p. 675-679.

Steinbrugge, K.V., and Zacher, E.G., 1960, Creep on the San Andreas fault. Fault creep and property damage: Seismological Society of America Bulletin, v. 50, no. 3, p. 389-396.

Wallace, R.E., 1970, Earthquake recurrence intervals on the San Andreas fault: Geological Society of America Bulletin, v. 81, no. 10 , p. $2875-2889$.

- 1973, Surface fracture patterns along the San Andreas fault, in Kovach, R.L., and Nur, Amos, eds., Proceedings of the conference on tectonic problems of the San Andreas fault system: Stanford, Calif., Stanford University Publications in the Geological Sciences, v. 13, p. 248-250.

- 1975, The San Andreas fault in the Carrizo Plain-Temblor Range region, California, in Crowell, J.C., ed., San Andreas fault in southern California: A guide to San Andreas fault from Mexico to Carrizo Plain: California Division of Mines and Geology Special Report 118, p. 241-250.

Weldon, R.J., and Humphreys, E.D., 1986, A kinematic model of Southern California: Tectonics, v. 5, no. 1, p. 33-48.

Working Group on California Earthquake Probabilities, 1988, Probabilities of large earthquakes occurring in California on the San Andreas fault: U.S. Geological Survey Open-File Report 88-398, $62 \mathrm{p}$. 


\section{- r.}

Nitis

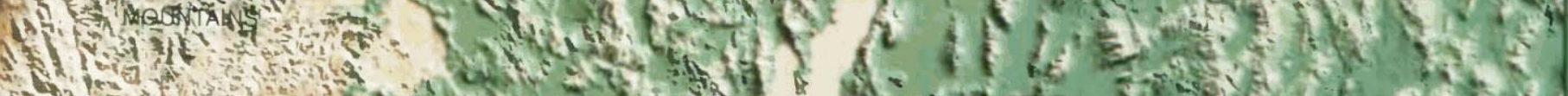

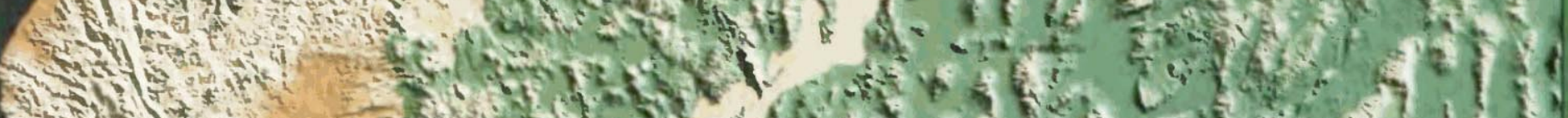

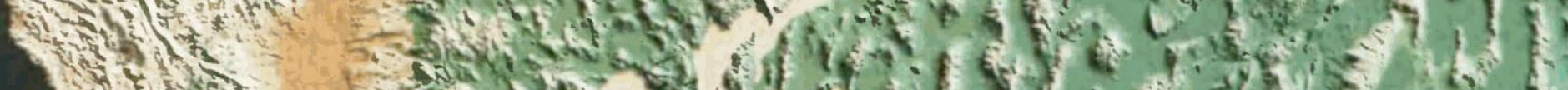

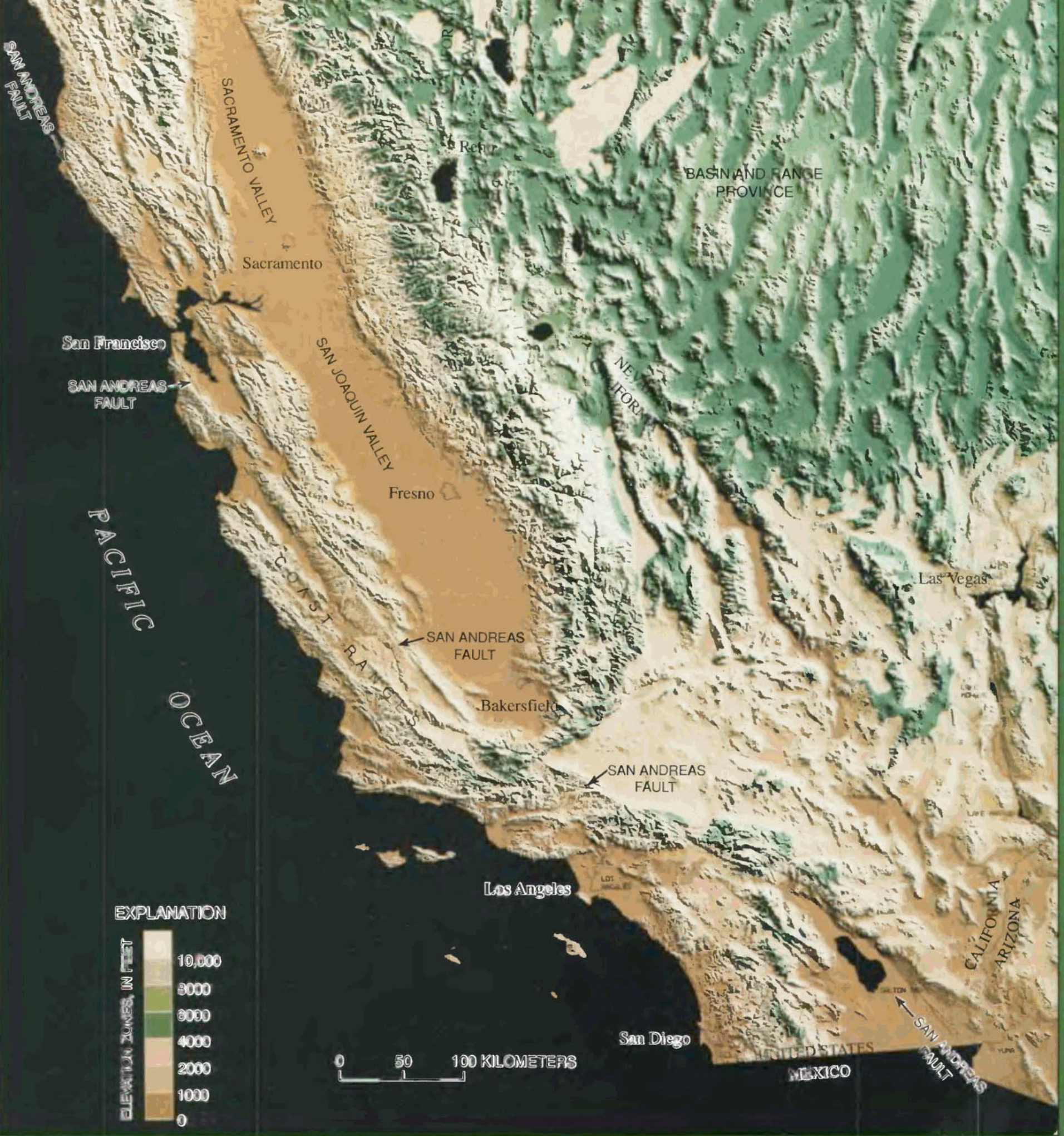



7 he San Andreas fault is marked in the landscape by a series of

1 linear valleys and mountain fronts, aligned lakes and bays, elongate ridges, and disrupted or offset stream channels.

\title{
2. GEOMORPHIC EXPRESSION
}

\author{
By Robert E. Wallace
}

\section{CONTENTS}

\section{REGIONAL FEATURES}

On maps, aerial photographs, or satellite images, at almost any scale, the San Andreas fault zone appears as a linear scar across the landscape. At scales small enough to display the entire fault length, valleys, bays, chains of lakes and ponds, linear flanks of mountain ranges, and elongate ridges bounding one side or the other of the fault are the principal features that reveal its location.

Erosion of the softer broken and sheared rocks in the several-hundred-meters- to $1-\mathrm{km}$-wide fault zone accounts for much of the valley-like expression of the fault, but differential vertical displacements also play a major role. The ratio of local horizontal to vertical displacement may be about 10 or 20 to 1 . Differential erosion of the various rock types juxtaposed by faulting also influences the geomorphic expression of the fault.

The San Andreas fault separates some mountain masses from adjacent broad regions of low relief, creating pronounced linear topographic discontinuities. Considering the large lateral displacements that have occurred, juxtaposition of some mountains against flatter, lower areas probably has come about by lateral slip. Some range-size blocks bounded by the fault, however, have risen or dropped hundreds of meters to create the linear topographic features. Elongate blocks of the crust bounded by branches and subparallel strands of the fault have been created and shuffled one block against another by both upward, downward, and lateral differential displacement within the broad shear zone. Such movements are reflected in the topography as elongate ridges and depressions. Whether lateral or vertical block displacement, or warping or folding, has dominated in the development of a specific landform, and what role erosion has played, have yet to be well analyzed for most topographic features within the fault system. Evidently, a complex interaction of tectonic, erosional and depositional processes has influenced the development of each feature, and the result is a linearity of topographic features along and parallel to the San Andreas fault.

From Point Arena southeastward to the vicinity of San Jose, Calif., the trace of the San Andreas fault is topographically conspicuous on regional maps and images as a series of linear valleys (see fig. 2.1 and maps at front of book for locations). Aligned linear valleys also mark the fault trace throughout central California between San Jose and the Carrizo Plain, but along that reach another important characteristic is that the fault trace crosses mountain ranges and major ridges at a low angle. These
FIGURE 2.1. - Shaded-relief map of California and western Nevada, showing the San Andreas fault as a series of linear valleys and ridges passing through a mountainous region, the Coast Ranges, the trends of which are a low angle to the fault. To the east, between the massive Sierra Nevada and the Coast Ranges, lie the broad, flat valleys of the Sacramento and San Joaquin Rivers. Farther east, in the Basin and
Range province, are myriad block-faulted mountains separated by intervening basins. Synthesized from digital terrain models of a 1:250,000-scale map series originally prepared by the U.S. Defense Mapping Agency, now maintained by the U.S. Geological Survey; compiler, Ray Batson, U.S. Geological Survey. Illumination is from north at elevation of $30^{\circ}$. 
mountain ranges and ridges, many of which are antiformal structures, trend from $5^{\circ}$ to $10^{\circ}$ more westerly than the strike of the fault. Thus, the altitude of the surface trace of the fault alternately rises and falls along strike.

In the Carrizo Plain-Temblor Range area, the surface trace of the fault does not lie at the base of the range but more within the Carrizo Plain, where the surface expression of the fault is narrowest, clearest, and best defined. Offset streams are especially well preserved here; individual strands of the fault reach a maximum length, from 9 to $18 \mathrm{~km}$, anywhere along the fault.

In the Big Bend area at the south end of the San Joaquin Valley, the fault trace rises to a high altitude as it passes through mountainous terrain. Along the Mojave segment to the northwest and southeast of Palmdale (see maps at front of book for locations), the fault trace is again marked by a distinct narrow, linear valley. In addition, a gross contrast between the high, rugged mountain masses of the Transverse Ranges and the relatively flat Mojave Desert block is apparent (fig. 2.1). The surface of the Mojave Desert itself stands $700 \mathrm{~m}$ or more above sea level and above the San Joaquin Valley. Clearly, the Mojave block has been uplifted, even though the adjacent mountain masses have risen more.

To the southeast of the Mojave segment, the San Andreas fault crosses the Transverse Ranges at a low angle and separates the high San Gabriel Mountains from the San Bernardino Mountains. An extremely complex structural knot, formed by branching of the San Jacinto fault and numerous other faults (fig. 2.1; see fig. 1.5) is reflected as a complex topographic region surrounding the Cajon Pass area, through which the San Andreas fault passes.

Southwest of the Cajon Pass area, the fault divides into a northern and a southern branch and numerous other smaller faults of different tectonic style. Each fault has its own distinctive geomorphic expression.

Southeast of the zone of major branching, the fault again is less conspicuously marked by contrasts of large topographic features, but it is readily visible on aerial photographs at scales of 1:50,000 and larger (see section below entitled "A Photographic Album of Fault Features").

\section{LOCAL GEOMORPHIC FEATURES WITHIN THE FAULT ZONE}

Within the fault zone, various geomorphic features are found that have their origin in both the lateral and vertical shuffling of fault-bounded slices, as well as in the persistent, large strike slip. These features include sag depressions and sag ponds, shutter ridges and medial ridges, offset and deflected stream channels, linear benches along valley walls, aligned notches and saddles on spurs, offset marine and river terraces, scarps, fault-controlled drainage, and folds and pressure ridges (fig. 2.2).

Along its entire length, the fault zone exhibits peculiar, anomalous drainage patterns. In regions where tectonic activity is less pronounced, streams generally flow more or less perpendicular to mountain blocks and highlands, and grade more or less regularly to the lowlands; not so along an active fault like the San Andreas. When drainage flowing from highlands meets the San Andreas fault, it is diverted subparallel to the trends of the highlands or is interrupted or blocked completely. In less active areas, erosion generally is the dominant factor in carving geomorphic forms, but displacements are so rapid within the fault zone that tectonic effects overwhelm erosion, and so the geomorphic features directly express fault movement.

Movement within the network of branching and anastomosing fault strands jostles the intervening blocks, compressing some, rotating some, or causing extension across others. Because the principal slip is horizontal and lateral, the blocks tend to be elongate parallel to the trend of the fault. Blocks under compression tend to be squeezed upward to form elongate ridges, whereas blocks under extension may drop downward to form sags, and laterally displaced slices or ridge spurs create shutters across drainage channels.

The dominantly lateral slip across the fault zone and the rate of slip, from $1 \mathrm{~cm}$ to a few centimeters per year, make stream channels that are offset right laterally, a common and characteristic geomorphic feature. Stream channels can be completely beheaded or merely offset while maintaining continuity of flow.

In addition to the effects of lateral slip, streams are extremely sensitive to vertical slip on faults and warping of the land surface. For example, only a small upward movement of a block on the downstream side of a fault crossing a stream may divert the stream either to the left or right, thus mimicking lateral slip on the fault. Similarly, warping of the land surface over folds adjacent to the fault or on pressure ridges within the fault zone can distort the patterns of streams. Combinations of these different tectonic processes can produce many unusual features. Both the tectonic and the erosional changes at times may occur almost instantaneously, and so the dominance of one or the other process suddenly may change. Between such periods of sudden change, very little may happen for decades or even centuries. The relative rates of erosional and tectonic processes, and the timing of sudden events, are critical to the landforms created. Some of the patterns of streams found in the Carrizo Plain area are illustrated in figure 2.3, and an example is shown in figure 2.5. 
The geomorphic forms created represent the results of a continuing contest between erosional changes and changes related to fault slip, folding, and warping. Where streams are large and rainfall is greater, only displacements of hundreds of meters or more are preserved for longer than a few centuries. In desert climates, however, as in the Carrizo Plain, the rate of fault slip outruns erosion, and the effects of only a few meters of fault slip may be preserved for hundreds of years, if not millennia, where small channels cross the fault (fig. 2.4).

As an example of how erosion and sedimentation interact with the faulting process, a straight channel that formerly crossed the fault at right angles is shown after having been offset by right-lateral strike slip (fig. 2.5). The strike slip partly or temporarily dams the stream, causing upstream alluviation at C. A fresh fault scarp is formed in the vicinity of $\mathrm{A}$, and successive offsets expose new scarp areas to the left of A. The dam at B is eroded, and the alluvium deposited earlier at $\mathrm{C}$ is dissected. $\mathrm{As}$ offset progresses further, the channel segment along the fault trace, between B and A, continually elongates, thus lowering the channel gradient more and more. Because of this decreasing gradient, alluvium is deposited upstream from $\mathrm{A}$ to and beyond $\mathrm{C}$, and eventually the stream, having difficulty maintaining a channel along that elongate course, spills across the fault trace and creates a new channel more nearly in alignment with the segment upstream from the fault.

After fault movement has progressed sufficiently, the downstream segments of other channels are brought into alignment, or nearly so, with the original channel. For example, in the vicinity of $\mathrm{D}$ in figure 2.5 , drainage flowing to the right in an adjacent channel would tend to erode headward toward $\mathrm{C}$, and capture of the original

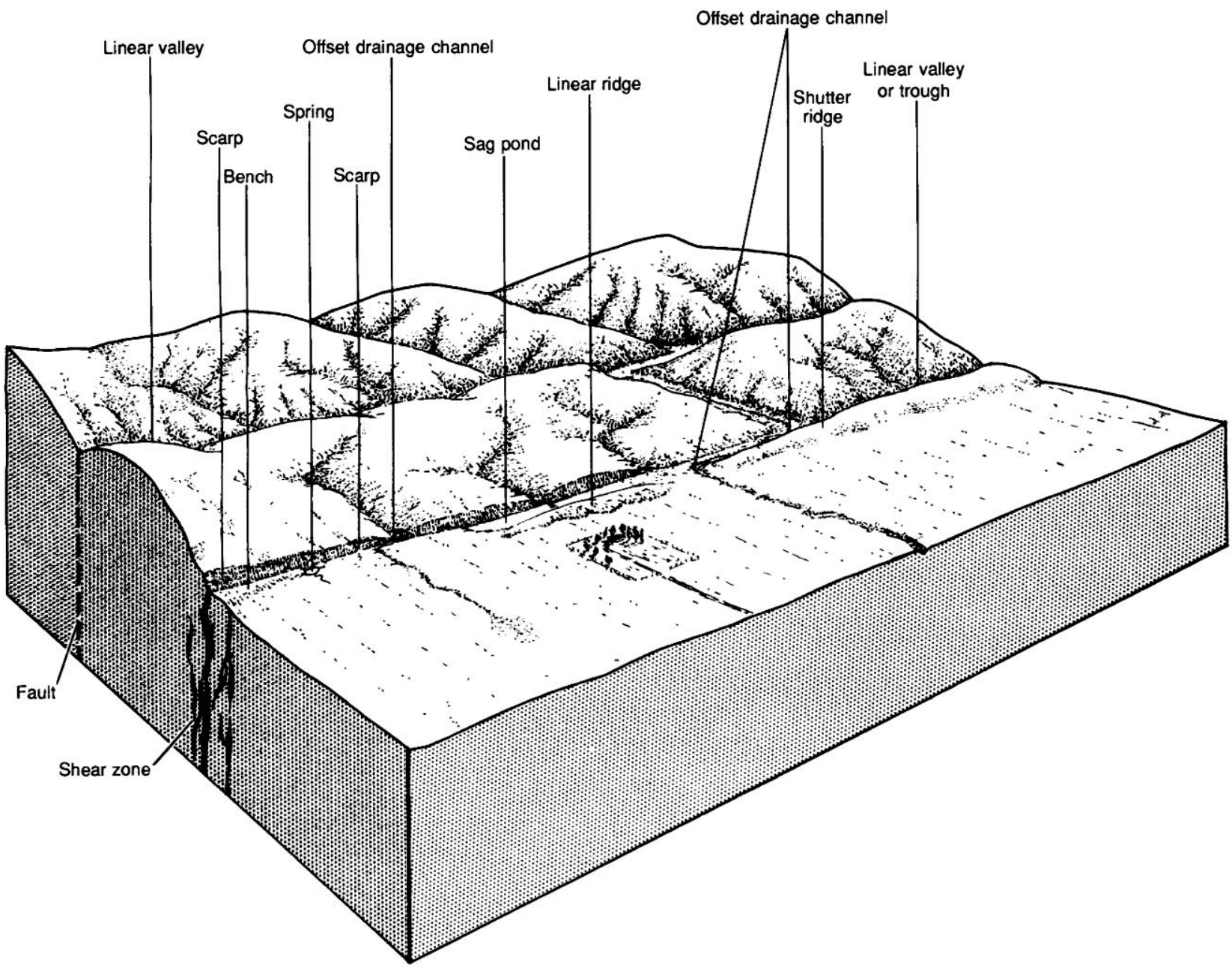

FIGURE 2.2. - Common landforms along the San Andreas fault system (from Vedder and Wallace, 1970). 

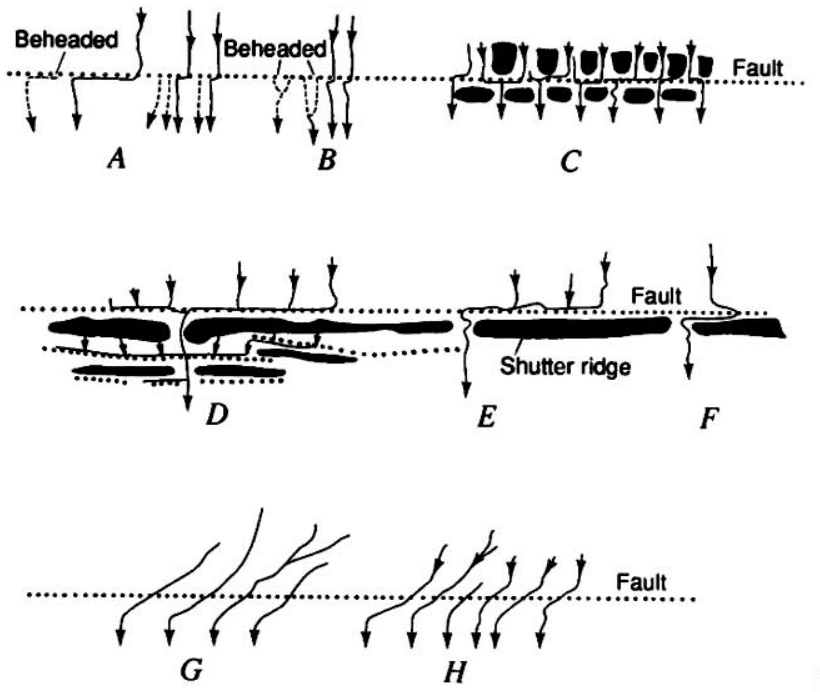

_ $\quad 400$ METERS Approximate scale

EXPLANATION

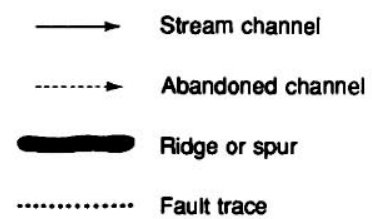

$<$

FIGURE 2.3. - Diagrammatic representation of patterns of fault-related stream channels found in the Carrizo Plain area (from Wallace, 1975): $A$, misalignment of single channels directly related to amount of fault displacement and age of channel-no ridge on downslope side of fault, beheading common; $B$, paired stream channels misaligned; $C$, compound offsets of ridge spurs, and offset and deflection of channels, both right and left deflection; $D$, trellis drainage produced by multiple fault strands, sliver ridges, and shutter ridges; $E$, exaggerated or reversed apparent offset, caused by offset plus deflection by shutter ridge; $F$, "Z" pattern, caused by capture by adjacent channel followed by right-lateral slip; $G$, false offset caused by differential uplift or warping; $H$, false offset caused by echelon fractures over fault zone, followed by subsequent streamflow.
,

FIGURE 2.4. - Topographic map of a segment of the San Andreas fault in the Carrizo Plain area, showing some characteristic small-scale geomorphic features. Markers (SAF) at the left and right margins indicate main fault trace. Between 300 and $500 \mathrm{~m}$ (see scale at bottom) is one of the best examples of a stream offset by right-lateral slip on the San Andreas fault (see fig. 2.20). To the northwest, between 100 and $300 \mathrm{~m}$, is an abandoned channel of the same stream. To the southeast, between 600 and $700 \mathrm{~m}$, small streams are offset about 10 $\mathrm{m}$; a few of these streams record multiple offsets of about 8 to $10 \mathrm{~m}$. The last offset presumably was during the great Fort Tejon earthquake of 1857 . Between 2,150 and and $2,250 \mathrm{~m}$ is a pair of streams that has been offset a few tens of meters. At 2,000 m, the downstream segments of those two streams have been beheaded completely, and at $2,100 \mathrm{~m}$ is another possible beheaded segment of the streams (see fig. 2.21). Between 2,300 and $2,700 \mathrm{~m}$ is a sag depression about $7 \mathrm{~m}$ deep, resulting from downdrop of a narrow block into the San Andreas fault zone. From Sieh and Wallace (1987); map prepared by U.S. Geological Survey from aerial photographs taken January 13, 1966.

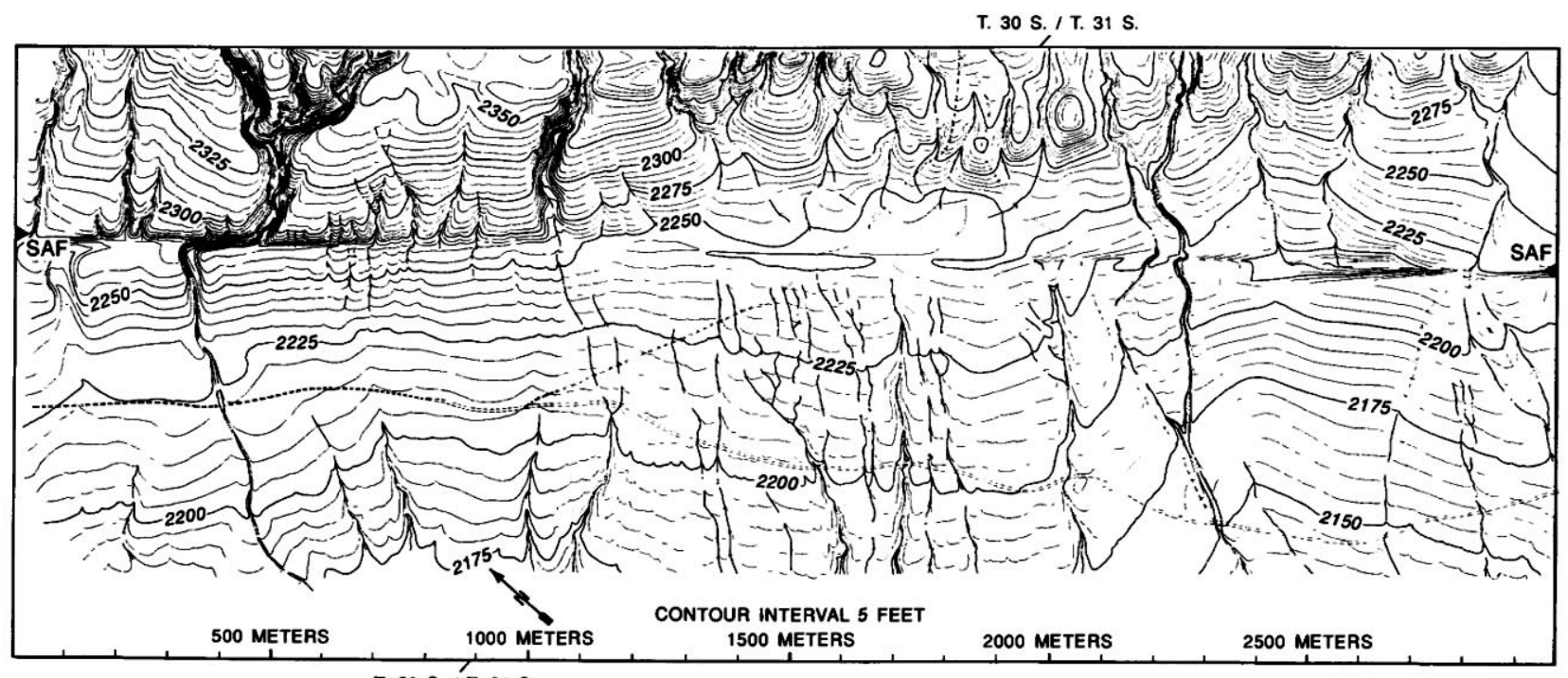

T. $30 \mathrm{~S} . / \mathrm{T} .31 \mathrm{~S}$. 
stream would take place. The gradient of this capturing segment, in which flow is to the right, progressively increases because right-lateral slip shortens the channel, thus accelerating erosion; at the same time, the channel flowing to the left elongates, gradient decreases, and erosion decelerates. An example of some geomorphic features that result is shown in figure 2.5.

\section{DETAILED MAPS OF THE FAULT SYSTEM}

The U.S. Geological Survey and the California Division of Mines and Geology have prepared numerous detailed maps of the faults within the San Andreas fault system. Maps prepared by the California Division of Mines and Geology address the problem of "active faults" as defined under the Alquist-Priolo Special Studies Zones Act of 1972. These maps, too numerous to list here, were indexed and described by Hart (1985); they constitute a rich data set about the San Andreas and other faults in California. Those readers interested in examining the features of the fault system in more detail or in the field are referred to the published "strip" maps and special fault maps, an index map of which is in figure 2.6.

\section{REFERENCES CITED}

Bortugno, E.J., 1982, Map showing recency of faulting, Santa Rosa Quadrangle, 1:250,000: California Division of Mines and Geology Regional Geologic Map Series, no. 2A, sheet 5.

Brown, R.D., Jr., 1970, Map showing recently active breaks along the San Andreas and related faults between the northern Gabilan Range and Cholame Valley, California: U.S. Geological Survey Miscellaneous Geologic Investigations Map I-575, scale 1:62,500. - compiler, 1972, Active faults, probable active faults, and associated fracture zones, San Mateo County, California: U.S. Geolog-

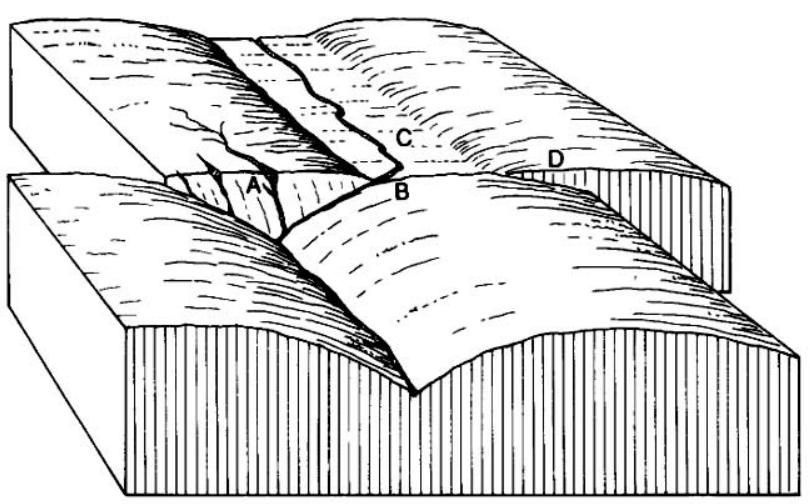

FIGURE 2.5.-General features and conditions produced where a stream channel is offset by strike slip on a fault. See text for discussion of A-D. ical Survey, San Francisco Bay Region Environment and Resources Planning Study Basic Data Contribution 44 (Miscellaneous Field Studies Map MF-355) scale 1:62,500.

Brown, R.D., Jr., and Wolfe, E.W., 1972, Map showing recently active breaks along the San Andreas fault between Point Delgada and Bolinas Bay, California: U.S. Geological Survey Miscellaneous Geologic Investigations Map I-692, scale 1:24,000, 2 sheets.

Clark, M.M., 1973, Map showing recently active breaks along the Garlock and associated faults, California: U.S. Geological Survey, Miscellaneous Geologic Investigations Map I-741, scale 1:24,000.

- 1982, Map showing recently active breaks along the Elsinore and associated faults, California, between Lake Henshaw and Mexico: U.S. Geological Survey Miscellaneous Investigations Series Map I-1329, scale 1:24,000.

_ 1984, Map showing recently active breaks along the San Andreas fault and associated faults between Salton Sea and Whitewater River-Mission Creek, California: U.S. Geological Survey Miscellaneous Investigations Series Map I-1483, 6 p., scale 1:24,000, 2 sheets.

Hart, E.W., 1985, Fault-rupture hazard zones in Califormia: AlquistPriolo Special Studies Zones Act of 1972 with index to special study zones maps: California Division of Mines and Geology Special Publication 42, $24 \mathrm{p}$.

Herd, D.G., 1977, Geologic map of the Las Positas, Greenville, and Verona faults, eastern Alameda County, California: U.S. Geological Survey Open-File Report 77-689, 25 p., scale 1:24,000.

Herd, D.G., and Helley, E.J., 1977, Faults with quaternary displacement, northwestern San Francisco Bay region, California: U.S. Geological Survey Miscellaneous Field Studies Map MF-818, scale $1: 125,000$.

Kahle, J.E., 1975, Recent fault features and related geology, Leona Valley area, southern California, in Crowell, J.C., ed., San Andreas fault in southern California: A guide to San Andreas fault from Mexico to Carrizo Plain: California Division of Mines and Geology Special Report 118, p. 203-207.

Lawson, A.C., chairman, 1908, The California earthquake of April 18, 1906: Report of the State Earthquake Investigation Commission: Carnegie Institution of Washington Publication 87, 2 v.

Matti, J.C., Morton, D.M., and Cox, B.F., 1985, Distribution and geologic relations of fault systems in the vicinity of the central Transverse Ranges, southern California: U.S. Geological Survey Open-File Report 85-365, 27 p., scale 1:250,000, 2 sheets.

McCulloch, D.S., 1987, Regional geology and hydrocarbon potential of offshore central California, in Scholl, D.W., Grantz, Arthur, and Vedder, J.G., eds., Geology and resource potential of the continental margin of western North America and adjacent ocean basins-Beaufort Sea to Baja California (Earth Science Series, v. 6): Houston, Tex., Circum-Pacific Council for Energy and Mineral Resources, p. 353-402.

McLaughlin, R.J., 1971, Geologic map of the Sargent fault zone in the vicinity of Mount Madonna, Santa Clara County, California: U.S. Geological Survey, San Francisco Bay Region Environment and Resources Planning Study Basic Data Contribution 13, scale 1:12,000, 2 sheets.

Pampeyan, E.H., Harsh, P.W., and Coakley, J.M., 1981, Preliminary map showing recently active breaks along the Maacama fault zone between Hopland and Laytonville, Mendocino County, California: U.S. Geological Survey Miscellaneous Field Studies Map MF-1217, 9 p., scale 1:24,000, 2 sheets.

Radbruch, D.H., 1967, Approximate location of fault traces and historic surface ruptures within the Hayward fault zone between San Pablo and Warm Springs, California: U.S. Geological Survey Miscellaneous Geologic Investigations Map I-522, scale 1:62,500.

Radbruch-Hall, D.H., 1974, Map showing recently active breaks along the Hayward fault zone and the southern part of Calaveras fault 


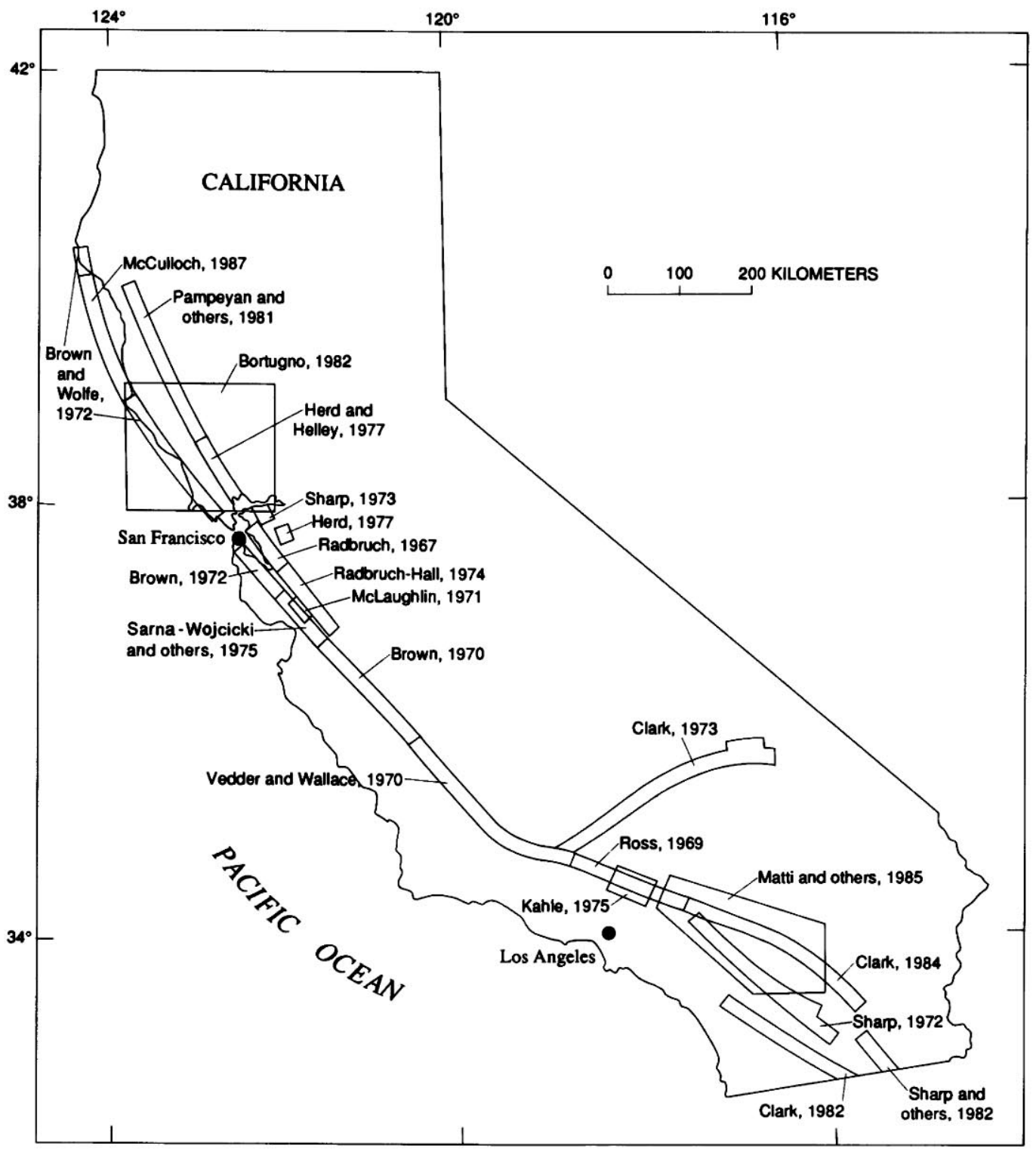

FIGURE 2.6. - Index map of California, showing locations of selected maps of surface traces of the San Andreas fault system.

zone, California: U.S. Geological Survey Miscellaneous Geologic Investigations Map I-813, scale 1:24,000, 2 sheets.

Ross, D.C., 1969, Map showing recently active breaks along the San Andreas fault between Tejon Pass and Cajon Pass, southern California: U.S. Geological Survey Miscellaneous Geologic Investigations Map I-553, scale 1:24,000.

Sarna-Wojcicki, A.M., Pampeyan, E.H., and Hall, N.T., 1975, Map showing recently active breaks along the San Andreas fault between the central Santa Cruz Mountains and the northern Gabilan Range, California: U.S. Geological Survey Miscellaneous Field Studies Map MF-650, scale 1: 24, 000, 2 sheets.

Sharp, R.V., 1972, Map showing recently active breaks along the San Jacinto fault zone between the San Bernardino area and Borrego
Valley, California: U.S. Geological Survey Miscellaneous Geologic Investigations Map I-675, scale 1:24,000, 3 sheets.

1973, Map showing recent tectonic movement on the Concord fault, Contra Costa and Solano Counties, California: U.S. Geological Survey, San Francisco Bay Region Environment and Resources Planning Study Basic Data Contribution 55, (Miscellaneous Field Studies Map MF-505), scale $1: 24,000$.

Sharp, R.V., Lienkaemper, J.J., Bonilla, M.G., Burke, D.B., Fox, B.F., Herd, D.G., Miller, D.M., Morton, D.M., Ponti, D.J., Rymer, M.J., Tinsley, J.C., Yount, J.C., Kahle, J.E., and Hart, E.W., 1982, Surface faulting in the central Imperial Valley, in The Imperial Valley, California, earthquake of October 15, 1979: U.S. Geological Survey Professional Paper 1254, p. 119-144. 
Sieh, K.E., and Jahns, R.H., 1984, Holocene activity of the San Andreas fault at Wallace Creek, California: Geological Society of America Bulletin, v. 95, no. 8, p. 883-896.

Sieh, K.E., and Wallace, R.E., 1987, The San Andreas fault at Wallace Creek, San Luis Obispo County, California: Geological Society of America, Cordilleran Section Centennial Field Guide, p. 233-238.

Steinbrugge, K.V., and Zacher, E.G., 1960, Creep on the San Andreas fault (California) - fault creep and property damage: Seismological Society of America Bulletin, v. 50, no. 3, p. 389-396.

U.S. Geological Survey, 1982, The Imperial Valley, California, earthquake of October 15, 1979: Professional Paper 1254, 451

Vedder, J.G., and Wallace, R.E., 1970, Map showing recently active breaks along the San Andreas and related faults between Cholame Valley and Tejon Pass, California: U.S. Geological Survey Miscellaneous Geologic Investigations Map I-574, scale 1:24,000.

Wallace, R.E., 1975, The San Andreas fault in the Carrizo PlainTemblor Range region, California, in Crowell, J.C., ed., San Andreas fault in southern California: A guide to San Andreas fault from Mexico to Carrizo Plain: California Division of Mines and Geology Special Report 118, p. 241-250.

Yerkes, R.F., Green, H.G., Tinsley, J.C., and Lajoie, K.R., 1980, Maps showing seismotectonic setting of the Santa Barbara Channel area, California: U.S. Geological Survey Miscellaneous Field Studies Map MF-1169, 25 p., scale 1:250,000. 



\section{A PHOTOGRAPHIC ALBUM OF FAULT FEATURES}

The characteristics of the landforms along the San Andreas fault system can be conveyed most vividly and completely by photographs, here arranged geographically from northwest to southeast (figs. 2.8-2.41). Photographs of branch faults are the last in the set. An accompanying map (fig. 2.7) shows the locations of the photographs. All photographs are my own except as otherwise credited in the captions. 


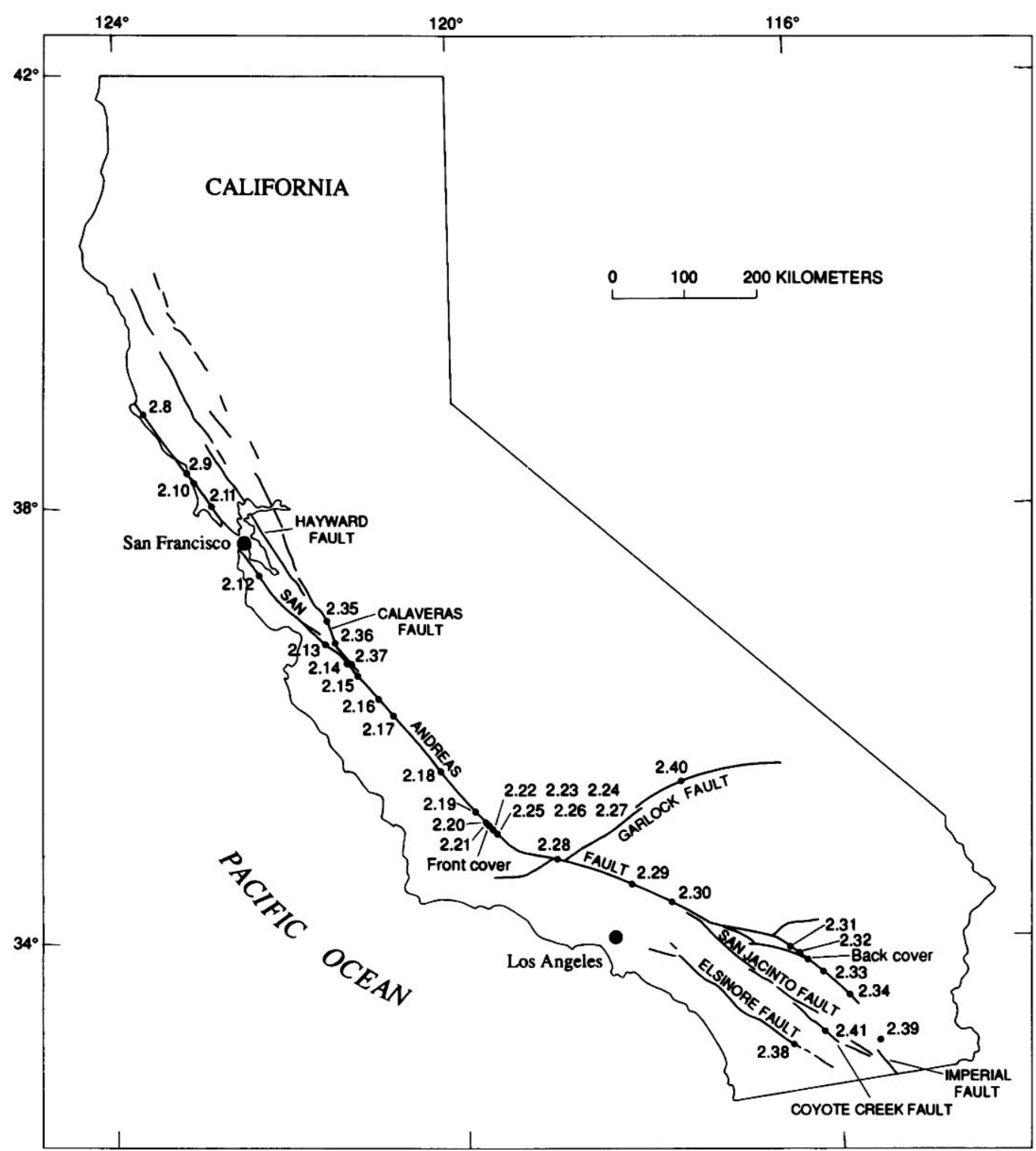

FIGURE 2.7. - Index map of the San Andreas fault system, showing locations of photographs in "photographic album" and locations of cover photographs. 


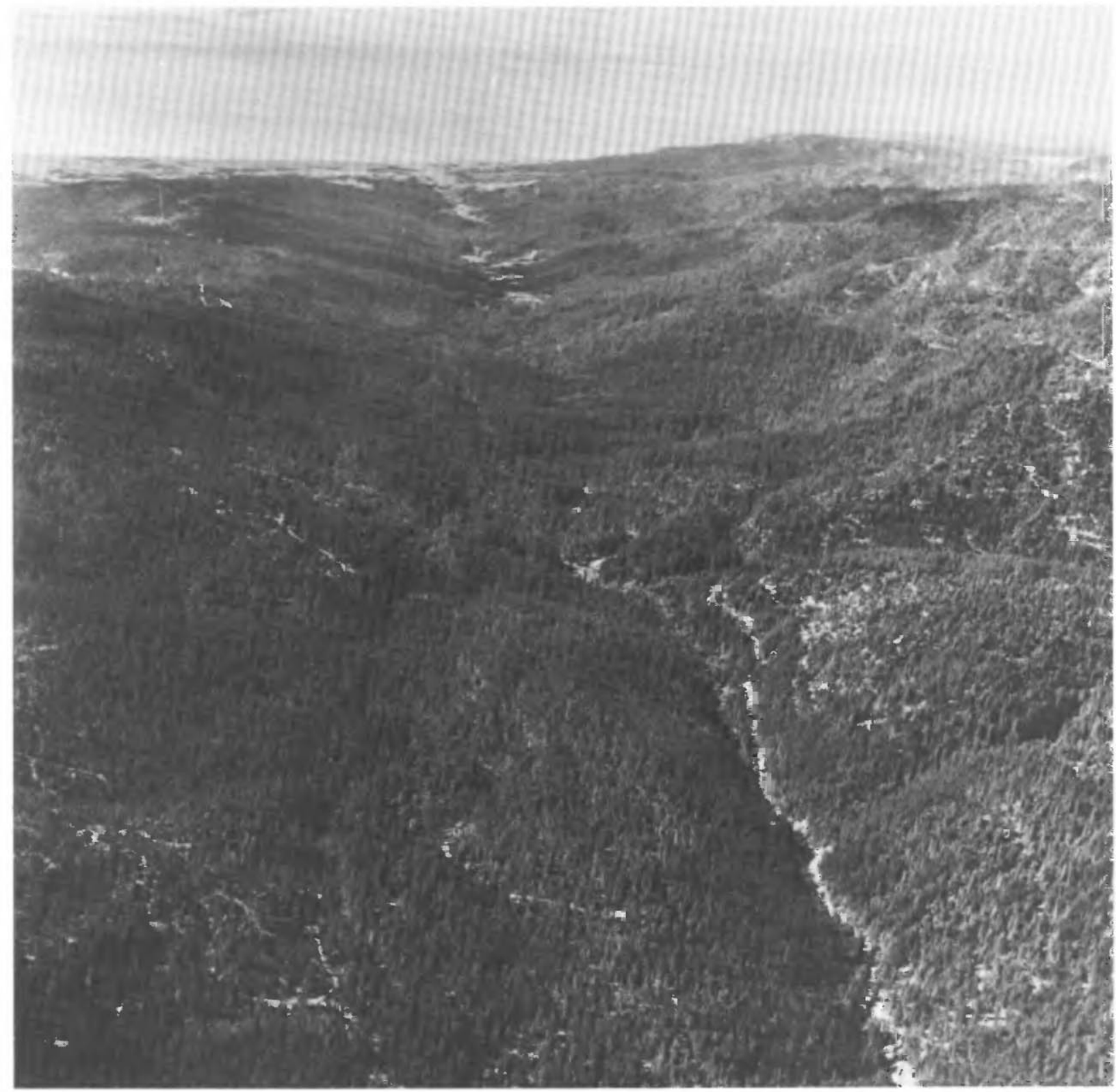

Figure 2.8. - Valley of Garcia Creek follows trace of the San Andreas fault near Point Arena. Most recently active trace lies on west (left) valley flank in foreground. View northwestward, with the Pacific Ocean in background. 


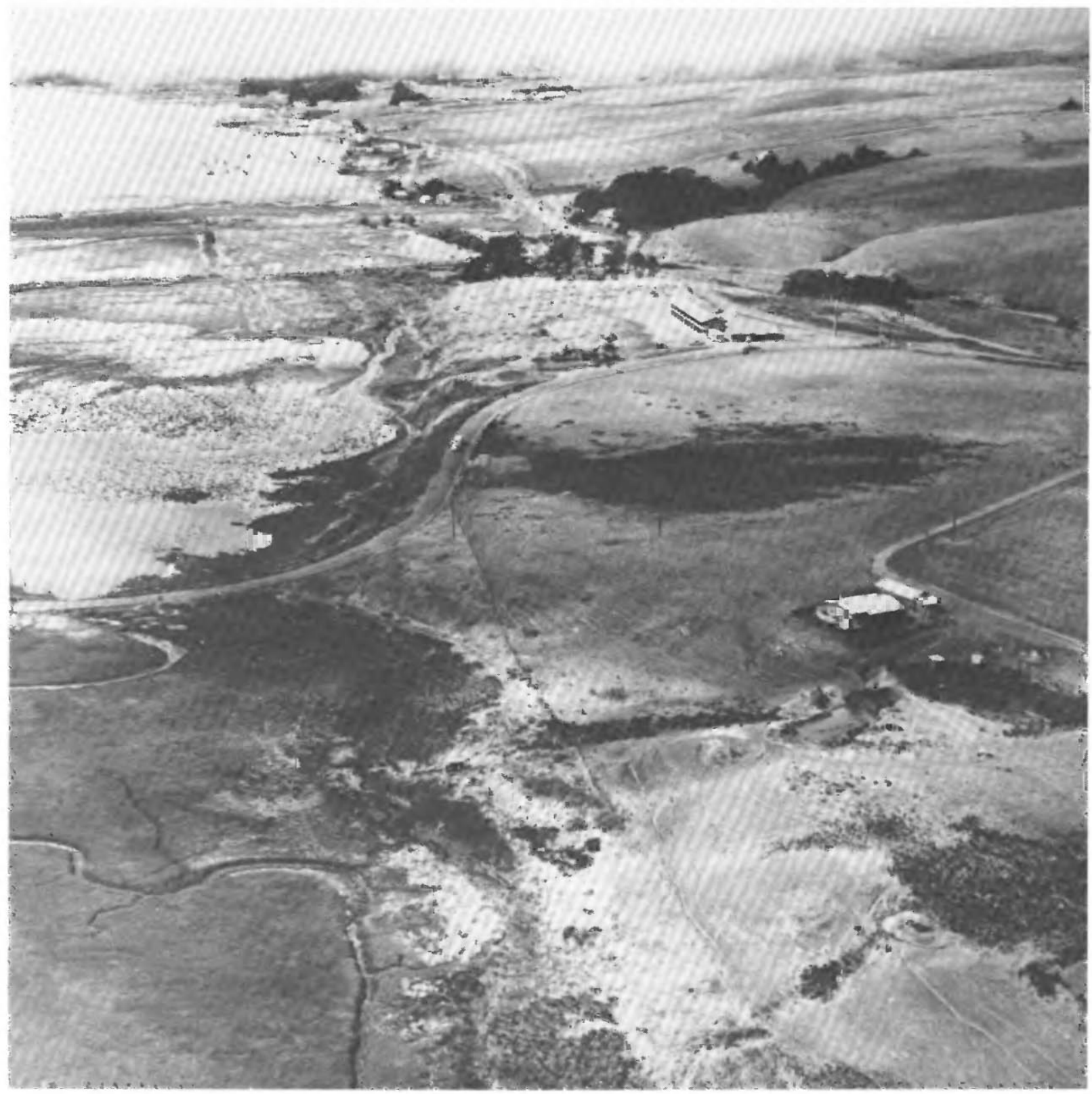

FigURE 2.9. - A scarp facing the Pacific Ocean, with marine terraces above, marks trace of the San Andreas fault at Bodega Bay, $70 \mathrm{~km}$ north of San Francisco. View northwestward. 


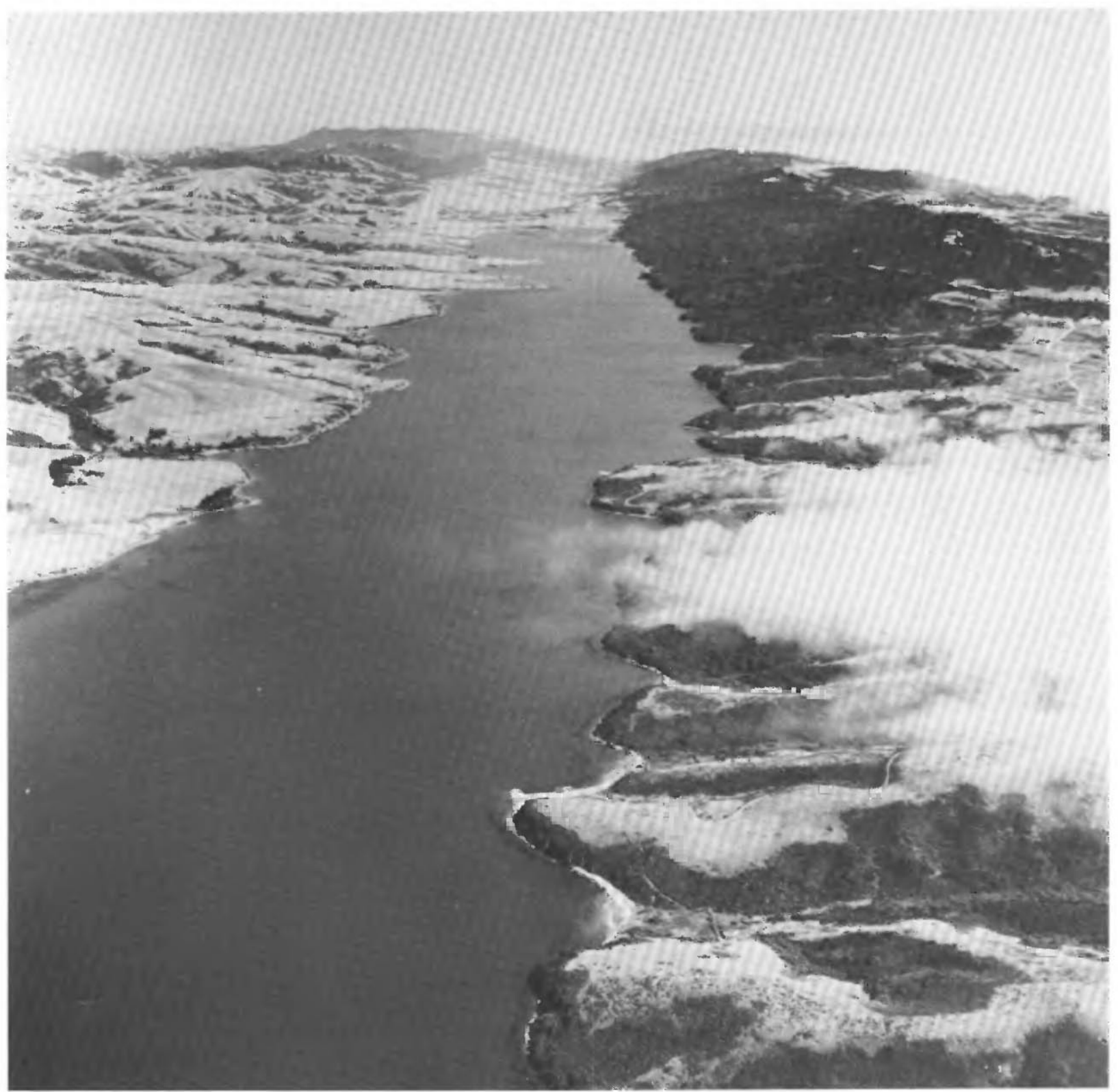

FiguRE 2.10. - Tomales Bay lies in an elongate depression along the San Andreas fault. In 1906, a maximum strike slip of $6 \mathrm{~m}$ on the fault was reported at the head of Tomales Bay, mid-distance in view; however, some of this slip may have been related to shifting of marshy sediment. The Point Reyes peninsula is to right (west); Mount Tamalpais is high-point in skyline at top left. View southeastward toward San Francisco, $55 \mathrm{~km}$ away. 


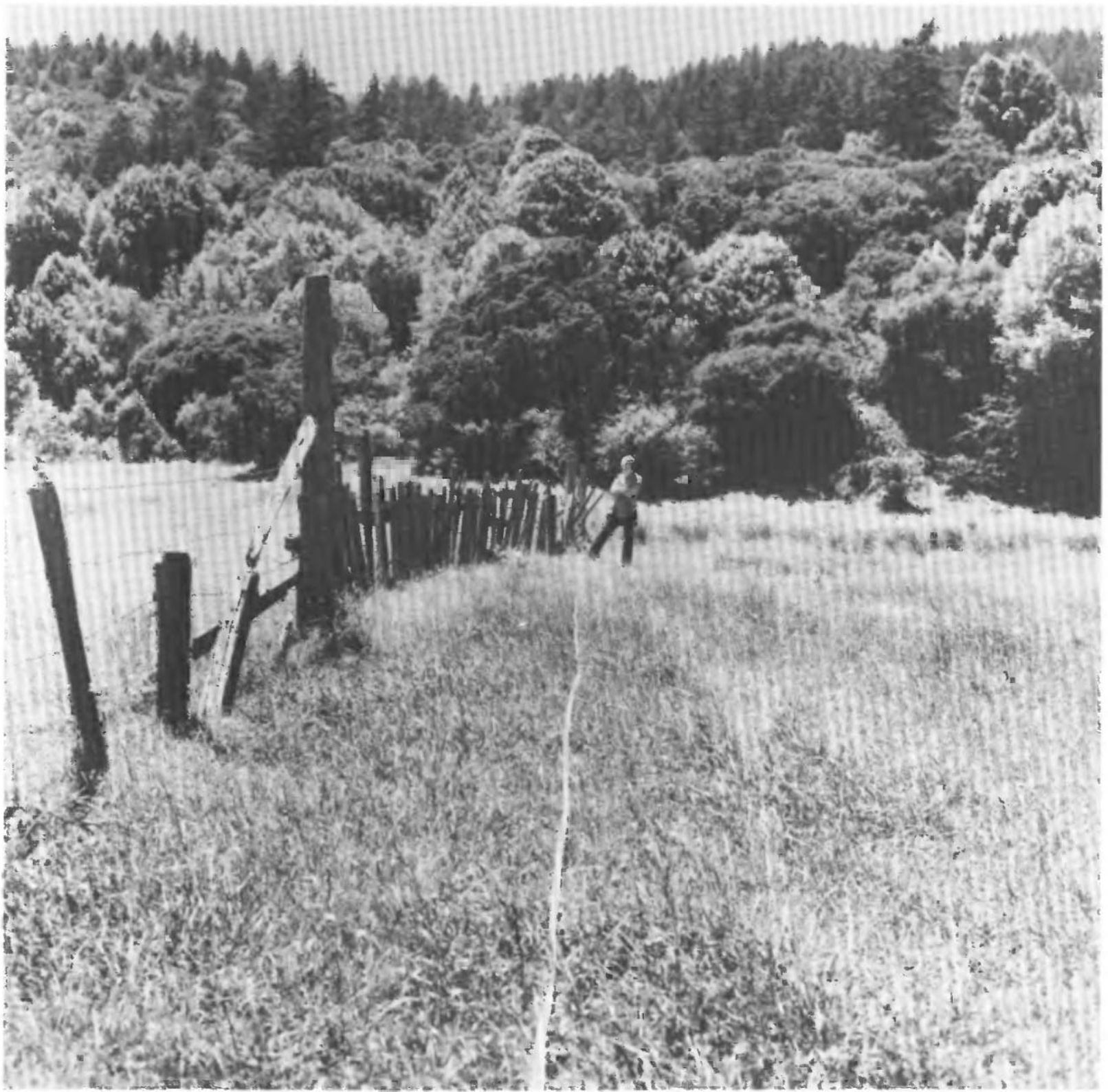

FiguRE 2.11. - A broad valley marks trace of the San Andreas fault on the Point Reyes peninsula. During the great San Francisco earthquake of 1906 , slip on one strand of the fault offset a fence about $2.5 \mathrm{~m}$. Fence beyond break (west side) is relatively straight and aligned with line of view and with tape in foreground; fence on near (east) side bows gradually to meet the fault. View southwestward along fence in southern part of the Strain Ranch (Lawson, 1908 , p. 70-71; Brown and Wolfe, 1972). 


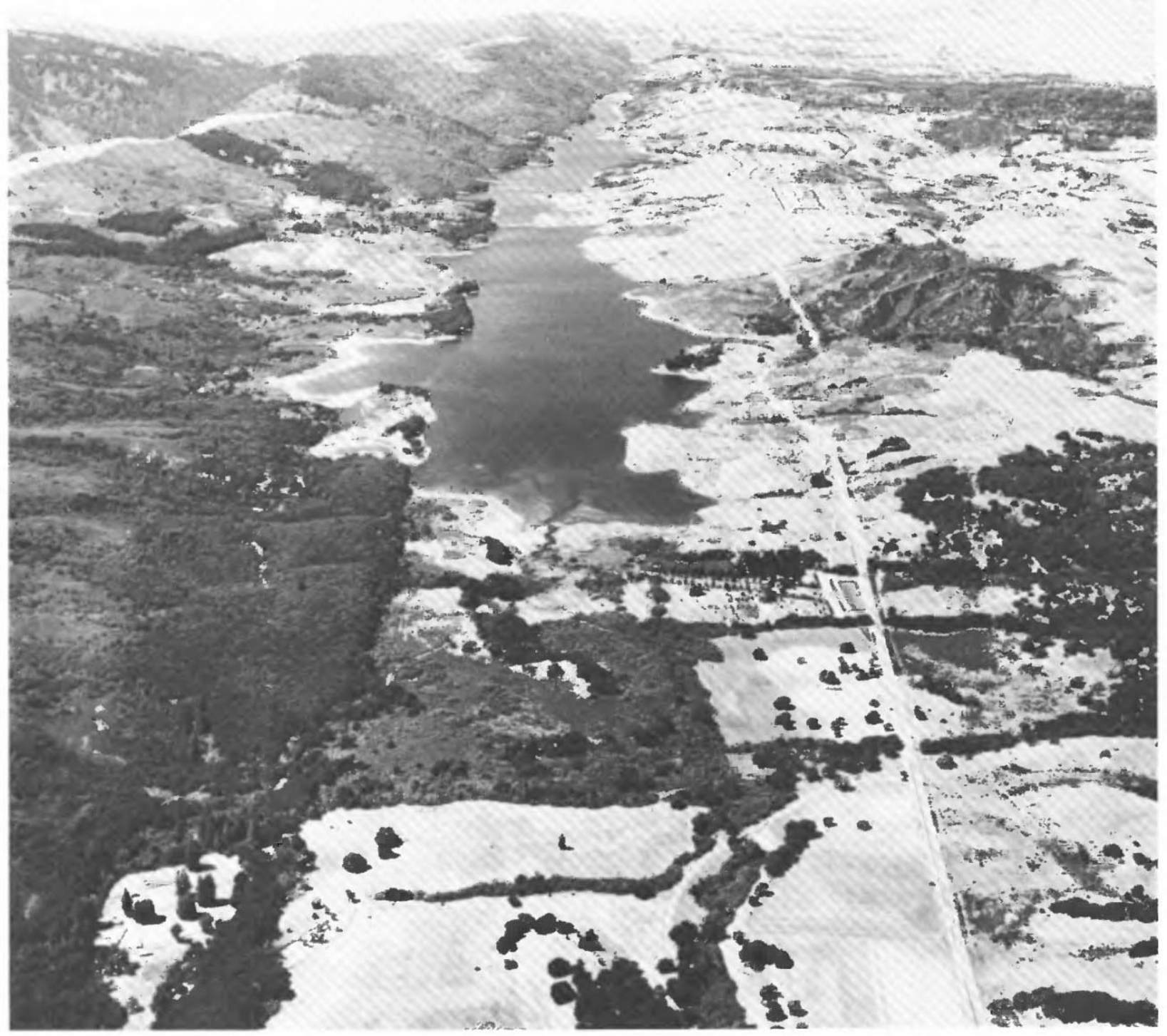

Figure 2.12. - Along the San Andreas fault zone near San Francisco. Displacement in 1906 was along linear trace on left (west) side of the Crystal Springs Reservoir (foreground). To northwest, active trace of fault bends to east side of the San Andreas Reservoir, which lies just beyond the Crystal Springs Reservoir. View northwestward. 


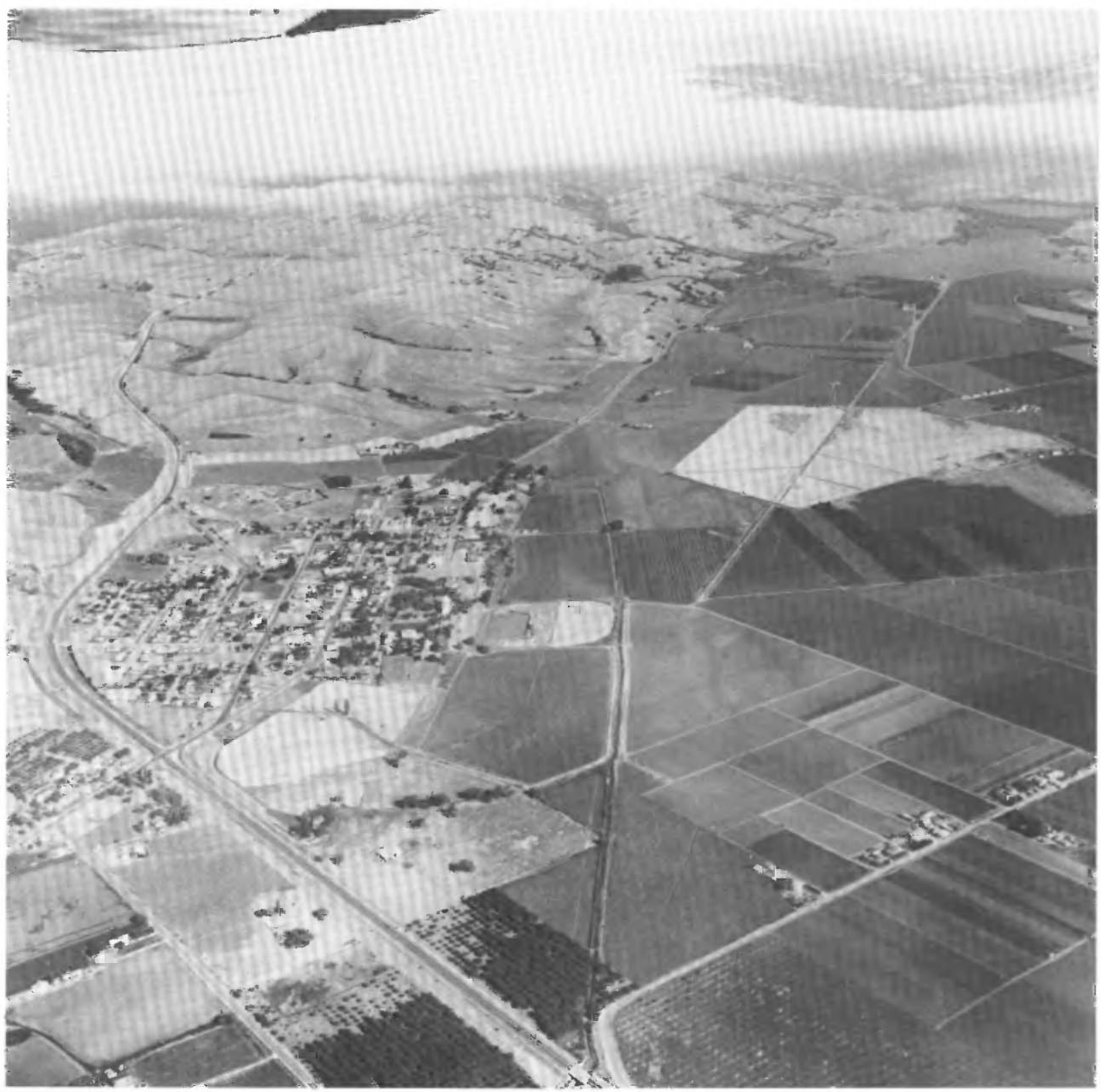

Figure 2.13. - The San Andreas fault at San Juan Bautista. In 1906, southeast end of surface rupture was just north of here. Northwest limit of creeping segment of fault is now at about the same point. Active trace of fault lies along scarp at northeast (right) edge of town, which is located on a tectonic upwarp along the fault. View northwestward. 


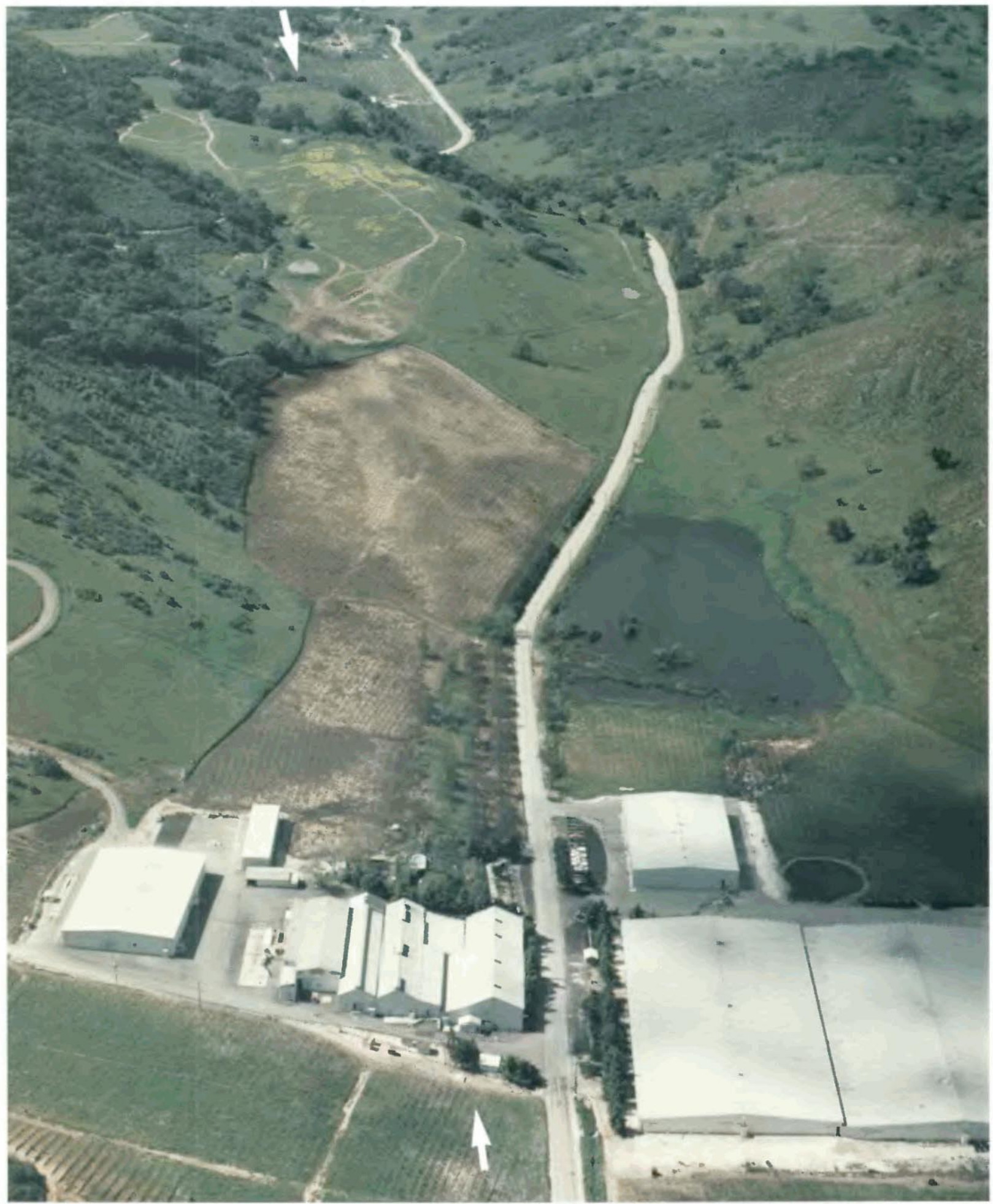

FIGURE 2.14. - Fault creep on the San Andreas fault was first reported at the Paicines Winery south of San Juan Bautista in 1960 by Steinbrugge and Zacher (1960). Fault trace (between arrows) passes under winery building, and walls of building are continually being displaced. View northwestward. 


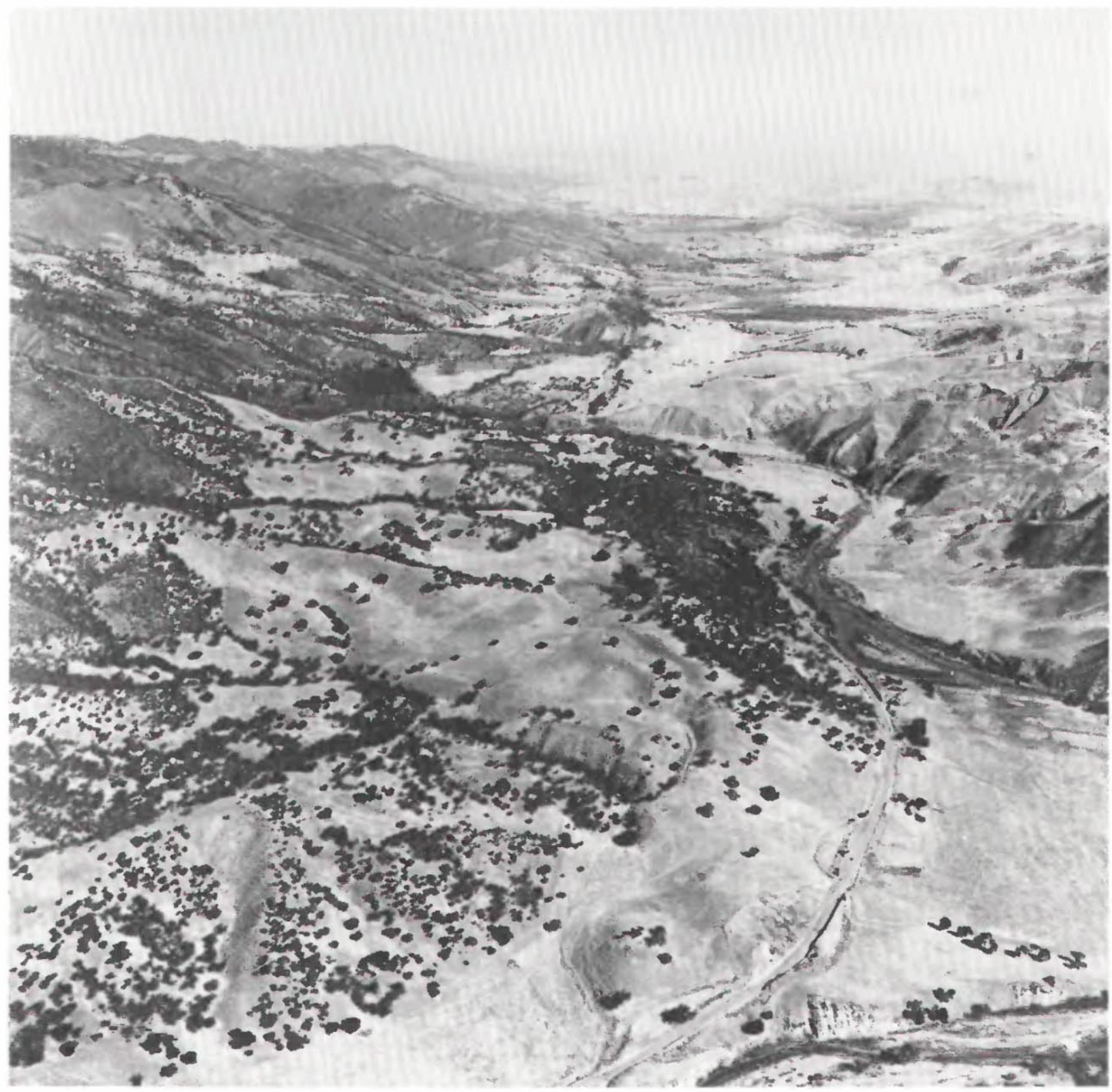

Figure 2.15. - The San Andreas fault about $40 \mathrm{~km}$ south of San Juan Bautista. Here, the Calaveras and San Andreas faults join. The Gabilan Range is on left; the San Benito River meanders across fault zone. View northwestward. 


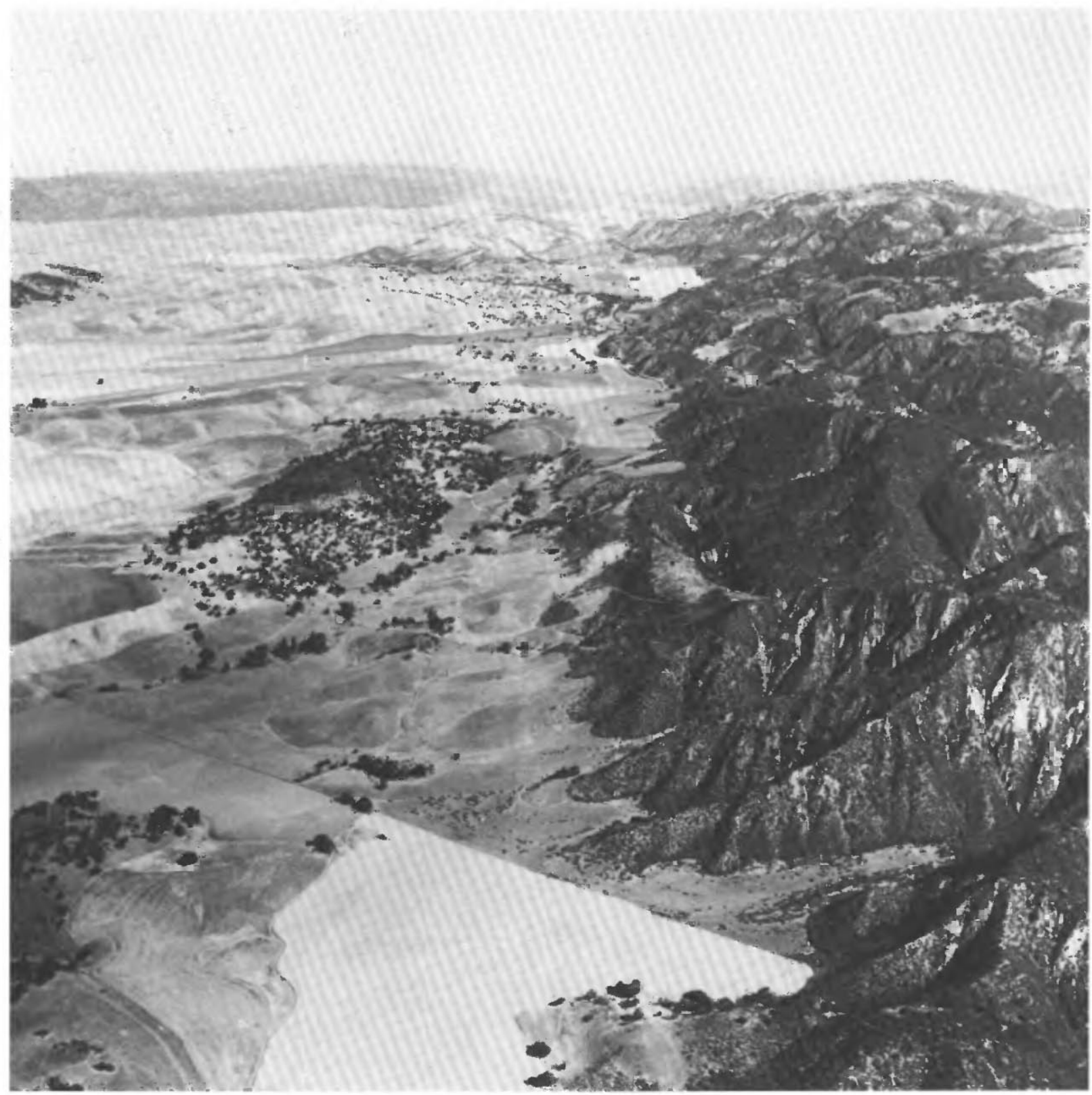

Figure 2.16. - The San Andreas fault about $70 \mathrm{~km}$ south of San Juan Bautista. The Diablo Range is on right (east); the Gabilan Range, displaying a broad, arched upland surface, is on skyline at upper left. View northwestward. 


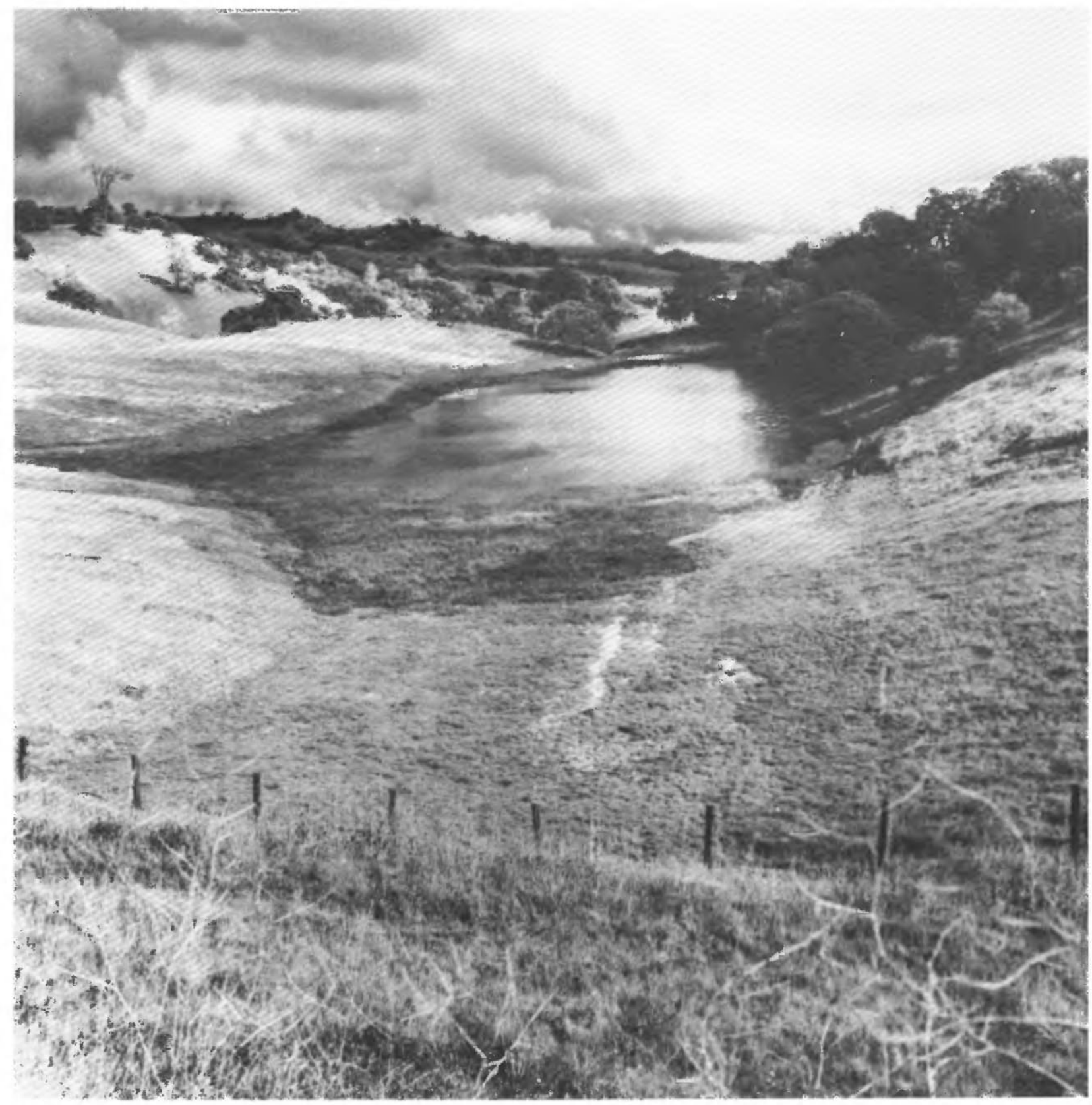

FIGURE 2.17. - From 65 to $80 \mathrm{~km}$ northwest of Cholame, trace of the San Andreas fault follows crest of a ridge. Fault trace is marked by a series of sag ponds, in seemingly anomalous position near crest of a major elongate topographic high. View southeastward from California Highway 198. 


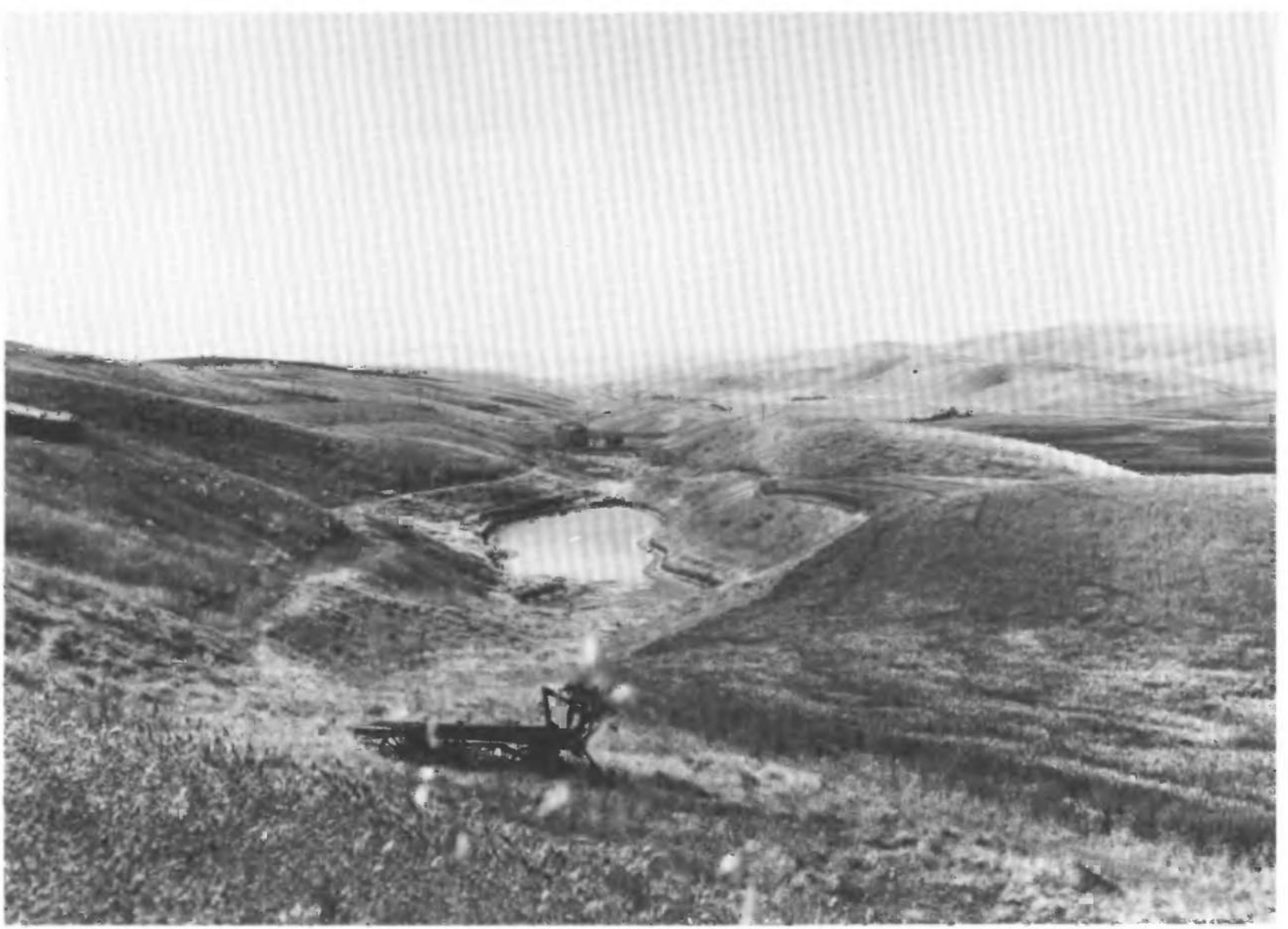

Figure 2.18. - Trace of the San Andreas fault in the Palo Prieta Pass, about $13 \mathrm{~km}$ southeast of Cholame. A sag pond is in foreground. View southeastward. 


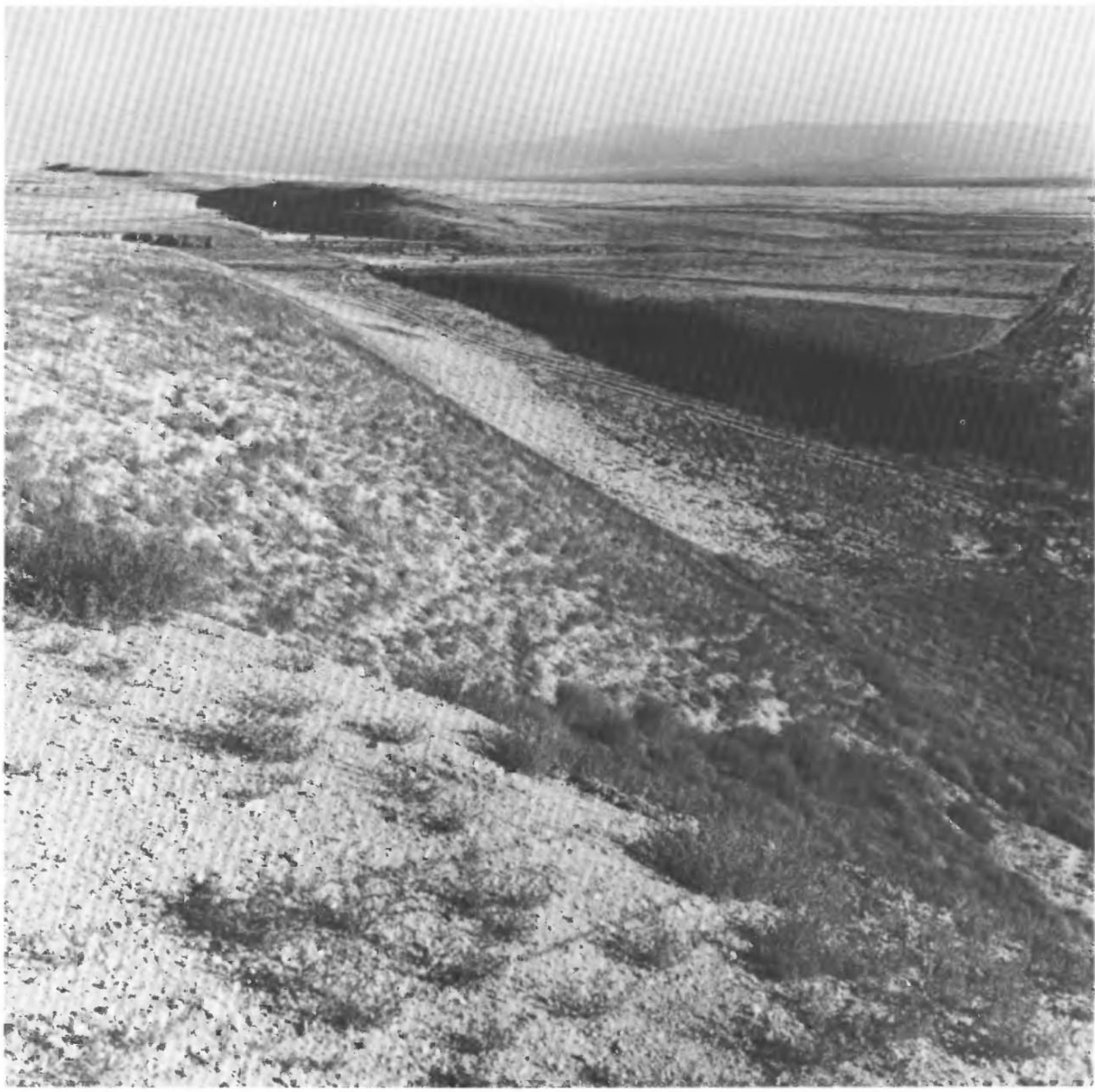

Figure 2.19. - A graben locally marks trace of the San Andreas fault near north end of the Carrizo Plain. The Caliente Range is on horizon in upper right. View southeastward. 

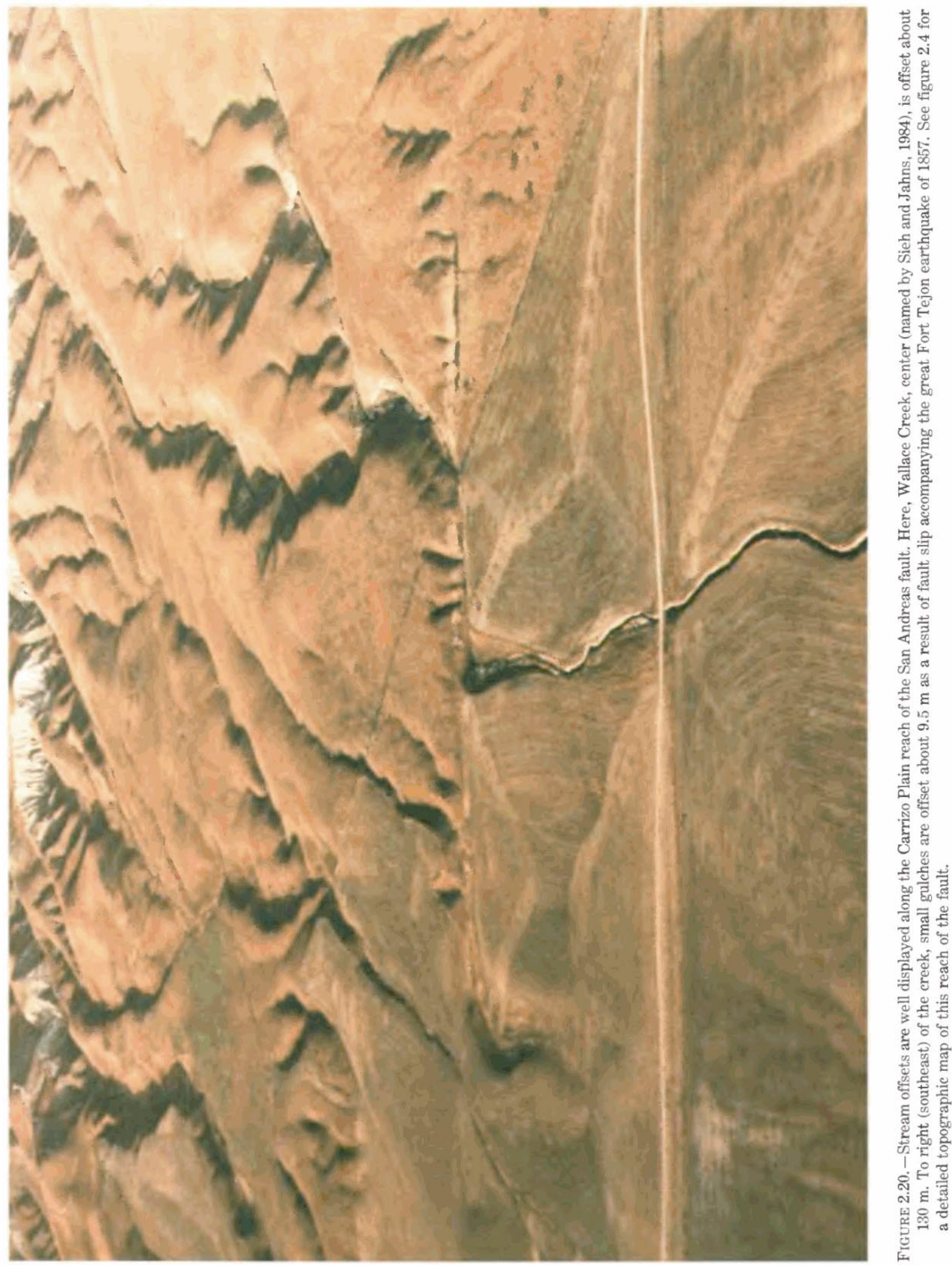


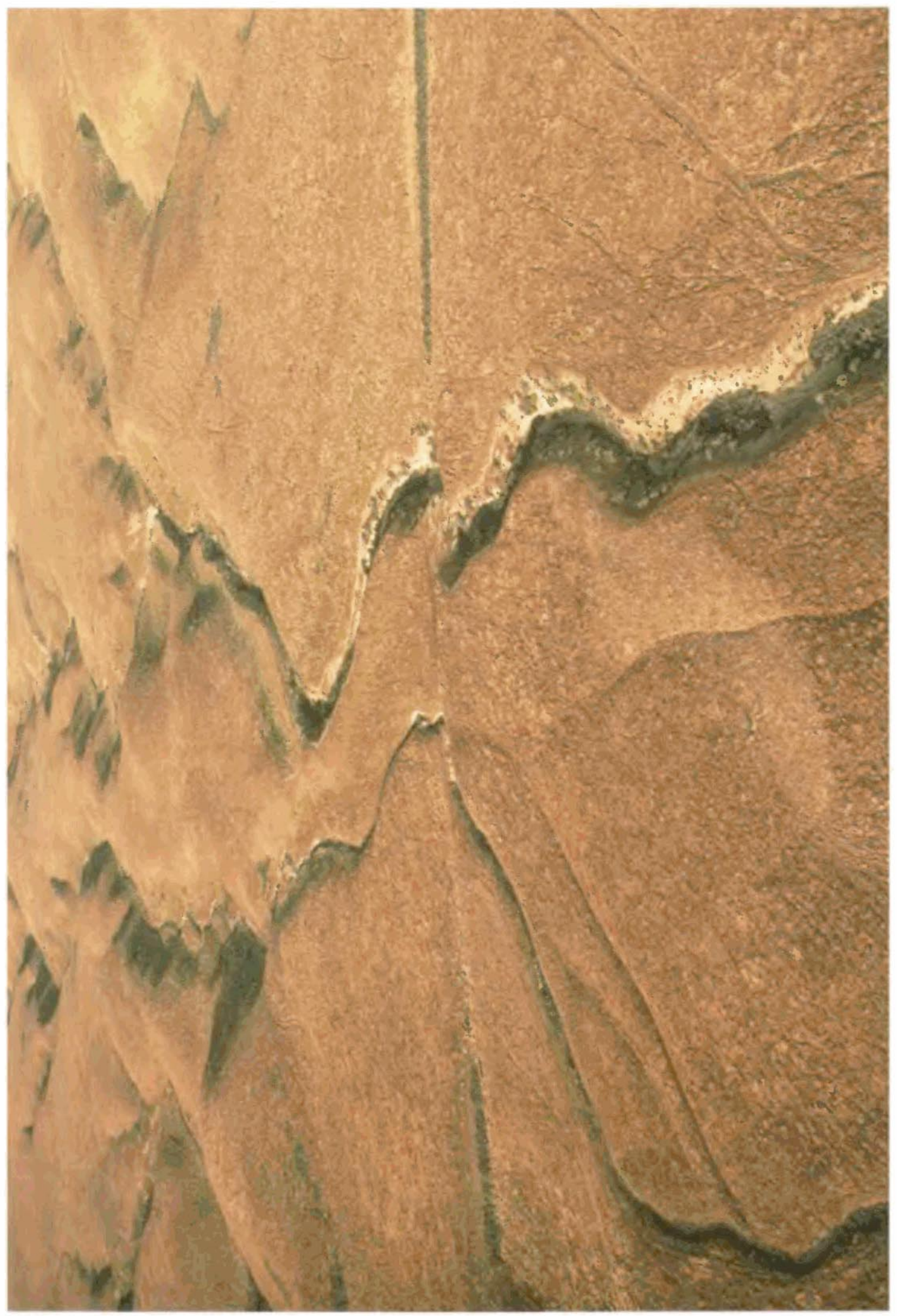




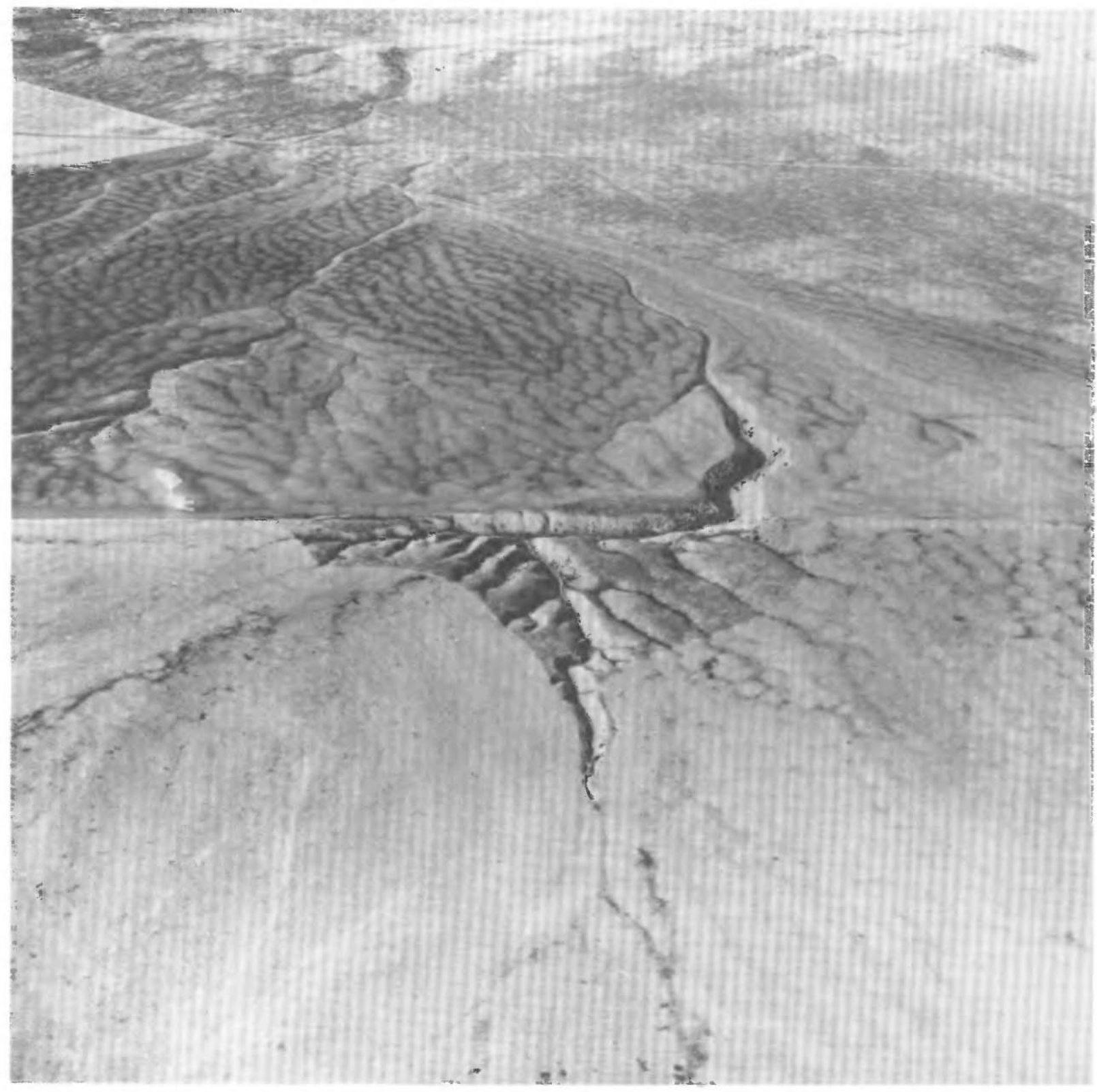

FIGURE 2.22. - Stream channel offset by the San Andreas fault. Southwest (far) side is raised along a fault sliver, which tends to preserve incised position of stream. Mound topography is believed to be ancient modified ground-squirrel burrows. View southwestward toward the Carrizo Plain. 


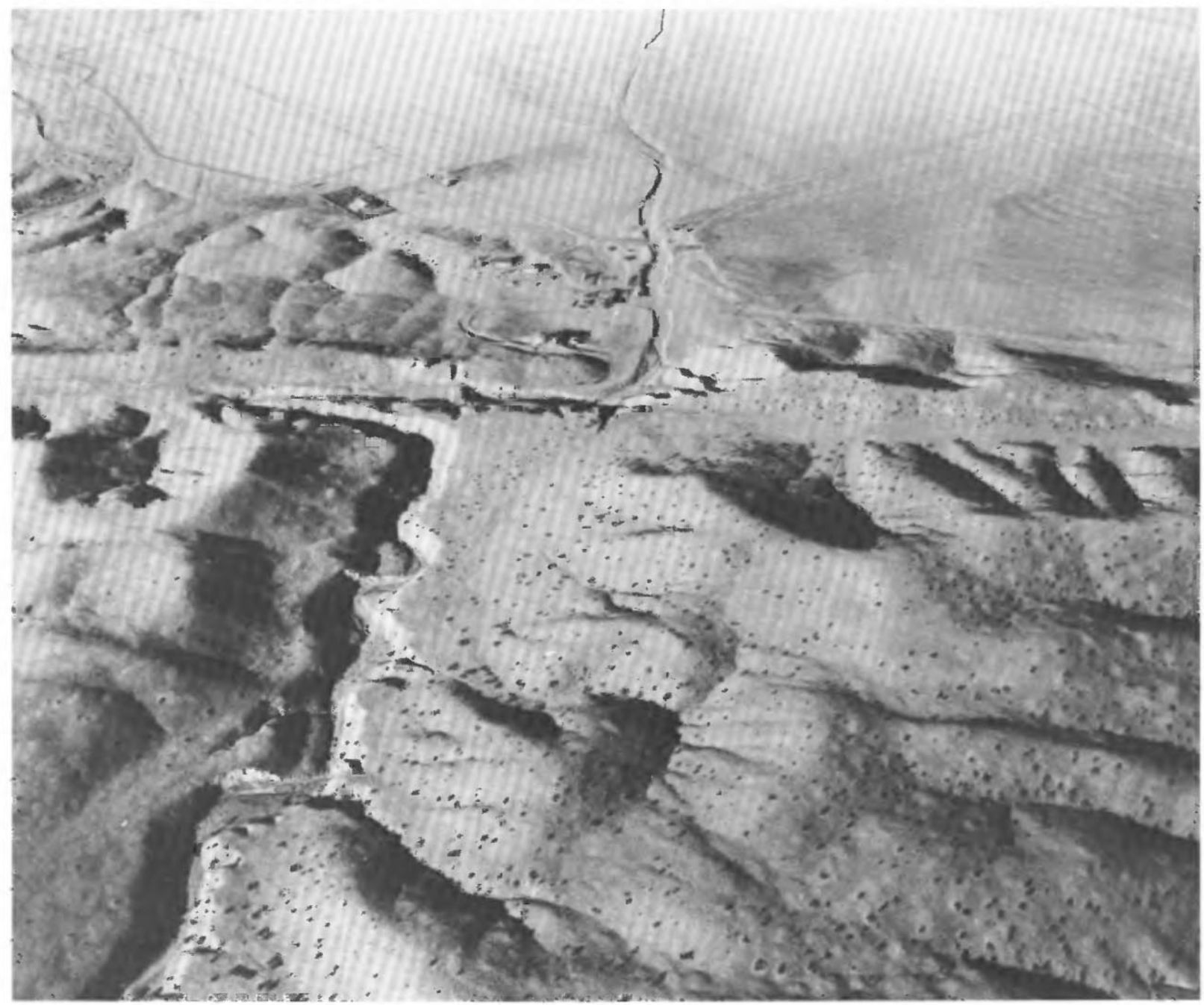

FIGURE 2.23. - A sigmoidal pattern of stream channel results from right-lateral offset, followed by stream capture producing left deflection, followed by further right-lateral offset. Fault extends from right to left; stream flows from bottom to top. View southwestward toward the Carrizo Plain. 


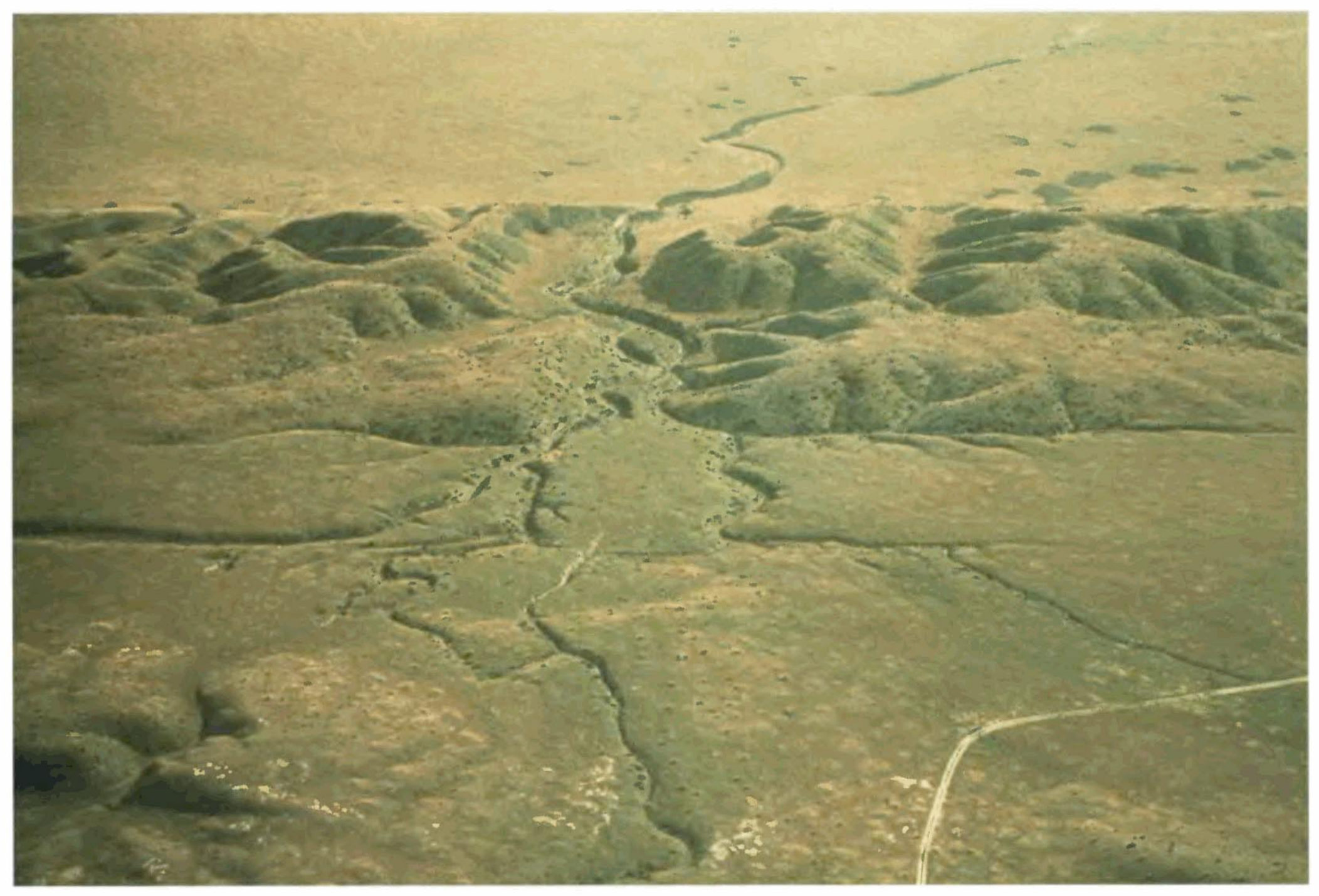

FIGURE 2.24. - Multiple fault strands are common along the San Andreas fault. Four parallel strands are reflected geomorphically here in the Carrizo Plain area. Nearest, most recently active strand (latest displacement in 1857) displays deflection of streams both to right and left. Although right-lateral slip causes displacement, either stream capture, surface warping, or uplift of downstream side can deflect drainage to either right or left. View southwestward. 


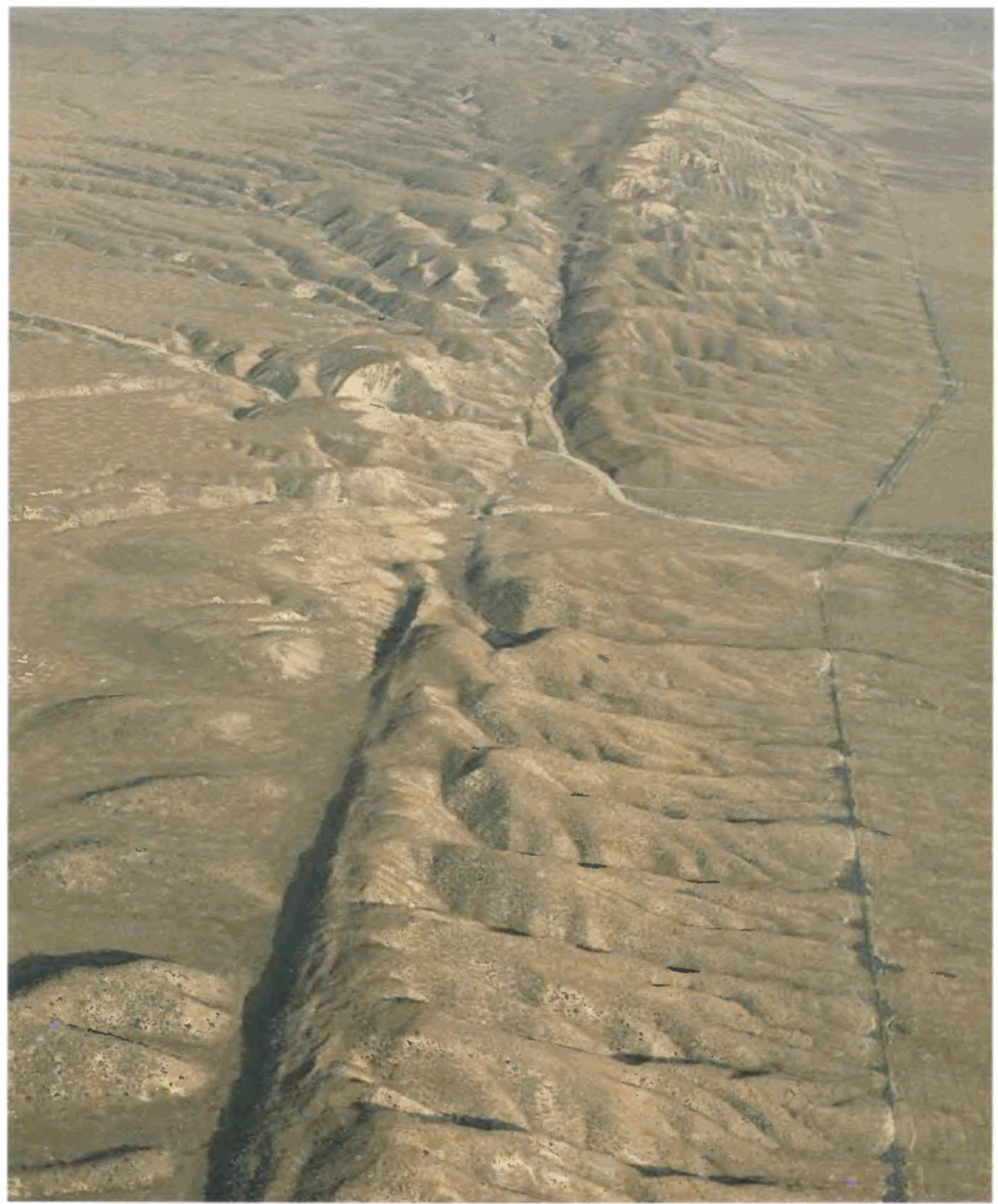

FiguRE 2.25. - Linear scar marks trace of the San Andreas fault in the Carrizo Plain area. Large stream entering fault zone from left has been displaced by movement on fault to debouch on right (southwest) side into the Carrizo Plain, thus displaying right-lateral slip. View southeastward. 


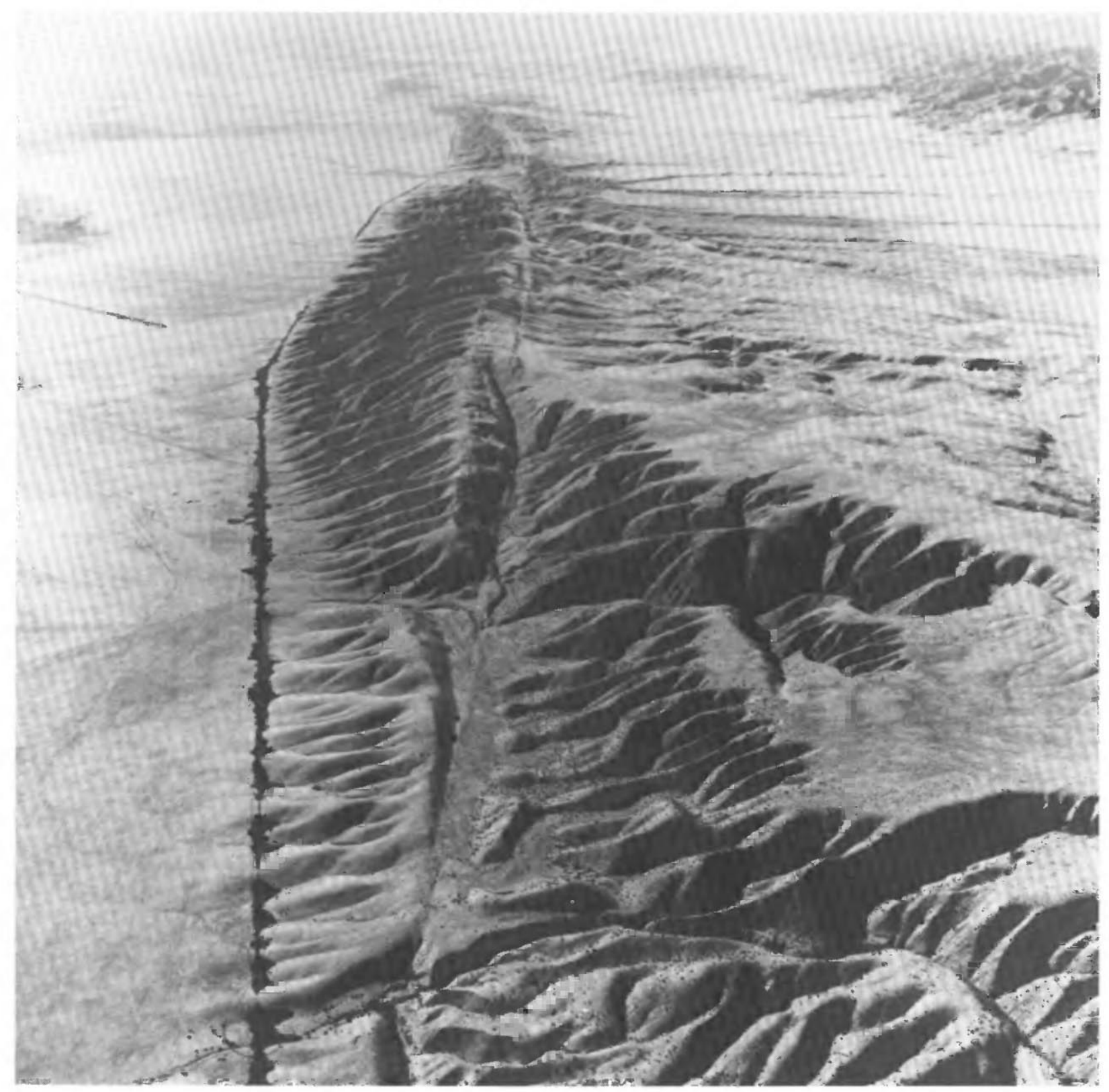

FigurE 2.26. - The San Andreas fault on east edge of the Carrizo Plain. Rugged, dissected terrain west (left) of fault trace is the Elkhorn scarp. The Elkhorn Plain is to right in distance (see Vedder and Wallace, 1970). 


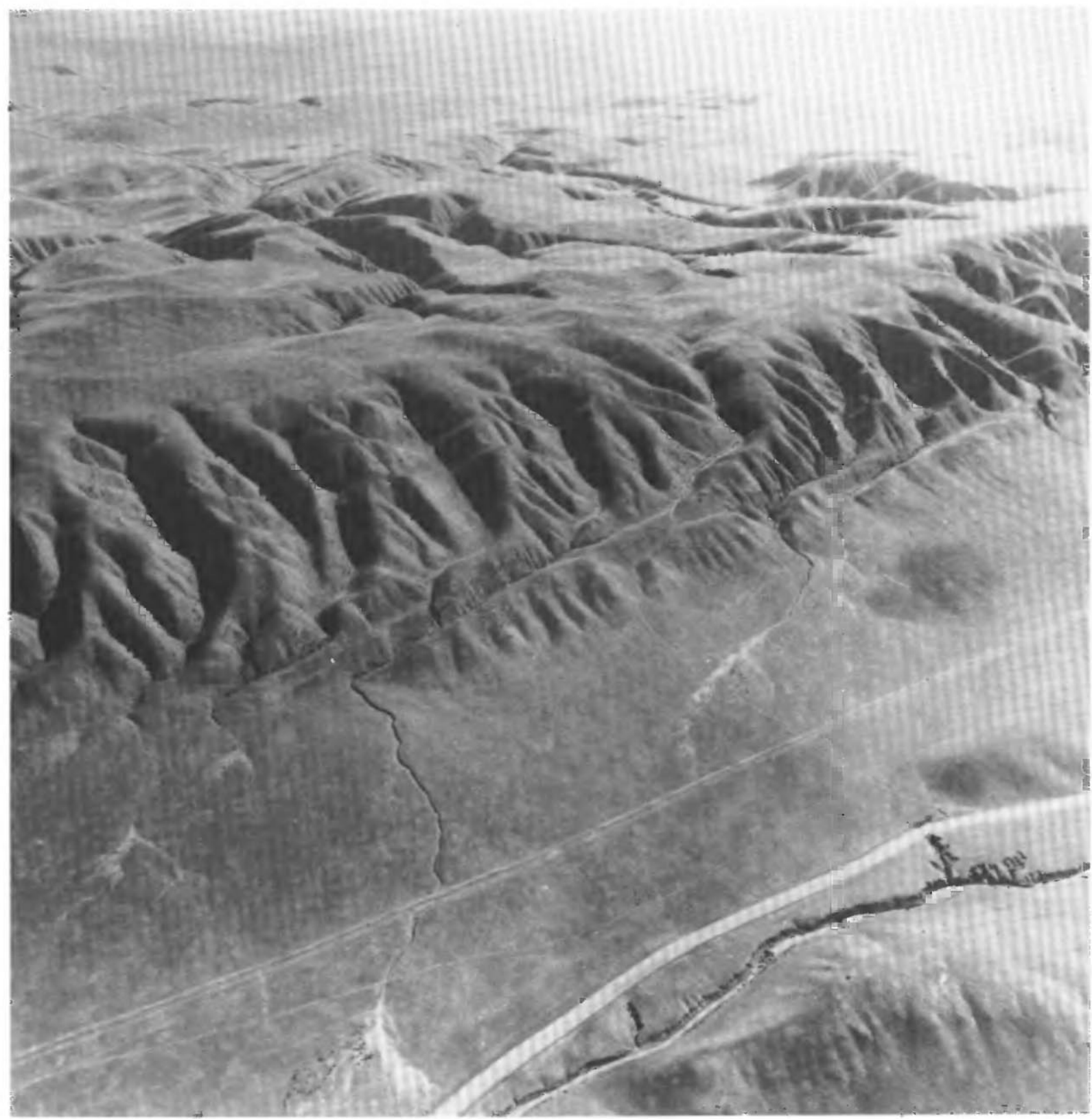

FIGURE 2.27.-A complex expression of the San Andreas fault forms west flank of the Elkhorn Hills. Upwarping of hills, in combination with echelon fractures along the San Andreas fault zone, helped control drainage. View southeastward. 


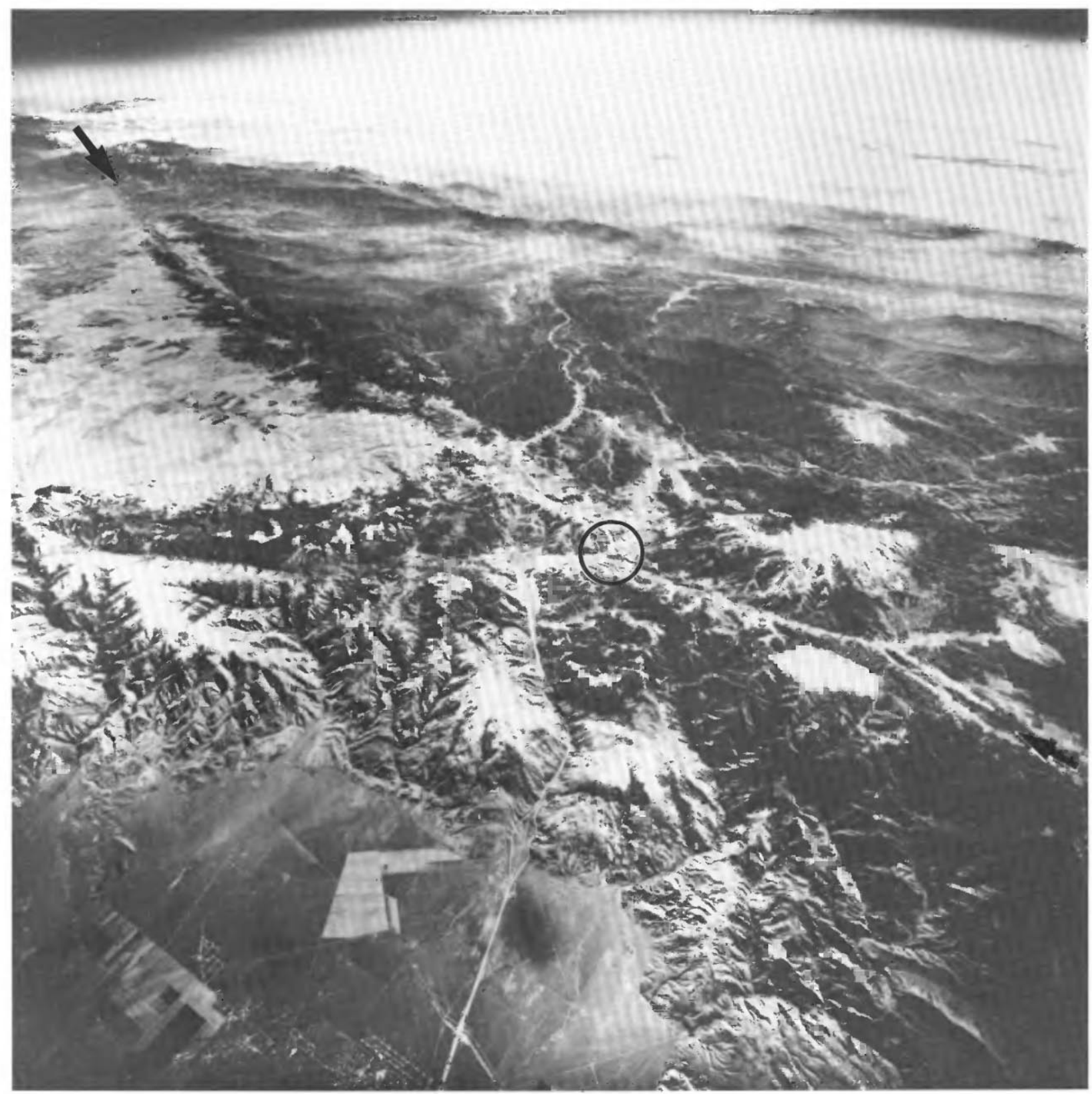

Figure 2.28. - In the Big Bend region of the San Andreas fault, the Garlock fault, which has left-lateral slip, branches eastward. Junction of these two great faults is near center (circle); trace of the Garlock fault extends to left (east), and that of the San Andreas fault (between arrows) extends east-southeastward from lower right to upper left corner of photograph. Light-colored mountain just west of fault junction is Fraser Mountain, an isolated thrust block placed there by compression across the Big Bend. U.S. Air Force photograph, taken November 27, 1967. 


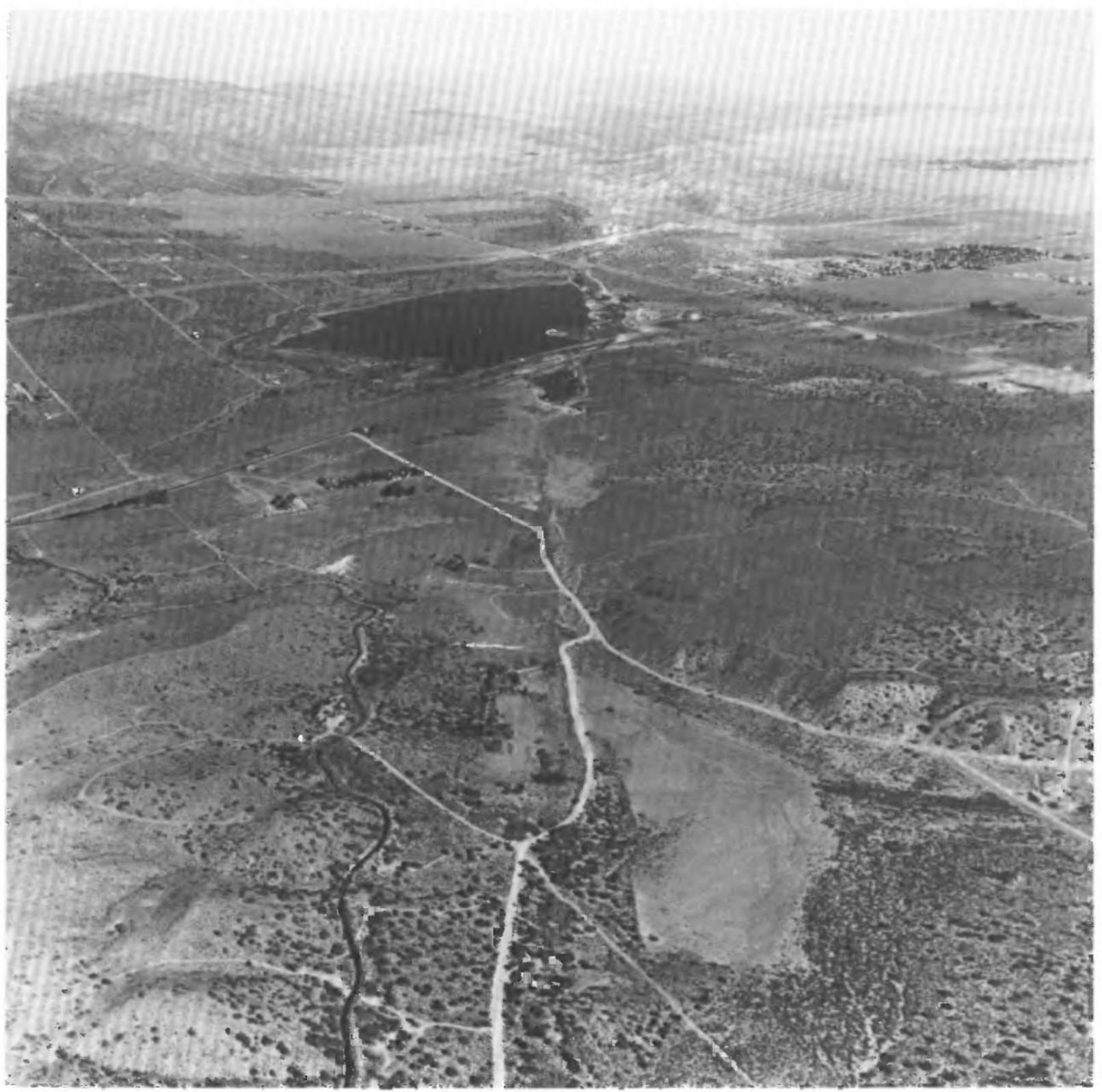

FiguRE 2.29. - The Palmdale Reservoir lies along the San Andreas fault north of the San Gabriel Mountains. The Mojave Desert is to northeast (right), and a series of ridges lies between the fault and the desert basin. View northwestward. 


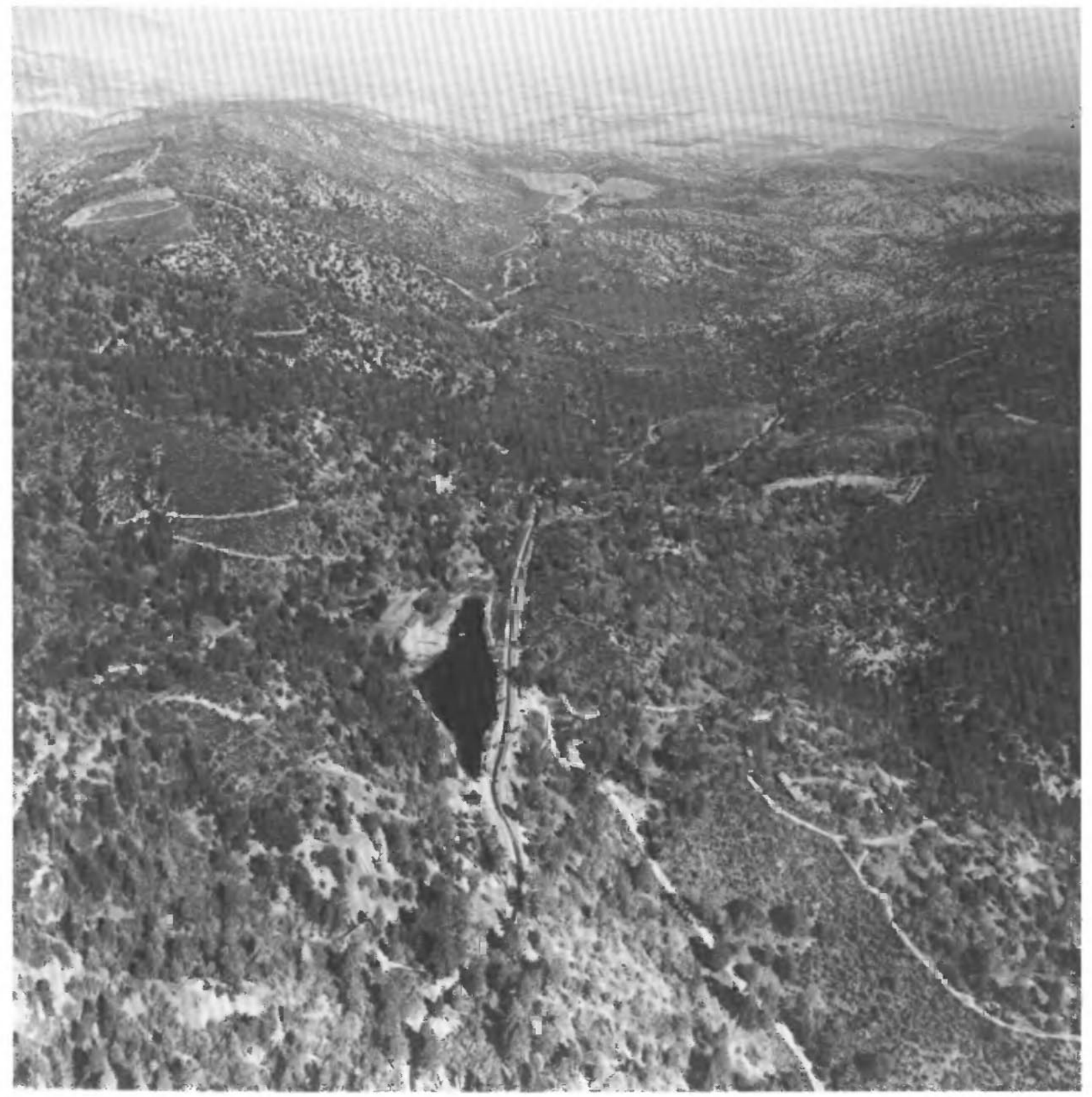

FigURE 2.30. - The San Andreas fault on northeast flank of the San Gabriel Mountains. View northwestward from Jackson Lake (foreground) toward Palmdale. 


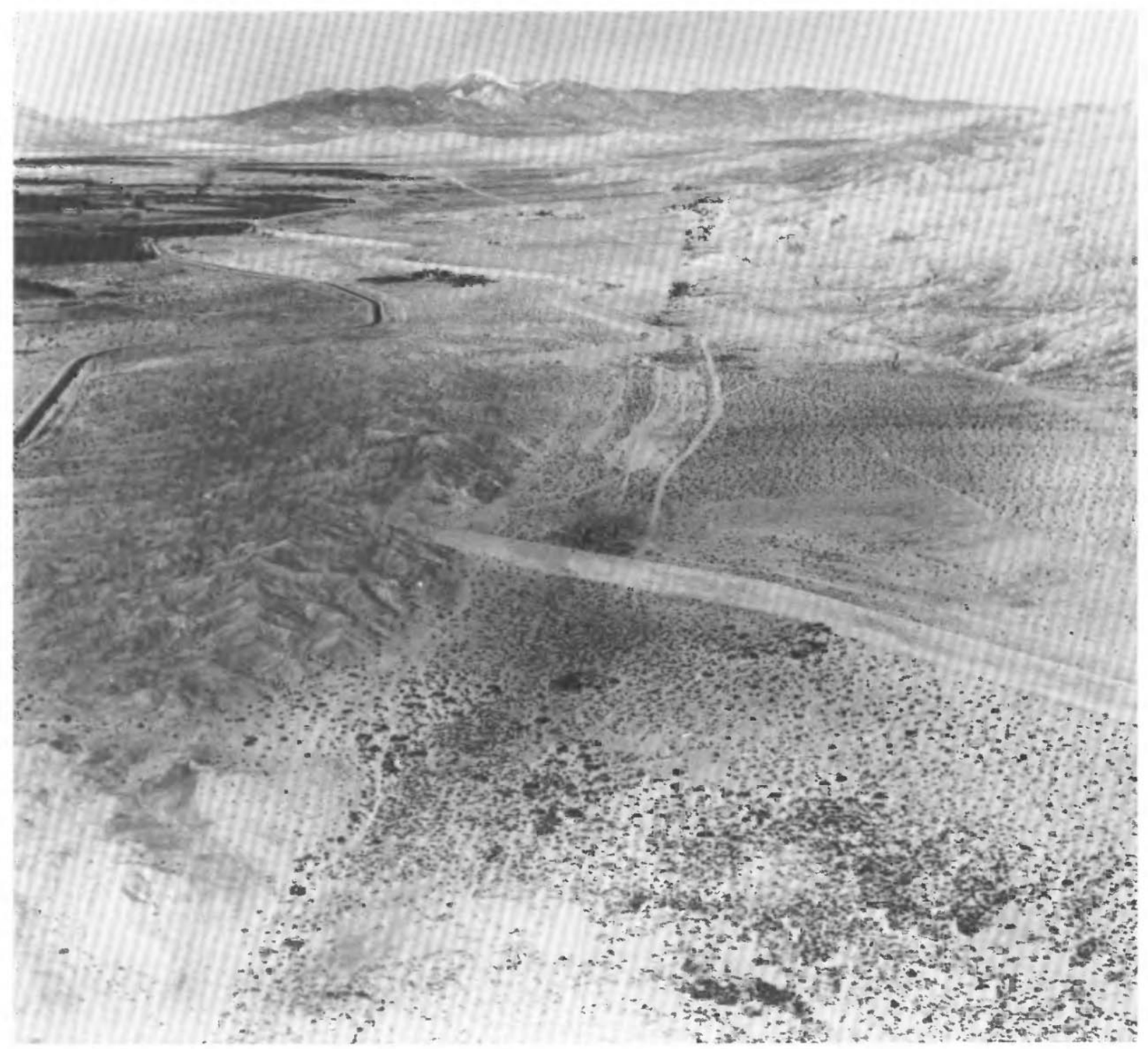

FIGURE 2.31. - Northern branch of the San Andreas fault in northern Coachella Valley. The San Gorgonio Pass is at left horizon, and the San Bernardino Mountains are at center of horizon. View northwestward. 


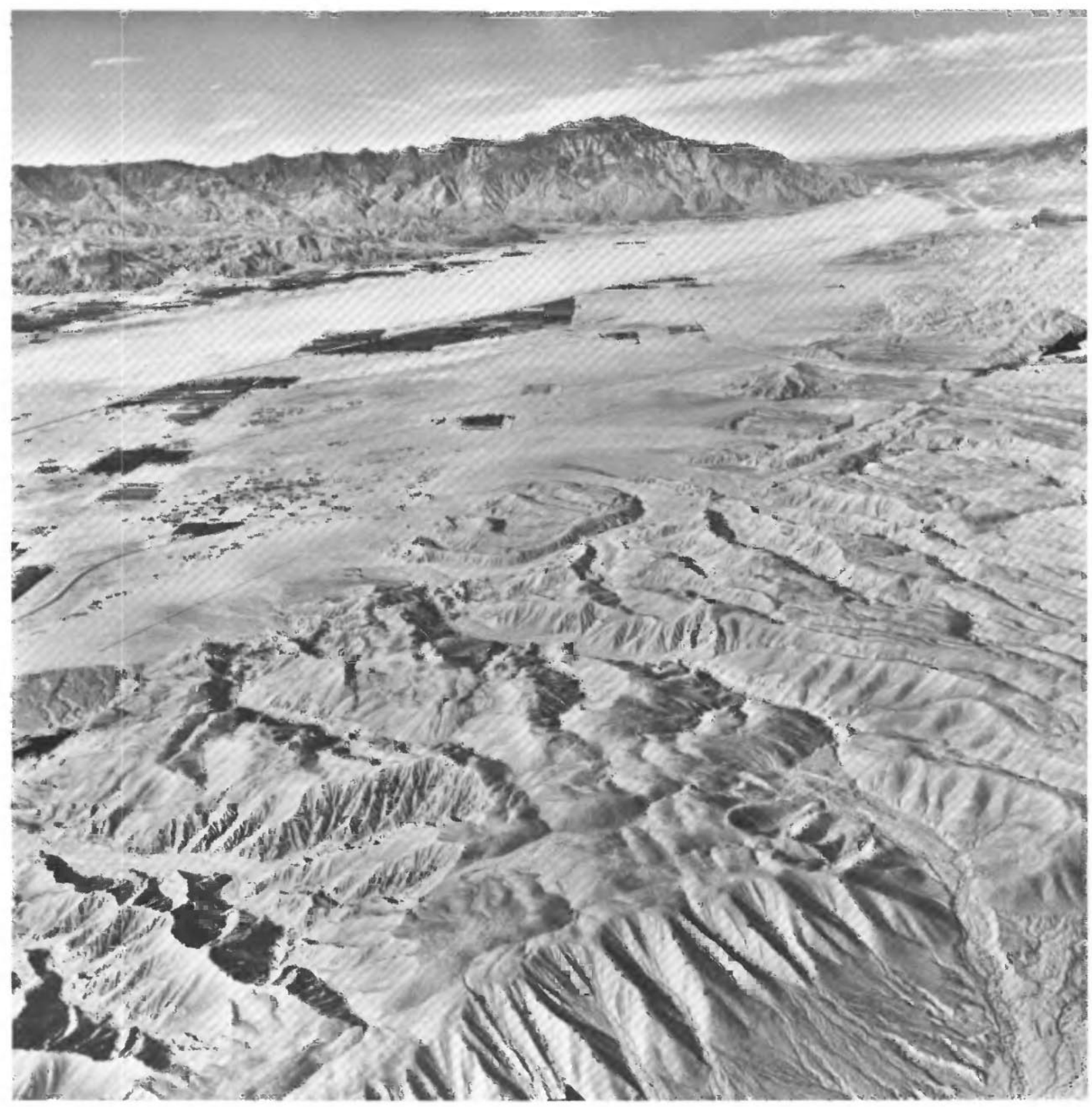

FIGURE 2.32.-The San Andreas fault (between arrows) in northern Coachella Valley, disrupts drainage, offsetting and beheading many channels. Mount San Jacinto is in center distance; the San Gorgonio Pass, a fault-controlled pass, is at right in the distance. View westward; U.S. Geological Survey photograph, taken November 15, 1956. 


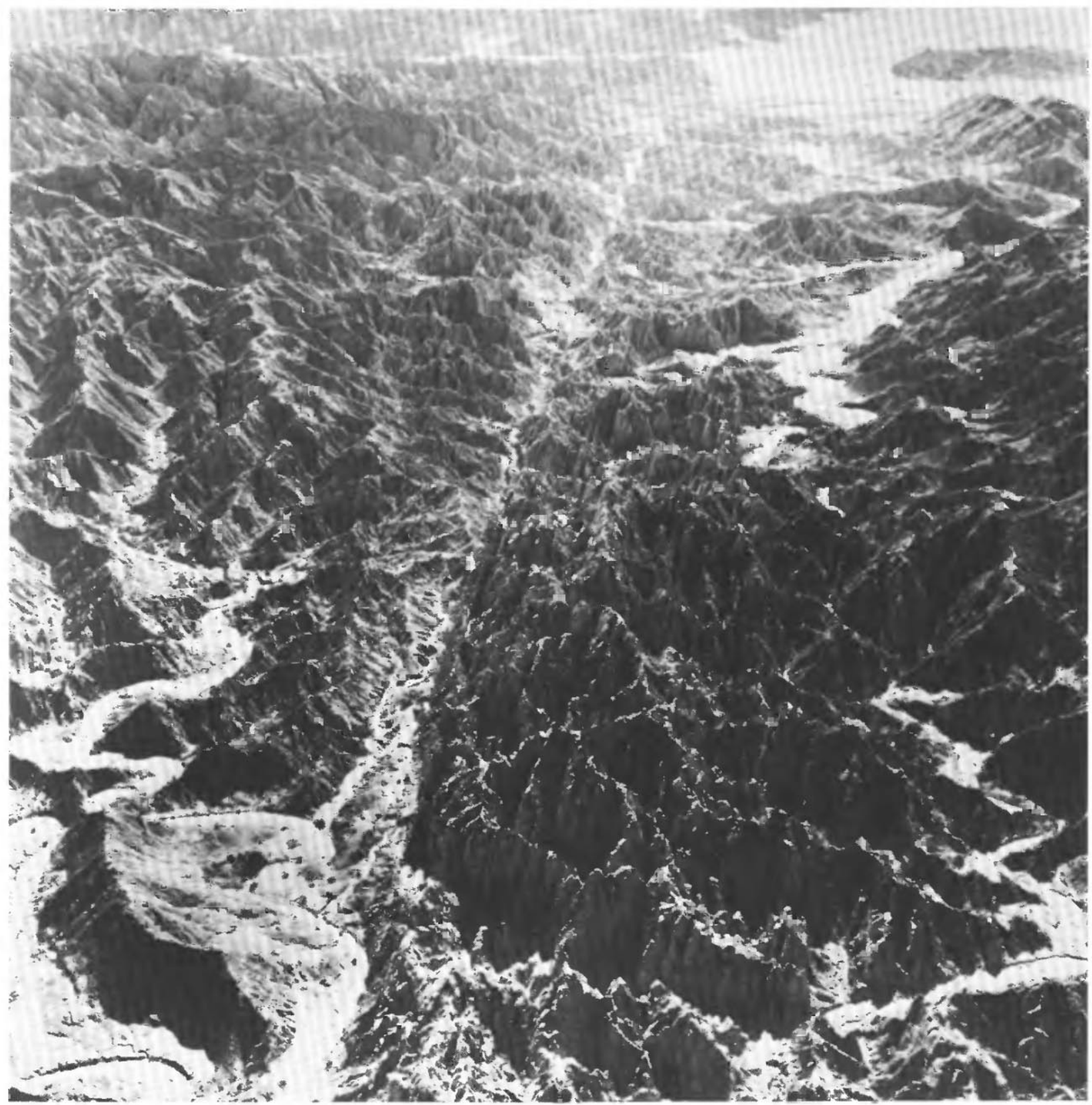

FigURE 2.33. - The San Andreas fault in badlands of the Mecca Hills, Coachella Valley. Sympathetic slip of as much as $1+\mathrm{cm}$ occurred here during the Borrego Mountain and Imperial Valley earthquakes of 1968 and 1979, respectively. 


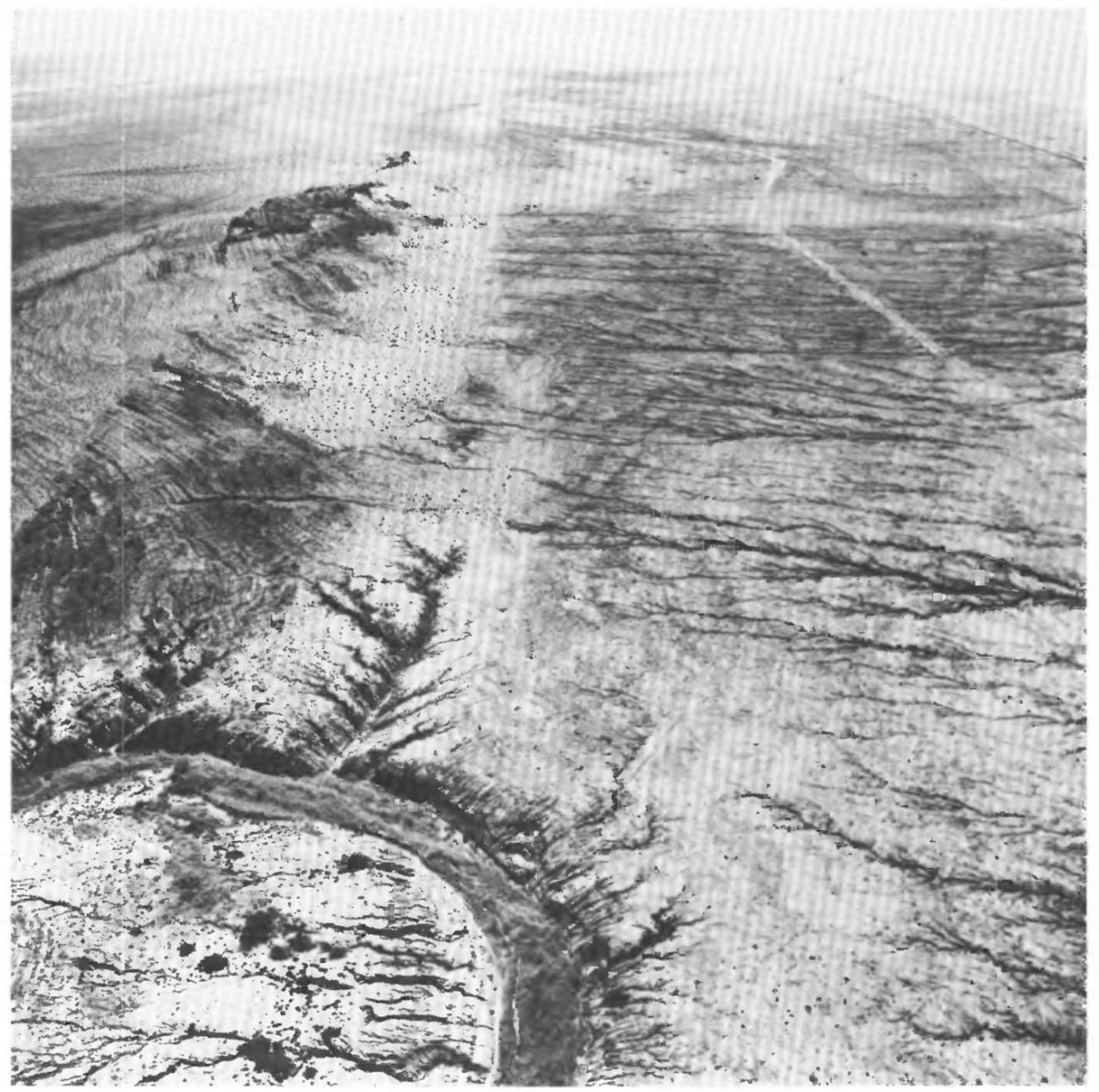

Figure 2.34. - The San Andreas fault near the Salton Sea, Imperial Valley. Salt Creek is in foreground; Bat Cave Buttes are dark hills at left, and the Salton Sea is in distance. View southeastward. 


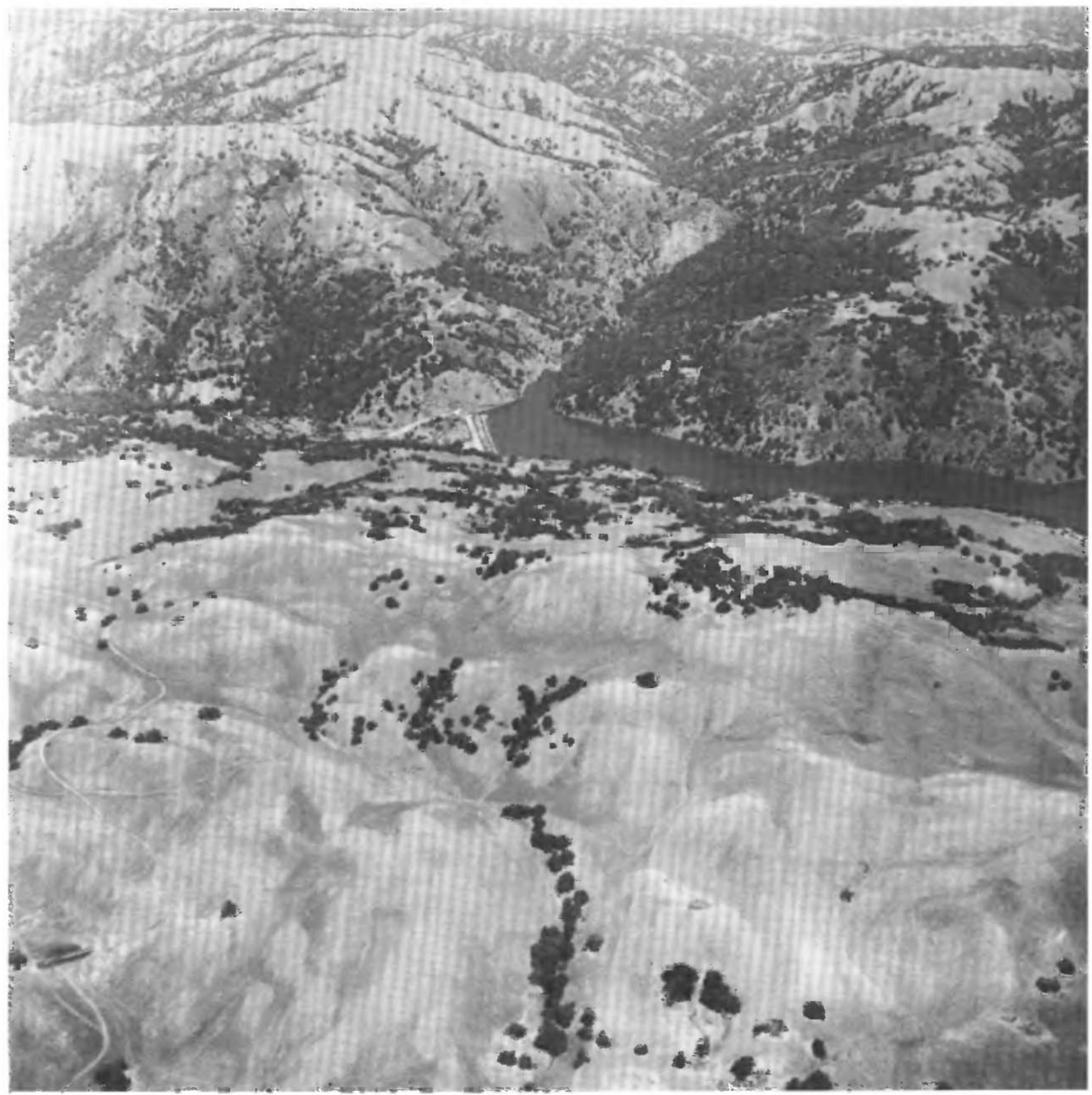

FIGURE 2.35. - The Coyote Lake Reservoir lies in a topographic trough along the Calaveras fault a few kilometers east of Morgan Hill, Calif. View eastward across fault. 


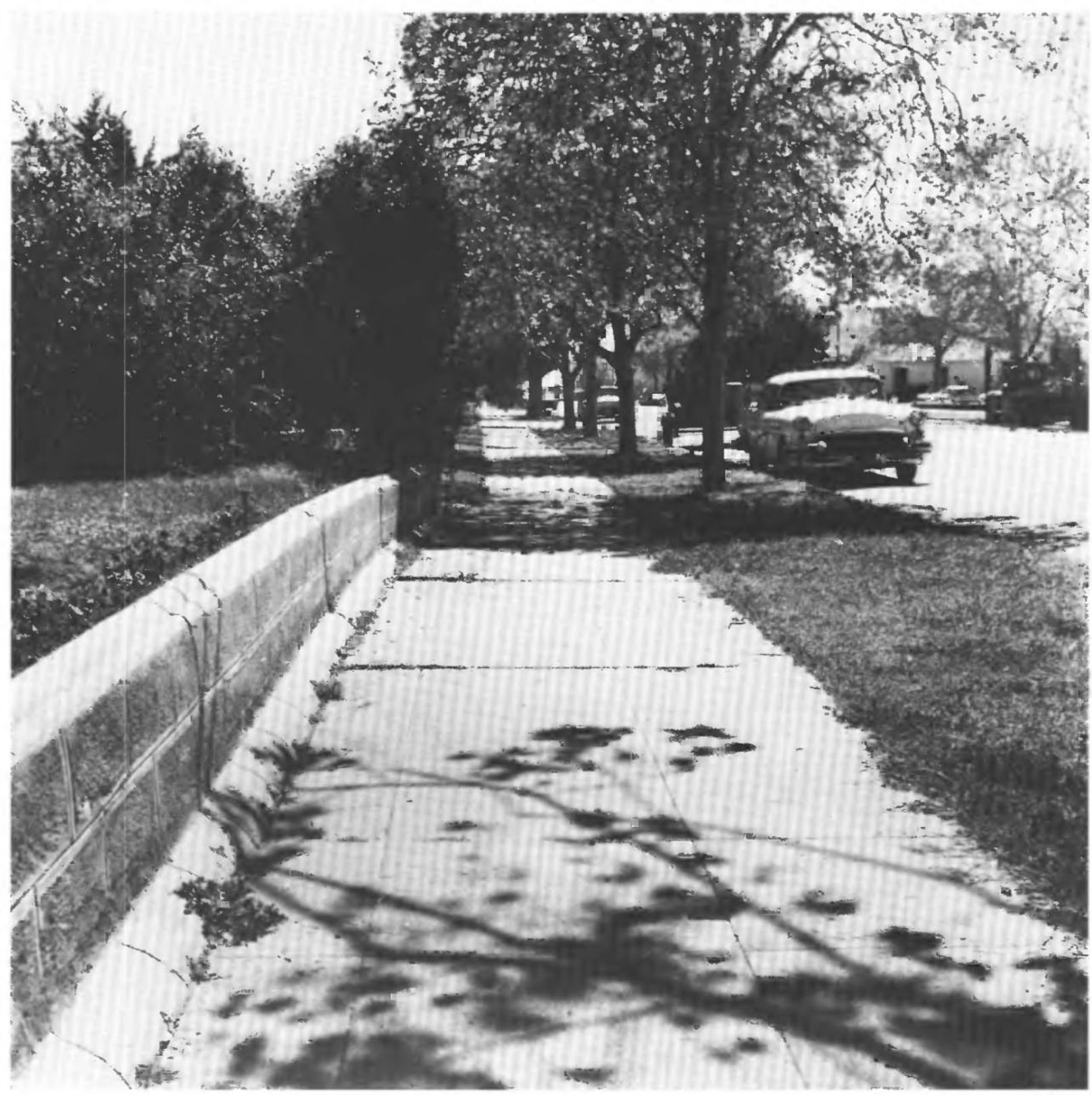

FigURE 2.36. - Creep of about $1 \mathrm{~cm} / \mathrm{yr}$ on the Calaveras fault in Hollister, Calif., has bowed walls, sidewalks, streets, and houses. View eastward at Sixth Street. 


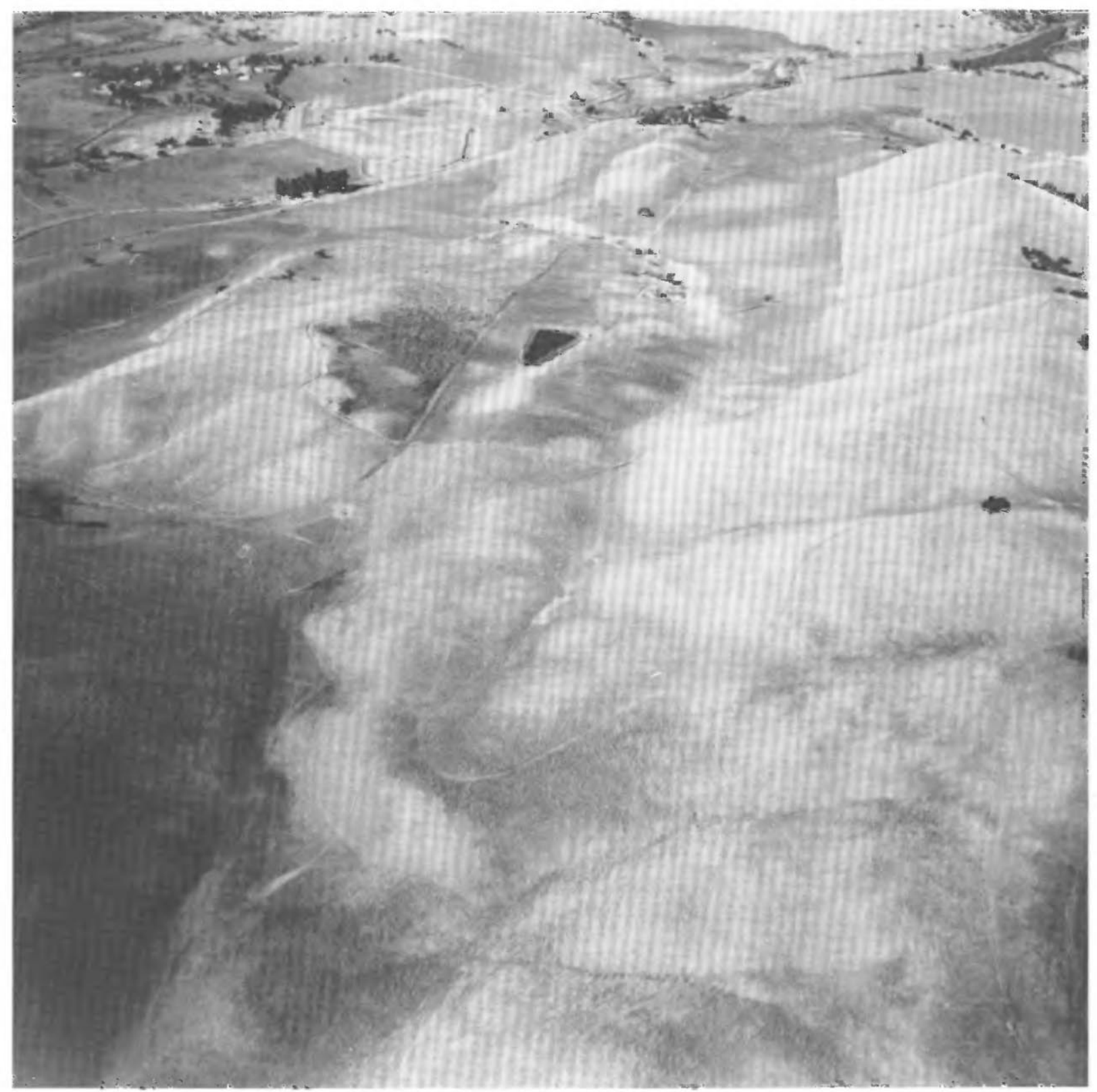

FIGURE 2.37. - Valleys and ponds mark trace of the Calaveras fault (first referred to at this location as the Paicines fault). View northwestward toward village of Paicines (top). 


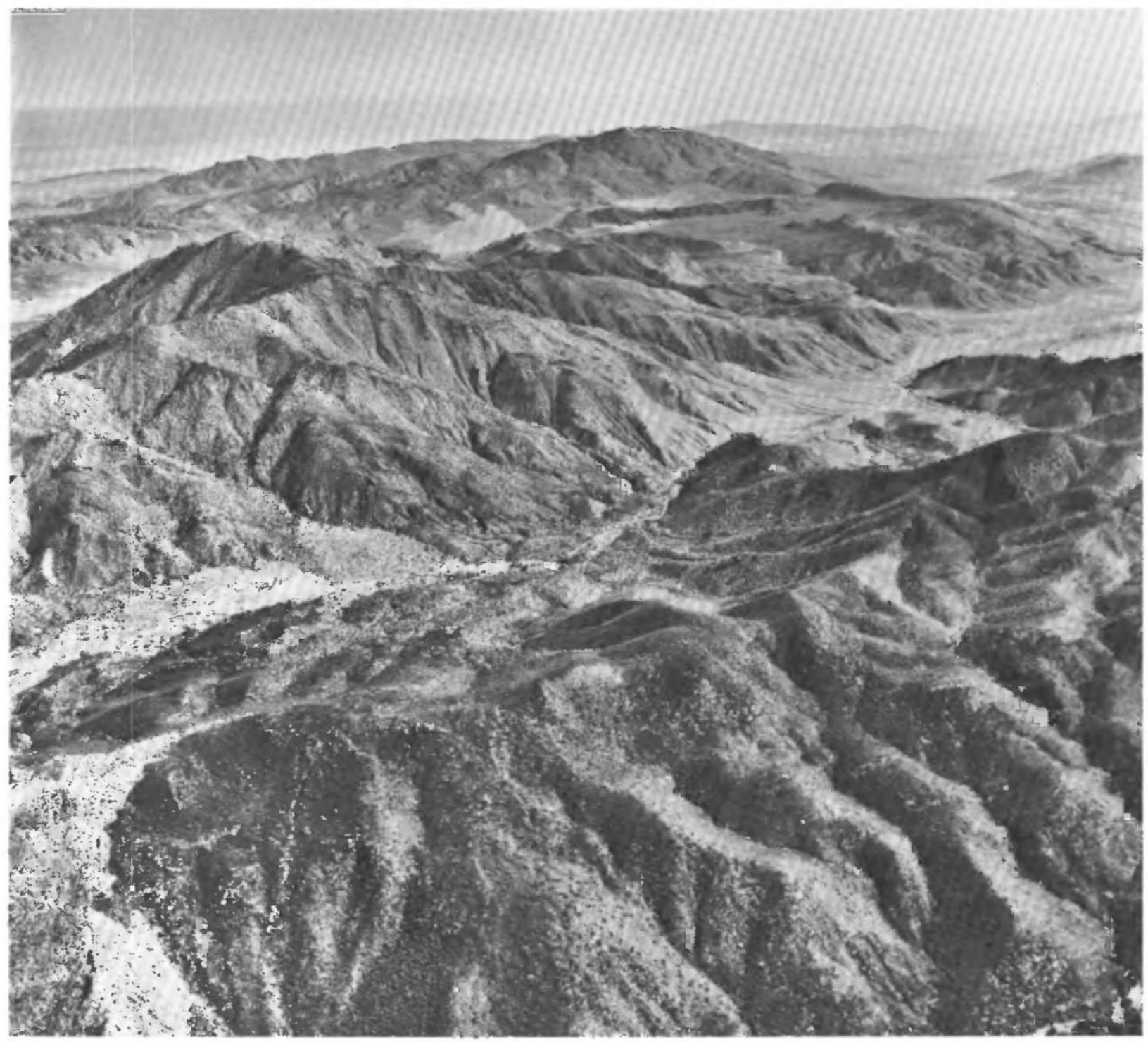

FIGURE 2.38. - The Elsinore fault just north of the United States-Mexican border is not as conspicuously displayed as the San Andreas and San Jacinto faults; however, this fault markedly influences the topography. Here, a major valley is eroded in the general fault zone, but traces of late Quaternary displacement are not as obvious as farther northwest along fault. U.S. Geological Survey photograph, taken October 13, 1956 . 


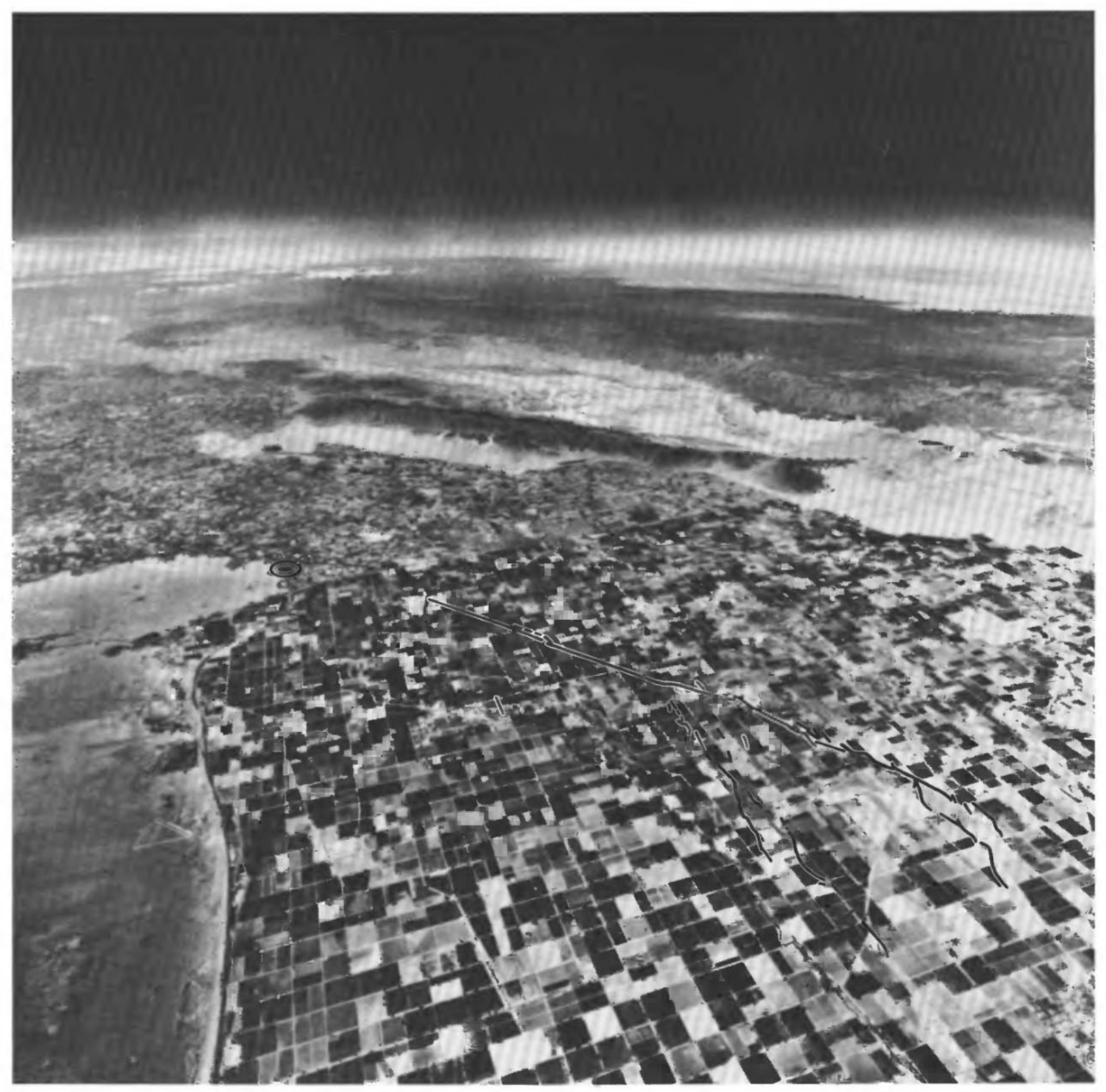

FIGURE 2.39. - Imperial fault south of the Salton Sea, southern California. During the Imperial Valley earthquake of October 15, 1979, surface rupture occurred along fault trace (black-and-white line). Bull's-eye denotes epicenter. From U.S. Geological Survey (1982, cover). U.S. Air Force photograph, taken July 17, 1968. 


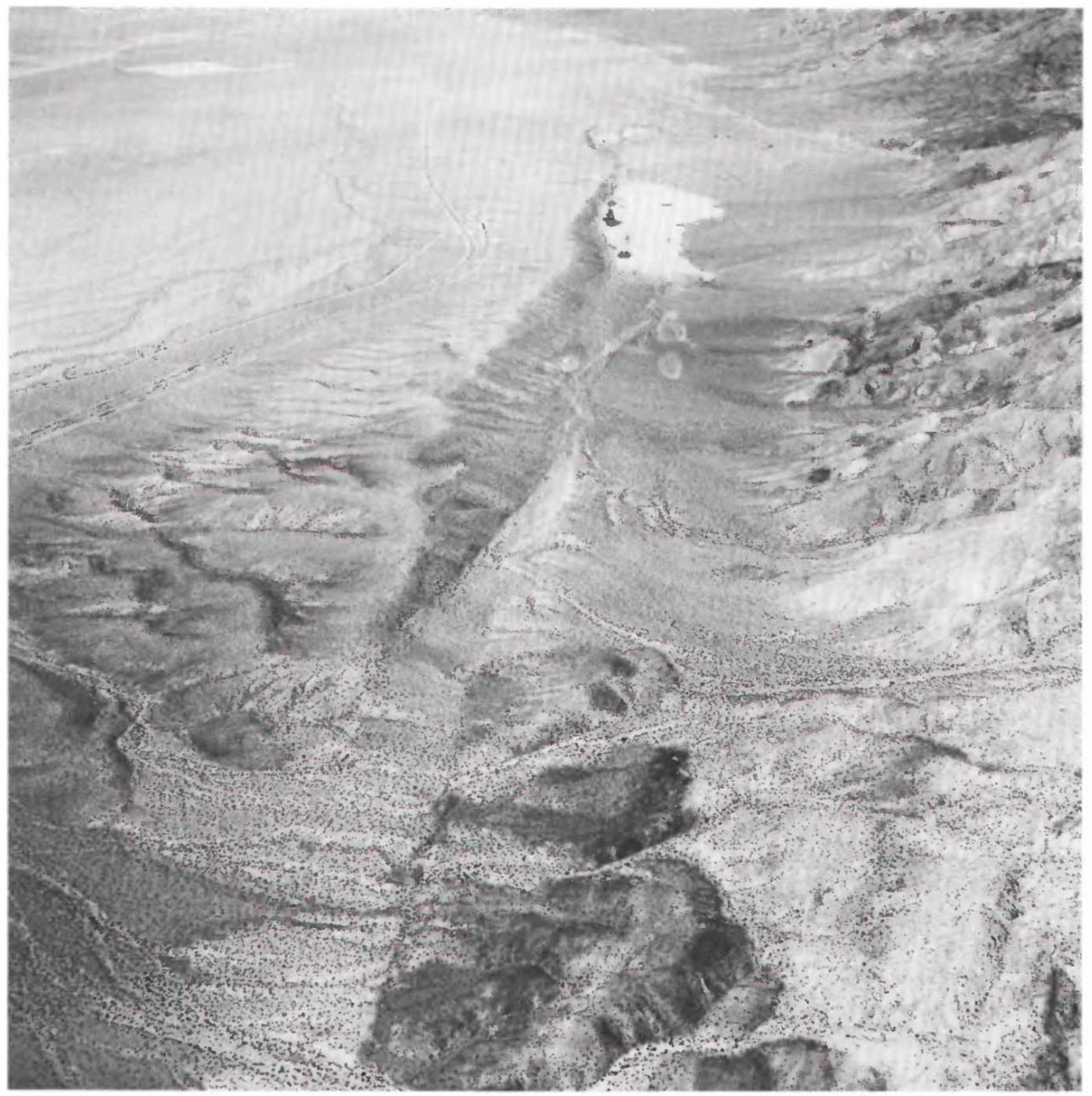

FIGURE 2.40.-Linear ridges and undrained sags mark trace of the Garlock fault along north edge of the Mojave Desert. Note left-lateral offset of gulches. View southwestward. 


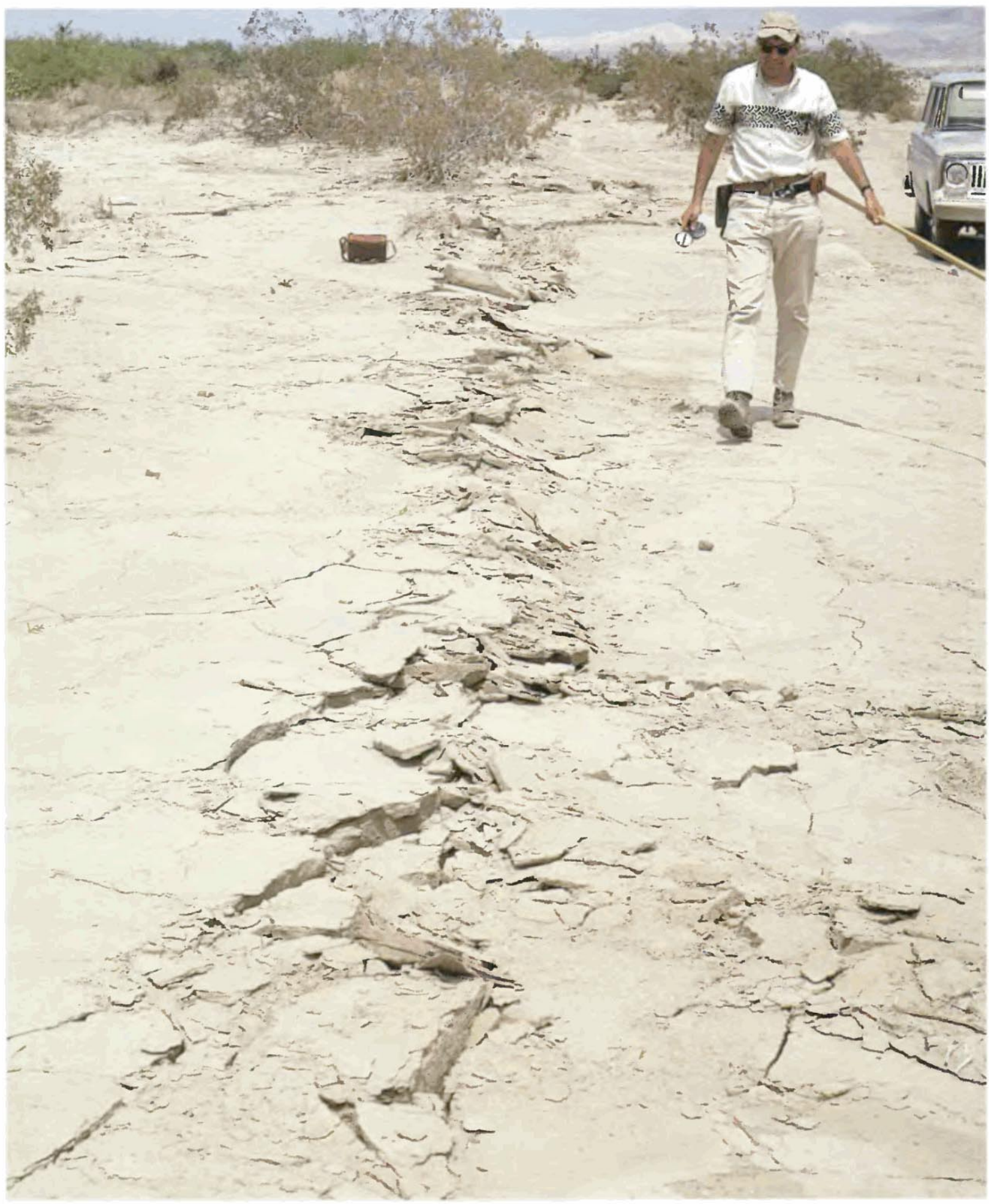

FIGURE 2.41. - Right-lateral slip accompanying an earthquake creates characteristic echelon fractures and zones of compression that produce a "mole track." This mole track formed along the Coyote Creek fault during the Borrego Mountain earthquake of 1968. 


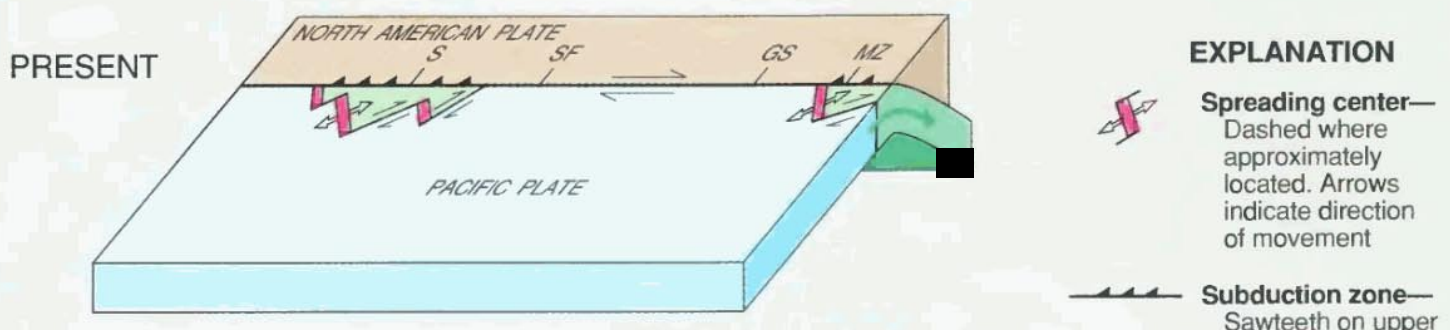

Whe Subduction zone-

Sawteeth on upper

plate

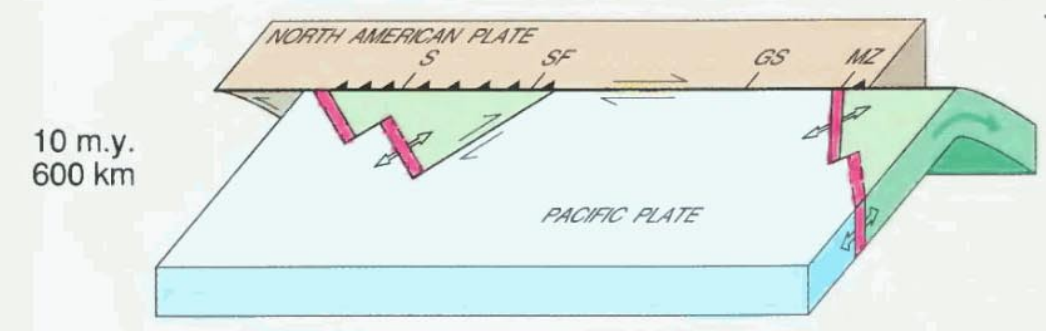

Fault-Arrows indicate direction of relative movement

20 m.y. $1200 \mathrm{~km}$

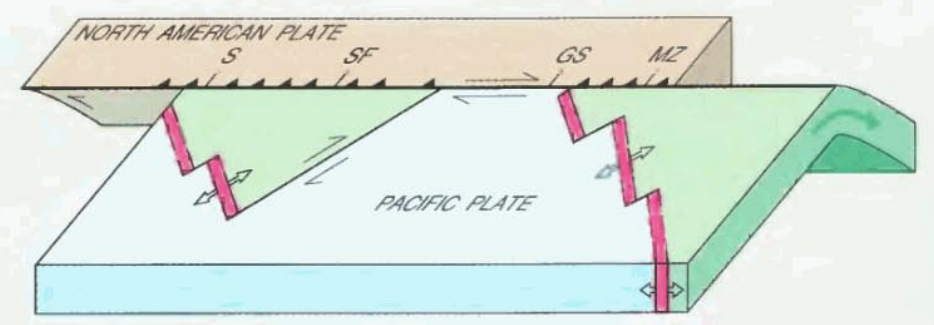

30 m.y. $1800 \mathrm{~km}$

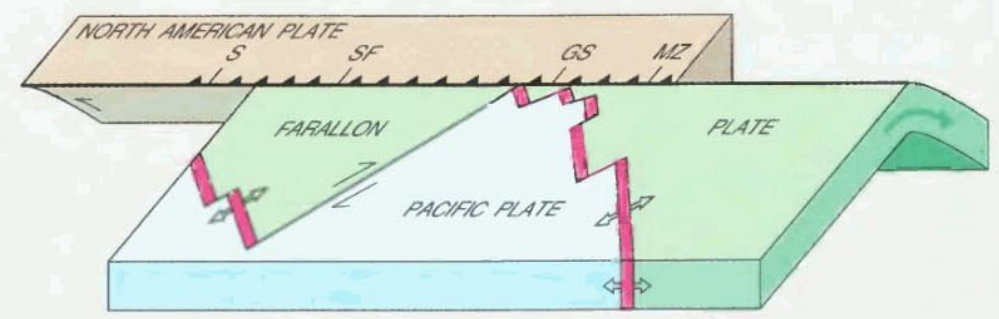

40 m.y. 2400 km

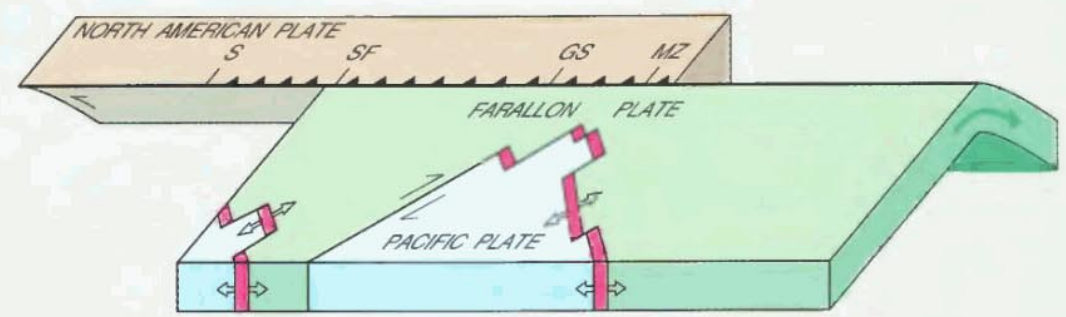





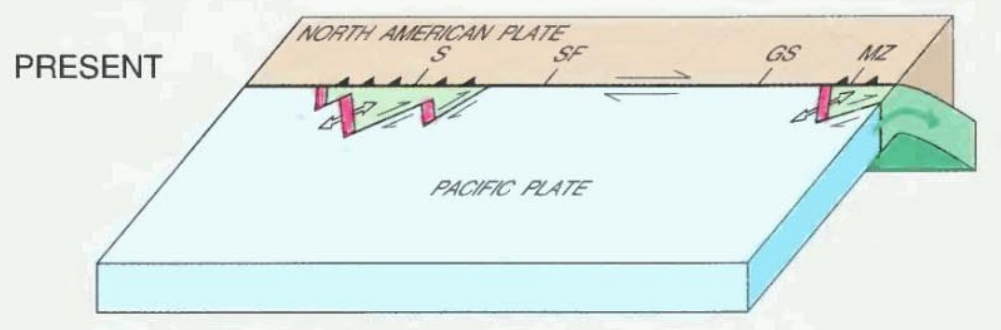

\section{EXPLANATION}

Spreading center-

Dashed where

approximately

located. Arrows

indicate direction

of movement

We Subduction zone-

Sawteeth on upper

plate

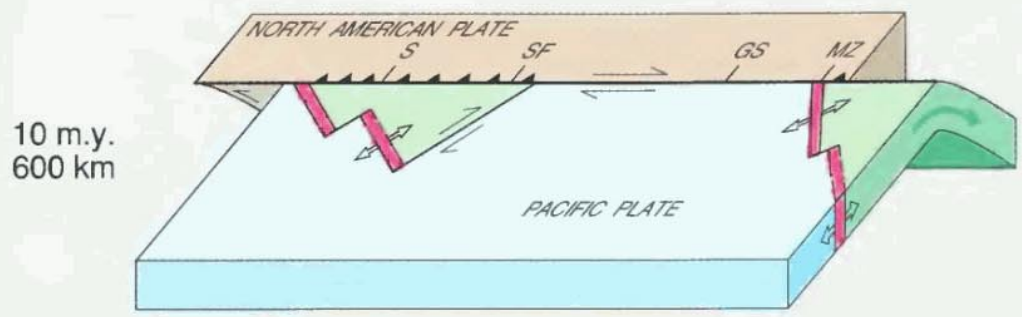

Fault-Arrows indicate direction of relative movement

20 m.y. $1200 \mathrm{~km}$

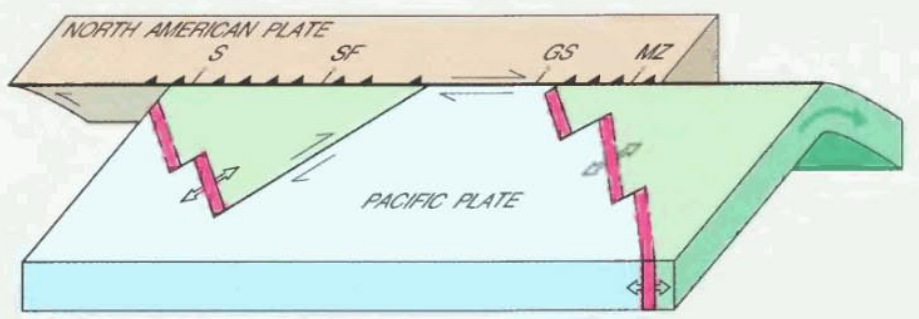

30 m.y.

$1800 \mathrm{~km}$

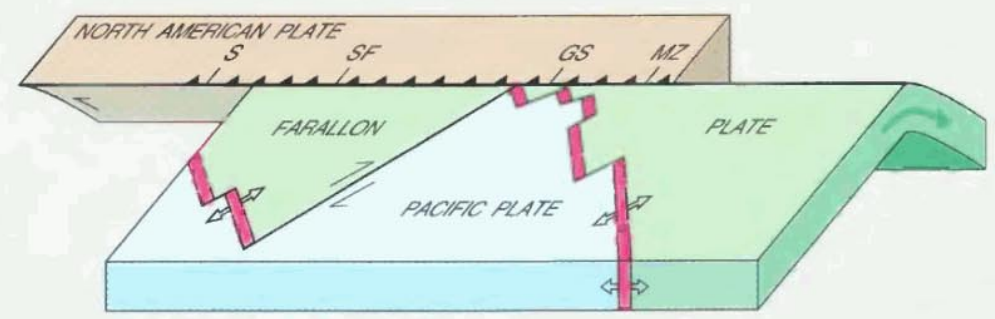

40 m.y.

$2400 \mathrm{~km}$

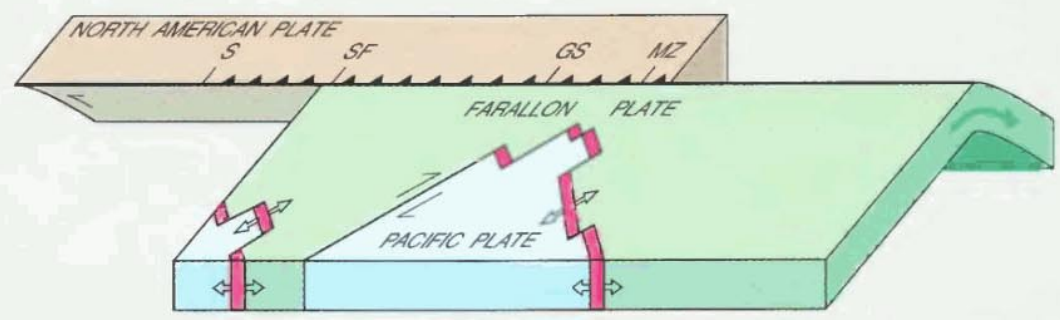


7 he San Andreas fault is a transform fault along the boundary the fault includes various lithologic units that range in age from Precambrian to Tertiary and younger. Some bedrock units that can be matched across the fault suggest strike-slip displacement of as much as $560 \mathrm{~km}$.

\section{GEOLOGY AND PLATE-TECTONIC DEVELOPMENT}

\begin{tabular}{|c|c|}
\hline \multicolumn{2}{|c|}{ By William P. Irwin } \\
\hline 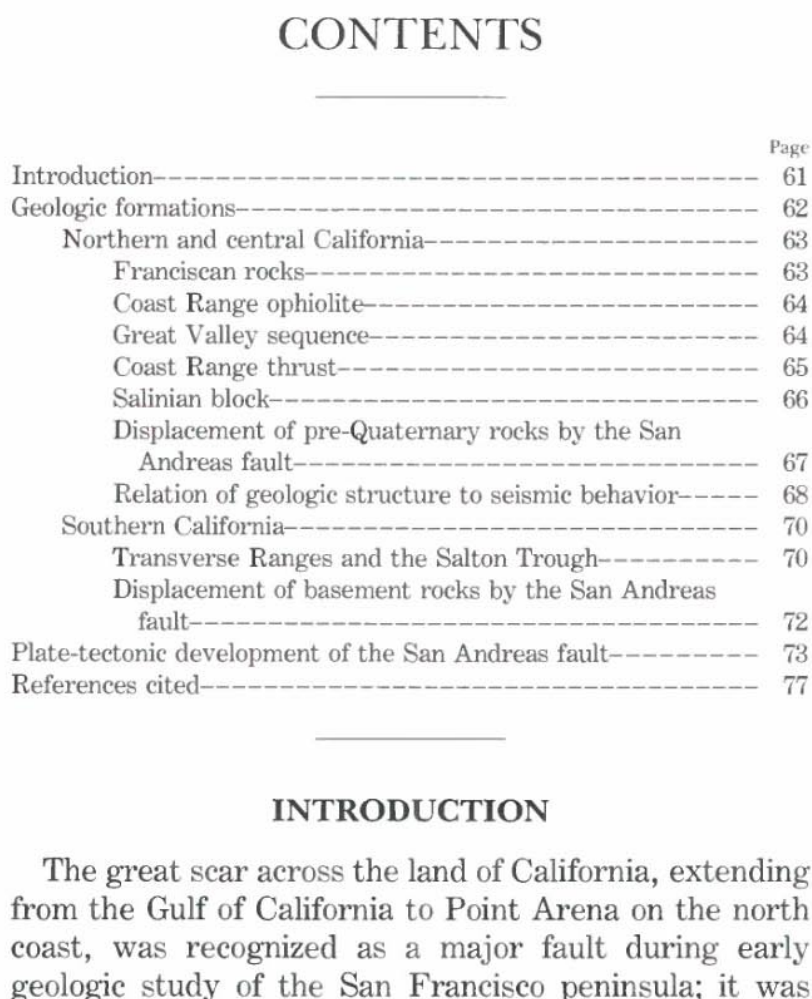 & $\begin{array}{l}\text { named for San Andreas Valley, which lies a few kilome- } \\
\text { ters south of San Francisco. Interest in the San Andreas } \\
\text { fault was heightened as a result of movement on the fault, } \\
\text { in some places as much as } 5 \text { m of strike-slip displacement, } \\
\text { that occurred during the great San Francisco earthquake } \\
\text { of } 1906 \text {. Because of this earthquake, a concerted study } \\
\text { was carried out by several leading geologists of that time } \\
\text { (Lawson, 1908) that dramatically increased our knowl- } \\
\text { edge of the regional extent and general features of the } \\
\text { fault. Much controversy ensued during the following } \\
\text { decades as to the time of origin of the fault, the } \\
\text { magnitude of cumulative displacement along it, and, } \\
\text { indeed, even whether the displacement might be princi- } \\
\text { pally dip slip rather than strike slip. An early proponent } \\
\text { of substantial lateral movement on the San Andreas fault } \\
\text { was Levi Noble (1927) of the U.S. Geological Survey, } \\
\text { who suggested a } 38 \text {-km right-lateral displacement based } \\
\text { on the similarity of Tertiary strata on opposite sides of } \\
\text { the San Andreas fault at Cajon Pass and Rock Creek (lat } \\
34^{\circ} 26^{\prime} \text { N., long } 117^{\circ} 50^{\prime} \text { W.). Substantial lateral offset of } \\
\text { Quaternary terraces along the Mojave segment of the } \\
\text { fault was recognized by R.E. Wallace (1949) while } \\
\text { working on his Ph.D. thesis at the California Institute of } \\
\text { Technology. He estimated a slip rate of } 0.4 \text { em/yr, which } \\
\text { he extrapolated to } 120 \text { km of right-lateral slip since } \\
\text { mid-Tertiary time (approx } 30 \text { Ma). In } 1953 \text {, a benchmark }\end{array}$ \\
\hline
\end{tabular}

Figure 3.1.-Sequential diagrams showing interactions between the North American, Farallon, and Pacific plates, assuming a constant relative motion of $6 \mathrm{~cm} / \mathrm{yr}$ parallel to the San Andreas fault (modified from Atwater, 1970). Position of the North American plate in each time frame is relative to those of the Farallon and Pacific plates rather than to outlines of diagram. Lengthening interface between the North
American and Pacific plates, shown in three upper diagrams, represents the San Andreas transform fault. Captions for each step indicate amount of time and lateral movement necessary for the North American plate to reach its present position relative to the Pacific plate. GS, Guaymas; MZ, Mazatlán; S, Seattle; SF, San Francisco. 
paper by M.L. Hill and T.W. Dibblee, Jr., of the Richfield Oil Corp. cited various evidence for great right-lateral offset along the San Andreas fault and speculated that the total offset amounts to $560 \mathrm{~km}$ or more since Jurassic time.

During middle and late 1960 's, a time of great ferment of concepts regarding the plate-tectonic development of the planet Earth, the foundation was laid for much of the present view of the tectonics of California and the San Andreas fault. A highly significant breakthrough to our understanding of the development of the fault system was the brilliantly simple construction by J. Tuzo Wilson (1965, fig. 9), who showed the San Andreas fault as a transform fault connecting two spreading oceanic ridges (figs. $3.1,3.2$ ). This view was soon modified by McKenzie and Morgan (1969) and Atwater (1970) to account for the effects of migrating triple junctions and for the timing, rates, and vectors of plate movement. Their platetectonic analysis of the San Andreas fault was based on

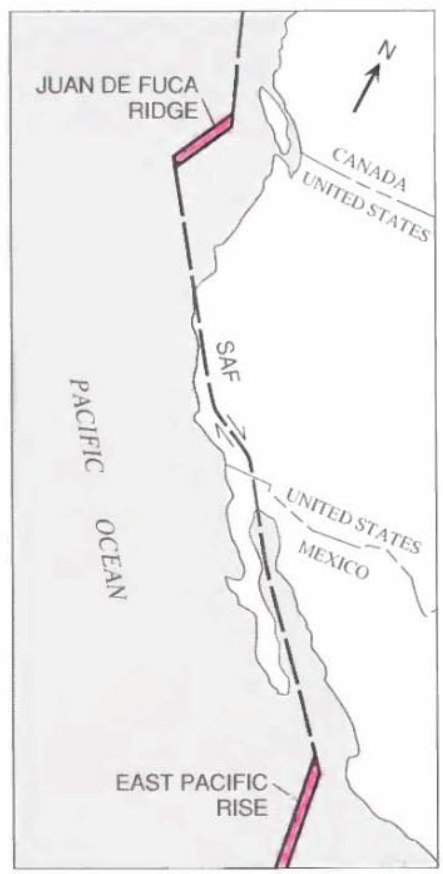

FiguRE 3.2.- Sketch map of part of the Pacific coast of North America, showing J. Tuzo Wilson's early idea of the San Andreas fault (SAF) as a right-lateral (arrows) transform fault connecting the termination of two spreading centers represented by the East Pacific Rise and the Juan de Fuca Ridge (modified from Wilson, 1965). calculations of plate motions between North America, Africa, India, Antarctica, and the Pacific, and many land-based geologists of the time would have agreed that it seemed "outrageous" to be "studying the San Andreas fault by using data that is no closer to California than $7,000 \mathrm{~km}$ " (Atwater and Molnar, 1973).

\section{GEOLOGIC FORMATIONS}

On its path through nearly the length of California, the San Andreas fault separates major crustal blocks (fig. 3.3). In much of northern and central California, the fault is a southeast-trending boundary between the Salinian block of granitic and metamorphic rocks on the west and the Franciscan assemblage and overlying strata of the Great Valley sequence on the east. In its southerly course the fault abruptly curves eastward to cut diagonally across the Transverse Ranges, and then splays into several auxiliary faults before the main strand terminates near the Gulf of California. In southern California the basement rocks cut by the San Andreas fault are mostly Precambrian and younger metamorphic and plutonic rocks, and the crustal blocks on either side of the fault generally do not show the distinctive lithologic contrast that is so striking in central and northern California.

FigURE 3.3.-Geologic sketch map of California, showing distribution of principal basement rocks. Cenozoic cover not shown except for the Modoc Plateau, northeastern Sierra Nevada, Great Valley, and Santa Barbara-Ventura Basin. Based on U.S. Geological Survey (1966), Jennings and others (1977), and Ross (1984). Units: 1, Quaternary alluvium-shown only in Great Valley; 2, basement rocks concealed by thick Upper Cretaceous and Tertiary deposits in the Santa Barbara, Ventura, and Los Angeles Basins; 3, Cenozoic volcanic rocks of the Modoc Plateau; 4, Great Valley sequence-Lower Jurassic to Upper Cretaceous strata, including Coast Range ophiolite at base; 5, Franciscan assemblage of Lower Jurassic to Tertiary oceanic rocks; 6 , Sierra Nevada batholith-dominantly Cretaceous granitic rocks; 7 , Sierra Nevada metamorphic belt-early Paleozoic to Late Jurassic rocks, including fragments of ophiolites, island arcs, and melanges, intruded by Mesozoic plutons: 8, Klamath Mountains-early Paleozoic to Late Jurassic ophiolites, island arcs, and melanges, intruded by early Paleozoic to Cretaceous plutons; 9 , Salinian block-dominantly Cretaceous plutons intruding metamorphic rocks of questionable age (Barrett Ridge slice [BRS], commonly shown as part of the Salinian block, is here shown as part of unit 11); 10, southern California batholith-dominantly Cretaceous plutons intruding sedimentary and volcanic rocks of Jurassic age and metamorphic rocks of mostly unknown age; 11, mainly Precambrian metamorphic and plutonic rocks, in part overlain by Paleozoic continental shelf deposits and intruded by Mesozoic plutons, locally underthrust in southwestern part of region by schist (similar in lithology to the Pelona Schist) of probable Cretaceous age. 
NORTHERN AND CENTRAL CALIFORNIA

FRANCISCAN ROCKS

Franciscan rocks form the east wall of the San Andreas fault for virtually its entire course through the Coast
Ranges of central and northern California, although the Franciscan is concealed along some reaches of the fault by overlying rocks. The Franciscan is a heterogeneous assemblage that consists largely of dismembered sequences of graywacke, shale, and lesser amounts of mafic volcanic rocks, thin-bedded chert, and rare limestone.

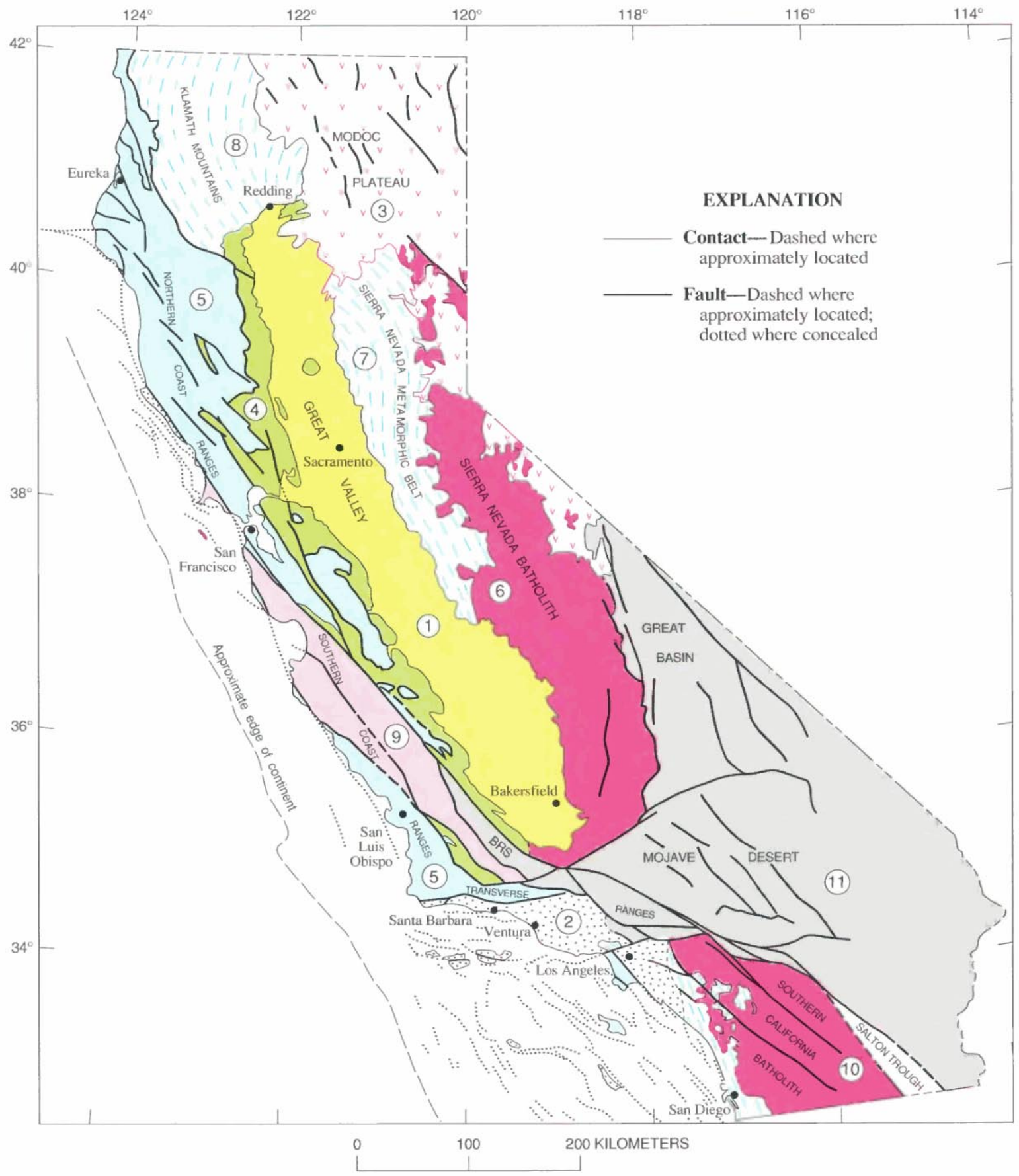


These rocks also occur with serpentinite and tectonic pods of blueschist in melange zones that are the locus of much shearing within the Franciscan and that generally separate blocks of the more coherent sequences. The sedimentary and volcanic Franciscan rocks were formed in a marine environment, as attested by the abundance of foraminifers in the limestone and by radiolarians in the chert. Most of these rocks are probably Late Jurassic and Cretaceous in age (Bailey and others, 1964), but some of the chert and associated volcanic rocks are as old as Early Jurassic (Pliensbachian) (Irwin and others, 1977; Blome and Irwin, 1983). In the northern Coast Ranges, some of the rocks assigned to the coastal belt of the Franciscan assemblage are as young as late Tertiary and are thought to have accreted to North America during post-middle Miocene time (McLaughlin and others, 1982). The age and origin of Franciscan melange is problematic. MidCretaceous limestone in melange near Laytonville in the northern Coast Ranges, $225 \mathrm{~km}$ northwest of San Francisco, has a paleomagnetic inclination that indicates an origin several thousand kilometers to the south (Alvarez and others, 1980). Similarly, Franciscan pillow basalt about $45 \mathrm{~km}$ northwest of San Francisco is thought to have moved northward $19^{\circ}$ of latitude (approx 2,000 km) from its site of origin (Grommé, 1984). These and other features indicate that some, possibly much, of the Franciscan has been transported great distances northward along the Pacific margin relative to a stable North America.

The Franciscan rocks are locally overlain structurally by the Coast Range ophiolite and the Great Valley sequence, and are separated from them by the Coast Range thrust (Bailey and others, 1970). The original extent of the Coast Range thrust is not clearly known because most of the ophiolite and Great Valley sequence that formed the upper plate of the thrust has been removed from the top of the Franciscan except in the general area of the Diablo antiform, which is marked by a line of windows from Mount Diablo to Parkfield, and along the west edge of the Great Valley (figs. 3.3, 3.4). A few small outliers of upper-plate rocks are present elsewhere east of the San Andreas fault as far north as Pillsbury Lake, $35 \mathrm{~km}$ east of Willits, and the Camp Meeker area, $17 \mathrm{~km}$ northeast of Bodega Head, and at several localities west of the Salinian block as far south as the Santa Ynez fault in the Transverse Ranges (see maps at front of book). Much of the serpentinite in Franciscan melange may well be sheared-in fragments of dismembered Coast Range ophiolite.

\section{COAST RANGE OPHIOLITE}

The Coast Range ophiolite represents oceanic crust on which much of the sedimentary rock of the Great Valley sequence was deposited. A complete ophiolite sequence consists of serpentinized harzburgite tectonite at the base, overlain by cumulate ultramafic and gabbroic rocks, passing upward into noncumulate gabbroic and related plutonic rocks, then into diabase dikes, and finally into pillow lavas. The Coast Range ophiolite, however, generally is highly sheared, dismembered, thinned, and locally missing, presumably as a result of faulting, at many places along the fault contact between Franciscan and Great Valley rocks. Only in a few places is a nearly complete lithologic sequence of Coast Range ophiolite preserved, and there the total stratigraphic thickness of the ophiolite is about 3 to $5 \mathrm{~km}$ (Hopson and others, 1981). Isotopic ages ranging from about 165 to $153 \mathrm{Ma}$ (Hopson and others, 1981) indicate that the Coast Range ophiolite is Middle and Late Jurassic in age. Paleontologic and paleomagnetic evidence suggests that the Coast Range ophiolite formed in an equatorial setting and was transported great distances northward before being accreted to North America and overlain by the Great Valley sequence (Pessagno and others, 1984; Hopson and others, 1986; McLaughlin and others, 1988).

\section{GREAT VALLEY SEQLENCE}

The Great Valley sequence consists of interbedded marine mudstone, sandstone, and conglomerate that range from Late Jurassic to Cretaceous in age (Bailey and others, 1964). It crops out as thick, monotonously bedded sections of strata that generally are markedly less deformed and more coherent than sedimentary sections of the Franciscan and also have greater lateral continuity. Where most fully developed, such as along the west side of the northern Great Valley, the aggregate stratigraphic thickness of Great Valley sequence is at least $12 \mathrm{~km}$. The strata normally lie depositionally on Coast Range ophiolite except where disrupted by faults, but at the north end and along the east side of the Great Valley they onlap the Nevadan and older basement terranes of the Klamath Mountains and Sierra Nevada. This enormous thickness of clastic detrital material probably represents submarine fans and turbidity deposits that formed as a result of rapid erosion of the ancestral Klamath Mountains and Sierra Nevada.

FIGURE 3.4.-Schematic block diagram of part of the Coast Ranges of California, showing gross structural relations between principal lithotectonic units cut by the San Andreas fault (modified from Irwin, 1977). The Coast Range ophiolite lies at base of the Great Valley sequence and is separated from underlying Franciscan rocks by the Coast Range thrust. Blueschist-facies metasedimentary and metavolcanic rocks that form border zone in the Franciscan immediately below the thrust are not shown. View southeastward along the San Andreas fault. 
COAST RANGE THRUST

The upper plate of the Coast Range thrust, consisting of Great Valley sequence with Coast Range ophiolite at the base, is cut by the San Andreas fault only along the west side of the Diablo Range in central California. There, the upper plate of the Coast Range thrust forms a broad blanket over the Franciscan rocks except in

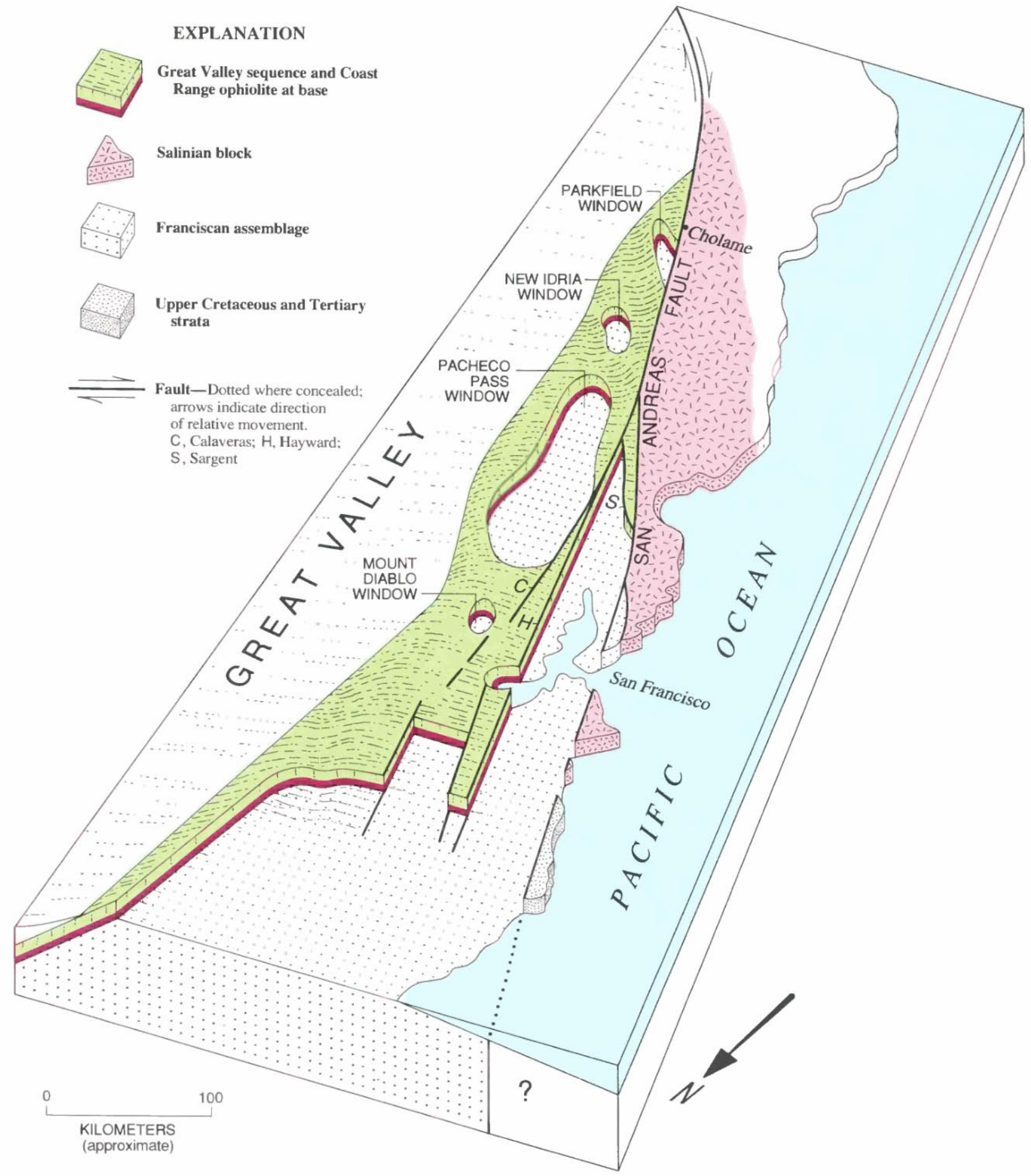


several places along the length of the Diablo Range where windows, or piercement structures, in the upper plate expose Franciscan rocks of the lower plate (fig. 3.4): at Mount Diablo, Pacheco Pass, New Idria, and Parkfield. This deformed antiformal structure (Bailey and others, 1964) is truncated on the west by the Hayward and Calaveras faults in its northern part and by the San Andreas fault in its southern part, and narrows to the southeast as the San Andreas fault converges with the south end of the Great Valley. The ophiolitic rocks are generally thinned and highly discontinuous along the faults that bound the windows except for the New Idria window, which is occupied mostly by serpentinite. South of the Pacheco Pass window, the structure is complicated by a series of west-northwest-trending synforms that cross the axis of the Diablo Range antiform at a low angle, and by multiple strands of the San Andreas fault. In the Parkfield area, the western part of the antiform has been virtually destroyed by its proximity to the San Andreas fault. The Franciscan rocks of the Parkfield window, and the associated serpentinite and Great Valley sequence of the highly dissected upper plate, now are mostly elongate fault slices that form part of the San Andreas fault zone (see Dibblee, 1980).

Most of the serpentinite of the Coast Ranges of California is related to the ultramafic parts of the Coast Range ophiolite. Serpentinite is strikingly absent along the San Andreas fault north of San Francisco, a situation that reflects the absence of the upper plate of the Coast Range thrust in that area. Although many elongate fault-bounded bodies of serpentinized ultramafic rocks in the Coast Ranges traditionally have been mapped and described as part of the Franciscan, most are probably dismembered and dislocated parts of the Coast Range ophiolite or equivalent. Recognition that the ultramafic rocks in most places belong to the Coast Range ophiolite rather than to the Franciscan assemblage is important to a tectonic analysis of the region. The common presence and possible seismotectonic significance of serpentinite along creeping segments of the San Andreas and related faults were described by Allen (1968) and Irwin and Barnes (1975).

\section{SALINIAN BLOCK}

The west wall of the San Andreas fault consists mainly of rocks of the Salinian block from the Transverse Ranges northward to Bodega Head. At the latitude of the San Francisco peninsula, the Salinian block is separated from the San Andreas fault by a narrow fault slice of Franciscan rocks (fig. 3.3). Northward, from just beyond Bodega Head to Point Arena, the rocks that crop out along the fault are chiefly Upper Cretaceous and Tertiary sedimentary strata, but because of the presence of a relatively small exposure of spilitic volcanic rocks that may be Franciscan, it is questionable whether these sedimentary rocks overlie granitic and metamorphic rocks of the Salinian block or whether they are separated from the Salinian block by another fault just off shore (Wentworth, 1968). The north end of the Salinian block off shore is thought to be at about the latitude of Point Arena (see McCulloch, 1987). At Point Delgada (see maps at front of book), which many workers consider to be the location of the northernmost onland trace of the San Andreas fault, the rocks on both sides of the fault are Franciscan.

The Salinian block is composite, consisting of central, western, and northern belts, and commonly is considered to include the Barrett Ridge slice (fig. 3.3; Ross, 1984). The basement rocks of the Barrett Ridge slice, though poorly exposed, are thought likely to be a northward continuation of the rocks of the San Gabriel Mountain area because they include similar-appearing metamorphic and granitic rocks, as well as schist similar to the Pelona Schist, along a possible exposure of the Vincent(?) thrust (Ross, 1984). The principal formations of these central, western, and northern belts are granitic and metamorphic rocks, locally overlain by Upper Cretaceous and younger strata. The metamorphic rocks, which commonly are moderate- to high-grade gneiss, granofels, impure quartzite, and minor schist and marble, probably represent a metamorphosed thin-bedded sequence of siltstone and sandstone, with lesser amounts of shaly, marly, and calcareous strata (Ross, 1978). The metamorphic rocks of the western belt are higher in metamorphic grade than those of the central and northern belts. The stratigraphic age of the protoliths of the metamorphic rocks is not known. The plutonic rocks are mostly granite and tonalite, but they range in composition to gabbro. $\mathrm{U}-\mathrm{Pb}$-isotopic measurements on zircon in the plutonic rocks indicate that plutonic activity began about 120-105 $\mathrm{Ma}$ in the northwestern part of the Salinian block and migrated southeastward over a period of $40 \mathrm{~m} . \mathrm{y}$., with the youngest plutons intruding the Barrett Ridge slice about 80-75 Ma (Mattinson and James, 1985).

The basement rocks of much of the Salinian block do not clearly differ from those of the Sierra Nevada, and so many workers have speculated that the Salinian block may be a displaced part of the Sierra Nevada (for example King, 1959; Page, 1981). According to Ross (1984), who compared the two terranes in considerable detail, the similarities are so great that strong data would be required to support an alternative origin. Paleomagnetic data, however, indicate that the Salinian block may have been displaced 2,500 $\mathrm{km}$ northward since Cretaceous time (Champion and others, 1984) and that it may have originated near the latitude of Central America or Mexico in the axial part of the Cordilleran Cretaceous plutonic arc (Page, 1982). 


\section{DISPLACEMENT OF PRE-QUATERNARY ROCKS BY THE SAN ANDREAS FAULT}

The largest offset on the San Andreas fault postulated by Hill and Dibblee (1953) is $560 \mathrm{~km}$, on the basis of the speculation that a contact between Sierran basement and Franciscan rocks near the south end of the Great Valley was cut by the fault and that the contact on the west side of the fault was offset northward to a point at sea north of Point Arena. This concept, however, is questionable not only because of the uncertain correlation of the Salinian block with rocks of the Sierra Nevada but also because the northernmost exposure of granitic rocks along the west side of the fault is at Bodega Head, about $90 \mathrm{~km}$ southeast of Point Arena, and neither the presence nor the type of a contact between Sierran-type basement and Franciscan rocks is known off shore north of Point Arena (see McCulloch, 1987). Nor is the significance clearly known of the possibly substantial lateral offset along the San Gregorio fault, which intersects the San Andreas at a low angle just west of the entrance to the San Francisco Bay. However, Upper Cretaceous strata that crop out near Gualala, on the west side of the San Andreas fault between Bodega Head and Point Arena, were thought by Ross and others (1973) also to have been offset $560 \mathrm{~km}$, consistent with Hill and Dibblee's concept. The strata near Gualala include quartz-plagioclase arkose and a conglomerate characterized by unusual quartzbearing mafic clasts, including volcanic rocks, diabase, and diorite to gabbro. Paleocurrent features indicate a source to the east of the fault. The source of the unusual gabbroic clasts is thought to be the Eagle Rest Peak area in the San Emigdio Mountains, just east of the San Andreas fault in the Transverse Ranges (fig. 3.5). This area may also be the source of relatively small fault slivers of similar mafic rocks that now lie $160 \mathrm{~km}$ northwest along the San Andreas fault at Gold Hill and $320 \mathrm{~km}$ northwest at Logan (Ross and others, 1973).

FIGURE 3.5. - Locations of some pre-Quaternary features offset by the San Andreas fault in the California Coast Ranges. The La Honda Basin is an offset segment of the San Joaquin sedimentary basin (Stanley, 1987); boundary dashed where approximately located. Circled x's, bedrock exposures of unusual quartz-bearing mafic rocks at Logan, Gold Hill, and Eagle Rest Peak (Ross and others, 1973); squares, locations of the Pinnacles and Neenach Volcanic Formations (see fig. 3.6) (Matthews, 1976). Numbered dots: 1, Butano Sandstone and Point of Rocks Sandstone Member (of Kreyenhagen Formation), representing offset parts of an Eocene deep-sea fan (Clarke and Nilsen, 1973); 2, steeply southwest-dipping slopes of the San Joaquin and La Honda Basins during late Zemorrian time (Stanley, 1987); 3, deepest parts of the San Joaquin and La Honda Basins adjacent to the San Andreas fault during Saucesian time (Stanley, 1987); 4, unusual clasts in upper Miocene conglomerate in the Temblor Range east of fault and their postulated source area in the Gabilan Range west of fault (Huffman, 1972).
Other features that suggested substantial right-lateral offset to Hill and Dibblee (1953) include (1) the south limit of Cretaceous strata near Fort Ross, offset $512 \mathrm{~km}$ from

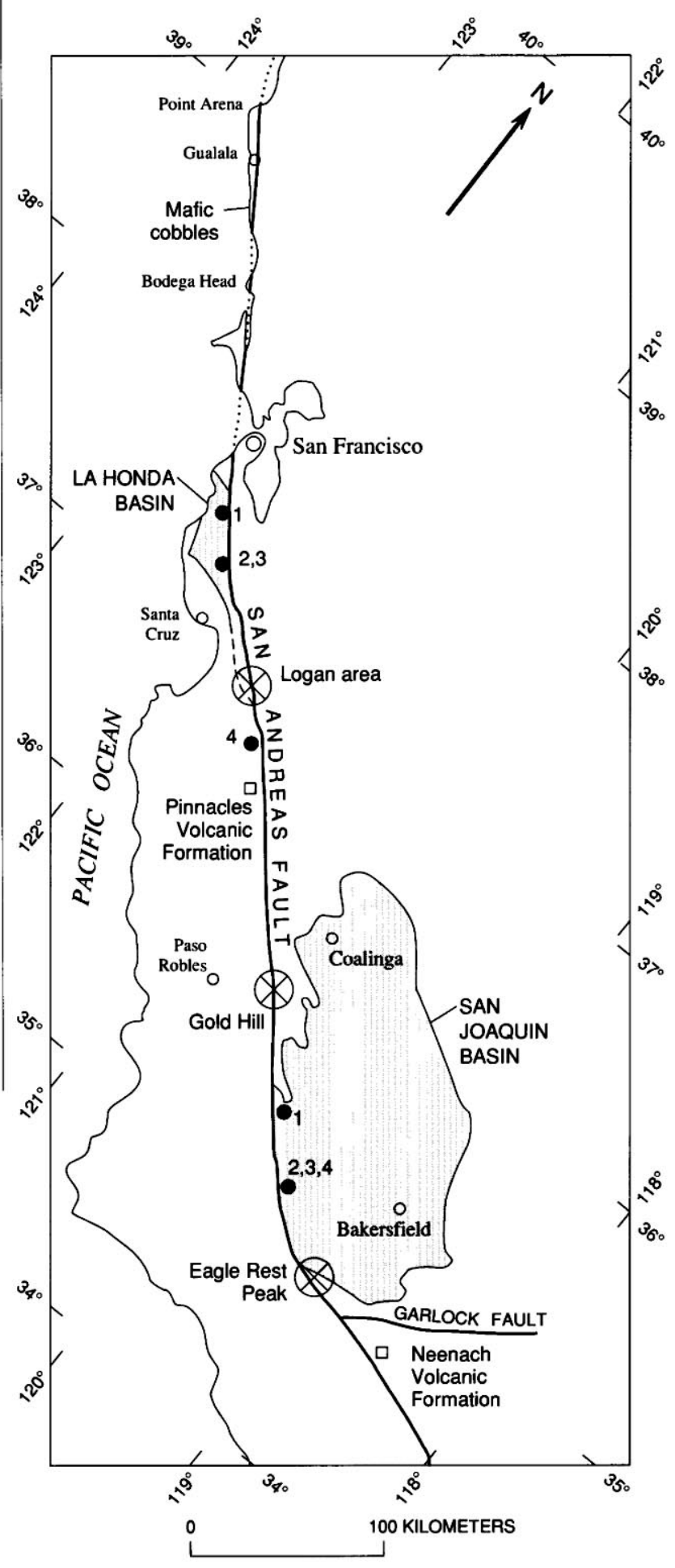


their south limit in the Temblor Range; (2) Eocene formations in the Santa Cruz Mountains, offset $360 \mathrm{~km}$ from lithologically and faunally similar formations in the Temblor-San Emigdio Mountains; (3) sequences of lower Miocene volcanic rocks, red beds, and Oligocene and lower Miocene marine deposits of the Gabilan Range, offset $280 \mathrm{~km}$ from similar sequences in the San Emigdio Mountains; (4) a facies transition from marine to continental middle and upper Miocene beds of the Carrizo Plain, offset $104 \mathrm{~km}$ from a similar transition projected from the south end of the Great Valley; and (5) $16 \mathrm{~km}$ of offset based on the juxtaposition of two facies of Pleistocene gravel south of the Temblor Range.

Offset of the Eocene formations was described in more detail by Clarke and Nilsen (1973), who considered the lower to upper Eocene sedimentary sequences to represent parts of a single deep-sea fan that have been offset $305 \mathrm{~km}$ along the San Andreas fault. These sequences are (1) the Twobar Shale Member of the San Lorenzo Formation and the Butano Sandstone, exposed in the Santa Cruz Mountains on the west side of the fault; and (2) the shale member and Point of Rocks Sandstone Member of the Kreyenhagen Formation, exposed along the southwest boundary of the Great Valley on the east side of the fault (fig. 3.5). Both sandstone units, which consist chiefly of detritus from the Salinian block, are thought to have been deposited as a submarine fan on the west side of a deep, northwest-trending offshore basin. The Eocene fan deposits on the east side of the fault are in a structurally complex area at the south end of the Diablo antiform. If they overlie Franciscan basement there and Salinian basement on the west side of the fault, they indicate that the Franciscan and Salinian basements had already been juxtaposed by Eocene time when the fan was deposited, as noted by Page and Engebretson (1984).

The strongest evidence for measuring the large amount of right-lateral displacement along the trace of the San Andreas fault through the Coast Ranges may be the correlation of the Pinnacles and Neenach Volcanic Formations (Matthews, 1976), which are exposed on opposite sides of the fault about $315 \mathrm{~km}$ apart (fig. 3.5). The Pinnacles Volcanic Formation is in the central Coast Ranges, on the west side of the Chalone fault, a parallel strand that is several kilometers west of the San Andreas. The Neenach Volcanic Formation is in the Mojave Desert, adjacent to the San Andreas fault on the northeast side, about $20 \mathrm{~km}$ southeast of its intersection with the Garlock fault. The volcanic rocks at both exposures rest on granitic basement rocks that are petrographically and chemically similar (Ross, 1984). As described by Matthews (1976), the volcanic rocks form stratigraphic sections that are remarkably similar in composition, lithologic sequence, and age; they consist of calc-alkaline andesite, dacite, and rhyolite flows interbedded with pyroclastic and volcaniclastic rocks (fig. 3.6). K-Arisotopic analyses of the volcanic rocks indicate an early Miocene age (23.5 Ma; Turner, 1970). The similarity of the $315-\mathrm{km}$ offset of the volcanic formations and the 305- $\mathrm{km}$ offset ascribed to the previously mentioned Eocene fan deposits suggests that little movement occurred along that section of the San Andreas fault during intervening Oligocene time (Clarke and Nilsen, 1973).

Paleobathymetric contour maps of middle Tertiary (late Oligocene to early Miocene) topographic features of the San Joaquin sedimentary basin match similar features across the fault in the La Honda Basin (fig. 3.5), according to Stanley (1987). The paleobathymetry is based on studies of the distribution of fossil foraminifers. In both basins, (1) the southwestern margins were bounded by shelf areas and steep north-facing slopes, (2) maximum water depth was about $2,000 \mathrm{~m},(3)$ the deepest part was truncated by the San Andreas fault, and (4) the paleobathymetric contours generally trend at large angles to the fault and are truncated by it. These features indicate a post-late Zemorrian (late Oligocene to early Miocene) displacement of 325 to $330 \mathrm{~km}$ and a postSaucesian (early Miocene) displacement of 320 to $325 \mathrm{~km}$.

Large offset along the San Andreas fault is also indicated by an anomalous distribution of upper Miocene sedimentary deposits that occur on both sides of the fault for more than $300 \mathrm{~km}$ in the central Coast Ranges. According to Huffman (1972), the clast composition of upper Miocene sedimentary rocks of the Temblor Range lying east of the fault in the southern Coast Ranges indicates that they were deposited adjacent to the Gabilan Range, which lies to the northwest on the opposite side of the fault, and that they subsequently have been displaced approximately $240 \mathrm{~km}$ (fig. 3.5).

The various aforementioned features that have been used to measure lateral offsets along the San Andreas fault are all situated near the present-day trace of the fault. They do not measure the substantial displacements that probably occurred along presently inactive older faults of the system, nor do they measure the large lateral movement (described below) that is thought to have occurred along the interface between continental and oceanic crust during the early plate-tectonic development of the fault system.

\section{RELATION OF GEOLOGIC STRUCTURE TO SEISMIC BEHAVIOR}

From the preceding descriptions, the San Andreas fault evidently cuts through many different types of rocks and regional structures along its traverse from the Transverse Ranges to the Mendocino triple junction, and the patterns of seismicity differ strikingly along various 
segments of the fault. These differences in seismic behavior coincide so closely with certain geologic situations along the San Andreas fault in central California as to suggest a causal relation.

Certain segments of the San Andreas fault in central California are characterized by frequent small-magnitude earthquakes and aseismic slippage (creep); creep also occurs along the San Andreas fault in Coachella Valley, the Imperial fault, and the Superstition Hills fault. Other segments, said to be "locked," are characterized by infrequent earthquakes, some of which have been historically of large magnitude, and by an absence of creep. The occurrence of creep has been described by Allen (1968), Wallace (1970), Nason and Tocher (1970), and Thatcher (see chap. 7), among others. The creep is mainly on faults along the west side of the Diablo antiform. The creeping segment of the San Andreas fault extends from Cholame to near San Juan Bautista. Other faults known to creep include segments of the Calaveras, Hayward, Concord, Green Valley, and Sargent faults (fig. 3.7). The locked segments of the San Andreas fault in central California extend northward from near San Juan Bautista and southward from Cholame. Though of no recognized significance, the creeping segment of the San Andreas fault terminates near the north end of the Barrett Ridge slice of the Salinian block.

The creeping segments in central California occur where the faults regionally cut the upper plate of the Coast Range thrust (figs. 3.4, 3.7; Irwin and Barnes, 1975). This position accounts for the common presence of serpentinite along the creeping segments of the San Andreas fault, because the serpentiniferous Coast Range ophiolite in the upper plate of the thrust is at the fault interface along these segments. The lower-plate Franciscan rocks form a geochemical province characterized by carbon dioxide-rich springs. Where the upper plate of the thrust is present, it may act as a hydraulic cap that helps to maintain high pore pressure caused by carbon dioxide in the underlying Franciscan rocks, and to direct fluid flow into the fault (Irwin and Barnes, 1975). The importance of pore pressure in relation to creep is its ability to reduce the frictional strength of rocks by lowering the effective confining pressure, as demonstrated by Byerlee and Brace (1972). The tectonic relations between carbon dioxide springs and seismicity were described by Irwin and Barnes (1980).

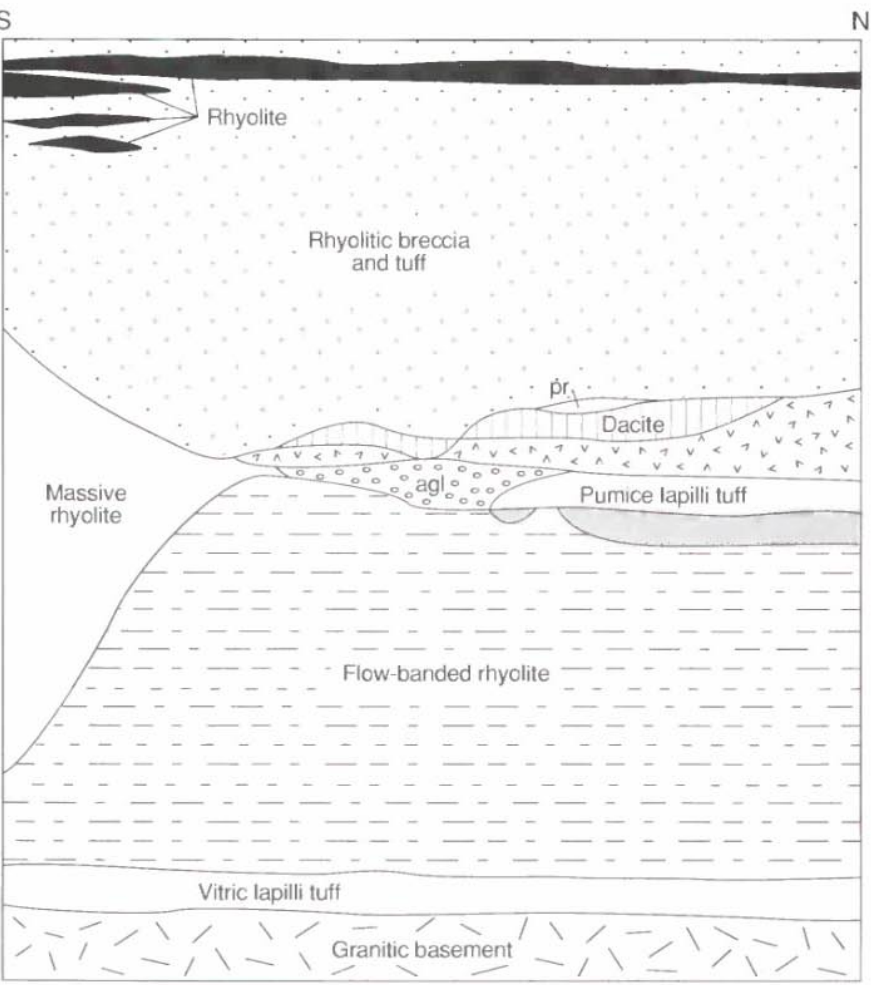

PINNACLES VOLCANIC FORMATION
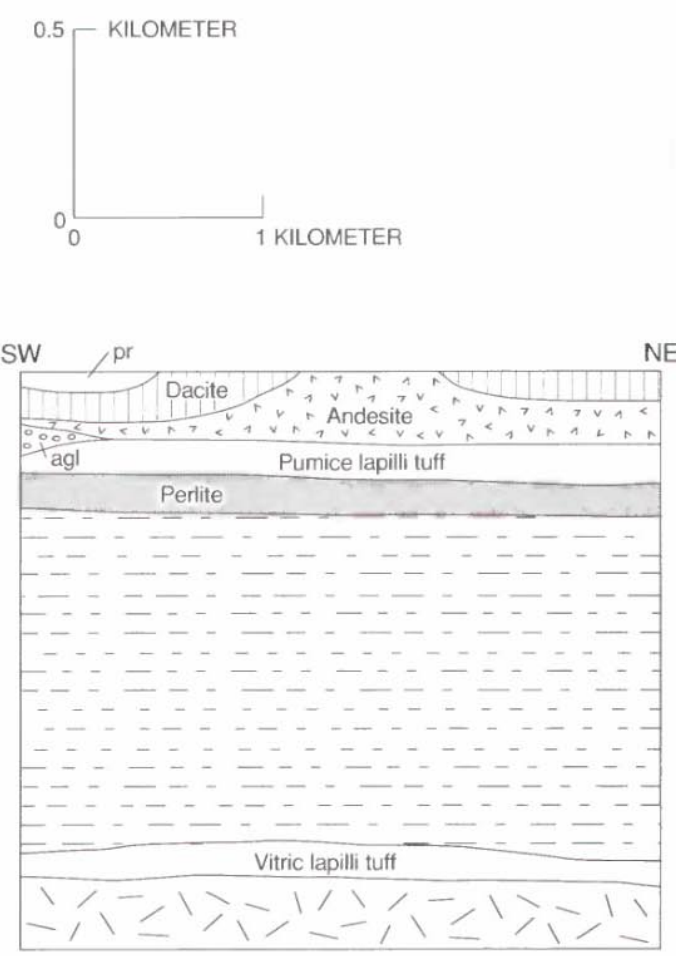

NEENACH VOLCANIC FORMATION

FIGURE 3.6. - Idealized cross sections showing stratigraphic and lithologic similarity of the Neenach Volcanic Formation, on northeast side of the San Andreas fault in southern California, to lower half of northern part of the Pinnacles Volcanic Formation several kilometers west of fault in central California (modified from Matthews, 1976) (see fig. 3.5 for locations). agl, agglomerate; pr, porphyritic rhyolite. 


\section{SOUTHERN CALIFORNIA}

\section{TRANSVERSE RANGES AND THE SALTON TROUGH}

Where the San Andreas fault bends eastward, near the south end of the Great Valley, it forms the boundary between the southern "tail" of the Sierra Nevada and rocks of the Transverse Ranges (fig. 3.3). Continuing southeastward along the Transverse Ranges, the fault trends along the north slope of the San Gabriel Mountains and the edge of the Mojave Desert for about $100 \mathrm{~km}$, and then cuts diagonally between the San Gabriel and San Bernardino Mountains, where a major strand (San Jacinto fault) splits off to the south. The rocks traversed by the San Andreas fault in the Transverse Ranges are mainly Mesozoic plutons and their Precambrian metamorphic and plutonic host rocks.

South of the Transverse Ranges, the bedrock along the fault is concealed by Quaternary deposits of the Salton Trough for a length of more than $200 \mathrm{~km}$. The Salton Trough, which includes the Coachella and Imperial Valleys, widens toward the southeast, and the number of

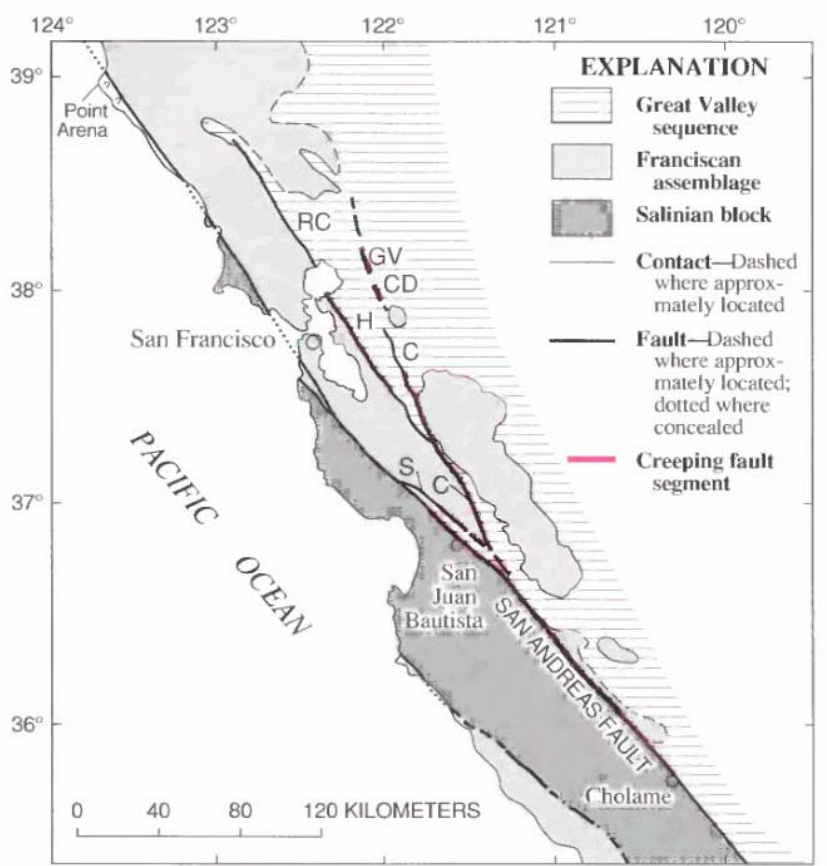

Figure 3.7.-Known creeping segments of the San Andreas and related faults in central and northern California. Data from Nason (1973), Frizzell and Brown (1976), Prescott and Burford (1976), Burford and Sharp (1982), and Harsh and Burford (1982). Faults: C, Calaveras; CD, Concord; GV, Green Valley; H, Hayward; RC, Rodgers Creek; S, Sargent. Compare creeping segments with concentrations of small earthquakes shown in figures 5.4 and 5.5. faults and complexity of the zone increase. The east wall of the trough is at the San Andreas fault, where it consists of Precambrian rocks and Mesozoic plutons and of schists like those exposed in the Orocopia and Chocolate Mountains (fig. 3.8). The west wall consists of Cretaceous plutonic rocks of the Southern California batholith and their metamorphic host rocks, similar to rocks exposed in the nearby San Jacinto Mountains. As shown by Fuis and others (1982), the trough is a gap in the crystalline basement that is filled with Quaternary and older Cenozoic sedimentary rocks. The gap increases irregularly in width from $20 \mathrm{~km}$ at the north end of the Salton Sea to $60 \mathrm{~km}$ at the United States-Mexican border. The enormous thickness of the sedimentary fill is indicated by a drill hole that bottoms in Pleistocene(?) sedimentary rocks at a depth of about $4 \mathrm{~km}$ (Muffler and Doe, 1968). Seismic-refraction studies show an interface with "basement" rocks at a depth of 5 to $6 \mathrm{~km}$, and the "basement" rocks below the 5- to 6-km-deep interface are thought actually to be metamorphosed Cenozoic fill (Fuis and others, 1982). Near the south end of the Salton Sea, the San Andreas appears to terminate as a transform fault at a spreading center, or pullapart zone, that is the most northerly in a series of spreading centers distributed along the length of the Gulf of California which form part of the East Pacific Rift. The proximity of this pullapart zone accounts for the abundant young volcanic and geothermal features in the area (Elders and others, 1972).

The Precambrian rocks and associated Mesozoic plutons that constitute much of the crystalline basement cut by the San Andreas in southern California are locally seen to lie in thrust-fault contact on relatively younger metamorphic rocks. In the San Gabriel Mountains, on the southwest side of the San Andreas fault, the principal country rocks are divided into two plates by the Vincent thrust (lat $34^{\circ} 19^{\prime}$ N., long $117^{\circ} 45^{\prime}$ W.). As described by Ehlig (1981), the upper plate of this thrust is a Precambrian gneiss-amphibolite-granite complex (U-Pb age, approx 1,700 Ma; Silver, 1966) intruded by a Precambrian anorthosite-syenite-gabbro complex (U-Pb age, 1,220 Ma; Silver, 1971), all of which are intruded by the Late Triassic Lowe Granodiorite (U-Pb age, $220 \mathrm{Ma}$; Silver, 1971), by mid-Mesozoic rhyolitic to basaltic dikes, and, finally, by granitic plutons of probable Late Cretaceous age (U-Pb age, $80 \mathrm{Ma}$; Carter and Silver, 1971). The oldest rocks in the upper plate are thought to be a remnant of a Precambrian craton. Northeast of the fault, in the Mojave Desert and San Bernardino Mountains, some Precambrian rocks are unconformably overlain by lower Paleozoic miogeoclinal strata that are thought to represent an essentially autochthonous part of the North American craton (Burchfiel and Davis, 1981; Ehlig, 1981). 
The lower plate of the Vincent thrust consists of the Pelona Schist, which is largely a sedimentary section of arkosic sandstone, siltstone, and shale that has been metamorphosed to white mica-quartz-albite schist and locally includes metavolcanic rocks, metachert, marble, and serpentinite (Ehlig, 1981). The section in the San Gabriel Mountains has an exposed thickness of $3.5 \mathrm{~km}$. The metamorphism decreases downward, away from the fault, and so sedimentary structures, including graded bedding, are well preserved in the lowest $1 \mathrm{~km}$ of section. This "upside down" metamorphism and other features indicate that the metamorphism of the lower-plate rocks occurred during thrusting. Pelona-type schist also occurs beneath Precambrian rocks of the Barrett Ridge slice west of the Tejon Pass and crops out in places along the Garlock fault (fig. 3.9). On the northeast side of the San Andreas fault in the Orocopia-Chocolate Mountains area, just east of the Salton Sea, the schist, there known as the Orocopia Schist, lies below the Orocopia thrust. Scattered exposures of Pelona-type schist and the VincentOrocopia thrust continue into southwesternmost Arizona (Haxel and Dillon, 1978).

The protoliths of the Pelona-type schist are thought to be deep-marine sedimentary rocks deposited on oceanic crust, possibly representing mostly the distal parts of turbidite fans. They probably were Jurassic or Cretaceous in age and are thought to have been metamorphosed by the thrusting that probably occurred no later than Late Cretaceous time (Haxel and others, 1985). The tectonics of the Pelona and Orocopia Schists is controversial. The Vincent-Orocopia thrust may have dipped southwest, and the Precambrian and other rocks of the upper plate been thrust northeastward over backarcbasin protoliths of the Pelona and Orocopia Schists (Haxel and Dillon, 1978). Conversely, the thrust relation may represent a gently north-northeast dipping subduction zone in which the protoliths of the schists were trench deposits similar to the Franciscan rocks and were thrust north-northeastward under the sialic North American plate (Burchfiel and Davis, 1981; Crowell, 1981). The Pelona-type schist is reminiscent of the Franciscanderived South Fork Mountain Schist and related semischists of northern California that form a narrow, virtually continuous selvage for hundreds of kilometers

Figure 3.8. - Salton Trough and north end of the Gulf of California, showing major spreading centers and termination of the San Andreas fault (modified from Fuis and others, 1982). Spreading centers: BZ, Brawley seismic zone; CP, Cerro Prieto geothermal area; W, Wagner Basin. Major transform faults: CPF, Cerro Prieto; IF, Imperial; SAF, San Andreas. Other major faults: E, Elsinore; EH, East Highland Canal seismicity lineament; LS, Laguna Salada; SJ, San Jacinto. along the west edge of the Klamath Mountains and the west side of the Great Valley, where they form the lower plate of the Coast Range thrust (Blake and others, 1967).
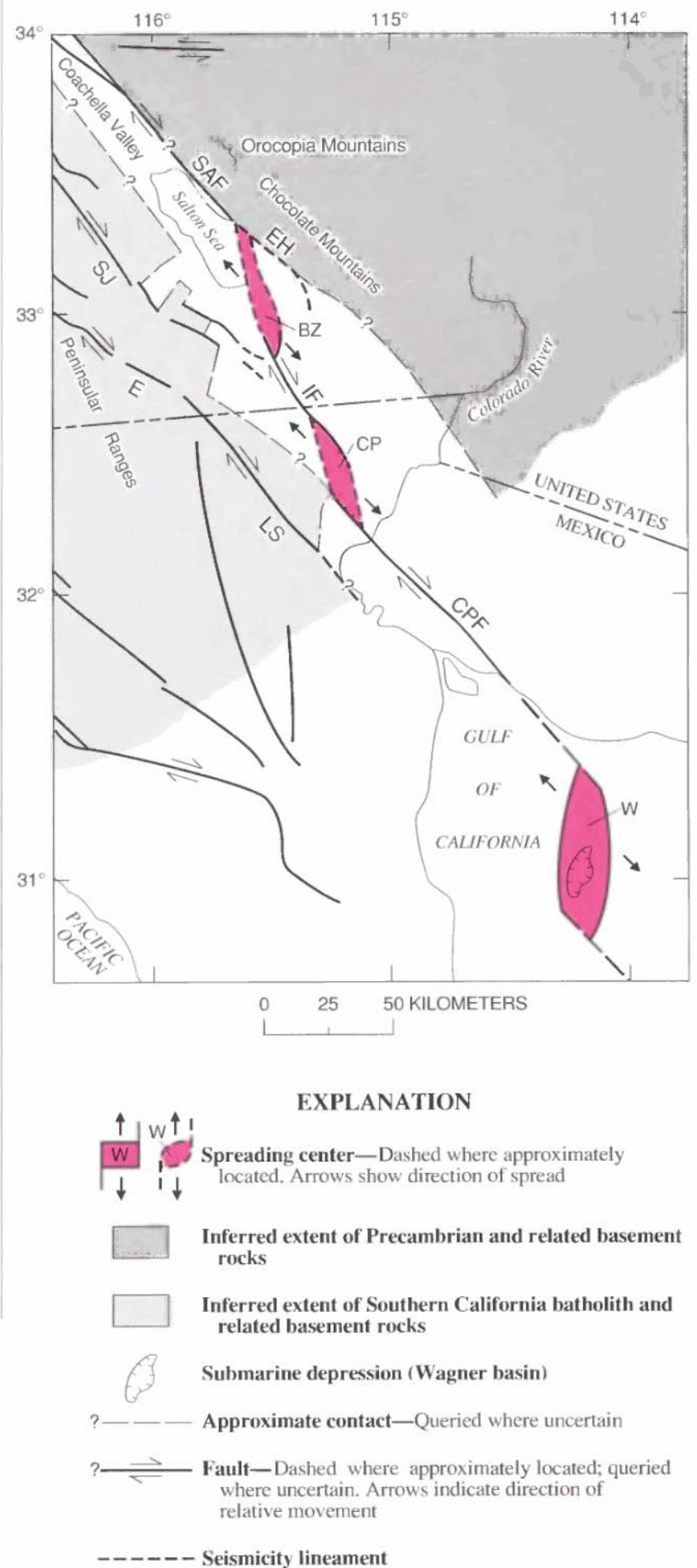


\section{DISPLACEMENT OF BASEMENT ROCKS BY THE SAN ANDREAS FAULT}

The distribution of the Pelona-type schist (fig. 3.9) has played an important role in many attempts to measure the slip on the San Andreas fault in southern California. In their classic report, Hill and Dibblee (1953) recognized the similarity of the Pelona Schist of the San Gabriel Mountains area to the Orocopia Schist east of the Salton Sea and postulated that these schists are offset $257 \mathrm{~km}$ from one another by the San Andreas fault. Crowell (1962) noted that the Precambrian rocks and Pelona-type schist of the Tejon area are separated from those of the San Gabriel Mountains area by the San Gabriel fault and that the Tejon, San Gabriel Mountains (Soledad), and Orocopia Mountains areas contain not only similar Precambrian rocks and Pelona-type schist but also similar Oligocene and other Tertiary strata. The similar lithologies and geologic histories of the rocks of these three areas indicated to him that these rocks once formed an east-west-trending belt which has been segmented and displaced by right-lateral slip of approximately $50 \mathrm{~km}$ on the San Gabriel fault and $210 \mathrm{~km}$ on the San Andreas fault. However, the validity of the concept that the Tertiary rocks of the San Gabriel (Soledad) and Orocopia Mountains areas once were parts of a single basin was questioned by Spittler and Arthur (1973), who believed that the Tertiary strata of these two areas were deposited in separate basins, consist of distinctly different flow rocks, and are dissimilar in age.

More recent schemes for measuring offset along the San Andreas fault in southern California have been proposed. Among them, Powell (1981) postulated that all major exposures of the Pelona-type schist are in the core of an antiformal fold and that they once formed a nearly continuous structure which subsequently has been disrupted by Cenozoic strike-slip faults (fig. 3.10). An important part of Powell's palinspastic reconstruction of the antiform is an old east-west-trending fault that is a composite of the San Francisquito, Fenner, and Clemens Well faults. This fault is thought to have had $80 \mathrm{~km}$ of right-lateral slip, cutting the antiform, and later was cut diagonally by the San Andreas fault. The axis of the antiformal structure is a linear feature that can be used as a "piercing point" in measuring offset where the axis appears on opposite sides of a fault. On this basis, the axis in the San Gabriel Mountains (Sierra Pelona) area is offset $220 \mathrm{~km}$ along the San Andreas fault from the axis in the Orocopia Mountains area (Powell, 1981). The Transverse Ranges segment of the San Andreas fault was described by Matti and others (1985) as consisting of several old strands (Wilson Creek, Mission Creek, and

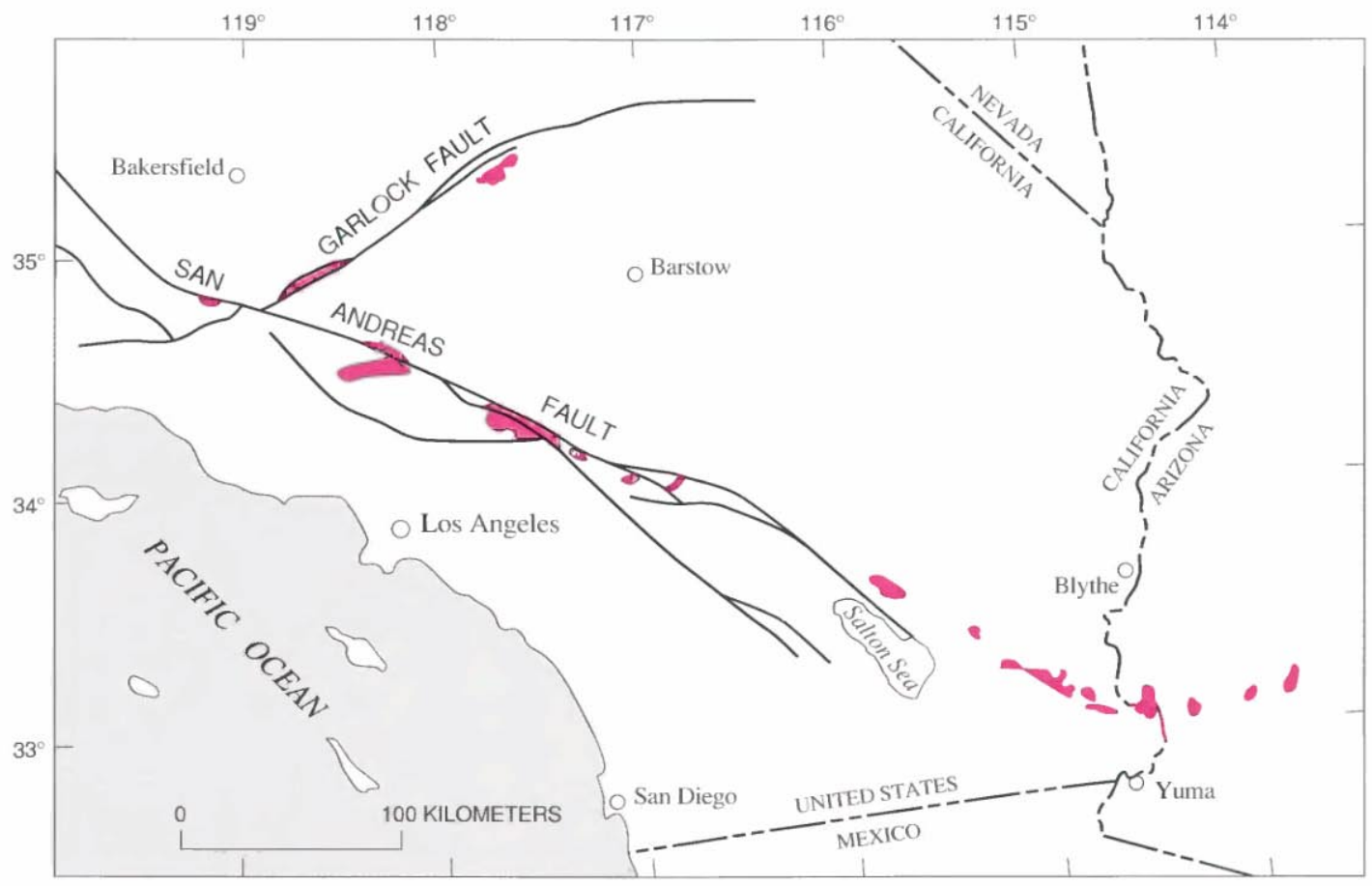

Figure 3.9.-Distribution of the Pelona Schist and lithologically similar schists in southern California and southwestern Arizona (modified from Haxel and Dillon, 1978). Northernmost occurrence along the San Andreas fault is in Barrett Ridge slice of the Salinian block. 
Mill Creek faults) and a young strand (San Bernardino strand). The total displacement across all of these strands is thought to be $160 \pm 10 \mathrm{~km}$ (Matti and others, 1986), on the basis of exposures of a distinctive Triassic megaphyric monzogranite. The exposures of this monzogranite, which are on the northeast side of the San Andreas fault in the San Bernardino Mountains but on the opposite side of the fault in Liebre Mountain (lat $34^{\circ} 43^{\prime}$ N., long $118^{\circ} 40^{\prime}$ W.), are thought to represent displaced parts of the same pluton.

\section{PLATE-TECTONIC DEVELOPMENT OF THE SAN ANDREAS FAULT}

The Pacific coast of North America is a highly mobile zone of tectonic interaction between continental crust on the east and oceanic crust on the west. At some times and places, the relative movements of these contrasting crustal domains have been sufficiently convergent that the oceanic crust has underthrust the continental crust and swept island ares and other crustal materials into the zone of interaction (Hamilton, 1969). However, much of the movement along this zone of interaction seems to have been oblique or lateral in an overall northwestsoutheast direction, and so as the two types of crust moved past one another, fragments of all sizes were sliced or pulled from them and carried various distances away from their source. By these processes of convergence and lateral translation, large crustal fragments referred to as "terranes" (Irwin, 1972; Coney and others, 1980; Schermer and others, 1984) are juxtaposed against others that may differ strikingly in lithology, age, genetic environment, stratigraphy, metamorphic facies, plutonism, and mineral deposits.

The general directions and rates of movement of the major crustal domains that converged along the western margin of North America are amenable to explanation by the theory of global plate tectonics as far back in time to

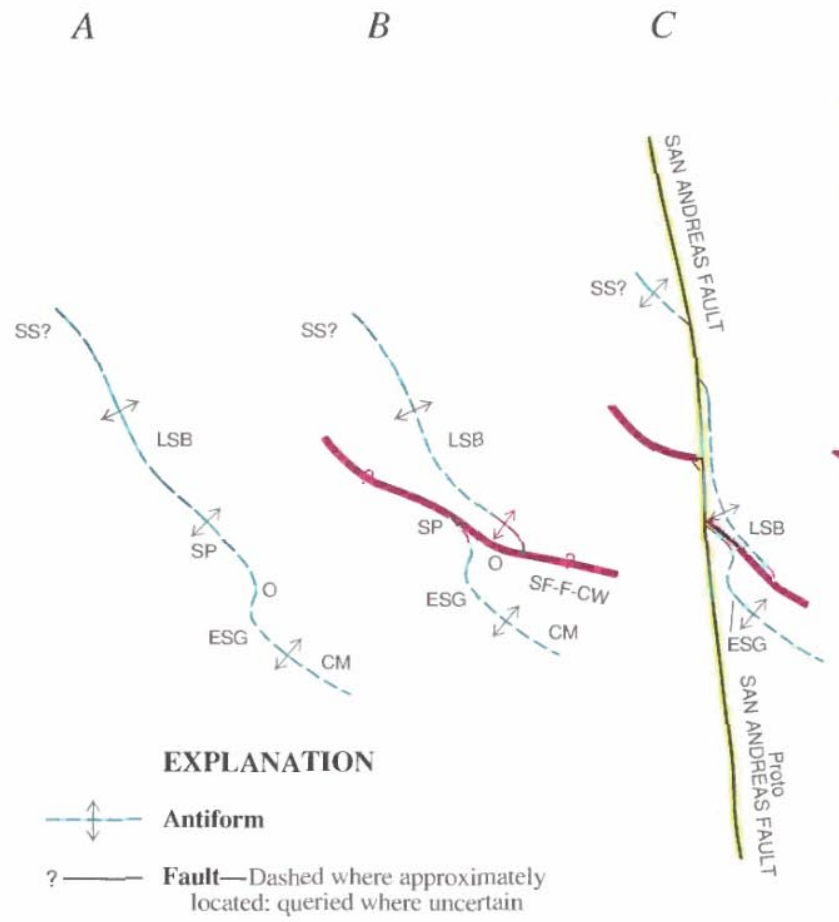

FIGURE 3.10.-Sequential diagrams showing evolution of the San Andreas fault system in southern California as proposed by Powell (1981). A, Approximately 30-15 Ma-formation of regional antiform cored by schist lithologically similar to the Pelona Schist. $B$, Approximately 20-10 Ma-displacement of antiform by the San Francisquito-Fenner-Clemens Well fault. C, Approximately 10-2 $\mathrm{Ma}-$ inception of San Andreas-San Gabriel strand of the San Andreas fault, displaying approximately $60 \mathrm{~km}$ of right-lateral displacement. $D$, Approximately $5-0 \mathrm{Ma}$-left-lateral bending of San Gabriel segment and possible inception of the Garlock fault. $E$, Approximate-
$\begin{array}{lll}D & E & F\end{array}$

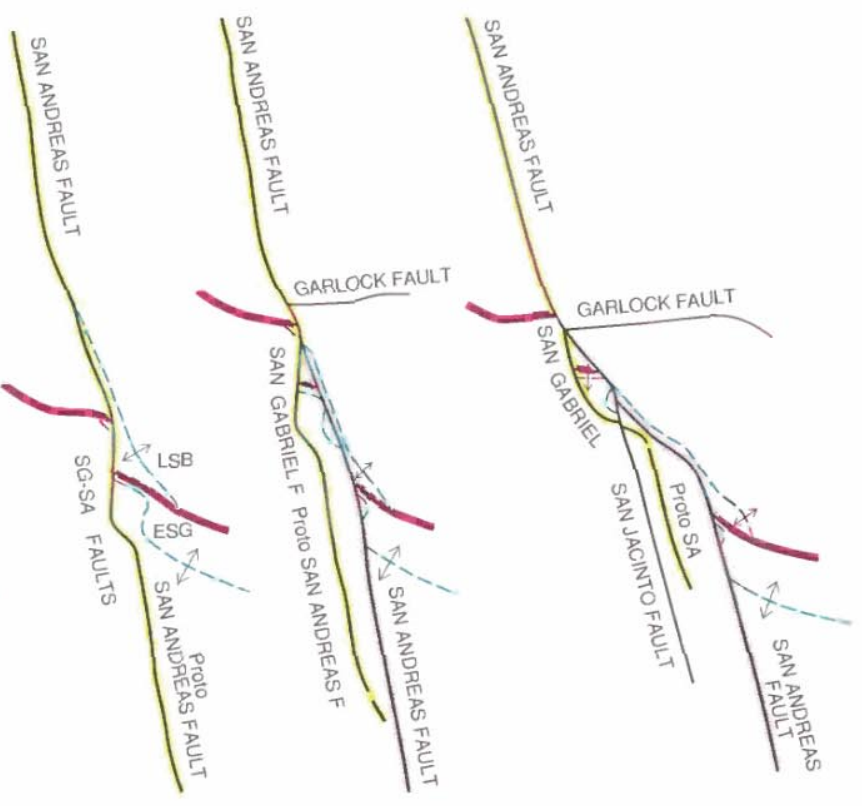

Iy 2-0 Ma-inception of modern southern-California segment of the San Andreas fault, displaying $220 \mathrm{~km}$ of right-lateral displacement. F, Approximately 2-0 Ma-left-lateral bending of Transverse Ranges segment of the San Andreas fault and development of the San Jacinto fault. Faults: CW, Clemens Well; F, Fenner; SA, San Andreas; SF, San Francisquito; SG, San Gabriel. Antiform segments: CM, Chocolate Mountains; ESG, Eastern San Gabriel Mountains; LSB, Little San Bernardino Mountains; O, Orocopia Mountains; SP, Sierra Pelona; SS, Sierra de Salinas. 
at least the Mesozoic (Engebretson and others, 1985). According to this theory, the crust of Earth is a mosaic of interacting rigid plates. Boundaries between the plates are spreading ridges where the plates pull apart, oceanic trenches above subduction zones where the plates converge, and transform faults where the plates slide laterally past one another. These boundaries are the loci of seismic activity. The corollaries of the theory of global plate tectonics have been enormously valuable as an aid in recognizing the genetic environments of the various terranes, whether oceanic or continental crust, volcanic island arc, or oceanic trench. The presence of multiple ophiolite and blueschist belts along parts of the western margin of North America (Irwin, 1977) indicates that some of these terranes were subduction related during Paleozoic and Mesozoic time. Although much has been learned of the relative motions between the oceanic and continental rocks for the past $180 \mathrm{~m} . \mathrm{y}$. (for example, Engebretson and others, 1985), the tectonics of the zone of allochthonous terranes is so complex, and the sites of origin of the various terranes generally so obscure, that much painstaking research remains to be done before the Paleozoic and Mesozoic margins of western North America can be palinspastically reassembled.

The tectonic setting of the continental margin during late Mesozoic time, before development of the San Andreas fault, is highly controversial. Some geologists (for example Dickinson, 1981) favor a model of highly convergent plate interaction to develop a continental margin of the Andean type (fig. 3.11). Others, however, interpret certain paleontologic and paleomagnetic evidence to indicate that some late Mesozoic rocks of the Coast Ranges were translated great distances northward from equatorial sites of origin during Late Jurassic time, before accretion to North America and deposition of the Great Valley sequence (Hopson and others, 1986). This movement is thought to have been followed in Late

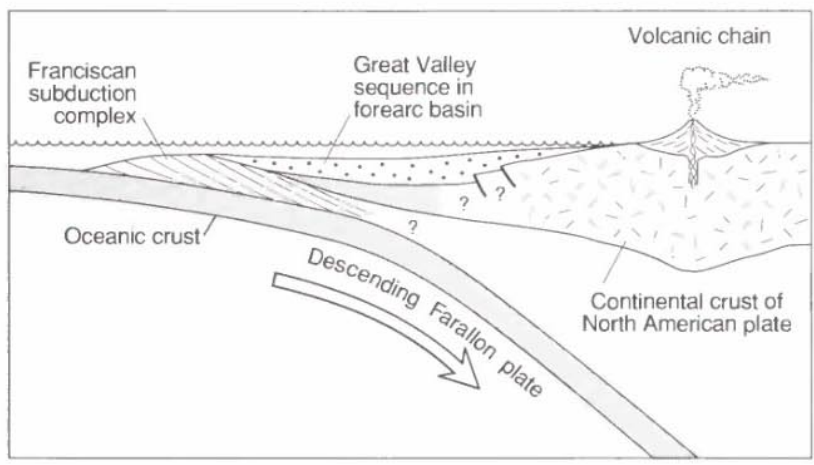

Figure 3.11.-Schematic diagram showing California as an Andeantype continental margin during late Mesozoic time (modified from Dickinson, 1981).
Cretaceous and early Tertiary time by a second episode of dextral translation during which part of the Franciscan assemblage was accreted and parts of the Coast Range ophiolite and overlying Great Valley sequence moved northward for distances as great as $1,120 \mathrm{~km}$ (McLaughlin and others, 1988).

The rates and relative directions of motion of the principal tectonic plates are based mainly on patterns of magnetic anomalies in the oceanic crust. These patterns indicate that a subduction-related trench lay offshore of western North America during early Tertiary time because of the convergence of the Farallon plate (see fig. 3.1 , and that strike-slip movement on faults of the San Andreas system began no earlier than approximately 30 $\mathrm{Ma}$ (late Oligocene), when the Pacific plate first impinged on the North American plate (McKenzie and Morgan, 1969; Atwater, 1970). Triple junctions formed at the point of contact of the Pacific plate with the North American plate and migrated to the northwest and southeast as subduction of the Farallon plate continued. These triple junctions are now approximately $2,500 \mathrm{~km}$ apart: The Mendocino triple junction is off the coast of northern California, and the Rivera triple junction is at the mouth of the Gulf of California. The relative motion along the transform fault that formed the lengthening boundary between the Pacific and North American plates was right lateral. This early transform movement probably was not along the modern trace of the San Andreas fault but must have been along other faults of the system that now lie mostly to the west and at the edge of the continent (fig. 3.12). The modern San Andreas fault apparently did not come into being in southern California until the opening of the Gulf of California during Pliocene time, about $4 \mathrm{Ma}$, since which time Baja California has moved $260 \mathrm{~km}$ away from mainland Mexico (Larson and others, 1968). The San Andreas fault is commonly referred to as the boundary between the Pacific and North American plates, which is true in the sense that the rocks on the west side of the fault are moving somewhat in concert with the Pacific plate, although those rocks actually are displaced fragments that once were part of the North American plate (fig. 3.13).

During the early development of the San Andreas fault system, the principal movement must have been along a transform fault that formed the boundary between rocks of the North American plate and newly formed oceanic crust of the Pacific plate as the triple junction migrated southward. At some point during southward migration of this triple junction, the transform apparently jumped eastward one or more times to positions within the North American plate, to become the northern section of the modern San Andreas fault. The modern trace of the San Andreas fault in central California probably had only minor slip until about $12.5-10 \mathrm{Ma}$ and probably was not 


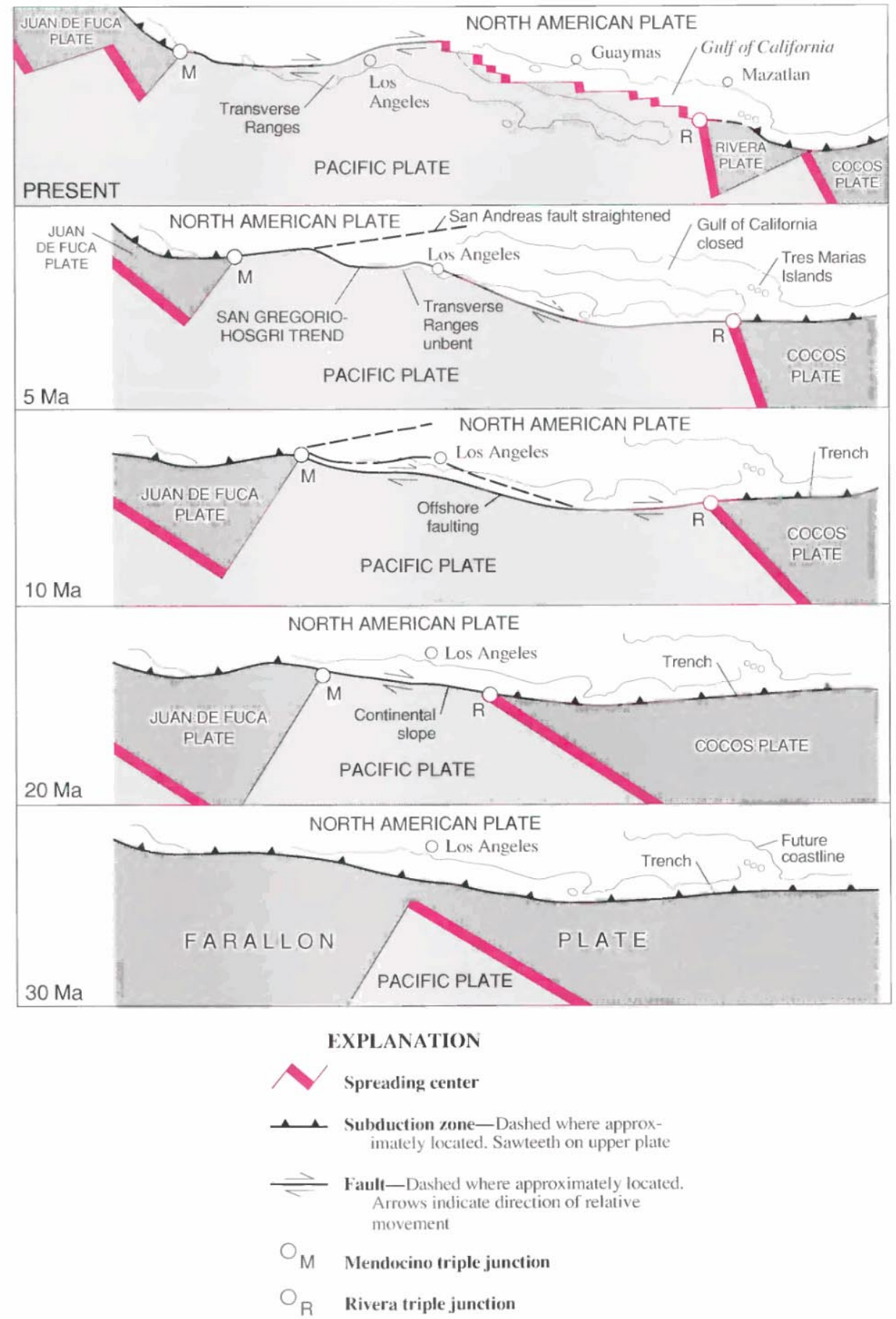

FIGURE 3.12.-Sequential diagrams showing plate-tectonic evolution of the San Andreas transform fault system (modified from Dickinson, 1981). Note that early transform faulting was west of the present-day San Andreas fault and presumably separated young oceanic rocks of the Pacific plate from rocks of the North American plate. Over time, the transform faulting has stepped eastward, and so virtually all the presently most active element, the present-day San Andreas fault, is now in rocks of North American plate aspect. In earlier diagrams, partial outline of the Gulf of California, which did not exist before 5 $\mathrm{Ma}$, is shown for reference only. 
the strand of dominant slip before 7.5-5 Ma (Dickinson $\mid$ San Andreas fault was formed by similar eastward jumps and Snyder, 1979). The southern section of the modern of the transform fault, resulting in opening of the Gulf of

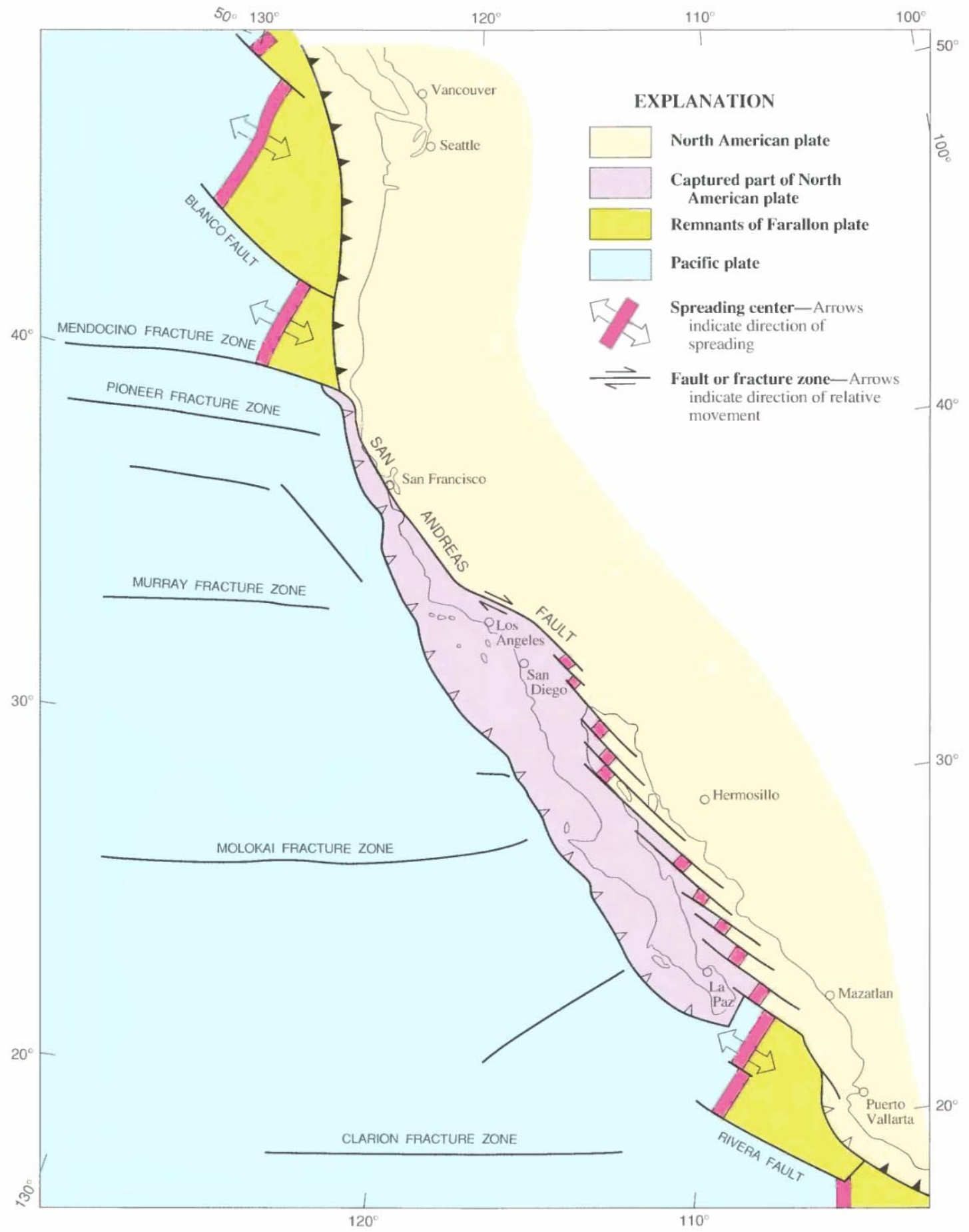


California. Some of the major faults that lie between the San Andreas fault and the continental margin may represent these earlier positions of the transform, and some of these faults are still active. Possible candidates for such early intermediate faults include, among others, the San Gregorio-Hosgri fault in central and northern California and the Elsinore and offshore faults in southern California. With our present state of knowledge, however, it is unclear which of the many faults in the Coast Ranges are early faults of the San Andreas system and which may have formed before mid-Tertiary initiation of the San Andreas system.

The models of McKenzie and Morgan (1969) and Atwater (1970) have been widely used in relating Pacific plate interactions to the tectonics and geology of California and other parts of western North America (fig. 3.1). A more actualistic developmental sequence of diagrams was drawn by Dickinson (1981), in which the position of an early San Andreas fault is shown before the opening of the Gulf of California (fig. 3.12). In figures 3.1 and 3.12, the boundary between the Pacific and North American plates is shown as a transform fault that was formed by the passage of migrating triple junctions. However, marine geologic studies offshore of California between Point Conception and Cape Mendocino indicate that this old interface between the Pacific and North American plates is an inactive east-dipping low-angle fault which is interpreted to be a fossil subduction zone (McCulloch, 1987). There, magnetic stripes of the oceanic (Pacific) plate can be traced some distance eastward-locally as much as $30 \mathrm{~km}$-beneath the leading edge of the upper (North American) plate, and both plates are covered along the suture by a thin veneer of undeformed Miocene strata. The presence of a Miocene or older subduction zone rather than a transform fault at the ocean-continent interface is difficult to reconcile with a strict interpretation of McKenzie and Morgan's (1969) and related models, although it is interpreted to indicate that the transform motion was accompanied by oblique convergence (McCulloch, 1987).

The present overall rate of relative movement between the Pacific and North American plates, earlier thought to be about $6 \mathrm{~cm} / \mathrm{yr}$ (Atwater, 1970) or $5.6 \mathrm{~cm} / \mathrm{yr}$ (Minster

$<$

FiguRE 3.13.-Western margin of North America, showing tectonic capture of part of the North American plate by the Pacific plate (plate-tectonic base modified from Moore, 1981). Captured part of the North American plate is now moving northwesterly with the Pacific plate and is commonly considered to be part of the Pacific plate. West boundary of captured part of the North American plate is inactive early transform fault with component of subduction (open sawteeth; see text); interfaces of the North American plate with remnants of the Farallon plate are active subduction zones (solid sawteeth). and Jordan, 1978), is now thought to be more likely about $4.8 \mathrm{~cm} / \mathrm{yr}$ (DeMets and others, 1987). This rate probably has varied over time (Atwater and Molnar, 1973); however, the rate of relative motion between the two plates is substantially greater than the slip rates based on measured offsets of geologic features along the San Andreas fault. For example, the $315-\mathrm{km}$ offset of the lower Miocene Pinnacles and Neenach Volcanic Formations indicates a minimum overall slip rate of 1.3 to 1.4 $\mathrm{cm} / \mathrm{yr}$ (Matthews, 1976), and the offset of the channel of Wallace Creek by the San Andreas fault in central California indicates a slip rate of about $3.4 \mathrm{~cm} / \mathrm{yr}$ for the past 3,700 $\mathrm{yr}$ and of $3.6 \mathrm{~cm} / \mathrm{yr}$ for the past $13,250 \mathrm{yr}$ (Sieh and Jahns, 1984). Geodetic-survey measurements indicate that slip rates during the past $90 \mathrm{yr}$ in central California average $2.9 \mathrm{~cm} / \mathrm{yr}$ for the upper $15 \mathrm{~km}$ of crust but $3.7 \mathrm{~cm} / \mathrm{yr}$ below $15 \mathrm{~km}$ (Thatcher, 1977). The discrepancy between the rate of relative motion between the Pacific and North American plates and the much smaller slip rate on the San Andreas fault has been noted by many workers (for example, Atwater, 1970; Minster and Jordan, 1978; Weldon and Humphreys, 1986). Part of the total slip along the boundary between the Pacific and North American plates probably is occurring in small increments along other faults in a broad zone of interaction that may extend from the continental margin eastward even as far as the Basin and Range province.

\section{REFERENCES CITED}

Allen, C.R., 1968, The tectonic environments of seismically active areas along the San Andreas fault system, in Dickinson, W.R., and Grantz, Arthur, eds., Proceedings of conference on geologic problems of San Andreas fault system: Stanford, Calif., Stanford University Publications in the Geological Sciences, v. 11, p. 70-82.

Alvarez, Walter, Kent, D.V., Silva, I.P., Schweickert, R.A., and Larson, R.A.,

- 1980, Franciscan Complex limestone deposited at $17^{\circ}$ south paleolatitude: Geological Society of America Bulletin, pt. 1, v. 91, no. 8 , p. $476-484$.

Atwater, Tanya, 1970, Implications of plate tectonics for the Cenozoic tectonic evolution of western North America: Geological Society of America Bulletin, v. 81, no. 12, p. 3513-3536.

Atwater, Tanya, and Molnar, Peter, 1973, Relative motion of the Pacific and North American plates deduced from sea-floor spreading in the Atlantic, Indian, and South Pacific Oceans, in Kovach, R.L., and Nur, Amos, eds., Proceedings of the conference on tectonic problems of the San Andreas fault system: Stanford, Calif., Stanford University Publications in the Geological Sciences, v. 13, p. 136-148.

Bailey, E.H., Blake, M.C., Jr., and Jones, D.L., 1970, On-land Mesozoic oceanic crust in California Coast Ranges, in Geological Survey research, 1970: U.S. Geological Survey Professional Paper 700-C, p. C70-C81.

Bailey, E.H., Irwin, W.P., and Jones, D.L., 1964, Franciscan and related rocks, and their significance in the geology of western California: California Division of Mines and Geology Bulletin 183, $177 \mathrm{p}$. 
Blake, M.C,, Jr., Irwin, W.P., and Coleman, R.G., 1967, Upside-down metamorphic zonation, blueschist facies, along a regional thrust in California and Oregon, in Geological Survey research, 1967: U.S. Geological Survey Professional Paper 575-C, p. C1-C9.

Blome, C.D., and Irwin, W.P., 1983, Tectonic significance of late Paleozoic to Jurassic radiolarians from the North Fork terrane, Klamath Mountains, California, in Stevens, C.H., ed., PreJurassic rocks in western North American suspect terranes: Los Angeles, Society of Economic Paleontologists and Mineralogists, Pacific Section, p. 77-89.

Burchfiel, B.C., and Davis, G.A., 1981, Mojave Desert and environs, in Ernst, W.G., ed., The geotectonic development of California (Rubey volume 1): Englewood Cliffs, N.J., Prentice-Hall, p. 217-252.

Burford, R.O., and Sharp, R.V., 1982, Slip on the Hayward and Calaveras faults determined from offset powerlines, in Hart, E.W., Hirschfeld, S.E., and Schulz, S.S., eds., Conference on Earthquake Hazards in the Eastern San Francisco Bay Area, Hayward, Calif., 1982, Proceedings: California Division of Mines and Geology Special Publication 62, p. 261-269.

Byerlee, J.D., and Brace, W.F., 1972, Fault stability and pore pressure: Seismological Society of America Bulletin, v. 62, no. 2, p. 657-660.

Carter, Bruce, and Silver, L.T., 1971, Post-emplacement structural history of the San Gabriel anorthosite complex [abs.]: Geological Society of America Abstracts with Programs, v. 3, no. 2, p. 92-93.

Champion, D.E., Howell, D.G., and Gromme', C.S., 1984, Paleomagnetic and geologic data indicating $2500 \mathrm{~km}$ of northward displacement for the Salinian and related terranes, California: Journal of Geophysical Research, v. 89, no. B9, p. 7736-7752.

Clarke, S.H., Jr., and Nilsen, T.H., 1973, Displacement of Eocene strata and implications for the history of offset along the San Andreas fault, central and northern California, in Kovach, R.L., and Nur, Amos, eds., Proceedings of the conference on tectonic problems of the San Andreas fault system: Stanford, Calif., Stanford University Publications in the Geological Sciences, v. 13, p. 358-367.

Coney, P.J., Jones, D.L., and Monger, J.W.H., 1980, Cordilleran suspect terranes: Nature, v. 288, no. 5789, p. 329-333.

Crowell, J.C., 1962, Displacement along the San Andreas fault, California: Geological Society of America Special Paper 71, 61 p.

- 1981, An outline of the tectonic history of southeastern California, in Ernst, W.G., ed., The geotectonic development of California (Rubey volume 1): Englewood Cliffs, N.J., Prentice-Hall, p.583-600.

DeMets, Charles, Gordon, R.G., Stein, Seth, and Argus, D.F., 1987, A revised estimate of Pacific-North American motion and implications for western North American plate boundary zone tectonics: Geophysical Research Letters, v. 14, no. 9, p. 911-914.

Dibblee, T.W., Jr., 1980, Geology along the San Andreas fault from Gilroy to Parkfield, in Streitz, Robert, and Sherburne, R.W., eds., Studies of the San Andreas fault zone in northern California: California Division of Mines and Geology Special Report 140, p. 3-18.

Dickinson, W.R., 1981, Plate tectonics and the continental margin of California, in Ernst, W.G., ed., The geotectonic development of California (Rubey volume 1): Englewood Cliffs, N.J., PrenticeHall, p. 1-28.

Dickinson, W.R., and Snyder, W.S., 1979, Geometry of triple junctions related to San Andreas transform: Journal of Geophysical Research, v. 84, no. B2, p. 561-572.

Ehlig, P.L., 1981, Origin and tectonic history of the basement terrane of the San Gabriel Mountains, central Transverse Ranges, in Ernst, W.G., ed., The geotectonic development of California
(Rubey volume 1): Englewood Cliffs, N.J., Prentice-Hall, p. 253-283.

Elders, W.A., Rex, R.W., Meidav, Tsvi, Robinson, P.T., and Biehler, Shawn, 1972, Crustal spreading in southern California: The Imperial Valley and the Gulf of California formed by the rifting apart of a continental plate: Science, v. 178, no. 4056, p. 15-24.

Engebretson, D.C., Cox, A.V., and Gordon, R.G., 1985, Relative motions between oceanic and continental plates in the Pacific basin: Geological Society of America Special Paper 206, 59 p.

Frizzell, V.A., and Brown, R.D., 1976, Map showing recently active breaks along the Green Valley fault, Napa and Solano Counties, California: U.S. Geological Survey Miscellaneous Field Studies Map MF-743, scale 1:24,000.

Fuis, G.S., Mooney, W.D., Healey, J.H., McMechan, G.A., and Lutter, W.J., 1982, Crustal structure in the Imperial Valley region, in The Imperial Valley, California, earthquake of October 15, 1979: U.S. Geological Survey Professional Paper 1254, p. 25-49.

Grommé, C.S., 1984, Paleomagnetism of Franciscan basalt, Marin County, California, in Blake, M.C., Jr., ed., Franciscan geology of northern California: Los Angeles, Society of Economic Paleontologists and Mineralogists, Pacific Section, v. 43, p. 113-119.

Hamilton, Warren, 1969, Mesozoic California and the underflow of Pacific mantle: Geological Society of America Bulletin, v. 80, no. 12 , p. 2409-2430.

Harsh, P.W., and Burford, R.O., 1982, Alinement-array measurements of fault slip in the eastern San Francisco Bay area, California, in Hart, E.W., Hirschfeld, S.E., and Schulz, S.S., eds., Conference on Earthquake Hazards in the Eastern San Francisco Bay Area, Hayward, Calif., 1982, Proceedings: California Division of Mines and Geology Special Publication 62, p. 251-260.

Haxel, G.B., and Dillon, J.T., 1978, The Pelona-Orocopia schist and Vincent-Chocolate Mountain thrust system, southern California, in Howell, D.G., and McDougall, K.A., eds., Mesozoic paleogeography of the Western United States: Pacific Coast Paleogeography Symposium 2: Los Angeles, Society of Economic Paleontologists and Mineralogists, Pacific Section, p. 453-469.

Haxel, G.B., Tosdal, R.M., and Dillon, J.T., 1985, Tectonic setting and lithology of the Winterhaven Formation: A new Mesozoic stratigraphic unit in southeasternmost California and southwestern Arizona: U.S. Geological Survey Bulletin 1599, 19 p.

Hill, M.L., and Dibblee, T.W., Jr., 1953, San Andreas, Garlock, and Big Pine faults, California-a study of the character, history, and tectonic significance of their displacements: Geological Society of America Bulletin, v. 64, no. 4, p. 443-458.

Hopson, C.A., Mattinson, J.M., and Pessagno, E.A., Jr., 1981, Coast Range ophiolite, western California, in Ernst, W.G., ed., The geotectonic development of California (Rubey volume 1): Englewood Cliffs, N.J., Prentice-Hall, 418-510.

Hopson, C.A., Beebe, W.J., Mattinson, J.M., Pessagno, E.A., Jr., and Blome, C.D., 1986, Coast Range ophiolite: Jurassic tectonics [abs.]: Eos (American Geophysical Union Transactions), v. 67, no. 44, p. 1232.

Huffman, O.F., 1972, Lateral displacement of Upper Miocene rocks and the Neogene history of offset along the San Andreas fault in central California: Geological Society of America Bulletin, v. 83, no. 10, p. 2913-2946.

Irwin, W.P., 1972, Terranes of the western Paleozoic and Triassic belt in the southern Klamath Mountains, California, in Geological Survey research, 1972: U.S. Geological Survey Professional Paper 800-C, p. C103-C111.

1977, Ophiolitic terranes of California, Oregon, and Nevada, in Coleman, R.G., and Irwin, W.P., eds., North American ophiolites: Oregon Department of Geology and Mineral Industries Bulletin 95 , p. $75-92$. 
Irwin, W.P., and Barnes, Ivan, 1975, Effect of geologic structure and metamorphic fluids on seismic behavior of the San Andreas fault system in central and northern California: Geology, v. 3, no. 12, p. 713-716.

1980, Tectonic relations of carbon dioxide discharges and earthquakes: Journal of Geophysical Research, v. 85, no. B6, p. 31153121.

Irwin, W.P., Jones, D.L., and Pessagno, E.A., Jr., 1977, Significance of Mesozoic radiolarians from the pre-Nevadan rocks of the southern Klamath Mountains, California: Geology, v. 5, no. 9, p. $557-562$.

Jennings, C.W., Strand, R.G., and Rogers, T.H., compilers, 1977, Geologic map of California: Sacramento, California Division of Mines and Geology, scale 1:750,000.

King, P.B., 1959, The evolution of North America: Princeton, N.J., Princeton University Press, $190 \mathrm{p}$.

Larson, R.L., Menard, H.W., and Smith, S.M., 1968, Gulf of California: A result of ocean-floor spreading and transform faulting: Science, v. 161 , no. 3843 , p. $781-784$.

Lawson, A.C., chairman, 1908, The California earthquake of April 18, 1906: Report of the State Earthquake Investigation Commission: Carnegie Institution of Washington Publication 87, 2 v.

Matthews, Vincent, III, 1976, Correlation of Pinnacles and Neenach Volcanic Formations and their bearing on San Andreas fault problem: American Association of Petroleum Geologists Bulletin, v. 60 , no. 12 , p. $2128-2141$.

Matti, J.C., Frizzell, V.A., and Mattinson, J.M., 1986, Distinctive Triassic megaporphyritic monzogranite displaced $160+10 \mathrm{~km}$ by the San Andreas fault, southern California: A new constraint for palinspastic reconstructions [abs.]: Geological Society of America Abstracts with Programs, v. 18, no. 2, p. 154

Matti, J.C., Morton, D.M., and Cox, B.F., 1985, Distribution and geologic relations of fault systems in the vicinity of the central Transverse Ranges, southern California: U.S. Geological Survey Open-File Report 85-365, scale 1:250,000, 2 sheets.

Mattinson, J.M., and James, E.W., 1985, Salinian block U/Pb age and isotopic variations: Implications for origin and emplacement of the Salinian terrane, in Howell, D.G., ed., Tectonostratigraphic terranes of the circum-Pacific region (Earth Science Series, no. 1): Houston, Tex., Circum-Pacific Council for Energy and Mineral Resources, p. 215-226.

McCulloch, D.S., 1987, Regional geology and hydrocarbon potential of offshore central California, chap. 16 of Scholl, D.W., Grantz, Arthur, and Vedder, J.G., eds., Geology and resource potential of the continental margin of western North America and adjacent ocean basins-Beaufort Sea to Baja California (Earth Science Series, no. 6): Houston, Tex., Circum-Pacific Council for Energy and Mineral Resources, p. 353-401.

McKenzie, D.P., and Morgan, W.J., 1969, Evolution of triple junctions: Nature, v. 224, no. 5215, p. 125-133.

McLaughlin, R.J., Blake, M.C., Jr., Griscom, Andrew, Blome, C.D., and Murchey, B.L., 1988, Tectonics of formation, translation, and dispersal of the Coast Range ophiolite of California: Tectonics, v. 7, no. 5, p. 1033-1056.

McLaughlin, R.J., Kling, S.A., Poore, R.Z., McDougall, K.A., and Beutner, E.C., 1982, Post-middle Miocene accretion of Franciscan rocks, northwestern California: Geological Society of America Bulletin, v. 93, no. 7, p. 595-605.

Minster, J.B., and Jordan, T.H., 1978, Present-day plate motions: Journal of Geophysical Research, v. 83, no. B11, p. 5331-5354. Moore, G.W., 1981, Plate perimeters and motion vectors, in Drummond, K.J., chairman, Plate-tectonic map of the circumPacific region: Tulsa, Okla., American Association of Petroleum Geologists, scale 1:10,000,000.
Muffler, L.J.P., and Doe, B.R., 1968, Composition and mean age of detritus of the Colorado River delta in the Salton Trough, southeastern California: Journal of Sedimentary Petrology, v. 38, no. 2, p. 384-399.

Nason, R.D., 1973, Fault creep and earthquakes on the San Andreas fault, in Kovach, R.L., and Nur, Amos, Proceedings of the conference on tectonic problems of the San Andreas fault system: Stanford, Calif., Stanford University Publications in the Geological Sciences, v. 13, p. 275-285.

Nason, R.D., and Tocher, Don, 1970, Measurement of movement on the San Andreas fault, in Mansinha, Lalu, Smylie, D.E., and Beck, A.E., eds., Earthquake displacement fields and the rotation of the earth: Dordrecht, Netherlands, Reidel, p. 246-254.

Noble, L.F., 1927, The San Andreas rift and some other active faults in the desert region of southeastern California: Seismological Society of America Bulletin, v. 17, no. 1, p. 25-39.

Page, B.M., 1981, The southern Coast Ranges, in Ernst, W.G., ed., The geotectonic development of California (Rubey volume 1): Englewood Cliffs, N.J., Prentice-Hall, p. 329-417.

- 1982, Migration of Salinian composite block, California, and disappearance of fragments: American Journal of Science, v. 282, no. 10, p. 1694-1734.

Pessagno, E.A., Jr., Blome, C.D., and Longoria, J.F., 1984, A revised radiolarian zonation for the Upper Jurassic of western North America: Bulletins of American Paleontology, v. 87, no. 320, 51 p.

Powell, R.E., 1981, Geology of the crystalline basement complex, eastern Transverse Ranges, southern California: Constraints on regional tectonic interpretation: Pasadena, California Institute of Technology, Ph.D. thesis, 441 p.

Prescott, W.H., and Burford, R.O., 1976, Slip on the Sargent fault: Seismological Society of America Bulletin, v. 66, no. 3, p. 1013-1016.

Ross, D.C., 1978, The Salinian block: A Mesozoic granitic orphan in the California Coast Ranges, in Howell, D.G., and McDougall, K,A., eds., Mesozoic paleogeography of the western United States: Pacific Coast Paleogeography Symposium 2: Los Angeles, Society of Economic Paleontologists and Mineralogists, Pacific Section, p. 509-522.

1984, Possible correlations of basement rocks across the San Andreas, San Gregorio-Hosgri, and Rinconada-Reliz-King City faults, California: U.S. Geological Survey Professional Paper 1317, $37 \mathrm{p}$.

Ross, D.C., Wentworth, C.M., and McKee, E.H., 1973, Cretaceous mafic conglomerate near Gualala offset 350 miles by San Andreas fault from oceanic crustal source near Eagle Rest Peak, California: U.S. Geological Survey Journal of Research, v. 1, no. 1, p. 45-52.

Schermer, E.R., Howell, D.G., and Jones, D.L., 1984, The origin of allochthonous terranes: Perspectives on the growth and shaping of continents: Annual Review of Earth and Planetary Sciences, v. 12, p. $107-131$.

Sieh, K.E., and Jahns, R.H., 1984, Holocene activity of the San Andreas fault at Wallace Creek, California: Geological Society of America Bulletin, v. 95, no. 8, p. 883-896.

Silver, L.T., 1966, Preliminary history for the crystalline complex of the central Transverse Ranges, Los Angeles County, California [abs.]: Geological Society of America, Annual Meeting, 79th, San Francisco, 1966, Program, p. 201-202.

- 1971, Problems of crystalline rocks of the Transverse Ranges [abs.]: Geological Society of America Abstracts with Programs, v. 3, no. 2, p. 193-194.

Spittler, T.E., and Arthur, M.A., 1973, Post early Miocene displacement along the San Andreas fault in southern California, in Kovach, R.L., and Nur, Amos, eds., Proceedings of the conference on tectonic problems of the San Andreas fault system: 
Stanford, Calif., Stanford University Publications in the Geological Sciences, v. 13, p. 374-382.

Stanley, R.G., 1987, New estimates of displacement along the San Andreas fault in central California based on paleobathymetry and paleogeography: Geology, v. 15, no. 2, p. 171-174.

Thatcher, Wayne, 1977, Secular deformation, episodic movements and relative plate motion in southern California [abs.]: Eos (American Geophysical Union Transactions), v. 58, no. 6, p. 496.

Turner, D.L., 1970, Potassium-argon dating of Pacific coast Miocene foraminiferal stages, in Bandy, L.L., ed., Radiometric dating and paleontologic zonation: Geological Society of America Special Paper 124, p. 91-129.

U.S. Geological Survey and California Division of Mines and Geology, compilers, 1966, Geologic map of California: U.S. Geological Survey Miscellaneous Geologic Investigations Map I-512, scale $1: 2,500,000$.
Wallace, R.E., 1949, Structure of a portion of the San Andreas rift in southern California: Geological Society of America Bulletin, v. 60, no. 4 , p. $781-806$.

1970, Earthquake recurrence intervals on the San Andreas fault: Geological Society of America Bulletin, v. 81, no. 10, p. 2875-2889.

Weldon, R.J., and Humphreys, E.D., 1986, A kinematic model of southern California: Tectonics, v. 5, no. 1, p. 33-48.

Wentworth, C.M., 1968, Upper Cretaceous and Lower Tertiary strata near Gualala, California, and inferred large right slip on the San Andreas fault, in Dickinson, W.R, and Grantz, Arthur, eds. Proceedings of conference on geologic problems of San Andreas fault system: Stanford, Calif., Stanford University Publications in the Geological Sciences, v. 11, p. 130-143.

Wilson, J.T., 1965, A new class of faults and their bearing on continental drift: Nature, v. 207 , no. 4995 , p. $343-347$. 


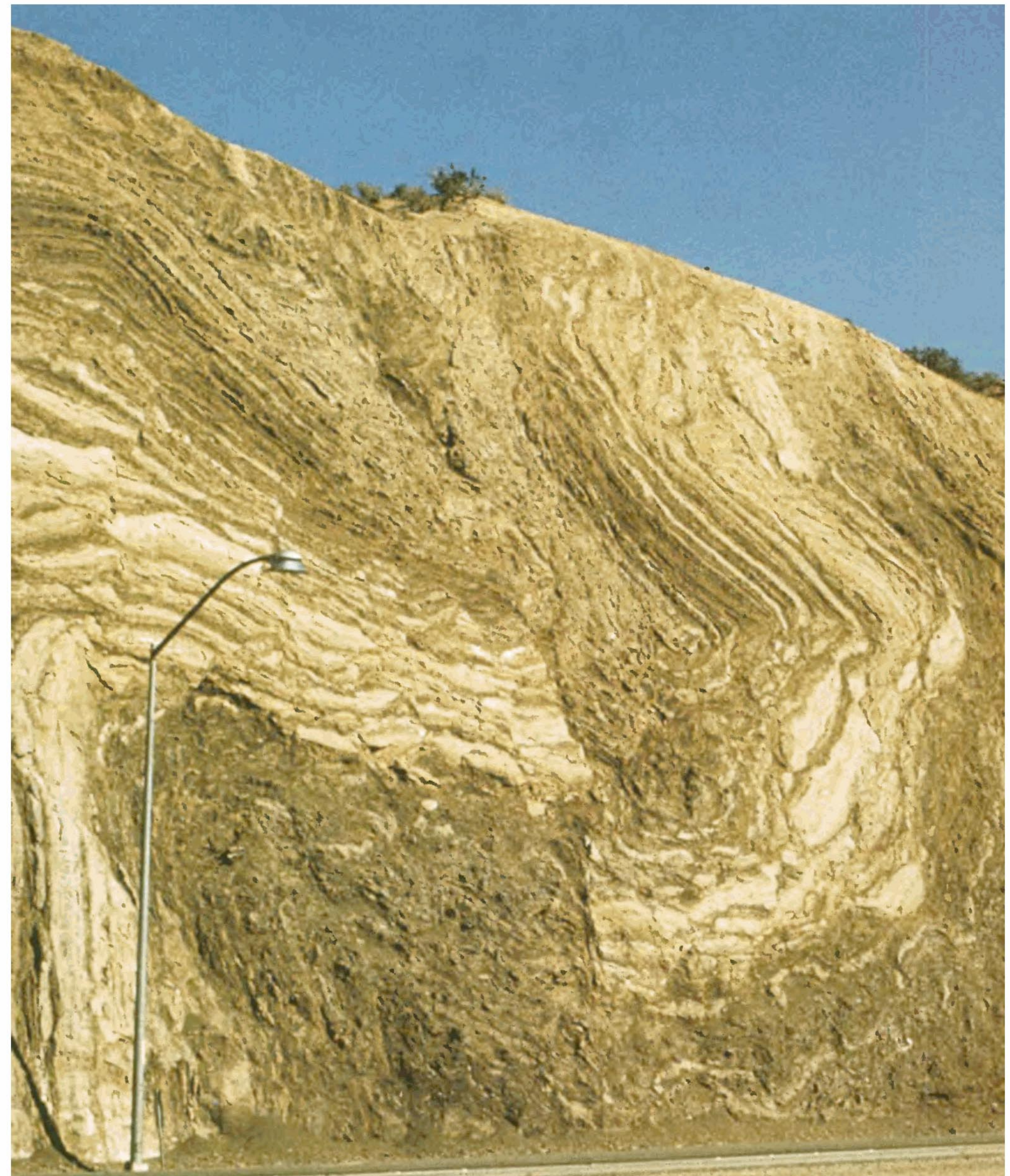



$D$ isplaced or deformed rock units and landforms record the past 2 m.y. of faulting, folding, uplift, and subsidence in California. Properly interpreted, such evidence provides a quantitative basis for predicting future earthquake activity and for relating many diverse structures and landforms to the $5 \mathrm{~cm} / \mathrm{yr}$ of horizontal motion at the boundary between the North American and Pacific plates.

\section{QUATERNARY DEFORMATION}

BY ROBERT D. Brown, JR.

\section{CONTENTS}

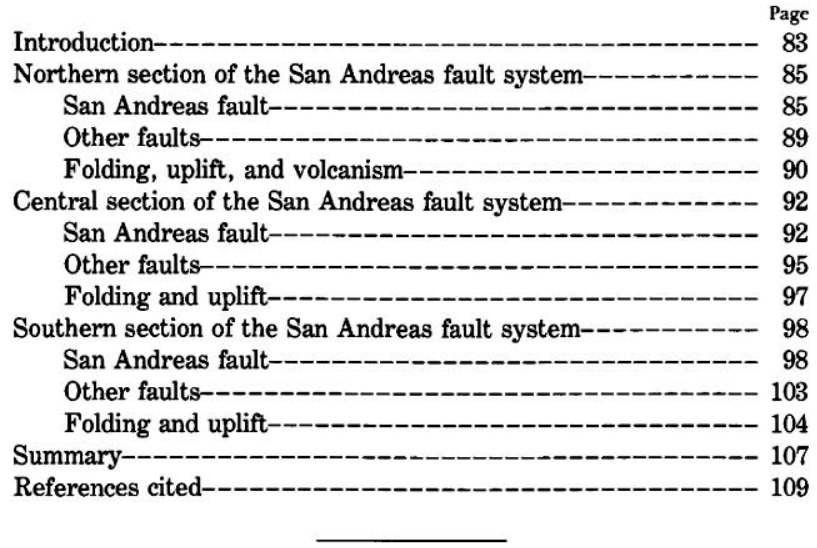

\section{INTRODUCTION}

Modern techniques of geologic dating and expanded research on earthquake hazards have greatly improved our knowledge of the San Andreas fault system. Much of this new knowledge has been gained since 1965, and that part which concerns crustal deformation during the past $2 \mathrm{~m} . \mathrm{y}$. is briefly summarized here.
In emphasizing recent work, I cite only a few of those earlier investigators who first recorded the extent and timing of deformation in upper Cenozoic deposits. Their contributions deserve a more complete accounting, and in several works cited herein such credit is given, most thoroughly by Wahrhaftig and Birman (1965). Also especially important in understanding the framework of the fault system are the $1: 250,000$-scale, $1^{\circ}$ by $2^{\circ}$ sheets of the "Geologic Atlas of California" published by the California Division of Mines and Geology, the 1:750,000scale "Geologic Map of California" (Jennings, 1977), and the 1:750,000-scale "Fault Map of California" (Jennings, 1975).

The Quaternary deformation processes-chiefly faulting, folding, and uplift-represent crustal changes that in many places continue today but at barely perceptible rates. The perspective of 2 m.y. of geologic time permits us to detect and measure these processes, and where historical deformation is evident-as shown by seismology, geodetic studies, or geologic investigations of recent earthquakes - the Quaternary record provides an independent check on the reliability of our observations and measurements. More importantly, we also use the Quaternary viewpoint to sketch the outlines of the currently active fault system, its intact crustal elements and major active faults, and how these faults propagate and change over time. From such evidence we can better understand

4 Figure 4.1. - Strata within a few hundred meters of the San Andreas fault are highly deformed. Here, folded and faulted beds of Pliocene age on the north side of the San Andreas fault are exposed in a roadcut along California Highway 14 just south of Palmdale along the southern margin of the Mojave Desert. Photograph by R.E. Wallace, U.S. Geological Survey. 
the pre-Quaternary history of the system and build the predictive kinematic models needed for earthquake hazard assessment.

Evidence of Quaternary deformation comes chiefly from the observed displacement of strata or geomorphic features (fig. 4.1). Where this displacement can be dated or, at least, bracketed in time, the age of deformation can be established, and its rate-generally an average-can be determined. In this report, most deformation rates are converted to units of centimeters per year, in part to facilitate comparison of different data sets but also because the dominant process, strike slip on major faults, is conveniently expressed in such units. Both the amount of displacement and the materials used to determine the age of displaced geologic markers require careful geologic analysis to ensure that field relations are unequivocal and correctly interpreted; the most reliable deformation rates depend on highly detailed analyses of local stratigraphy, which provide multiple measures of displacement over broad timespans, typically thousands to tens of thousands of years.

Deposits of Quaternary age can be dated by several methods, most of which ultimately depend on geochemical analyses that require highly sophisticated laboratory practices and expertise, as well as carefully chosen samples. The principal methods of dating Pleistocene and Holocene deposits within the San Andreas fault system (fig. 4.2) include radiocarbon, soil chronostratigraphy, correlation with standard sea-level stages (chiefly used for uplifted marine terraces), tephrochronology, and mammalian and invertebrate paleontology; supplementary techniques include paleomagnetism, uranium-series analysis, and amino-acid racemization. The underlying theory and limitations of these methods (for example, Pierce, 1986) are beyond the scope of this review. Each method, however, differs in resolving power, the timespan over which it is effective, and applicability to different rock types.

Difficulties in dating deformed Quaternary deposits are not the only deterrent to reconstructing the history of faulting. Large areas within the fault system are nearly devoid of Quaternary deposits; others are masked by landslide deposits, which conceal Quaternary folds and faults. Few published geologic maps differentiate between faults with Quaternary movement and those that have long been inactive, and for even the best known faults our knowledge of Quaternary faulting is still incomplete. Quaternary reverse and thrust faults, more difficult to identify and map than their strike-slip counterparts, are surely underrepresented on published geologic maps and in the literature.

Our knowledge of Quaternary deformation is thus incomplete and biased. We have learned much, and are rapidly learning more, about the Holocene and latest
Pleistocene, but the view much beyond the past $100 \mathrm{ka}$ is still poorly resolved. Despite the problems, the results of the past 2 decades of Quaternary research have brought

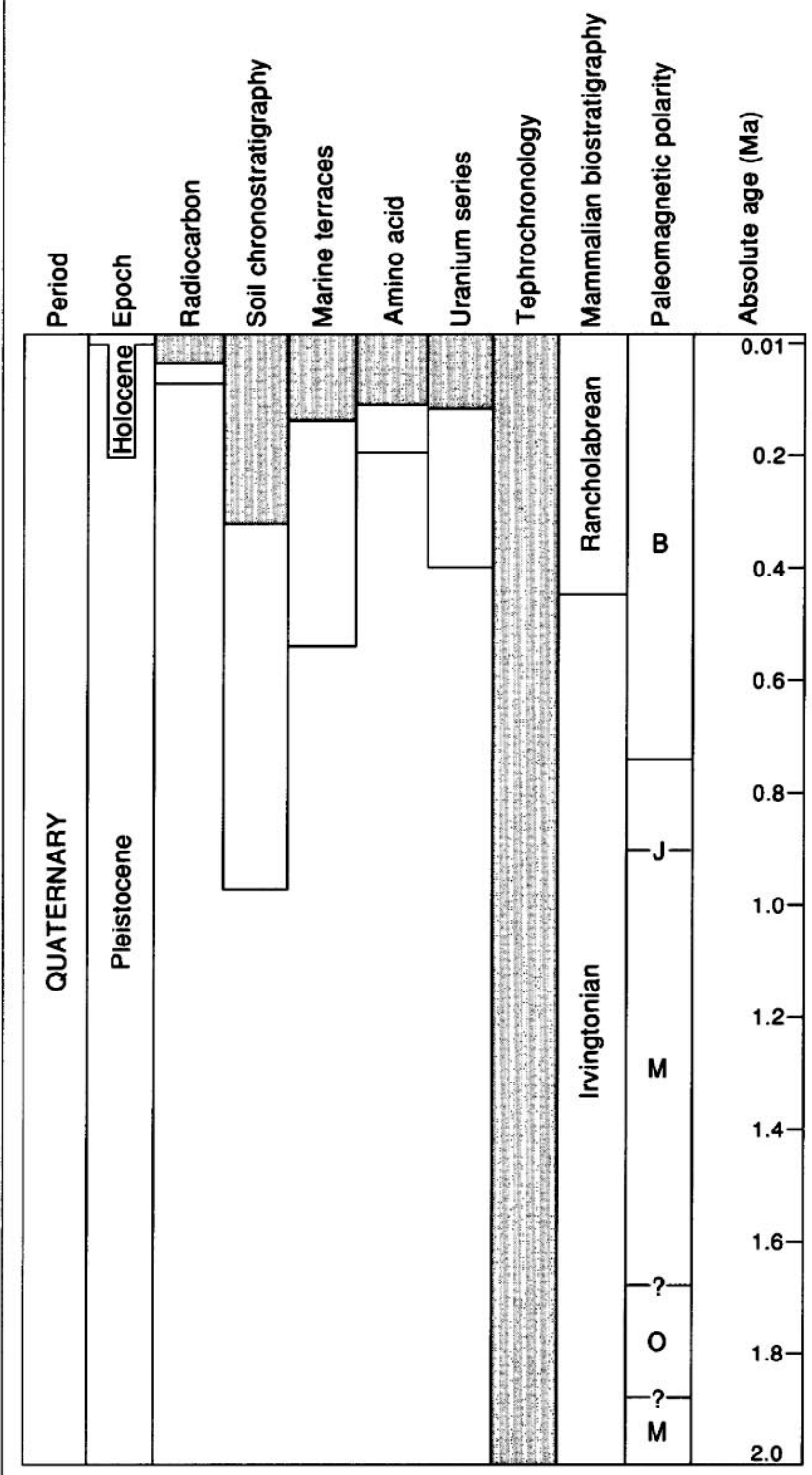

FIGURE 4.2.-Dating methods used in studies of the Quaternary deposits of the San Andreas fault system. Shading shows principal methods and timespans over which they have been most effectively used; open bars indicate potential range of the methods. Other available methods of Quaternary dating, some of which are not shown, either are little used or have produced few or no reported data on Quaternary deformation within the fault system. Paleomagnetic polarities: B, Brunhes Normal-Polarity Chron; J, Jaramillo NormalPolarity Subchron; M, Matuyama Reversed-Polarity Chron; 0, Olduvai Normal-Polarity Subchron. 
new insights into the mechanics of the fault system and the promise of more discoveries yet to come.

\section{NORTHERN SECTION OF THE SAN ANDREAS FAULT SYSTEM}

\section{SAN ANDREAS FAULT}

The northern section of the San Andreas fault system, as defined here, extends from Punta Gorda, $40 \mathrm{~km}$ southeast of the Mendocino triple junction, to the northern Gabilan Range (fig. 4.3). This belt of Quaternaryand earlier-faulting and folding, about $120 \mathrm{~km}$ wide by $500 \mathrm{~km}$ long, includes the San Andreas, at least four major related faults, and several smaller faults, 5 to 20 $\mathrm{km}$ long. All of these faults displace Quaternary deposits or landforms, and all are seismically active. From west to east, major faults within the system are the San Gregorio, San Andreas, Hayward (and its northern, rightstepping extensions, the Rodgers Creek-Healdsburg and Maacama faults), Calaveras (and its northern, rightstepping extensions, the Concord and Green Valley faults), and an ill-defined, possibly discontinuous fault zone along the eastern margin of the Coast Ranges that includes, from north to south, the Stony Creek, Greenville, and Ortigalita faults.

The offshore counterpart of the main San Andreas fault, which trends seaward and westward from Punta Gorda to the Mendocino triple junction, represents the latest segment of the northward-growing transform. This east-west-trending, offshore segment of the fault is located chiefly on seismic and bathymetric evidence; it follows along the north face of the Gorda Escarpment (along lat $40^{\circ} 23^{\prime} \mathrm{N}$. and west of long $124^{\circ} 39^{\prime} \mathrm{W}$.) and the south wall of Mattole Canyon (from the east end of the Gorda Escarpment southeast to lat $40^{\circ} 17^{\prime}$ N., long $124^{\circ} 27^{\prime}$ W.), but water depths of as much as $2,000 \mathrm{~m}$, high

\section{EXPLANATION}

Alluvial and estuarine deposits (Quaternary) — Chiefly basin fill; may also include some Pliocene deposits

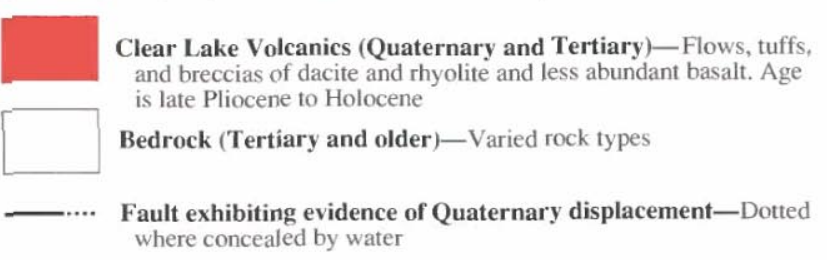

Figure 4.3.-Geologic sketch map of the northern Coast Ranges, central California, showing faults with Quaternary activity and basin deposits in northern section of the San Andreas fault system. Fault patterns are generalized, and only major faults are shown. Several Quaternary basins are fault bounded and aligned parallel to strikeslip faults, a relation most apparent along the Hayward-Rodgers Creek-Maacama fault trend. submarine relief, and sea-floor deposits of young sediment (Silver, 1971; McCulloch and others, 1985) obscure details of its Quaternary history.

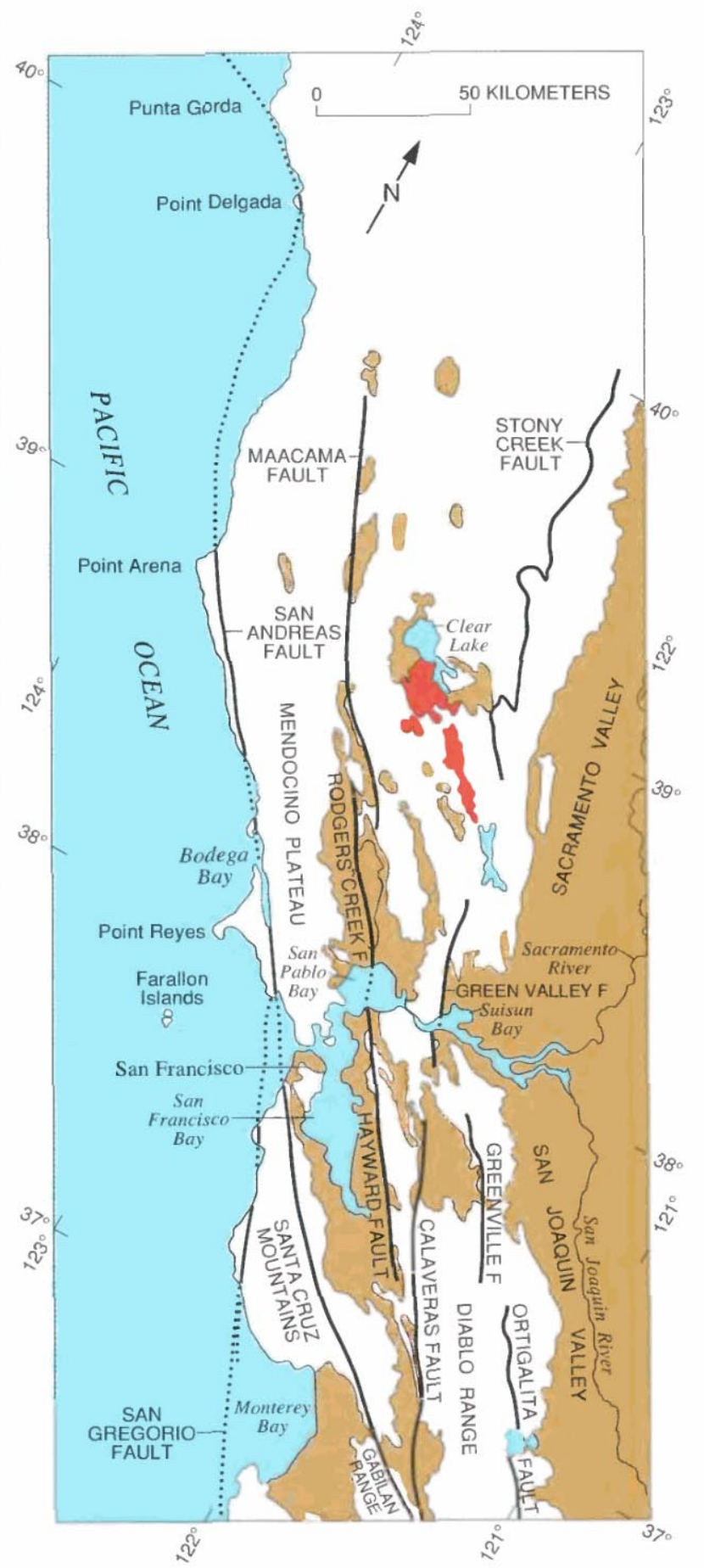


From Punta Gorda southward to Point Arena the fault is almost entirely off shore; its location is known from sea-floor features, coastal geomorphology, and relations at Point Delgada, where it locally intersects the coastline. A line of coastal bluffs, 350 to $850 \mathrm{~m}$ high and sloping $33^{\circ}-43^{\circ}$, trends N. $50^{\circ} \mathrm{W}$. for $20 \mathrm{~km}$ northwest of Point Delgada. At the base of the bluffline, Lajoie and others (1982) measured Holocene uplift rates of about $0.5 \mathrm{~cm} / \mathrm{yr}$ from dated molluscan fossils in beach ridges $30 \mathrm{~m}$ above present sea level. Seaward of the bluffs, the Spanish and Delgada Submarine Canyons head near the present coast, 2 to $3 \mathrm{~km}$ landward of the $100-\mathrm{m}$ bathymetric contour, which approximately defines the late Wisconsin sea level. Shoreward of this contour, both canyons are linear, and neither they nor the intervening sea floor exhibits evidence of vertical or horizontal displacement. These relations are consistent with a near-shore San Andreas fault, located in or near the surf zone and close to the base of the coastal bluffs. The unusually large component of vertical slip $(0.5 \mathrm{~cm} / \mathrm{yr}$, northeast side up) for this segment of the fault may result from its more westerly trend than that of segments farther south, which exhibit almost pure strike slip; or, as suggested by Merritts and Bull (1989), it may result from the late Quaternary passage of the Mendocino triple junction along this part of the coast.

The fault intersects the coastline about $6 \mathrm{~km}$ northwest of Point Delgada, cuts across the point, and locally separates upper Pleistocene marine terrace gravel and younger alluvium (McLaughlin and others, 1983) along the coast from intensely deformed bedrock inland. Other locations have been suggested (Curry and Nason, 1967; Beutner and others, 1980; McLaughlin and others, 1983) for the fault here, but several lines of independent evidence support this trend, including fault slip during the 1906 earthquake (Lawson and others, 1908, p. 54-58), the alignment of scarps, sags, and saddles along the 1906 fault trend, bedrock faulting colinear with 1906 faulting (Brown and Wolfe, 1972), and continuity to the north and south with offshore and nearshore evidence of recent faulting.

From Point Delgada southward to Point Arena, a distance of $125 \mathrm{~km}$, the fault is defined by aligned, chiefly west-facing scarps on the sea floor, the right-lateral deflection of Noyo Submarine Canyon, straight boundaries of irregular submarine topography, and a 2- to 5 -km-wide zone of disturbed reflective layers evident in continuous seismic-reflection profiles (Curray and Nason, 1967). The shapes and dimensions of sea-floor features, as shown by seismic-reflection profiles and modern bathymetric maps, resemble fault-formed features on land and provide similar evidence for right- lateral strike slip. The offshore data, however, are insufficient to determine the amount of Quaternary displacement.

Onland segments of the fault between Point Arena and the Gabilan Range exhibit abundant geomorphic and geologic evidence of Quaternary displacement, some of which can be translated into slip rates. Trunk streams, systematically displaced from their headwaters by at least $10 \mathrm{~km}$, record cumulative strike-slip faulting that must span much of Quaternary time. For example, the fault-deflected, northwest-trending courses of the Garcia and Gualala Rivers follow the fault zone for $50 \mathrm{~km}$ between Point Arena and Fort Ross; their present alignment (fig. 4.4) documents a long and complex history of channel extension and stream piracy. Three streams east of the fault-the Garcia River and the Wheatfield and South Forks of the Gualala River-exhibit similar offsets of about $13.5 \mathrm{~km}$ from possible former outlets to the sea west of the fault: the Garcia River from its present mouth near Point Arena, the Wheatfield Fork from the present mouth of the Gualala River near Gualala, and the South Fork from a low gap (110-m elevation) in the coastal ridge near the Sea Ranch. The average rate of post-Pliocene slip across the boundary between the North American and Pacific plates, derived from spreading rates at the mouth of the Gulf of California (DeMets and others, 1987, p. 912), is estimated at $5.1 \mathrm{~cm} / \mathrm{yr}$. In northern California, this slip is distributed chiefly on the San Andreas and other active faults to the east. On the San Andreas fault at Point Arena, Prentice (1989) obtained a maximum slip rate of $2.6 \pm 0.3$ $\mathrm{cm} / \mathrm{yr}$ from a faulted stream channel ${ }^{14} \mathrm{C}$ dated at 2,350 to $2,710 \mathrm{yr}$. Together with the assumed $13.5-\mathrm{km}$ offsets, this rate implies that the postulated drainage diversions required about $519 \mathrm{ka}$. Other lines of evidence indicate much greater antiquity for this and nearby parallel strands of the fault.

Despite abundant evidence of Quaternary faulting along the northern section of the San Andreas fault, other examples of measurable fault displacement of dated upper Pliocene and Quaternary deposits are sparse. Much of the fault lies off shore, and most onshore segments cut older, highly deformed rocks of the Franciscan complex, from which the upper Cenozoic deposits have been eroded. Some reliable indicators of Quaternary slip, however, come from geologic and geomorphic relations observed from San Francisco southward.

On the San Francisco peninsula and farther south in the Santa Cruz Mountains, estimates of Quaternary slip on the San Andreas fault have been derived from offset biofacies and lithofacies relations. The fault offsets are in discontinuously exposed upper Cenozoic strata, which 


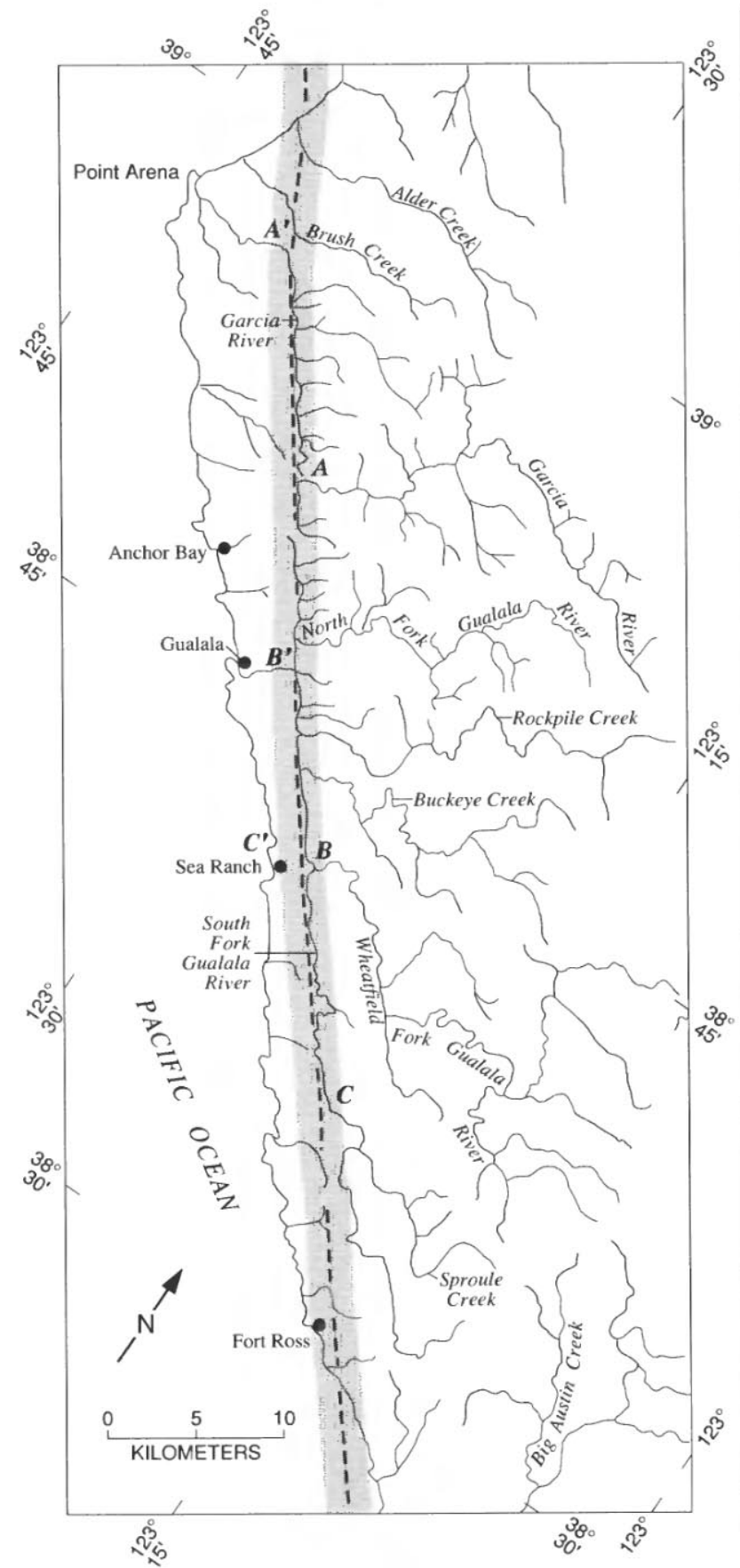

FIGURE 4.4.-Sketch map of part of northern California, showing coastal drainages south of Point Arena, systematically diverted by right-lateral slip on the San Andreas fault (dashed and shaded line). Possible offsets of $13.5 \mathrm{~km}$ are indicated for the Garcia River $\left(A-A^{\prime}\right)$, the Wheatfield Fork of the Gualala River $\left(B-B^{\prime}\right)$, and the South Fork of the Gualala River $\left(C-C^{\prime}\right)$. have been assigned by different investigators to the marine Merced, or Merced(?), Formation and the nonmarine Santa Clara Formation. East of the San Andreas fault, both the Merced and Santa Clara Formations contain, in their upper parts, the 400-ka-old Rockland ash bed of Sarna-Wojcicki and others (1985), thus establishing at least a partial age equivalence of these two units.

The upper, Rockland ash-bearing part of the Merced Formation (Clifton and others, 1988) is fault bounded on the southwest and juxtaposed against a ridge of older rock for $11 \mathrm{~km}$ southeast of San Francisco (fig. 4.5). The minimum offset of $11 \mathrm{~km}$ from any western counterpart of the Merced outcrop belt and the 0.4- to 2.0-m.y. age of the faulted Merced strata require a minimum slip rate of $1.7 \pm 1.0 \mathrm{~cm} / \mathrm{yr}$ for this section of the San Andreas fault.

A similar rate can be derived from the present distribution of upper Pleistocene marine deposits, which Addicott (1969) interpreted as the faulted remnants of a narrow marine embayment that once extended southeastward across the San Andreas. The fault separation of 35 to $40 \mathrm{~km}$ (Addicott, 1969, fig. 2) and an assumed 2- to 3-m.y. age for the embayment yield a geologic slip rate of $1.6 \pm 0.4 \mathrm{~cm} / \mathrm{yr}$.

Additional evidence for Quaternary strike slip (Dibblee, 1966; Cummings, 1968) comes from the southern Santa Cruz Mountains south and west of San Jose. Distinctive reworked conglomerate clasts in the Corte Madera facies of the Santa Clara Formation west of the San Andreas fault are displaced $28 \mathrm{~km}$ from their source, an Upper Cretaceous pebble conglomerate lens on the east side of the fault. The age of the Corte Madera facies is poorly constrained, but Cummings (1968) assumed a probable age range of 1 to $3 \mathrm{~m} . \mathrm{y}$., which yields slip rates of about 1 to $3 \mathrm{~cm} / \mathrm{yr}$.

These slip rates carry uncertainties as great as \pm 1 $\mathrm{cm} / \mathrm{yr}$, but because they integrate slip over millions of years of geologic time, short-term changes in fault activity influence them only slightly. For comparison, a late Holocene slip rate is available from a site on the San Francisco peninsula, $11 \mathrm{~km}$ south of San Francisco. There, displaced and abandoned stream channels and relict alluvial deposits (fig. 4.6) were explored and described by Hall (1984; N.T. Hall, written commun., 1986). The alluvium, ${ }^{14} \mathrm{C}$ dated at $1,130 \pm 160 \mathrm{yr}$, accumulated along a northwest-flowing stream and behind a northwest-trending shutter ridge along the main fault trace. Alluviation ceased when fault slip, unusually high seasonal streamflow, or stream piracy caused the stream to abandon its fault-extended course and to carve a shorter, steeper, southwest-flowing channel across the fault and directly down the slope. This younger channel now exhibits $13.5 \mathrm{~m}$ of right-lateral offset where it is 
crossed by the fault; about $2.7 \mathrm{~m}$ of this total offset can be attributed to fault displacement during the 1906 earthquake. Hall's (1984) analysis of this sequence of depositional, erosional, and faulting events yields a minimum slip rate for the past 1,200 yr of about $1.25 \mathrm{~cm} / \mathrm{yr}$.

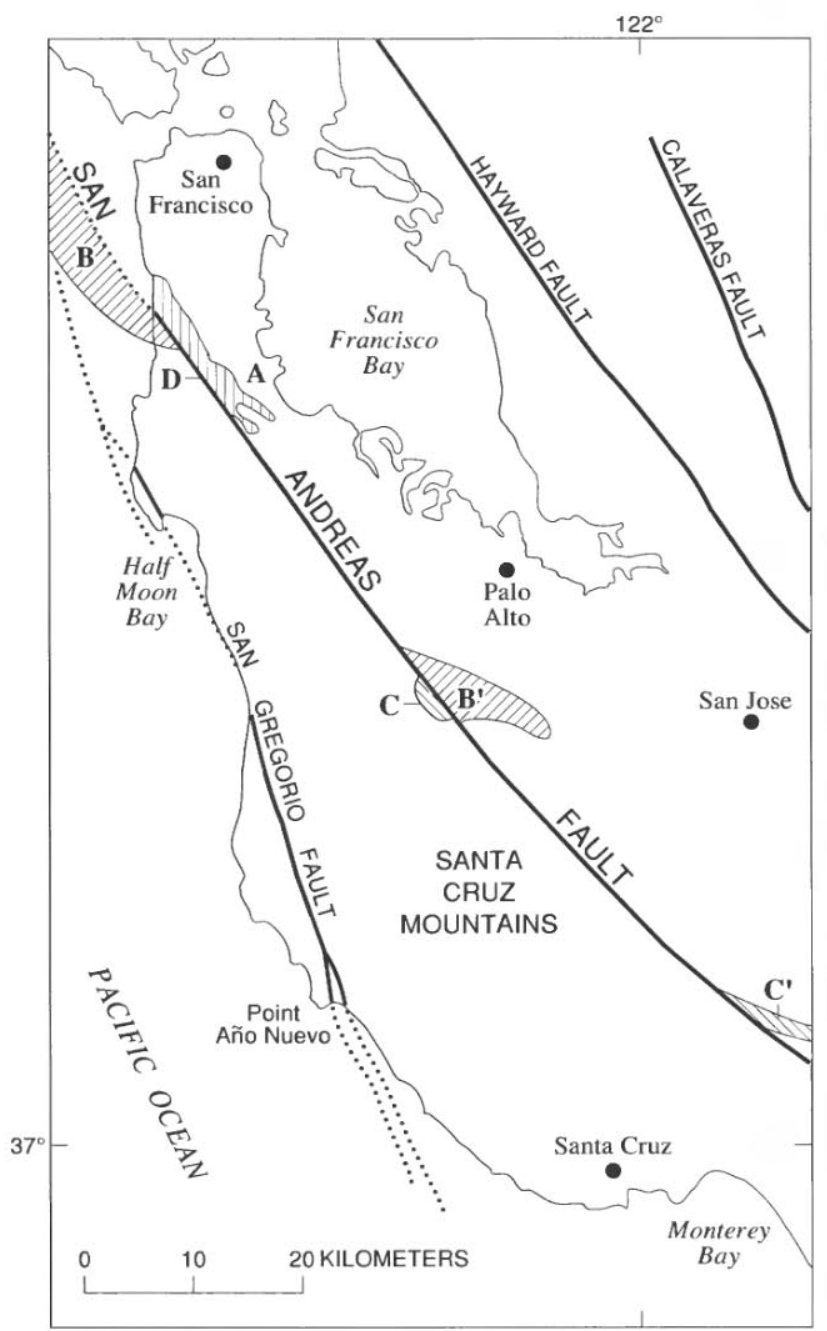

FIGURE 4.5.-Fault-displaced geologic units on the San Francisco peninsula provide a basis for estimating the rate of strike slip on this section of the San Andreas fault - about $1.5 \mathrm{~cm} / \mathrm{yr}$ for the Quaternary. Critical field relations include: A, outcrop belt of the marine Merced Formation, 2.0-0.4 Ma, truncated and faulted against older rocks for $11 \mathrm{~km}$ on the southwest; B-B', fault-displaced parts of a 3.0- to 2.0-Ma, late Pleistocene marine embayment (Addicott, 1969); $\mathrm{C}-\mathrm{C}^{\prime}$, 3.0- to 1.0-Ma nonmarine conglomerate of the Corte Madera facies of the Santa Clara Formation west of the fault and its source area east of the fault (Cummings, 1968); D, site where 1.2-ka (late Holocene) slip rate of about $1.25 \mathrm{~cm} / \mathrm{yr}$ (Hall, 1984) was measured. Quaternary slip has also occurred on the San Gregorio, Hayward, and Calaveras faults. Faults dotted where concealed by water.
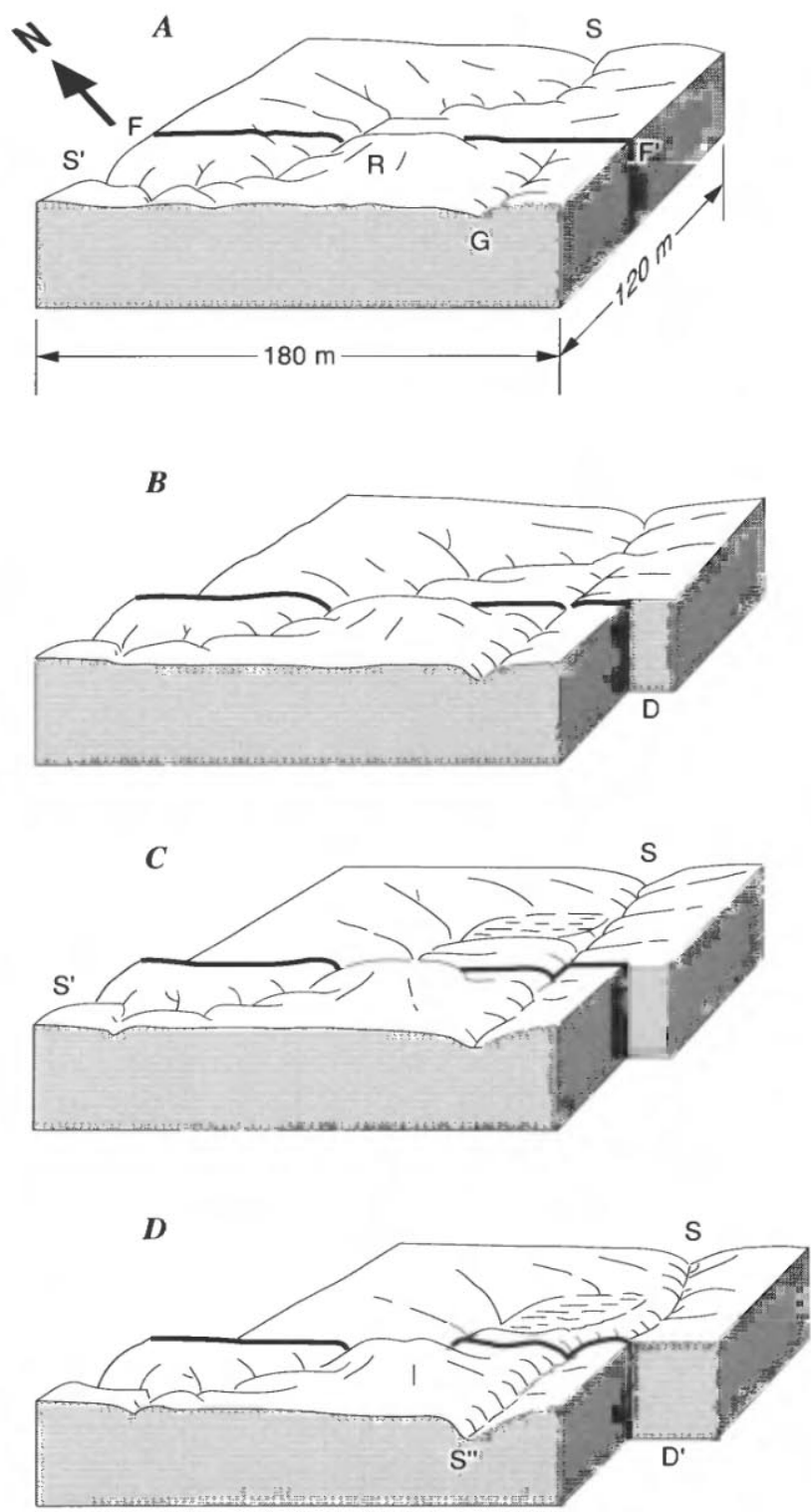

FIGURE 4.6. - Interpretative block diagrams, based on relations described by Hall (1984), for a site on the San Andreas fault $11 \mathrm{~km}$ south of San Francisco. Rate of fault slip, about $1.25 \mathrm{~cm} / \mathrm{yr}$, is derived from observed 13.5-m stream offset, which postdates alluviation along original (precapture) streamcourse. $A$, Stream, flowing obliquely downslope from $S$ to $S^{\prime}$, is partly diverted by ridge $(R)$ where stream crosses the San Andreas fault $\left(F-F^{\prime}\right)$. Gully $(G)$ heads southwest of fault, flowing toward observer. $B$, Displacements (D), caused by fault slip, offset stream and lengthen its channel; gully erodes headward across fault. $C$, Low gradient of stream channel causes alluviation upstream from fault, facilitating capture of its headwaters by gully and abandonment of streamcourse S-S'. Date of alluviation, $1,130 \pm 160 \mathrm{yr}$ B.P., from detrital charcoal dated by ${ }^{14} \mathrm{C}$ methods. $D$, Renewed fault displacements $\left(\mathrm{D}^{\prime}\right)$ offset captured stream (S-S") by $13.5 \mathrm{~m}$, an amount that includes $2.7 \mathrm{~m}$ of slip in 1906 . 


\section{OTHER FAULTS}

The rate of Quaternary strike slip along the northern section of the San Andreas fault south of San Francisco, about $1.5 \mathrm{~cm} / \mathrm{yr}$, is less than either the $5.1 \mathrm{~cm} / \mathrm{yr}$ attributed to the plate boundary or the 2.5 to 3.5 $\mathrm{cm} / \mathrm{yr}$ observed along more southerly segments of the fault. Much of this slip deficit can be accounted for by distributed slip on several other northern California faults that nearly parallel the main trace of the San Andreas.

One of these faults, the San Gregorio, is the northernmost of a 400-km-long set of coastal faults lying southwest of the main trace of the San Andreas. The San Gregorio fault extends northward from Monterey Bay, joining the San Andreas about $20 \mathrm{~km}$ northwest of San Francisco, near Bolinas Bay. Where it cuts the coastline near Point Año Nuevo, the San Gregorio is a complex, 3to 5 -km-wide zone of near-vertical strike-slip and northeast-dipping reverse faults. Faults in this zone offset stream channels incised into marine and nonmarine strata that were deposited on a 105-ka-old wave-cut platform; the faults also offset the shoreline angle of this and at least one older wave-cut platform (fig. 4.7). Evidence from offset shoreline angles and faulted strata indicates a late Pleistocene, right-lateral slip rate of 0.6 to $1.1 \mathrm{~cm} / \mathrm{yr}$ across the fault zone (Weber and Cotton, 1981, p. 16, 72-75); Hamilton and others (1979), however, argued for rates of only $0.1 \mathrm{~cm} / \mathrm{yr}$ in the same area.

If the higher slip rate on the San Gregorio fault and the rates estimated for the San Andreas fault south of San Francisco are correct, Quaternary slip on the San Andreas north of its junction with the San Gregorio must be about $2.6 \mathrm{~cm} / \mathrm{yr}$-the sum of the rates on the two separate faults. This rate agrees closely with that previously cited for the San Andreas near Point Arena (Prentice, 1989).

Additional slip occurs along faults northeast of the San Andreas, as shown by geomorphic evidence, alignment of earthquake epicenters, and, on some faults, gradual fault creep amounting to as much as $1 \mathrm{~cm} / \mathrm{yr}$. Direct geologic evidence of Quaternary slip on such faults as the Hayward, Calaveras, and Green Valley is abundant, but the age and crossfault correlation of displaced stratigraphic markers are uncertain, and Quaternary slip rates are only weakly constrained. These rates, however, can be estimated from such other criteria as modern creep rates, geologic slip rates for displaced pre-Quaternary markers, and geomorphic expression relative to that along the San Andreas fault.

On such evidence, the most active fault trend, with Quaternary slip rates estimated to range from 0.5 to 1.0 $\mathrm{cm} / \mathrm{yr}$, is that defined by the southern section of the Calaveras fault and by the Hayward, Rodgers Creek-
Healdsburg, and Maacama faults (fig. 4.3). Together, these faults extend for $375 \mathrm{~km}$ as a series of chiefly right-stepping breaks that exhibit abundant geomorphic evidence of recent movement. The seismically active Green Valley fault, locally as well defined as the Rodgers Creek and $27 \mathrm{~km}$ farther east, offsets cultural features that record right-lateral creep of $0.5 \mathrm{~cm} / \mathrm{yr}$ between 1922 and 1974 (Frizzell and Brown, 1976).

The east boundary of the northern section of the San Andreas fault system follows a series of faults that trend north-northwest, exhibit recognizable components of right-lateral strike slip, and approximately separate the Coast Ranges from the Great Valley. This discontinuous

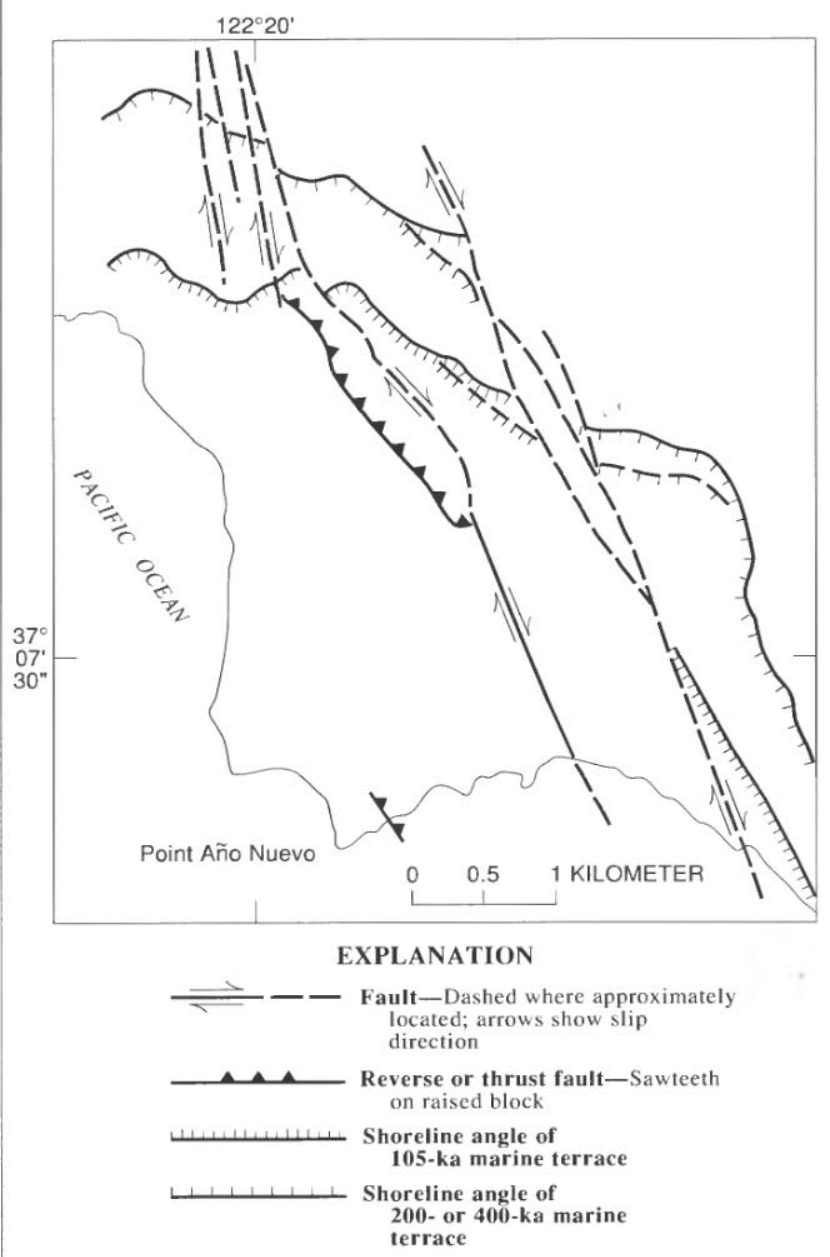

Figure 4.7.-Sketch map of Point Año Nuevo area, northern California, showing fault-displaced shoreline angles in the San Gregorio fault zone. Broken segments of shoreline angles indicate possible alternative locations. This figure, simplified from Weber and Cotton (1981), shows the difficulty of accurately measuring displacement where faults intersect a relict shoreline at acute angles (see fig. $4.8 \mathrm{~A}$ ). 
and somewhat diffuse belt of faulting includes, from north to south, the Stony Creek, Greenville, and Ortigalita faults. No obvious surface faulting bridges the $100-\mathrm{km}$ interval between the Stony Creek and Greenville faults, but major earthquakes in 1892 at Vacaville (lat $38^{\circ} 12.5^{\prime} \mathrm{N}$., long $121^{\circ} 35^{\prime} \mathrm{W}$ ) and Winters (lat $38^{\circ} 18.5^{\prime} \mathrm{N}$., long $121^{\circ} 34^{\prime}$ W.) may signify fault continuity at depth on this trend.

The historically aseismic Stony Creek fault follows and locally truncates a major detachment surface (the Coast Range thrust) that has been rotated to vertical or overturned. It now exhibits a steep east-facing scarp along the front of the Coast Ranges and separates a mountainous Franciscan terrane on the west from less deformed rocks on the east. Stream-terrace and fan deposits of Quaternary age east of the fault terminate at its scarp and are gently tilted and dissected by erosion. Sparse geologic evidence of renewed Quaternary faulting favors dominantly vertical slip, up to the west, but a right-lateral strike-slip component is indicated by asymmetric cusps and bays in the mapped trace of the fault and by nearby southeasterly-plunging folds that deform rocks at least as young as late Pliocene (Fox, 1983, p. 22).

System-boundary faults to the south exhibit both local seismic activity and evidence of Quaternary slip. The Greenville fault, here (fig. 4.3) combined with the Marsh Creek and Clayton faults, displaces Quaternary streamterrace deposits and soils, as well as fold axes in middle to upper Tertiary marine deposits. Right-lateral slip rates on these faults range from 0.01 to $0.30 \mathrm{~cm} / \mathrm{yr}$, but most Quaternary rates are less than $0.1 \mathrm{~cm} / \mathrm{yr}$ (Sweeney, 1982; Wright and others, 1982). These relatively low rates are consistent with weak geomorphic expression along this fault trend.

\section{FOLDING, UPLIFT, AND VOLCANISM}

Northwest- or east-west-trending folds deform much of the San Andreas fault system except for the relatively undeformed Sebastopol block (Fox, 1983) between the San Andreas fault and the fault trend defined by the Hayward, Rodgers Creek, and Maacama faults. The relative structural simplicity of this block is most evident between San Francisco Bay and about lat $39^{\circ} 30^{\prime}$ N. (fig. 4.3), where flat-lying upper Miocene and Pliocene strata of the Wilson Grove (Fox, 1983) and Ohlson Ranch (Higgins, 1960) Formations extend across much of its surface. The erosional surface of this part of the block, the Mendocino Plateau (Lawson, 1894; Wahrhaftig and Birman, 1965, p. 323; Fox, 1983, p. 22-24), is a planar or gently warped upland with accordant ridge crests at elevations of 300 to $600 \mathrm{~m}$. Fox (1983) contrasted the apparent stability of his Sebastopol block with a more typical, highly deformed region to the east, his Santa Rosa block.

In the Santa Rosa block and in other more easterly parts of the Coast Ranges, Quaternary folding and faulting have left uplifted or anticlinal ridges and downwarped or downfaulted basins. Some of the larger basins, now filled with locally derived sediment of Pliocene and Quaternary age, are the southern arm of the San Francisco Bay, Napa and Livermore Valleys (lat $38^{\circ} 20^{\prime}$ N., long $122^{\circ} 20^{\prime}$ W., and lat $37^{\circ} 40^{\prime}$ N.,long $121^{\circ} 50^{\prime}$ W.), and the topographic basin surrounding Clear Lake (lat $39^{\circ} 01^{\prime}$ N., long $122^{\circ} 30^{\prime}$ W.). Smaller aligned or linear basins that follow northwest-trending faults or synclinal folds (fig. 4.3) clearly are structurally controlled.

Rates of folding and uplift are best known for coastal regions. Marine terraces between San Francisco and Monterey Bay indicate general uplift of 120 to $180 \mathrm{~m}$ during the past 0.5 to $1 \mathrm{~m} . \mathrm{y}$. (Helley and others, 1979, p. 18) - an uplift rate of about $0.02 \mathrm{~cm} / \mathrm{yr}$. Local variation in uplift is shown by the deformed shoreline angle and wave-cut platform of the youngest ( $82 \mathrm{ka}$ ) terrace (fig. 4.8); near Half Moon Bay, the wave-cut platform has been warped by northwest-trending folds into a surface that exhibits $60 \mathrm{~m}$ of structural relief over a distance of about $11 \mathrm{~km}$ (Lajoie, 1986, fig. 6.21). About $10 \mathrm{~km}$ west of Santa Cruz, this terrace is about $14 \mathrm{~m}$ above modern sea level (Bradley, 1957; Bradley and Griggs, 1976; Hanks and others, 1984, p. 5776-5777), indicating a local uplift rate of $0.04 \mathrm{~cm} / \mathrm{yr}$.

Coastal uplift south of San Francisco contrasts with Quaternary crustal subsidence 25 to $30 \mathrm{~km}$ inland and east of the San Andreas fault (figs. 4.3, 4.5). Estuarine, stream-laid, and freshwater-swamp deposits of Quaternary age underlie the northwest-trending structural basin containing the San Francisco Bay and the Santa Clara Valley (lat $37^{\circ} 10^{\prime} \mathrm{N}$., long $121^{\circ} 40^{\prime}$ W.) to depths greater than $200 \mathrm{~m}$ below sea level. This prolonged Quaternary downwarping (Wahrhaftig and Birman, 1965) locally attained subsidence rates of 0.02 to 0.04 $\mathrm{cm} / \mathrm{yr}$ (Atwater and others, 1977) during post-Sangamon time.

Despite such local variations in the amount and orientation of crustal processes, Quaternary uplift (fig. 4.9) prevails throughout the northern Coast Ranges. Regional uplift, at least partly of Quaternary age, is greatest and most evident east of the Hayward-Rodgers Creek-Maacama fault trend. Summit elevations north of Clear Lake exceed 1,500 $\mathrm{m}$ (Wahrhaftig and Birman, 1965, fig. 9), and those in the Diablo Range, south of the Livermore Valley, range from 600 to 1,200 m (Christensen, 1965, pl. 1). Both of these colinear uplands exhibit high relief, evidence of rapid downcutting, and cores of the emergent Franciscan complex flanked by outward-dipping strata of Pliocene and Quaternary age. 
Volcanic rocks of late Cenozoic age, widely distributed between the San Pablo Bay and Clear Lake, define a triangular, northwest-trending outcrop area, $120 \mathrm{~km}$ long by $35 \mathrm{~km}$ wide, with its most acute, north apex at Clear Lake. These rocks are assigned to two geographically separated extrusive sequences: the late Miocene and Pliocene Sonoma Volcanics to the south, and the younger, more areally restricted Clear Lake Volcanics (fig. 4.3) to the north. The Clear Lake Volcanics is almost wholly

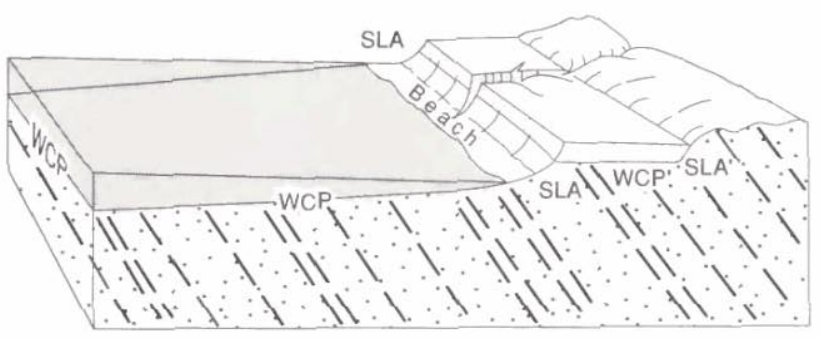

A

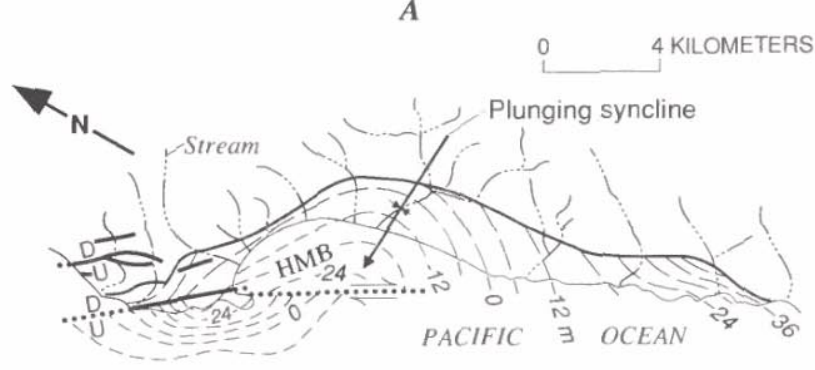

$\boldsymbol{B}$

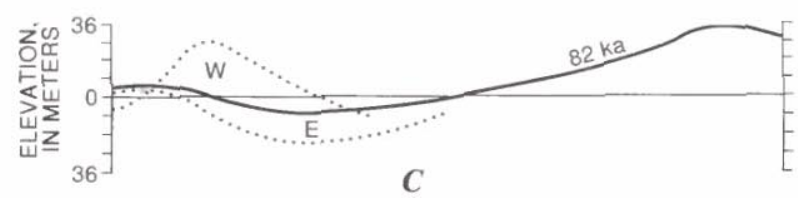

FIGURE 4.8.-Local variability in coastal uplift shown by deformed shoreline angle and wave-cut platform. A, Coastal geomorphic features used to measure Quaternary deformation. SLA, shoreline angle carved by marine erosion at present sea level; WCP, wave-cut platform; WCP' and SLA', elevated surface and shoreline angle, respectively, of an older wave-cut platform now mantled by marine terrace deposits and terrestrial sediment (light stippling). Normal seaward slope of wave-cut platform, exaggerated in diagram, is about $1^{\circ}-2^{\circ} . B$, Folding and right-lateral faulting along the Seal Cove branch of the San Gregorio fault zone near Half Moon Bay (HMB), as shown by warped surface of an 82 -ka wave-cut platform and deformation of its landward edge, the shoreline angle (heavy line). Structure contours (long dash on land, short dash off shore) on platform are derived from shallow boreholes and seismic-refraction data. Arrows on fault (dotted where concealed) indicate direction of relative movement: $\mathrm{U}$, upthrown side; $\mathrm{D}$, downthrown side. Modified from Lajoie (1986). C, Platform profiles on fault plane (dotted lines: E, east; W, west), showing vertical separation across fault and deformation relative to shoreline angle (heavy line). Modified from Lajoie (1986). of Quaternary age. Flow surfaces, volcanoes, cinder cones, obsidian domes, and craters retain their original
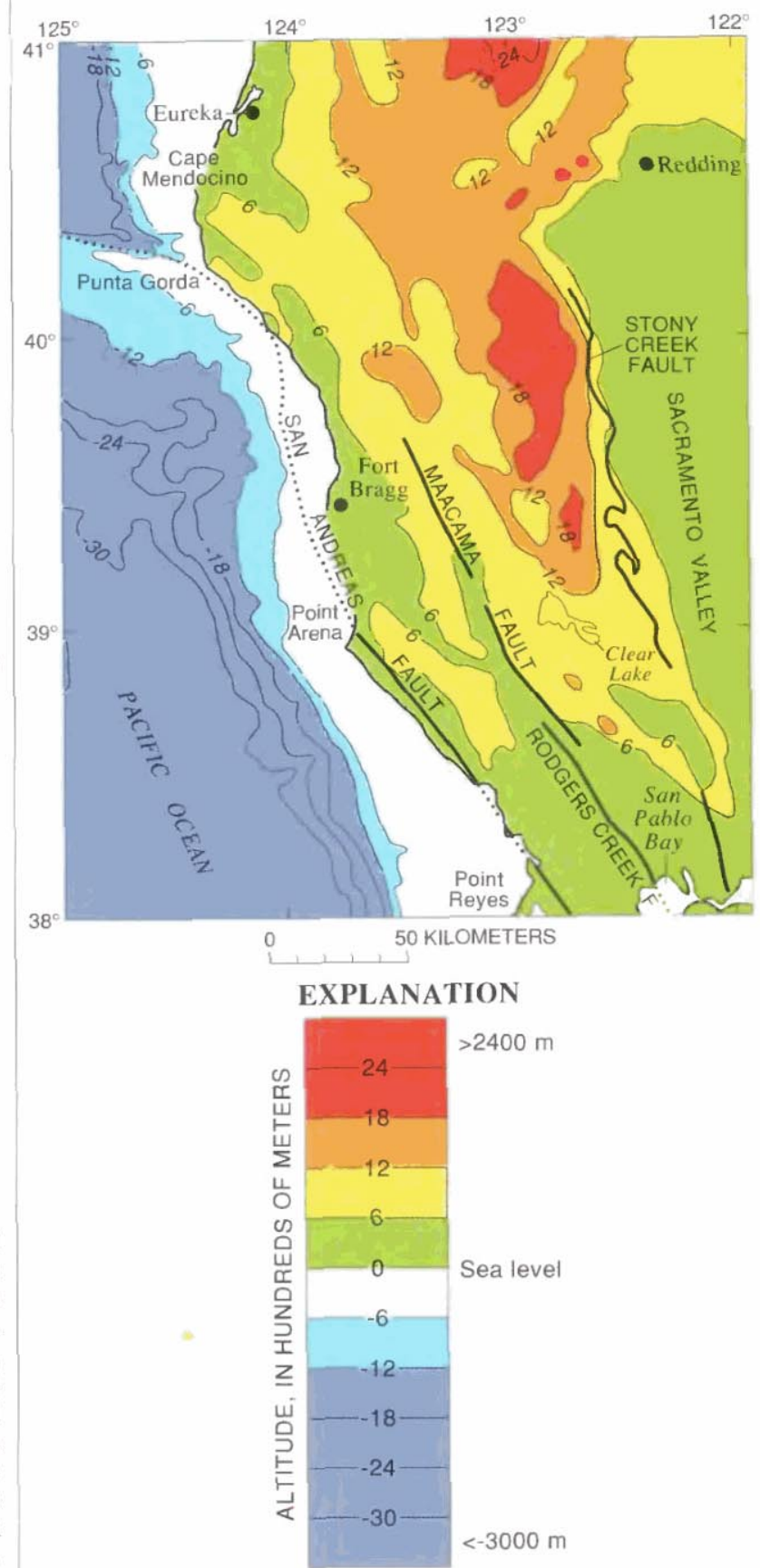

FIGURE 4.9.-Generalized surface on summit altitudes (Gipfelflur) in the Coast Ranges north of San Francisco, showing major faults with Quaternary activity in the San Andreas fault system - that part of the map south of Cape Mendocino and west of the Sacramento Valley. Gipfelflur approximately defines regions of Quaternary uplift and crustal blocks bounded by strike- and dip-slip faulting (dotted where concealed). Generalized from Wahrhaftig and Birman (1965). 
constructional form, and the Geysers Hot Springs area on the west side of the main volcanic field attests to continuing geothermal activity. Lava flows range in composition from olivine basalt to rhyolitic obsidian, and pyroclastic deposits are nearly as varied. The oldest well-dated rocks in the Clear Lake Volcanics yield K-Ar ages near $2.1 \mathrm{Ma}$; the youngest-ash beds in lake sediment beneath Clear Lake-yield ${ }^{14} \mathrm{C}$ ages of about 11 ka (Hearn and others, 1976; Sims and Rymer, 1975).

The sustained late Cenozoic volcanic episode recorded by the Sonoma and Clear Lake Volcanics is unique within the San Andreas fault system, although similar but less extensive Quaternary volcanism marks the northern end of the Gulf of California ridge-transform system in the Salton Trough (lat $33^{\circ} 19^{\prime}$ N., long $115^{\circ} 50^{\prime}$ W.).

\section{CENTRAL SECTION OF THE SAN ANDREAS FAULT SYSTEM}

\section{SAN ANDREAS FAULT}

From the Gabilan Range southward to the Transverse Ranges, the San Andreas fault itself dominates the fault system. Except for the San Gregorio-Hosgri set of coastal faults, branch faults are few and short, and exhibit less evidence of Quaternary activity than those farther north. This relatively simple pattern changes at the northern margin of the Transverse Ranges, where major folds and faults trend more east-westerly and incorporate large components of reverse and thrust motion. In this chapter, faults in the western Transverse Ranges and southern Coast Ranges are grouped together as components of the central section of the San Andreas fault system. This combination of two different structural and physiographic provinces stresses that the transition from compressional structures in the Transverse Ranges to strike-slip structures in the Coast Ranges is more gradual and less sharply defined than the physiographic boundary.

This section of the fault system, $340 \mathrm{~km}$ long by $140 \mathrm{~km}$ wide, extends from the northern Gabilan Range to the southern Transverse Ranges, near lat $34^{\circ}$ N. (fig. 4.10). Besides the San Andreas, faults with Quaternary slip include the Hosgri, San Simeon, and Rinconada in the north; the Big Pine, Ozena, South Cuyama, and Morales to the south and in the Coast Ranges; and the eastwest-trending reverse and thrust faults in the Transverse Ranges. Several faults in the Transverse Ranges continue offshore into the Santa Barbara Basin.

The San Andreas fault trends S. $40^{\circ} \mathrm{E}$. from the northern Gabilan Range to the Carrizo Plain; there, it bends eastward and ultimately attains a S. $75^{\circ} \mathrm{E}$. trend in the Transverse Ranges. North of the bend, it follows a series of nearly aligned stream valleys, which separate the Diablo Range and parts of the Temblor Range on the

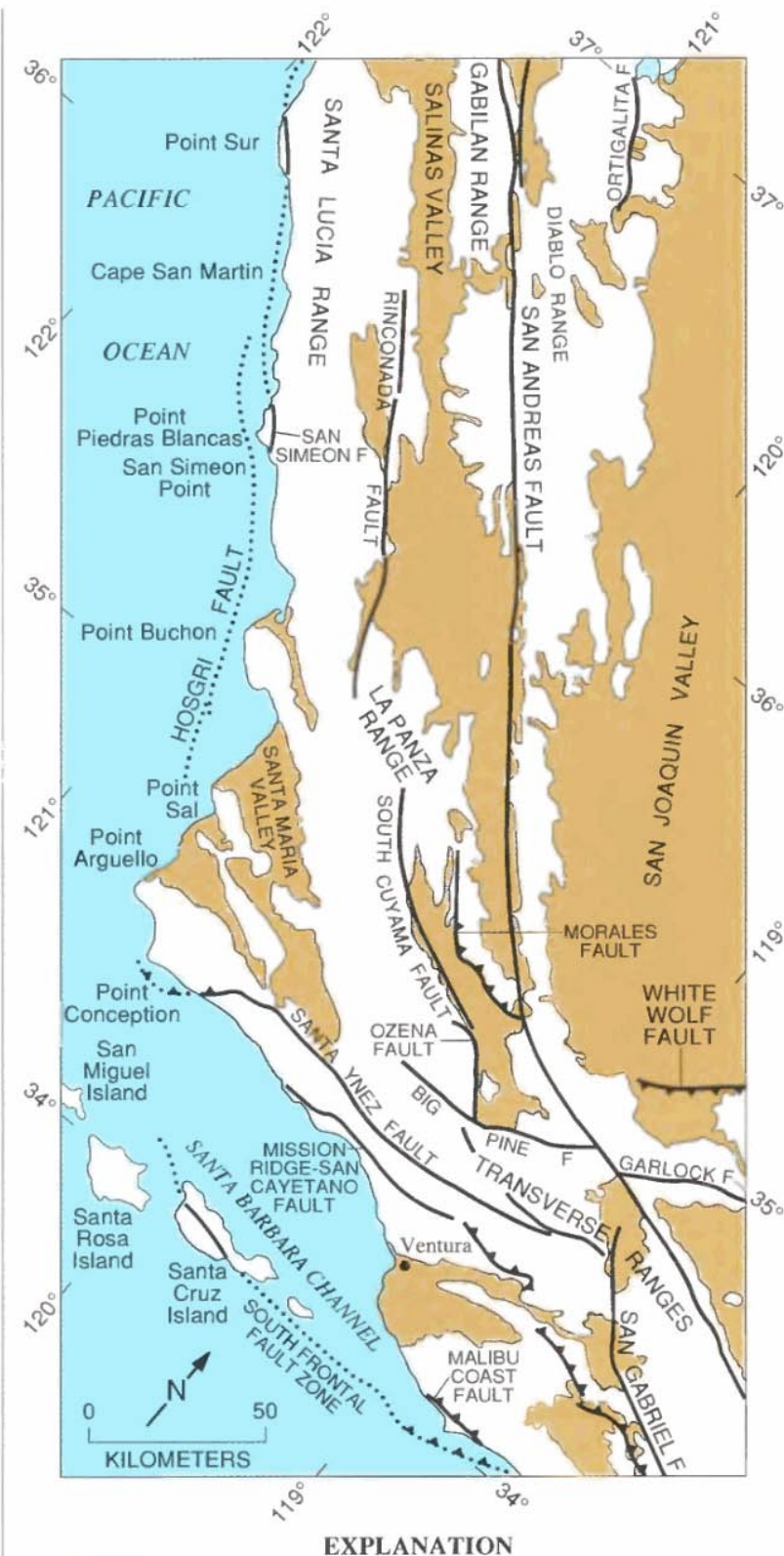

Alluvial and estuarine deposits (Quaternary) - Chiefly basin fill; may also include some deposits of Pliocene age

Bedrock (Tertiary and older)—Varied rock types

_.... Fault exhibiting evidence of Quaternary displacement - Sawteeth on upthrown block of reverse or thrust fault; dotted where concealed by water

FigURE 4.10.- Sketch map of southern Coast Ranges and western Transverse Ranges, southern California, showing faults with Quaternary activity and basin deposits in the central section of the San Andreas fault system. Fault patterns are generalized, and only major faults are shown. 
northeast from the Gabilan Range, Cholame Hills (lat $35^{\circ} 27^{\prime}$ N., long $120^{\circ} 18^{\prime}$ W.), and Caliente Range (lat $35^{\circ} 02^{\prime}$ N., long $119^{\circ} 46^{\prime}$ W.) on the southwest (Brown, 1970; Vedder and Wallace, 1970). An actively creeping length of the fault, with historical slip rates as high as 3.4 $\mathrm{cm} / \mathrm{yr}$, extends $160 \mathrm{~km}$ southward from the northern Gabilan Range to the south end of the Diablo Range.

To the south, along the boundary between the Transverse Ranges and the Mojave Desert, the fault continues as a series of closely aligned echelon breaks, in a narrow $(0.5 \mathrm{~km}$ wide) linear trench. This segment, which also displays abundant geomorphic evidence of Quaternary slip (Ross, 1969), is currently locked and seismically quiet.

Hill and Dibblee (1953, p. 446), in proposing large sustained strike slip on the San Andreas fault, described fault-juxtaposed gravels of similar age but different lithologies in the area between the Temblor Range and the Transverse Ranges (fig. 4.11). Pebble gravel in the Paso Robles Formation, of Pleistocene and Pliocene age, consists chiefly of porcellanite and siliceous shale clasts derived from the Miocene Monterey Formation of the western Coast Ranges and the Temblor Range. These distinctive Paso Robles gravel beds are most extensive southwest of the San Andreas fault, but northeast of the fault they extend as a narrow band to about lat $35^{\circ} \mathrm{N}$. For several kilometers near this latitude, they are faulted against Pleistocene gravel containing clasts of plutonic and metamorphic rock and indurated sandstone, derived from the San Emigdio Mountains to the south. According to Hill and Dibblee (1953, fig. 2), the depositional contact between the two gravel lithologies is displaced about 16 $\mathrm{km}$ from its prefaulting location.

Farther north, between lat $35^{\circ} 30^{\prime}$ and $35^{\circ} 45^{\prime}$ N., Galehouse (1967, p. 974-976) described different clast compositions and heavy-mineral assemblages in Paso Robles strata on opposite sides of the fault. These differences are reasonably and consistently resolved if 40 $\mathrm{km}$ of right-lateral fault slip is removed, restoring the offset facies to their original positions.

These displaced stratigraphic relations imply Quaternary slip of 16 to $40 \mathrm{~km}$, but the uncertain age of the faulted strata makes estimates of the slip rate unreliable. More accurate measurements of fault slip have been obtained at three localities north of the Transverse Ranges: two in the creeping segment and one in the more southerly, currently locked segment that produced the 1857 earthquake.

At the northernmost locality (lat $36^{\circ} 34.9^{\prime}$ N., long $121^{\circ} 10.4^{\prime}$ W.), along the San Benito River near the east boundary of the Gabilan Range, the fault displaces the risers of river terraces (fig. 4.12), exhibiting $64 \mathrm{~m}$ of right slip. Trenches on the terrace near the fault disclosed a fluvial scarp and a distinctive sand bed, both offset about $17.7 \mathrm{~m}$ by faulting during the past $790 \pm 144{ }^{14} \mathrm{C}$ yr

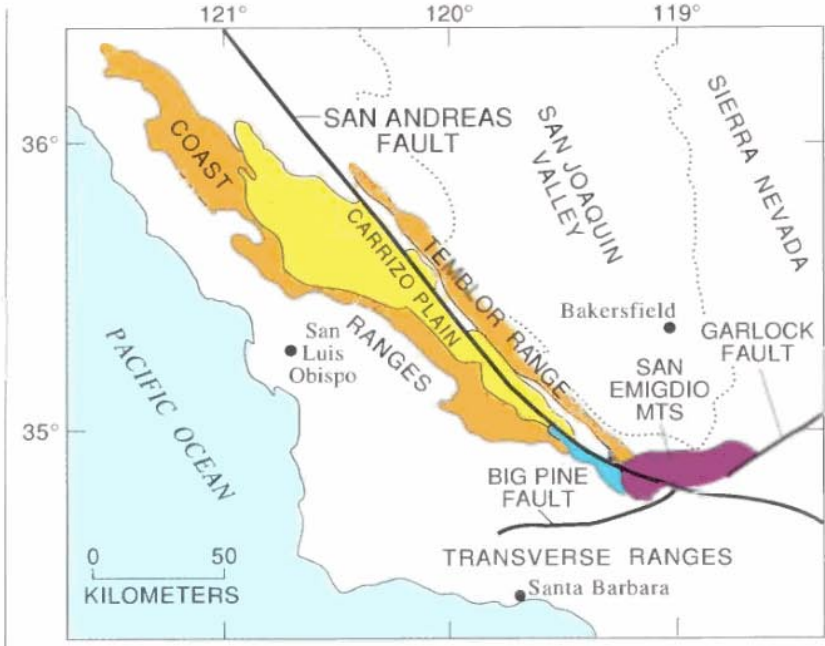

EXPLANATION

[Distribution of rock units shown only for region adjacent to San Andreas fault]

Coast Ranges

Paso Robles Formation (Pleistocene and Pliocene)Chiefly gravel, sand, and clay: gravel clasts. derived from sources in the Coast Ranges and Temblor Range, consist chiefly of porcellanite and siliceous shale from the Monterey Formation

Monterey Formation (Miocene)-Well-bedded siliceous shale, porcellanite, and sandstone. Source unit for the type Paso Robles Formation of the southern Coast Ranges

San Emigdio Mountains

Deformed alluvial deposits of Vedder (1970) (Pleistocene)Chiefly gravel and sand; gravel clasts, derived from sources in the San Emigdio Mountains, consist chiefly of plutonic and metamorphic rocks and indurated sandstone. Mapped by some authors as Paso Robles Formation

Plutonic, metamorphic, and sedimentary rocks (Paleogene and pre-Tertiary) - Source rocks for conglomerate near the San Emigdio Mountains

FigurE 4.11.-Midway between Bakersfield and Santa Barbara, Calif., the San Andreas fault locally juxtaposes conglomerates of similar age but different lithologies. Porcellanite and siliceous shale clasts immediately northeast of the fault were derived chiefly from the folded and uplifted Monterey Formation in the southern Coast Ranges; plutonic, metamorphic, and sedimentary clasts across the fault to the southwest were derived from the San Emigdio Mountains of the northern Transverse Ranges. Total displacement and precise age of conglomerate units are unknown, but mapped offset of at least $16 \mathrm{~km}$ requires sustained Quaternary strike slip, as recognized by Hill and Dibblee (1953). 
(Perkins and others, 1989). The slip rate calculated from these data, about $2.2 \mathrm{~cm} / \mathrm{yr}$, agrees closely with creep rates currently observed along this section of the fault.

In Bitterwater Valley (lat $36^{\circ} 23.9^{\prime}$ N., long $120^{\circ} 58.9^{\prime}$ W.), $27 \mathrm{~km}$ southeast of the San Benito River locality, fault-displaced buried channels in an alluvial fan of Quaternary age record a slip rate over the past $1 \mathrm{ka}$ of about $2.8 \mathrm{~cm} / \mathrm{yr}$ (Cotton and others, 1986), but the slip rate, as well as its distribution within the fault zone, has varied over time. The historical slip rate, $3.4 \mathrm{~cm} / \mathrm{yr}$, represents chiefly gradual fault creep and is based on offsets observed in fences built in 1908 and in channels that presumably date from about 1885 . According to Cotton and others (1986), at least one episode of slower movement is evident, and, during the past $1 \mathrm{ka}$, slip across the 20 -m-wide fault zone has followed different breaks.

Sieh and Jahns (1984) measured and dated late Quaternary displacement on the San Andreas fault at Wallace Creek (lat $35^{\circ} 16.3^{\prime}$ N., long $119^{\circ} 49.7^{\prime}$ W.), near the southwestern margin of the Temblor Range. "Wallace Creek," an informal name (Sieh and Jahns, 1984, p. 896) for a previously unnamed drainage, does not appear on published U.S. Geological Survey topographic maps. At this locality, dated fan and channel deposits, stratigraphic and geomorphic relations, and fault offsets of both abandoned and existing stream channels document $128 \pm 1 \mathrm{~m}$ of strike-slip displacement (fig. 4.13). This record of cumulative fault slip began with incision of the existing channel of Wallace Creek sometime after $3,680 \pm 155 \mathrm{yr}$ ago and ended with the nearly $10 \mathrm{~m}$ of fault slip that accompanied the 1857 earthquake. Because the $3,680-\mathrm{yr}{ }^{14} \mathrm{C}$ age is measured relative to A.D. 1950 , the appropriate timespan for the measured slip is $3,680-(1,950-1,857)$, or $3,587 \mathrm{yr}$. The minimum rate is

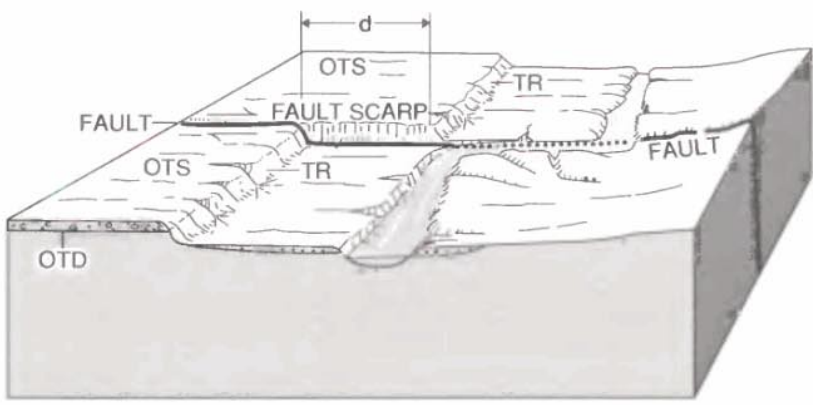

FigURE 4.12.-Fault displacement (d) of stream-terrace risers (TR) postdates old terrace deposits (OTD), which underlie old terrace surface (OTS). Dating of terrace deposits gives a maximum age for displacement and thus a minimum slip rate for the fault (arrows indicate direction of relative movement; fault dotted where concealed by stream). The unrealistically simple relations shown in this sketch eliminate the effects of multiple terraces, changing rates of lateral erosion by the stream, and other processes that, under normal field exposures, make analysis much more difficult. thus $128 \mathrm{~m} / 3,587 \mathrm{yr}$, or $3.57 \pm 0.2 \mathrm{~cm} / \mathrm{yr}$; the maximum rate, based on the stratigraphy and geometry of the abandoned channel, is $3.53 \pm 0.2 \mathrm{~cm} / \mathrm{yr}$. When these maximum and minimum values are combined and adjusted to incorporate uncertainty in the state of strain at the beginning of the time interval, a preferred slip rate (Sieh and Jahns, 1984, p. 891) of $3.39 \pm 0.3 \mathrm{~cm} / \mathrm{yr}$ is obtained. A similar but more complex analysis of 13,250-yr-old fan deposits displaced $475 \mathrm{~m}$ from their source gullies yields a slip rate of $3.58 \pm 0.5 \mathrm{~cm} / \mathrm{yr}$ (Sieh and Jahns, 1984, p. 891-892) for the past $13,250 \mathrm{yr}$. The close agreement of these rates suggests that the average rate of late

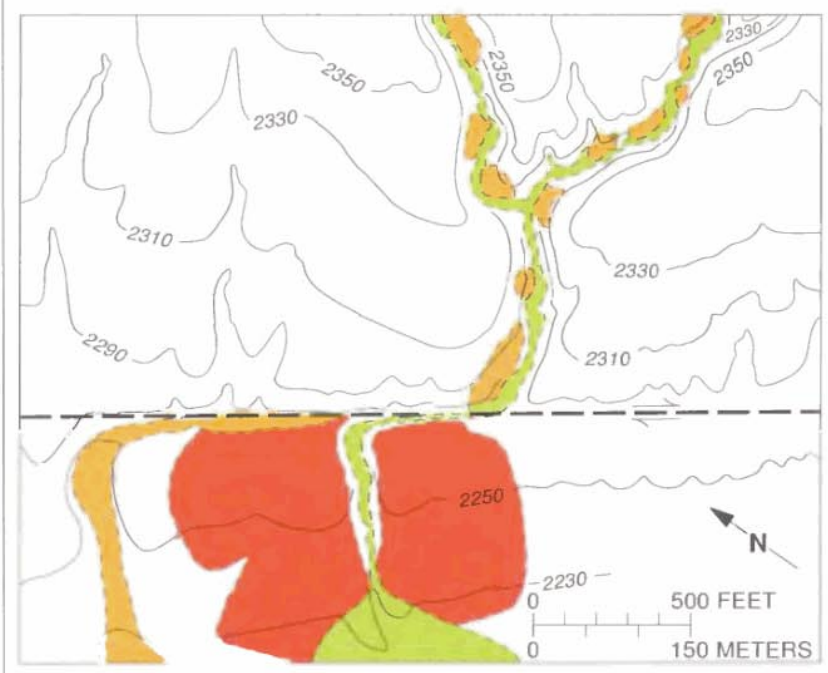

EXPLANATION

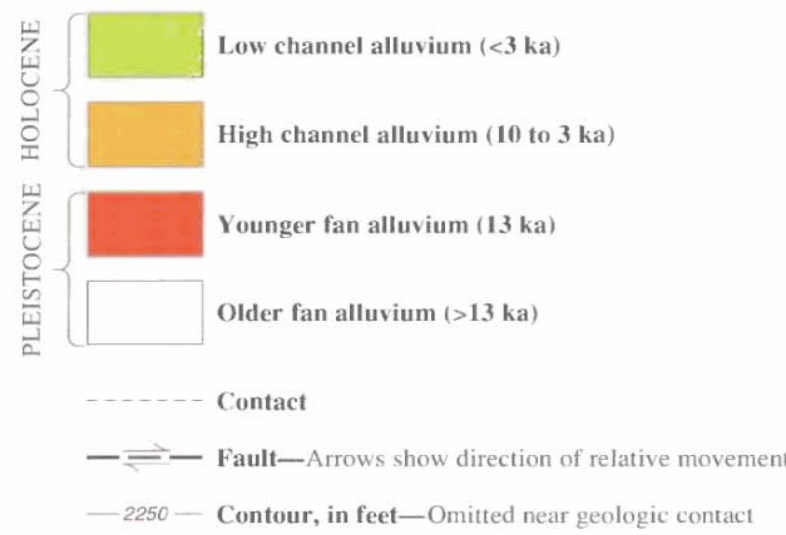

FIgURE 4.13. - Slip on the San Andreas fault at Wallace Creek (lat $35^{\circ} 16.3^{\prime}$ N., long $119^{\circ} 49.7^{\prime}$ W.) has displaced dated alluvial deposits, as well as stream channels and other geomorphic features. Trenches excavated across and parallel to fault at this locality disclose details of stratigraphy, origin of stratigraphic units, and their age as determined from detrital charcoal. Displacements of different ages yield similar average slip rates of about $3.4 \mathrm{~cm} / \mathrm{yr}$. Original source drainages for older fan alluvium are near or southeast of right margin of figure. Simplified from Sieh and Jahns (1984, fig. 2). 
Quaternary fault slip has been relative uniform at this locality.

Horizontal slip rates on the San Andreas fault are less well constrained in the western Transverse Ranges. Davis (1983, p. 368) and Rust (1982) independently estimated slip rates in the range $2-5 \mathrm{~cm} / \mathrm{yr}$ for areas 70 $\mathrm{km}$ apart and on opposite sides of the junction of the Garlock fault with the San Andreas. These estimates involve substantial uncertainty in the amount and (or) timing of slip; they also apply to different parts of the Quaternary - no more than the past $400 \mathrm{ka}$ for displaced gravel deposits in the San Emigdio Mountains (Davis, 1983), and no more than the past 2 ka for offset landslide deposits $32 \mathrm{~km}$ southeast of the Garlock-San Andreas fault junction (Rust, 1982). These rates, however, are broadly consistent with those measured to the north. Moreover, they indicate that much Quaternary strike slip in the western Transverse Ranges has followed the main trace of the San Andreas-a departure from pre-Quaternary history, when the San Gabriel fault to the southwest accommodated much of the fault slip (Crowell, 1975).

\section{OTHER FAULTS}

Other faults with known or probable Quaternary slip in the central Coast Ranges include the Rinconada, Big Pine, Ozena, South Cuyama, Morales, and a coastal fault defined by its aligned but separately named segments: Hosgri, San Simeon, Sur (lat $36^{\circ} 10.8^{\prime}$ N., long $121^{\circ} 32^{\prime}$ W.), Monterey Bay (lat $36^{\circ} 40^{\prime}$ N., long $122^{\circ} 06^{\prime}$ W.), and San Gregorio. For most of these faults, the evidence of Quaternary activity is sparse, discontinuous along strike, and in places arguable. It includes weakly expressed scarps and drainage offsets, displaced deposits of late Pliocene and Quaternary age, and historical seismicity along some fault trends. The geologic and geophysical evidence for Quaternary activity is somewhat more convincing for the Hosgri fault and its northern, colinear counterparts than for faults farther inland.

The Hosgri and similarly aligned coastal faults trend north-northwesterly from near Point Conception (Steritz and others, 1986) to the latitude of Monterey Bay (Silver and Normark, 1978), where they continue northward as the San Gregorio fault. For most of its length, this coastal fault zone is a complex, multistrand break a few kilometers off shore; it is recognized and mapped from juxtaposed stratal units interpreted from seismic-reflection profiles and truncated magnetic anomalies. Locally, seafloor scarps and displaced Holocene deposits, interpreted from the seismic-reflection profiles, confirm its Quaternary activity (Wagner, 1974; Leslie, 1981).

The San Simeon fault (fig. 4.14), which may be an onshore segment of the Hosgri (Leslie, 1981), is also a multistrand break; it cuts and displaces late Pleistocene marine terraces and Holocene dune sands near San Simeon Point (Weber, 1983). Although faulted shorelineangle geometry and the correlation of wave-cut platforms across this fault are subject to some uncertainty, Weber (1983, p. 56-59) and Hanson and others (1987) suggested a horizontal right-slip component of about $0.5 \mathrm{~cm} / \mathrm{yr}$. Earthquake focal mechanisms along the San Simeon fault indicate a dip of $55^{\circ} \mathrm{E}$. and nearly equal components of reverse and strike slip (Eaton, 1984). Right-oblique slip at a rate of about $0.5 \mathrm{~cm} / \mathrm{yr}$ on the Hosgri fault is indicated by earthquake focal mechanisms, sea-floor scarps, the distribution of late Quaternary wave-cut platforms, and faulted seismic-reflection horizons of late Cenozoic age. Much of this evidence is documented from investigations near the Diablo Canyon Powerplant (Pacific Gas and Electric Co., 1988), where it has been interpreted as pure strike slip.

In the western Transverse Ranges, faults with Quaternary displacement include some, like the San Andreas and San Gabriel, that exhibit chiefly strike slip and others, trending east-west or southwest, that exhibit reverse or oblique slip. The left-lateral Santa Ynez fault is an exception to the more general pattern of reverse and thrust faults. The reverse- and oblique-slip faults in the Transverse Ranges are complicated by splays, offsets, and changes in strike, but from north to south they define at least four major continuous, or nearly continuous, fault zones of different lengths: the Santa Ynez $(130 \mathrm{~km})$; the More Ranch-Mission Ridge-San Cayetano $(110 \mathrm{~km})$, from the coast near Santa Barbara, eastward; the Mission Hills-San Fernando-Sierra Madre $(56 \mathrm{~km})$, along the southwest side of the San Gabriel Mountains; and the South Frontal $(250 \mathrm{~km})$. Many of these faults exhibit evidence of Holocene movement, and the San Fernando fault produced the surface rupture and destructive $M=$ 6.6 earthquake of February 1971. Some of these faults, and others with east-westward trends, extend offshore into the Santa Barbara Channel (lat $34^{\circ} 09^{\prime}$ N., long $119^{\circ} 33^{\prime}$ W.), where they also cut Pleistocene or Holocene deposits (Clarke and others, 1985). Ziony and Yerkes (1985, p. 43-60) provided more detailed descriptions and maps of the late Quaternary faults in this and nearby areas; they also noted (p. 44) a profound increase in deformation rates in and near the Transverse Ranges during the past $750 \mathrm{ka}$. This pulse of orogenic activitymanifested by the growth of folds, uplift, and accelerated slip on reverse and thrust faults-coincides with middle Pleistocene and younger deformation observed to the south (Woodford and others, 1954, p. 77-78) in the Los Angeles Basin.

Maximum and minimum slip rates for many of the faults in the Transverse Ranges are deduced from offsets observed in drainages, fan surfaces, river terraces, and wave-cut platforms. Reported by numerous investiga- 
tors (Clark and others, 1984), these rates of chiefly oblique slip cluster around a few tenths of a centimeter per year, but dip-slip components as great as $0.9 \mathrm{~cm} / \mathrm{yr}$ are reported (Rockwell, 1988) for the San Cayetano fault. Observed slip rates may represent only a fraction of the total structural growth of the ranges because much of the late Quaternary deformation is by folding and uplift.
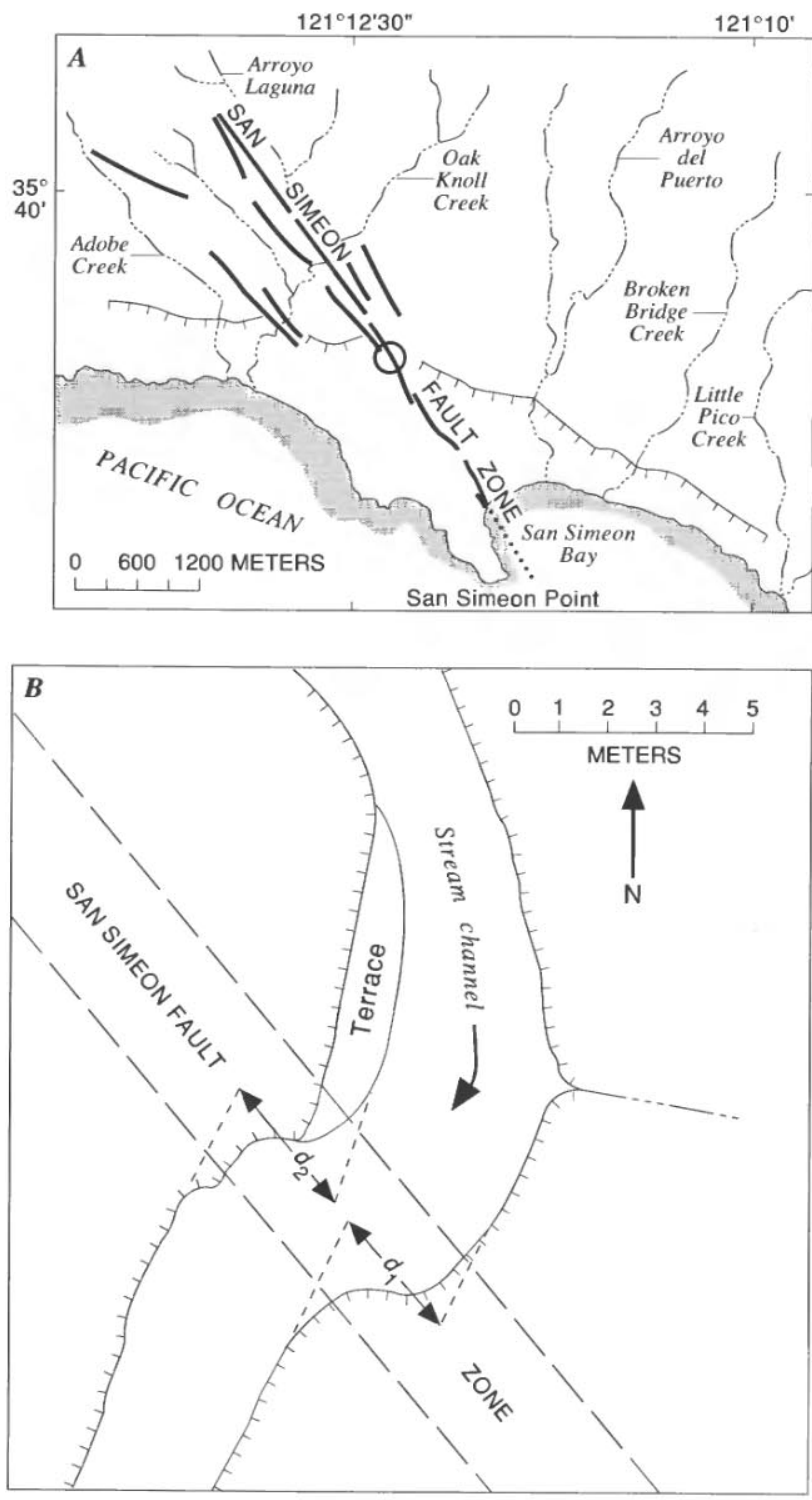

FIGURE 4.14. - Sketch maps and columnar section of San Simeon area, central California, showing selected examples of Quaternary faulting on the San Simeon fault zone. A, Displacement of shoreline angle (hachured line) of 124-ka wave-cut platform; other younger and older marine terraces, mapped by Weber (1983), are not shown. B, 3-m offset $\left(d_{1}\right.$ and $\left.d_{2}\right)$ of stream channel near circled locality in figure 4.14A. $C$, Faulted paleosols and possibly faulted modern soil in
Although most Quaternary faulting south of the Gabilan Range is confined to structural blocks west and south of the San Andreas, two major faults, the Garlock and White Wolf, diverge northeastward from the San Andreas near the north boundary of the Transverse Ranges (fig. 4.10). Neither of these faults exhibits a clearly defined junction with the San Andreas, but together they

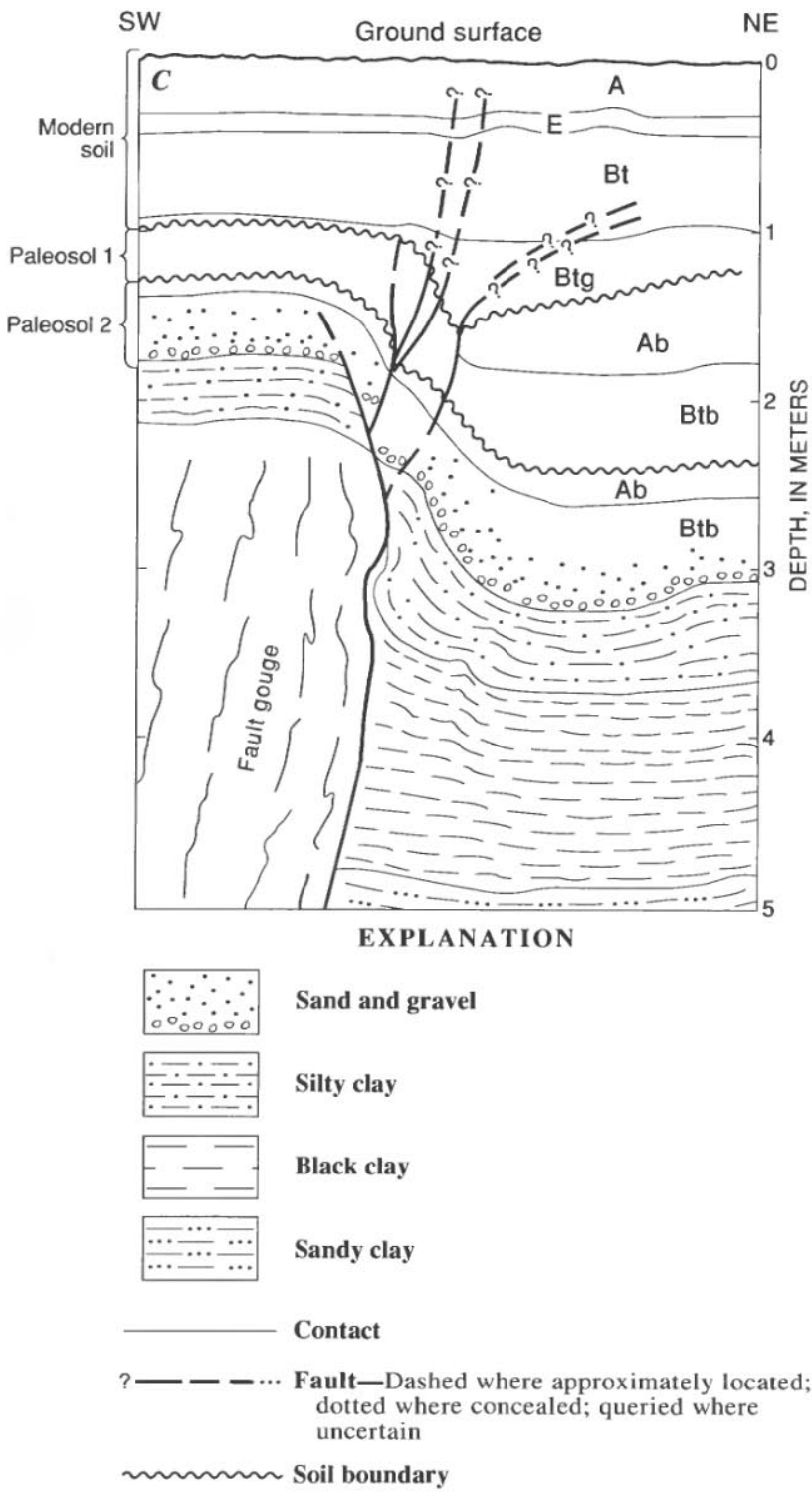

trench exposure near circled locality in figure $4.14 \mathrm{~A}$; letters on right designate soil classifications. Quaternary strike-slip rate for this fault at the surface is about $0.5 \mathrm{~cm} / \mathrm{yr}$, but earthquake focal mechanisms (Eaton, 1984) indicate right-reverse slip at 6.6-km depth. From Pacific Gas and Electric Co. (unpub. data, 1986; see Pacific Gas and Electric Co., 1988). 
bound the horstlike block of Sierran basement that makes up the Tehachapi Mountains. The White Wolf, a southeast-dipping reverse fault that was the source of the Kern County $M=7.7$ earthquake of July 1952 , exhibits geomorphic evidence of recent slip at the range front but is concealed to the west beneath the southern San Joaquin Valley. The Garlock, devoid of major historical seismicity, exhibits clear evidence of left-lateral Quaternary slip (Clark, 1973) that increases eastward from $0.2 \mathrm{~cm} / \mathrm{yr}$ at a point $55 \mathrm{~km}$ east of the San Andreas to $1.1 \mathrm{~cm} / \mathrm{yr}$ at a point $75 \mathrm{~km}$ to the east (Clark and others, 1984).

\section{FOLDING AND UPLIFT}

Typically, Quaternary folds are more intense and better defined in thick Tertiary marine sequences than near or above such basement blocks as the granitic and metamorphic complexes of the Santa Lucia, La Panza, and Gabilan Ranges or the Franciscan core of the Diablo Range. Thus, some of the best expressed Quaternary folds are in the western Transverse Ranges (Bailey and
Jahns, 1954, p. 95-98), the west side of the San Joaquin Valley (Harding, 1976), the Santa Maria Basin (Woodring and Bramlette, 1950 , p. 109-116), and the southeast flank of the Santa Lucia Range (Compton, 1966). Harding (1976) used subsurface geologic data from oil fields northeast of the San Andreas fault to demonstrate that folding has moved outward from the San Andreas over time-the more northeasterly folds along the west side of the San Joaquin Valley being the youngest.

Rates of Quaternary folding in the westernmost Transverse Ranges exceed those elsewhere in the fault system. On the coast near Ventura (lat $34^{\circ} 07^{\prime}$ N., long $119^{\circ} 18^{\prime}$ W.), Pleistocene basin deposits more than $4 \mathrm{~km}$ thick have been intensely folded and faulted during the past $200 \mathrm{ka}$, attaining dips of $32^{\circ}-45^{\circ}$ in the southern limb of the Ventura Avenue anticline (fig. 4.15); uplift rates of about $1 \mathrm{~cm} / \mathrm{yr}$ (Yeats, 1977; Lajoie and others, 1982) characterize the axis and southern limb of this fold. Uplift and folding elsewhere in the western Transverse Ranges may be slower but probably still exceeds deformation rates elsewhere in the fault system.

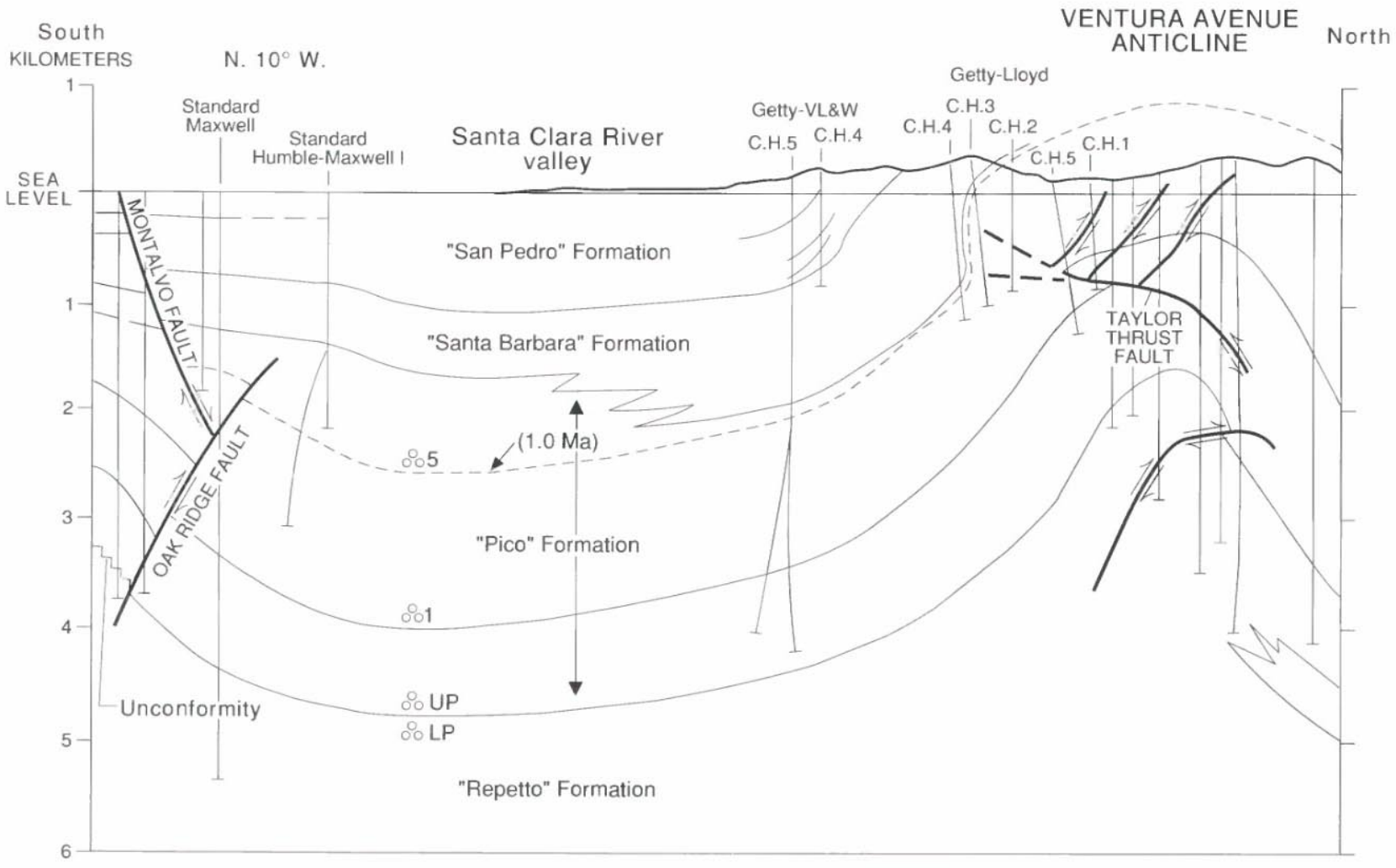

FIGURE 4.15. - Many drill holes penetrate well-dated Quaternary strata near the Ventura Avenue anticline. Besides the provincial microfaunal control shown here (3 small circles), Lajoie and others (1982b) employed a marine terrace $(0.1-0.08 \mathrm{Ma})$ and 3 ash beds $(0.6$, 0.7 , and 1.2 Ma) in the "San Pedro," "Santa Barbara," and "Pico" Formations of Yeats (1982) to estimate an average uplift rate of 1.25 $\mathrm{cm} / \mathrm{yr}$ at the fold crest during the past $200 \mathrm{ka}$. Nearly all of this uplift is Quaternary in age; most is late Quaternary, as this highly generalized figure shows. Modified from Yeats (1982, fig. 7). Contacts and faults dashed where approximately located; arrows on faults indicate direction of relative movement. C.H., corehole; LP, lower Pliocene; UP, upper Pliocene; 1 and 5, provincial microfaunal markers. 
Evidence for Quaternary uplift in this part of the San Andreas fault system is abundant and varied. Highstanding ranges (Diablo, Santa Lucia, La Panza, and Transverse) emerge from a cover of their own eroded debris, represented by the Paso Robles Formation of the Coast Ranges, the Tulare Formation of the San Joaquin Valley and northern San Emigdio Mountains, and the Saugus Formation (and equivalent marine deposits) of the western Transverse Ranges. These upper Tertiary and Quaternary strata consist chiefly of alluvial debris, which has been deposited in fans, channels, and flood basins. Although the stratified deposits have been tilted, uplifted, and eroded (Bailey and Jahns, 1954; Christensen, 1965; Compton, 1966; Yeats, 1977; Davis, 1983), the map pattern of their remnants documents regional patterns of uplift.

Christensen (1965) employed such evidence (fig. 4.16) to document uplift of $600 \mathrm{~m}$ in the Diablo, Santa Lucia, and La Panza Ranges and to establish general systemwide uplift, north of the Transverse Ranges, of about 300 $\mathrm{m}$. This broad pattern of late Pliocene and Quaternary uplift is reversed chiefly in the Salinas and Santa Maria Valleys (lat $36^{\circ} 09^{\prime}$ N., long $121^{\circ} 09^{\prime}$ W., and lat $34^{\circ} 34^{\prime}$ N., long $120^{\circ} 15^{\prime}$ W.), Kettleman Plain (lat $35^{\circ} 55^{\prime}$ N., long $120^{\circ} 05^{\prime}$ W.), and southern San Joaquin Valley, where elongate deep (100-900 m) but local basins have formed at the edge of basement blocks.

Late Pliocene and Quaternary uplift of the northern San Emigdio Mountains totals about 1,800 m (Davis, 1983 , p. 299-300), the present average height of a Pliocene erosion surface preserved on accordant ridge crests near the summit of the mountains. Relatively rapid uplift of the western Transverse Ranges was also accompanied by local downwarping of narrow basins - for example, the offshore Santa Barbara Basin and the Santa Clara River valley (fig. 4.15) east of Ventura.

Evidence that uplift is still continuing is found in raised, paired stream terraces and youthful drainage patterns in the Santa Lucia, Diablo, and western Transverse Ranges, in elevated Holocene marine terraces near Ventura (Lajoie and others, 1982), and in the radially segmented slopes of Holocene alluvial fans that record progressive episodes of deformation along the east front of the Diablo Range (Bull, 1964).

\section{SOUTHERN SECTION OF THE SAN ANDREAS FAULT SYSTEM}

\section{SAN ANDREAS FAULT}

South of the Transverse Ranges, the San Andreas fault system (fig. 4.17) extends to the latitude of the Salton Sea as a broad belt of northwest-trending strike-slip faults bounded on the northeast by the San Andreas and on the southwest by the offshore Santa Cruz-Catalina Ridge fault zone. Between the Salton Sea and the Gulf of California, the San Andreas fault system merges with a complex pattern of active ridge segments and transform faults that continues beneath the gulf for more than 1,200 km (see chap. 3). Alluvium of the Colorado River, lake deposits, and the waters of the gulf obscure the transition
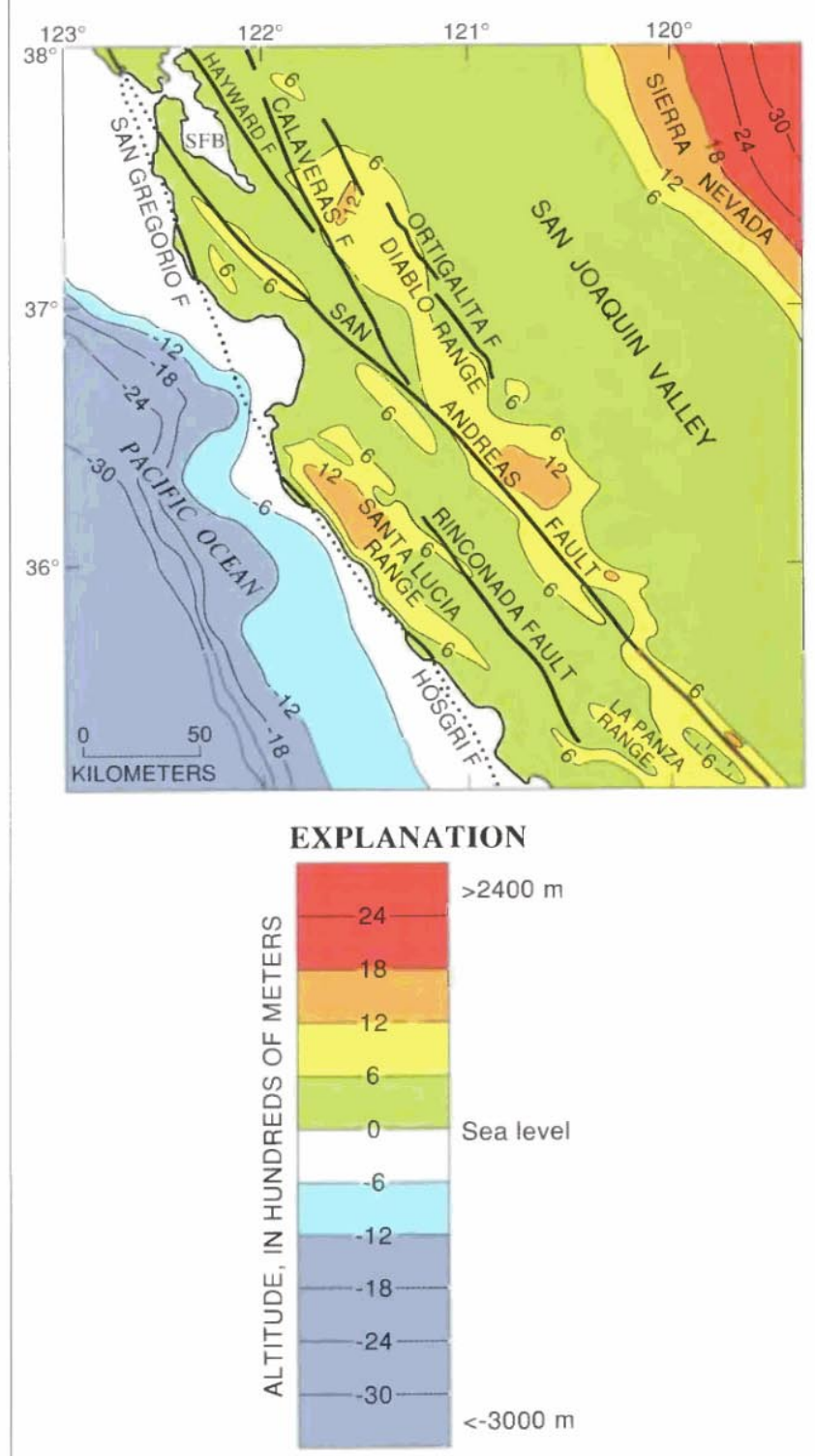

FIGURE 4.16.-Generalized topographic map of central California between the San Francisco Bay (SFB) and the La Panza Range, showing major faults with Quaternary activity in the San Andreas fault system. Modified from Christensen (1965, pl. 1). Faults dotted where concealed by water; hachures on contours indicate area of closed low. Compare with figure 4.9. 
from the San Andreas pattern of deformation, dominated by northwest-trending strike-slip faults, to the ridgetransform pattern of the gulf, but current practice (see chap. 3; Crowell, 1981, p. 596-597) places the south boundary of the fault system near the latitude of the Salton Sea. Thus defined, the southern section of the San Andreas fault system is about $200 \mathrm{~km}$ long by 150 to 175 $\mathrm{km}$ wide.

Late Quaternary faulting in this region follows several major breaks, of which the San Andreas is the most easterly and most active. The dominant role of the San Andreas fades south of Cajon Canyon (lat $34^{\circ} 18^{\prime}$ N., long $117^{\circ} 28^{\prime}$ W.), where the San Jacinto fault diverges from it, and farther south along the south front of the San Bernardino Mountains, where it merges into the Banning and Mission Creek reverse faults (lat $33^{\circ} 56^{\prime}$ N., long $116^{\circ} 47^{\prime}$ W., and lat $34^{\circ} 00^{\prime}$ N., long $116^{\circ} 33^{\prime}$ W.). Despite such complexities, continuity of Quaternary faulting on the main San Andreas can be traced at least as far south as the Salton Sea.

Large increments of Quaternary strike slip on the segment of the San Andreas fault along the San Gabriel Range front near Palmdale (lat $34^{\circ} 34^{\prime}$ N., long $118^{\circ} 07^{\prime}$ W.) were first recognized by systematic right-lateral stream offsets and by Pleistocene fan and terrace deposits displaced 2 to $8 \mathrm{~km}$ from their source regions across the fault (Wallace, 1949 , p. 799-802; Noble, 1954, p. 46). Underlain by distinctive bodies of plutonic and metamorphic rocks, the ranges have contributed eroded debris to fans that spread across the range-front faults. Subse-

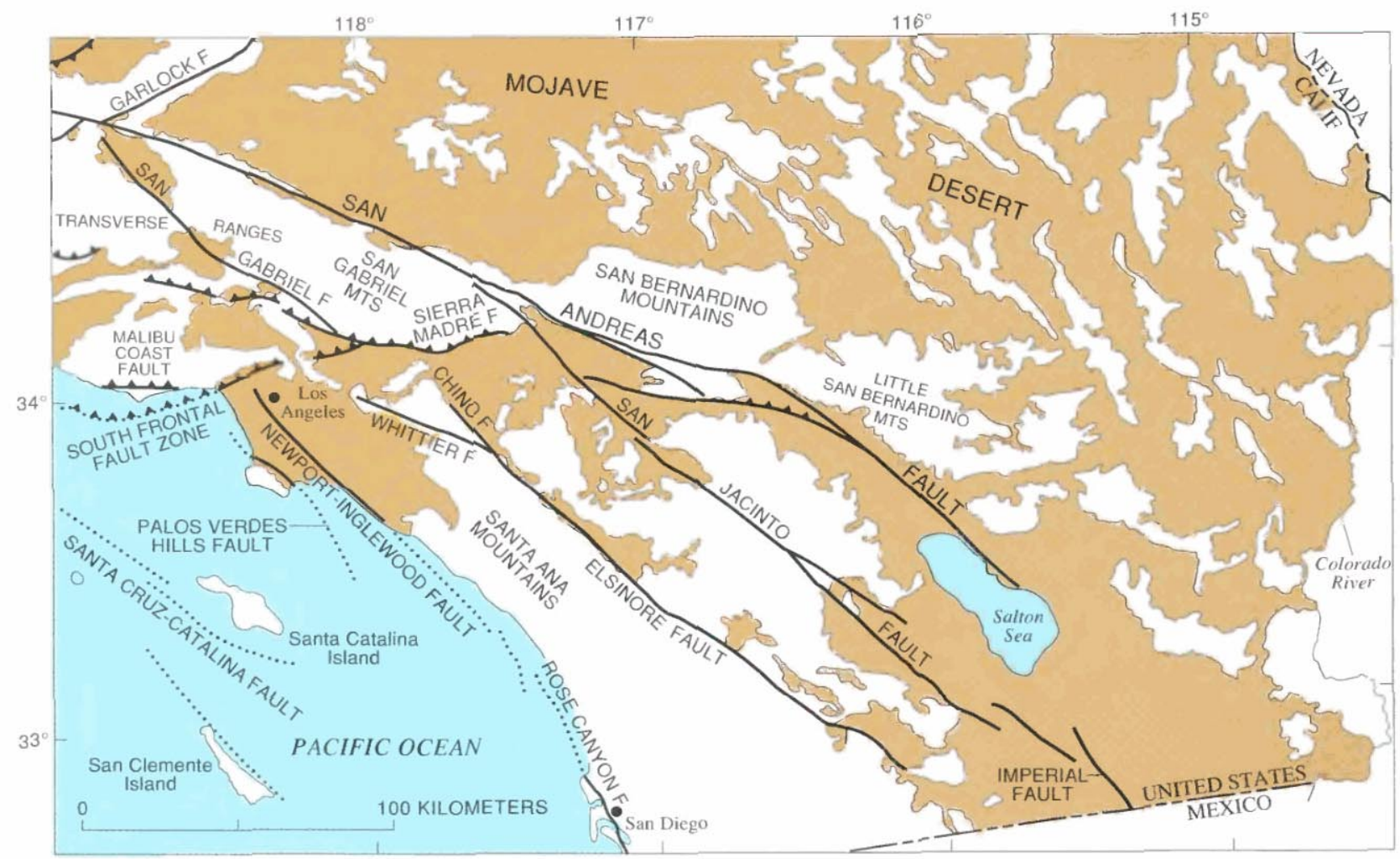

EXPLANATION

Alluvial and estuarine deposits (Quaternary)—Chiefly basin fill; may also include some deposits of Pliocene age

Bedrock (Tertiary and older)-Varied rock types

Fault, exhibiting evidence of Quaternary displacement-Sawteeth on upthrown block of reverse or thrust fault; dotted where concealed by water

FigURE 4.17. - Sketch map of the eastern Transverse Ranges, Mojave Desert, and Salton Trough area, southern California, showing faults with Quaternary activity and basin deposits in the southern section of the San Andreas fault system. Fault patterns are generalized, and only major faults are shown. 
quent strike slip along these faults has displaced the distal parts of the fans laterally, separating them from their source rocks and opposing them against unlike rock types in nearby parts of the range front. Recent mapping (Barrows and others, 1985, p. 195-197) along the fault segment first described by Wallace (1949) and Noble (1954) constrains the slip rate there to values of 1.5 to 3.0 $\mathrm{cm} / \mathrm{yr}$ (fig. 4.18).

Most historical slip on the San Andreas fault has accompanied earthquakes of $M \geq 6$. A remarkable record of earlier earthquake-related faulting has been interpreted (Sieh, 1978, 1984; Sieh and others, 1989) from natural and manmade exposures across the fault at Pallett Creek, about $55 \mathrm{~km}$ northeast of Los Angeles, within the eastern part of the segment mapped by Barrows and others (1985). At Pallett Creek, Sieh described sandblows and other liquefaction structures, buried scarps, and truncated fault strands in dated peat and alluvium that record (fig. 4.19) a history of 12 earthquakes during the past 1,700 yr. The latest 10 episodes of faulting

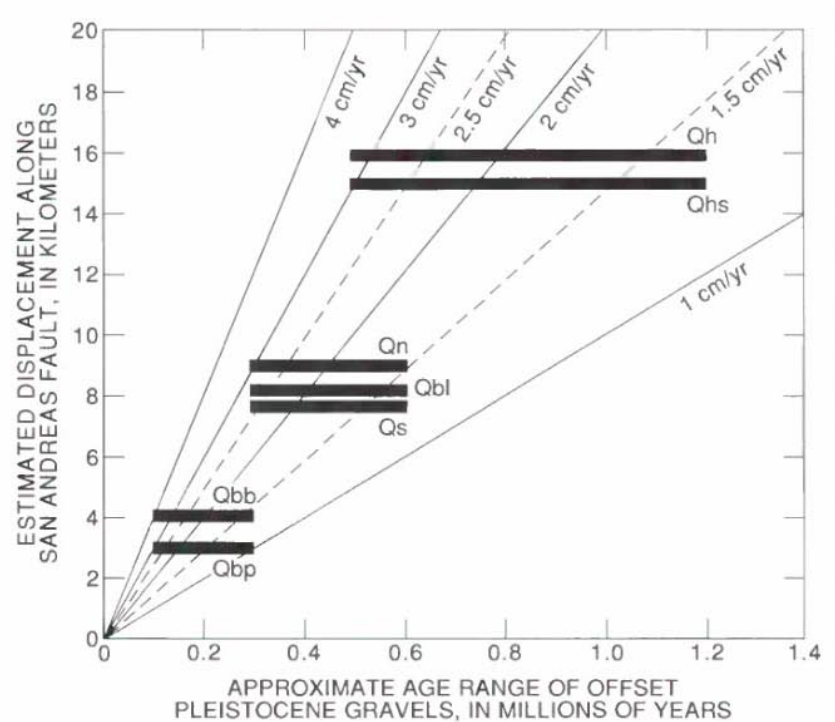

EXPLANATION

Qh Harold Formation (undifferentiated)

Qhs Harold Formation (schist and sandstone clast member)

Qn Nadeau Gravel

$\mathrm{Qbl}$ Boulder gravel (Little Rock Creek)

Qs Shoemaker Gravel

Qbb Boulder gravel (Big Rock Creek)

Qbp Boulder gravel (Pallet Creek)

FIGURE 4.18. - Estimated ranges in strike-slip rate on a 90-km segment of the main San Andreas fault north of Los Angeles. Stratigraphic nomenclature (from Barrows and others, 1985, fig. 4) identifies lithologically distinctive Quaternary deposits that have been horizontally displaced by fault slip on the San Andreas fault system. establish an average recurrence interval of about $132 \mathrm{yr}$ (Sieh, 1989) but show an irregular, clustered distribution over time for large earthquakes on this section of the fault.

Slip rates along the San Andreas south of Pallett Creek are lower than those in the central section of the fault system; in part, this difference is accounted for by slip on the San Jacinto and other, more westerly faults.

A site on the San Andreas fault in Cajon Canyon (lat $34^{\circ} 16.4^{\prime} \mathrm{N}$., long $117^{\circ} 27.9^{\prime} \mathrm{W}$.) about $100 \mathrm{~km}$ east of Los Angeles, establishes a consistent slip rate (Weldon and Sieh, 1985) for the late Pleistocene and Holocene time. Along Cajon and Lone Pine Creeks, the fault displaces terrace risers, buried and active stream channels, and landslides. The alluvial and swamp deposits have yielded $14{ }^{14} \mathrm{C}$ ages. These dated fault displacements, in combination with a reconstructed fluvial history of the site, provide four independent measurements of fault slip that document an average slip rate for the past 14.4 ka of $2.5 \pm 0.4 \mathrm{~cm} / \mathrm{yr}$ (fig. 4.20 ; Weldon and Sieh, 1985).

Harden and Matti (1989) reported slip rates that are less well constrained and possibly more variable for the San Andreas fault near Yucaipa, $45 \mathrm{~km}$ southeast of Cajon Canyon. There, displaced alluvial fans yielded average slip rates of 1.4 to $2.5 \mathrm{~cm} / \mathrm{yr}$ for the past $14 \mathrm{ka}$, 2.2 to $3.4 \mathrm{~cm} / \mathrm{yr}$ for the past $30 \mathrm{ka}$, and 1.2 to $1.6 \mathrm{~cm} / \mathrm{yr}$ for the past 65 or $90 \mathrm{ka}$. These rates imply an accelerating rate of latest Quaternary slip, but uncertainties in measurements of displacement and age permit rates that are constant or even diminishing over time.

Paired stream offsets along the southern branch of the San Andreas fault (lat $34^{\circ} 07.5^{\prime}$ N., long $117^{\circ} 10.0^{\prime}$ W.), between Yucaipa and Cajon Canyon and in San Bernardino (lat $34^{\circ} 06^{\prime} \mathrm{N}$., long $117^{\circ} 17^{\prime} \mathrm{W}$.), indicate a maximum slip rate of $2.5 \mathrm{~cm} / \mathrm{yr}$ (Rasmussen, 1982, p. 112) based on estimated ages of 30 and $50 \mathrm{ka}$ for faulted alluvial units. If, as Rasmussen suggested, these are minimum ages, the actual slip rate may be somewhat lower.

On the San Andreas fault and about $30 \mathrm{~km}$ north of the Salton Sea (lat $33^{\circ} 46.9^{\prime}$ N., long $116^{\circ} 14.4^{\prime}$ W.), Keller and others (1982) mapped a total offset of $700 \mathrm{~m}$ where two strands of the fault cut an alluvial fan. Soils developed on the fan surface indicate an age of 30 to $20 \mathrm{ka}$, bracketing the slip rate between 2.3 and $3.5 \mathrm{~cm} / \mathrm{yr}$. At a nearby locality, a rate of only a few tenths of a centimeter per year can be derived from displaced $(1 \mathrm{~m})$ sedimentary deposits associated with the latest highstands of former Lake Cahuilla, 700-300 yr B.P. (Sieh, 1981). These deposits, however, may be too young to record slip accompanying large earthquakes with recurrence times longer than $700 \mathrm{yr}$.

The San Andreas follows the east side of the Salton Sea southward for about $30 \mathrm{~km}$; its trace is marked by offset 


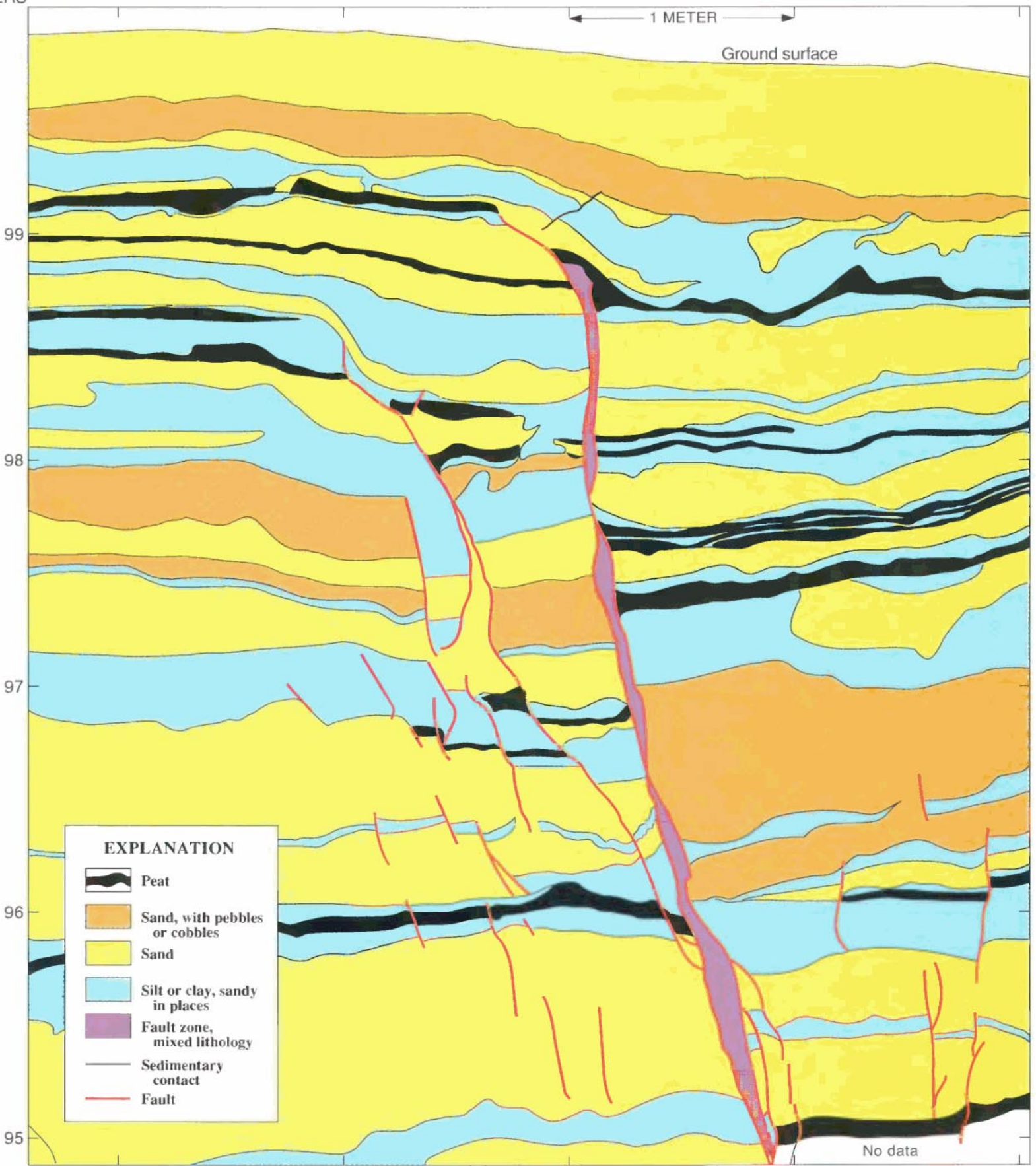

Figure 4.19. - San Andreas fault exposed in southeast wall of a trench at Pallett Creek, Calif., $55 \mathrm{~km}$ northeast of Los Angeles. Black strata are peat layers, datable by ${ }^{14} \mathrm{C}$ methods, that show increasing amounts of vertical displacement with depth, owing to cumulative slip from repeated earthquakes. Vertical component of displacement visible here is a few percent of net displacement, which is chiefly strike slip, approximately normal to trench wall, with block on right moving toward observer. Uppermost, unfaulted deposits postdate 1857 earthquake; lowermost peat bed on southwest side of fault was deposited about A.D. 800. Modified from Sieh (1978). 


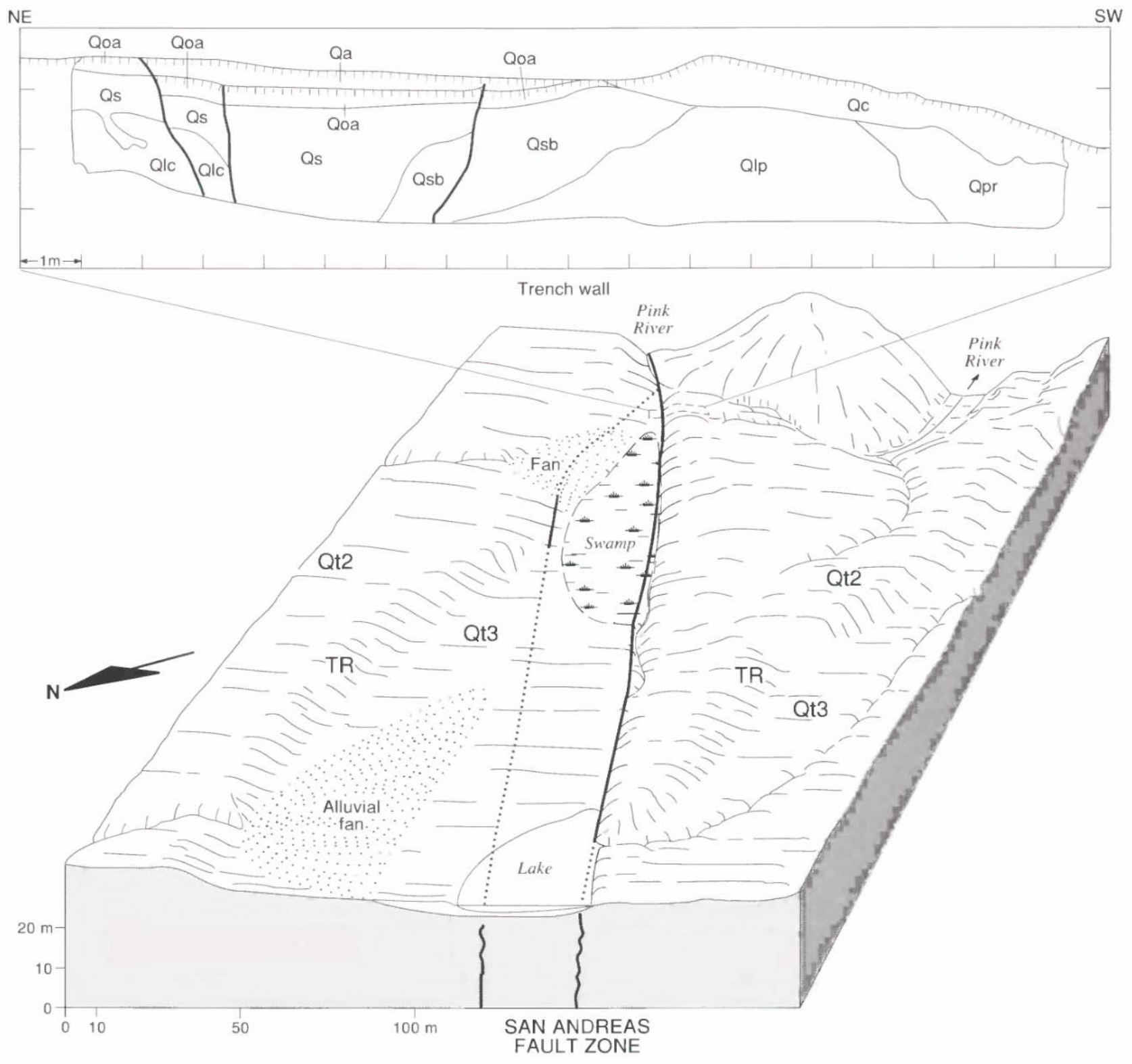

EXPLANATION

[Units exposed in trench wall]

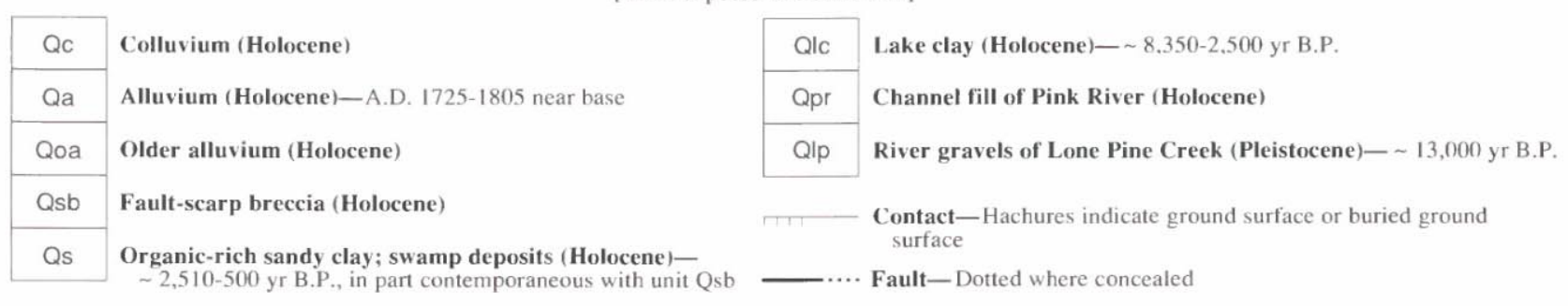


Holocene features and at least two historical slip events (Sharp, 1982, p. 9). Farther south, in the Imperial Valley, evidence of surface faulting disappears, and a $40-\mathrm{km}$ gap separates the south end of the San Andreas from the north end of the Imperial fault. This gap, nearby geothermal and volcanic activity, and the broad structural trough occupied by the Salton Sea and the Imperial Valley indicate a major change in deformation processes and a transition from the San Andreas fault system to the ridge-transform system of the Gulf of California.

\section{OTHER FAULTS}

The seismically active San Jacinto fault diverges from the San Andreas northwest of Cajon Canyon and follows a nearly straight course for $215 \mathrm{~km}$, ending along the southwest side of the Salton Trough. On small-scale maps, it appears as a linear southward extension of the San Andreas segment bounding the San Gabriel Mountains-a simpler, more direct break than the arcuate, branching pattern of the nearly parallel San Andreas, 45 $\mathrm{km}$ to the northeast. Geomorphic and geologic evidence of Quaternary strike slip (Sharp, 1967, 1972, 1981) resembles that for the main San Andreas, but locally vertical motion, southwest side up, may account for as much as 10 percent of the net slip.

Sharp (1981) determined minimum slip rates for two active segments of the San Jacinto fault zone: the Clark fault near Anza Valley and the Coyote Creek fault, $80 \mathrm{~km}$ farther south. At the Anza Valley locality (lat $33^{\circ} 34^{\prime}$ N., long $116^{\circ} 39^{\prime} \mathrm{W}$.), the base of a distinctive gravel marker bed, displaced at least $5.7 \mathrm{~km}$ from its source terrane of schist, gneiss, and amphibolite, overlies $30 \mathrm{~m}$ of sediment which, in turn, overlie a rhyolite ash layer dated at $730 \mathrm{ka}$ and correlated with the air-fall ash at the base of the Bishop Tuff. Geologic data require a slip rate of at least $0.8 \mathrm{~cm} / \mathrm{yr}$ (Sharp, 1981, p. 1755-1757), and a higher rate, as high as $2.5 \mathrm{~cm} / \mathrm{yr}$, is possible (R.V. Sharp, in Clark and others, 1984). North of Anza, geologic relations during

$<$

Figure 4.20.-Near Cajon Canyon, $75 \mathrm{~km}$ east-northeast of Los Angeles, a displaced terrace riser (TR) between two Quaternary terrace levels (Qt2 and Qt3 of Lone Pine Creek, out of view in foreground) records slip on the San Andreas fault. Sketch, based on a planetable map (Weldon and Sieh, 1985, fig. 5), exaggerates relief by about $1.4 \times$; terrace risers actually slope no more than $25^{\circ}$. Relations used to establish Holocene history of faulting and a slip rate of about $2.5 \mathrm{~cm} / \mathrm{yr}$ are derived from trench-wall exposures, here generalized from Weldon and Sieh (1985, fig. 12), and from geomorphic and stratigraphic evidence of stream piracy and other fluvial processes. the past 30 ka yield evidence of average slip rates of 1.2 to $1.7 \mathrm{~cm} / \mathrm{yr}$ (Merifield and others, 1987) for this fault. The minimum Holocene slip rate for the past $6 \mathrm{ka}$ on the Coyote Creek fault-derived from a 14C-dated, displaced channel margin (lat $33^{\circ} 05.4^{\prime} \mathrm{N}$., long $116^{\circ} 02.7^{\prime} \mathrm{W}$.) - is $0.3 \mathrm{~cm} / \mathrm{yr}$, but a much higher rate is possible (R.V. Sharp, oral commun., 1986). Upper limits for the slip rate on the San Jacinto fault (Prentice and others, 1986; Rockwell and others, 1986; Merifield and others, 1987) thus range from 1.0 to $1.7 \mathrm{~cm} / \mathrm{yr}$, in close agreement with Sharp's (1981) estimate of 0.8 to $1.2 \mathrm{~cm} / \mathrm{yr}$ for the late Quaternary.

The Elsinore fault and its northern branches, the Whittier and Chino faults, lie about $35 \mathrm{~km}$ to the southwest of the San Jacinto fault. Seismic activity, occurring chiefly as small earthquakes, increases southward, but the strongest evidence for Quaternary faulting is along the north half of the fault, where Kennedy (1977) and Ziony and Yerkes (1985, table 5) reported examples of offset stratigraphy and landforms. South of lat $33^{\circ} 30^{\prime}$ $\mathrm{N}$., evidence of recent movement on the fault is sparse and widely spaced (Clark, 1975), although faulted Holocene fan deposits within $25 \mathrm{~km}$ of the United StatesMexican border indicate a strike-slip rate of about $0.4 \pm 0.1 \mathrm{~cm} / \mathrm{yr}$ (Pinault and Rockwell, 1984).

South of its junction with the northeast-dipping Whittier reverse fault, the northern section of the Elsinore fault displays consistent evidence of oblique, dominantly horizontal slip. The vertical component is up to the southwest (Jahns, 1954, p. 45-46; Kennedy, 1977; Heath and others, 1982), as it is along the San Jacinto fault. For $100 \mathrm{~km}$, the northern section of the Elsinore fault follows the northeast front of the Santa Ana and Elsinore Mountains, juxtaposing a thick Quaternary sedimentary fill on the northeast against pre-Tertiary crystalline and sedimentary rocks in the mountain blocks. South of Lake Elsinore (lat $33^{\circ} 39^{\prime}$ N., long $117^{\circ} 21^{\prime}$ W.), a facies boundary between sandstone and conglomerate, dated at about $700 \mathrm{ka}$ by a layer of the Bishop Tuff, is offset $5 \mathrm{~km}$ (Kennedy, 1977, p. 5, 9), indicating a strike-slip rate of $0.7 \mathrm{~cm} / \mathrm{yr}$. North of Lake Elsinore, Millman and Rockwell (1985) reported at least $1.6 \mathrm{~km}$ of strike-slip offset since the middle Quaternary, equivalent to a minimum slip rate of about $0.2 \mathrm{~cm} / \mathrm{yr}$. These observations and other geologic and geomorphic evidence along the fault suggest that the component of horizontal slip on the northern section of the Elsinore fault during the late Quaternary has been somewhat less than on the San Jacinto and probably does not exceed $0.7 \mathrm{~cm} / \mathrm{yr}$.

The Newport-Inglewood zone of deformation (Hill, 1971, p. 2958), $40 \mathrm{~km}$ southwest of the Elsinore fault, is a narrow (1-3 km wide) belt of echelon folds and 
left-stepping fault segments, characterized by oblique right slip, chiefly down to the west (Harding, 1973, fig. 5). This zone contains six major oil fields, within which subsurface structural relations in upper Cenozoic strata are well defined by drilling. Quaternary folding and faulting is expressed as an aligned series of anticlinal hills and by deformed and faulted upper Pliocene and Pleistocene deposits (Poland and others, 1959; Barrows, 1974). The overall structural trend is commonly mapped as the Newport-Inglewood fault (fig. 4.17), but individual segments are less continuous and less closely aligned than along other major strike-slip faults in the San Andreas system. Moreover, many anticlines along the zone retain their original ellipsoidal form even where they are cut by strike-slip faults (Harding, 1973, figs. 2, $4,7,9-15)$.

The onshore, northern part of the Newport-Inglewood fault zone extends $65 \mathrm{~km}$ from the Santa Monica Mountains (lat $34^{\circ} 03^{\prime} \mathrm{N}$., long $118^{\circ} 24^{\prime} \mathrm{W}$.) at the southern margin of the Transverse Ranges southeastward to Newport Beach. Farther southeast, the offshore part of the zone continues for about $70 \mathrm{~km}$, defined by folding and faulting in Tertiary and Quaternary deposits (Clarke and others, 1985, p. 359) beneath the sea floor. Whether this zone of deformation is continuous with aligned but more distant offshore faults, such as the Rose Canyon fault near San Diego, is unresolved; if the zone is continuous, its overall length is at least $240 \mathrm{~km}$.

Aligned swales and discontinuous eroded scarps, a few meters to as much as $80 \mathrm{~m}$ high, delineate individual fault segments; many of these scarps cut folded Pleistocene deposits. At the Inglewood and Long Beach oil fields on the northern, onshore part of the fault, folding and faulting are nearly as great in upper Pliocene strata as in older rocks (California Division of Oil and Gas, 1961, p. $577,595)$, indicating that most of the deformation is Quaternary in age. Historical faulting is evident from the 1933 Long Beach earthquake $(M=6.3)$ on an offshore segment of the zone, and from faulted artificial fill near Newport Beach (lat $33^{\circ} 22^{\prime}$ N., long $117^{\circ} 33^{\prime}$ W.) (Guptill and Heath, 1981). The horizontal slip in upper Pliocene strata, estimated from offset fold axes and from structure-contour maps of producing zones in faulted anticlines (Poland and others, 1959, p. 75; California Division of Oil and Gas, 1961), is about $1.5 \mathrm{~km}$, equivalent to a slip rate of less than $0.1 \mathrm{~cm} / \mathrm{yr}$. Vertical components of slip are about a fifth as large, and vertical separation of faulted basal Pleistocene deposits rarely exceeds $60 \mathrm{~m}$ (Yerkes and others, 1965, p. A48).

West of the Newport-Inglewood fault zone, northwesttrending faults that exhibit evidence of Quaternary slip (Clarke and others, 1985, fig. 185) include the Palos Verdes Hills fault, and the offshore San Pedro Basin and Santa Cruz-Catalina Ridge faults. The direction and amount of Quaternary displacement on these faults are ill defined, but they probably have strike-slip components smaller than those on the San Jacinto and San Andreas faults.

Many northwest-trending faults end near the 34th parallel against a major structural boundary that extends westward $250 \mathrm{~km}$ from the San Jacinto fault to Santa Cruz Island. This boundary separates the east-westtrending structures of the Transverse Ranges, Santa Barbara Basin, and northern Channel Islands (lat $34^{\circ} \mathrm{N}$., long $120^{\circ} \mathrm{W}$.) from northwest-trending structures to the south; it also separates higher land and sea floor to the north from lower to the south. A north-dipping zone of aligned or echelon faults (Yerkes and Lee, 1987; Ziony and Jones, 1988), here named the "South Frontal fault zone" (of the Transverse Ranges block), follows the structural boundary and includes, from west to east, the Santa Cruz Island, Anacapa, Santa Monica, Hollywood, Raymond, Sierra Madre, and Cucamonga faults. All of these faults are down to the south, all exhibit evidence of Quaternary activity, and many have been active during the Holocene. The San Fernando fault, an element of the Sierra Madre trend, was the source of the damaging $M=6.6$ San Fernando earthquake in 1971.

Slip rates on the South Frontal fault zone are probably lower than $0.5 \mathrm{~cm} / \mathrm{yr}$ but are difficult to measure because most of the best exposed range-front faults consist of several branches. Typically, the youngest branches are farthest from the range front (Bull and others, 1979; McFadden and others, 1982) and cut tectonically derived fan deposits.

The vertical component of slip on the Cucamonga fault, about $0.3 \mathrm{~cm} / \mathrm{yr}$ (Matti and others, 1982), is derived from a progressive increase in scarp heights - all close multiples of $2 \mathrm{~m}$-in successively older alluvial-fan deposits. These deposits range in age from middle Pleistocene (approx. $700 \mathrm{ka}$ ) to late Holocene. The ages are based on stratigraphic relations, the maturity of soils developed on the fan surface (McFadden and others, 1982), and correlation of these soils with others (Bull and others, 1979) on ancient stream terraces in the San Gabriel Mountains.

\section{FOLDING AND UPLIFT}

The southern section of the San Andreas fault system resembles an inclined block (fig. 4.21), with its raised northeast edge along the San Andreas fault and its downtilted southwest half submerged beneath the Pacific Ocean. Near Los Angeles, topographic relief across this block exceeds 4,300 m: from Mount San Antonio (3,067 m) in the San Gabriel Mountains to the floor of the Catalina Basin $(-1,300 \mathrm{~m})$. This sloping and apparently tilted surface actually incorporates the results of strike-slip and reverse or thrust faulting, and regional uplift. 
Marine Quaternary deposits of the Los Angeles Basin, Ventura Basin, and adjoining offshore areas are locally as thick as 1,200 m (Yerkes, 1972), and lower Pleistocene beds, folded along northwestward trends, exhibit structural relief of more than $1 \mathrm{~km}$ in some parts of the Los Angeles Basin. Upper Pleistocene strata are deformed nearly as much, and evidence from drill holes and surface geologic mapping (Durham and Yerkes, 1964; Yerkes and others, 1965; Yerkes, 1972; Shoellhamer and others, 1981) show that much of the folding is of late Quaternary age. Offshore Pliocene and Quaternary basins and folds also trend northwest. These basins, which border the coast as far south as San Diego (Howell and others, 1978), contain a thinner section of Upper Cenozoic strata than the Los Angeles Basin.

Some of the Quaternary folding, like that along the Newport-Inglewood fault zone, is probably directly related to strike slip on deeper wrench faults (Wilcox and others, 1973). Other, more westerly striking folds may reflect a compressional component of deformation similar
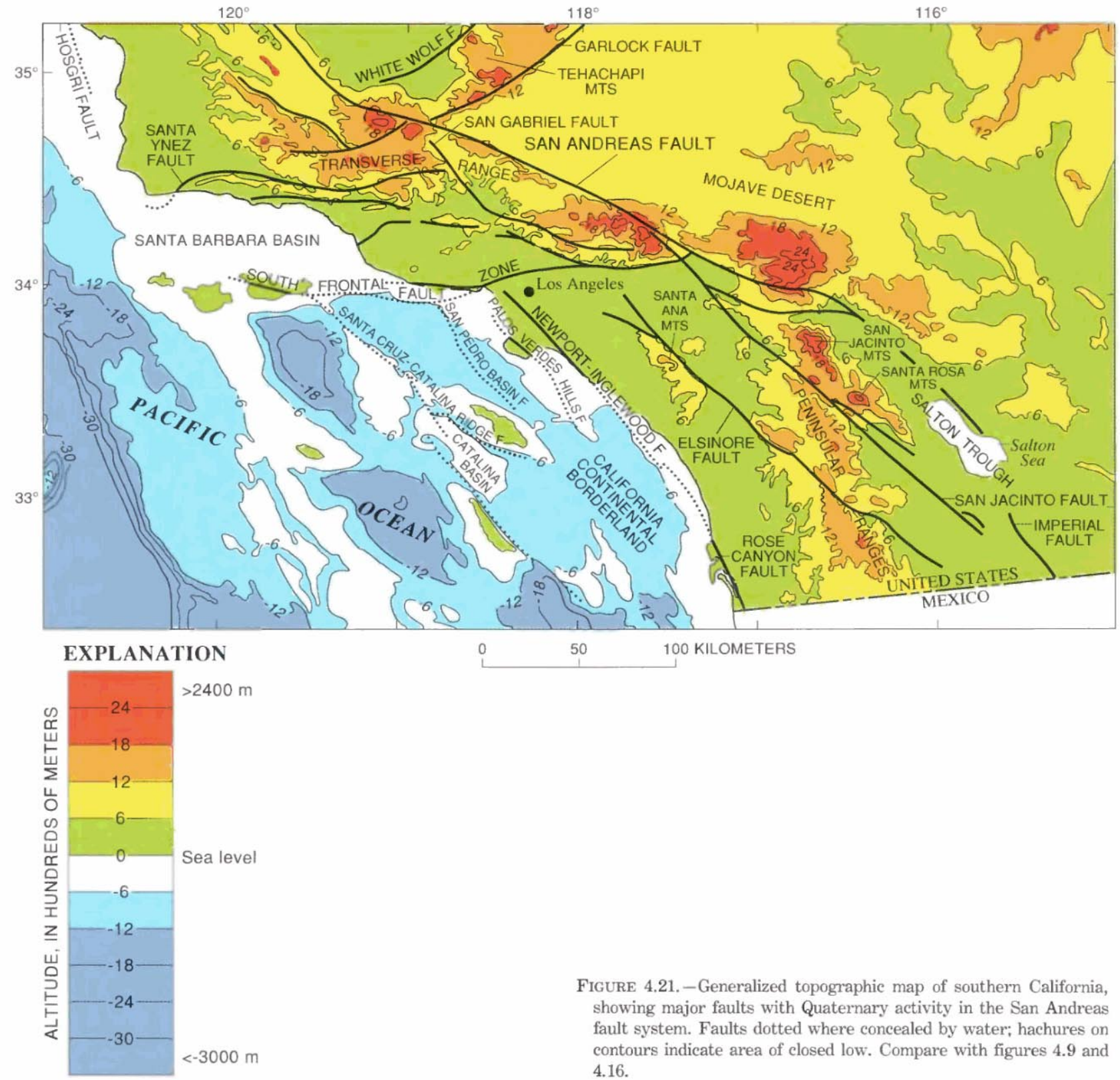

FiguRE 4.21.-Generalized topographic map of southern California, showing major faults with Quaternary activity in the San Andreas fault system. Faults dotted where concealed by water; hachures on contours indicate area of closed low. Compare with figures 4.9 and 4.16. 
to that shown by folds in the central and southern Coast Ranges. Fold patterns in the Los Angeles Basin are complicated by unknown amounts of differential compaction over a faulted and folded basement surface. This surface, nearly $10,000 \mathrm{~m}$ deep at the center of the basin (Yerkes and others, 1965, fig. 2), underlies a nearly complete section of marine Neogene strata, of which the near-surface Quaternary deposits make up a small part. The basin fill thus records almost continuous subsidence and marine deposition from Miocene time to the present.

Northeast of these late Cenozoic coastal basins, crystalline basement rocks either crop out or lie within a few hundred meters of the surface. Neogene subsidence of the coastal marine basins contrasts sharply with sustained and evidently rapid uplift, accompanied by thrust faulting, of the mountainous region to the east and northeast. The north-dipping San Fernando fault provided an example of such range-front tectonics in February 1971. Failure on this fault caused an $M=6.6$ earthquake, opened a 15-km-long zone of surface thrusting, and elevated the land north of the fault by as much as $2 \mathrm{~m}$. Similarly, major Quaternary upwarping and faulting have helped shape the San Gabriel and San Jacinto Mountains; the San Bernardino Mountains (just beyond the boundary of the fault system as defined here) also display evidence of Quaternary uplift and thrust faulting and have apparently deformed with the other ranges.

Geologically recent uplift and tilting of the mountain ranges is indicated by extensive summit areas above $2,000 \mathrm{~m}$, steep southwesterly-flowing streams in narrow $\mathrm{V}$-shaped canyons, extensive alluvial fans and fan complexes at the northeast and southwest range fronts, and incompletely dissected Quaternary surfaces at elevations near $2,000 \mathrm{~m}$. The dissected upland surfaces, most evident in the San Bernardino (Dibblee, 1975) and San Gabriel Mountains, appear as accordant ridge crests and as remnants of originally extensive uplands, some of which are underlain by Quaternary fan deposits and alluvium.

Other geologic evidence also implies rapid late Pleistocene and Holocene uplift. The Blackhawk and Silver Reef debris-avalanche deposits at the north edge of the San Bernardino Mountains record high-velocity $(31 \mathrm{~m} / \mathrm{s})$, voluminous $\left(0.28 \times 10^{9} \mathrm{~m}^{3}\right)$ debris flows (Woodford and Harriss, 1928; Shreve, 1968), which surged northward from the range front as recently as $17.4 \mathrm{ka}$ (Stout, 1975, 1977), leaving relict lobes of slide debris on the desert floor $10 \mathrm{~km}$ from the slide source. Smaller and slower debris flows and rock slides still occur from time to time in both the San Gabriel and San Bernardino Mountains.

Rates of late Quaternary uplift can be estimated for parts of the southern and central San Gabriel Mountains: near the mouth of Little Tujunga Canyon (lat $34^{\circ} 17^{\prime} \mathrm{N}$., long $118^{\circ} 22^{\prime}$ W.) (Menges and others, 1979), on the North
Fork of the San Gabriel River (lat $34^{\circ} 09^{\prime}$ N., long $117^{\circ} 31^{\prime}$ W.) (McFadden and others, 1982), and across the Cucamonga fault (lat $34^{\circ} 10^{\prime}$ N., long $117^{\circ} 31^{\prime}$ W.) (Matti and others, 1982). Strath and fill terraces at the first two localities have been dated by physiographic position, ${ }^{14} \mathrm{C}$ methods, and soil maturity; they range in age from middle Pleistocene to late Holocene (approx 1,000-700 ka). Terrace elevations above modern stream channels reflect both climatic and tectonic influences, but Bull and others (1979) and Menges and others (1979) separated these effects to obtain uplift rates of about $0.3 \mathrm{~cm} / \mathrm{yr}$ for the Holocene and about $0.03 \mathrm{~cm} / \mathrm{yr}$ for the late Pleistocene. Interpretation (Matti and others, 1982) of the displacement history across strands of the Cucamonga fault, as discussed above, also results in an uplift rate of about $0.3 \mathrm{~cm} / \mathrm{yr}$ for the latest Pleistocene and Holocene at the south front of the range. Together, these consistent estimates of uplift rate sample a 78-km segment of the San Gabriel front. Regional uplift rates to the north and northwest and within the main body of the Transverse Ranges are probably somewhat higher; rates for the western Transverse Ranges, as discussed in the section above entitled "Central Section of the San Andreas Fault System," are locally as high as $1 \mathrm{~cm} / \mathrm{yr}$ near Ventura.

Elevated wave-cut platforms and marine-terrace deposits document Quaternary uplift of the southern California coast from the Transverse Ranges southward to San Diego. Mappable, well-dated (450-85 ka) marine terraces, which correlate with major worldwide highstands of the sea, show nearly uniform coastal uplift at rates that range from about 0.01 to $0.05 \mathrm{~cm} / \mathrm{yr}$ (Lajoie and others, 1979).

Similar uplift rates (approx $0.02 \mathrm{~cm} / \mathrm{yr}$ ) can be interpreted from the elevations and estimated ages of Quaternary erosional surfaces on the Perris structural block, which lies between the Elsinore and San Jacinto faults. Late Quaternary drainage systems on the Paloma erosional surface are presumed to be superimposed from the Gavilan-Lakeview surface (Woodford and others, 1971), which is nearly $200 \mathrm{~m}$ higher and an estimated $1 \mathrm{Ma}$ older than the Paloma surface. Persistent uplift of the Perris block must be geologically recent because a late Miocene erosional surface, overlain by basalt dated at $8.3 \pm 0.5 \mathrm{Ma}$ (J.W. Hawkins, in Woodford and others, 1971), is at an altitude intermediate between the two younger surfaces. The nearly horizontal remnants of the late Miocene erosional surface and the relatively undeformed detrital and eruptive strata of Neogene age attest to long-term vertical stability of the Perris structural block.

Together, the Quaternary geomorphic and geologic evidence south of the Transverse Ranges implies systemwide Pleistocene and Holocene uplift, but at higher rates toward the northeast than on the Perris and coastal blocks. 


\section{SUMMARY}

Right-lateral strike slip on fewer than 10 major faults dominates the Quaternary record of deformation within the San Andreas fault system. Of these faults, the San Andreas is the longest and most active, but the fault system includes other structural elements, such as shorter or discontinuous strike-slip faults, reverse and thrust faults, regional fold systems, minor folds genetically related to strike slip along wrench faults, and tilted, uplifted, or depressed crustal blocks. All of these structures result from relative, predominantly horizontal motion at the boundary separating the Pacific and North American plates.

Though chiefly strike slip, the detailed pattern of Quaternary deformation differs from place to place within the fault system. Although the ultimate causes of these different structural patterns are ill defined and the subjects of continuing research, some geologic controls are evident: (1) the lithology and structure of basement rocks (see chap. 3), (2) the thickness of upper Mesozoic and Cenozoic strata overlying geologic basement, (3) the geometric orientation of major strike-slip faults, especially the San Andreas, and (4) the slip rates along structures controlling deformation.

Plutonic basement includes the granitic and associated metamorphic rocks of the Salinian block west of the San Andreas fault in the central Coast Ranges, similar rocks of the southern California batholith in the Peninsular Ranges, and a more complex suite of metamorphic and crystalline rocks in the central and eastern Transverse Ranges. Elsewhere in the fault system, the dominant basement-rock unit is the intensely sheared and broken Franciscan complex, which locally contains ophiolite bodies and remobilized, cold intrusive masses of serpentinite. The simplest patterns of Quaternary deformation are within regions of exposed or near-surface plutonic basement, where block-bounding strike-slip faults and block uplift or tilting prevail. Deformation is greater and more complex in regions of exposed or near-surface Franciscan basement, where broad anticlinoria, local basins, and distributed shearing are more evident. It is most intense and complex where basement rocks are covered by a kilometer or more of stratified upper Mesozoic or Cenozoic rocks.

Control of Quaternary deformation processes by fault geometry, or the interdependence of process and geometry, is best shown at the Big Bend in the San Andreas fault near the north boundary of the Transverse Ranges. There, west-northwest-trending folds and northwesttrending strike-slip faults of the northern and central sections of the fault system abut against a compressional domain characterized by east-west-trending folds, active thrust and reverse faults, and accelerated rates of vertical uplift. On much smaller scales, similar changes in structural trend and pattern appear at other changes in strike of the San Andreas or major branch faults.

The effect of different slip rates is demonstrated by the contrast in structural style along the San Andreas fault in central California and along the Newport-Inglewood fault zone in southern California. At a slip rate of $3.5 \mathrm{~cm} / \mathrm{yr}$, the San Andreas has displaced middle Pleistocene (1 Ma) outcrop belts and major structures by about $35 \mathrm{~km}$, effectively creating - on opposite sides of the fault - two independent structural domains, each of which responds differently to its new structural setting. In the same period of time, the much lower slip rates on the NewportInglewood fault zone have separated Quaternary structures by less than $500 \mathrm{~m}$, leaving the initial structural patterns at least partly intact and connected.

Our current knowledge of Quaternary deformation within the San Andreas fault system can be expressed in terms of estimated rates for deformation processes (fig. 4.22 ), even though reliable quantitative measurements of slip, folding, and uplift are few. Other lines of evidence from geologic mapping and geophysical investigations permit reasonable inferences regarding regional rates of deformation and the history of the fault system. Although some of these interpretations may change as new data are acquired, several major characteristics of the fault system and its Quaternary history are documented by the available evidence:

1. Quaternary tectonism within the San Andreas fault system has deformed an area of $160,000 \mathrm{~km}^{2}$, extending from Punta Gorda to the Salton Sea, a system length of about $1,100 \mathrm{~km}$, and from the Great Valley and the Mojave Desert to fault zones off shore in the Pacific Ocean, an average system width of about 145 $\mathrm{km}$.

2. Throughout the fault system, the rate of right-lateral strike slip on northwesterly-trending faults typically exceeds the geologically determined rates for other deformation processes by an order of magnitude. Despite some important exceptions, horizontal slip approximately parallel to the plate boundary dominates the Quaternary history of the fault system.

3. In the central section of the fault system, between lat $35^{\circ} 45^{\prime}$ and $36^{\circ} 30^{\prime}$ N., most of this slip has followed the main San Andreas fault; slip rates on this section of the fault are the highest observed to date within the system, averaging about $3.5 \mathrm{~cm} / \mathrm{yr}$.

4. Strike slip is distributed more broadly in both the northern and southern sections of the fault system, where the main San Andreas splits into several active branches; slip rates on some of these branches may equal or exceed the rate on nearby parts of the main fault. 
5. Observed rates of Quaternary faulting, summed across the fault system, are insufficient to account for all of the relative movement $(5.1 \mathrm{~cm} / \mathrm{yr})$ attributed to the Pacific-North American plate boundary, but neither the magnitude of the difference nor its cause is well constrained.

6. East-westerly- to northwesterly-trending reverse and thrust faults occur near many strike-slip faults and elsewhere in the system; they are longer, more active, and best defined in and near the Transverse Ranges (between lat $33^{\circ} 45^{\prime}$ and $35^{\circ} 00^{\prime}$ N.), where they accompany rapid Quaternary uplift and intense folding on east-west-trending axes.

7. Major west-northwest-trending fold belts deform Quaternary and older strata overlying deeply buried (1-5 km deep) basement rocks; most regional fold belts strike obliquely to strike-slip faults and are consistent with wrench-fault structural patterns, but the age and intensity of folding differ from place to place.

8. Several fault-bounded basement blocks are internally little deformed: the Sebastopol block in northern California (Franciscan basement between the San Andreas and Rodgers Creek faults), the Salinian block in central California (granitic basement between the Rinconada and San Andreas faults), and the Perris block in southern California (granitic basement between the Elsinore and San Jacinto faults).

9. Throughout the Quaternary, widespread uplift has characterized most of the fault system; locally downwarped, fault-controlled basins that reverse this general pattern are the San Francisco Bay and Santa Clara Valley (northern California), the Santa Clara River valley-Ventura Basin (southern California), the Los Angeles Basin, and basins near the southern and southwestern margin of the San Joaquin Valley.

10. Maximum observed uplift rates $(0.5-1.0 \mathrm{~cm} / \mathrm{yr})$ for the late Quaternary occur near Punta Gorda and in the Transverse Ranges; elsewhere, measured uplift rates average about $0.05 \mathrm{~cm} / \mathrm{yr}$, but in large areas of the fault system no reliable measurements of uplift rates are available.

11. Major strike-slip faults bound the west edge of several uplifted blocks in northern California: the Santa Rosa block, bounded by the Rodgers Creek and Maacama faults; the Diablo Range and Temblor Range blocks, bounded by the Calaveras and San Andreas faults; and the Santa Cruz Mountains and Santa Lucia Range blocks, bounded by the San Gregorio, San Simeon, and Hosgri faults.

12. In the Transverse and Peninsular Ranges of south-

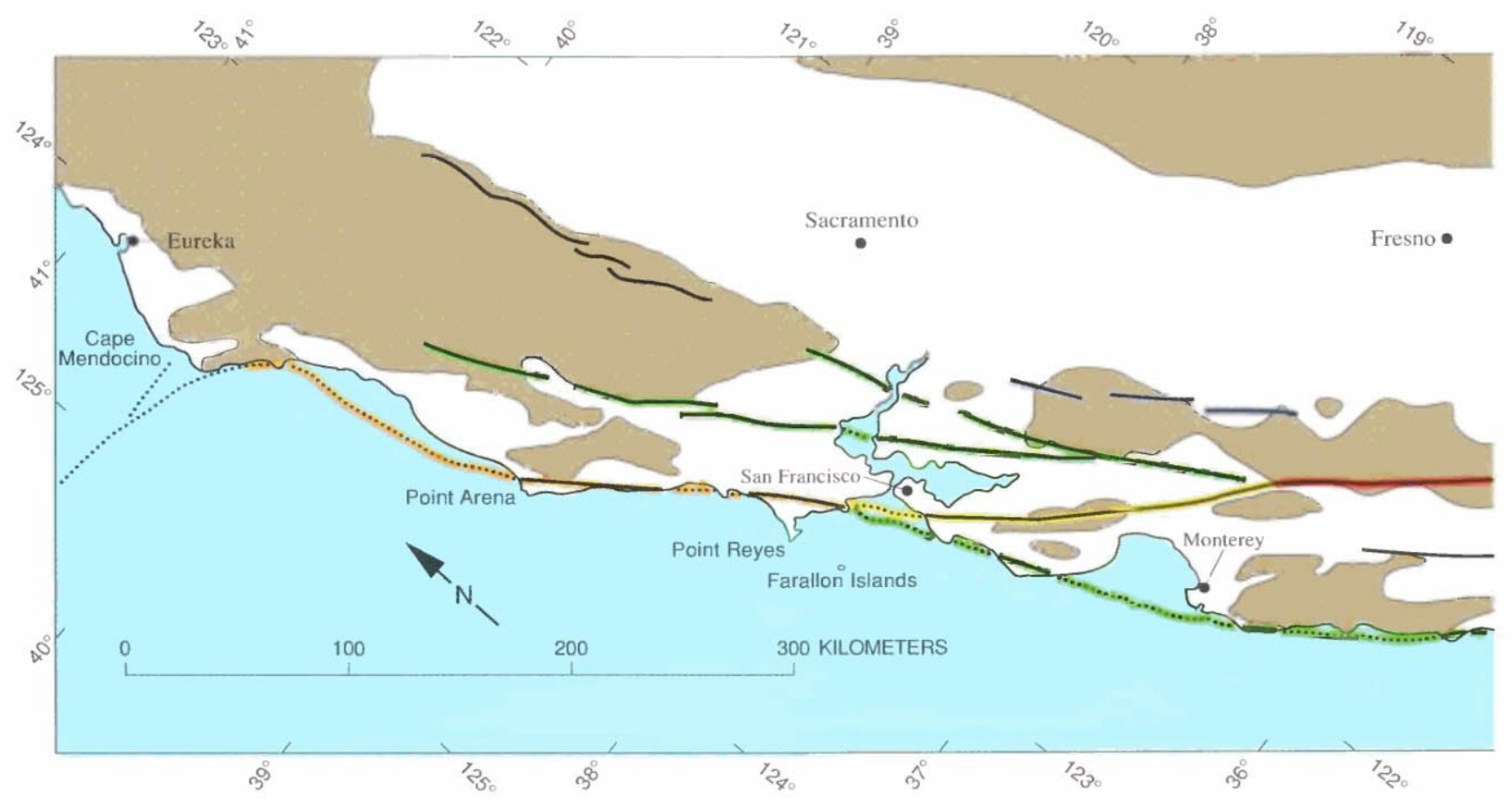

FIGURE 4.22. - Sketch map of western and southwestern California, showing selected major faults exhibiting evidence of Quaternary activity in the San Andreas fault system. Average Quaternary slip rates are based on measured values from published sources and, where measurements are incomplete or unavailable, on interpreted geologic and geomorphic evidence. Slip components on northwest-trending faults are predominantly horizontal, right lateral, and consistent with North American-Pacific plate motion. Group of east-west-trending faults between 
ern California, Quaternary uplift near strike-slip faults has produced two nearly orthogonal mountain chains: (1) the west-northwesterly-trending ranges that separate the Mojave Desert from coastal lowlands and that lie along the trend of Transverse Ranges thrust faults and the southern branch of the San Andreas fault, and (2) the north-south-trending mountain system composed of discrete, northwesttrending ranges that are separated and possibly offset by the Elsinore and San Jacinto faults west of the Salton Sea.

13. Rates of Quaternary faulting, folding, and uplift resemble those for the pre-Quaternary fault system; significantly higher rates, evident near Punta Gorda and in the Transverse Ranges, signify late pulses of accelerated tectonic activity that are still underway.

Despite many still-unsolved problems and unanswered questions, the San Andreas fault system has proved a productive laboratory in which to pursue three tasks: to quantitatively evaluate earthquake hazards in the densely populated, high-risk regions of California; to develop new investigative and analytical methods that can be applied in other regions of high earthquake risk; and to better understand how geologic processes deform the Earth's crust at plate margins. None of these tasks is finished, but the progress so far has improved our knowledge of crustal-deformation processes and aided our efforts to reduce the hazards from damaging earthquakes.

\section{REFERENCES CITED}

Addicott, W.O., 1969, Late Pliocene mollusks from San Francisco Peninsula, California, and their paleogeographic significance: California Academy of Sciences Proceedings, ser. 4, v. 37, no. 3, p. $57-93$.

Atwater, B.F., Hedel, C.W., and Helley, E.J., 1977, Late Quaternary depositional history, Holocene sea-level changes, and vertical crustal movement, southern San Francisco Bay, California: U.S. Geological Survey Professional Paper 1014, 15 p.

Bailey, T.L., and Jahns, R.H., 1954, Geology of the Transverse Range province, southern California, [pt.] 6 of Geology of the natural provinces, chap. 2 of Jahns, R.H., ed., Geology of southerm California: California Division of Mines Bulletin 170, v. 1, p. 83-106.

Barrows, A.G., 1974, A review of the geology and earthquake history of the Newport-Inglewood structural zone, southern California: California Division of Mines and Geology Special Report 114, 115 p.

Barrows, A.G., Kahle, J.E., and Beeby, D.J., 1985, Earthquake hazards and tectonic history of the San Andreas fault zone, Los Angeles County, California: California Division of Mines and Geology Open-File Report 85-10LA, 236 p.

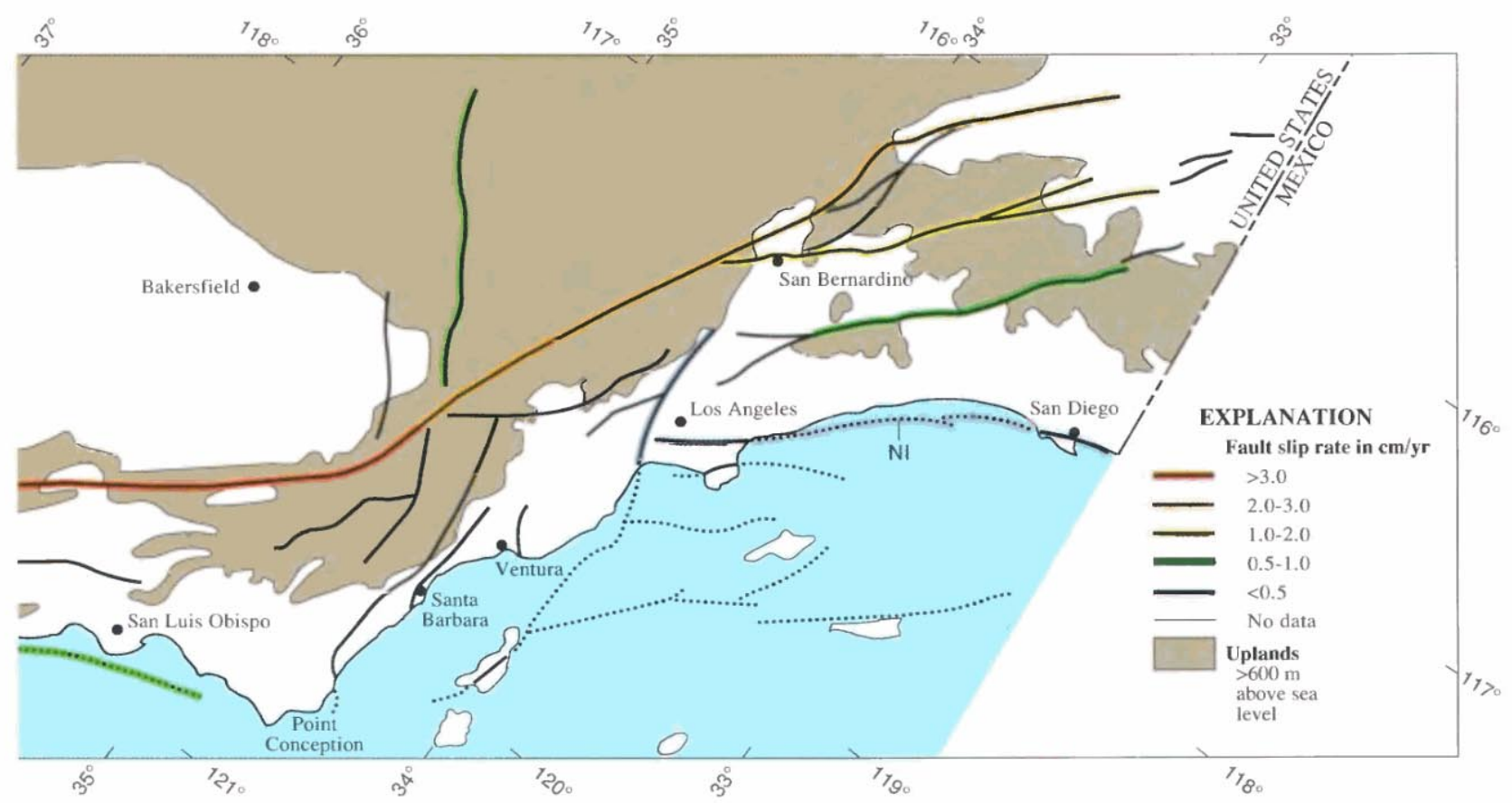

lat $34^{\circ} 00^{\prime}$ and $35^{\circ} 30^{\prime} \mathrm{N}$. exhibit a more complex slip pattern, including chiefly reverse faulting but also some strike slip. Areas above 600 -m elevation (colored) exhibit evidence of late Cenozoic uplift and enclose most areas of Quaternary uplift, but elevation pattern reveals no such major local uplifts as those near Ventura (approx $1 \mathrm{~cm} / \mathrm{yr}$ ) and along the Newport-Inglewood fault zone (NI). Faults dotted where concealed by water. 
Beutner, E.C., McLaughlin, R.J., Ohlin, H.N., and Sorg, D.H., 1980, Geologic map of the King Range and Chemise Mountain Instant Study Areas, northern California: U.S. Geological Survey Miscellaneous Field Studies Map MF-1196-A, scale 1:62,500.

Bradley, W.C., 1957, Origin of marine-terrace deposits in the Santa Cruz area, California: Geological Society of America Bulletin, v. 68 , no. 4 , p. $421-444$.

Bradley, W.C., and Griggs, G.B., 1976, Form, genesis, and deformation of central California wave-cut platforms: Geological Society of America Bulletin, v. 87, no. 3, p. 433-449.

Brown, R.D., Jr., 1970, Map showing recently active breaks along the San Andreas and related faults between the northern Gabilan Range and Cholame Valley, California: U.S. Geological Survey Miscellaneous Geologic Investigations Map I-575, scale 1:62,500.

Brown, R.D., Jr., and Wolfe, E.W., 1972, Map showing recently active breaks along the San Andreas fault between Point Delgada and Bolinas Bay, California: U.S. Geological Survey Miscellaneous Geologic Investigations Map I-692, scale 1:24,000, 2 sheets.

Bull, W.B., 1964, Geomorphology of segmented alluvial fans in western Fresno County, California: U.S. Geological Survey Professional Paper 352-E, p. 89-129.

Bull, W.B., Menges, C.M., and McFadden, L.D., 1979, Landforms and Quaternary tectonism of a thrust-faulted mountain front [abs.]: Geological Society of America Abstracts with Programs, v. 11, no. 7, p. 396.

California Division of Oil and Gas, 1961, California oil and gas fields, maps and data sheets, pt. 2, Los Angeles-Ventura basins and central coastal regions: San Francisco, p. 496-913.

Christensen, M.N., 1965, Late Cenozoic deformation in the central Coast Ranges of California: Geological Society of America Bulletin, v. 76 , no. 10 , p. $1105-1124$.

Clark, M.M., 1973, Map showing recently active breaks along the Garlock and associated faults, California: U.S. Geological Survey Miscellaneous Geologic Investigations Map I-741, scale 1:24,000, 3 sheets.

1975, Character and distribution of recent movement along the southeastern part of the Elsinore fault zone, southern California [abs.]: Geological Society of America Abstracts with Programs, v. 7, no. 3, p. 304.

Clark, M.M., Harms, K.K., Lienkaemper, J.J., Harwood, D.S., Lajoie, K.R., Matti, J.C., Perkins, J.A., Rymer, M.J., Sarna-Wojcicki, A.M., Sharp, R.V., Sims, J.D., Tinsley, J.C., and Ziony, J.I., 1984, Preliminary slip-rate table and map of late-Quaternary faults of California: U.S. Geological Survey Open-File Report 84-106, 13 p., scale $1: 1,000,000,5$ sheets.

Clarke, S.H., Greene, H.G., and Kennedy, M.P., 1985, Identifying potentially active faults and unstable slopes offshore, in Ziony, J.I., ed., Evaluating earthquake hazards in the Los Angeles region-an earth-science perspective: U.S. Geological Survey Professional Paper 1360, p. 347-373.

Clifton, H.E., Hunter, R.E., and Gardner, J.V., 1988, Analysis of eustatic, tectonic, and sedimentologic influences on transgressive and regressive cycles in the Upper Cenozoic Merced Formation, San Francisco, California, in Kleinspehn, K.L. and Paola, Chris, eds., New perspectives in basin analysis: New York, SpringerVerlag, p. 109-128.

Compton, R.R., 1966, Analyses of Pliocene-Pleistocene deformation and stresses in northern Santa Lucia Range, California: Geological Society of America Bulletin, v. 77, no. 12, 1361-1380.

Cotton, W.R., Hall, N.T., and Hay, E.A., 1986, Holocene styles of surface faulting along the creeping segment of the San Andreas fault, San Juan Bautista to Cholame, California: Final technical report to U.S. Geological Survey under Contract 21355, 12 p.

Crowell, J.C., 1975, The San Gabriel fault and Ridge Basin, southern California, in Crowell, J.C., ed., San Andreas fault in southern
California: A guide to San Andreas fault from Mexico to Carrizo Plain: California Division of Mines and Geology Special Report 118 , p. 208-219.

1981, An outline of the tectonic history of southeastern California, in Ernst, W.G., ed., The geotectonic development of California (Rubey volume 1): Englewood Cliffs, N.J., Prentice-Hall, p. $584-600$.

Cummings, J.C., 1968, The Santa Clara Formation and possible post-Pliocene slip on the San Andreas fault in central California, in Dickinson. W.R., and Grantz, Arthur, eds., Proceedings of conference on geologic problems of San Andreas fault system: Stanford, Calif., Stanford University Publications in the Geological Sciences, v. 11, p. 191-207.

Curray, J.R., and Nason, R.D., 1967, San Andreas fault north of Point Arena, California: Geological Society of America Bulletin, v. 78, no. 3 , p. 413-418,

Davis, Thomas, 1983, Late Cenozoic structure and tectonic history of the western "Big Bend" of the San Andreas fault and adjacent San Emigdio Mountains: Santa Barbara, University of California, Ph.D. thesis, 509 p.

DeMets, Charles, Gordon, R.G., Stein, Seth, and Argus, D.F., 1987, A revised estimate of Pacific-North America motion and implications for western North America plate boundary zone tectonics: Geophysical Research Letters, v. 14, no. 9, p. 911-914.

Dibblee, T.W., Jr., 1966, Geology and sections of the Palo Alto 15' quadrangle, Santa Clara and San Mateo Counties, California: California Division of Mines and Geology Map Sheet 8, scale 1:62,000.

1975, Late Quaternary uplift of the San Bernardino Mountains on the San Andreas and related faults, in Crowell, J.C., ed., San Andreas fault in southern California: A guide to San Andreas fault from Mexico to Carrizo Plain: California Division of Mines and Geology Special Report 118, p. 127-135.

Durham, D.L., and Yerkes, R.F., 1964, Geology and oil resources of the eastern Puente Hills area, southern California: U.S. Geological Survey Professional Paper 420-B, p. B1-B62.

Eaton, J.P., 1984, Focal mechanisms of near-shore earthquakes between Santa Barbara and Monterey, California: U.S. Geological Survey Open-File Report 84-477, 10 p.

Fox, K.F., 1983, Tectonic setting of Late Miocene, Pliocene, and Pleistocene rocks in part of the Coast Ranges north of San Francisco, California: U.S. Geological Survey Professional Paper $1239,33 \mathrm{p}$.

Frizzell, V.A., Jr., and Brown, R.D., Jr., 1976, Map showing recently active breaks along the Green Valley fault, Napa and Solano Counties, California: U.S. Geological Survey Miscellaneous Field Studies Map MF-743, scale 1:24,000.

Galehouse, J.S., 1967, Provenance and paleocurrents of the Paso Robles Formation, California: Geological Society of America Bulletin, v. 78 , no. 8, p. 951-978.

Guptill, P.D., and Heath, E.G., 1981, Surface faulting along the Newport-Inglewood zone of deformation: California Geology, v. 34 , no. 7 , p. $142-148$.

Hall, N.T., 1984, Holocene history of the San Andreas fault between Crystal Springs Reservoir and San Andreas Dam, San Mateo County, California: Seismological Society of America Bulletin, v. 74 , no. 1, p. 281-299.

Hamilton, D.H., Fisher, D.L., and Jahns, R.H., 1979, Evidence of Quaternary right slip and other deformation along the San Gregorio fault, California; another view [abs.]: Geological Society of America Abstracts with Programs, v. 11, no. 7, p. 437-438.

Hanks, T.C., Bucknam, R.C., Lajoie, K.R., and Wallace, R.E., 1984, Modification of wave-cut and faulting controlled landforms: Jour$\mathrm{nal}$ of Geophysical Research, v. 89, no. B7, p. 5771-5790.

Hanson, K.L., Lettis, W.R., Mezger, E.L., and Weber, G.E., 1987, 
Late Pleistocene deformation along the San Simeon fault zone near San Simeon, California [abs]: Geological Society of America Abstracts with Programs, v. 19, no. 6, p. 386.

Harden, J.W., and Matti, J.C., 1989, Holocene and late Pleistocene slip rates on the San Andreas fault in Yucaipa, California, using displaced alluvial-fan deposits and soil chronology: Geological Society of America Bulletin, v. 10l, no. 9, p. 1107-1117.

Harding, T.P., 1973, Newport-Inglewood trend, California-an example of wrenching style of deformation: American Association of Petroleum Geologists Bulletin, v. 57, no. 1, p. 97-116.

- 1976, Tectonic significance and hydrocarbon trapping consequences of sequential folding synchronous with San Andreas faulting, San Joaquin Valley, California: American Association of Petroleum Geologists Bulletin, v. 60, no. 3, p. 356-378.

Hearn, B.C., Jr., Donnelly, J.M., and Goff, F.E., 1976, Preliminary geologic map and cross-section of the Clear Lake Volcanic field, Lake County, California: U.S. Geological Survey Open-File Map 76-751, scale 1:24,000, 2 sheets.

Heath, E.G., Jensen, D.E., and Lukesh, D.W., 1982, Style and age of deformation on the Chino fault, in Cooper, J.D., compiler, Neotectonics in southern California: Geological Society of America, Cordilleran Section Annual Meeting, 78th, Guidebook, p. 123-134.

Helley, E.J., Lajoie, K.R., Spangle, W.E., and Blair, M.L., 1979, Flatland deposits of the San Francisco Bay region, Californiatheir geology and engineering properties, and their importance to comprehensive planning: U.S. Geological Survey Professional Paper 943, 88 p.

Higgins, C.G., 1960, Ohlson Ranch Formation, Pliocene, northwestern Sonoma County, California: Berkeley, University of California Publications in Geological Sciences, v. 36, no. 3, p. 199-232.

Hill, M.L., 1971, Newport-Inglewood zone and Mesozoic subduction, California: Geological Society of America Bulletin, v. 82, no. 10, p. 2957-2962.

Hill, M.L., and Dibblee, T.W., Jr., 1953, San Andreas, Garlock, and Big Pine faults, California-a study of the character, history, and tectonic significance of their displacements: Geological Society of America Bulletin, v. 64 , no. 4, p. 443-458.

Howell, D.G., McCulloch, D.S., and Vedder, J.G., 1978, General geology, petroleum appraisal, and nature of environmental hazards Eastern Pacific Shelf latitude $28^{\circ}$ to $38^{\circ}$ north: U.S. Geological Survey Circular 786, 29 p.

Jahns, R.H., 1954, Geology of the Peninsular Range province, southern California and Baja California, [pt.] 3 of Geology of the natural provinces, chap. 3 of Jahns, R.H., ed., Geology of southern California: California Division of Mines Bulletin 170, v. 1, p. 29-52.

Jennings, C.W., compiler, 1975, Fault map of California with locations of volcanoes, thermal springs, and thermal wells: California Division of Mines and Geology Geologic Data Map 1, scale 1:750,000.

- compiler, 1977, Geologic map of California: California Division of Mines and Geology Geologic Data Map 2, scale 1:750,000.

Keller, E.A., Bonkowski, M.S., Korsch, R.J., and Shlemon, R.J., 1982, Tectonic geomorphology of the San Andreas fault zone in the southern Indio Hills, Coachella Valley, California: Geological Society of America Bulletin, v. 93, no. 1, p. 46-56.

Kennedy, M.P., 1977, Recency and character of faulting along the Elsinore fault zone in southern Riverside County, California: California Division of Mines and Geology Special Report 131, 12 p.

Lajoie, K.R., 1986, Coastal tectonics, in Active tectonics: Washington, National Academy Press, p. 95-124.

Lajoie, K.R., Kern, J.P., Wehmiller, J.F., Kennedy, G.L., Mathieson, S.A., Sarna-Wojcicki, A.M., Yerkes, R.F., and McCrory, P.F., 1979, Quaternary marine shorelines and crustal deformation, San Diego to Santa Barbara, California, in Abbott, P.L., ed., Geolog- ical excursions in the southern California area: San Diego, Calif., San Diego State University, Department of Geological Sciences guidebook for field trips, p. 3-15.

Lajoie, K.R., Sarna-Wojcicki, A.M., and Ota, Yoko, 1982a, Emergent Holocene terraces at Ventura and Cape Mendocino, Californiaindicators of high tectonic uplift rates [abs.]: Geological Society of America Abstracts with Programs, v. 14, no. 4, p. 178.

Lajoie, K.R., Sarna-Wojcicki, A.M., and Yerkes, R.F., 1982b, Quaternary chronology and rates of crustal deformation in the Ventura area, California, in Cooper, J.D., compiler, Neotectonics in southern California: Geological Society of America, Cordilleran Section Annual Meeting, 78th, guidebook, p. 43-51.

Lawson, A.C., 1894, The geomorphogeny of the coast of northern California: Berkeley, University of California, Department of Geology Bulletin, v. 1, p. 241-272.

_ chairman, 1908, The California earthquake of April 18, 1906: Report of the State Earthquake Investigation Commission: Carnegie Institution of Washington Publication 87, $2 \mathrm{v}$.

Leslie, R.B., 1981, Continuity and tectonic implications of the San Simeon-Hosgri fault zone, central California: U.S. Geological Survey Open-File Report 81-430, 59 p.

Matti, J.C., Tinsley, J.C., Morton, D.M., and McFadden, L.D., 1982, Holocene faulting history as recorded by alluvial stratigraphy within the Cucamonga fault zone: A preliminary view, in Tinsley, J.C., Matti, J.C., and McFadden, L.D., eds., Late Quaternary pedogenesis and alluvial chronologies of the Los Angeles and San Gabriel Mountains areas, southern California, and Holocene faulting and alluvial stratigraphy within the Cucamonga fault zone: A preliminary view: Geological Society of America, Cordilleran Section Annual Meeting, 78th, Anaheim, Calif., 1982, Guidebook 12 , p. 29-44.

McCulloch, D.S., Utter, P.A., and Menack, J.S., 1985, Maps showing locations of selected pre-Quaternary rock samples from $34^{\circ} 30^{\prime}$ North latitude to 42 North latitude, California continental margin: U.S. Geological Survey Miscellaneous Field Studies Map MF1719,38 p., scale $1: 250,000,4$ sheets.

McFadden, L.D., Tinsley, J.C., and Bull, W.B., 1982, Late Quaternary pedogenesis and alluvial chronologies of the Los Angeles basin and San Gabriel Mountains areas, southern California, in Tinsley, J.C., Matti, J.C., and McFadden, L.D., eds., Late Quaternary pedogenesis and alluvial chronologies of the Los Angeles and San Gabriel Mountains areas, southern California, and Holocene faulting and alluvial stratigraphy within the Cucamonga fault zone: A preliminary view: Geological Society of America, Cordilleran Section Annual Meeting, 78th, Anaheim, Calif., 1982, Guidebook 12 , p. 1-19.

McLaughlin, R.J., Lajoie, K.R., Sorg, D.H., Morrison, S.D., and Wolfe, J.A., 1983, Tectonic uplift of a middle Wisconsin marine platform near the Mendocino triple junction, California: Geology, v. 11 , no. 1, p. $35-39$.

Menges, C.M., McFadden, L.D., and Bull, W.B., 1979, Terrace development in a thrust-faulted terrane, San Fernando area, southern California [abs.]: Geological Society of America Abstracts with Programs, v. 11, no. 7, p. 478.

Merifield, P.M., Rockwell, T.K., and Loughman, C.C., 1987, Slip rate on the San Jacinto fault zone in the Anza seismic gap, southern California [abs]: Geological Society of America Abstracts with Programs, v. 19 , no. 6, p. 431-432.

Merritts, Dorothy, and Bull, William, 1989, Interpreting Quaternary uplift rates at the Mendocino triple junction, from uplifted marine terraces: Geology, v. 17, no. 11, p. 1020-1024.

Millman, D.E. and Rockwell, T.K., 1985, Lateral offset of mid- and late Quaternary deposits along the northern Elsinore fault, southern California [abs.]: Geological Society of America Abstracts with Programs, v. 17, no. 6, p. 370. 
Noble, Levi, 1954, The San Andreas fault zone from Soledad Pass to Cajon Pass, California, [pt.] 5 of Structural features, chap. 4 of Jahns, R.H., ed., Geology of southern California: California Division of Mines Bulletin 170, v. 1, p. 37-48.

Pacific Gas and Electric Co., 1988, Final Report of the Diablo Canyon Long Term Seismic Program-July 1988: San Francisco, 650 p.

Perkins, J.A., Sims, J.D., and Sturgess, S.S., 1989, Late Holocene movement along the San Andreas fault at Melendy ranch: Implications for the distribution of fault slip in central California: Journal of Geophysical Research, v. 94, no. B8, p. 10217-10230.

Pierce, K.L., 1986, Dating methods, in Active tectonics: Washington, National Academy Press, p. 195-214.

Pinault, C.T., and Rockwell, T.K., 1984, Rates and sense of Holocene faulting on the southern Elsinore fault: Further constraints on the distribution of dextral shear between the Pacific and North American plates [abs.]: Geological Society of America Abstracts with Programs, v. 16, no. 6, p. 624.

Poland, J.F., Garrett, A.A., and Sinnott, Allen, 1959, Geology, hydrology, and chemical character of ground waters in the Torrance-Santa Monica area, California: U.S. Geological Survey Water-Supply Paper 1461, 425 p.

Prentice, C.S., 1989, The northern San Andreas fault: Russian River to Point Arena, in Sylvester, A.G., and Crowell, J.C., leaders, The San Andreas Transform Belt: International Geological Congress Field Trip, 28th, guidebook T309, p. T309:49-T309:51.

Prentice, C.S., Weldon, R.J., and Sieh, K.E., 1986, Distribution of slip between the San Andreas and San Jacinto faults near San Bernardino, southern California [abs.]: Geological Society of America Abstracts with Programs, v. 18, no. 2, p. 172.

Rasmussen, G.S., 1982, Geologic features and rate of movement along the south branch of the San Andreas fault, San Bernardino, California, in Cooper, J.D., compiler, Neotectonics in southern California: Geological Society of America, Cordilleran Section Annual Meeting, 78th, guidebook, p. 109-114.

Rockwell, T.K., 1988, Neotectonics of the San Cayetano fault, Transverse Ranges, California: Geological Society of America Bulletin, v. 100 , no. 4 , p. $500-513$.

Rockwell, T.K., Merifield, P.M., and Loughman, C.C., 1986, Holocene activity of the San Jacinto fault in the Anza seismic gap, southern California [abs.] Geological Society of America Abstracts with Programs, v. 18, no. 2, p. 177.

Ross, D.C., 1969, Map showing recently active breaks along the San Andreas fault between Tejon Pass and Cajon Pass, southern California: U.S. Geological Survey Miscellaneous Geologic Investigations Map I-553, scale 1:24,000.

Rust, D.J., 1982, Radiocarbon dates for the most recent large prehistoric earthquake and for late Holocene slip rates: San Andreas fault in part of the Transverse Ranges north of Los Angeles [abs.]: Geological Society of America Abstracts with Programs, v. 14, no. 4, p. 229.

Sarna-Wojcicki, A.M., Meyer, C.E., Bowman, H.R., Hall, N.T., Russell, P.C., Woodward, M.J., and Slate, J.L., 1985, Correlation of the Rockland ash bed, a 400,000-year-old stratigraphic marker in northern California and western Nevada, and implications for middle Pleistocene paleogeography of central California: Quaternary Research, v. 23, no. 2, p. 236-257.

Schoellhamer, J.E., Vedder, J.G., Yerkes, R.F., and Kinney, D.M., 1981, Geology of the northern Santa Ana Mountains, California: U.S. Geological Survey Professional Paper 420-D, D1-D109.

Sharp, R.V., 1967, San Jacinto fault zone in the Peninsular Ranges of Southern California: Geological Society of America Bulletin, v. 78, no. 6, p. 705-729.

- 1972, Map showing recently active breaks along the San Jacinto fault zone between the San Bernardino area and Borrego Valley, California: U.S. Geological Survey Miscellaneous Geologic Inves- tigations Map I-675, scale 1:24,000, 3 sheets.

1981, Variable rates of late Quaternary strike slip on the San Jacinto fault zone, southern California: Journal of Geophysical Research, v. 86, no. B3, p. 1754-1762.

1982, Tectonic setting of the Imperial Valley region, in The Imperial Valley, California, earthquake of October 15, 1979: U.S. Geological Survey Professional Paper 1254, p. 5-14.

Shreve, R.L., 1968, The Blackhawk landslide: Geological Society of America Special Paper 108, 47 p.

Sieh, K.E., 1978, Prehistoric large earthquakes produced by slip on the San Andreas fault at Pallett Creek, California: Journal of Geophysical Research, v. 83, no. B8, p. 3907-3939.

_ 1981, Seismic potential of the southern $200 \mathrm{~km}$ of the San Andreas fault [abs.]: Eos (American Geophysical Union Transactions), v. 62 , no. 45 , p. 1048.

- 1984, Lateral offsets and revised dates of large prehistoric earthquakes at Pallett Creek, southern California: Journal of Geophysical Research, v. 89, no. B9, p. 7641-7670.

Sieh, K.E., and Jahns, R.H., 1984, Holocene activity of the San Andreas fault at Wallace Creek, California: Geological Society of America Bulletin, v. 95, no. 8, p. 883-896.

Sieh, K.E., Stuiver, Minze, and Brillinger, David, 1989, A more precise chronology of earthquakes produced by the San Andreas fault in southern California: Journal of Geophysical Research, v. 94, no. B1, p. 603-623.

Silver, E.A., 1971, Tectonics of the Mendocino triple junction: Geological Society of America Bulletin, v. 82, no. 11, 2965-2977.

Silver, E.A., and Normark, W.R., eds., 1978, San Gregorio-Hosgri fault zone, California: California Division of Mines and Geology Special Report 137, 56 p.

Sims, J.D., and Rymer, M.J., 1975, Preliminary description of cores and radiographs from Clear Lake, Lake County, California: Core F: U.S. Geological Survey Open-File Report 75-144, 21 p.

Steritz, J.W., Luyendyk, B.P., and Slaughter, P.C., 1986, Southern termination of the Hosgri fault, offshore California [abs.]: Geological Society of America Abstracts with Programs, v. 18, no. 2, p. 189.

Stout, M.L., 1975, Age of the Blackhawk landslide, southern California [abs.]: Geological Society of America Abstracts with Programs, v. 7 , no. 3, p. 378-379.

— 1977, Radiocarbon dating of landslides in southern California: California Geology, v. 30, no. 5, p. 99-105.

Sweeney, J.J., 1982, Magnitudes of slip along the Greenville fault in the Diablo Range and Corral Hollow areas, in Hart, E.W., Hirschfeld, S.E., and Schulz, S.S., eds., Conference on Earthquake Hazards in the Eastern San Francisco Bay Area, Hayward, Calif., 1982, Proceedings: California Division of Mines and Geology Special Publication 62, p. 137-146.

Vedder, J.G., 1970, Geologic map of the Wells Ranch and Elkhorn Hills quadrangles, San Luis Obispo and Kern Counties, California, showing juxtaposed Cenozoic rocks along the San Andreas fault: U.S. Geological Survey Miscellaneous Geologic Investigations Map I-585, scale 1:24,000, 2 sheets.

Vedder, J.G., and Wallace, R.E., 1970, Map showing recently active breaks along the San Andreas and related faults between Cholame Valley and Tejon Pass, California: U.S. Geological Survey Miscellaneous Geologic Investigations Map I-574, scale 1:24,000, 2 sheets.

Wagner, H.C., 1974, Marine geology between Cape San Martin and Pt. Sal, south-central California offshore: U.S. Geological Survey Open-File Report 74-252, 17 p.

Wahrhaftig, Clyde, and Birman, J.H., 1965, The Quaternary of the Pacific mountain system in California, in Wright, H.E., Jr., and Frey, D.G., eds., The Quaternary of the United States: Princeton, N.J., Princeton University Press, p. 299-340. 
Wallace, R.E., 1949, Structure of a portion of the San Andreas rift in southern California: Geological Society of America Bulletin, v. 60, no. 4 , p. $781-806$.

Weber, G.E., 1983, Geological investigation of the marine terraces of the San Simeon region and Pleistocene activity on the San Simeon fault zone, San Luis Obispo County, California: Menlo Park, Calif., technical report to U.S. Geological Survey under Contract 1408-00001-18230, $66 \mathrm{p}$.

Weber, G.E., and Cotton, W.R., 1981, Geologic investigation of recurrence intervals and recency of faulting along the San Gregorio fault zone, San Mateo County, California: U.S. Geological Survey Open-File Report 81-263, 99 p.

Weldon, R.J., and Sieh, K.E., 1985, Holocene rate of slip and tentative recurrence interval for large earthquakes on the San Andreas fault, Cajon Pass, southern California: Geological Society of America Bulletin, v. 96 , no.6, p. $793-812$.

Wilcox, R.E., Harding, T.P., and Seely, D.R., 1973, Basic wrench tectonics: American Association of Petroleum Geologists Bulletin, v. 57 , no. 1 , p. $74-96$.

Woodford, A.O., and Harriss, T.F., 1928, Geology of Blackhawk Canyon, San Bernardino Mountains, California: Berkeley, University of California Publications, Department of Geological Sciences Bulletin, v. 17, no. 8, p. 265-304.

Woodford, A.O., Schoellhamer, J.E., Vedder, J.G., and Yerkes, R.F., 1954, Geology of the Los Angeles basin, [pt.] 5 of Geology of the natural provinces, chap 2 of Jahns, R.H., ed., Geology of southern California: California Division of Mines Bulletin 170, v. 1, p. 65-81.

Woodford, A.O., Shelton, J.S., Doehring, D.O., and Morton, R.K., 1971, Pliocene-Pleistocene history of the Perris block, southern California: Geological Society of America Bulletin, v. 82, no. 12, p. 3421-3447.

Woodring, W.P., and Bramlette, M.N., 1950, Geology and paleontology of the Santa Maria district, California: U.S. Geological Survey Professional Paper 222, 185 p.
Wright, H.E., Jr., and Frey, D.G., eds., 1965, The Quaternary of the United States: Princeton, N.J., Princeton University Press, 922 p.

Wright, R.H., Hamilton, D.H., Hunt, J.D., Traubenik, M.L., and Shlemon, R.J., 1982, Character and activity of the Greenville structural trend, in Hart, E.W., Hirschfeld, S.E., and Schulz, S.S., eds., Conference on Earthquake Hazards in the Eastern San Francisco Bay Area, Hayward, Calif., 1982, Proceedings: California Division of Mines and Geology Special Publication 62, p. $187-196$.

Yeats, R.S., 1977, High rates of vertical crustal movement near Ventura, California: Science, v. 196, no. 4287, p. 295-298.

— 1982, Low-shake faults of the Ventura basin, California, in Cooper, John, compiler, Neotectonics in southern California: Geological Society of America, Cordilleran Section Annual Meeting, 78th, Guidebook, p. 3-15.

Yerkes, R.F., 1972, Geology and oil resources of the western Puente Hills area, southern California: U.S. Geological Survey Professional Paper 420-C, p. C1-C63.

Yerkes, R.F., and Lee, W.H.K., 1987, Late Quaternary deformation in the western Transverse Ranges, in Recent reverse faulting in the Transverse Ranges, California: U.S. Geological Survey Professional Paper 1339, p. 71-82.

Yerkes, R.F., McCulloh, T.H., Schoellhamer, J.E., and Vedder, J.G., 1965, Geology of the Los Angeles basin, California-an introduction: U.S. Geological Survey Professional Paper 420-A, A1-A57.

Ziony, J.I., and Jones, L.M., 1988, Map showing late Quaternary faults and 1978-84 seismicity of the Los Angeles region, California: U.S. Geological Survey Miscellaneous Field Studies Map MF-1964, 23 p., scale 1:250,000.

Ziony, J.I., and Yerkes, R.F., 1985, Evaluating earthquake and surface-faulting potential, in Ziony, J.I., ed., Evaluating earthquake hazards in the Los Angeles region-an earth-science perspective: U.S. Geological Survey Professional Paper 1360, p. 43-91. 


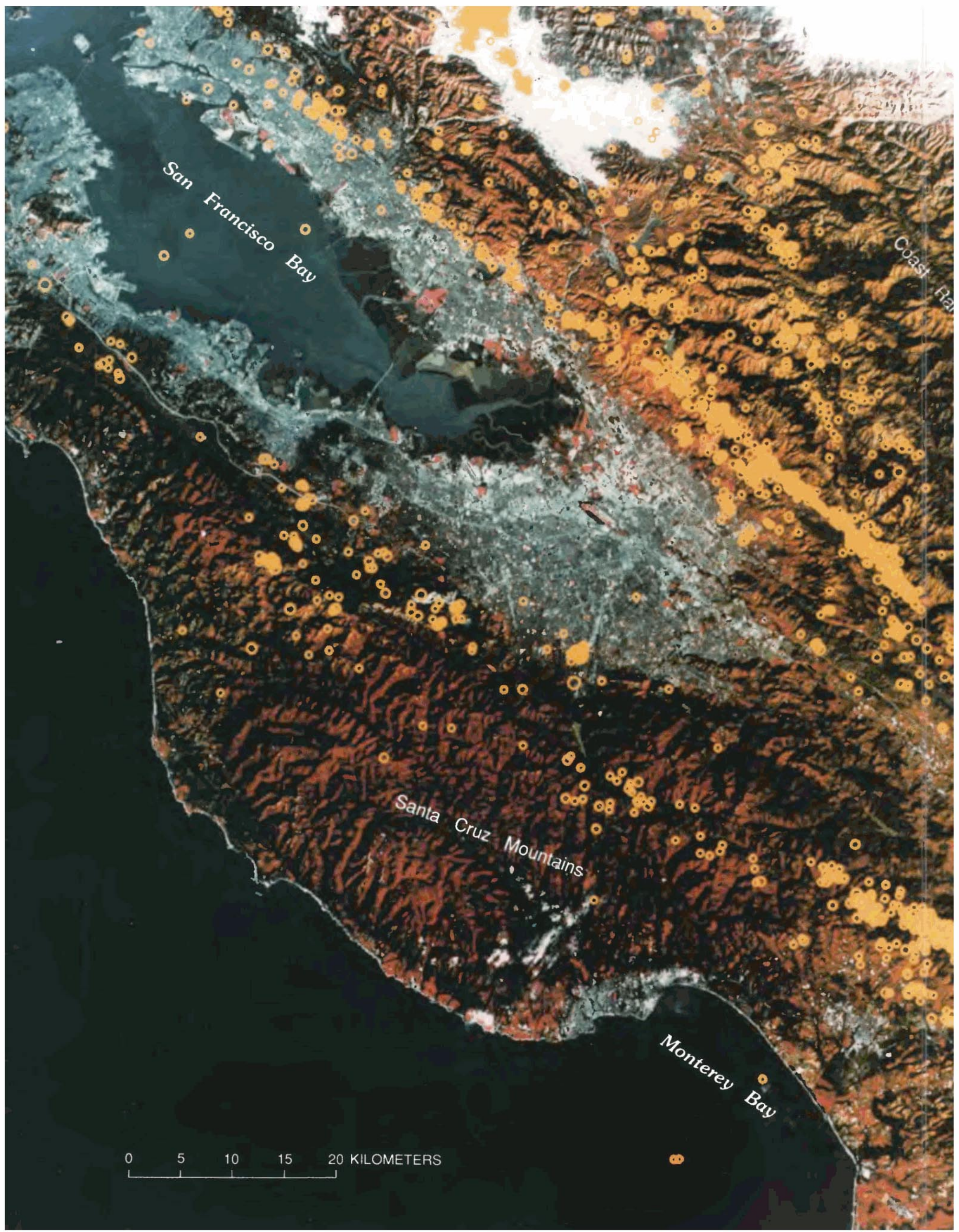


7 ens of thousands of small earthquakes occur in California $\perp$ each year, reflecting brittle deformation of the margins of the Pacific and North American plates as they grind inexorably past one another along the San Andreas fault system. The deformational patterns revealed by this ongoing earthquake activity provide a wealth of information on the tectonic processes along this major transform boundary that, every few hundred years, culminate in rupture of the San Andreas fault in a great $(\mathrm{M} \approx 8)$ earthquake.

\section{SEISMICITY, 1980-86}

By David P. Hill, Jerry P. Eaton, and Lucile M. Jones

\section{CONTENTS}

\begin{tabular}{|c|c|}
\hline Page & \\
\hline 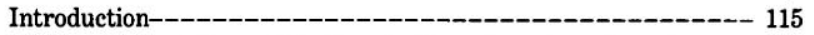 & Focal mechanisms and transform-boundary kinematics-Continued \\
\hline Regional seismicity and the San Andreas transform boundary - & Fragmentation of the southeast corner of the Gorda plate -- 143 \\
\hline Seismicity along the San Andreas Fault system------------- 120 & 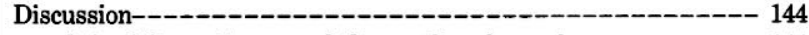 \\
\hline Mendocino triple junction--_-_- & Seismicity patterns and the earthquake cycle----------- 144 \\
\hline The 1906 break and the northern Coast Ranges-------- 124 & Distributed seismicity and deformation of the plate margins- 145 \\
\hline Central creeping section-- & Deformation of the Gorda plate--_-_---- 145 \\
\hline The 1857 break and the Transverse Ranges-- & The San Andreas discrepancy---------- \\
\hline Southern section of the San Andreas fault system--- & Convergence normal to the San Andreas fault system-- 145 \\
\hline Southern branch of the San Andreas fault----- & Extensional deformation and the souther \\
\hline Associated faults- - - & San Andreas fault syst \\
\hline Focal mechanisms and transform-boundary kinematics------- 136 & Maximum focal depths and thickness of the seismogenic \\
\hline Strike-slip kinematics of the San Andreas fault system- -- 136 & crust----1-- \\
\hline $\begin{array}{l}\text { Crustal convergence adjacent to the San Andreas fault } \\
\text { system- }\end{array}$ & $\begin{array}{l}\text { Decollement at the base of the seismogenic crust?- - } 148 \\
\text { Conclusions- }\end{array}$ \\
\hline $\begin{array}{l}\text { East-west extension in the Sierra Ne } \\
\text { Conjugate faulting in the Sierra Neva }\end{array}$ & References c \\
\hline
\end{tabular}

\section{INTRODUCTION}

Earthquake activity along the San Andreas fault system (fig. 5.1) reflects brittle accommodation of the crust to the relative motion along the dextral transform boundary between the Pacific and North American plates (see chap. 3). Great $(M \approx 8)$ earthquakes along the main branch of the San Andreas fault accommodate most of this relative plate motion. These plate-boundary earthquakes rupture the entire $15-$ to $20-\mathrm{km}$ thickness of the brittle crust with right-lateral offsets of as much as $10 \mathrm{~m}$ extending for several hundred kilometers along the fault trace, and they recur along a given section of the San Andreas fault at intervals of several hundred years (Sieh, 1981; Sieh and Jahns, 1984). The 1857 Fort Tejon

FIGURE 5.1. - Seismicity from 1969 to 1980 superimposed on color Landsat image for the central Coast Ranges between the San Francisco Bay and Monterey Bay. Size of earthquake epicenters (yellow circles) increases with earthquake magnitude from 1.5 to 6.0. Compiled by Jean Olsen. 
earthquake in southern California and the 1906 San Francisco earthquake in northern California are only the two most recent such great events along the San Andreas fault (see chap. 6).

In this chapter, we focus on the smaller, more frequent earthquakes that dominate the seismicity within the San Andreas fault system between recurrences of great, plate-boundary events. Although this interevent seismicity contributes only marginally to relative plate motion, it is symptomatic of processes underlying the earthquake cycle. In particular, the wealth of data generated by frequent smaller events provides important clues to the seismotectonic fabric, kinematics, and state of stress within the brittle crust and, ultimately, to the seismogenic processes common to earthquakes of all sizes within the San Andreas fault system. This persistent, interevent seismicity also captures widespread popular interest because it includes most of the felt earthquakes in California (earthquakes of $M \geq 3$ can be locally felt), and the larger of these interevent earthquakes $(M=6-7)$ can cause extensive damage and loss of life when they strike near major population centers.

We examine here the detailed patterns of earthquake occurrence along the San Andreas fault system recorded by the combined northern and southern California seismograph networks for the 7-yr interval 1980-86. These networks, which had evolved to much their present configuration (fig. 5.2) by mid-1979, enable uniform detection and location of all earthquakes of $M \geq 1.5$ throughout the San Andreas fault system and of $M \geq 2$ throughout most of California. The telemetered seismic stations in the combined networks approach 550 in number. Signals from the 300 central and northern California stations are recorded and processed at the U.S. Geological Survey's (USGS) offices in Menlo Park; signals from the 250 southern California stations are recorded and processed under a joint USGS-California Institute of Technology (Caltech) effort on the Caltech campus in Pasadena. These dense telemetered networks overlie regional seismic networks operated by the University of California, Berkeley, and Caltech that provide records of $M \geq 3$ earthquakes in northern and southern California, respectively, from the early 1930 's onward (table 5.1; Hileman and others, 1973; Bolt and Miller, 1975).

After a brief overview of the San Andreas fault system in the context of a broad transform boundary, we focus on the three-dimensional distribution of earthquakes along the San Andreas fault system itself on the basis of a series of detailed seismicity maps and cross sections for the years 1980-86. We then review selected focal mechanisms for the larger of these earthquakes as a guide to the kinematics of seismogenic deformation along the fault system. Finally, we discuss the implications of these seismicity patterns in terms of current tectonic processes along the transform boundary.

The seismicity maps and cross sections in this chapter, which form the core of our presentation, are largely self-explanatory. The following points, however, deserve special emphasis:

1. The reliability of hypocentral locations correlates closely with the local density of the seismograph network (fig. 5.2). Relative epicentral locations are better than $\pm 0.5 \mathrm{~km}$ for earthquakes within the densest sections of the network (corresponding focal depths are better than $\pm 1.0 \mathrm{~km}$ ). Relative locations may be uncertain by several kilometers or more, however, for earthquakes occurring beyond the margins of the network.

2. All cross sections have a $2 \times$ vertical exaggeration as a means of illustrating patterns in the depth distribution of earthquakes beneath profiles that are many times longer than the limited range of focal depths (less than $15 \mathrm{~km}$ along most of the fault system).

3. Hypocentral locations are plotted using small circles that scale only weakly with magnitude, to better emphasize detailed spatial structures within the seismicity patterns.

4. The locations of the most commonly used place names and faults in this chapter are shown in figure 5.3 (see front of book for a more complete map).

\section{REGIONAL SEISMICITY AND THE SAN ANDREAS TRANSFORM BOUNDARY}

Dickinson (1981), among others, emphasized that the San Andreas fault system and the San Andreas transform boundary are not strictly equivalent structures. The latter is more general, incorporating, for example, the concept of temporal evolution of Pacific-North American plate interaction and the recognition that the faults accommodating most of the plate motion have changed over time. In this section, we emphasize that, although great earthquakes along the San Andreas fault system currently accommodate most of the relative plate motion, plate interactions along the transform boundary influence deformation of the brittle crust over a much broader region.

The breadth of the seismicity pattern in California and western Nevada (fig. 5.4) suggests the lateral extent of deformation associated with the San Andreas transform boundary. Indeed, it corresponds closely to the zone of distributed shear between those plates as interpreted by Ward (1988) from more than 5 years of very long baseline interferometry (VLBI) observations at 20 Western United States stations from 1982 through 1987. Figure 5.4 includes all $M \geq 1.5$ events recorded by the telemetered 
seismic networks in figure 5.2 during the 7-yr interval $1980-86$, as well as events recorded by adjacent telemetered networks in Nevada (see Rogers and others, in press). Although details within this seismicity pattern fluctuate from year to year, the broad aspects of the pattern have remained stable for the entire historical
TABLE 5.1.-Number of short-period seismic stations in California

\begin{tabular}{crrrrr}
\hline Year & 1940 & 1965 & 1971 & 1975 & 1981 \\
\hline Northern California--.-- & $<10$ & $<20$ & $\approx 100$ & $\approx 200$ & $\approx 300$ \\
Southern California - & $<10$ & $<20$ & $\approx 30$ & $\approx 100$ & $\approx 200$ \\
\hline
\end{tabular}

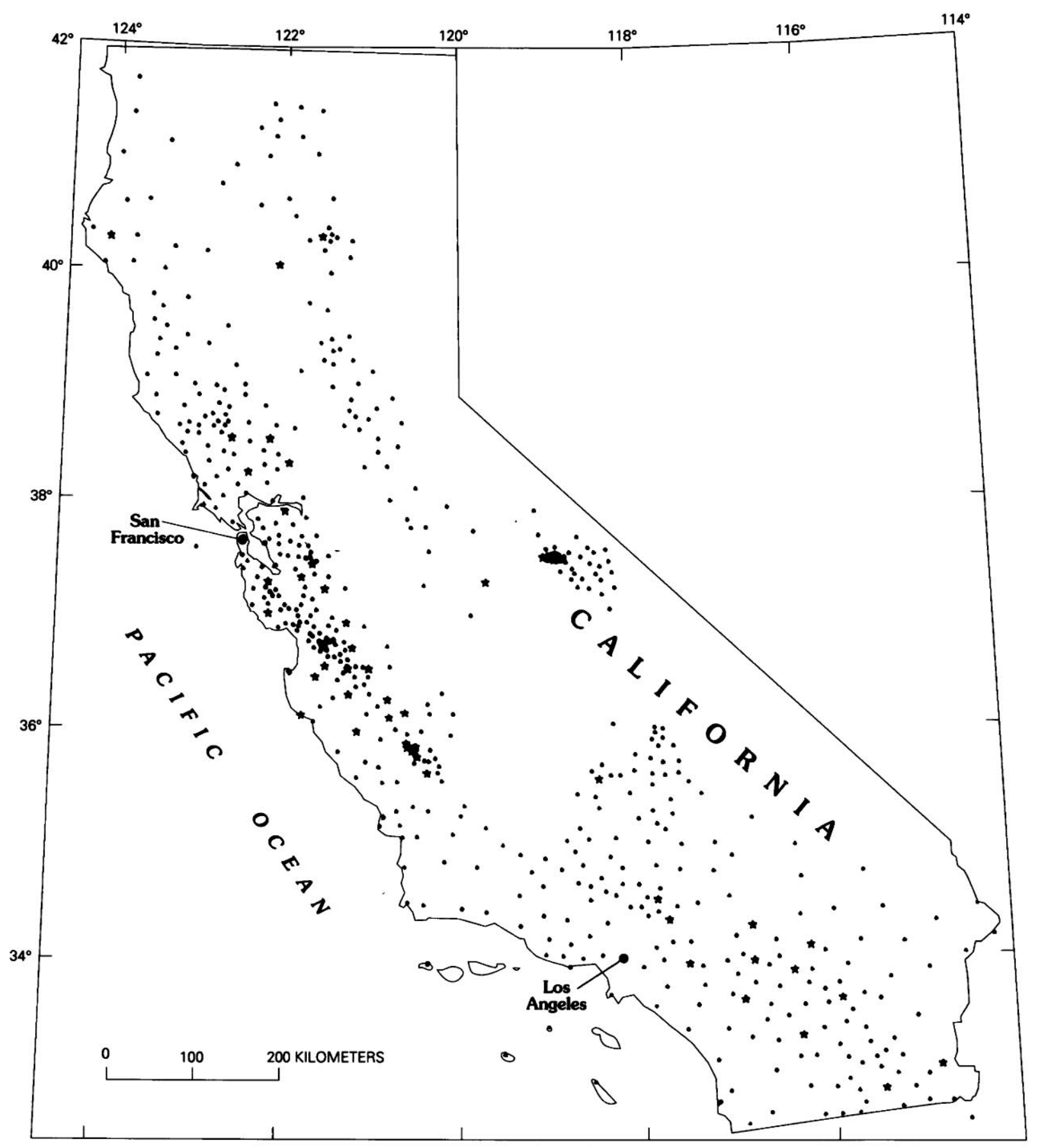

FIGURE 5.2. -Stations in telemetered seismic networks in California operating during 1986. Dot, single (vertical)-component station; star, multicomponent station. 
record of earthquake occurrence in California (see chap. 6; Ellsworth and others, 1981; Hill and others, in press; Hutton and others, in press).
In outline, the seismicity pattern for California and western Nevada forms a hollow ellipse with its long axis nearly coincident with the transform boundary. This

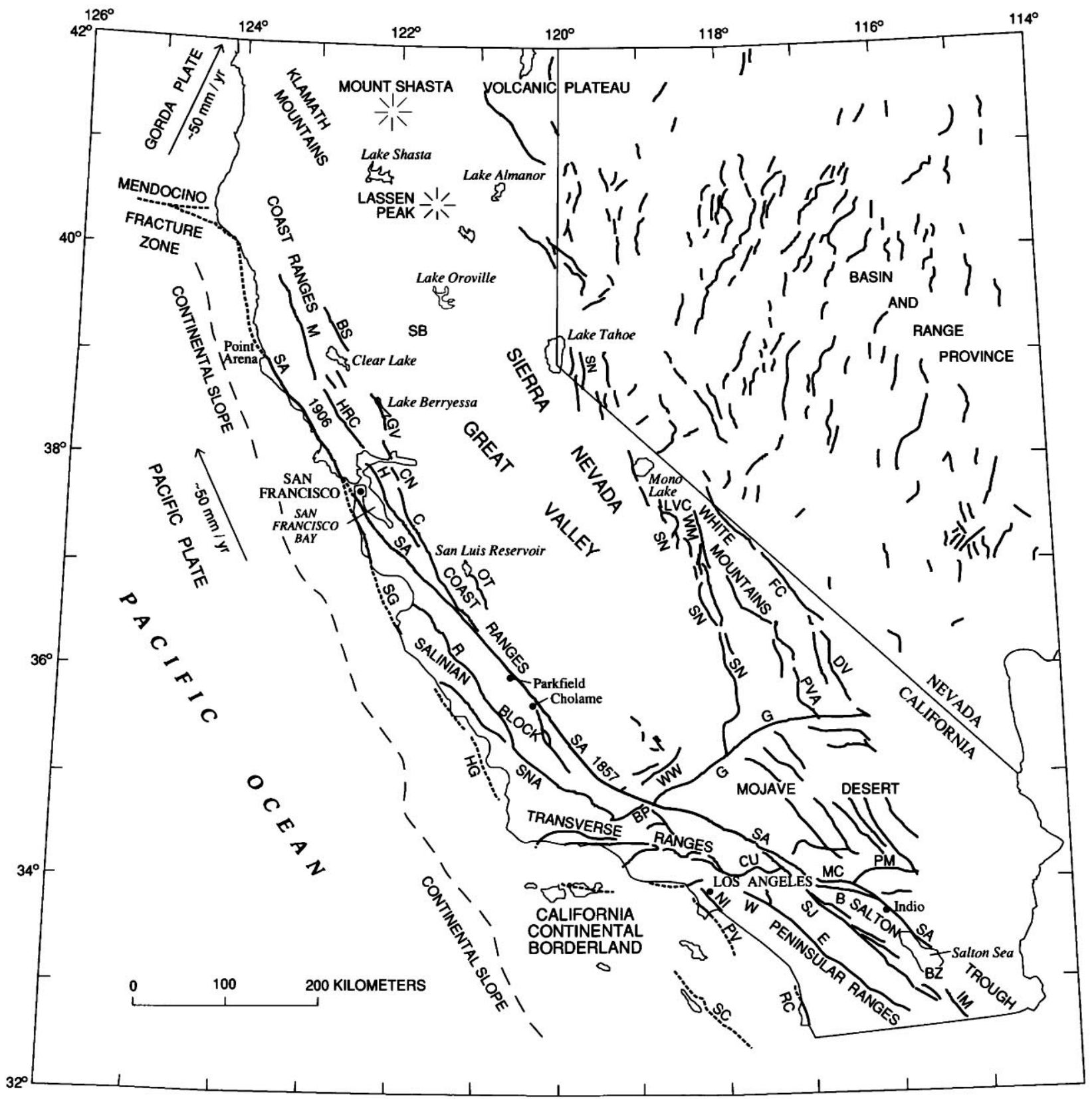

FiguRE 5.3.-Place names and faults most commonly used in text (see front of book for more complete maps of place names and faults). Faults (dotted where concealed): B, Banning; BP, Big Pine; BS, Bartlett Springs; BZ, Brawley seismic zone; C, Calaveras; CN, Concord; CU, Cucamonga; DV, Death Valley; E, Elsinore; FC, Furnace Creek; G, Garlock; GV, Green Valley; H, Hayward; HG, Hosgri; HRC, Healdsburg-Rodgers Creek; IM, Imperial; LVC, Long Valley caldera; M, Maacama; MC, Mission Creek; NI, Newport-
Inglewood; OT, Ortigalita; PM, Pinto Mountain; PV, Palos Verdes; PVA, Panamint Valley; R, Rinconada; RC, Rose Canyon; SA, San Andreas; SC, San Clemente Island; SG, San Gregorio; SJ, San Jacinto; SN, Sierra Nevada; SNA, Sur-Nacimiento; W, Whittier; WM, White Mountains; WW, White Wolf. Arrows and numbers indicate direction and amount of motion, respectively, of Pacific and Gorda plates with respect to North American plate to the east; red lines indicate 1857 and 1906 ruptures of San Andreas fault. 
pattern is widest across central California, where it approaches nearly a third of the $1,100-\mathrm{km}$ length of the transform boundary, from the Mendocino triple junction in the north to the head of the Gulf of California at the south. Extended alignments of epicenters within this pattern suggest a coarse structural fabric linking the broad distribution of earthquakes to the transform boundary. Seismicity along the San Andreas fault system itself stands out as a series of subparallel, northwesttrending lineations extending the length of coastal California. The alignment of epicenter clusters along the east side of the Sierra Nevada in eastern California branches northward from the south end of the San Andreas fault system in the Salton Trough only to bend back toward the north terminus of the San Andreas fault system at the Mendocino triple junction in northern California. The

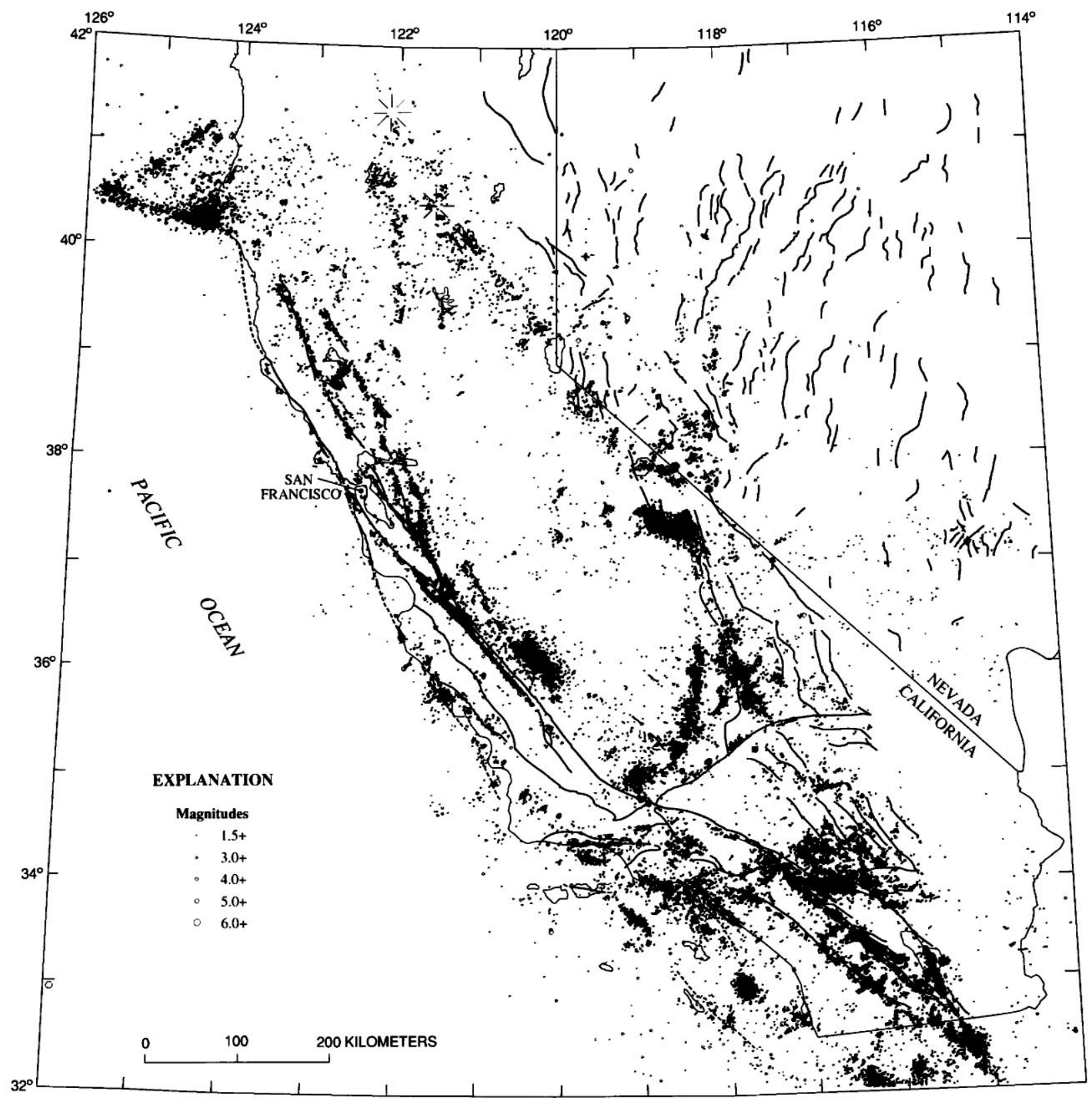

FIGURE 5.4. - Locations of $64,000 M \geq 1.5$ earthquakes in California and western Nevada during 1980-86 and mapped Holocene faults (dotted where concealed; major branches of the San Andreas fault system marked in red). 
Sierra Nevada-Great Valley and western Mojave Desert blocks form a broad quiescent region between the San Andreas and eastern California seismicity bands. In southern California, pronounced transverse seismicity belts coincident with the southern margin of the Sierra Nevada and Transverse Ranges, respectively, span this otherwise-quiescent region. A weaker, more diffuse seismicity belt near lat $37^{\circ} \mathrm{N}$. spans the Sierra NevadaGreat Valley block in central California, forming a visual, if not structural, link between the San Andreas fault system and the dense cluster of epicenters in eastern California. This major cluster in the eastern Sierra Nevada represents an episode of intense earthquake activity in Long Valley caldera and vicinity that began in 1978 and has persisted to the present (Van Wormer and Ryall, 1980; Hill and others, 1985b).

The displacement pattern associated with earthquakes throughout California and western Nevada is broadly consistent with deformation under a coherent, regional stress field dominated by plate-boundary interaction along a northwest-striking, dextral transform boundary (Hill, 1982). Strike-slip focal mechanisms with rightlateral slip on northwest- to north-northwest-striking planes, for example, are common through most of the region. Regional variations within this pattern include a tendency toward normal slip on northerly-striking planes along the western margin of the extensional Basin and Range province in eastern California, and toward reverse slip on easterly-striking planes in the Transverse Ranges of southern California. Compressional deformation perpendicular to the San Andreas fault within the Coast Ranges, however, represents an important deviation from this regional pattern.

\section{SEISMICITY ALONG THE SAN ANDREAS FAULT SYSTEM}

Sections of the San Andreas fault system stand out on seismicity maps as a network of northward-branching alignments of epicenters through the central and northern Coast Ranges and as subparallel lineations of clusters of epicenters that branch northward from the south end of the Imperial fault toward the Transverse Ranges in southern California (fig. 5.4). One of the most remarkable aspects of the seismicity pattern associated with the fault system, however, is the nearly complete absence of earthquake activity down to even the smallest magnitudes $(M \approx 1.5)$ along those sections of the fault that have ruptured with the largest historical earthquakes, the great $(M \approx 8) 1857$ and 1906 earthquakes (see figs. 5.3, 5.4). The southernmost section of the San Andreas fault, from Indio to the Salton Sea, also lacks microseismicity, although no large earthquake has ruptured this section in the past $200 \mathrm{yr}$. These quiescent ("locked") segments of the fault stand in sharp contrast to the segments marked by persistent linear concentrations of small to moderate earthquakes.

This dual expression of the fault system evident on current seismicity maps apparently reflects fundamental differences in the long-term behavior of the respective segments. In particular, seismic activity along the "locked" segments of the main trace of the San Andreas fault may be limited to the recurrence of major earthquakes at intervals of 100 to $300 \mathrm{yr}$ accompanied by immediate foreshock and aftershock sequences, and these segments may remain quiescent for most of the interevent time associated with the cycle between great earthquakes (Ellsworth and others, 1981). In contrast, those segments with persistent microearthquake activity probably seldom, if ever, rupture with great earthquakes, although they may be capable of generating earthquakes as large as $M \approx 6$.

Aseismic creep also characterizes and is largely confined to those fault segments along the San Andreas fault system that show persistent microearthquake activity (Wesson and others, 1973; Schulz and others, 1982). Creep is most pronounced along the central California segments of the fault system, where average creep rates match the long-term displacement rates of 32 to 34 $\mathrm{mm} / \mathrm{yr}$. Louie and others (1985) documented creep along sections of the seismically active fault segments in the Salton Trough, and Astiz and Allen (1983) documented creep along a section of the Garlock fault that is marked by microearthquake activity. The creep rates in these two areas, however, are more than an order of magnitude less than the long-term deformation rates.

In the following subsections, we consider the 1980-86 seismicity along and adjacent to the major sections of the San Andreas fault system in more detail. We begin with the Mendocino triple junction in the north and move southward, generalizing slightly Allen's (1968) subdivision of the fault system into four major sections of contrasting seismic behavior: (1) the quiescent 1906 break and subparallel branches, (2) branches forming the central California active (creeping) section, (3) the quiescent 1857 break, and (4) branches forming the southern California active section south of the Transverse Ranges.

\section{MENDOCINO TRIPLE JUNCTION}

The three lithospheric plates that dominate the modern tectonics of coastal California meet at the Mendocino triple junction, which is marked by a dense cluster of epicenters just off Cape Mendocino (fig. 5.5A; see chap. 3). North of this triple junction, oblique subduction dominates, with the eastern margin of the Gorda plate 
(the southernmost section of the Juan de Fuca plate) slipping beneath the North American plate north-northeastward at a rate of 30 to $50 \mathrm{~mm} / \mathrm{yr}$ (Wilson, 1986). South of the triple junction, the Pacific plate is moving past the North American plate along the San Andreas transform boundary on a heading of $35^{\circ}-38^{\circ} \mathrm{W}$. of $\mathrm{N}$. at a rate of approximately $50 \mathrm{~mm} / \mathrm{yr}$ (DeMets and others, 1987).

The dense lineation of epicenters that trends westnorthwest from Cape Mendocino corresponds closely to the Mendocino Fracture Zone (MFZ) and the PacificGorda plate boundary but follows a slightly more northerly trend. Details of how the San Andreas fault ties into the triple junction, however, are unclear. The trace of the San Andreas fault lies off shore north of Point Arena, and the broad area of seismic quiescence south of the triple junction offers few clues to the kinematics of this northernmost segment of the fault.

The conspicuous linear zone of epicenters marking a northeast-trending slice across the southwest corner of the Gorda plate is the aftershock zone of the $M=7.2$ Eureka earthquake of November 8, 1980. This was the largest earthquake to occur in California during the interval $1980-86$. The N. $53^{\circ}$ E. trend of its aftershock zone agrees closely with the strike of the left-lateral slip plane inferred from the focal mechanism of the main shock, which was located about a fourth of the way downstrike from the northeastern end of the aftershock zone (Eaton, 1989). The aftershocks from this earthquake

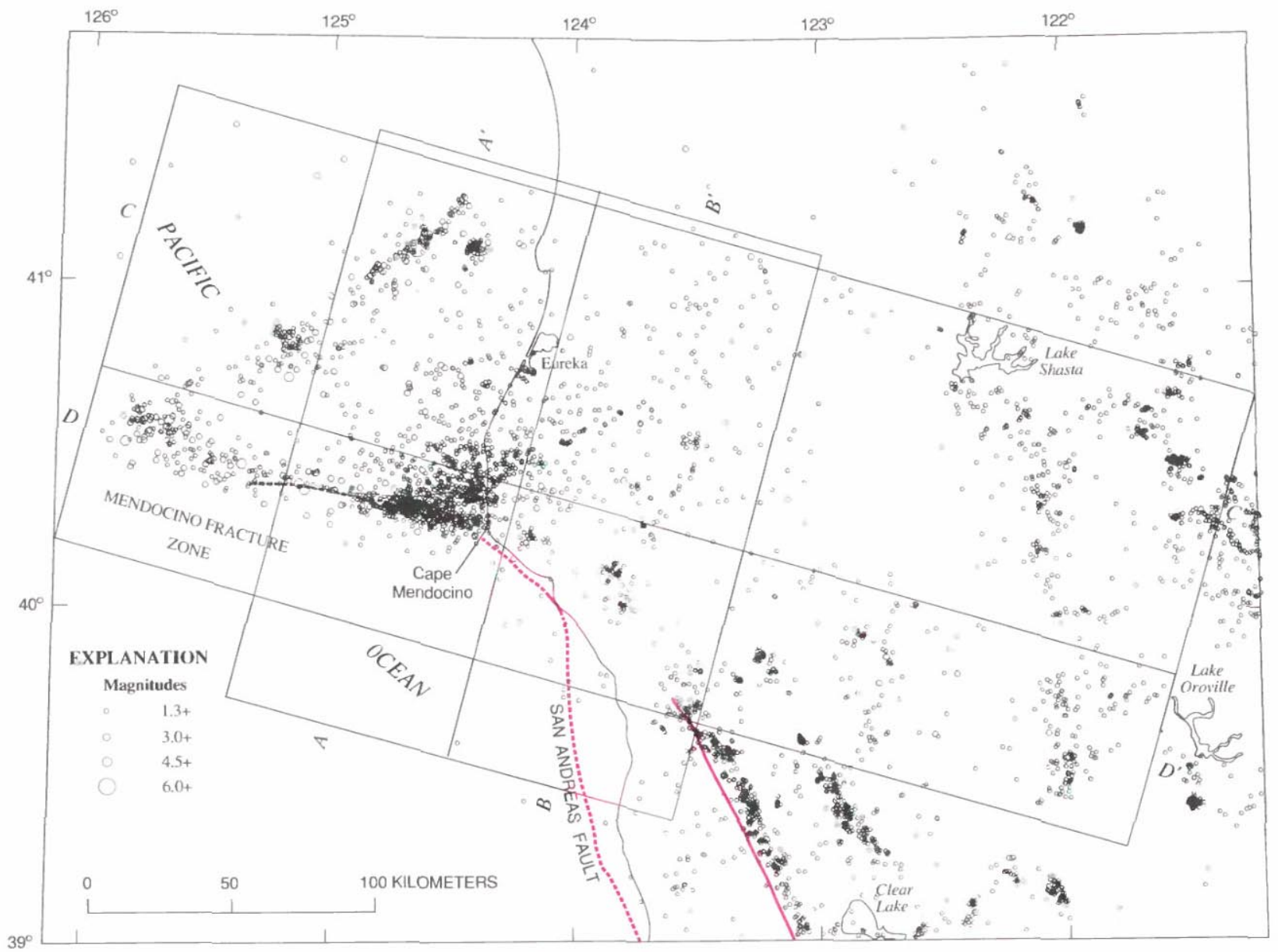

$A$

Figure 5.5.--Seismicity in the Mendocino triple junction area, northern California. A, Earthquake locations, showing major branches of the San Andreas fault system in red; faults dotted where concealed. Magnitude symbols shown in explanation are scaled with enlarge- ment of cross section. $B$, Depth sections perpendicular to N. $75^{\circ} \mathrm{W}$. trend of the Mendocino Fracture Zone $\left(A-A^{\prime}\right.$ and $B-B^{\prime}$ outlined in fig. $5.5 A$ ). $C$, Depth sections parallel to N. $75^{\circ} \mathrm{W}$. trend of the Mendocino Fracture Zone $\left(C-C^{\prime}\right.$ and $D-D^{\prime}$ outlined in fig. 5.5A). 
died off within a few months after the main shock-a notably short aftershock sequence for an earthquake of this size.

A third, more diffuse group of earthquakes in the vicinity of the triple junction shows little tendency to concentrate in linear zones. These epicenters form an irregular zone with the greatest concentration in the vicinity of Cape Mendocino, gradually dying off with distance to the north, east, and west. To the south, the seismicity dies off abruptly across the MFZ and its landward extension.

The three-dimensional aspects of this triple junction seismicity are illustrated by four cross sections (figs. $5.5 \mathrm{~B}, 5.5 \mathrm{C}$ ). The two cross sections perpendicular to the $\mathrm{N}$. $75^{\circ} \mathrm{W}$. trend of the MFZ (fig. $5.5 \mathrm{~B}$ ) compare the distribution of focal depths within the submarine section of the Gorda plate adjacent to the triple junction $\left(A-A^{\prime}\right)$ with that within the adjacent, subducted section of the Gorda plate and the overlying North American plate
$\left(B-B^{\prime}\right)$. Earthquake hypocenters along the southern margin of the submarine Gorda plate define a dense, vertically elongate zone beneath the MFZ that dips $70^{\circ}-75^{\circ} \mathrm{N}$. and extends to depths of nearly $35 \mathrm{~km}$. Earthquakes north of this zone cluster in a somewhat less dense, wedge-shaped core outlined by a northward shallowing of maximum focal depths accompanied by a northward deepening of minimum focal depths that converge at a depth of about $20 \mathrm{~km}$ (Eaton, 1989). Overlying this relatively dense wedge is a more diffuse distribution of hypocenters, the northernmost of which represent the $1980 M=7.2$ event and adjacent aftershocks. The absence of seismicity south of the MFZ indicates that the northeast corner of the Pacific plate behaves as a rigid block in its interaction with the younger, thinner, and internally deforming Gorda plate (Wilson, 1986; Eaton, 1989).

In the onshore cross section $\left(B-B^{\prime}\right.$, fig. $\left.5.5 B\right)$, the intense seismicity associated with the MFZ loses most of

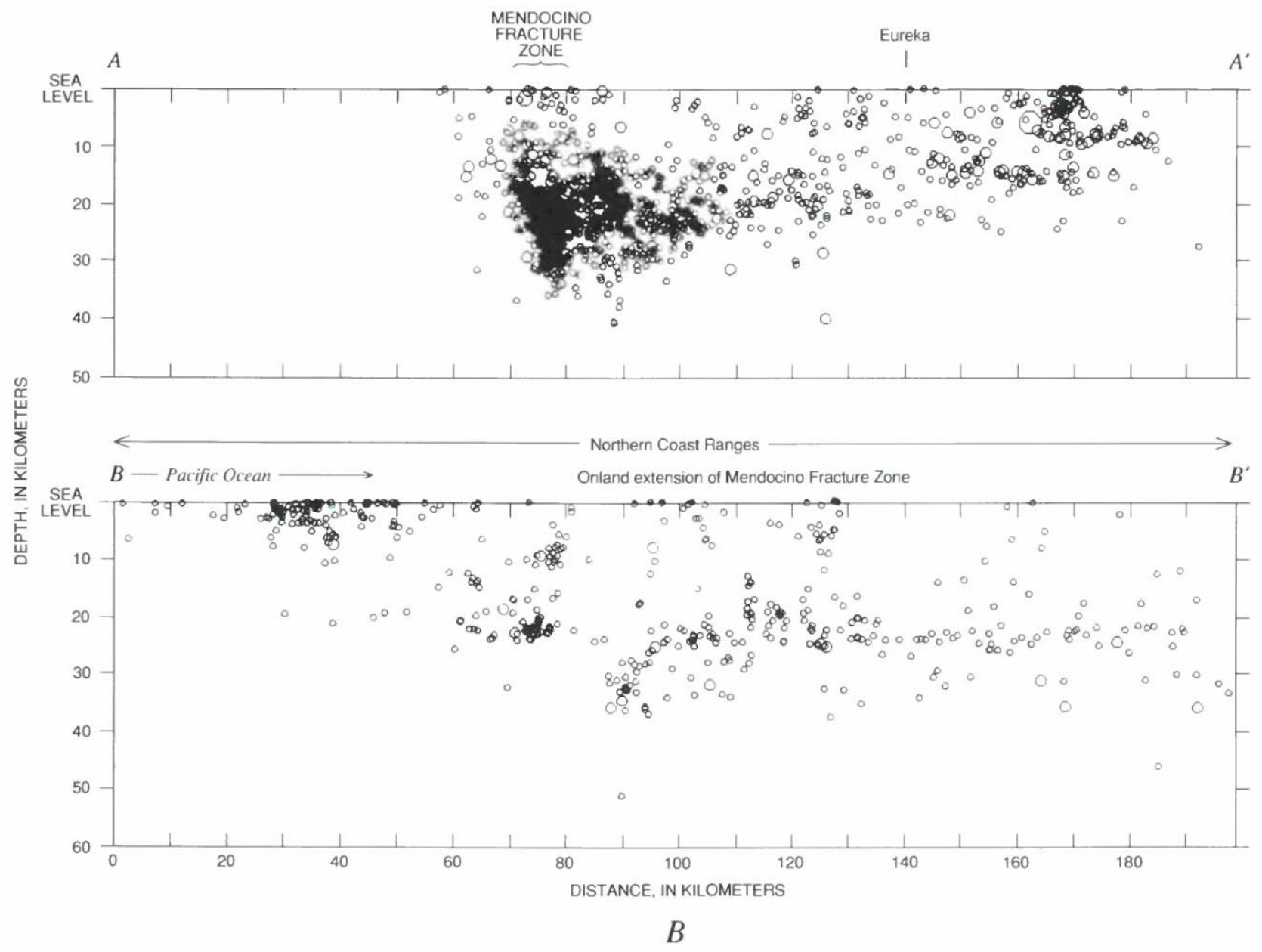

FiguRE 5.5.-Continued. 
its expression. Here, the southern margin of the subducted Gorda plate is marked only by isolated clusters of hypocenters at depths of 10 and $25 \mathrm{~km}$. To the north, however, a band of hypocenters concentrated at about a depth of $20 \mathrm{~km}$ corresponds closely to the base of the wedge-shaped distribution beneath the submarine section of the Gorda plate, including the downward flexing of this band as it approaches the southern margin of the Gorda plate. South of the landward extension of the MFZ, the seismicity shallows rather abruptly, reflecting the edge of the subducted Gorda plate beneath the North American plate and the rather thin seismogenic crust associated with the San Andreas fault system to the south.

The cross section parallel to and including the MFZ and its landward extension $\left(D-D^{\prime}\right.$, fig. $\left.5.5 C\right)$ reveals that the dense seismicity cluster along the MFZ near the triple junction tapers westward along the MFZ with a wedgelike geometry to a 20 -km-deep band of hypocenters, much the same as it does to the north (cross sec. $A-A^{\prime}$, fig. 5.5B). (The pronounced linear concentration of hypocenters at 15-km-depth beneath the submarine Gorda plate in cross sections $A-A^{\prime}$ and $D-D^{\prime}$ represents the default focal depth for the more poorly located earthquakes beyond the perimeter of the onshore seismic network.) The landward extension of the MFZ shows up only weakly as a diffuse scattering of hypocenters extending to a small, isolated cluster of 25 -km-deep hypocenters some $50 \mathrm{~km}$ east of the triple junction $(\Delta=190 \mathrm{~km}$, cross sec. $\left.D-D^{\prime}\right)$ and, possibly, as far as a handful of 30 to 50-km-deep hypocenters $100 \mathrm{~km}$ east of the triple junction $\left(\Delta=260 \mathrm{~km}\right.$, cross sec. $\left.D-D^{\prime}\right)$. Focal depths of the shallow seismicity in the northern Coast Ranges are confined to the upper $10 \mathrm{~km}$ of the crust. Farther east, however, focal depths increase again to depths of 35 to 40 $\mathrm{km}$ beneath the north end of the Great Valley. An east-dipping quiescent band, about $10 \mathrm{~km}$ thick, appears to separate the seismicity associated with the MFZ from that beneath the northern Coast Ranges and the Great Valley to the east. The geometry of this band suggests that it may somehow be related to the geometry of the subducted Gorda plate beneath the western margin of the North American plate.

The parallel cross section immediately to the north $\left(C-C^{\prime}\right.$, fig. $\left.5.5 C\right)$ reinforces the impression that the distribution of hypocenters carries an image of subduct-

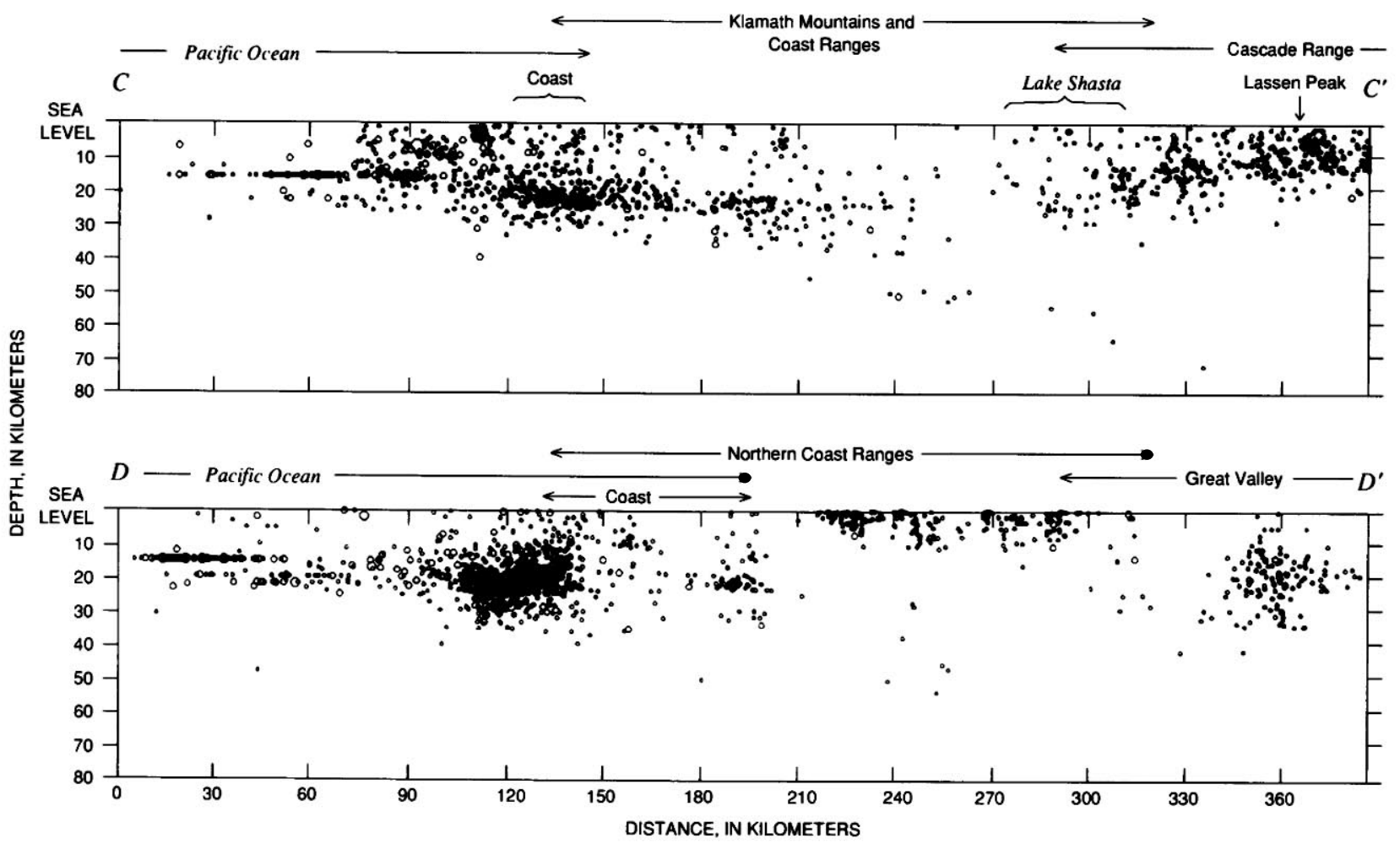

C

FIGURE 5.5.-Continued. 
ed-Gorda-plate geometry. Maximum focal depths increase systematically from 25 to $30 \mathrm{~km}$ beneath the submarine Gorda plate to nearly $80 \mathrm{~km}$ beneath the southern Cascade volcanoes. Although the easternmost of these deep earthquakes are small and few, their locations are well constrained (Cockerham, 1984; Walter, 1986). As in the section of the fault to the south, a seismically quiescent, east-dipping band appears to separate earthquakes within the Gorda plate from those in the overlying North American plate.

\section{THE 1906 BREAK AND THE NORTHERN COAST RANGES}

Aside from a light scattering of epicenters about the trace of the San Andreas fault through the San Francisco peninsula and the Santa Cruz Mountains to the south, the rupture zone of the 1906 earthquake is nearly aseismic. This pattern has persisted not only through the period 1980-86 shown in figure 5.6 but also at least since the mid-1930's, when instrumental data became available for reliable earthquake locations in the area (see Bolt and Miller, 1975; Hill and others, in press). It was interrupted, however, by the $M=7.1$ Loma Prieta earthquake on October 17, 1989, which ruptured the southernmost 45 km of the 1906 break (cross sec. $L-L^{\prime}$, fig. 5.7; see chap. 6 ). The cluster of epicenters along the fault just west of San Francisco coincides closely with Boore's (1977) estimate of the epicentral location for the 1906 main shock. We note that the greatest offsets along the 1906 rupture occurred north of the epicenter along the stretch of the fault that now shows the lowest seismicity (see Thatcher and Lisowski, 1987).

The pair of subparallel epicenter lineations through the northern Coast Ranges east of the 1906 break closely follow the Rodgers Creek-Healdsburg-Maacama fault zone (west) and the Green Valley-Bartlett Springs fault zone (east). In both lineations, the epicenters tend to cluster along the eastern margins of these 2- to 3$\mathrm{km}$-wide fault zones, which are characterized by multiple strands of subparallel, curvilinear fault traces (see maps at front of book; Dehlinger and Bolt, 1984). These fault zones are essentially colinear with the Hayward and Calaveras faults to the south, although an aseismic interval coincident with the eastern arm of the San Francisco Bay (San Pablo and Suisun Bays) obscures the connection between these branches of the fault system. Most of the earthquakes defining the pair of subparallel lineations through the northern Coast Ranges are small $(M \leq 3)$, and, indeed, these fault zones were not recognized as seismically active branches of the San Andreas system until after the northern Coast Ranges section of the telemetered network (fig. 5.2) became operational in late 1979.
Dense clusters of epicenters just south of Clear Lake define a northeast trending pattern transverse to and midway along these northern two branches of the San Andreas fault system. The southwesternmost of these clusters represents microearthquake activity associated with the Geysers geothermal field (Eberhart-Phillips and Oppenheimer, 1984; Oppenheimer, 1986). The cluster just to the northeast underlies the Clear Lake volcanic field, which last erupted about $10 \mathrm{ka}$ (Donnelly-Nolan and others, 1981). Scattered clusters farther to the northeast suggest a tenuous link between this Geysers-Clear Lake trend and the north-south-trending lineation of epicenters along the axis of the north end of the Great Valley.

In longitudinal cross section ( $H-H^{\prime}$, fig. 5.6), earthquakes occurring along the two northern branches of the San Andreas fault system are moderate in number and rather evenly distributed except for the dense, shallow cluster beneath the Geysers-Clear Lake area. The depth to the base of the continuously seismogenic crust shows considerable relief, deepening to between 12 and $13 \mathrm{~km}$ south of the Geysers-Clear Lake area and shallowing to only $5 \mathrm{~km}$ beneath and just north of the geothermal field. Farther north, the base of the seismogenic crust deepens gradually to a maximum of about $10 \mathrm{~km}$. Note the isolated cluster of small but well-located events at depths of 13 to $18 \mathrm{~km}$ beneath Clear Lake, just north of the shallowest depths to the base of the continuously seismogenic crust. Another isolated cluster of deep earthquakes located beneath Suisun Bay have focal depths as great as 15 to 25 $\mathrm{km}$. The more numerous earthquakes along branches of the fault system south of Suisun Bay paint in a dense distribution of hypocenters throughout the upper 10 to 15 km of the crust.

Although the two transverse cross sections across the northern Coast Ranges ( $E-E^{\prime}, F-F^{\prime}$, fig. 5.8A) show the concentration of hypocenters around the Rodgers Creek and Green Valley branches of the San Andreas fault, they provide no hint of the location of the main branch of the San Andreas fault that ruptured in 1906. The southern of these two cross sections $\left(F-F^{\prime}\right)$ includes the dense, shallow cluster of events associated with the GeysersClear Lake activity, as well as the cluster of deeper events beneath the eastern margin of the Coast Ranges. Focal depths in the latter cluster, which falls at the northeast end of the Geysers-Clear Lake lineation and at the south end of the north-south-trending lineation beneath the Great Valley, range from 10 to $25 \mathrm{~km}$, a depth range common to earthquakes near the north end of this Great Valley seismicity lineation (cross sec. $D-D^{\prime}$, fig. 5.5C). Maximum focal depths increase by several kilometers from west to east in both cross sections. Farther east, they increase abruptly to depths of $25 \mathrm{~km}$ or so along the Great Valley lineation. 


\section{CENTRAL CREEPING SECTION}

Densely aligned epicenters mark the nearly straight, creeping section of the San Andreas fault that separates the south end of the 1906 break near San Juan Bautista from the north end of the 1857 break near Cholame (fig. $5.6 B$ ). Densely aligned epicenters follow the Calaveras fault northward to a point just east of the south tip of the San Francisco Bay, where the Hayward fault branches to the west and the Greenville fault zone branches to the east. Few epicenters fall along the northward extension of the Calaveras fault beyond this branching point, although a diffuse cluster of epicenters coincides with the right-stepping offset between the north end of the Calaveras fault and the Concord fault (fig. 5.6A). This dilatational offset was the site of pronounced earthquake swarms in June 1970 and August 1976 (Lee and others, 1971; Weaver and Hill, 1978/79).

Although these dense alignments of epicenters coincide closely with the mapped surface trace of the San Andreas fault system as first documented by Eaton and others (1970a), the coincidence is not everywhere perfect (fig. $5.6 B$ ). In the region where the Calaveras fault branches from the main trace of the San Andreas fault, for example, the densely aligned epicenters appear to be systematically displaced 3 to $4 \mathrm{~km}$ westward of the surface trace of the San Andreas fault and a somewhat smaller distance eastward of the surface trace of the Calaveras fault. Much of this apparent offset results from a strong contrast in rock type and $P$-wave velocity across the faults that is not adequately accounted for in routine hypocenter locations (Mayer-Rosa, 1973; Pavoni, 1973; Spieth, 1981). When the hypocenter locations are recalculated using a more appropriate, two-dimensional structural model, these offsets are much reduced but not completely eliminated. The remaining offsets reflect deviation of the faults from the vertical, with the San Andreas fault dipping $70^{\circ} \mathrm{W}$. (Pavoni, 1973; Spieth, 1981) and the Calaveras fault dipping $80^{\circ} \mathrm{E}$. (Reasenberg and Ellsworth, 1982).

Wesson and others (1973) recognized the close correlation between active creep and persistent microseismic activity along the 200-km-long section of the San Andreas fault north of Parkfield and proposed that this correlation may hold for other branches of the fault in central California as well. Allen (1981) and Schultz and others (1982) pointed out that this correlation holds for the Calaveras-Hayward fault system, but creep measurements have yet to be made on the subparallel Rodgers Creek-Healdsburg-Maacama and Green Valley-Bartlett Springs faults. Creep is the dominant process for shallow slip along the central section of the San Andreas fault, and geodetic measurements spanning this section of the fault indicate that the long-term slip rate of $32 \mathrm{~mm} / \mathrm{yr}$ along the fault accommodates nearly all of the local plate motion. Because it appears that little, if any, shear strain is accumulating in the blocks on either side of the fault, most seismologists believe that this section of the fault is unlikely to rupture in a great earthquake (see chap. 7).

The creeping section of the fault system, however, has produced several moderate earthquakes during historical time (see chap. 6). The most recent of these events, which occurred along the right-branching segments northeast of the San Andreas fault, where creep rates average several millimeters per year, include (1) the $M=5.9$ Coyote Lake earthquake of August 6, 1979, and the $M=6.2$ Morgan Hill earthquake of April 24, 1984, which ruptured adjacent $20-\mathrm{km}$-long segments of the Calaveras fault south of its junction with the Hayward fault (Reasenberg and Ellsworth, 1982; Bakun and others, 1984); and (2) the $M=5.5$ and 5.8 Livermore events of January 24 and 27,1980 , which ruptured a $20-\mathrm{km}$-long stretch of the Greenville fault north of Livermore (Bolt and others, 1981).

The most noteworthy sequence of moderate earthquakes along the central section of the San Andreas fault involve the five virtually identical $M=6$ events that have ruptured the same 30-km-long stretch near Parkfield at nearly 22-year intervals since 1881 (Bakun and McEvilly, 1984). This stretch of the fault is defined by a $1-\mathrm{km}$ right-stepping offset on the south and a $5^{\circ} \mathrm{W}$. bend on the north; it coincides with the transition between the south end of the creeping section of the fault and the north end of the 1857 break (see Bakun and Lindh, 1985, fig. 1). The most recent of these characteristic Parkfield earthquakes occurred in 1966, and an intensive monitoring experiment is underway to capture a detailed instrumental record of the next Parkfield earthquake, which is predicted to occur sometime within a 10-year window centered on 1987-88 (Bakun and Lindh, 1985).

The scattered seismicity within the Coast Ranges surrounding the San Andreas fault system is distinctly more intense in the Franciscan terrane east of the fault than in the granitic Salinian block to the west. The large, dense cluster of epicenters along the eastern margin of the Coast Ranges adjacent to the south end of the creeping section represents the aftershocks of the $M=6.7$ Coalinga earthquake of May 2, 1983, and the $M=5.7$ Kettleman Hills earthquake of August 4, 1985, both of which involved reverse slip on northwest-striking planes subparallel to the adjacent section of the San Andreas fault (Stein and King, 1984; Eaton, 1989). Scattered clusters of epicenters within the Franciscan terrane show a crude northwest-trending alignment with the southwest edge of the Coalinga-Kettleman Hills aftershock zone and the Ortigalita fault, the north end of which passes beneath the San Luis Reservoir (LaForge and Lee, 1982). This weakly defined lineation is essentially 
colinear with the Greenville fault, east of the San Francisco Bay (fig. 5.4).

The Salinian block west of the central section of the San Andreas fault and east of the Sur-Nacimiento fault forms a broad, nearly aseismic swath along the west flank of the Coast Ranges. These two seismically active fault zones separate the granitic Salinian block from the Franciscan terrane on either side (see chap. 3). The Rinconada fault, within the Salinian block, appears to be nearly aseismic except, possibly, toward the south where it approaches the Sur-Nacimiento fault zone. The small cluster of epicenters just east of the midpoint of the Rinconada fault represents a persistent spot of microearthquake activity at depths of 8 to $10 \mathrm{~km}$ near the San Ardo oil field (Poley, 1988).

In the cross section along the central section of the San Andreas fault ( $L-L^{\prime}$, fig. 5.7), the actively creeping section of the fault shows up as a densely mottled distribution of hypocenters within the upper 12 to $15 \mathrm{~km}$ of the crust. The density of hypocenters within this creeping section tends to decrease with depth, and the denser clusters generally are concentrated at depths of less than 5 to $8 \mathrm{~km}$. The base of the seismogenic zone undulates about an average depth of some $13 \mathrm{~km}$ beneath most of the creeping section, but it deepens to $15 \mathrm{~km}$ beneath both the northern and southern transitions to the locked sections of the fault. In contrast to the creeping section of the fault, the sparse seismicity associated with the locked segments that ruptured in 1906 (north) and 1857 (south) tends to be concentrated toward the deeper parts of the seismogenic crust. Note that the 1989 Loma Prieta $M=7.1$ earthquake ruptured the 45-km-long section of the San Andreas fault with a pronounced U-shaped gap in shallow earthquakes immediately north of the creeping section of the fault (cross sec. $L-L^{\prime}$, fig. 5.7 ; see chap. 6).

The cross sections transverse to the central San Andreas fault system $\left(G-G^{\prime}\right.$, fig. $5.8 A ; I-I^{\prime}, J-J^{\prime}, K-K^{\prime}$, fig. $5.8 B$ ) reveal the seismically active, creeping branches of the fault as narrow, near-vertical hypocenter distributions coincident with the fault plane. The broadened distribution in cross sections $I-I^{\prime}$ and $J_{-} J^{\prime}$ (fig. $5.8 B$ ) reflects the oblique projection of earthquakes along the Calaveras fault zone and the clustering northeast of the fault in the Bear Valley region (Ellsworth, 1975), respectively. These transverse cross sections also emphasize the quiescence of the Salinian block relative to the Franciscan terrane on either side (note, however, the isolated cluster of deep events beneath San Ardo in the Salinian block in cross sec. $K-K^{\prime}$ ), and the fairly uniform depth of 12 to $15 \mathrm{~km}$ to the base of the seismogenic zone that persists throughout the central Coast Ranges. As in the area farther north, however, maximum focal depths increase rather abruptly to $25 \mathrm{~km}$ beneath the eastern margin of the Coast Ranges and the Great Valley. This increase in focal depth is particularly pronounced beneath the dense cluster of hypocenters associated with the 1983 Coalinga earthquake and its aftershocks (cross sec. $G-G^{\prime}$, fig. $5.8 B$ ).

\section{THE 1857 BREAK AND THE TRANSVERSE RANGES}

The 1857 rupture of the San Andreas fault began near Parkfield at the south end of the creeping section of the fault and propagated southeastward along the straight segment, through the Carrizo Plain and around the Big Bend near Tejon Pass, and thence along the relatively straight, east-southeastward trend of the Mojave segment to Cajon Pass, where the San Jacinto fault branches to the south (figs. 5.3, 5.9A). Right-lateral offsets associated with this great earthquake generally decreased from $9 \mathrm{~m}$ along the Carrizo Plain segment, through $6 \mathrm{~m}$ around Fort Tejon, to 3-4 $\mathrm{m}$ along the Mojave segment (Sieh, 1978).

The pronounced bends in the San Andreas fault at either end of the east-southeast-trending Mojave segment involve strong structural complexities and clusters of persistent seismic activity. Both bends, for example, spawn major left-lateral faults that form conjugate sets to the San Andreas system. Sykes and Seeber (1985) proposed that these two major bends in the San Andreas fault system represent large-scale asperities that exert a strong influence on the rupture patterns of great earthquakes along the San Andreas fault in southern California. The San Andreas fault appears to maintain its integrity as a single, more or less continuous zone through the $30^{\circ}$ bend at Fort Tejon. Convergence resulting from the pronounced counterclockwise cant of the Mojave segment of the San Andreas fault (N. $66^{\circ} \mathrm{W}$.) with respect to the average $N 37^{\circ} \mathrm{W}$. orientation of the transform boundary largely accounts for the crustal uplift and shortening expressed in the Transverse Ranges.

The straight Carrizo Plain segment is, except for a small cluster of events near Simmler (lat $35^{\circ} 25^{\prime}$ N., long $120^{\circ} 00^{\prime}$ W.), almost completely aseismic, much like the Point Arena segment of the 1906 break. The straight part of the Mojave segment also is seismically very quiet. The southernmost $80 \mathrm{~km}$ of the 1857 rupture zone produces few earthquakes, forming a sinuous lineation around the fault. Again, an analogy can be drawn with the 1906 rupture zone: The southernmost 80 to $100 \mathrm{~km}$ of the 1906 rupture, which exhibited less slip than the rupture zone farther north, also has a slightly higher background seismicity rate than that to the north. The Mojave earthquakes are temporally clustered (Sauber and others, 1983) and, because of their reverse focal mechanisms and displacement from the surface trace of the San 


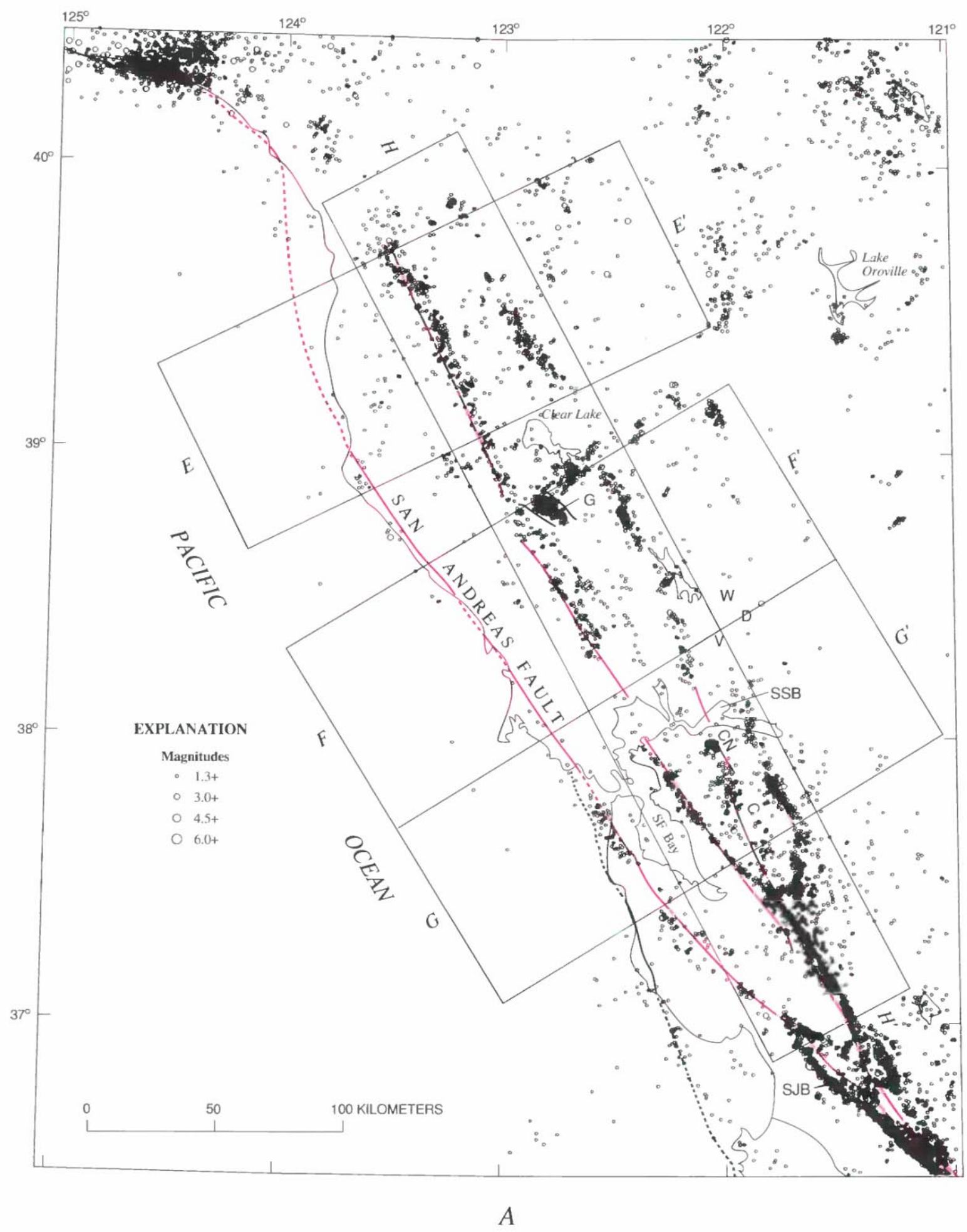

FigURE 5.6. - Seismicity in the northern $(A)$ and central $(B)$ Coast Ranges. Major branches of the San Andreas fault marked in red; faults dotted where concealed. Earthquakes within rectangles are plotted in corresponding depth sections in figures 5.7 and 5.8. C, Calaveras fault; CN, Concord fault; G, The Geysers; SF Bay, San Francisco Bay; SJB, San Juan Bautista; SSB, Suisun Bay; D, Dixon; V, Vacaville; W, Winters. 
Andreas, are thought to be on secondary fault structures rather than on the San Andreas fault itself.

Within the area of the Big Bend of the San Andreas fault near Tejon Pass, the level of seismicity is much higher than in the adjoining regions. Much of this activity is associated with the Pleito-White Wolf fault system, which abuts the San Andreas fault in the northern bend, some $40 \mathrm{~km}$ west of the junction with the Garlock-Big
Pine faults (fig. $5.9 A$; cross sec. $N-N^{\prime}$, fig. $5.9 B$; see fig. 5.12). The White Wolf fault ruptured in 1952 with the $M=7.7$ Kern County earthquake, accompanied by leftoblique reverse slip on a southeast-dipping fault plane (Richter, 1958; Stein and Thatcher, 1981). This is the largest earthquake to occur in California since the $M \approx 8$ San Francisco earthquake. In contrast to the quiescent 1906 rupture, however, the White Wolf fault continues to

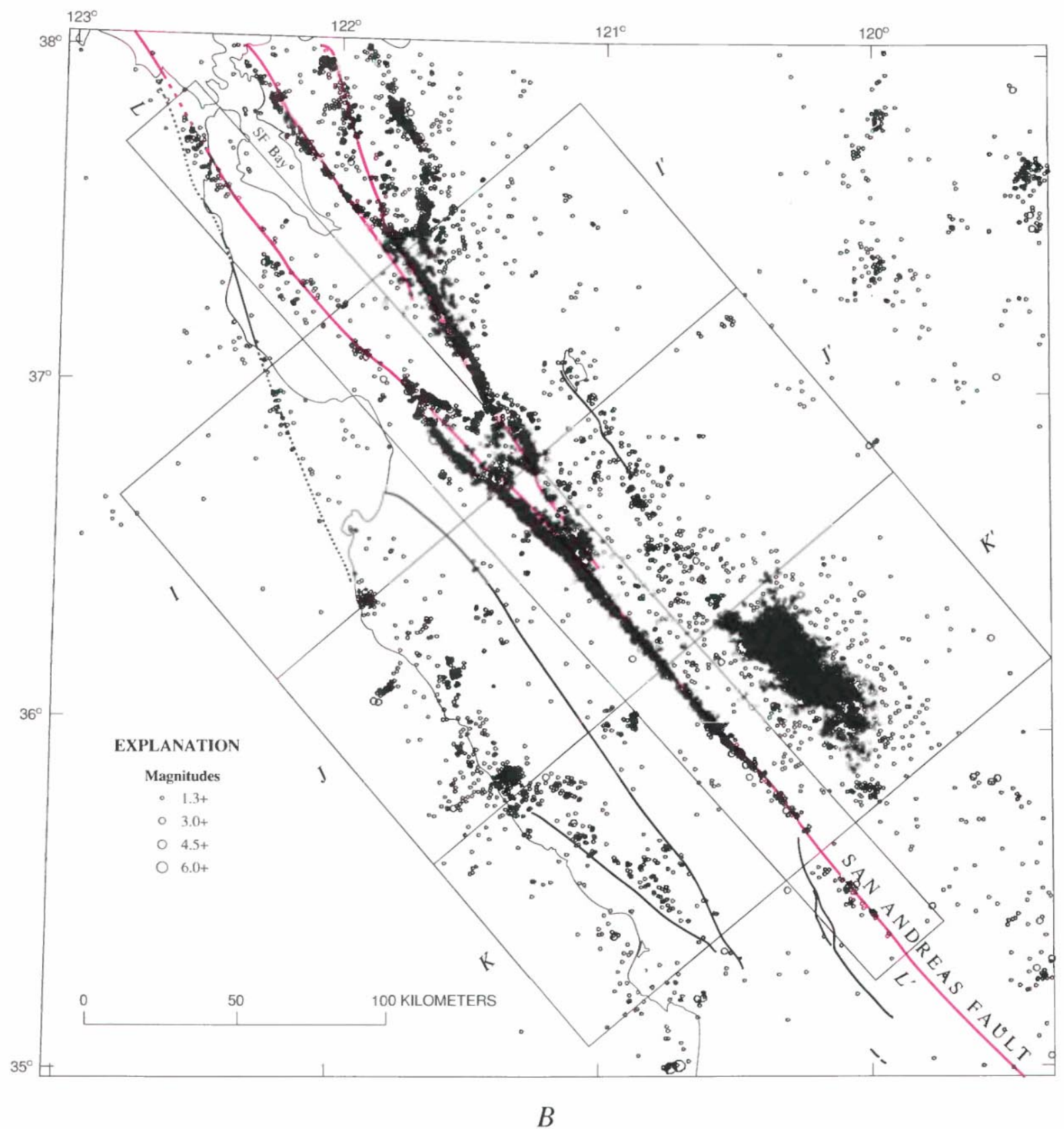

Figure 5.6.-Continued. 
be marked by persistent aftershocks of the 1952 Kern County earthquake. The Garlock and Big Pine faults are essentially quiescent within 40 to $50 \mathrm{~km}$ of the San Andreas, although two small clusters of epicenters form a nearly symmetrical pattern on either side of the junction of these sinistral faults with the San Andreas.

Seismicity increases markedly near the south end of the 1857 rupture zone, where the San Jacinto fault and the east-west-striking Cucamonga fault, which forms the south front of the central Transverse Ranges, intersect the San Andreas fault. A bulbous lobe of epicenters extends westward along the Cucamonga fault from this junction. Scattered epicenters fill in the wedge of the Transverse Ranges between the Cucamonga and San Jacinto faults. In figure 5.9A, note the tight lineation of epicenters that appears to follow the trace of the Cucamonga fault westward to its intersection with the Elsinore fault (Chino branch). The significance of this lineation is unclear because the Cucamonga fault presumably dips north beneath the central Transverse Ranges (Morton, 1987).

The cross section along the Mojave segment of the San Andreas fault $\left(M-M^{\prime}\right.$, fig. $\left.5.9 B\right)$ shows a wide variation in focal depths. The few events along the straight section of the Mojave segment are strongly clustered around depths of $10 \mathrm{~km}$, with the maximum focal depth always above $15 \mathrm{~km}$ and almost no shallow earthquakes. This pattern is similar to the concentration of hypocenters in the lower half of the seismogenic crust beneath the locked 1906 segment (compare with cross sec. $L-L^{\prime}$, fig. 5.7). In contrast, the earthquakes at Tejon Pass cover the full depth range from 0 to $25 \mathrm{~km}$. At the southeast end of the 1857 rupture zone at Cajon Pass, maximum focal depths increase with the seismicity level to a maximum of $20 \mathrm{~km}$. In this section, there are no shallow (less than $5 \mathrm{~km}$ deep) events.

Note, in particular, that focal depths of more than 20 $\mathrm{km}$ are broadly associated with the convergent tectonics of the Transverse Ranges; they are not limited to the seismicity clusters in the vicinity of the bends in the San Andreas fault system as might be inferred from cross section $M-M^{\prime}$ (fig. $5.9 B$ ). Cross sections $N-N^{\prime}$ and $O-O^{\prime}$ (fig. $5.9 B$ ), for example, illustrate that the seismogenic crust reaches thicknesses of 20 to $25 \mathrm{~km}$ beneath the Santa Barbara Channel and the western Transverse Ranges, as well as beneath the Tehachapi Mountains to the east.

\section{SOUTHERN SECTION OF THE SAN ANDREAS FAULT SYSTEM}

Southeast of the 1857 rupture, the San Andreas fault splays into several branches associated with intense

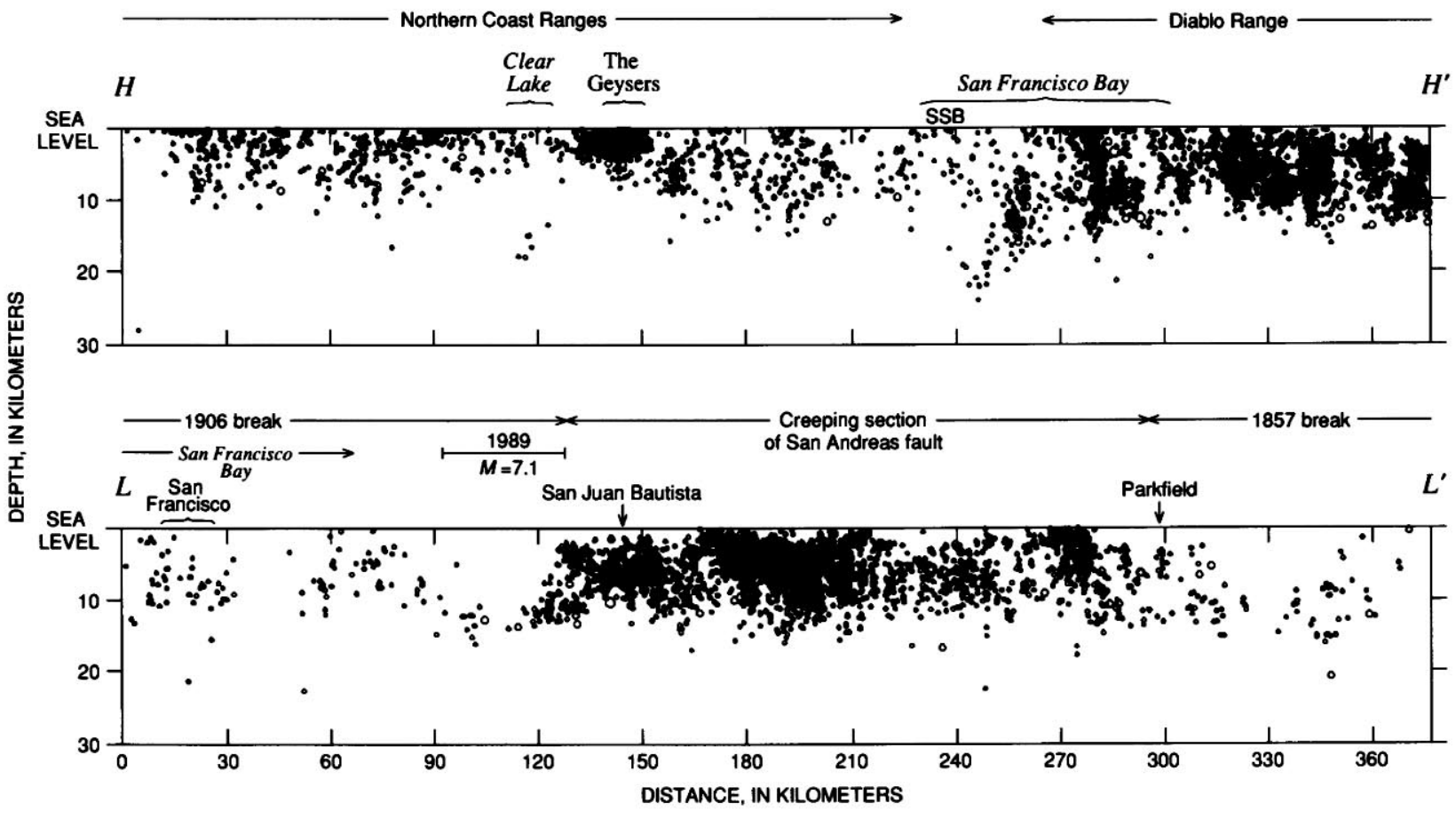

FigURE 5.7.-Longitudinal depth sections along the San Andreas fault system in the northern and central Coast Ranges. Bar above section $L-L^{\prime}$ indicates rupture extent of the October 17, 1989, Loma Prieta $M=7.1$ earthquake (see chap. 6). SSB, Suisun Bay. See figure 5.6 for locations of sections and explanation of symbols, which are scaled with scale change of cross sections. 
seismicity in the Banning-San Gorgonio area. Like the Tejon Pass bend in the 1857 rupture zone, the San Gorgonio bend spawns a major left-lateral fault (the Pinto Mountain fault) conjugate to the San Andreas system. Unlike the situation at Tejon Pass, however, the San Andreas fault at San Gorgonio splays into a complex pattern of branching and intersecting fault segments. South of San Gorgonio, the San Andreas fault reconverges into a single strand and bends again to the more southeasterly trend that characterizes the southern section of the fault system.

This section of the fault system south of the Transverse Ranges is transitional from oblique spreading along the axis of the Gulf of California to the obliquely convergent strike-slip displacement that dominates deformation along the continental section of the San Andreas transform boundary to the north. Several major strike-slip faults run west of and subparallel to the main strand of the San Andreas fault south of the Transverse Ranges. These faults, which are considered part of the San Andreas system and include the Imperial, San Jacinto, and Elsinore faults, accommodate a significant proportion of the plate-boundary motion. The Imperial and San Jacinto faults, in particular, have produced more moderate earthquakes than any other segment within the fault system (see chap. 6; Hanks and others, 1975).

\section{SOUTHERN BRANCH OF THE SAN ANDREAS FAULT}

The most intense seismicity along the main trace of the southern section of the San Andreas fault is associated with the San Gorgonio bend and is concentrated between the two principal branches of the San Andreas fault: (1) the Mission Creek fault, or northern branch of the San Andreas; and (2) the Banning fault, which runs nearly due west from the south end of the Mission Creek fault toward an ambiguous junction with the San Jacinto fault just south of San Bernardino (see fig. 5.3A and maps at front of book). Neither strand forms a continuous structure through the bend. This San Gorgonio seismicity cluster produced numerous $M=5.0-6.5$ earthquakes in the 1930 's and 1940's, and in 1986 it produced the $M_{L}=5.6$ North Palm Springs earthquake, which involved dextral strike-slip displacement on the north-dipping Banning fault (Jones and others, 1986). The background seismicity in this area is the highest in southern California, but it is distributed throughout a volume and cannot be clearly associated with any fault. To the west, seismicity associated with the Banning cluster abuts the dense lineation of epicenters coincident with the northernmost segment of the San Jacinto fault. Nicholson and others (1986) suggested that much of the seismicity within the upper 10 $\mathrm{km}$ of the crust in this cluster involves left-lateral slip on a series of northeast-striking faults; however, Jones
(1988) pointed out that the evidence for northeasttrending lineations of epicenters within the Banning cluster is less than clear.

Diffuse seismicity extends northward from the Banning cluster into the San Bernardino Mountains and eastward into the Pinto Mountains, with no clear lineations along the sinistral Pinto Mountain fault. Indeed, a diffuse, north-south-trending lineation of epicenters seems to cut directly across the Pinto Mountain fault from the west-central Pinto Mountains. Two $M=5.2$ earthquakes (see events 75,76 , fig. $5.11 A$ ) with rightlateral strike-slip planes parallel to this trend occurred at the north end of this zone in 1975 and 1979. Somewhat farther south, however, a broad, east-west-trending lineation appears to coincide with the Blue Cut fault. Even farther south, a second broad lineation extends eastward from near the junction of the Banning and Mission Creek branches, although this lineation does not coincide with a mapped fault.

The southernmost section of the San Andreas fault, the Indio segment, which extends from the junction of the Banning and Mission Creek branches southward to the end of the San Andreas at the Salton Sea, has been almost completely aseismic in historical time. At the north end of this segment, periodic swarms of small $(M \leq 4)$ earthquakes a few kilometers east of the San Andreas appear to occur on small northeast-trending structures (for example, Norris and others, 1986; Jones, 1988). The sparse background seismicity is also offset a few kilometers to the east from the surface trace of the San Andreas. Although the possibility of systematic offsets related to $P$-wave-velocity contrasts across the fault has not been investigated in detail, the observed offset seems too large to be explained entirely by lateral velocity contrasts.

Although it has not ruptured with a major earthquake in historical time, the aseismic Indio segment of the San Andreas fault seems to have much in common with the 1857 and 1906 rupture zones. Sieh (1986) presented geologic evidence for at least four major ruptures along the Indio segment since A.D. 1000; the last occurred approximately $300 \mathrm{yr}$ ago. Unlike the two major locked sections, however, the south end of the Indio segment adjacent to the Salton Sea shows minor aseismic creep (Louie and others, 1985) and has shown episodes of sympathetic slip accompanying $M \approx 6$ earthquakes on the Imperial fault and the southern section of the San Jacinto fault (Sieh, 1982). Not only is the Indio segment aseismic, but also the entire Coachella block extending from the San Andreas fault on the northeast to the crest of the San Jacinto Mountains on the southwest.

A cross section of hypocenters along the southern branch of the San Andreas fault ( $M-M^{\prime}$, fig. $\left.5.9 B\right)$ shows that the earthquakes associated with the bend at San 

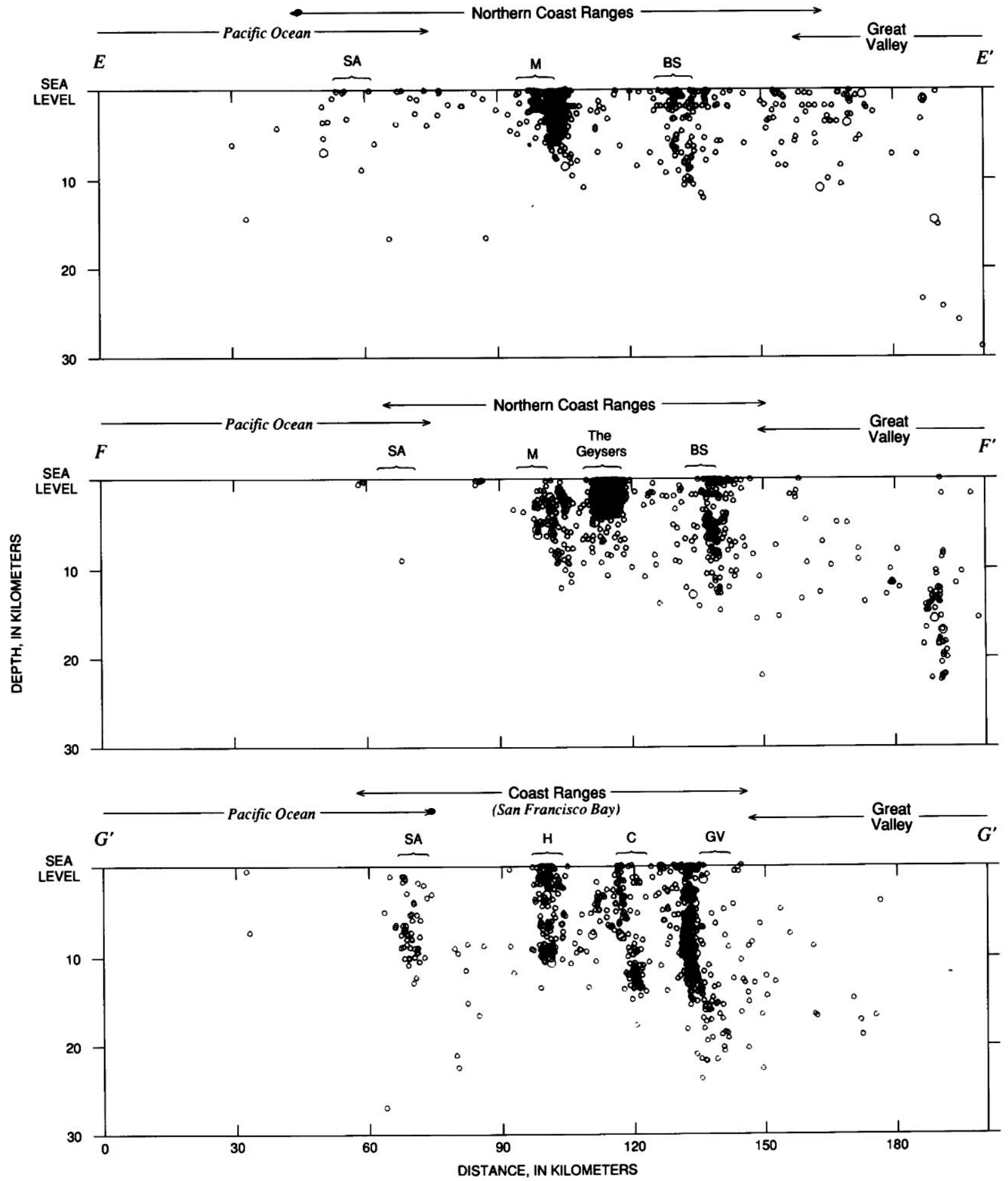

A

FIGURE 5.8. - Transverse depth sections across the San Andreas fault system in the northern $(A)$ and central $(B)$ Coast Ranges. See figure 5.6 for locations of sections and explanation of symbols, which are scaled with enlargement of cross sections. Faults: BS, Bartlett
Springs; C, Calaveras; GV, Greenville; H, Hayward; M, Maacama; R, Rinconada; SA, San Andreas; SG, San Gregorio; SNA, SurNacimiento. BV, Bear Valley on cross section $J-J^{\prime}$. FRT, Franciscan terrane. 


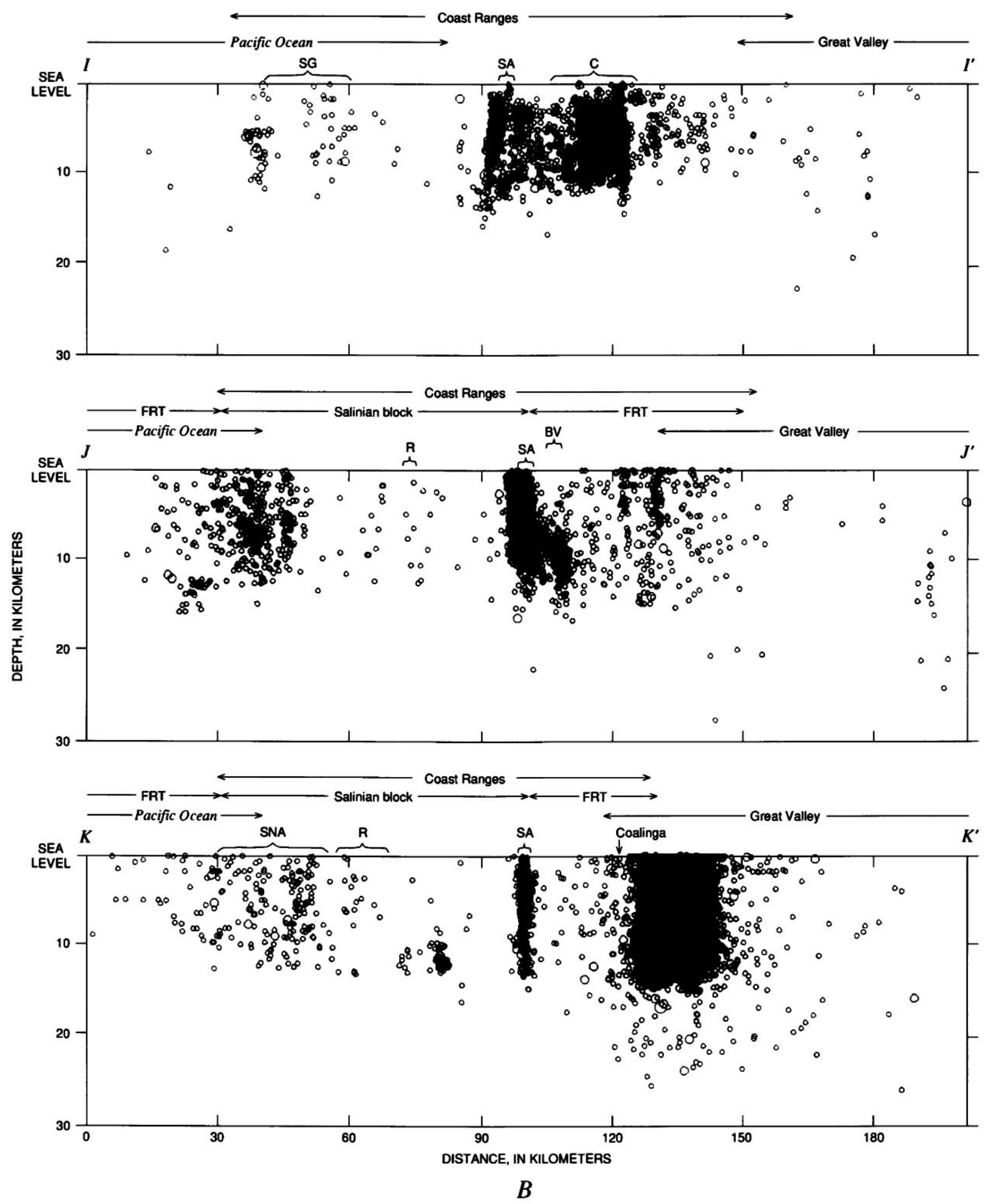

Figure 5.8.-Continued. 
Gorgonio are among the deepest in southern California, with maximum focal depths approaching $25 \mathrm{~km}$. The maximum focal depths deepen southward along the San Andreas fault from about $12 \mathrm{~km}$ beneath the Mojave segment to $25 \mathrm{~km}$ beneath the San Gorgonio fault. At the south end of the San Gorgonio area, however, maximum focal depths abruptly decrease to $10 \mathrm{~km}$. This shallowing of seismicity is associated with a shift in the most concentrated seismicity from between the two segments (Mission Creek and Banning) of the San Andreas to east of the Mission Creek fault. The sparse seismicity of the Indio segment is limited to depths of $5 \mathrm{~km}$ or less.

\section{ASSOCIATED FALLTS}

Although the southernmost section of the San Andreas fault is almost completely aseismic, associated subparal- lel faults are extremely active. These faults are marked by the three bold north-south- to northwest-trending alignments of epicenters that dominate the seismicity pattern within the San Andreas fault system south of the Transverse Ranges (fig. 5.10A), from east to west: (1) the Brawley seismic zone (Johnson, 1979), defined by a dense, spindle-shaped cluster of epicenters connecting the north end of the Imperial fault and the south end of the Indio segment of the San Andreas fault; (2) the northwestward alignment of densely clustered epicenters along the San Jacinto fault zone, which appears to branch from the northern section of the Imperial fault; and (3) the northwestward alignment of more diffusely clustered epicenters along the Elsinore fault, which appears to branch from somewhere near the south end of the Imperial fault.

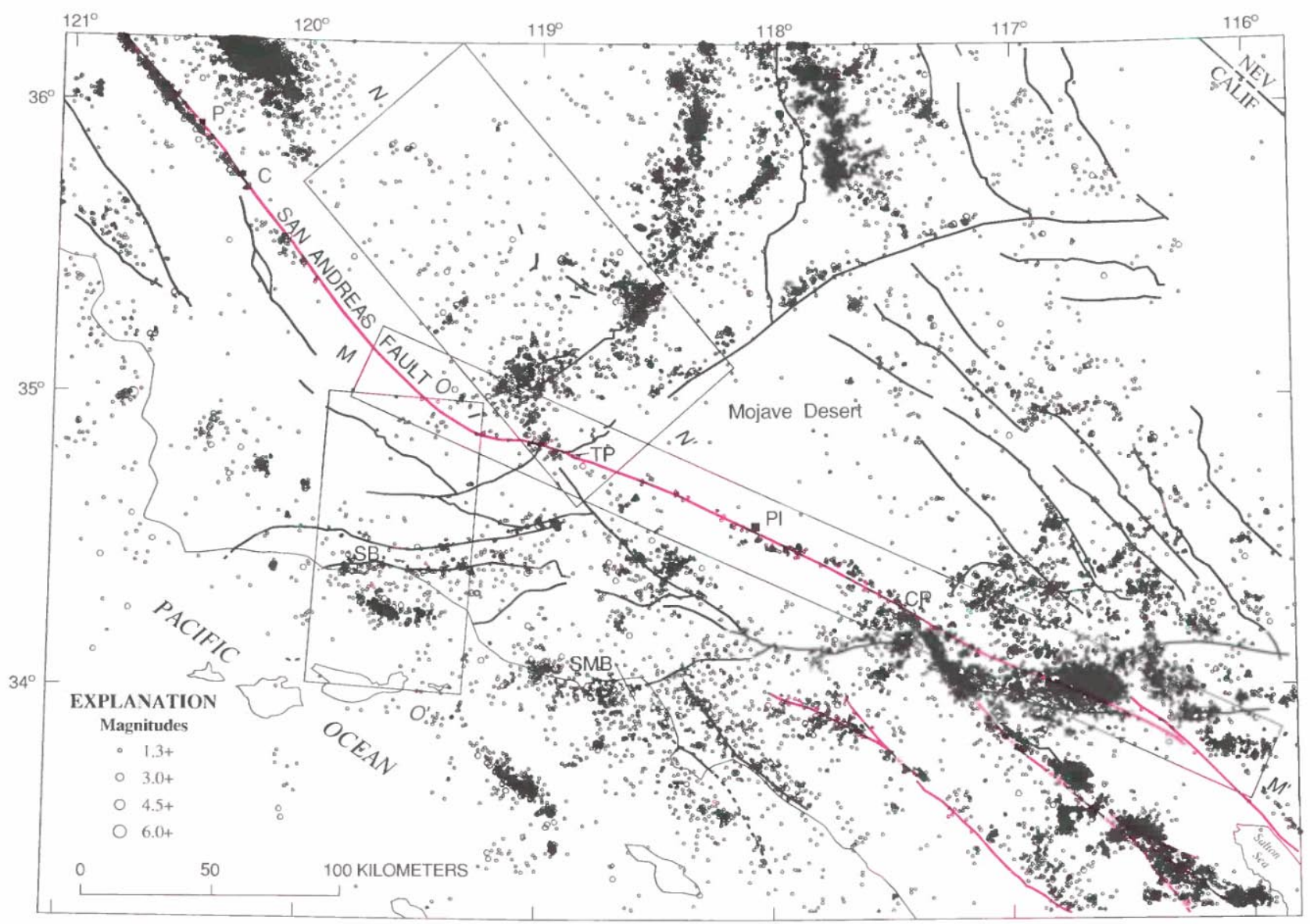

A

FIGURE 5.9.-Seismicity in the southern Coast Ranges and Transverse Ranges. A, Earthquake locations, showing major branches of the San Andreas fault system in red; faults dotted where concealed. Magnitude symbols shown in explanation are scaled with enlargement of cross sections. C, Cholame; CP, Cajon Pass; P, Parkfield; Pl,
Palmdale; SB, Santa Barbara; SMB, Santa Monica Bay; TP, Tejon Pass. B, Depth sections outlined in figure 5.9A. Faults: B, Banning; G, Garlock; MC, Mission Creek; N.Br.SA, northern branch of the San Andreas; PM, Pinto Mountain; SA, San Andreas, SJ, San Jacinto; WW, White Wolf. 


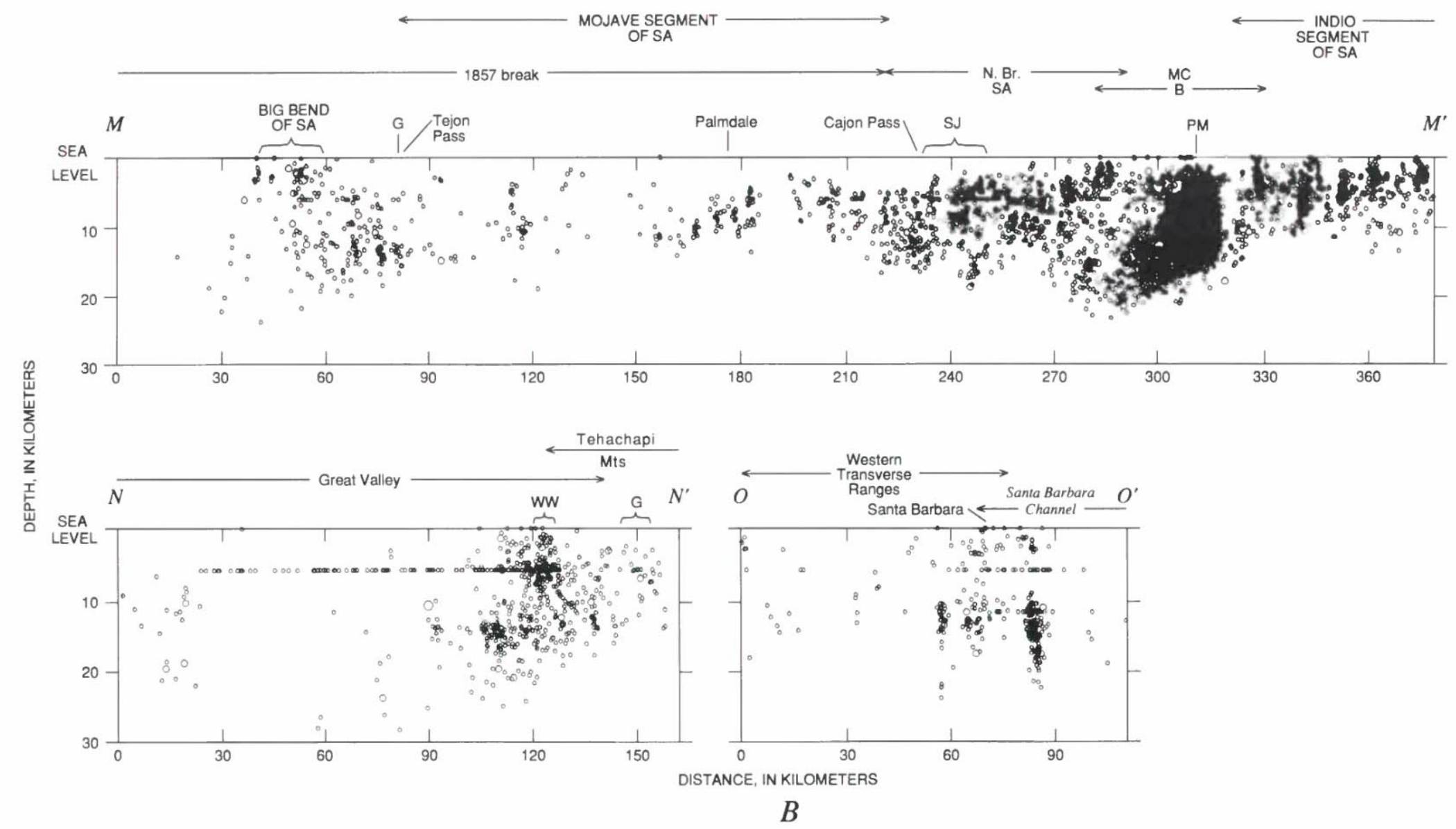


The Brawley seismic zone and the cluster of epicenters at the south end of the Imperial fault (coincident with the Cerro Prieto volcanic-geothermal field in Mexico) represent the two northernmost in the series of small spreading centers offset by right-lateral transform faults that characterize oblique spreading in the Gulf of California (Lomnitz and others, 1970; Johnson and Hill, 1982). The Imperial fault itself, which is marked by a scattered alignment of epicenters, serves as the transform fault between these two small spreading centers. The $M=7.1$ El Centro earthquake ruptured the entire length of the Imperial fault in 1940, and the $M=6.6$ Imperial Valley earthquake of 1979 ruptured the north two-thirds of the fault; intensity data suggest that moderate earthquakes $(5.5<M<6.3)$ in 1906, 1915, 1917, and 1927 may also have been located on the Imperial fault (Johnson and Hill, 1982). Most of the aftershocks associated with the 1979 Imperial Valley earthquake were concentrated in the south half of the Brawley seismic zone, which was first recognized because of the many earthquake swarms it produced from 1973 through mid-1979 (Hill and others, 1975; Johnson 1979; Johnson and Hutton, 1982). Many of the individual swarm sequences, as well as individual clusters of events in the aftershock sequence, defined lineations transverse to the strike of the Imperial fault and the long axis of the Brawley seismic zone. Most earthquakes within the Brawley seismic zone have strike-slip focal mechanisms; thus, kinematically, these transverse lineations represent conjugate structures to the dominant north-northwestward trend of the Imperial-Brawley fault system.

Irregular clusters of epicenters mark the San Jacinto fault zone, which runs along the southwest base of the Santa Rosa and San Jacinto Mountains. These clusters tend to be concentrated near bends and junctions within the complex set of multiple fault strands that form the surface expression of this fault zone. In several places, particularly within the southern and northern sections of the fault zone, epicenters define linear concentrations that tend to be closely aligned with mapped fault traces. The San Jacinto fault zone has produced at least 10 earthquakes of $M=6.0-6.6$ since 1890 , the most recent of which were the $M=6.2$ earthquake of 1954 , the $M=6.6$ Borrego Mountain earthquake of 1968 , and the $M=6.6$ Superstition Hills earthquake of 1987. Thatcher and others (1975) pointed out that this series of historical $M>6$ earthquakes along the San Jacinto fault zone has left two seismic gaps: one along the northern $40 \mathrm{~km}$ of the fault, and the other along a $20-\mathrm{km}$-long stretch of the central section of the fault zone (the Anza gap). The Anza gap shows up in figure $5.10 \mathrm{~A}$ as a relatively quiescent stretch of the fault zone between two dense clusters, with a third cluster located off the fault zone some $20 \mathrm{~km}$ southwest of the gap (see Fletcher and others, 1987; Sanders and Kanamori, 1984).

The Elsinore fault zone is defined not so much by a coincident alignment of epicenters as by the loci of western end points for clusters of epicenters elongate northeastward between the Elsinore and San Jacinto fault zones. This pattern is most pronounced along the southeast half of the fault; the northwest half, which defines the northeast scarp of the Elsinore Mountains, is marked by scattered clusters of epicenters. As the Elsinore fault enters the Los Angeles Basin to the north, it splays into the Whittier and Chino faults. Historical seismicity levels are considerably lower along the Elsinore fault than either the San Jacinto fault zone or the Imperial fault/Brawley seismic zone. The largest historical earthquake on the Elsinore fault was an $M=6$ event in 1910 in the central section. The Whittier Narrows earthquake $\left(M_{L}=5.9\right)$ of 1987 , which caused over $\$ 300$ million in damage, was located at the north end of the Elsinore-Whittier fault. Because its mechanism was thrust faulting on an east-west-striking plane with a shallow dip, however, it does not appear to be simply related to the Elsinore system.

Seismicity in the relatively quiescent southwestern corner of California between the Elsinore fault and the coast shows up in figure $5.10 \mathrm{~A}$ as small, sparsely scattered clusters of epicenters. Activity picks up again, however, in the vicinity of the major northwest-striking faults along the coast (the Rose Canyon fault through San Diego and the Newport-Inglewood and Palos Verdes faults along the western margin of the Los Angeles Basin). Except for weak alignments along the NewportInglewood fault, which ruptured with an $M=6.3$ earthquake in 1933 (Richter, 1958), the seismicity patterns associated with these faults show little tendency to align along mapped fault traces.

The cross sections in figure $5.10 \mathrm{~B}$ emphasize that, except in the immediate vicinity of the Salton Sea, maximum focal depths associated with earthquakes aligned along the principal branches of the southern section of the San Andreas fault system are systematically deeper than those aligned along its central and northern sections. Maximum focal depths, for example, decrease from 15 to $18 \mathrm{~km}$ beneath the central section of the Imperial fault near the United States-Mexican border to less than $10 \mathrm{~km}$ beneath the north end of the Brawley seismic zone at the southeast tip of the Salton Sea (cross sec. $Q-Q^{\prime}$, fig. $5.10 B$ ). The focal depths associated with earthquakes along the Coyote Creek, Superstition Hills, and Superstition Mountain faults forming the southwestern section of the San Jacinto fault zone adjacent to the Salton Sea are concentrated in the upper $10 \mathrm{~km}$ of the crust (cross sec. $P-P^{\prime}$, fig. $5.10 B$ ). 
Those segments of the San Andreas fault system in southern California with maximum focal depths shallower than 12 to $15 \mathrm{~km}$ are also those that show evidence of aseismic creep (see Louie and others, 1985). Indeed, actively creeping segments of the San Andreas fault system throughout California seem to be confined to those along which microearthquakes are concentrated in the shallow crust (focal depths of less than 12-15 km).

Moving northwestward along the San Jacinto fault zone, the base of the seismogenic crust deepens systematically to a maximum of $20 \mathrm{~km}$ beneath the stretch adjacent to San Jacinto Mountain (which at $3,293 \mathrm{~m}$, is the second highest point in southern California) midway along the fault zone (cross sec. $P-P^{\prime}$, fig. 5.10B). The base of the seismogenic crust maintains this $20-\mathrm{km}$ depth farther northwestward along the fault zone to its junction with the Banning fault just south of San Bernardino (fig. $5.10 \mathrm{~A}$ ), beyond which it begins to shallow again. Note, in particular, that earthquakes tend to be concentrated between $10-$ and $20-\mathrm{km}$ depth beneath the San Jacinto fault zone, leaving the upper $10 \mathrm{~km}$ of the crust relatively quiescent along the middle stretch of the fault zone. The dense knot of hypocenters in the upper $5 \mathrm{~km}$ of the crust midway along cross section $P-P^{\prime}$ corresponds to the cluster of epicenters $15 \mathrm{~km}$ southwest of the fault zone near the Anza gap (fig. 5.10A). The Anza gap itself shows up between $\Delta=120$ and $140 \mathrm{~km}$ in cross section $P-P^{\prime}$ as a quiescent zone below and southeast of the shallow cluster of hypocenters (Fletcher and others, 1987; Sanders, 1987). The distribution of hypocenters beneath the Elsinore fault zone (cross sec. $R-R^{\prime}$, fig. $5.10 B$ ) is in many ways similar to that beneath the San Jacinto fault zone. Maximum focal depths increase northwestward from 12-15 km at the southeast end of the fault near the United States-Mexican border to about $20 \mathrm{~km}$ midway along the fault zone (generally coincident with the highest topography in this section of the Peninsular Ranges) and then gradually decrease farther northwestward toward the Los Angeles Basin. Maximum focal depths show evidence of increasing again at the northwest end of the fault as it approaches the Transverse Ranges and branches into the Whittier and Chino faults. The hypocenters along the south half of the Elsinore fault also tend to concentrate in the lower $10 \mathrm{~km}$ of the seismogenic crust, although this pattern is not as well defined in the diffuse seismicity of the Elsinore fault zone as in the dense clustering along the San Jacinto fault zone.

\section{FOCAL MECHANISMS AND TRANSFORM-BOUNDARY KINEMATICS}

Focal mechanisms of selected earthquakes recorded in California from 1933 through 1988 are shown in figure $5.11 \mathrm{~A}$, and the corresponding source parameters are listed in tables 5.2 and 5.3. Primary considerations in the selection of these events were (1) size-larger events were chosen where available, because they represent large-scale processes along major boundaries; (2) date of occurrence-the quality of data for focal-mechanism determinations improved significantly during the mid1970's; and (3) location-some larger events were omitted because they were redundant in terms of mechanism and location, and some smaller events were included because they occurred in regions of significant seismicity where no larger events were available. Most focal mechanisms were determined from first arrivals at stations in the northern and southern California seismic networks. The evolving capability of these networks for such studies is reflected in the number of stations in the networks, summarized in table 5.1. Fault-plane solutions for the few large earthquakes on the list before the mid-1970's were supported by observations from stations outside the California networks.

Since the mid-1970's, focal mechanisms have been determined for only a fraction of the events for which adequate local first-motion data were available. Therefore, in addition to the three considerations listed above, there was a fourth, the interests of the investigators who analyzed the data. These interests included topical studies of large earthquakes and aftershock sequences, analyses of regional traveltimes on the basis of $M \geq 4$ earthquakes, and a special study of the focal mechanisms of earthquakes on or near the San Andreas fault in southern California (Jones, 1988).

Focal mechanisms discussed in the first two subsections below are for earthquakes in the contiguous Coast Ranges-Transverse/Peninsular Ranges-Mojave Desert region associated with the principal seismic expression of the San Andreas fault system, where the seismic networks are best developed. Outside that region, except for the Cape Mendocino area and the vicinity of Long Valley caldera, the few well-determined focal mechanisms that are available provide only limited information on tectonic processes.

\section{STRIKE-SLIP KINEMATICS OF THE SAN ANDREAS FAULT SYSTEM}

Most moderate and large $(M \geq 3)$ earthquakes along the San Andreas fault and its major branches produce nearly pure right-lateral displacements along near-vertical planes that closely follow the surface traces of the respective fault segments. This relatively simple kinematic pattern holds for the great earthquakes that rupture "locked" sections of the fault every few hundred years (Sieh, 1981), as well as for nearly all the moderate earthquakes that rupture limited patches along persistently active segments of the fault system (Ellsworth and others, 1982; Jones, 1988). Displacements associated with 
these earthquakes dominate the kinematic pattern along the transform boundary in California. DeMets and others (1987) and Minster and Jordan (1987), for example, argued that the cumulative displacement from earthquakes along the faults in the San Andreas system, together with the contribution from aseismic slip along its creeping segments, accounts for 60 to 70 percent of the total displacement between the Pacific and North American plates.

The fault-parallel strike-slip displacements typical of San Andreas earthquakes are illustrated in figure 5.11A by focal mechanisms along the San Andreas fault and its major branches from the United States-Mexican border to north of Clear Lake. In central California, such mechanisms mark the San Andreas fault itself from San Francisco to Cholame (events 26, 36, 38, 45, 46), the Calaveras-Greenville fault (events 23, 28-34) and the Hayward fault (event 27). Farther north, such mecha- nisms occur along the Green Valley-Bartlett Springs fault (event 15) and the Rodgers Creek-HealdsburgMaacama faults (events 16, 17, 19, 20). In southern California, such mechanisms mark the San Jacinto fault (events 78, 82-85) and the Imperial fault (event 89). Along the coast west of the San Andreas fault, similar focal mechanisms occur along the San Gregorio-Palo Colorado fault (events 39, 40) in northern California and along the Newport-Inglewood fault zone (events 62, 71), the Rose Canyon fault (event 73), and the San Clemente fault (event 70) in southern California.

Exceptions to this simple pattern for moderate $(M \geq 4)$ events along the San Andreas fault and its major branches appear to be limited to regions of unusual complexity, such as the major bends in the San Andreas near Cajon Pass (event 69) and San Gorgonio Pass (event 80). Jones and others (1986) attributed the July 8, 1986, earthquake (event 80 ) to right-lateral slip on the Banning

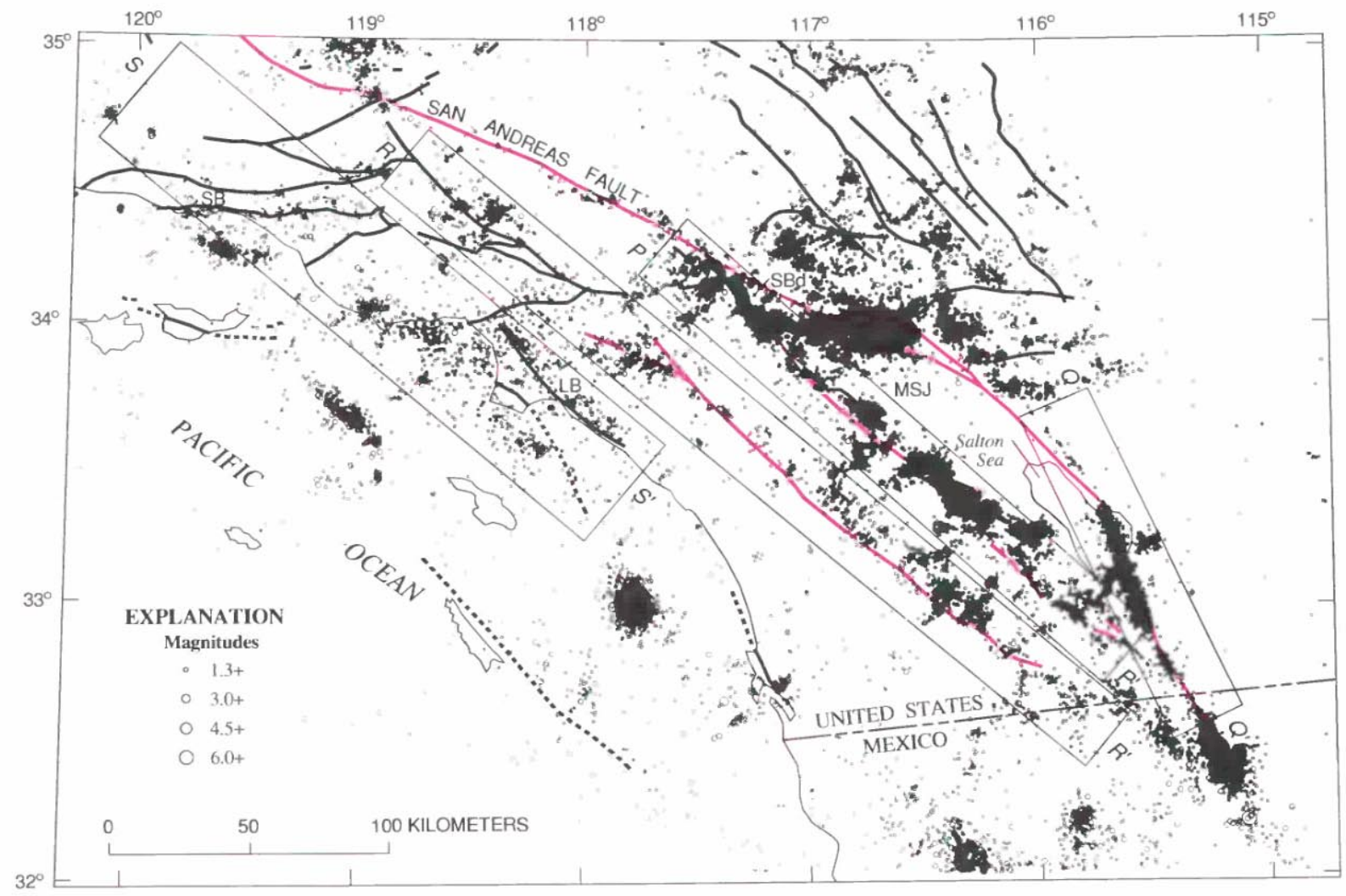

A

FIGURE 5.10.-Seismicity along the southern section of the San Andreas fault system. A, Earthquake locations, showing major branches of the San Andreas fault system in red; faults dotted where concealed. Magnitude symbols shown in explanation are scaled with enlargement of cross sections. BZ, Brawley seismic zone; LB, Long Beach; MSJ, Mount San Jacinto; SB, Santa Barbara, SBd, San Bernardino. B, Depth sections outlined in 5.10A. Faults: CU, Cucamonga; NI, Newport-Inglewood; W, Whittier. 


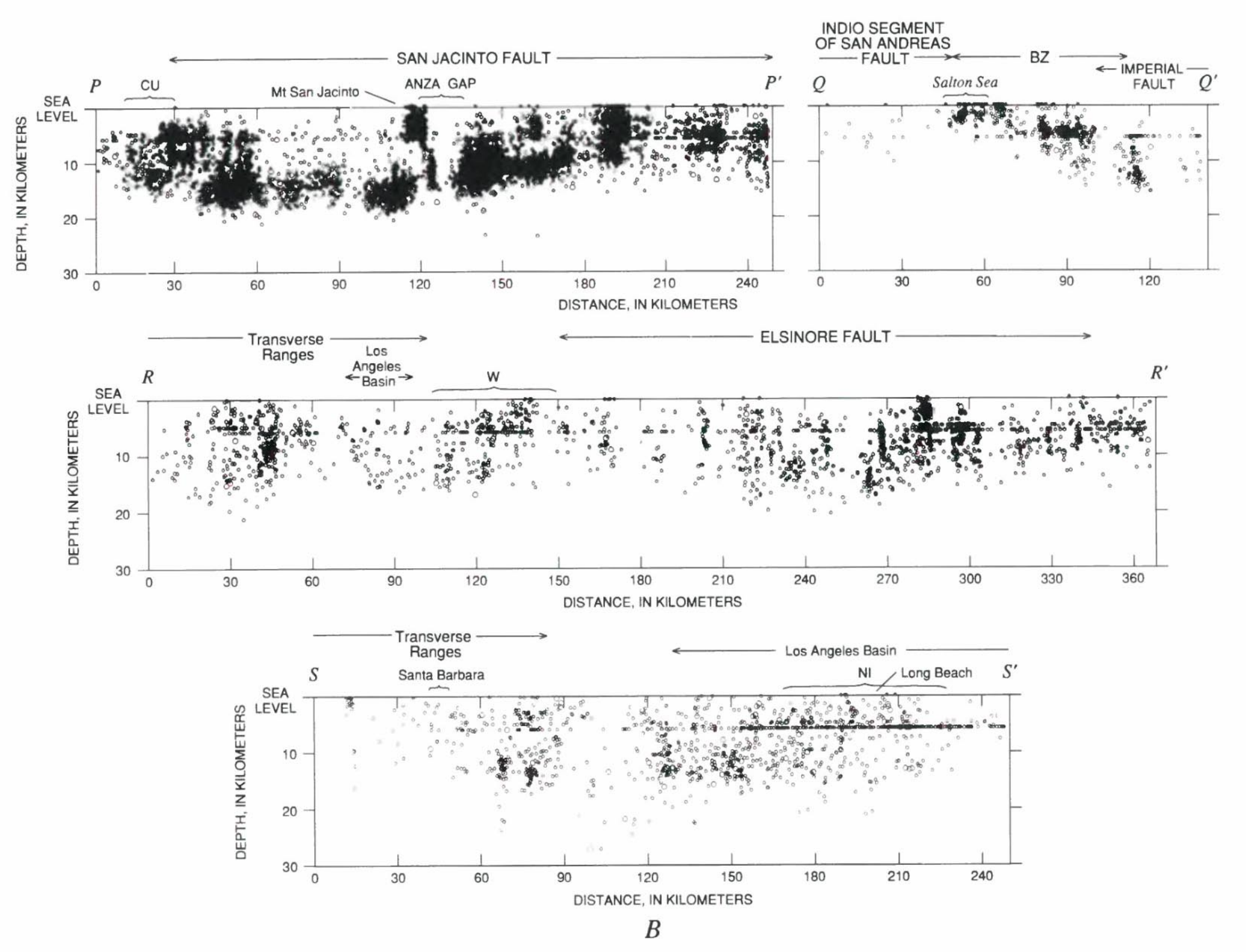


segment of the San Andreas fault where it dips $45^{\circ}$ N. through the Santa Cruz Mountains and dips $70^{\circ}$ SW. (see beneath the San Bernardino Mountains. The October 17, 1989, $M=7.1$ Loma Prieta earthquake involved nearly equal amounts of right and reverse slip along a section of the San Andreas fault that takes a slight westerly bend

chap. 6). Smaller $(M<4)$ events near, but probably not on, the fault show a great variety of focal mechanisms that reflect varying conditions along the fault; these mechanisms range from reverse or reverse-oblique slip

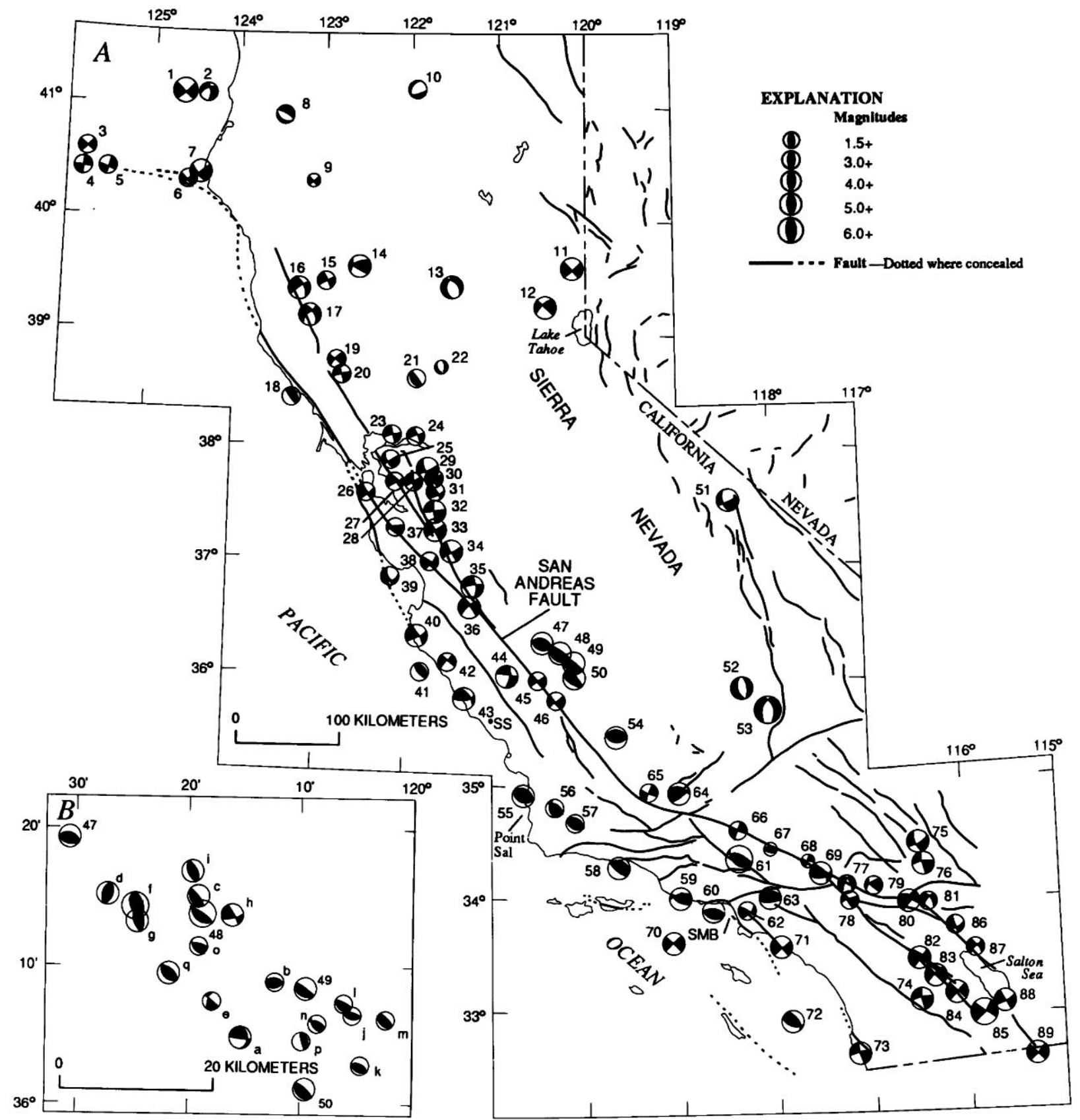

FIGURE 5.11.-Focal mechanisms for larger earthquakes. A, California. SMB, Santa Monica Bay; SS, San Simeon. Numbers refer to table 5.2. $B$, Coalinga-Kettleman Hills region (events 47-50, fig. 5.11A). Letters and numbers refer to table 5.3. Circle size increases with magnitude from 3.5 to 6.7 . 
TABLE 5.2.-Locations and focal-mechanism parameters for selected earthquakes in California

$\left[M_{L}\right.$, estimated local magnitude. For $M_{L}<3$, estimate is based on coda magnitude (see Lee and Stewart, 1981); for $M_{L}>3$, estimate is based on peak amplitude and associated period (see Eaton and others, 1970). Focal-mechanism parameters: DA, dip angle; DD, dip azimuth]

\begin{tabular}{|c|c|c|c|c|c|c|c|c|c|}
\hline \multirow{2}{*}{ Event } & \multirow{2}{*}{$\begin{array}{c}\text { Date } \\
(\mathrm{yr} / \mathrm{mo} / \mathrm{d})\end{array}$} & \multirow{2}{*}{$\begin{array}{c}\text { Time } \\
\text { (G.m.t.) }\end{array}$} & \multirow{2}{*}{ Lat $\mathbf{N}$. } & \multirow{2}{*}{ Long W. } & \multirow{2}{*}{$\begin{array}{c}\text { Depth } \\
(\mathrm{km})\end{array}$} & \multirow{2}{*}{$M_{L}$} & \multicolumn{3}{|c|}{$\begin{array}{l}\text { Focal-mechanism } \\
\text { parameters }\end{array}$} \\
\hline & & & & & & & $\mathrm{DD}\left({ }^{\circ}\right)$ & $\mathrm{DA}\left({ }^{\circ}\right)$ & Rake $\left({ }^{\circ}\right)$ \\
\hline 1 & 801108 & $1027: 32.5$ & $41^{\circ} 06.96^{\prime}$ & $124^{\circ} 39.87^{\prime}$ & 6.0 & 7 & 138 & 82 & -8 \\
\hline 2 & 801110 & 0624:07.3 & $41^{\circ} 06.79^{\prime}$ & $124^{\circ} 24.06^{\prime}$ & 7.5 & 4 & 337 & 52 & -391 \\
\hline 3 & 801109 & 0409:07.5 & $40^{\circ} 35.62^{\prime}$ & $125^{\circ} 46.45^{\prime}$ & 15 & 5.4 & 134 & 90 & 0 \\
\hline 4 & 801108 & $1125: 34.6$ & $40^{\circ} 25.22^{\prime}$ & $125^{\circ} 48.83^{\prime}$ & 15 & 4 & 5 & 90 & 180 \\
\hline 5 & 831220 & 1041:05.2 & $40^{\circ} 25.44^{\prime}$ & $125^{\circ} 31.35^{\prime}$ & 15 & 5.7 & 21 & 90 & 180 \\
\hline 6 & 810916 & $1241: 14.7$ & $40^{\circ} 20.38^{\prime}$ & $124^{\circ} 35.64^{\prime}$ & 28.9 & 4.8 & 319 & 80 & 0 \\
\hline 7 & 870731 & $2356: 58.0$ & $40^{\circ} 25.33^{\prime}$ & $124^{\circ} 26.61^{\prime}$ & 16.4 & 5.8 & 146 & 90 & -20 \\
\hline 8 & 870409 & 2034:09.0 & $40^{\circ} 56.32^{\prime}$ & $123^{\circ} 29.14^{\prime}$ & 26.2 & 4.1 & 27 & 68 & -93 \\
\hline 9 & 820912 & 0651:31.9 & $40^{\circ} 21.57^{\prime}$ & $123^{\circ} 08.52^{\prime}$ & 50.7 & 3 & 52 & 78 & -170 \\
\hline 10 & 820621 & 0643:37.6 & $41^{\circ} 10.66^{\prime}$ & $121^{\circ} 56.64^{\prime}$ & 7.3 & 4.3 & 168 & 64 & -59 \\
\hline 11 & 660912 & $1641: 02.6$ & $39^{\circ} 36.28^{\prime}$ & $120^{\circ} 09.61^{\prime}$ & 10 & 6 & 134 & 80 & 0 \\
\hline 12 & 801128 & $1821: 12.2$ & $39^{\circ} 16.32^{\prime}$ & $120^{\circ} 27.74^{\prime}$ & 21.8 & 5.5 & 314 & 60 & 0 \\
\hline 13 & 750801 & 2020:12.8 & $39^{\circ} 26.33^{\prime}$ & $121^{\circ} 31.71^{\prime}$ & 5.5 & 5.7 & 270 & 65 & -70 \\
\hline 14 & 820903 & $1858: 24.1$ & $39^{\circ} 36.92^{\prime}$ & $122^{\circ} 34.96^{\prime}$ & 14.6 & 4.2 & 214 & 74 & 127 \\
\hline 15 & 781112 & $1307: 57.0$ & $39^{\circ} 29.46^{\prime}$ & $122^{\circ} 57.09^{\prime}$ & 10.2 & 4.3 & 60 & 80 & 180 \\
\hline 16 & 771122 & 2115:52.2 & $39^{\circ} 25.10^{\prime}$ & $123^{\circ} 16.19^{\prime}$ & 6.6 & 5.1 & 65 & 44 & -166 \\
\hline 17 & 780326 & 0027:03.8 & $39^{\circ} 11.82^{\prime}$ & $123^{\circ} 08.49^{\prime}$ & 6.0 & 4.7 & 55 & 54 & -169 \\
\hline 18 & 780331 & 0103:26.8 & $38^{\circ} 28.92^{\prime}$ & $123^{\circ} 20.04^{\prime}$ & 6.4 & 3.6 & 56 & 20 & 90 \\
\hline 19 & 820529 & 1302:23.9 & $38^{\circ} 47.87^{\prime}$ & $122^{\circ} 49.35^{\prime}$ & 4.8 & 4.3 & 39 & 90 & -167 \\
\hline 20 & 770911 & $2346: 11.5$ & $38^{\circ} 39.96^{\prime}$ & $122^{\circ} 45.61^{\prime}$ & 7.0 & 3.7 & 76 & 90 & -167 \\
\hline 21 & 780908 & $1659: 47.6$ & $38^{\circ} 37.86^{\prime}$ & $121^{\circ} 54.59^{\prime}$ & 8.1 & 4.3 & 239 & 20 & 90 \\
\hline 22 & 870103 & $1354: 18.0$ & $38^{\circ} 44.89^{\prime}$ & $121^{\circ} 37.90^{\prime}$ & 11.4 & 1.8 & 90 & 56 & -68 \\
\hline 23 & 770905 & $1745: 28.0$ & $38^{\circ} 09.68^{\prime}$ & $122^{\circ} 10.44^{\prime}$ & 7.5 & 3.7 & 76 & 90 & 180 \\
\hline 24 & 770604 & 2057:07.8 & $38^{\circ} 09.42^{\prime}$ & $121^{\circ} 54.51^{\prime}$ & 18.3 & 3.6 & 70 & 80 & 180 \\
\hline 25 & 770108 & 0938:07.0 & $37^{\circ} 54.94^{\prime}$ & $122^{\circ} 11.58^{\prime}$ & 10.4 & 4.5 & 240 & 66 & 180 \\
\hline 26 & 790428 & $0044: 44.7$ & $37^{\circ} 37.32^{\prime}$ & $122^{\circ} 27.68^{\prime}$ & 11.6 & 4.2 & 49 & 70 & 169 \\
\hline 27 & 840327 & 0336:35.3 & $37^{\circ} 43.48^{\prime}$ & $122^{\circ} 08.41^{\prime}$ & 3.3 & 4.5 & 55 & 56 & 173 \\
\hline 28 & 770814 & $1425: 34.4$ & $37^{\circ} 43.42^{\prime}$ & $121^{\circ} 56.40^{\prime}$ & 6.5 & 3.5 & 60 & 84 & 180 \\
\hline 29 & 800124 & 1900:09.1 & $37^{\circ} 50.20^{\prime}$ & $121^{\circ} 46.88^{\prime}$ & 11.9 & 5.9 & 247 & 75 & -170 \\
\hline 30 & 800127 & 0233:35.8 & $37^{\circ} 45.12^{\prime}$ & $121^{\circ} 42.54^{\prime}$ & 12.4 & 5.3 & 232 & 78 & 180 \\
\hline 31 & 770621 & 0243:06.7 & $37^{\circ} 37.83^{\prime}$ & $121^{\circ} 40.55^{\prime}$ & 10.3 & 4.6 & 59 & 80 & 157 \\
\hline 32 & 860331 & $1155: 39.9$ & $37^{\circ} 28.05^{\prime}$ & $121^{\circ} 41.63^{\prime}$ & 8.3 & 5.8 & 262 & 80 & 180 \\
\hline 33 & 840424 & 2115:18.8 & $37^{\circ} 18.56^{\prime}$ & $121^{\circ} 40.68^{\prime}$ & 8.4 & 6.2 & 236 & 82 & 180 \\
\hline 34 & 790806 & 1705:22.3 & $37^{\circ} 06.70^{\prime}$ & $121^{\circ} 30.03^{\prime}$ & 9.6 & 5.9 & 240 & 84 & 180 \\
\hline 35 & 860126 & 1920:51.2 & $36^{\circ} 48.53^{\prime}$ & $121^{\circ} 16.10^{\prime}$ & 4.8 & 5.8 & 87 & 70 & -170 \\
\hline 36 & 820811 & $0746: 43.0$ & $36^{\circ} 37.60^{\prime}$ & $121^{\circ} 18.02^{\prime}$ & 9.2 & 4.5 & 53 & 85 & -166 \\
\hline 37 & 770727 & 2151:17.2 & $37^{\circ} 19.06^{\prime}$ & $122^{\circ} 07.24^{\prime}$ & 6.8 & 3.5 & 212 & 48 & 124 \\
\hline 38 & 820818 & 0843:49.5 & $37^{\circ} 01.34^{\prime}$ & $121^{\circ} 44.66^{\prime}$ & 11.8 & 4.3 & 38 & 80 & 166 \\
\hline 39 & 780702 & $1157: 56.7$ & $36^{\circ} 53.40^{\prime}$ & $122^{\circ} 10.86^{\prime}$ & 6.2 & 4 & 249 & 78 & -147 \\
\hline 40 & 840123 & 0540:19.9 & $36^{\circ} 22.13^{\prime}$ & $121^{\circ} 52.74^{\prime}$ & 7.7 & 5.2 & 60 & 78 & 173 \\
\hline 41 & 860708 & 0040:23.0 & $36^{\circ} 03.81^{\prime}$ & $121^{\circ} 50.17^{\prime}$ & 11.9 & 4.4 & 60 & 34 & 90 \\
\hline 42 & 830721 & 0123:33.0 & $36^{\circ} 09.17^{\prime}$ & $121^{\circ} 32.64^{\prime}$ & 5.2 & 3.9 & 41 & 90 & -175 \\
\hline$\overline{43}$ & 830829 & $1010: 30.9$ & $35^{\circ} 50.17^{\prime}$ & $121^{\circ} 20.70^{\prime}$ & 6.6 & 5.4 & 51 & 55 & 139 \\
\hline 44 & 851124 & 1921:38.6 & $36^{\circ} 01.16^{\prime}$ & $120^{\circ} 53.12^{\prime}$ & 11.3 & 4.4 & 102 & 70 & -170 \\
\hline 54 & 820625 & 0358:23.0 & $35^{\circ} 57.43^{\prime}$ & $120^{\circ} 33.11^{\prime}$ & 9.1 & 4.2 & 51 & 80 & 180 \\
\hline 46 & 660702 & $1216: 15$ & $35^{\circ} 47.3-$ & $120^{\circ} 20.6-$ & 9.1 & 3.5 & 231 & 78 & 180 \\
\hline 47 & 821025 & $2226: 03.7$ & $36^{\circ} 19.31^{\prime}$ & $120^{\circ} 30.44^{\prime}$ & 11.0 & 5.5 & 198 & 28 & 90 \\
\hline 48 & 830502 & 2342:38.1 & $36^{\circ} 13.96^{\prime}$ & $120^{\circ} 18.57^{\prime}$ & 10.0 & 6.7 & 217 & 23 & 90 \\
\hline 49 & 850804 & $1201: 55.8$ & $36^{\circ} 08.59^{\prime}$ & $120^{\circ} 09.44^{\prime}$ & 11.4 & 5.7 & 217 & 14 & 90 \\
\hline 50 & 850807 & 0016:03.41 & $36^{\circ} 01.13^{\prime}$ & $120^{\circ} 09.46^{\prime}$ & 14.9 & 4.6 & 216 & 20 & 82 \\
\hline 51 & 860721 & 1442:26.1 & $37^{\circ} 31.91^{\prime}$ & $118^{\circ} 26.67^{\prime}$ & 9.1 & 6.5 & 245 & 58 & 180 \\
\hline 52 & 831021 & 2244:00 & $35^{\circ} 54.9^{\prime}$ & $118^{\circ} 19.9^{\prime}$ & 4.4 & 4.5 & 83 & 46 & -85 \\
\hline 53 & 460315 & $\overline{1349: 35.9}$ & $35^{\circ} 43.50^{\prime}$ & $118^{\circ} 03.27^{\prime}$ & 22 & 6.3 & 76 & 45 & -117 \\
\hline 54 & 880222 & 0743:12.8 & $35^{\circ} 29.84^{\prime}$ & $119^{\circ} 42.13^{\prime}$ & $\overline{19.1}$ & 4.2 & 182 & 44 & 90 \\
\hline 55 & 800529 & 0338:47.5 & $34^{\circ} 58.65^{\prime}$ & $120^{\circ} 42.37^{\prime}$ & 9.2 & 5.1 & 28 & 34 & 98 \\
\hline 56 & 820923 & 2042:50.6 & $34^{\circ} 52.19^{\prime}$ & $120^{\circ} 21.76^{\prime}$ & 4.8 & 4 & 36 & 56 & 63 \\
\hline 57 & 841025 & 1036:02.4 & $34^{\circ} 44.21^{\prime}$ & $120^{\circ} 08.85^{\prime}$ & 6 & 4.5 & 211 & 43 & 90 \\
\hline 58 & 780813 & 2254:53.4 & $34^{\circ} 20.82^{\prime}$ & $119^{\circ} 41.75^{\prime}$ & 12.1 & 5.1 & 10 & 26 & 57 \\
\hline 59 & 730221 & $1445: 57.3$ & $34^{\circ} 03.89^{\prime}$ & $119^{\circ} 02.10^{\prime}$ & 8 & 5.9 & 350 & 36 & 55 \\
\hline 60 & 790101 & 2314:38.9 & $33^{\circ} 56.65^{\prime}$ & $118^{\circ} 40.88^{\prime}$ & 11.1 & 5 & 10 & 60 & 85 \\
\hline 61 & 710209 & $1400: 41.8$ & $34^{\circ} 24.67^{\prime}$ & $118^{\circ} 24.03^{\prime}$ & 8.1 & 6.4 & 20 & 54 & 76 \\
\hline
\end{tabular}


TABLE 5.2.-Locations and focal-mechanism parameters for selected earthquakes in California-Continued

\begin{tabular}{|c|c|c|c|c|c|c|c|c|c|}
\hline \multirow{2}{*}{ Event } & \multirow{2}{*}{$\begin{array}{c}\text { Date } \\
(\mathrm{yr} / \mathrm{mo} / \mathrm{d})\end{array}$} & \multirow{2}{*}{$\begin{array}{c}\text { Time } \\
\text { (G.m.t.) }\end{array}$} & \multirow{2}{*}{ Lat $\mathbf{N}$. } & \multirow{2}{*}{ Long W. } & \multirow{2}{*}{$\begin{array}{l}\text { Depth } \\
(\mathrm{km})\end{array}$} & \multirow{2}{*}{$M_{L}$} & \multicolumn{3}{|c|}{$\begin{array}{l}\text { Focal-mechanism } \\
\text { parameters }\end{array}$} \\
\hline & & & & & & & $\mathrm{DD}\left({ }^{\circ}\right)$ & $\mathrm{DA}\left({ }^{\circ}\right)$ & Rake $\left({ }^{\circ}\right)$ \\
\hline 62 & 790227 & $1540: 58.9$ & $33^{\circ} 56.7-^{\prime}$ & $118^{\circ} 19.5^{\prime}{ }^{\prime}$ & 9.7 & 3 & 135 & 60 & 20 \\
\hline 63 & 871001 & $1442: 19.8$ & $34^{\circ} 03.11^{\prime}$ & $118^{\circ} 04.56^{\prime}$ & 14.7 & 6.1 & 175 & G5 & \\
\hline 64 & 520721 & $1152: 14$ & $35^{\circ} 00 .{ }^{\prime}$ & $119^{\circ} 01 .-^{\prime}$ & 0 & 7.7 & 140 & 63 & 49 \\
\hline 65 & 820421 & $2119: 30.2$ & $35^{\circ} 00.48^{\prime}$ & $119^{\circ} 20.94^{\prime}$ & 15.0 & 3.2 & 201 & 76 & 170 \\
\hline 66 & 781107 & $0028: 45.6$ & $34^{\circ} 39.93^{\prime}$ & $118^{\circ} 24.27^{\prime}$ & 13.4 & 2.6 & 200 & 85 & 176 \\
\hline 67 & 840414 & 0227:02.6 & $34^{\circ} 29.51^{\prime}$ & $118^{\circ} 04.01^{\prime}$ & 11.9 & 2.9 & 357 & 56 & 80 \\
\hline 68 & 850719 & $1617: 01.7$ & $34^{\circ} 23.20^{\prime}$ & $117^{\circ} 39.79^{\prime}$ & 8.1 & 2.8 & 196 & 80 & 169 \\
\hline 69 & 700912 & $1430: 53.0$ & $34^{\circ} 16.18^{\prime}$ & $117^{\circ} 32.40^{\prime}$ & 8 & 5.4 & 55 & 60 & 140 \\
\hline 70 & 810904 & $1550: 50.3$ & $33^{\circ} 40.26^{\prime}$ & $119^{\circ} 06.67^{\prime}$ & 5 & 5.3 & 315 & 80 & 0 \\
\hline 71 & 330311 & 0154:07.8 & $33^{\circ} 36.99^{\prime}$ & $117^{\circ} 58.00^{\prime}$ & 0 & 6.3 & 320 & 90 & 0 \\
\hline 72 & 860713 & $1347: 08.2$ & $32^{\circ} 58.24^{\prime}$ & $117^{\circ} 52.19^{\prime}$ & 6 & 5.3 & 50 & 50 & 110 \\
\hline 73 & 850618 & $0428: 14.8$ & $32^{\circ} 40.22^{\prime}$ & $117^{\circ} 10.33^{\prime}$ & 12.1 & 4 & 255 & 85 & 175 \\
\hline 74 & 841010 & 2122:58.9 & $33^{\circ} 08.26^{\prime}$ & $116^{\circ} 30.06^{\prime}$ & 11.6 & 4.5 & 260 & 80 & 191 \\
\hline 75 & 750601 & $0138: 49.2$ & $34^{\circ} 30.94^{\prime}$ & $116^{\circ} 29.72^{\prime}$ & 4.1 & 5.2 & 247 & 70 & -165 \\
\hline 76 & 790315 & 2107:16.5 & $34^{\circ} 19.63^{\prime}$ & $116^{\circ} 26.68^{\prime}$ & 2.1 & 5.2 & 258 & 81 & 167 \\
\hline 77 & 810912 & 2123:07.3 & $34^{\circ} 09.90^{\prime}$ & $117^{\circ} 15.93^{\prime}$ & 4.2 & 3.8 & 294 & 63 & -52 \\
\hline 78 & 851002 & $2344: 12.4$ & $34^{\circ} 01.40^{\prime}$ & $117^{\circ} 14.71^{\prime}$ & 15.2 & 4.8 & 242 & 75 & 165 \\
\hline 79 & 781120 & 0655:09.1 & $34^{\circ} 09.07^{\prime}$ & $116^{\circ} 58.52^{\prime}$ & 12.9 & 4.3 & 227 & 75 & 145 \\
\hline 80 & 860708 & 0920:44.5 & $33^{\circ} 59.91^{\prime}$ & $116^{\circ} 36.38^{\prime}$ & 11.1 & 5.6 & 30 & 45 & 170 \\
\hline 81 & 850119 & $0030: 13.0$ & $33^{\circ} 59.64^{\prime}$ & $116^{\circ} 23.83^{\prime}$ & 2.9 & 3.9 & 310 & 63 & -40 \\
\hline 82 & 800225 & 1047:38.5 & $33^{\circ} 30.05^{\prime}$ & $116^{\circ} 30.79^{\prime}$ & 13.9 & 5.5 & 38 & 68 & 191 \\
\hline 83 & 690428 & $2320: 42.9$ & $33^{\circ} 20.60^{\prime}$ & $116^{\circ} 20.78^{\prime}$ & 20 & 5.8 & 230 & 80 & 191 \\
\hline 84 & 680409 & $0228: 59.1$ & $33^{\circ} 11.39^{\prime}$ & $116^{\circ} 07.72^{\prime}$ & 11 & 6.4 & 42 & 90 & 180 \\
\hline 85 & 871124 & $1315: 56.4$ & $33^{\circ} 00.69^{\prime}$ & $115^{\circ} 51.31^{\prime}$ & 1.7 & 6.2 & 125 & 80 & 0 \\
\hline 86 & 831227 & 2134:37.7 & $33^{\circ} 46.79^{\prime}$ & $116^{\circ} 07.32^{\prime}$ & 2.7 & 3.1 & 251 & 82 & -148 \\
\hline 87 & 791204 & 0828:17.6 & $33^{\circ} 34.55^{\prime}$ & $115^{\circ} 54.75^{\prime}$ & 5.1 & 2.7 & 51 & 71 & -165 \\
\hline 88 & 810426 & $1209: 28.4$ & $33^{\circ} 05.90^{\prime}$ & $115^{\circ} 37.90^{\prime}$ & 3.0 & 5.7 & 150 & 80 & 0 \\
\hline 89 & 791015 & $2316: 53.4$ & $32^{\circ} 36.81^{\prime}$ & $115^{\circ} 19.09^{\prime}$ & 12.1 & 6.6 & 42 & 90 & 180 \\
\hline
\end{tabular}

on easterly-striking planes (events 37, 67), through right-lateral strike slip on planes parallel to the San Andreas fault (events 65, 66, 68, 87), to normal or normal-oblique slip on northerly-striking planes (events 77, 81).

Moderate earthquakes with strike-slip focal-mechanisms that are not located on major faults of the San Andreas system but yet are broadly associated with it commonly have right-slip planes, with strikes ranging from northwestward (event 42) to north-southward (events $35,44,74,75,76,86$ ). In most cases, these right-slip planes agree in strike with local mapped faults or with alignments of epicenters that strongly suggest active faults (events 75,76 ).

\section{CRUSTAL CONVERGENCE ADJACENT TO THE SAN ANDREAS FAULT SYSTEM}

One of the more important results to emerge from high-resolution focal-mechanism studies in recent years is that earthquakes occurring even a short distance off faults of the San Andreas system can involve displacements that diverge sharply from local San Andreas strike-slip displacements. This pattern is particularly pronounced in the strong component of reverse slip at large angles (more than $60^{\circ}$ ) to the local strike of the San Andreas fault on both sides of the San Andreas fault system in both the Transverse and Coast Ranges.

North-south convergence within the Transverse Ranges is dominated by reverse slip on easterly-striking planes. The $M=7.7$ Kern County earthquake of 1952 (event 64), which occurred on the south-dipping White Wolf fault along the north flank of the Transverse Ranges about $25 \mathrm{~km}$ north of the junction of the San Andreas and Garlock faults, and the $M=6.6$ San Fernando earthquake of 1971 (event 71), which ruptured a 20-km-long stretch of the northeast-dipping San Gabriel-San Fernando thrust faults (Whitcomb, 1971; Heaton, 1982), are two striking examples of this deformation. So, also, is the alignment of $M=5-6$ reverse-slip earthquakes (events 59 , $60,63)$ along the southern margin of the Transverse Ranges. The reverse slip on east-west-striking planes associated with these earthquakes suggests that the north-dipping Santa Monica-Cucamonga fault serves as an important convergent boundary between the Peninsular and Transverse Ranges.

Figure 5.11 $\mathrm{A}$ also shows that the east-west-trending zone of convergence associated with these earthquakes 
TABLE 5.3.-Locations and focal-mechanism parameters for earthquakes in the CoalingaKettleman Hills region

[Same symbols as in table 5.2]

\begin{tabular}{|c|c|c|c|c|c|c|c|c|c|}
\hline \multirow{2}{*}{ Event } & \multirow{2}{*}{$\underset{(\mathrm{yr} / \mathrm{mo} / \mathrm{d})}{\text { Date }}$} & \multirow{2}{*}{$\begin{array}{l}\text { Time } \\
\text { (G.m.t.) }\end{array}$} & \multirow{2}{*}{ Lat $\mathrm{N}}$. & \multirow{2}{*}{ Long W. } & \multirow{2}{*}{$\begin{array}{l}\text { Depth } \\
(\mathbf{k m})\end{array}$} & \multirow{2}{*}{$M_{L}$} & \multicolumn{3}{|c|}{$\begin{array}{l}\text { Focal-mechanism } \\
\text { parameters }\end{array}$} \\
\hline & & & & & & & $\mathrm{DD}\left({ }^{\circ}\right)$ & $\mathrm{DA}\left({ }^{\circ}\right)$ & Rake ( $\left.{ }^{\circ}\right)$ \\
\hline a & 760114 & 2143:59.5 & $36^{\circ} 04.88^{\prime}$ & $120^{\circ} 15.09^{\prime}$ & 9.0 & 4.7 & 85 & 42 & 168 \\
\hline 47 & 821025 & 2226:03.7 & $36^{\circ} 19.31^{\prime}$ & $120^{\circ} 30.44^{\prime}$ & 10.9 & 5.5 & 198 & 28 & 90 \\
\hline 48 & 830502 & 2342:38.1 & $36^{\circ} 13.96^{\prime}$ & $120^{\circ} 18.57^{\prime}$ & 10.0 & 6.7 & 217 & 23 & 90 \\
\hline $\mathrm{b}$ & 830522 & 0839:21.7 & $36^{\circ} 09.03^{\prime}$ & $120^{\circ} 12.09^{\prime}$ & 10.5 & 4.2 & 164 & 40 & 73 \\
\hline c & 830524 & 0902:17.7 & $36^{\circ} 15.24^{\prime}$ & $120^{\circ} 19.00^{\prime}$ & 8.9 & 4.7 & 256 & 18 & 111 \\
\hline d & 830611 & 0309:52.2 & $36^{\circ} 15.33^{\prime}$ & $120^{\circ} 27.01^{\prime}$ & 2.4 & 5.2 & 107 & 50 & 90 \\
\hline $\mathrm{e}$ & 830612 & 0131:27.5 & $36^{\circ} 07.55^{\prime}$ & $120^{\circ} 17.71^{\prime}$ & 14.5 & 4.0 & 296 & 44 & 168 \\
\hline f & 830722 & 0239:54.1 & $36^{\circ} 14.44^{\prime}$ & $120^{\circ} 24.53^{\prime}$ & 7.3 & 6.0 & 85 & 38 & 102 \\
\hline g & 830722 & 0343:01.0 & $36^{\circ} 13.31^{\prime}$ & $120^{\circ} 24.37^{\prime}$ & 7.9 & 5.0 & 72 & 30 & 85 \\
\hline $\mathrm{h}$ & 830909 & 0916:13.5 & $36^{\circ} 13.91^{\prime}$ & $120^{\circ} 15.90^{\prime}$ & 6.7 & 5.3 & 64 & 75 & 161 \\
\hline $\mathrm{i}$ & 840219 & 0943:09.4 & $36^{\circ} 17.10^{\prime}$ & $120^{\circ} 19.47^{\prime}$ & 10.7 & 4.5 & 66 & 52 & 90 \\
\hline 49 & 850804 & $1201: 55.8$ & $36^{\circ} 08.59^{\prime}$ & $120^{\circ} 09.44^{\prime}$ & 11.4 & 5.7 & 217 & 14 & 90 \\
\hline $\mathbf{j}$ & 850804 & 1208:41.3 & $36^{\circ} 06.67^{\prime}$ & $120^{\circ} 05.23^{\prime}$ & 10.9 & 4.3 & 188 & 44 & 85 \\
\hline $\mathbf{k}$ & 850804 & 1515:39.3 & $36^{\circ} 02.85^{\prime}$ & $120^{\circ} 04.57^{\prime}$ & 11.1 & 4.4 & 203 & 26 & 90 \\
\hline 1 & 850805 & 1445:37.8 & $36^{\circ} 07.48^{\prime}$ & $120^{\circ} 05.99^{\prime}$ & 7.5 & 4.4 & 229 & 20 & 105 \\
\hline 50 & 850807 & 0016:03.4 & $36^{\circ} 01.13^{\prime}$ & $120^{\circ} 09.46^{\prime}$ & 14.9 & 4.6 & 216 & 20 & 82 \\
\hline $\mathrm{m}$ & 850809 & $0847: 09.7$ & $36^{\circ} 06.36^{\prime}$ & $120^{\circ} 02.32^{\prime}$ & 9.9 & 3.6 & 218 & 30 & 82 \\
\hline $\mathrm{n}$ & 850809 & 1242:18.8 & $36^{\circ} 05.94^{\prime}$ & $120^{\circ} 08.39^{\prime}$ & 6.1 & 3.8 & 233 & 38 & 113 \\
\hline$o$ & 850914 & 0302:44.6 & $36^{\circ} 11.57^{\prime}$ & $120^{\circ} 18.89^{\prime}$ & 9.4 & 3.6 & 225 & 44 & 112 \\
\hline p & 850915 & $0909: 46.8$ & $36^{\circ} 04.72^{\prime}$ & $120^{\circ} 09.68^{\prime}$ & 13.1 & 3.5 & 77 & 16 & 90 \\
\hline$q$ & 870214 & $0726: 50.3$ & $36^{\circ} 09.56^{\prime}$ & $120^{\circ} 21.53^{\prime}$ & 14.6 & 5.2 & 238 & 48 & 98 \\
\hline
\end{tabular}

curves northward near Santa Monica Bay and continues northwestward along the coast at least as far as Point Sal and probably as far as San Simeon. Focal mechanisms of earthquakes along this zone from Point Sal to Whittier (events 55-60,63) are predominantly reverse slip, with slip directions nearly normal to the local trend of the zone. The focal mechanism of event 43 near San Simeon, which indicates right-oblique reverse slip on a northeastdipping plane parallel to the coast, is intermediate between those of event 40 at Point Sur and event 55 at Point Sal.

Reverse-slip focal mechanisms for offshore events 18 and 41 in central California and for event 72 in southern California suggest that the offshore crust is undergoing compression normal to the coastline throughout the length of the San Andreas fault system. The CoalingaKettleman Hills earthquake sequence of 1982-85 (events 47-50, fig. 5.11A) emphasizes the important role of crustal convergence along the southern Coast RangesGreat Valley boundary in central California. The principal events in this sequence (event 48, Coalinga, and event 49, Kettleman Hills, fig. 5.11A) involved reverse slip on subparallel planes at depths of 10 to $12 \mathrm{~km}$ that dip gently (approx $20^{\circ}$ ) southwest. Much of the aftershock activity, however, occurred at shallower depths and involved high-angle reverse slip on planes dipping steeply ( $45^{\circ}-$ $70^{\circ}$ ) northeast (events f, g, i, o, q, fig. 5.11B). Displacements associated with these earthquakes, which are nearly perpendicular to the San Andreas fault, represent a convergent process in which Franciscan melange on the west is being wedged between crystalline basement and the overlying Great Valley sedimentary sequence on the east (Wentworth and others, 1983; Eaton, 1990).

The boundary between the Coast Ranges and Great Valley is marked by reverse-slip earthquakes throughout much of its length: event 54 southeast of the Kettleman Hills, the Coalinga-Kettleman Hills sequence, event 21 near Winters east of Lake Berryessa, and event 14 west of Oroville. The similarity in focal mechanism of event 21 near Winters to the Coalinga and Kettleman Hills main shocks suggests that the convergent process acting in the southern Coast Ranges is common to the entire eastern margin of the Coast Ranges. Indeed, the strong earthquakes that shook the Winters-Vacaville-Dixon area in 1892 , just south of event 21 , resemble the CoalingaKettleman Hills sequence in both setting and intensity distribution. Focal mechanisms of smaller earthquakes along the Coast Ranges-Great Valley boundary in central California studied by Wong and others (1988) also suggest convergence across that boundary.

Convergence normal to the strike of the San Andreas fault is not limited to the coast and the Coast RangesGreat Valley boundary described above. In a detailed examination of the focal mechanisms of aftershocks of the 1984 Morgan Hill earthquake, Oppenheimer and others (1988) concluded that the direction of maximum compression immediately adjacent to the Calaveras branch of the San Andreas fault is at an angle of about $80^{\circ}$ to the N. $10^{\circ}$ 
W. strike of the fault. Along the entire stretch of the San Andreas fault from Parkfield to the Salton Sea, Jones (1988) found a constant angle of $65^{\circ}$ between the strike of the fault and the maximum-principal-stress direction for earthquakes occurring off the fault.

This evidence from earthquake focal mechanisms and other stress indicators (such as borehole breakouts and fold axes) that the maximum principal compressive stress may be oriented at a high angle to the local strike of the San Andreas fault seems to contradict long-accepted ideas for brittle failure in the crust based on laboratory experiments in rock mechanics. Zoback and others (1987) and Oppenheimer and others (1988) suggested that these relations can be explained by an exceptionally low average shear strength for the San Andreas fault system. As pointed out by Lachenbruch and McGarr in chapter 10 , however, the strength and state of stress along the San Andreas fault are still matters for discussion.

\section{EAST-WEST EXTENSION IN THE SIERRA NEVADA}

The three moderate-earthquake focal mechanisms for the Sierra Nevada and its western foothills shown in figure $5.11 \mathrm{~A}$ all indicate normal faulting on northerlystriking planes and suggest pervasive east-west extension throughout the Sierra Nevada. Event 52 is in a dense north-south-trending band of epicenters about $15 \mathrm{~km}$ east of the Kern River canyon, and event 53 is in a northsouth-trending band of earthquakes about $10 \mathrm{~km}$ west of the Sierra frontal fault near Walker Pass. These relations suggest that the east-west spreading and associated normal faulting on northerly-striking faults of the Great Basin are encroaching into the southeast corner of the Sierra Nevada block (Jones and Dollar, 1986).

Event 13 is the main shock $(M=5.7)$ of an earthquake sequence on a north-south-striking, west-dipping normal fault near the Oroville Dam that occurred in 1975. The uplift of the Sierra Nevada relative to the Great Valley to the west indicated by the focal mechanism of this event is also visible in the Chico monocline, which marks the Sierra Nevada-Great Valley boundary northwest of Oroville.

\section{CONJUGATE FAULTING IN \\ THE SIERRA NEVADA-GREAT BASIN BOUNDARY ZONE}

The Sierra Nevada-Great Basin boundary zone is represented in figure $5.11 \mathrm{~A}$ by three focal mechanisms. Events 11 and 12 lie northwest of Lake Tahoe along the edge of a minor gap in the band of seismicity along the east edge of the Sierra Nevada. Both events appear to have resulted from left-lateral slip along steeply dipping, northeast-striking faults; both events had aftershock regions that were elongate northeast-southwest. About
$250 \mathrm{~km}$ southeast, the $M=6.4$ July 21,1986 , Chalfant Valley earthquake (event 51) resulted from right-lateral strike-slip displacement on a north-northwest-striking surface dipping $60^{\circ} \mathrm{SW}$. An $M=5.7$ foreshock on July 20 resulted from left-lateral strike slip on a northeaststriking, northwest-dipping surface. These two conjugate slip surfaces merge at their north ends (Cockerham and Corbett, 1987; Smith and Priestly, 1988).

The zone of intense seismicity in the vicinity of Long Valley caldera and the Sierra Nevada block to the south produced $11 M \geq 5.5$ earthquakes from 1978 through 1984 (Savage and Cockerham, 1987), as well as many thousands of smaller events and numerous earthquake swarms. Most of the larger events occurred in the Sierra Nevada block south of Long Valley caldera, involving left-lateral slip along near-vertical, north-south- to northnortheast-striking faults. One of four $M \approx 6$ events that occurred on May 25-27, 1980, however, was located within the south moat of the caldera along the westnorthwest-striking fault zone that produced most of the earthquake swarms (see Hill and others, 1985a, b).

\section{FRAGMENTATION OF THE SOUTHEAST CORNER OF THE GORDA PLATE}

The 1980 Eureka $M=7.2$ earthquake occurred along a fault break that extended from the continental slope 40 $\mathrm{km}$ west of the coastline at lat $41^{\circ} \mathrm{N}$. for a distance of 140 $\mathrm{km}$ southwestward to the MFZ, virtually cutting off the southeast corner of the Gorda plate. Focal mechanisms of the main shock and largest aftershock (events 1, 3, fig. $5.11 A$ ) both indicate left-lateral strike-slip displacement along a vertical fault that coincides with the line of aftershocks. Some early aftershocks, including event 4 and other moderate events farther east along the MFZ, have focal mechanisms that indicate right-lateral slip along the MFZ. Although the main shock occurred beneath the Continental Shelf, it seems clear that the 1980 earthquake primarily involved the Gorda plate because the fault broke well beyond the base of the continental slope and the edge of the North American plate. Moreover, left-lateral slip along the 1980 break stimulated right-lateral slip along the adjacent part of the MFZ. Ongoing right-lateral displacement along the MFZ is also indicated by event 5 (Dec. 1983).

Two moderate earthquakes near Cape Mendocino in 1981 and 1987 (events 6 and 7, respectively) had focal mechanisms similar to that of the 1980 Eureka earthquake, indicating left-lateral strike-slip displacement on steeply dipping, northeast-striking planes. Aftershocks of the $1987 M=5.8$ event outlined a narrow, steeply dipping, northeast-trending, 20-km-long zone between about 15- and 25-km depth that extended southwestward from the shoreline just north of Cape Mendocino to the 
MFZ. This aftershock zone appears to cut off the southeasternmost corner of the Gorda plate just north of the abrupt eastward termination of intense seismicity along the MFZ, at a point that might be taken as the Mendocino triple junction from the viewpoint of seismicity.

Relative horizontal extension at seismogenic depths is suggested by events 2 and 8 . Event 2 (Nov. 10, 1980; 7 $\mathrm{km}$ deep) was the largest in a detached cluster of shallow aftershocks $20 \mathrm{~km}$ east of the 1980 main shock, and event 8 (Apr. 9, 1987; $26 \mathrm{~km}$ deep) occurred about $100 \mathrm{~km}$ east of the 1980 main shock in the zone of seismicity associated with the subducting Gorda plate.

\section{DISCUSSION}

The Pacific plate moved northwestward with respect to the North American plate by 300 to $400 \mathrm{~mm}$ during the 7-yr interval 1980-86. Earthquakes occurring along the San Andreas fault system during the same interval, however, accommodated only a small fraction of this relative plate motion. Only four earthquakes of $M>5$ occurred along branches of the San Andreas fault system during 1980-86: the pair of $M=5.9-5.3$ Livermore earthquakes (events 29,30 , fig. $5.10 \mathrm{~A}$ ) on the Greenville fault (Jan. 24-27, 1980), the $M=6.2$ Morgan Hill earthquake (event 33) on the Calaveras fault (Apr. 24, 1984), and the $M=5.6$ North Palm Springs earthquake (event 80 ) on the Banning segment of the San Andreas fault (July 8, 1986). Each of these moderate San Andreas earthquakes ruptured fault segments limited to 20 to $30 \mathrm{~km}$ in length, with average displacements over the respective rupture surfaces of 100 to $200 \mathrm{~mm}$ (see Hartzell and Heaton, 1986). As is typical of earthquakes along the San Andreas fault system, each of these events involved nearly pure right-lateral strike-slip displacement coincident with the local strike of the fault. As is also typical of San Andreas earthquakes, slip on the first three events occurred on near-vertical fault planes with a northwestward to northnorthwestward strike. The North Palm Springs earthquake, which ruptured a section of the east-west-striking Banning fault in the structurally complex San Gorgonio bend in the fault system at the southern margin of the Transverse Ranges, represents an important deviation from typical San Andreas earthquakes. Although its displacement was dominantly right-lateral strike slip, it occurred along a plane that dips $45^{\circ} \mathrm{N}$. (Jones and others, 1986) and included a small but significant component of reverse slip (Mendoza and Hartzell, 1988). With the arguable exception of the North Palm Springs earthquake (arguable because of the complex section of the fault system in which it occurred), however, none of these $M>5$ earthquakes ruptured the main trace of the San Andreas fault. Indeed, the two most recent $M>5$ earth- quakes to clearly do so were the $M=6$ Parkfield earthquake of 1966 (Bakun and McEvilly, 1984) and the $M=7.1$ Loma Prieta earthquake of 1989 (see chap. 6).

Thus, aside from the displacement accommodated by steady aseismic slip at a rate of 32 to $37 \mathrm{~mm} / \mathrm{yr}$ along the creeping section of the fault in central California, most relative plate motion across the San Andreas transform boundary during this 7-yr interval accumulated as elastic shear strain. Accordingly, the earthquakes plotted in figures 5.3 through 5.9 are symptomatic of accumulating strain along the San Andreas fault system rather than of effective strain release. The latter requires rupture with a major earthquake along one of the locked stretches of the San Andreas fault.

\section{SEISMICITY PATTERNS AND THE EARTHQUAKE CYCLE}

What changes in spatial-temporal patterns of earthquake occurrence might we expect to see as the next great earthquake on the San Andreas fault approaches? Both historical and instrumental seismicity records indicate that the spatial distribution of earthquakes in California changes only slowly over periods of decades to centuries, although the intensity of activity within this distribution fluctuates year to year (Ellsworth and others, 1981; Hill and others, in press; Hutton and others, in press). Temporal fluctuations in activity during the intervil 1980-86, for example, were dominated by a short-lived aftershock sequence following the 1980 Eureka $M=7.2$ earthquake and by the long-lived aftershock sequence following the 1983 Coalinga $M=6.7$ earthquake. The overall spatial distribution of earthquakes in California, however, remained nearly stationary throughout this 7-yr interval. Furthermore, the spatial pattern defined by $1980-86$ seismicity is much the same as that outlined by the record of $M \geq 5$ earthquakes that extends back nearly $200 \mathrm{yr}$ (see chap. 6).

Variations in the historical rate of moderate to large $(M>5)$ earthquakes in central California before and after the 1906 San Francisco earthquake appear to mimic those described by Fedotov (1965) and Mogi (1968) for the earthquake cycle associated with great, subduction-zone earthquakes in Japan, Kamchatka, and the Kurile Islands (see chap. 6; Ellsworth and others, 1981). The history of instrumentally recorded $M<5$ earthquakes in California is too short, however, to indicate whether we might expect to see distinctive changes in the seismicity pattern a short time (months to years) before the next great earthquake on the San Andreas fault. We have yet to see, for example, whether the quiescent (locked) segments of the San Andreas fault remain aseismic except for the rupture of a great earthquake, or whether these segments become active with small to moderate earthquakes as foreshock activity to great earthquakes. 


\section{DISTRIBUTED SEISMICITY AND DEFORMATION OF THE PLATE MARGINS}

The two largest earthquakes in California during the interval 1980-86 occurred off the faults of the San Andreas system, and their occurrence emphasizes the importance of deformation within the plate margins along the San Andreas transform boundary. The $M=7.2$ Eureka event (Nov. 8, 1980), for example, involved deformation internal to the Gorda plate; and the $M=6.7$ Coalinga event (May 2, 1983) involved crustal shortening with reverse slip perpendicular to the San Andreas fault. These two earthquakes and the many smaller, "off fault" events (fig. 5.4A) reflect local deviations from the simple rigid-plate approximation of plate tectonics.

\section{DEFORMATION OF THE GORDA PLATE}

As the small, youthful Gorda plate is subducted obliquely northeastward beneath the North American plate, it is being subjected to north-south compression in response to a component of convergence between the larger, older Juan de Fuca plate to the north and the Pacific plate to the south (Jachens and Griscom, 1983; Wilson, 1986). Distorted marine magnetic anomalies within the Gorda plate indicate that it has undergone progressive internal deformation over the past $5 \mathrm{Ma}$ in response to this compression (Silver, 1971), and current seismicity within the plate (fig. 5.4) indicates that this deformation continues to the present.

The 1980 Eureka $M=7.2$ earthquake emphasizes that part of this deformation occurs with left-lateral slip on northeast-striking faults within the plate. The seismicity map and cross sections (fig. 5.4) demonstrate that deformation associated with the Gorda plate terminates abruptly against the Pacific plate in a steeply northdipping zone of interaction along the MFZ, which can be followed on shore beneath the North American plate as a gently east-dipping, subhorizontal zone of widely scattered small to moderate earthquakes. Thus, convergence between the Gorda and Pacific plates across the MFZ apparently occurs by crushing and thickening of the southern margin of the Gorda plate as it is jammed against the anvil-like mass formed by the thicker and colder Pacific plate. Diminished east-west stress in the Gorda plate resulting from the subducting limb of the plate farther east serves to increase the difference between the maximum (north-south) and minimum (eastwest) compressive stresses within the plate, leading to left-lateral strike-slip displacements along northeaststriking faults, as in the $M=7.2$ Eureka earthquake. This process accommodates the convergent component of Gorda-Pacific plate motion along the east end of the MFZ at the expense of fragmentation and eastward expansion of the Gorda plate north of the MFZ.

\section{THE SAN ANDREAS DISCREPANCY}

Much of the seismicity adjacent to the San Andreas fault system is attributable to differences between the long-term slip rate and direction (slip vector) along the San Andreas fault system and that predicted for relative motion between the Pacific and North American plates along the San Andreas transform boundary on the basis of global models of plate motion. Minster and Jordan $(1978,1987)$ predicted that the direction of dextral slip between the Pacific and North American plates along the San Andreas transform boundary in central California is N. $35^{\circ} \mathrm{W}$. The main trace of the San Andreas system, however, strikes N. $41^{\circ} \mathrm{W}$. through central and northern California and N. $65^{\circ}-70^{\circ} \mathrm{W}$. through the Transverse Ranges in southern California. DeMets and others (1987) concluded that the marine magnetic anomalies at the mouth of the Gulf of California constrain the slip rate to an average of $49 \mathrm{~mm} / \mathrm{yr}$ over the past 3 to $4 \mathrm{Ma}$. Both long-term geologic offset data and geodetic data measured over the past several decades, however, indicate that the average slip rate along the San Andreas fault system is only about $35 \mathrm{~mm} / \mathrm{yr}$. The contribution to deformation of the western margin of the North American plate from spreading across the Basin and Range province is about $10 \mathrm{~mm} / \mathrm{yr}$ in a N. $56^{\circ} \mathrm{W}$. direction (Minster and Jordan,1987). Ellsworth (see chap. 6) suggests that most of the San Andreas discrepancy can be explained if the component of dextral slip associated with historical Basin and Range earthquakes reflects a longterm trend superimposed on the N. $56^{\circ} \mathrm{W}$. spreading direction. If so, then the residual component of Basin and Range extension perpendicular to the San Andreas fault system is approximately balanced by convergence across the Coast Ranges and continental margin.

\section{CONVERGENCE NORMAL TO \\ THE SAN ANDREAS FAULT SYSTEM}

Focal mechanisms of earthquakes occurring off the San Andreas fault system suggest that the component of the San Andreas discrepancy normal to the fault system may, indeed, be accommodated by distributed brittle deformation on either side of the fault system. These mechanisms range from dextral strike slip on planes subparallel to the San Andreas fault, through obliquereverse slip, to nearly pure reverse slip with a slip direction perpendicular to the San Andreas fault.

The Coalinga-North Kettleman Hills earthquake sequence provides clear evidence for crustal convergence perpendicular to the San Andreas fault system in the 
Coast Ranges. The several smaller events with similar mechanisms to the north along both the eastern and western (coastal) margins of the Coast Ranges (fig. 5.11) suggest that the convergence responsible for the Coalinga earthquake may be active the length of the Coast Ranges (Wong and others, 1988; Eaton and Rymer,
1990). The subparallelism of fold axes within the Coast Ranges with the San Andreas fault indicates that faultnormal convergence has been important for the past $3 \mathrm{Ma}$ in central California (fig. 5.12; Page and Engebretson, 1984). Namson and Davis (1988) proposed that the entire system of Coast Range folds may be genetically related to

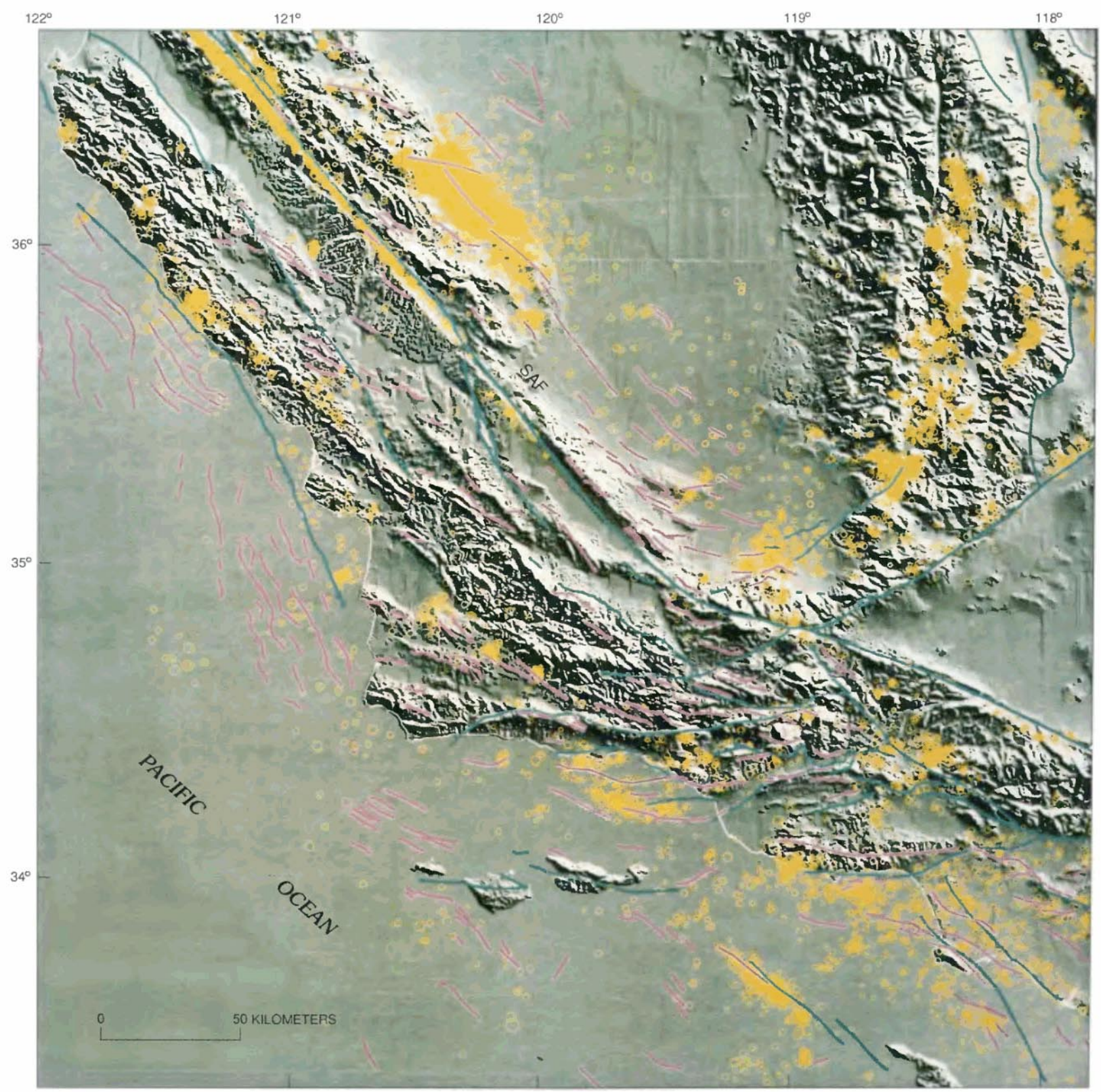

FIGURE 5.12.-Seismicity from 1980 to 1986 superimposed on digital shaded-relief image of central California, showing faults (blue) and fold axes (red). Size of symbol for epicenters (yellow) increases with magnitude from 1 to 6 . Shaded relief by Raymond Batson, U.S. Geological Survey (illumination from north at $30^{\circ}$ ); overlays from Ross Stein (unpub. data, 1989). SAF, San Andreas fault. 
Coalinga-like earthquake sequences and low-angle (blind) thrust faults that are rooted in a decollement near the base of the seismogenic crust. The reverse focal mechanisms for earthquakes associated with offshore faults along the western margin of the Coast Ranges suggest that, here, convergence involves westward thrusting of the Coast Ranges over oceanic crust of the Pacific plate.

The pronounced discrepancy in the strike of the San Andreas fault through the Transverse Ranges with respect to the Pacific-North American plate slip direction provides an obvious source of local crustal convergence (Hill and Dibblee, 1953; Atwater, 1970), and the associated structural complexities serve to distribute brittle deformation (seismicity) much more widely about the San Andreas fault system in southern California than about the relatively straight sections of the fault system in central and northern California. The largest earthquake in California since the great 1906 San Francisco earthquake occurred near the northern margin of this convergent regime; this $M=7.7$ Kern County earthquake ruptured some $35 \mathrm{~km}$ of the southeast-dipping White Wolf fault with left-oblique reverse slip on July 21, 1952.

The focal mechanisms of larger Transverse Range earthquakes, together with the mapped attitudes of major faults with Holocene offsets, show that much of this convergence occurs with slip on north-dipping thrust faults within and along the southern margin of the central Transverse Ranges (fig. 5.11A). For earthquakes in the western Transverse Ranges, the direction of reverse slip is more southwestward, consistent with thrusting of the western Transverse Ranges over the Pacific plate similar to that in the Coast Ranges to the north.

\section{EXTENSIONAL DEFORMATION AND THE SOUTHERN SECTION OF THE SAN ANDREAS FAULT SYSTEM}

The fault-normal convergence that dominates deformation adjacent to the San Andreas fault system through both the Coast Ranges and Transverse Ranges gives way rather abruptly to the extensional regime of the Salton Trough near the southern margin of the intensely active San Gorgonio bend in the fault. Focal mechanisms of earthquakes occurring on secondary structures adjacent to the seismically quiescent Indio segment of the San Andreas fault, for example, show a mix of strike- and dip-slip mechanisms. As is the case farther north, however, $P$-axes for these earthquakes tend to be oriented at a high angle $\left(60^{\circ}-65^{\circ}\right)$ to the fault, suggesting that the Indio segment of the fault may also be relatively weak (Jones, 1988).

One particularly noteworthy aspect of seismicity south of the Transverse Ranges is the tendency for earthquakes to occur along conjugate strike-slip structures. Recall that the Sierra Nevada-Great Basin boundary zone also shows this tendency and that both regions are subject to extensional deformation, earthquake swarms, and late Quaternary volcanism. Earthquake sequences within the southern section of the San Andreas fault system commonly produce epicenter lineations that intersect at nearly a $90^{\circ}$ angle with the northwest-striking right-slip plane and the northeast-striking left-slip plane. Earthquake-swarm sequences in the Brawley seismic zone, for example, typically occur along northeast-striking lineations normal to the trace of the adjacent Imperial fault (Johnson, 1979), and the $M=5.7$ Westmorland earthquake of 1981 involved left-lateral slip along several subparallel, northeast-striking planes (Johnson and Hutton, 1982). The diffuse lineations of epicenters spanning the area of the Peninsular Ranges between the San Jacinto and Elsinore faults also tend to be orthogonal to these two branches of the San Andreas fault system (fig. $5.10 A$ ). An impressive recent example of this orthogonal conjugate pattern is the $M=6.2$ and 6.6 Superstition Hills earthquakes of November 24, 1987 (Magistrale and others, 1988).

The kinematics of these conjugate structures remains a matter of conjecture. Dextral slip along throughgoing faults of the San Andreas system must certainly dominate deformation, and the shorter, northeast-striking structures must play only a secondary role. Nicholson and others (1986) proposed that the northeast-striking lineations represent the boundaries between blocks rotating clockwise much like roller bearings, between subparallel pairs of dextral strike-slip faults. Hill (1977) and Weaver and Hill (1978/79) suggested that within local spreading centers, such as the Brawley seismic zone, conjugate strike-slip structures form miniature triple junctions with a dike or normal fault that subtends the acute angle between the conjugate strike-slip faults.

\section{MAXIMUM FOCAL DEPTHS AND THICKNESS OF THE SEISMOGENIC CRUST}

Maximum focal depths of earthquakes beneath the San Andreas transform boundary range from less than $5 \mathrm{~km}$ beneath the Geysers geothermal field in the northern Coast Ranges to more than $20 \mathrm{~km}$ beneath the Transverse Ranges, the eastern margin of the Coast Ranges, and the San Jacinto and Elsinore faults in southernmost California. Beneath relatively straight segments of the San Andreas fault system through central California, maximum focal depths range from 12 to $15 \mathrm{~km}$ (figs. 5.7, 5.8). Sibson (1983) pointed out that these variations in maximum focal depth along the San Andreas fault system are inversely correlated with surficial heat flow, and he argued that the maximum depth of earthquakes coincides with the temperature-dependent transition from brittle failure in the upper crust to aseismic, quasi-plastic flow in 
the lower crust and upper mantle. For quartz-bearing rocks typical of the upper crust and deformation rates typical of the San Andreas fault system $\left(1 \times 10^{-14}\right.$ to $\left.1 \times 10^{-13} \mathrm{~s}^{-1}\right)$, this brittle/ductile transition occurs at about $300{ }^{\circ} \mathrm{C}$ (Sibson, 1983). By this interpretation, the thin seismogenic crust beneath both the Geysers and Brawley geothermal fields in northern and southern California, respectively, reflects elevated temperatures in the shallow crust, whereas the relatively thick seismogenic crust beneath the Transverse Ranges and the eastern margin of the Coast Ranges reflects depressed temperatures in the midcrust associated with crustal convergence. Although temperature may dominantly influence the thickness of the seismogenic crust, local variations in rock composition (particularly the presence or absence of modal quartz and structural water) and in strain rate can also be important. These variations, for example, may help explain isolated clusters of deep earthquakes, such as the 20- to 24-km-deep events north of San Pablo Bay in central California (see cross secs. $F-F^{\prime}, G-G^{\prime}$, fig. $5.8 B)$.

In any case, the thickness of the seismogenic crust beneath the San Andreas transform boundary seems to be much more strongly related to temperatures in the crust than to the structural thickness of crust defined by the depth to the Moho (see chap. 8). This relation is strikingly illustrated by the twofold increase in thickness of the seismogenic crust beneath the rootless Transverse Ranges.

\section{DECOLLEMENT AT THE BASE OF THE SEISMOGENIC CRUST?}

A theme common to models of crustal convergence along the San Andreas fault system involves low-angle reverse slip on decollement surfaces near the base of the seismogenic crust (Wentworth and others, 1983; Webb and Kanamori, 1985; Namson and Davis, 1988; Eaton and Rymer, 1990). A natural extension of this theme leads to a view of the seismogenic crust as a conglomeration of relatively rigid blocks interacting by frictional slip along weak preexisting faults (block boundaries) in response to regional stresses transmitted through both the brittle crust and quasi-plastic deformation in the underlying lithosphere (Hill, 1982). However, the nature of a decollement surface at the base of the brittle crust and the relation of the seismogenic San Andreas fault system to the aseismic transform boundary in the underlying lithosphere remain speculative. It is not yet clear, for example, whether the San Andreas fault continues below the seismogenic crust as a narrow, near-vertical boundary (possibly offset a substantial distance from the seismogenic fault by slip on the horizontal decollement surface) that slips by quasi-plastic, mylonitic deformation or whether it broadens rapidly with depth into a wide shear zone spanning, say, the entire width of the Coast Ranges (see chap. 7; Sibson, 1983).

\section{CONCLUSIONS}

The spatial-temporal pattern of earthquake occurrence within the seismogenic crust along the San Andreas fault system is the brittle manifestation of distributed deformation of the lithosphere between the Pacific and North American plates along the San Andreas transform boundary. As we develop a more complete model of the long-term behavior of the seismogenic crust, including relations between great, plate-boundary earthquakes that periodically rupture the principal strand of the San Andreas fault system and the persistent background of small to moderate earthquakes on adjacent structures, our image of the deeper deformation will improve. Together will come a more complete understanding of the processes controlling deformation along the transform boundary and of the earthquake cycle.

\section{REFERENCES CITED}

Allen, C.R., 1968, The tectonic environments of seismically active and inactive areas along the San Andreas fault system, in Dickinson, W.R., and Grantz, Arthur, eds., Proceedings of conference on geologic problems of San Andreas fault system: Stanford, Calif., Stanford University Publications in the Geological Sciences, v. 11, p. $70-82$.

- 1981, The modern San Andreas fault, in Ernst, W.G., ed., The geotectonic development of California (Ruby volume 1): Englewood Cliffs, N.J., Prentice-Hall, p. 511-534.

Astiz, Luciana, and Allen, C.R., 1983, Seismicity of the Garlock fault, California: Seismological Society of America Bulletin, v. 73, no. 6, pt. A, p. 1721-1734.

Atwater, Tanya, 1970, Implications of plate tectonics for the Cenozoic evolution of western North America: Geological Society of America Bulletin, v. 81 , no. 12, p. 3513-3535.

Bakun, W.H., Clark, M.M., Cockerham, R.S., Ellsworth, W.L., Lindh, A.G., Prescott, W.H., Shakal, A.F., and Spudich, Paul, 1984, The 1984 Morgan Hill, California, earthquake: Science, v. 225 , no. 4659 , p. $288-291$.

Bakun, W.H., and Lindh, A.G., 1985, The Parkfield, California, earthquake prediction experiment: Science, v. 229, no. 4714, p. $619-623$.

Bakun, W.H., and McEvilly, T.V., 1984, Recurrence models and Parkfield, California earthquakes: Journal of Geophysical Research, v. 89, no. B5, p. 3051-3058.

Bolt, B.A., McEvilly, T.V., and Uhrhammer, R.A., 1981, The Livermore Valley, California, sequence of January 1980: Seismological Society of America Bulletin, v. 71, no. 2, p. 451-463.

Bolt, B.A., and Miller, R.D., 1975, Catalogue of earthquakes in northern California and adjoining areas 1 January 1910-31 December 1972: Berkeley, University of California, Seismographic Station, $567 \mathrm{p}$.

Boore, D.M., 1977, Strong-motion recordings of the California earthquake of April 18, 1906: Seismological Society of America Bulletin, v. 67 , no. 3 , p. $561-577$. 
Cockerham, R.S., 1984, Evidence for a 180-km-long subducted slab beneath northern California: Seismological Society of America Bulletin, v. 74, no. 2, p. 569-576.

Cockerham, R.S., and Corbett, E.J., 1987, The 1986 Chalfant Valley, California, earthquake sequence: Preliminary results: Seismological Society of America Bulletin, v. 77, no. 1, p. 280-289.

Dehlinger, Peter, and Bolt, B.A., 1984, Seismic parameters along the Bartlett Springs fault zone in the Coast Ranges of northern California: Seismological Society of America Bulletin, v. 74, no. 5, p. 1785-1798.

DeMets, Charles, Gordon, R.G., Stein, Seth, and Argus, D.F., 1987, A revised estimate of the Pacific-North America motion and implications for western North America plate boundary zone tectonics: Geophysical Research Letters, v. 14, no. 9, p. 911-914.

Dickinson, W.R., 1981, Plate tectonics and the continental margin of California, in Ernst, G.W. ed., The geotectonic development of California (Ruby volume 1): Englewood Cliffs, N.J., PrenticeHall, p. 2-28.

Donnelly-Nolan, J.M., Hearn, B.C., Jr., Curtis, G.H., and Drake, R.E., 1981, Geochronology and evolution of the Clear Lake Volcanics, in McLaughlin, R.J., and Donnelly-Nolan, J.M., eds., Research in the Geysers-Clear Lake geothermal area, northern California: U.S. Geological Survey Professional Paper 1141, p. 47-60.

Eaton, J.P., 1989, Dense microearthquake network study of northern California earthquakes, chap. 13 of Litehiser, J.J., ed., Observatory seismology, a centennial symposium for the Berkeley Seismographic Stations: Berkeley, University of California Press, p. $199-224$

- 1990, The earthquake and its aftershocks from May 2 through September 30,1983, chap. 8 of Rymer, M.J., and Ellsworth, W.E., eds., The Coalinga, California, earthquake of May 2, 1983: U.S. Geological Survey Professional Paper 1487, p. 113-170.

Eaton, J.P., Lee, W.H.K., and Pakiser, L.C., 1970a, Use of microearthquakes in the study of the mechanics of earthquake generation along the San Andreas fault in central California: Tectonophysics, v. 9, no. 2-3, p. 259-282.

Eaton, J.P., O'Neill, M.E., and Murdock, J.N., 1970b, Aftershocks of the 1966 Parkfield-Cholame, California, earthquake: A detailed study: Seismological Society of America Bulletin, v. 60, no. 4, p. 1151-1197.

Eaton, J.P., and Rymer, M.J., 1990, Regional seismotectonic model for the southern Coast Ranges, chap. 7, of The Coalinga, California, earthquake of May 2, 1983: U.S. Geological Survey Professional Paper 1487, p. 97-111.

Eberhart-Phillips, Donna, and Oppenheimer, D.H., 1984, Induced seismicity in the Geysers geothermal area, California: Journal of Geophysical Research, v. 89, no. B2, p. 1191-1207.

Ellsworth, W.L., 1975, Bear Valley, California, earthquake sequence of February-March 1972: Seismological Society of America Bulletin, v. 65 , no. 2 , p. $483-506$.

Ellsworth, W.L., Lindh, A.G., Prescott, W.H., and Herd, D.G., 1981, The 1906 San Francisco earthquake and the seismic cycle, in Simpson, D.W., and Richards, P.G., eds., Earthquake prediction: An international review (Maurice Ewing Series 4): Washington, American Geophysical Union, p. 126-140.

Ellsworth, W.L., Olson, J.A., Shijo, L.N., and Marks, S.M., 1982, Seismicity and active faults in the eastern San Francisco Bay region, in Hart, E.W., Hirschfeld, S.E., and Schulz, S.S., eds., Conference on Earthquake Hazards in the Eastern San Francisco Bay Area, Hayward, Calif., 1982, Proceedings: California Division of Mines and Geology Special Publication 62, p. 83-91.

Fletcher, J.B., Haar, L.C., Hanks, T.C., Baker, L.M., Vernon, F.L., Berger, Jon, and Brune, J.N., 1987, The digital array at Anza California: Processing and initial interpretation of source param- eters: Journal of Geophysical Research, v. 92, no. B1, p. 369-382. Fedotov, S.A., 1965, Regularities in the distribution of strong earthquakes in Kamchatka, the Kuril Islands and northeastern Japan: Akademia Nauk SSSR, Institut Fiziki Zemli Trudy, v. 36, p. 66-93.

Hanks, T.C., Hileman, J.A., and Thatcher, Wayne, 1975, Seismic moments of the larger earthquakes of the southern California region: Geological Society of America Bulletin, v. 86, no. 8, p. 1131-1139.

Hartzell, S.H., and Heaton, T.H., 1986, Rupture history of the 1984 Morgan Hill, California, earthquake from the inversion of strong motion records: Seismological Society of America Bulletin, v. 76, no. 3 , p. 649-674.

Heaton, T.H., 1982, The 1971 San Fernando, [California], earthquake: A double event?: Seismological Society of America Bulletin, v. 72, no. 6, p. 2037-2062.

Hileman, J.A., Allen, C.R., and Nordquist, J.M., 1973, Seismicity of the southern California region 1 January 1932 to 31 December 1972: Pasadena, California Institute of Technology, Seismological Laboratory, $487 \mathrm{p}$.

Hill, D.P., 1977, A model for earthquake swarms: Journal of Geophysical Research, v. 82 , no. 8 , p. 1347-1352.

— 1982, Contemporary block tectonics: California and Nevada: Journal of Geophysical Research, v. 87, no. B7, p. 5433-5450.

Hill, D.P., Bailey, R.A., and Ryall, A.S., 1985a, Active tectonic and magmatic processes beneath Long Valley caldera, eastern California: An overview: Journal of Geophysical Research, v. 90, no. B13, p. 11111-11120.

Hill, D.P., Eaton, J.E., Ellsworth, W.L., Cockerham, R.S., Lester, F.W., and Corbett, E.J., in press, The Seismotectonic fabric of central California, in Slemmons, D.B., Engdahl, E.R., Blackwell, D.D., Schwartz, D.P., and Zoback, M.D., eds., Neotectonics of North America (DNAG Associated Volume GSMV-1): Boulder Colo., Geological Society of America.

Hill, D.P., Mowinckel, Penelope, and Peake, L.G., 1975, Earthquakes, active faults, and geothermal areas in the Imperial Valley, California: Science, v. 188 , no. 4195 , p. 1306-1308.

Hill, D.P., Wallace, R.E., and Cockerham, R.S., 1985b, Review of evidence on the potential for major earthquakes and volcanism in the Long Valley-Mono Craters-White Mountains regions of eastern California: Earthquake Prediction Research, v. 3, no. 3-4, p. 571-594.

Hill, M.L., and Dibblee, T.W., 1953, San Andreas, Garlock, and Big Pine faults-a study of the character, history, and tectonic significance of their displacements: Geological Society of America Bulletin, v. 64 , no. 4 , p. $435-438$.

Hutton, L.K., Jones, L.M., Hauksson, Egill, and Given, D.D., in press, Seismotectonics of southern California, in Slemmons, D.B., Engdahl, E.R., Blackwell, D.D., Schwartz, D.P., and Zoback, M.D., eds., Neotectonics of North America (DNAG Associated Volume GSMV-1): Boulder, Colo., Geological Society of America.

Jachens, R.C., and Griscom, Andrew, 1983, Three-dimensional geometry of the Gorda plate beneath northern California: Journal of Geophysical Research, v. 88, no. B11, p. 9375-9392.

Johnson, C.E., 1979, I, CEDAR - an approach to the computer automation of short-period local seismic networks; seismotectonics of the Imperial Valley of southern California: Pasadena, California Institute of Technology, Ph.D. thesis, $343 \mathrm{p}$.

Johnson, C.E., and Hill, D.P., 1982, Seismicity of the Imperial Valley, in The Imperial Valley, California, earthquake of October 15, 1979: U.S. Geological Survey Professional Paper 1254, p. 59-76.

Johnson, C.E., and Hutton, L.K., 1982, Aftershocks and preearthquake seismicity, in The Imperial Valley, California, earthquake of October 15, 1979: U.S. Geological Survey Professional Paper 1254 , p. 15-24. 
Jones, L.M., 1988, Focal mechanisms and the state of stress on the San Andreas fault in southern California: Journal of Geophysical Research, v. 93, no. B8, p. 8869-8891.

Jones, L.M., and Dollar, R.S., 1986, Evidence for basin-and-range extensional tectonics in the Sierra Nevada: The Durwood Meadows swarm, Tulare County, California (1983-1984): Seismological Society of America Bulletin, v. 76, no. 2, p. 439-462.

Jones, L.M., Hutton, L.K., Given, D.D., and Allen, C.R., 1986, The North Palm Springs, California, earthquake sequence of July 1986: Seismological Society of America Bulletin, v. 76, no. 6, p. 1830-1837.

LaForge, R., and Lee, W.H.K., 1982, Seismicity and tectonics of the Ortigalita fault and southeast Diablo Range, California, in Hart, E.W., Hirschfeld, S.E., and Schulz, S.S., eds., Conference on Earthquake Hazards in the Eastern San Francisco Bay Area, Hayward Calif., 1982, Proceedings: California Division of Mines and Geology Special Publication 62, p. 93-101.

Lee, W.H.K., Eaton, M.S., and Brabb, E.E., 1971, The earthquake sequence near Danville, California, 1970: Seismological Society of America Bulletin, v. 61, no. 6, p. 1771-1794.

Lee, W.H.K., and Stewart, S.W., 1981, Principles and applications of microearthquake networks: New York, Academic Press, 293 p.

Lomnitz, Cinna, Mosser, Federico, Allen, C.R., Brune, J.N., and Thatcher, Wayne, 1970, Seismicity and tectonics of the northern Gulf of California region, Mexico. Preliminary results: Geofisica Internacional, v. 10 , no. 2, p. 27-48.

Louie, J.N., Allen, C.R., Johnson, D.C., Haase, P.C., and Cohn, S.N., 1985, Fault slip in southern California: Seismological Society of America Bulletin, v. 75, no. 3, p. 811-833.

Magistrale, Harold, Jones, L.M., and Kanamori, Hiroo, 1988, The Superstition Hills, California, earthquakes of 24 November 1987: Seismological Society of America Bulletin, v. 79, no. 2, p. 239-251.

Mayer-Rosa, Dieter, 1973, Travel-time anomalies and distribution of earthquakes along the Calaveras fault zone, California: Seismological Society of America Bulletin, v. 63, no. 2, p. 713-729.

Mendoza, Carlos, and Hartzell, S.H., 1988, Inversion for slip distribution using teleseismic $P$ waveforms: North Palm Springs, Borah Peak, and Michoacan earthquakes: Seismological Society of America Bulletin, v. 78, no. 3, p. 1092-1111.

Minster, J.B., and Jordan, T.H., 1978, Present-day plate motions: Journal of Geophysical Research, v. 83, no. B11, p. 5331-5354.

Minster, J.B., and Jordan, T.H., 1987, Vector constraints on western U.S. deformation from space geodesy, neotectonics, and plate motions: Journal of Geophysical Research, v. 92, no. B6, p. 4798-4804.

Mogi, Kiyoo, 1968, Some features of recent seismic activity in and near Japan (1): University of Tokyo, Earthquake Research Institute Bulletin, v. 46, pt. 6, sec. A, p. 1225-1235.

Morton, D.M., and Matti, J.C., 1987, The Cucamonga fault zone: geologic setting and Quaternary history, chap. 12 of Recent reverse faulting in the Transverse Ranges, California: U.S. Geological Survey Professional Paper 1339, p. 179-203.

Namson, J.S., and Davis, T.L., 1988, Seismically active fold and thrust belt in the San Joaquin Valley, central California: Geological Society of America Bulletin, v. 100, no. 2, p. 257-273.

Nicholson, Craig, Seeber, Leonardo, Williams, Patrick, and Sykes, L.R., 1986, Seismicity and fault kinematics through the eastern Transverse Ranges, California: Block rotation, strike-slip faulting and low-angle thrusts: Journal of Geophysical Research, v. 91, no. B5, p. 4891-4908.

Norris, Robert, Jones, L.M., and Hutton, K.L., 1986, The Southern California Network Bulletin, July 01 through December 31, 1985: U.S. Geological Survey Open-File Report 86-337, 15 p.
Oppenheimer, D.H., 1986, Extensional tectonics at The Geysers geothermal area, California: Journal of Geophysical Research, v. 91 , no. B11, p. 11463-11476.

Oppenheimer, D.H., Reasenberg, P.A., and Simpson, R.W., 1988, Fault-plane solutions for the 1984 Morgan Hill, California, earthquake sequence: Evidence for the state of stress on the Calaveras fault: Journal of Geophysical Research, v. 93, no. B8, p. 9007-9026.

Page, B.M., and Engebretson, D.C., 1984, Correlation between the geologic record and computed plate motions for central California: Tectonics, v. 3, no. 2, p. 133-155.

Pavoni, Nazario, 1973, A structural model for the San Andreas fault zone along the northeast side of the Gabilan Range, in Kovach, R.L., and Nur, Amos, eds., Proceedings of the conference on tectonic problems of the San Andreas fault system: Stanford, Calif., Stanford University Publications in the Geological Sciences, v. 13, p. 259-267.

Poley, C.M., 1988, The San Ardo, California, earthquake of 24 November 1985: Seismological of America Bulletin, v. 78, no. 3, p. 1360-1366.

Reasenberg, P.A., and Ellsworth, W.L., 1982, Aftershocks of the Coyote Lake, California, earthquake of August 6, 1979: A detailed study: Journal of Geophysical Research, v.87, no. B13, p 1063710655.

Richter, C.F., 1958, Elementary seismology: San Francisco, W.H. Freeman, 768 p.

Rogers, A.M, Harmsen, S.C., Corbett, E.J., Priestley, K.F., and DePolo, D.M., in press, The seismicity of Nevada and some adjacent areas of the Great Basin, in Slemmons, D.B., Engdahl, E.R., Blackwell, D.D., Schwartz, D.P., and Zoback, M.D., eds., Neotectonics of North America (DNAG Associated Volume GSMV-1): Boulder, Colo., Geological Society of America.

Sanders, C.0., and Kanamori, Hiroo, 1984, A seismotectonic analysis of the Anza seismic gap, San Jacinto fault zone, southern California: Journal of Geophysical Research, v. 89, no. B7, p. 5873-5890.

Sauber, Jeanne, McNally, K.C., Pechmann, J.C., and Kanamori, Hiroo, 1983, Seismicity near Palmdale, California, and its relation to strain changes: Journal of Geophysical Research, v. 88, no. B3, p. 2213-2219.

Savage, J.C., and Cockerham, R.S., 1987, Quasi-periodic occurrence of earthquakes in the 1978-1986 Bishop-Mammoth Lakes sequence, eastern California: Seismological Society of America Bulletin, v. 77, no. 4, p. 1347-1358.

Schulz, S.S., Mavko, G.M., Burford, R.O., and Stuart, W.D., 1982, Long-term fault creep observations in central California: Journal of Geophysical Research, v. 87, no. B8, p. 6977-6982.

Sibson, R.H., 1983, Continental fault structure and the shallow earthquake source: Geological Society of London Journal, v. 140, no. 5, p. 741-767.

Sieh, K.E., 1978, Slip along the San Andreas fault associated with the great 1857 earthquake: Seismological Society of America Bulletin, v. 68 , no. 5 , p. $1421-1448$.

- 1981, A review of geological evidence for recurrence times of large earthquakes, in Simpson, D.W., and Richards, P.G., eds., Earthquake prediction: An international review (Maurice Ewing Series 4): Washington, American Geophysical Union, p. 181-207.

- 1986, Slip rate across the San Andreas fault and prehistoric earthquakes at Indio, California [abs.]: Eos (American Geophysical Union Transactions), v. 67, no. 44, p. 1200.

Sieh, K.E., and Jahns, R.H., 1984, Holocene activity of the San Andreas fault at Wallace Creek, California: Geological Society of America Bulletin, v. 95, no. 8, p. 883-896.

Silver, E.A., 1971, Tectonics of the Mendocino triple junction: Geological Society of America Bulletin, v. 82, no. 11, p. 9265-2878. 
Smith, K.D., and Priestly K.F., 1988, The foreshock sequence of the 1986 Chalfant, California, earthquake: Seismological Society of America Bulletin, v. 78, no. 1, p. 172-187.

Spieth, M.A., 1981, Two detailed seismic studies in central California. Part I: Earthquake clustering and crustal structure studies of the San Andreas fault near San Juan Bautista. Part II: Seismic velocity structure along the Sierra foothills near Oroville, California: Stanford, Calif., Stanford University, Ph.D. thesis, 174 p.

Stein, R.S., and King, G.C.P., 1984, Seismic potential revealed by surface folding: 1983 Coalinga, California, earthquake: Science, v. 224 , no. 4651 , p. 869-871.

Stein, R.S., and Thatcher, Wayne, 1981, Seismic and aseismic deformation associated with the 1952 Kern County, California, earthquake and relationship to the Quaternary history of the White Wolf fault: Journal of Geophysical Research, v. 86, no. B6, p. $4913-4928$.

Sykes, L.R., and Seeber, Leonardo, 1985, Great earthquakes and great asperities, San Andreas fault, southern California: Geology, v. 13, no. 12, p. $835-838$.

Thatcher, Wayne, Hileman, J.A., and Hanks, T.C., 1975, Seismic slip distribution along the San Jacinto fault zone, southern California, and its implications: Geological Society of America Bulletin, v. 86, no. 8, p. 1140-1146.

Thatcher, Wayne, and Lisowski, Michael, 1987, Long-term seismic potential of the San Andreas fault southeast of San Francisco, California: Journal of Geophysical Research, v. 92, no. B6, p. $4771-4784$.

Van Wormer, J.D., and Ryall, A.S., 1980, Sierra Nevada-Great Basin boundary zone: Earthquake hazards related to structure, active tectonic processes, and anomalous patterns of earthquake occurrence: Seismological Society of America Bulletin, v. 70, no. 5, p. $1557-1572$.

Walter, S.R., 1986, Intermediate-focus earthquakes associated with Gorda plate subduction in northern California: Seismological Society of America Bulletin, v. 76, no. 2, p. 583-588.

Ward, S.N., 1988, North America-Pacific plate boundary, an elasticplastic megashear: evidence from very long baseline interferom- etry: Journal of Geophysical Research, v. 93, no. B7, p. 7716-7728. Weaver, C.S., and Hill, D.P., 1978/79, Earthquake swarms and local crustal spreading along major strike-slip faults in California: Pure and Applied Geophysies, v. 117, no. 1-2, p. 51-64.

Webb, T.H., and Kanamori, Hiroo, 1985, Earthquake focal mechanisms in the eastern Transverse Ranges and San Emigdio Mountains, southern California and evidence for a regional decollement: Seismological Society of America Bulletin, v. 75, no. 3, p. 737-757.

Wentworth, C.M., Walter, A.W., Bartow, J.A., and Zoback, M.D., 1983, Evidence on the tectonic setting of the 1983 Coalinga earthquakes from deep reflection and refraction profiles across the southeastern end of Kettleman Hills, in Bennett, J.H., and Sherburne, R.W., eds., The 1983 Coalinga, California earthquakes: California Division of Mines and Geology Special Publication 66 , p. 113-126.

Wesson, R.L., Burford, R.O., and Ellsworth, W.L., 1973, Relationship between seismicity, fault creep, and crustal loading along the central San Andreas fault, in Kovach, R.L., and Nur, Amos, eds. Proceedings of the conference on tectonic problems of the San Andreas fault system: Stanford, Calif., Stanford University Publications in the Geological Sciences, v. 13, p. 303-321.

Whitcomb, J.H., 1971, Fault-plane solutions of the February 9, 1971, San Fernando earthquake and some aftershocks, in The San Fernando, California, earthquake of February 9, 1971: U.S. Geological Survey Professional Paper 733, p. 30-33.

Wilson, D.S. 1986, A kinematic model for the Gorda deformation zone as a diffuse southern boundary of the Juan de Fuca plate: Journal of Geophysical Research, v. 91, no. B10, p. 10259-10269.

Wong, I.G., Ely, R.W., and Kollmann, A.C., 1988, Contemporary seismicity and tectonics of the northern and central Coast RangesSierran Block boundary zone, California: Journal of Geophysical Research, v. 93 , no. B7, p. 7813-7833.

Zoback, M.D., Zoback, M.L., Mount, V.S., Suppe, John, Eaton, J.P., Healy, J.H., Oppenheimer, D.H., Reasenberg, P.A., Jones, L.M., Raleigh, C.B., Wong, I.G., Scotti, Oona, and Wentworth, C.M., 1987, New evidence on the state of stress of the San Andreas fault system: Science, v. 238 , no. 4830 , p. $1105-1111$. 


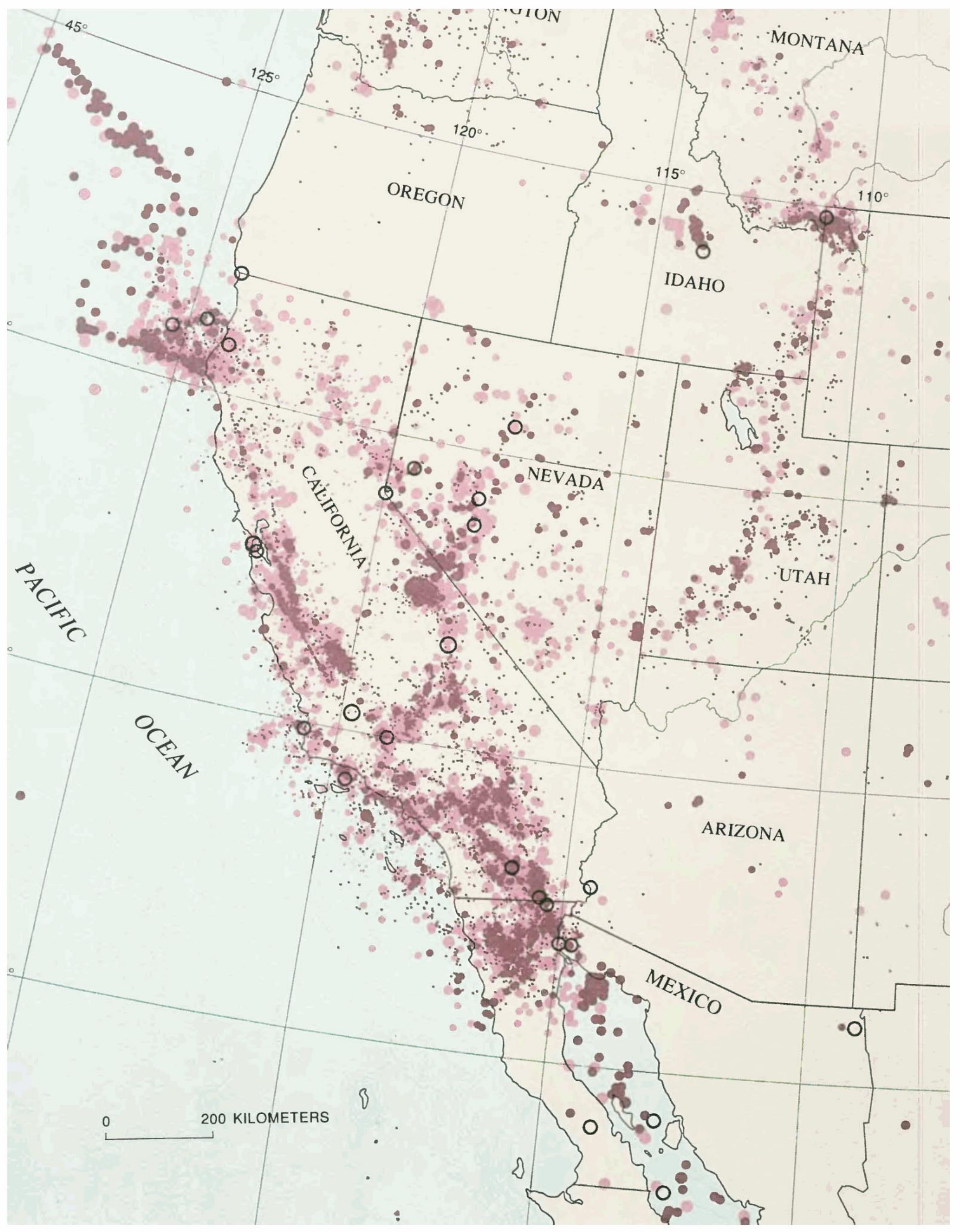




\begin{abstract}
19tion between the North American and Pacific plates at the 1 latitude of the San Andreas fault produces a broad zone of large-magnitude earthquake activity extending more than $500 \mathrm{~km}$ into the continental interior. The San Andreas fault system defines the western limits of plate interaction and dominates the overall pattern of seismic strain release. Few of the $\mathrm{M} \geq 6$ earthquakes that have occurred in the past 2 centuries were located on the San Andreas fault proper, an observation emphasizing the importance of secondary faults for both seismic-hazard assessment and tectonic processes.
\end{abstract}

\title{
6. EARTHQUAKE HISTORY, 1769-1989
}

\author{
By William L. Ellsworth
}

\section{CONTENTS}

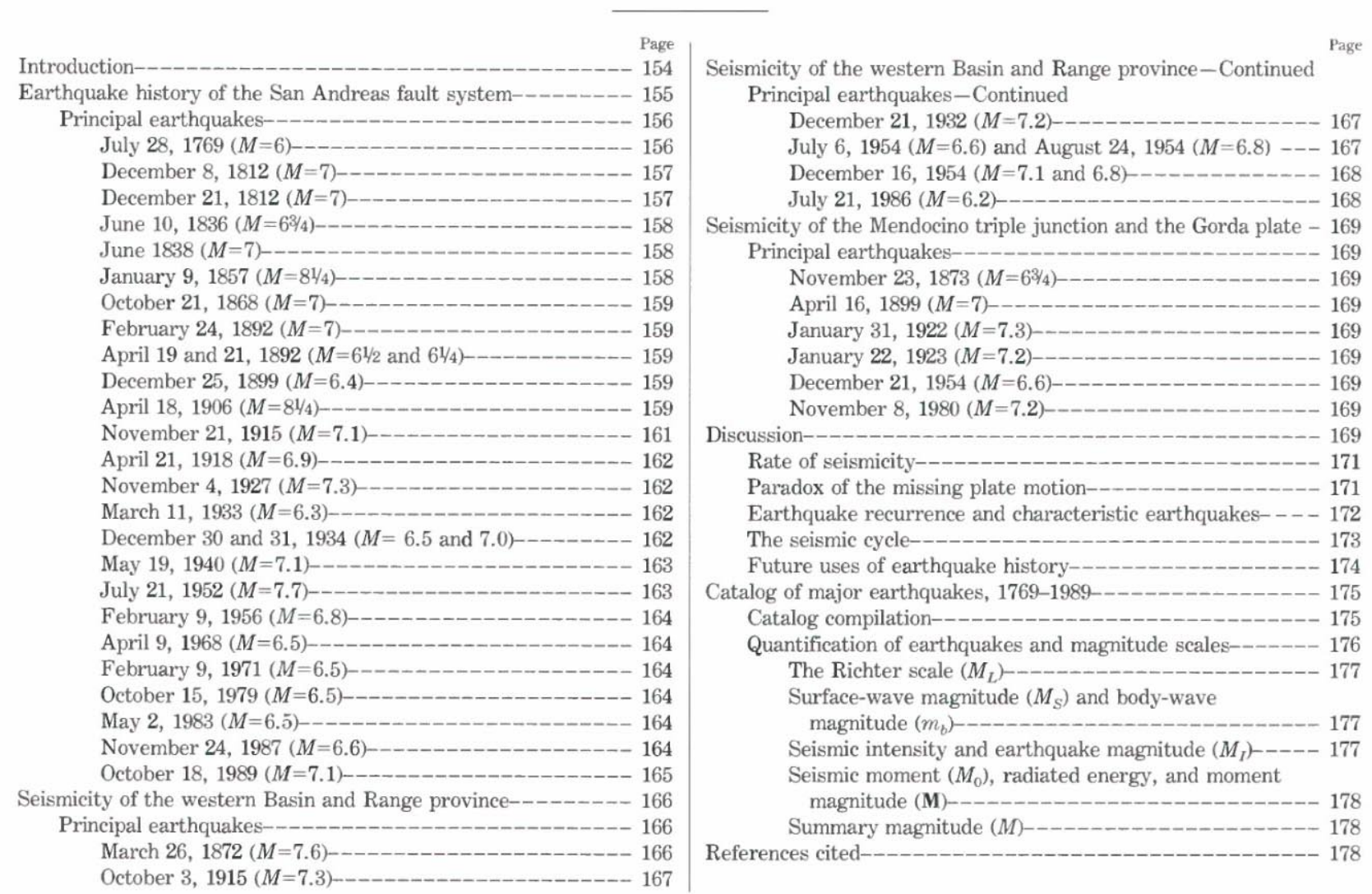

Figure 6.1.-Seismicity highlights broad and complex zones of active tectonism in the western United States. Dots, earthquakes scaled by magnitude in unit-magnitude steps, smallest for $M<4$; circles, earthquakes of $M>7$; red dots, recent events, generally since 1975; pink symbols, historical events. From Engdahl and Rinehart (1988).

THE SAN ANDREAS FAULT SYSTEM, CALIFORNIA: U.S. GEOLOGICAL SURVEY PROFESSIONAL PAPER 1515 


\section{INTRODUCTION}

Between Punta Gorda on the northern California coast and the head of the Gulf of California, 1,350 km to the southeast, lies the active transform boundary that forms the modern San Andreas fault system (fig. 6.1). Dextral motion between the North American and Pacific plates along this system is accommodated within an elongate zone, broadening from about $100 \mathrm{~km}$ at its north end to about $300 \mathrm{~km}$ in southern California. The San Andreas fault proper hugs the east side of this zone at its south terminus and gradually migrates across the zone, lying on the west edge of the zone at its north terminus. The
San Andreas fault system transmits about three-fourths of the relative motion across the plate boundary, as shown by various geologic and geodetic evidence. Much of this motion is stored elastically in the upper crust along the major faults in the system, ultimately to be released in large plate-boundary earthquakes. These large earthquakes and their implications for the mechanics of North American-Pacific plate interactions are the subject of this chapter.

Earthquake activity in California and Nevada at the latitude of the San Andreas fault extends well beyond the confines of the San Andreas system (fig. 6.2). In the past century alone, only about half of the $M \geq 6$ activity has

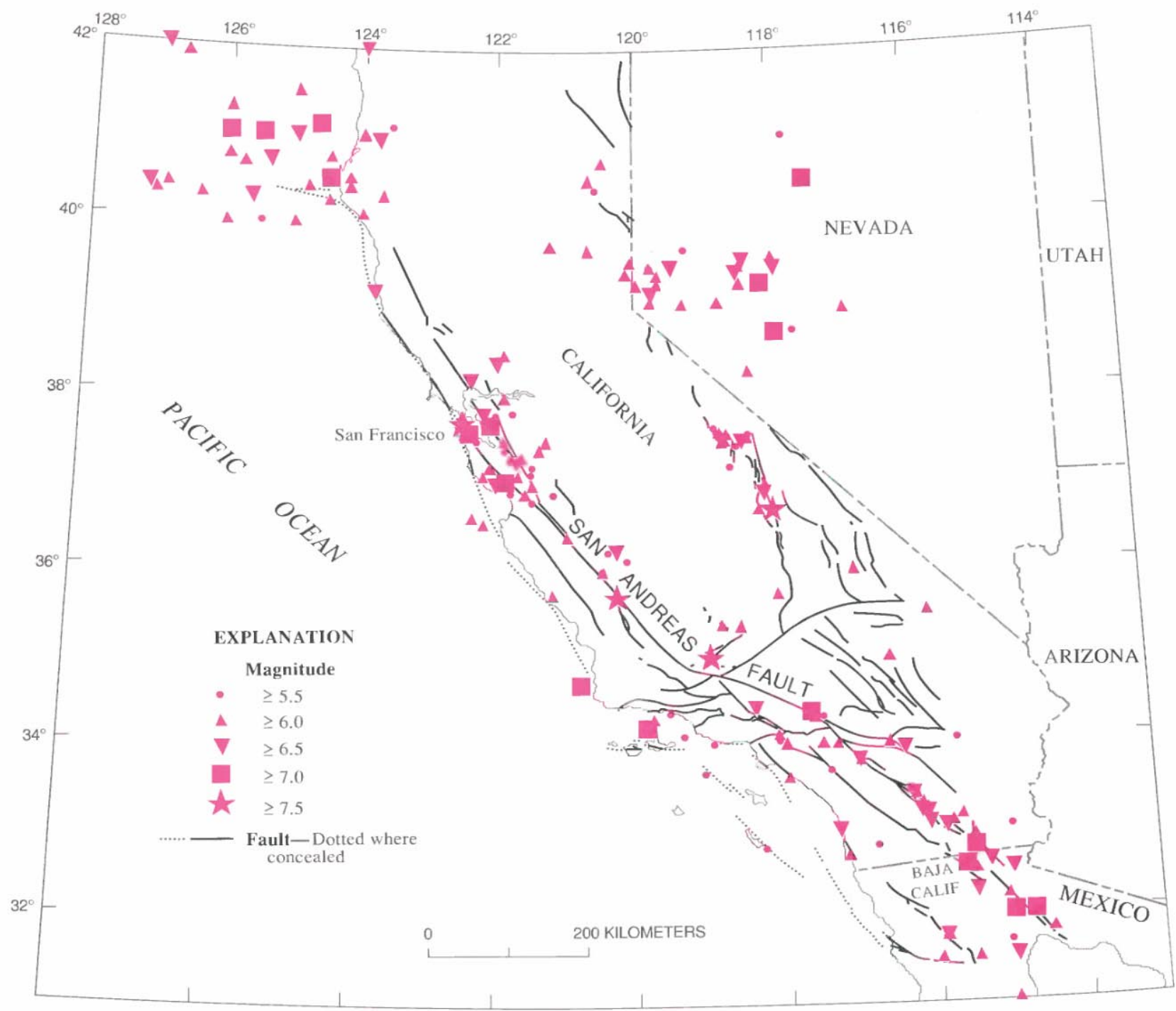

Figure 6.2.-Seismicity of California, Nevada, and northern Baja California, 1769-1989. Earthquakes are listed in table 6.1 and plotted by magnitude class. 
fallen within the San Andreas system; of the rest, half is associated with the western Basin and Range province, and the other half with the Mendocino triple junction and the Gorda plate. Although activity in the latter region reflects the tectonics of the triple junction and the collision of the Gorda plate with the North American plate, seismicity east of the San Andreas system along the east flank of the Sierra Nevada and in the Basin and Range province reflects the incomplete accommodation of plate motion along the San Andreas fault system. A significant proportion of this "missing" motion occurs in the Basin and Range, the seismicity of which plays an integral role in the tectonics of the plate boundary.

\section{EARTHQUAKE HISTORY OF THE SAN ANDREAS FAULT SYSTEM}

The historical record of major earthquakes affecting California, western Nevada, and northernmost Baja California (table 6.1) includes basic seismologic data on 206 of the largest earthquakes occurring between 1769 and 1989. This catalog lists all known events of $M \geq 6$ and includes new and updated information on their locations.

The record of seismicity within the San Andreas fault system and surrounding regions is both geographically and temporally uneven and incomplete before the introduction of practical seismographic instrumentation around the turn of the 20th century. In general, the density and distribution of people who left written accounts of their experiences determines the reliability of the catalog during the preinstrumental period. From the establishment of the Franciscan missions beginning in 1769 until their secularization in the 1830's, detailed accounts of events that damaged the missions are available, and these accounts form the primary source material for earthquakes occurring during this period. Life in California was a constant struggle for survival at that time; posting to a mission evidently was considered a hardship assignment, and so essentially nothing was recorded about events that were only felt, even when they were destructive at nearby missions. After secularization and before the gold rush, the quality of the record degrades with the cessation of the annual reports of the missions. Other sources of records also are notably weak during the Mexican period, from the early 1830's until 1846.

The discovery of gold in 1848 transformed the written record of earthquakes with the advent of newspapers throughout the gold fields in the Sierran foothills and in the San Francisco Bay region. Printed accounts of earthquakes have been extensively used, notably by Toppozada and others (1988), to quantify the seismicity of California from 1850 onward. They estimated that their historical catalog is probably complete for the San
Francisco Bay region and central Sierra Nevada from 1850 on for earthquakes of $M \approx 6$. The same level of completeness is not achieved, however, for the San Andreas fault system in southern California until the 1890 's. Statewide, the catalog of earthquakes is substantially complete for earthquakes of $M \approx 7$ after about 1850 (see Agnew, 1985). The quality of the catalog for central Nevada, where much significant 20th century seismicity has occurred, is less complete. Questions remain today about purported events as late as 1903 in this region (Slemmons and others, 1959).

Reports of the local effects of earthquakes continue to play a major role in determining the locations and sizes of earthquakes well into the 20th century. The earliest seismographs capable of systematically detecting California and Nevada earthquakes were installed throughout the world by John Milne beginning in 1896 . Seismograms from these instruments and their successors provide useful instrumental magnitudes from 1898 onward. However, not until the development of the Wood-Anderson seismograph and its deployment throughout California beginning in 1926 do instrumental measurements fully supplant noninstrumental magnitudes and epicentral locations.

The objective in assembling a single catalog from these many sources, spanning many different types and qualities of information, has been to achieve uniform spatial coverage without sacrificing any events of historical significance. $M=6$ was chosen as the threshold magnitude because probably all events of this magnitude are known from the instrumental period beginning in 1898, and the preinstrumental record is reasonably complete at this level in some areas for an additional half-century. All earthquakes with at least one reported magnitude of at least 6.0 have been included in the catalog. Because magnitude is an estimated quantity and has some inherent uncertainty, events with reported magnitudes within a few tenths of a unit of 6.0 are also included. In addition to those earthquakes with cataloged magnitudes, original documents for others with reported high intensities or of particular historical significance have been reexamined in an attempt to refine their locations and magnitudes.

A word of introduction should be added about earthquake locations and magnitude scales and their use in this chapter. Earthquakes are complex physical processes generated by sudden slip on faults, and as such they can only be grossly characterized by simple concepts. Two seismologic conventions are in common use for assigning a single geographic coordinate to an earthquake: One measures the center of energy release, frequently as estimated from the intensity distribution for preinstrumental events; the other measures the location of the initial point of rupture, or hypocenter, as determined from seismic traveltime measurements. Either point on 
the Earth's surface above the hypocenter or the center of the intensity distribution is sometimes referred to as the epicenter, and each type of location appears in table 6.1, with preference given to instrumental epicenters. Fortunately, the geographic differences between these distinct physical measures become significant only for the largest events, $M \approx 7$, when viewed at the scale of the entire San Andreas fault system.

Magnitude, as commonly used to compare the sizes of different earthquakes, also represents an extreme simplification of the earthquake process and by itself cannot fully characterize the size of any event. Traditionally, seismologists have developed a suite of magnitude scales, each with its own purpose and range of validity to measure an earthquake. Because no single magnitude scale can be systematically applied to the entire historical record, a summary magnitude, $M$, is introduced here to facilitate comparisons between events. As described below in the subsection entitled "Quantification of Earthquakes and Magnitude Scales," $M$ is taken as the surface-wave magnitude $\left(M_{S}\right)$, when available, and as a modified intensity magnitude $\left(M_{I}\right)$ during the preinstrumental era. Generally speaking, $M$ provides a better relative measure of the static, geologic increment of fault slip in the earthquake than it does of the severity of shaking.

The earthquake history of California, western Nevada, and northern Baja California presented here has apparent limitations and can doubtlessly be improved through further research. Nevertheless, it provides a firm observational basis for assessing the tectonic implications of the 2-century-long seismic history, as well as of the prospects for future earthquake activity.

\section{PRINCIPAL EARTHQUAKES}

In this section, we briefly discuss some events of particular historical, social, or scientific significance. Although each of the 117 San Andreas fault system events in table 6.1 merits discussion, this task is far beyond the scope of this review, and so the reader is referred to the reports by Richter (1958), Coffman and others (1982), and Townley and Allen (1939) for an introduction to many of these events. Table 6.1 also omits several historically significant events with magnitudes well below the nominal threshold of $M=6$ adopted here, and so it something less than a complete reference on San Andreas seismicity.

My major effort in constructing this catalog has gone into identifying and validating all reported events of $M \geq 6$. Two conspicuous omissions from table 6.1, events that are commonly mentioned in the literature but that could not be substantiated upon further inspection, should be noted. The first is the 1852 earthquake alleged to have ruptured the Big Pine fault (for example, Jennings, 1975). Toppozada and others (1981) failed to find any evidence supporting the occurrence of a major earthquake at that time in the region. Geologic inspection of the surface trace of the fault by M.M. Clark (oral commun., 1988) similarly failed to provide evidence of any historical activity. The other deleted event appears on the seismicity map by Goter (1988) at lat $35^{\circ} \mathrm{N}$., long $125^{\circ} \mathrm{W}$., with an epicenter from the catalog of Abe and Noguchi (1983). Although a large $\left(M_{S}=6.8\right)$ earthquake certainly took place on March 22, 1902, no evidence has been uncovered to support a location anywhere on shore in California or, for that matter, in the Western United States. The original location determined by Milne in 1903 placed the event well off the California-Oregon coast at lat $42^{\circ} \mathrm{N}$., long $130^{\circ} \mathrm{W}$.

\section{JULY 28, $1769(M=6)$}

The earthquake history of California serendipitously begins with the first overland expedition through the State in 1769. In response to the perceived threat posed by Russian expansion into the northern Pacific and growing British presence in the northwestern Pacific, Spain embarked on the colonization of present-day California through the establishment of a series of Franciscan missions, supported by military garrisons at San Diego and Monterey. In the summer of 1769, Gaspar de Portolá led the first expedition from San Diego to establish a land route to Monterey.

On July 28, while camped along the Santa Ana River, about $50 \mathrm{~km}$ southeast of Los Angeles, a sharp earthquake was felt that "*** lasted about half as long as an Ave Maria" (fig. 6.3). From the diaries of three members of the expedition, we know that earthquakes were felt on nearly a daily basis through August 3, as the party traveled northwestward to near San Gabriel and then westward across Los Angeles to the Pacific. The diary of Fray Juan Crespi (Bolton, 1927) mentions no fewer than a dozen aftershocks, some described as violent. After August 4, no further earthquakes were mentioned as the expedition traveled into the San Fernando Valley and exited to the north.

These sketchy reports suggest that the explorers traveled near or through the epicentral area of a moderate earthquake (Richter, 1973; Toppozada and others, 1981). Comparisons between the accounts of the aftershocks and more recent events suggest an event of similar size and location to the 1933 Long Beach, 1971 San Fernando, or 1987 Whittier Narrows earthquake. If significance is placed on the absence of aftershocks while crossing the source region of the 1971 San Fernando earthquake, the evidence would seem to favor a source in the Los Angeles Basin. An event on either the San 
Andreas or San Jacinto faults, some $50 \mathrm{~km}$ to the northeast, could conceivably have been the source of the 1769 earthquake. The description of the duration of strong shaking, however, suggests a magnitude more of 5-6 than of 7-8.

A more distant source would make the long, felt aftershock sequence even more remarkable because it would be well removed from the expedition route.

\section{DECEMBER 8, $1812(M=7)$}

The first of two significant earthquakes to occur in southern California in 1812 occurred on December 8 and destroyed the church at Mission San Juan Capistrano, killing 40 neophytes (fig. 6.4); damage was also sustained

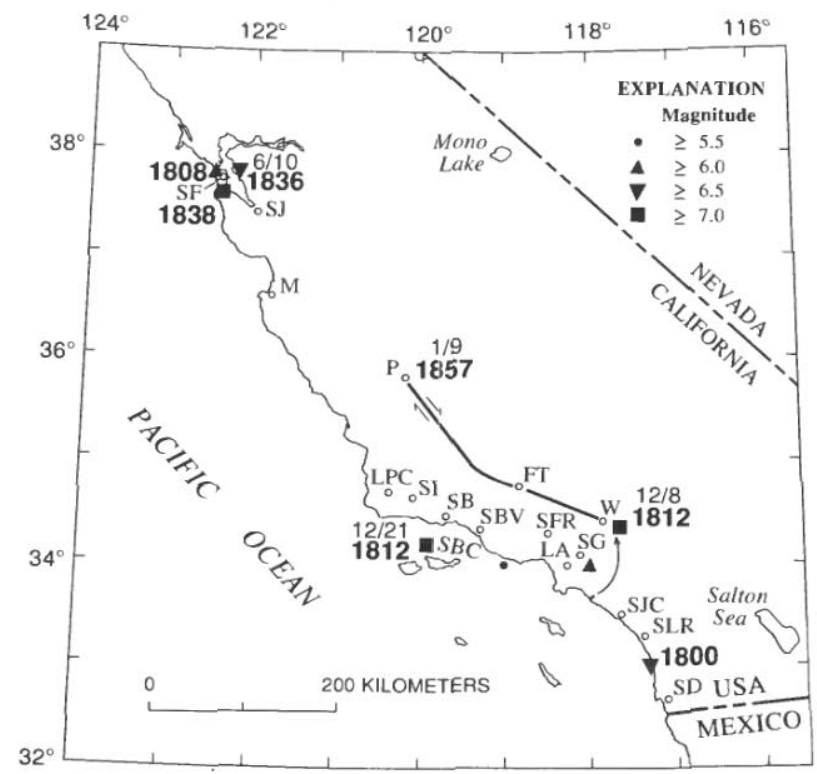

FIGURE 6.3.-Early accounts of significant earthquakes reflect the sparse settlement of California in a narrow coastal corridor before the population explosion accompanying the gold rush in 1849. Accounts of the few well-documented events (dates shown) principally derive from mission records at San Diego (SD), San Luis Rey (SLR), San Juan Capistrano (SJC), San Gabriel (SG), San Fernando Rey (SFR), San Buenaventura (SBV), Santa Barbara (SB), Santa Inez (SI), and La Purisima Concepción (LPC), and from the towns of Los Angeles (LA) and Fort Tejon (FT) in southern California. Accounts from the Spanish capital Monterey (M), San Francisco (SF), and San Jose (SJ), as well as mission sources, detail events in north half of the State. Uncertainties in the interpretation of every event before the great earthquake of 1857 (rupture shown; arrows indicate direction of relative movement) are well illustrated by newly uncovered evidence suggesting a San Andreas origin for the December 8, 1812, shock near Wrightwood (head of connecting arrow), well inland of traditional location along the coastal Newport-Inglewood fault itail of arrow). Earthquake of December 21, 1812, locates in the Santa Barbara Channel (SBC). Foreshocks of the great earthquake of 1857 locate near Parkfield (P), suggesting unilateral rupture propagation to the southeast. at San Gabriel. The accounts of this earthquake and the later one on December 21 cannot be readily disentangled at San Fernando Rey and at San Buenaventura, considerably complicating the interpretation of this event.

Analyses of these scanty data by Toppozada and others (1981) and Evernden and Thompson (1985) place the epicenter along the south half of the Newport-Inglewood fault zone (fig. 6.3). This location is somewhat constrained by the interpretation of no damage at Buenaventura during the event. The Los Angeles Star of January 10, 1857, however, stated that the December 8 event severely damaged the church tower (Agnew and Sieh, 1978). The same story attributed the collapse of the stone arch roof of the church at San Juan Capistrano to poor construction, a possibility made credible by the death of the master mason before completion of the church (fig. 6.3; Duncan Agnew, oral commun., 1988).

Recently, Jacoby and others (1988) proposed that this event ruptured the San Andreas fault at Wrightwood (fig. 6.3), on the basis of dendrochronologic dating of distress to trees growing on the fault trace. Sieh and others (1989) argued that this rupture extended at least $25 \mathrm{~km}$ northwestward into the peat bog at Pallet Creek. The fault rupture in this event preserved at Pallet Creek is comparable in size to the rupture formed in the 1857 earthquake.

The preferred location of the December 8, 1812, earthquake on the San Andreas fault as proposed by Jacoby and others appears in table 6.1. A magnitude of about 7 is consistent with the inferred extent of damage. The lateral extent of rupture is unconstrained to the southeast and may well have extended into the San Bernardino Valley. However, the accounts of the earthquake from Indians living in the San Bernardino Valley that were thought to place some constraint on the rupture are now believed to be fictitious (Harley, 1988), leaving Mission San Gabriel, some $40 \mathrm{~km}$ from the rupture, as the nearest point of observation.

\section{DECEMBER $21,1812(M=7)$}

The second major episode of earthquake activity in 1812 damaged the missions along the Santa Barbara Channel and western Transverse Ranges just 13 days later, on December 21 (fig. 6.3). All investigators place this event in the Santa Barbara Channel and assign a magnitude of about 7 (see Toppozada and others, 1981, and Evernden and Thompson, 1985, for two recent analyses). This sequence appears to have involved two events of comparable magnitude separated in time by about 15 minutes. A vigorous aftershock sequence accompanied the earthquakes and lasted until the end of the year at Mission Santa Barbara and Mission La Purisima Concepción. Reports of a tsunami appear to be exagger- 
ated, although some kind of wave activity probably accompanied the earthquake (Toppozada and others, 1981; McCulloch, 1985).

\section{JUNE $10,1836(M=63 / 4)$}

Little is known about the strong earthquake of June 10, 1836, that struck the then lightly populated San Francisco Bay region. An account of the event, published in the aftermath of the 1868 earthquake, provides the principal rationale for associating this event with the Hayward fault. Louderback (1947) systematically compared the two events and concluded that the 1836 earthquake probably ruptured the Hayward fault. Lindh (1983) proposed that the 1836 event ruptured the north half of the fault, whereas the 1868 event is known to have ruptured the south half, thereby avoiding the paradox of two large events on the same segment separated by a scant 32 years.

\section{JUNE $1838(M=7)$}

The pioneering historical work of Louderback (1947) reveals that a major earthquake with probable rupture of the San Andreas fault occurred in June 1838. Documentation of the event is so poor that its date cannot be fixed more precisely than "late June." Louderback concluded that the shock was comparable in magnitude to the 1906 earthquake. Current opinion suggests a smaller event involving only the $60+-\mathrm{km}$-long segment of the fault on the San Francisco peninsula (Working Group on Earthquake Probabilities, 1988).
JANUARY 9, $1857(M=81 / 4)$

The great Fort Tejon earthquake of January 9, 1857, ruptured $300 \mathrm{~km}$ of the San Andreas fault from near Parkfield to Wrightwood and offset the fault by as much as $9 \frac{1}{2} \mathrm{~m}$ on the Carrizo Plain. The fault rupture and the effects of the earthquake have been extensively studied, notably by Agnew and Sieh (1978) and Sieh (1978b). The epicenter of this event appears to have been at the extreme northwest end of the fault rupture, as determined by the intensity patterns of two $M=6$ foreshocks centered near Parkfield (Sieh, 1978a). Strong shaking lasted from 1 to 3 minutes, consistent with unilateral rupture propagation to the southeast (fig. 6.3).

The earthquake caused only two deaths in the sparsely settled southern California region. Damage was most severe along the fault zone; nearly every building sustained damage at Fort Tejon. In Los Angeles, then a city of about 4,000 people located approximately $60 \mathrm{~km}$ from the fault, some houses were cracked, but none were severely damaged (Agnew and Sieh, 1978). Modified Mercalli intensities (MMI's) of VII or more occurred in the San Fernando Valley, San Gabriel Valley, and Ventura region.

It is natural to compare the 1857 and 1906 earthquakes, the two greatest earthquakes of the San Andreas fault in historical time. The 1906 fault break was longer, whereas maximum and average surface offsets were larger in 1857. These differences approximately balance each other, and so the seismic moments of the two events are approximately equal. Moment magnitudes computed using comparable data are $\boldsymbol{M}=7.8$ for the 1857 earthquake

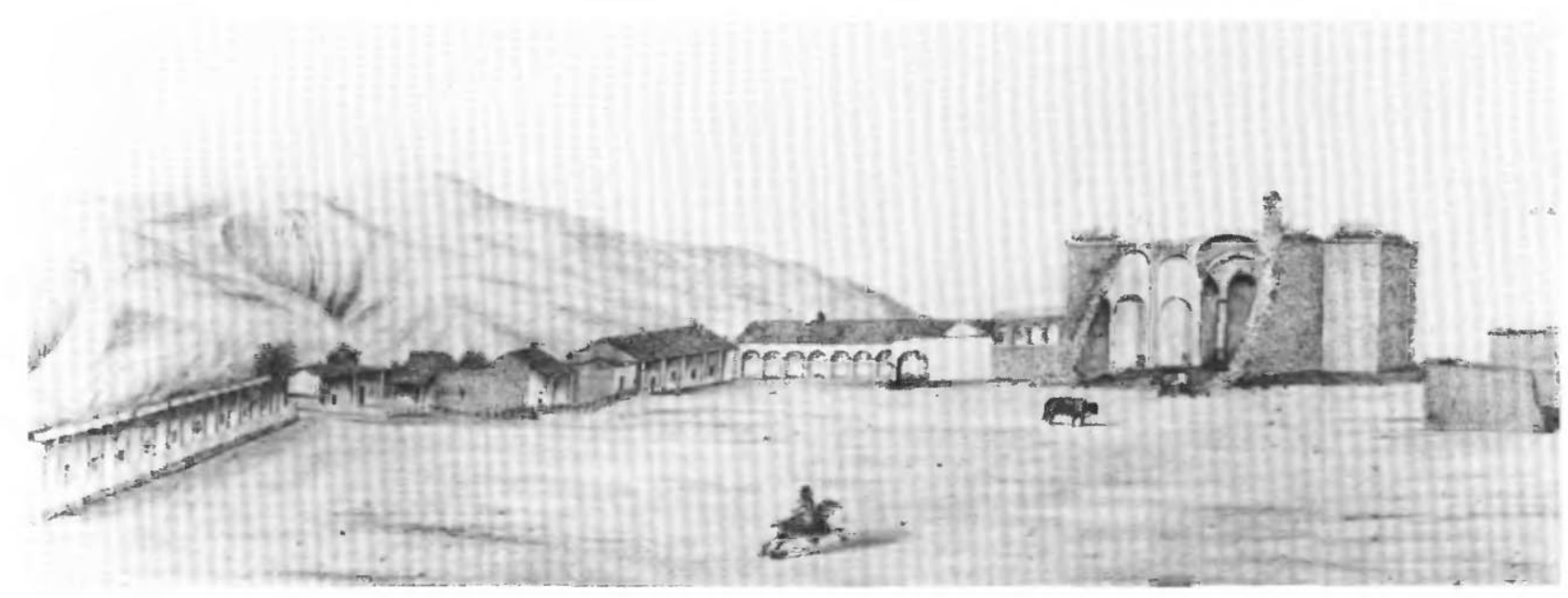

Figure 6.4. - Mission San Juan Capistrano as drawn by Henry Miller in 1856, 43 years after the December 8, 1812, earthquake. Vaulted stone church at right collapsed in that earthquake, killing 40 worshipers. Photograph courtesy of the Bancroft Library. 
and $\mathbf{M}=7.7$ for the 1906 event. A summary magnitude of $M=81 \frac{1}{4}$ was assigned by analogy with the 1906 earthquake.

\section{OCTOBER 21, $1868(M=7)$}

Known as the "great San Francisco earthquake" until 1906, one of California's most destructive earthquakes occurred on October 12, 1868, resulting from slip on the Hayward fault. Heavy damage occurred in communities situated along the fault and in San Francisco and San Jose (fig. 6.5). Sadly, many of the engineering lessons learned from this earthquake and openly discussed at the time, such as the hazards of building on "made ground" reclaimed from the San Francisco Bay or the admonition to "build no more cornices," were long forgotten by the time of the 1906 earthquake.

\section{FEBRUARY 24, $1892(M=7)$}

The strong earthquake of February 24, 1892, located near the United States-Mexican border was assigned to the Agua Caliente fault north of the border by Toppozada and others (1981) and to the Laguna Salada fault in Baja California by Strand (1980). The literature on earthquakes in Baja California contains numerous references to this earthquake as having originated near the Agua Blanca fault, about $100 \mathrm{~km}$ southwest of Strand's epicenter (for example, Richter, 1958). The two recent intensity maps clearly rule out this epicenter and place it on the southern section of the Elsinore fault system.

APRIL 19 AND 21, $1892\left(M=6 \frac{1}{1} / 2\right.$ AND 61/4)

A pair of strong earthquakes rocked the west side of the Sacramento Valley on April 19 and 21, 1892, heavily damaging the towns of Vacaville, Dixon, and Winters. The first shock was stronger and caused heavy damage at Vacaville; the aftershock was more severe at Winters. The earthquakes are reminiscent of the 1983 Coalinga, Calif., earthquake, in that both sequences were positioned along the western margin of the Central Valley. Focal mechanisms of small earthquakes located along this boundary zone show numerous examples of low-anglethrust focal-mechanism solutions of similar orientation to the Coalinga earthquake, in addition to strike-slip mechanisms (see chap. 5; Wong and others, 1988), suggesting the possibility of a similar mechanism for these 1892 earthquakes.

\section{DECEMBER 25, $1899(M=6.4)$}

Heavy damage occurred in the towns of San Jacinto and Hemet, located along the San Jacinto fault, from an earthquake on Christmas Day 1899. Six fatalities were attributed to the earthquake.

$$
\text { APRIL 18, } 1906(M=81 / 4)
$$

The California earthquake of April 18, 1906, ranks as one of the most significant earthquakes of all time. Today, its importance comes more from the wealth of scientific knowledge derived from it than from its sheer size. Rupturing the northernmost $430 \mathrm{~km}$ of the San Andreas fault from northwest of San Juan Bautista to the triple junction at Cape Mendocino (fig. 6.6), the earthquake confounded contemporary geologists with its large, horizontal displacements and great rupture length. Indeed, the significance of the fault and recognition of its large cumulative offset would not be fully appreciated until the advent of plate tectonics more than half a century later. Analysis of the 1906 displacements and strain in the surrounding crust led Reid (1910) to formulate his elastic-rebound theory of the earthquake source, which remains today the principal model of the earthquake cycle.

As a basic reference about the earthquake and the damage it caused, geologic observations of the fault rupture and shaking effects, and other consequences of the earthquake, Lawson's (1908) report remains the authoritative work, as well as arguably the most important study of a single earthquake. In the public's mind, this earthquake is perhaps remembered most for the fire it spawned in San Francisco, giving it the somewhat misleading appellation of the "San Francisco earthquake" (fig. 6.7). Shaking damage, however, was equally severe in many other places along the fault rupture. The frequently quoted value of 700 deaths caused by the earthquake and fire is now believed to underestimate the total loss of life by a factor of 3 or 4 . Most of the fatalities occurred in San Francisco, and 189 were reported elsewhere.

At almost precisely 5:12 a.m. local time, a foreshock occurred with sufficient force to be felt widely throughout the San Francisco Bay area. The great earthquake broke loose some 20 to 25 s later, with an epicenter near San Francisco (Bolt, 1968; Boore, 1977). Violent shocks punctuated the strong shaking, which lasted some 45 to $60 \mathrm{~s}$. The earthquake was felt from southern Oregon to south of Los Angeles and inland as far as central Nevada (fig. 6.6). The highest MMI's of VII to IX paralleled the length of the rupture, extending as far as $80 \mathrm{~km}$ inland from the fault trace. One important characteristic of the shaking intensity noted in Lawson's (1908) report was the clear correlation of intensity with underlying geologic conditions. Areas situated in sediment-filled valleys sustained stronger shaking than nearby bedrock sites, and the strongest shaking occurred in areas where ground 


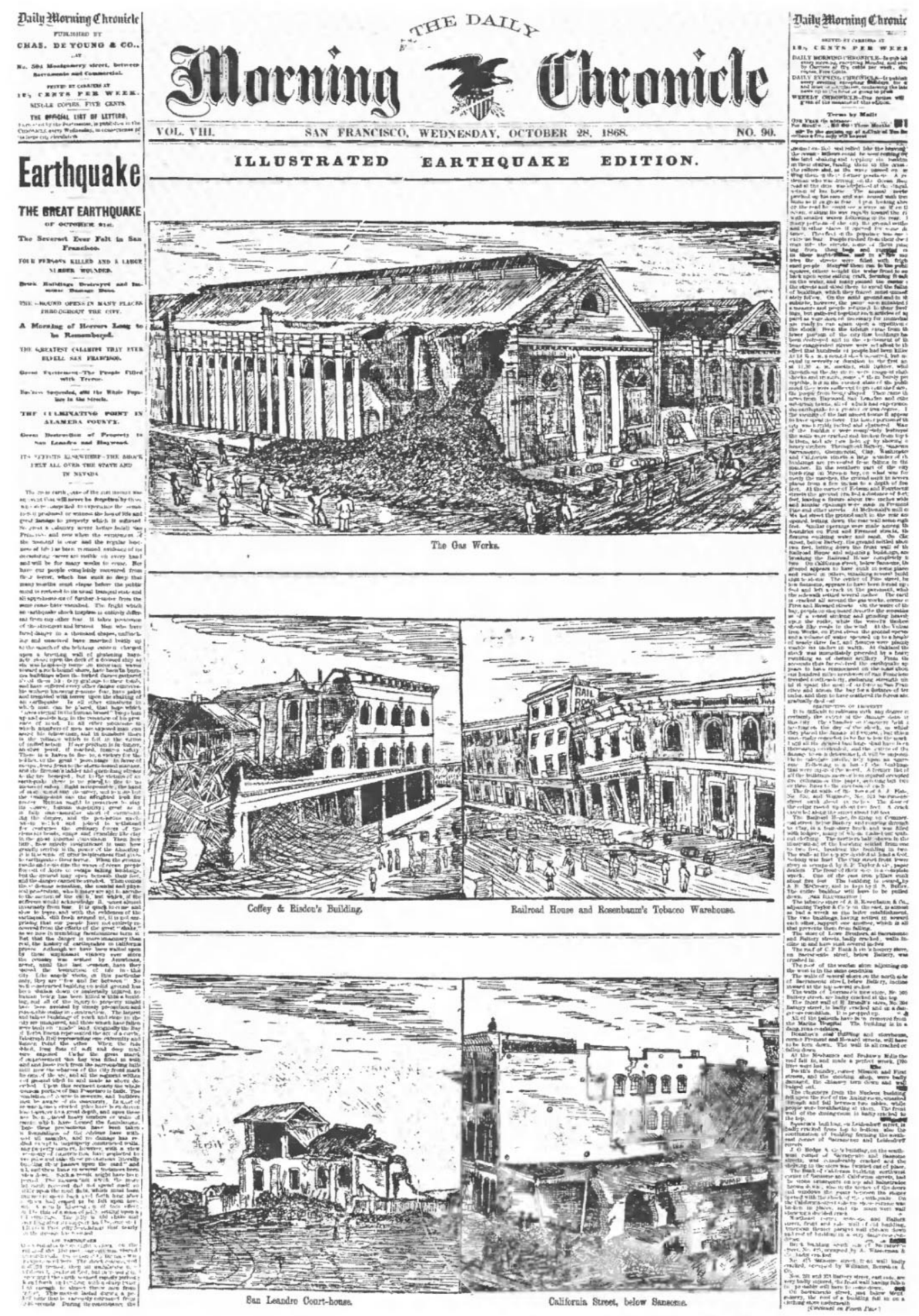

Figure 6.5.-San Francisco Morning Chronicle of October 28, 1868, richly illustrates severe damage sustained by buildings of poor design or located on filled land during earthquake on the Hayward fault. Reduction of this figure from its original publication size has made some type illegible; it is not needed to convey information intended by this illustration. Photograph courtesy of the Bancroft Library. 
reclaimed from San Francisco Bay failed in the earthquake. Modern seismic-zonation practice accounts for the differences in seismic hazard posed by varying geologic conditions (see Borcherdt, 1975, and Ziony, 1985, for analyses of the San Francisco Bay and Los Angeles regions, respectively).

The characteristics and amount of surface fault slip in this earthquake varied to a remarkable degree along the length of the rupture. Peak displacements of $6 \mathrm{~m}$ were measured near Olema on the Point Reyes peninsula, where the surface trace of the rupture formed a sharp, well-defined break (fig. 6.8). In contrast, the fault break was extremely difficult to recognize along its southernmost $90 \mathrm{~km}$, where the surface offset averaged only about $1 \frac{1}{2} \mathrm{~m}$ or less (see chap. 7).

The magnitude of 8.3 commonly quoted for the 1906 earthquake comes from Richter (1958) and, within the precision of reporting, is identical to the $8^{1 / 4}$ listed by Gutenberg and Richter (1954). Table 6.1 also lists other magnitudes for this earthquake, derived from recent analyses of both the same data used by Gutenberg and Richter and new data. Strictly speaking, a "Richter magnitude" $\left(M_{L}\right)$ for the earthquake cannot be determined because no appropriate seismographs were in

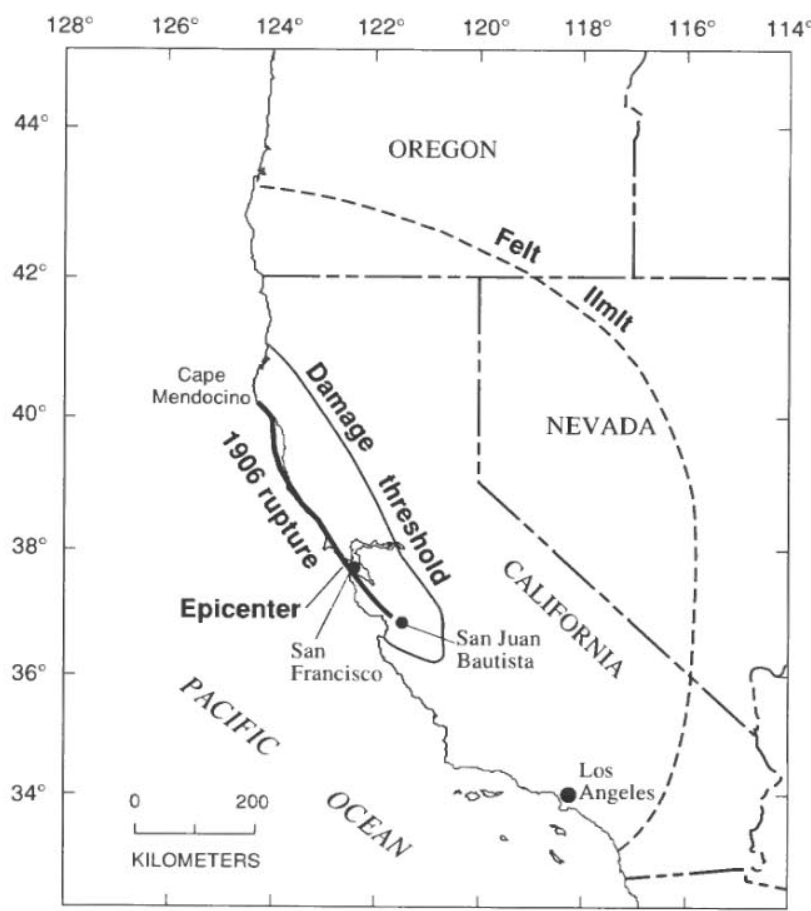

FIGURE 6.6.-California earthquake of 1906 showing extent of fault rupture along the San Andreas fault, location of epicenter near San Francisco, maximum extent of structural damage, and limits of perception of shock. Modified from Lawson (1908) and Toppozada and Parke (1982). operation at the time. Jennings and Kanamori (1979) used related measurements extracted from simple pendulums at Yountville, Calif., and Carson City, Nev., to derive $M_{L}=6.9$, substantially smaller than the traditionally quoted value. $M_{L}$, which is based on the single largest peak on a seismogram at approximately 1 -s period and takes into account neither the duration of the event nor longer period motions, is saturated for this event.

Geller and Kanamori (1977) used the unpublished worksheets of Gutenberg and Richter to compute a body-wave magnitude of $m_{b}=7.4$, using the procedure of Gutenberg and Richter (1956). Because long-period (14 s) $P$-waves were used in this calculation, it cannot be directly compared to the short-period $m_{b}$ values routinely reported today.

Other workers since Gutenberg and Richter have studied the long-period surface waves of the 1906 earthquake and computed $M_{S}$ values. Bolt (1968) confirmed an $M_{S}$ of about $8 \frac{1}{4}$, whereas Lienkaemper (1984) found $M_{S}=$ 8.3 from an analysis of all the records collected by Reid (1910). Lienkaemper's magnitude combined data from both damped and undamped instruments, correcting each for magnification at the appropriate period of motion. Abe (1988), who analyzed only the undamped Milne seismograms, obtained $M_{S}=7.8$, using slightly different procedures and a systematic set of station-magnitude corrections. Also, the four damped seismometers (all in Europe) give $M_{S}=8.1$. Longer period (50-100 s) surface waves analyzed by Thatcher (1975) indicate a seismic moment of $4 \times 10^{27}$ dyne-cm, equivalent to $\mathbf{M}=7.7$, in agreement with the seismic moment of $5 \times 10^{27}$ dyne-cm obtained from geodetic data, thus giving $\mathbf{M}=7.8$ (Thatcher and Lisowski, 1987). Finally, Toppozada and Parke (1982) assigned an intensity magnitude $\left(M_{I}\right)$ of 7.8 on the basis of the total area $\left(48,000 \mathrm{~km}^{2}\right)$ undergoing shaking of MMI VII or higher.

The "traditional" magnitude of $8 \frac{1 / 4}{4}$ is retained here, except where seismic moment is used for quantitative purposes.

\section{NOVEMBER 21, $1915(M=7.1)$}

The major earthquake of November 21, 1915, triggered a spectacular steam eruption of a mud volcano, creating a $100+-m$ crater in Volcano Lake, Baja California, near the north terminus of the Cerro Prieto fault. Extensive cracking of the levee around the lake was noted at the time of the shock, but no tectonic ground displacements were found (Seismological Society of America Bulletin, 1916). This event may well be related to the November 29,1852 , earthquake $(M=61 / 2 \pm)$, which also triggered a mud-volcano eruption at Volcano Lake that was observed at Fort Yuma, Ariz. Each of these events was probably associated with the Cerro Prieto fault. 
APRIL 21, $1918(M=6.9)$

The communities of Hemet and San Jacinto were severely damaged for the second time in 19 years by the large earthquake of April 21, 1918, on the San Jacinto fault. Both the 1899 and 1918 earthquakes produced similar intensity patterns throughout the southern California region, and these two events have been compared to each other. However, surface waves on Milne seismograms at common stations (Victoria, British Colombia, and Toronto, Ontario, Canada; San Fernando, Spain) average 3 times larger for the 1918 earthquake, corresponding to a difference in $M_{S}$ of $1 / 2$ unit. As with the 1836 and 1868 earthquakes on the Hayward fault, the relation between the rupture zones in these two events is unclear. Surprisingly, no surface rupture was found for an event of this size, despite a specific search for it.

\section{NOVEMBER 4, $1927(M=7.3)$}

The Lompoc earthquake of November 4, 1927, is the largest known event in the San Andreas system west of the San Andreas fault proper. This event produced a tsunami with local runup heights of 1.5 to $1.8 \mathrm{~m}$ (McCulloch, 1985). The exact location of the earthquake and its association with any causative structure remain the subject of a spirited debate (Gawthrop, 1978, 1981; Hanks 1979, 1981).

\section{MARCH $11,1933(M=6.3)$}

Rupture of the Newport-Inglewood fault on March 11, 1933, caused major damage and a loss of 115 lives in Long Beach and surrounding parts of the Los Angeles Basin. Structural damage to public schools was particularly serious, and had the event occurred when schools were in session, the calamity would have been far worse. The Field Act, mandating construction standards for schools in California, was enacted as a consequence of the earthquake.

\section{DECEMBER 30 AND $31,1934(M=6.5$ AND 7.0$)$}

The major sequence that occurred along the Cerro Prieto fault on December 30 and 31, 1934, appears to

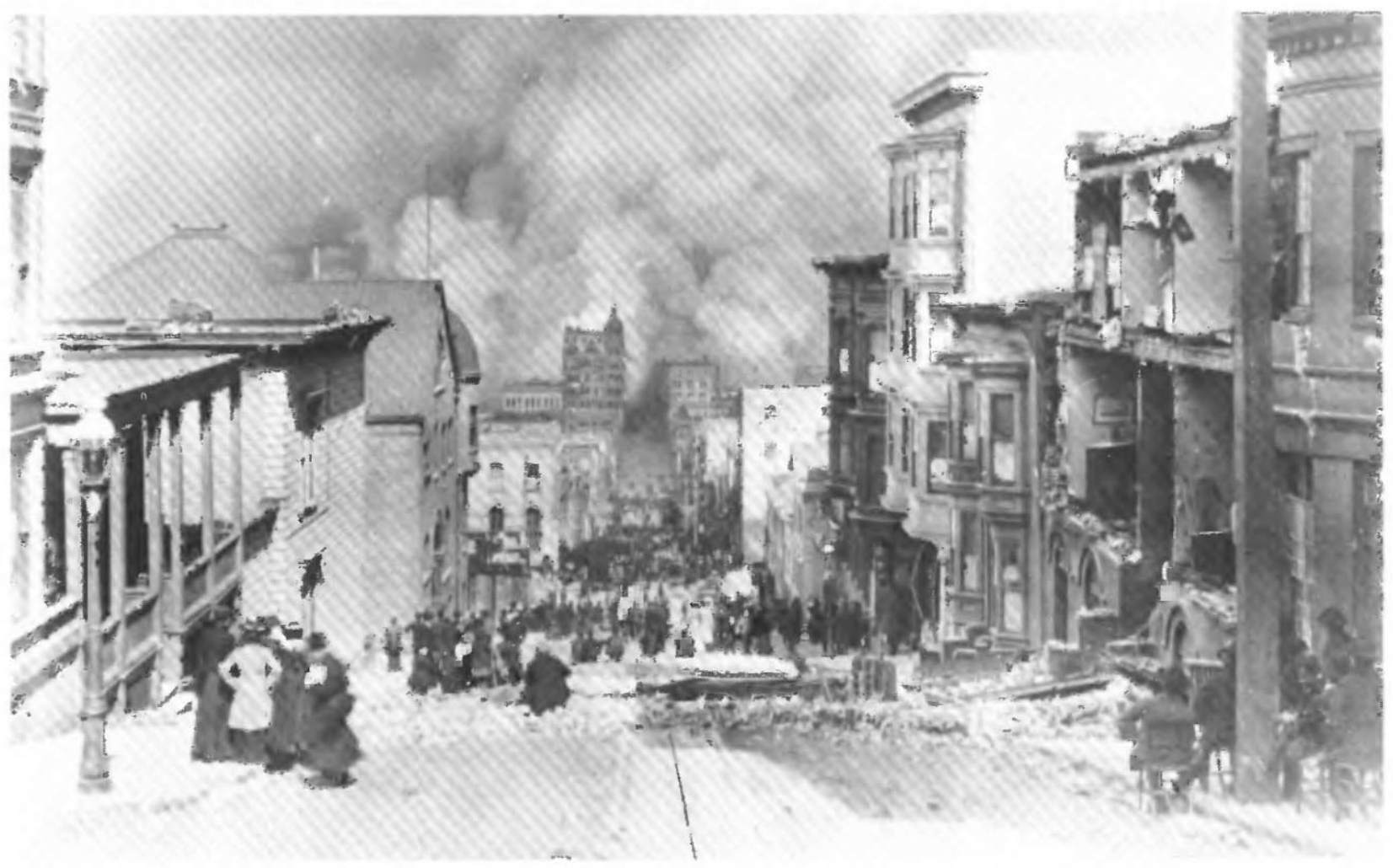

FIGURE 6.7. -San Francisco, Calif., on the morning of April 18, 1906. This famous photograph by Arnold Genthe shows Sacramento Street and approaching fire in the distance. Although some buildings sustained heavy damage in the earthquake, this and many other photographs taken of the city before fire swept through show no visible evidence of damage in most structures. Photograph courtesy of the Fine Arts Museums of San Francisco, Achenbach Foundation for Graphic Arts. 
have ruptured the surface trace of the fault near where it enters the Gulf of California. Aerial photographs of the fault crossing a tidal flat taken in 1935 show very fresh appearing fault morphology; subsequent photographs display a substantially subdued morphology (Kovach and others, 1962).

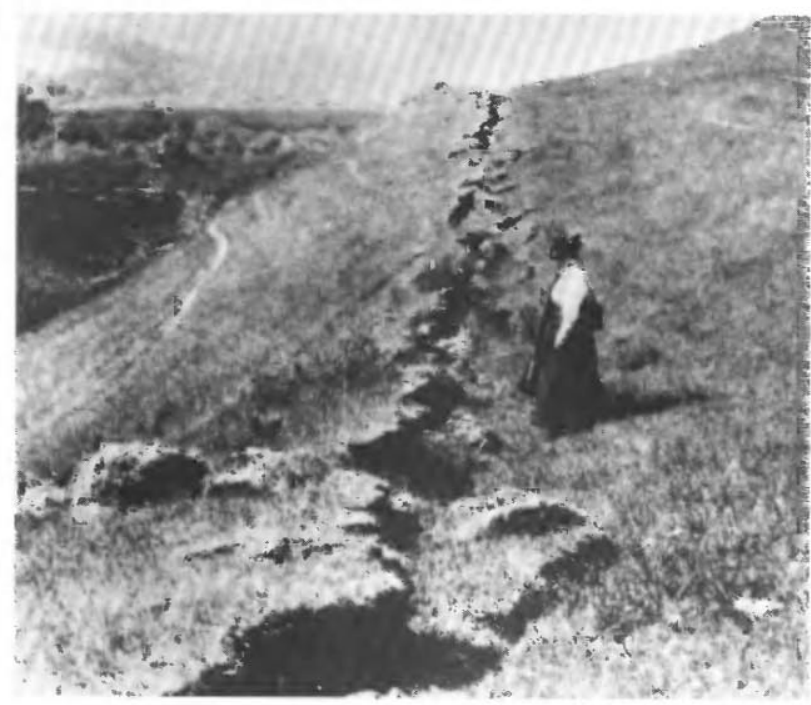

FIGURE 6.8. - Trace of 1906 earthquake rupture near point of maximum offset $(6 \mathrm{~m})$ near Olema on the Point Reyes peninsula north of San Francisco. Photograph by G.K. Gilbert. View northwestward.
MAY $19,1940(M=7.1)$

The Imperial fault was discovered from its $60+-$ $\mathrm{km}$-long rupture in the Imperial Valley earthquake of May 19, 1940. Faulting was predominantly right-lateral strike slip and attained a peak offset of more than $6 \mathrm{~m}$ at the United States-Mexican border (fig. 6.9). The first instrumental measurement of strong ground motion adjacent to a fault rupture was obtained from an accelerograph located about $7 \mathrm{~km}$ from the surface trace. This record, which provides clear evidence of irregular seismic-energy release during the course of the event (Trifunac and Brune, 1970), has played a major role in shaping building codes for earthquake-resistant design.

\section{JULY 21, $1952(M=7.7)$}

The Kern County or Arvin-Tehachapi earthquake of July 21, 1952, ruptured the White Wolf fault in the largest event to strike California since 1906. The earthquake led to 12 fatalities, and 2 more occurred during a large aftershock on August 22. Field studies of the earthquake (Oakeshott, 1955) describe the geologic, seismologic, and engineering aspects of the earthquake. From a tectonic standpoint, this event is notable for its conjugate relation to the San Andreas fault. Left-lateral slip with a significant reverse-slip component occurred on the northeast-striking, south-dipping fault plane.

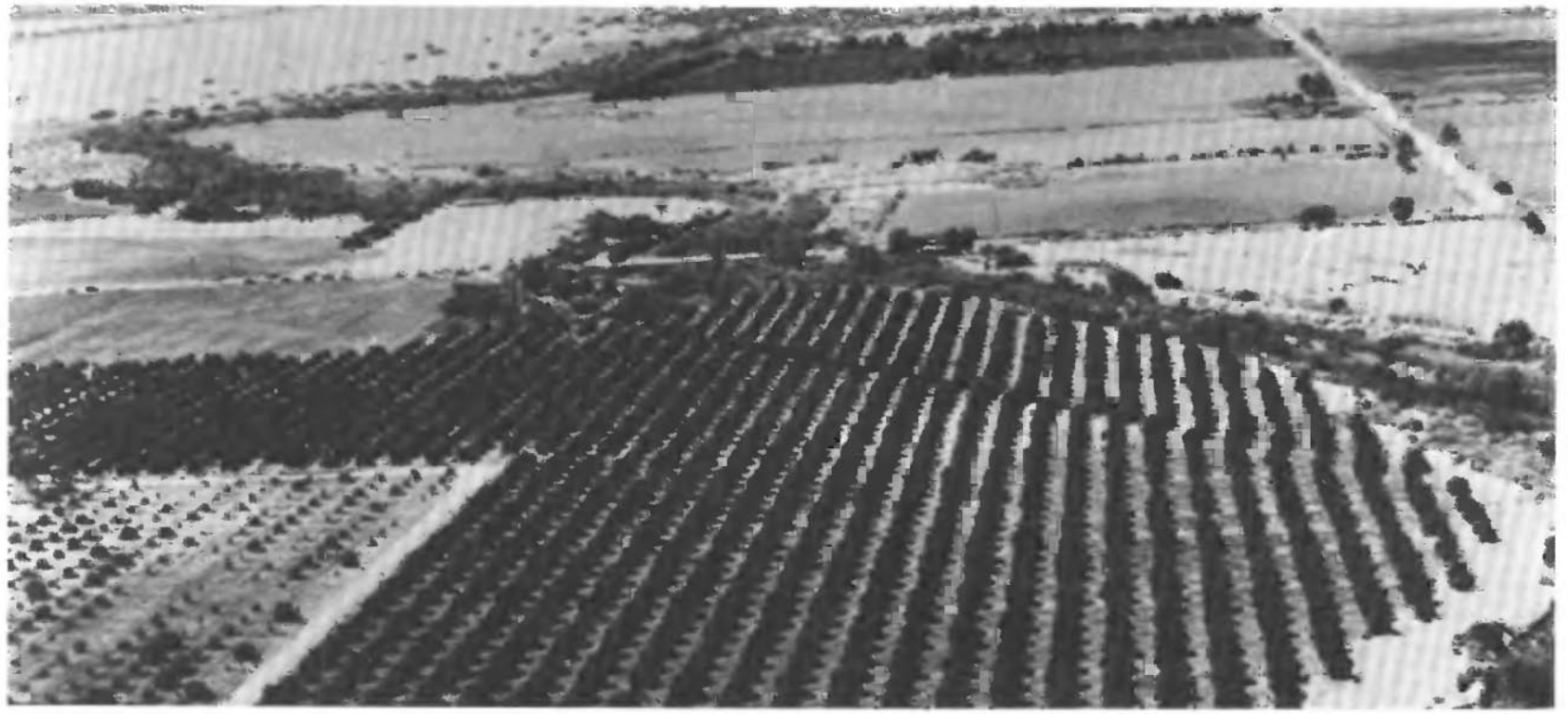

FIGURE 6.9. - Surface faulting in 1940 Imperial Valley earthquake offset $(6 \mathrm{~m})$ regular rows of orange trees. Fault displacement along this section of the Imperial fault was confined to a narrow zone. 


\section{FEBRUARY 9, $1956(M=6.8)$}

More than $19 \mathrm{~km}$ of the hitherto-unknown San Miguel fault in Baja California ruptured in the earthquake sequence of February 9, 1956. The fault offset was consistently right lateral and up to the northwest, and attained maximum horizontal and vertical separations of 78 and $91 \mathrm{~cm}$, respectively (Shor and Roberts, 1958). The sequence contained numerous aftershocks, including three of $M \geq 6$. About 2 years earlier, a pair of $M=6$ events that occurred to the south and west of the San Miguel fault may have been associated with the Agua Blanca fault.

APRIL 9, $1968(M=6.5)$

The Borrego Mountain earthquake of April 9, 1968, produced the first documented rupture of the San Jacinto fault system when right-lateral displacements of nearly $0.4 \mathrm{~m}$ occurred along a $30-\mathrm{km}$-long segment of the Coyote Creek fault. The U.S. Geological Survey (1972) published a detailed description of the event.

\section{FEBRUARY 9, $1971(M=6.5)$}

The San Fernando earthquake of February 9, 1971, ranks as one of the most serious California earthquakes in historical time. The event claimed 58 lives and caused more than half a billion dollars in property damage, including the destruction of two hospitals, a freeway interchange, and the Van Norman Dam. The earthquake ruptured north-dipping, high-angle reverse faults beneath the southern margin of the San Gabriel Mountains and broke the surface along a discontinuous, $15-\mathrm{km}$-long zone. Surface displacements averaged about $1 \mathrm{~m}$. Seismograms of the earthquake reveal a steeply dipping deep fault and a more shallowly dipping near-surface fault (Langston, 1978; Heaton, 1982). Numerous publications report on detailed investigations of this event, including the summary report published by the U.S. Geological Survey (1971).

\section{OCTOBER $15,1979(M=6.5)$}

The Imperial fault ruptured for the second time in less than 40 years in a major surface-faulting earthquake on October 15, 1979 (U.S. Geological Survey, 1982). The event broke the north $30 \mathrm{~km}$ of the fault, or approximately half the length of the 1940 fault break. However, it was clearly much smaller than the earlier event; maximum surface offsets were well under $1 \mathrm{~m}$, in contrast to $6 \mathrm{~m}$ observed in 1940, and the seismic moment was smaller by nearly an order of magnitude. Within the zone of overlapping surface rupture, the two events display nearly identical displacement profiles (Sharp, 1982), suggesting that the 1979 earthquake represents a characteristic rupture of this segment of the fault. Strong-groundmotion records for the 1979 earthquake form an unparalleled suite of near-field recordings and have stimulated numerous investigations into the dynamics of the source.

$$
\text { MAY 2, } 1983(M=6.5)
$$

Our understanding of the nature of the earthquake hazard posed by active faults in the San Andreas fault system was fundamentally altered by the occurrence of the Coalinga earthquake of May 2, 1983, on a low-angle thrust fault deep beneath the western margin of the San Joaquin Valley (Rymer and Ellsworth, 1990). Before this event, it had been thought that the major, seismically active faults in California could be recognized on the basis of their surface exposures and record of late Quaternary activity. However, no surface expression exists for the fault system responsible for either this event or the $M=5.9$ North Kettleman Hills earthquake of August 4, 1985 , that adjoins it to the southeast. Instead of a surface fault, the buried deformation is expressed at the surface by active folds (the Coalinga anticline and the Kettleman Hills) that grew during the earthquakes (Stein and King, 1984).

The orientation of the fault and the style of movement on it present another major challenge to prevailing models of the San Andreas system, because this earthquake resulted from a release of compressive forces oriented nearly perpendicular to the trace of the San Andreas fault. Accumulating evidence on the orientation of the stress field astride the San Andreas fault suggests that only a small component of the total stress acts to accommodate the plate motion along the San Andreas fault itself (Mount and Suppe, 1987; Zoback and others, 1987).

NOVEMBER 24, $1987(M=6.6)$

The Superstition Hills fault ruptured in its entirety on November 24, 1987. The total amount of separation substantially increased by persistent afterslip in the months after the main shock; in fact, the rate of afterslip was so great on the south half of the surface break as to leave open the possibility that all of its displacement occurred as afterslip. The earthquake was preceded by a major foreshock $(M=6.2)$, on a conjugate, northeasttrending, left-lateral strike-slip fault that intersected the Superstition Hills fault at the main-shock epicenter. The surface-faulting pattern of the entire sequence was particularly remarkable for the occurrence of numerous breaks on other conjugate faults in the north quadrant around the main break (see Hanks and Allen, 1989). 
OCTOBER 18, $1989(M=7.1)$

In the late afternoon of October 17, 1989, the San Andreas fault ruptured in its first major earthquake since 1906 at 5:04 p.m. P.d.t. (0004 G.m.t. on Oct. 18). Centered along a remote segment of the fault in the southern Santa Cruz Mountains, the Loma Prieta earthquake reruptured the southernmost $40 \mathrm{~km}$ of the 1906 fault break, producing the Nation's most costly natural disaster. The earthquake claimed 62 lives and injured an additional 3,757 people. It destroyed 963 homes and damaged more than 18,000 others, displacing 12,000 people from their residences. The combined dollar loss to the private and public sectors exceeded $\$ 6$ billion (Plafker and Galloway, 1989).

Damage in the epicentral region was most severe where the earthquake shaking was compounded by local ground failures, commonly involving landslide movement but also including some fractures of probable tectonic origin; the shaking clearly reactivated some fissures observed in 1906. Primary fault displacement, however, did not reach the surface. In the hard-hit communities of Santa Cruz, Watsonville, and Los Gatos, unreinforcedmasonry buildings bore the brunt to the damage, and ground conditions played a significant role in the damage patterns.

The earthquake also caused grave damage and claimed the greatest number of lives far to the north, in San Francisco and Oakland, about $100 \mathrm{~km}$ from the epicenter. There, the earthquake selectively destroyed structures known to be at risk or located on poor ground (Plafker and Galloway, 1989). The root cause of the devastation in the Marina District of San Francisco (fig. 6.10), as well as at most other sites along the margin of the San Francisco Bay, was liquefaction-induced ground failure. All of these localities sit on land reclaimed from the bay and are underlain by young, water-saturated sedimentary deposits. As we know from the clear lessons of history, provided by the earthquakes of 1865, 1868, and 1906 (Lawson, 1908), such materials perform poorly even under modest levels of earthquake shaking. The collapse of the double-decked section of California Interstate Highway 880 in Oakland (fig. 6.10), where 41 people died, resulted principally from design defects. The section of the viaduct that collapsed was founded on soft estuarine sedimentary deposits that amplified the strong ground motion; the adjoining section, founded on alluvium, rode through the earthquake.

The earthquake broke the San Andreas fault where it makes a conspicuous leftward bend, connecting straighter subparallel segments to the north and south. The fault plane dips $70^{\circ} \mathrm{SW}$., and movement in the earthquake involved comparable amounts of right-lateral strike slip and reverse slip, a kinematic response driven by the need to remove material from this compressional fault bend as the Pacific plate moves to the northwest around it. The rupture nucleated at the base of the seismic zone, at $18-\mathrm{km}$ depth, and spread unilaterally upward and bilaterally along strike, filling a conspicuous void in the preevent seismicity. Geodetic data collected immediately after the event suggest an average strike-slip displacement of $1.6 \mathrm{~m}$ and an average reverse-slip displacement of $1.2 \mathrm{~m}$, rising from the hypocenter at $18 \mathrm{~km}$ to within 6 $\mathrm{km}$ of the surface.

The Loma Prieta earthquake fulfilled a long-term forecast for the rupture of this specific segment of the San Andreas fault (Lindh, 1983; Sykes and Nishenko,
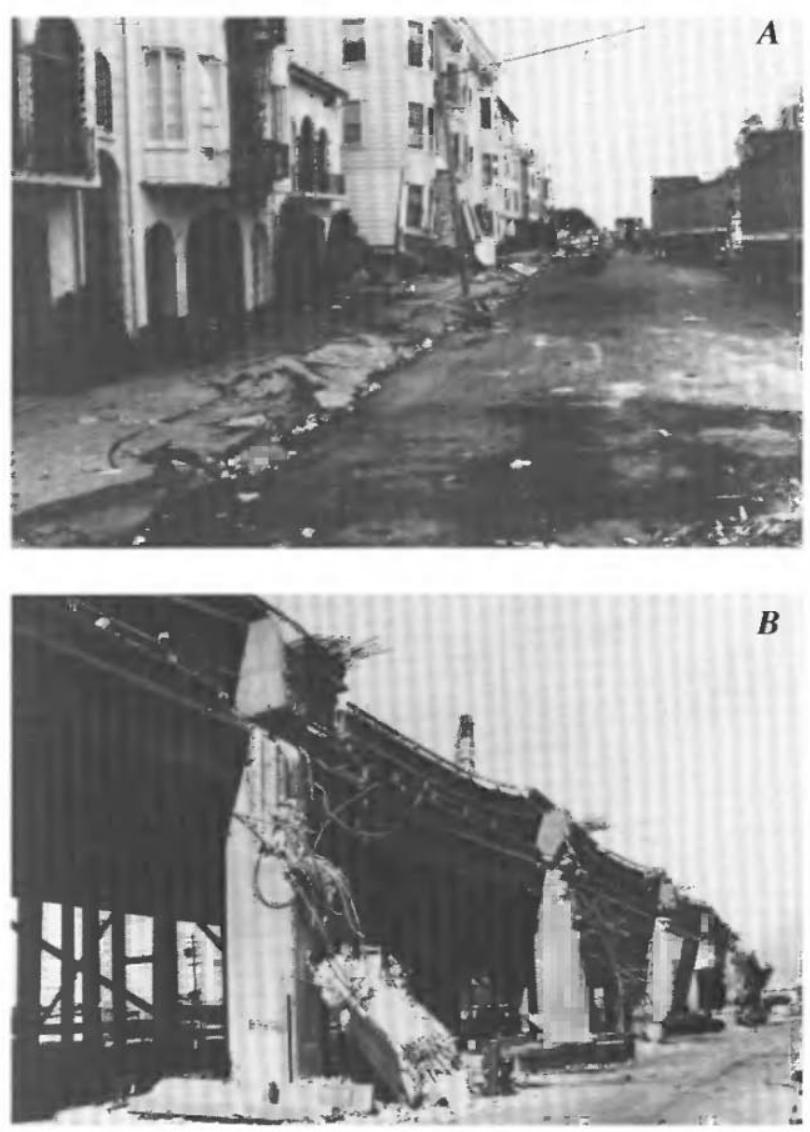

Figure 6.10.-Damage in October 18, 1989, Loma Prieta earthquake occurred at distances as far as $100 \mathrm{~km}$ from the epicenter in areas underlain by water-saturated, unconsolidated material. $A$, Liquefaction-induced ground failure in the Marina district of San Francisco (top) was restricted to land reclaimed from the San Francisco Bay. B, In Oakland, the second deck of Interstate Highway 880 collapsed onto the first deck. Here, poor design was the principal culprit, although failed section sits atop estuarine sedimentary deposits that amplified the shaking. 
1984; Working Group on California Earthquake Probabilities, 1988). The high earthquake potential assigned to this segment stemmed from its behavior in the 1906 earthquake, when the fault displacement, as measured at the surface, averaged about $1.5 \mathrm{~m}$, far less than the average for the entire rupture. Estimates of the longterm slip rate along this segment of the San Andreas fault suggested that the strain released in the 1906 earthquake would be renewed in 75 to 136 years, implying that another earthquake was possible in the coming decades. With its occurrence, the Loma Prieta earthquake became the second event in 2 years to fill a recognized seismic gap along the San Andreas; the first was the 1987 Superstition Hills earthquake. The Loma Prieta earthquake also represents the third historical rupture of this segment of the San Andreas fault; the first was the October 8, 1865, earthquake, nominally assigned $M=6 \frac{1}{2}$, which also caused liquefaction-induced ground failure in San Francisco.

\section{SEISMICITY OF THE WESTERN BASIN AND RANGE PROVINCE}

The advent of plate tectonics and its application to western North America by Atwater (1970) provided a unifying framework for the contemporary tectonics of the western Basin and Range and its interaction with the San Andreas fault system to the west. Deformation within the province reflects soft coupling of the San Andreas fault system to the North American craton and distribution of the relative plate motion-by mechanisms yet unknown-well over $500 \mathrm{~km}$ into the continental interior. The ubiquity of normal-fault-bounded ranges throughout the province tends to belie the underlying nature of present-day deformation within the region. Within historical time, this region has undergone nearly equal proportions of extension on normal faults and dextral shear on strike-slip faults.

The earthquake history of the western Basin and Range province is poorly known before the instrumental period, owing to sparse settlement of this high-desert region. The deficiencies of this record are illustrated by the uncertainties associated with fresh-appearing fault scarps discovered in 1911 near the north end of what would become the rupture zone of the 1954 Fairview Peak earthquake. Upon reviewing the scant historical evidence, Slemmons and others (1959) concluded that these scarps formed about 1903 . The absence of an event of sufficient size in the instrumental record, however, suggests that the scarp forming event is older (or substantially smaller than $M=6$ ). Current understanding of 19th-century seismicity includes an episode of activity along the California-Nevada State line, including a probable rupture of the Olinghouse fault on December 27,
1869 (Sanders and Slemmons, 1979), although this conclusion was questioned by Toppozada and others (1981).

Surface faulting has accompanied numerous earthquakes in the region, the most significant of which are discussed below. Notable additional surface-faulting events include the $M=6.3$ Excelsior Mountain, Nev., earthquake of 1934 and the $M_{L}=5.6$ Fort Sage Mountain earthquake of December 14, 1950, located in northeastern California (Gianella, 1957). Ground rupture may have also accompanied the $M=6$ earthquake of January 24, 1875 (see Gianella, 1957). If so, this observation would move the epicenter listed in table 6.1 to lat $39^{3} / 4^{\circ} \mathrm{N}$., long $120^{1} / 2^{\circ} \mathrm{W}$.

\section{PRINCIPAL EARTHQUAKES}

MARCH $26,1872(M=7.6)$

The town of Lone Pine, Calif., was virtually leveled when the entire 100 to $110-\mathrm{km}$ length of the Owens Valley fault ruptured on March 26, 1872, in one of the largest earthquakes in U.S. history. This fault, which lies in the middle of Owens Valley, is distinct from the normal faults bounding the front of the Sierra Nevada to the west. Considerable confusion has existed in the literature regarding the style of faulting in the 1872 earthquake, including interpretations of right-lateral, left-lateral, and normal-fault movement. A recent study of the earthquake offsets by Beanland and Clark (in press) unambiguously demonstrates that fault movement was predominately right-lateral strike slip, with an average horizontal displacement of $6 \mathrm{~m}$ (fig. 6.10). The vertical offsets were clearly smaller and averaged about $1 \mathrm{~m}$ down to the east. Beanland and Clark estimate a moment magnitude of $\mathbf{M}=7.5-7.7$. Faulting in 1872 largely reactivated earlier Holocene scarps, as recognized by G.K. Gilbert when he visited the area in 1883 .

The event was felt throughout most of California and Nevada, and as far east as Salt Lake City, Utah. Adobe and brick buildings in Owens Valley sustained the brunt of the damage. Minor damage also occurred in the San Joaquin and Sacramento Valleys on the opposite side of the Sierra Nevada, at distances of as far as $400 \mathrm{~km}$. In Yosemite Valley, John Muir witnessed a spectacular rockfall triggered by the earthquake. As severe as the ground shaking must have been, it was noted in the Inyo, Calif., Independent of April 6,1982, “*** that not a person would have been killed or hurt had their houses all been made of wood." It is of some historical interest that the first long-term earthquake forecast, made by G.K. Gilbert in 1883 to the citizens of Salt Lake City, was based in part on his observations of the 1872 earthquake. In it, he noted that the rebuilding of Independence with wood-frame buildings was an extravagance, because this 
great shock had relieved the accumulated strain, and so many generations would pass before conditions would permit another similar shock to occur (Gilbert, 1884):

The old maxim, "Lightning never strikes in the same spot twice" is unsound in theory and false in fact; but something similar might truly be said about earthquakes. The spot which is the focus of an earthquake (of the type here discussed [1872 Owens Valley]) is thereby exempted for a long time.

Many comparisons have been drawn between the Owens Valley earthquake and the great San Andreas earthquakes of 1857 and 1906. The size of the regions shaken in all three events are comparable, as are the maximum fault displacements. The two San Andreas events have significantly longer rupture lengths, and their seismic moments are larger by a factor of 2 to 3 . Whether or not any or all of these earthquakes can be classified as "great" earthquakes becomes a question of semantics. All of them can be classified as great on the basis of their rupture lengths of $100 \mathrm{~km}$ or more (Kanamori, 1977), but they all have seismic moments more than 100 times smaller than the largest known earthquakes, such as the $\mathbf{M}=9.2$ Alaska earthquake of 1964 . Practically speaking, these events are among the largest known strike-slip events, and they must be close to the size of the largest possible strike-slip events along the San Andreas fault system.

\section{OCTOBER 3, $1915(M=7.3)$}

The 1915 Pleasant Valley, Nev., earthquake of October 15,1915 , created a series of spectacular normal-fault scarps in the central Nevada seismic zone of the Basin and Range province (figs. 6.11, 6.12). Four major scarps formed during the earthquake, with an aggregate length of $59 \mathrm{~km}$, and reruptured Holocene scarps at the base of the mountain blocks (Wallace, 1984). Fault movement in the earthquake appears to have been purely dip slip and averaged about $2 \mathrm{~m}$ on the steeply dipping fault plane. The earthquake was felt from western Utah to the Pacific coast and from northeastern Oregon to the United States-Mexican border. Instrumental measures of the magnitude range from 7.3 to $73 / 4$ and exceed the moment magnitude of 7.2 derived from field measurements $\left(M_{0}=6.1 \times 10^{27}\right.$ dyne-cm).

The Pleasant Valley earthquake lies at the north end of a 500 -km-long belt of historical surface-faulting earthquakes within the central Nevada seismic zone and Owens Valley fault system. The four major earthquake sequences in this zone since 1872 leave two conspicuous seismic gaps that have been discussed as the potential loci of future major earthquake activity (fig. 6.11; Wallace, 1984).
DECEMBER $21,1932(M=7.2)$

The second historical surface-faulting event in the central Nevada seismic zone on December 21, 1932, produced a discontinuous zone of surface faulting and fissures in the valleys west and north of Cedar Mountain (Gianella and Callaghan, 1934). Within the 60-km-long, north-northwest-trending zone where faulting was observed, most breaks struck east of north and showed clear evidence of right-lateral displacements (fig. 6.11).

\section{JULY 6, $1954(M=6.6)$, AND AUGUST 24, $1954(M=6.8)$}

The Rainbow Mountain earthquakes of July 6 and August 24, 1954, produced a zone of east-facing normalfault scarps along the base of Rainbow Mountain, extend-

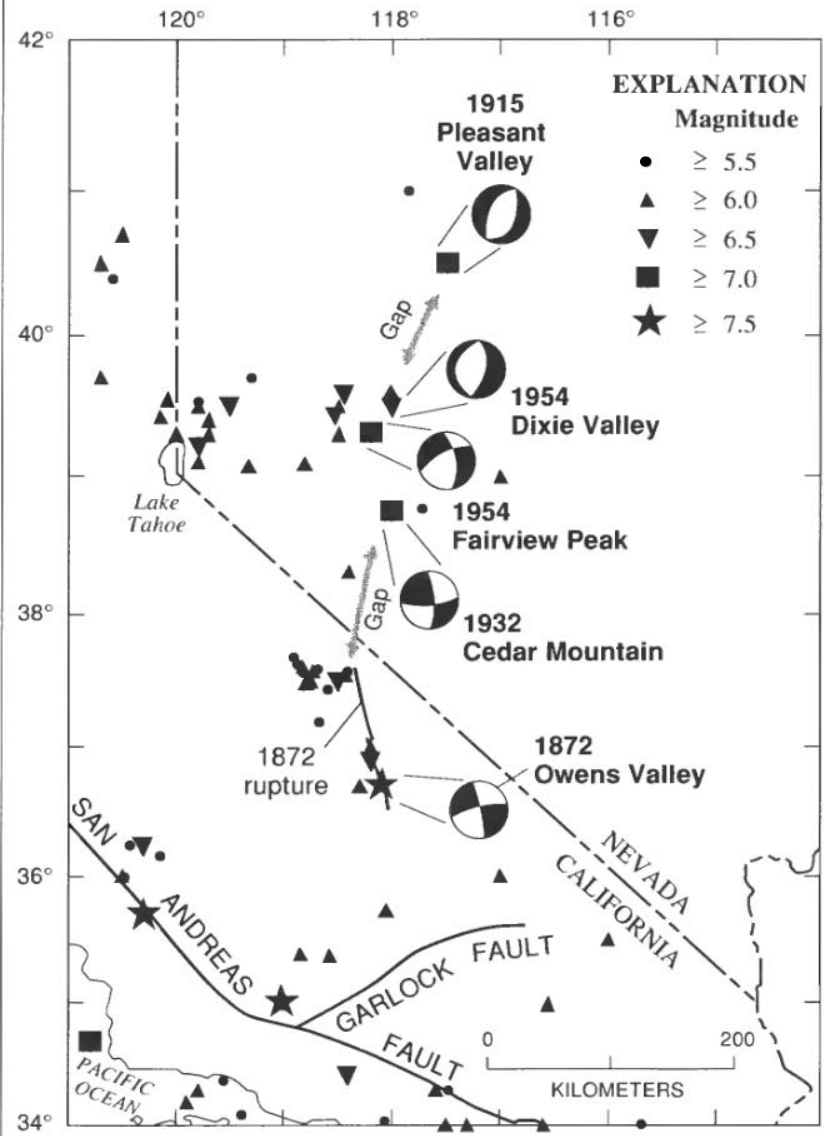

FIGURE 6.11.-California-Nevada region, showing locations of major historical earthquakes in the western Basin and Range province, 1857-1989. Focal mechanisms of five largest events in lower-hemisphere projection show compressional quadrant shaded and indicate significant shear as well as extensional strain in province. Seismic gaps (labeled) are potential loci of future major earthquake activity (Wallace, 1984). 
ing northward into the Carson Sink. The July 6 event produced an 18-km-long surface rupture at the south end of this zone striking N. $15^{\circ} \mathrm{E}$., with maximum displacements of about $30 \mathrm{~cm}$. The August 24 shock extended the zone by $22 \mathrm{~km}$ in a N. $20^{\circ} \mathrm{E}$. direction, with as much as $75 \mathrm{~cm}$ of normal-fault slip. Tocher (1956) noted that the displacement on the northern part of the July 6 break approximately doubled in amplitude between July 16 and September 9; the timing of the additional slip could not be determined.

\section{DECEMBER $16,1954(M=7.1$ AND 6.8$)$}

The Dixie Valley-Fairview Peak earthquakes of December 16, 1954, produced a 90-km-long zone of rightlateral oblique and normal faulting in the central Nevada seismic zone (fig. 6.11; Slemmons, 1957). The first shock, which occurred east of Fairview Peak, produced lateral displacements of more than $4 \mathrm{~m}$ and vertical displacements of as much as $3 \mathrm{~m}$. Faulting along this $50-\mathrm{km}$-long zone was predominantly down to the east opposite Fairview Peak and changed polarity to the north. The second shock, which occurred 4 minutes later, had an epicenter on the east side of Dixie Valley in a leftstepping echelon arrangement with the earlier event. Normal-fault scarps formed along a $40-\mathrm{km}$-long zone at the base of the Stillwater Range some $20 \mathrm{~km}$ west of the
Rainbow Mountain faulting. Vertical displacements exceeded $2 \mathrm{~m}$, and consistent strike-slip displacements were absent.

\section{JULY 21, $1986(M=6.2)$}

The Chalfant Valley earthquake of July 21, 1986, is the largest event to date in a series of 33 earthquakes of $M_{L} \geq 5$ to occur since 1978 in the White Mountain seismic gap (Savage and Cockerham, 1987). Other principal events in this series include the May 25-27, 1980, Mammoth Lakes earthquakes $(M=6.1,5.9,5.8,6.0)$ and the November 23, 1984, Round Valley earthquake $(M=5.7)$. The series of shocks is of interest not only because of its wide geographic distribution in the White Mountain seismic gap but also because of the contemporaneous uplift of Long Valley caldera (Hill and others, 1985). The Chalfant Valley earthquake created a 10+$\mathrm{km}$-long zone of fractures with as much as a few centimeters of dextral slip on the frontal-fault zone of the White Mountains (Lienkaemper and others, 1987). The earthquake focal mechanism and aftershock distribution show that the predominately dextral strike-slip displacement associated with this event occurred on a westdipping fault plane that projects upward to meet the surface break.

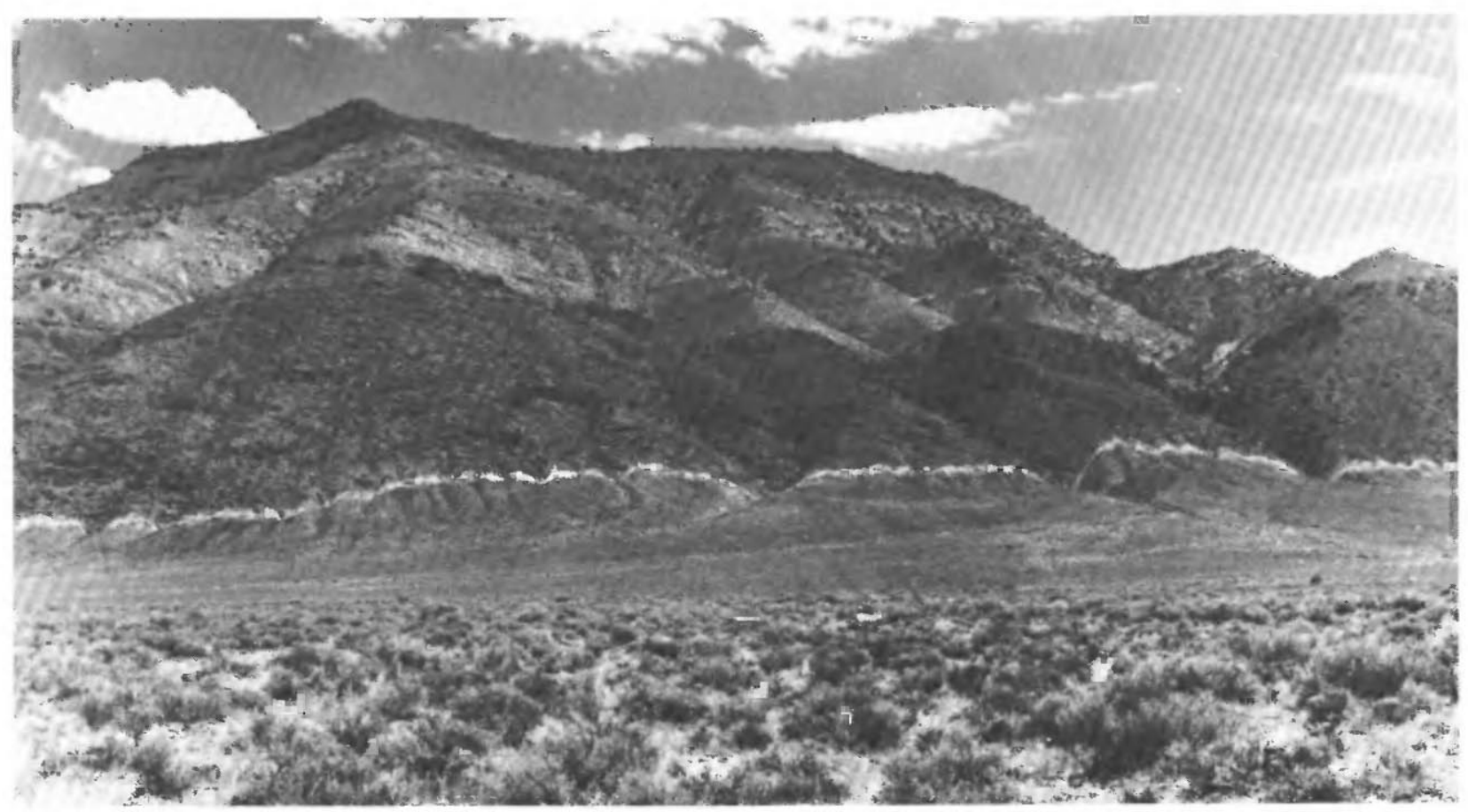

FigURE 6.12.-Fault trace of 1915 Pleasant Valley, Nev., earthquake remains clearly visible in this photograph by R.E. Wallace more than 60 years after event (Wallace, 1984). 


\section{SEISMICITY OF THE MENDOCINO TRIPLE JUNCTION AND THE GORDA PLATE}

The San Andreas fault terminates at its north end in a transform/transform/trench triple junction just seaward of Punta Gorda. Major earthquake activity lies along the Mendocino Fracture Zone, where it is an active transform fault, and to the north within the Gorda plate, which is undergoing intense internal deformation. The WadatiBenioff zone is well defined to a depth of $30 \mathrm{~km}$ and can be traced eastward to a depth of more than $80 \mathrm{~km}$ (see fig. 5.5; Walter, 1986). Strong earthquakes within the Gorda plate locate off shore and span the position of the megathrust; these events appear to lie entirely within the oceanic lithosphere. The 1980 Eureka earthquake, for example, ruptured the Gorda plate from the landward to the seaward side of the megathrust. Despite the high level of seismicity, underthrusting events are rare.

\section{PRINCIPAL EARTHQUAKES}

NOVEMBER $23,1873\left(M=6^{3 / 4}\right)$

The severe earthquake of November 23, 1873, was felt from San Francisco to Portland, Oreg.; it inflicted the heaviest damage to Crescent City, Calif., and surrounding communities in the Klamath Mountains. The macroseismic epicenter near the California-Oregon State line and probably inland of the coastline is unique within both the historical and instrumental records.

\section{APRIL 16, $1899(M=7)$}

Little is known about the large earthquake of April 16, 1899 , with an epicenter seaward of Eureka, where it was described as "one of the severest shocks of earthquake ever experienced." Toppozada and others (1981) corrected the origin time of this event and assigned a nearshore epicenter and an $M_{I}$ of 5.7. The earthquake was assigned an epicenter in the Gulf of Alaska by Milne (1901) on the basis of the traveltime of the maximum amplitude from the five reporting stations; however, a California location satisfies his data equally well. The absence of significant damage along the coast suggests an epicenter well out to sea. An instrumental magnitude $\left(M_{S}\right)$ of 7.0 is derived from the surface-wave amplitudes reported by Milne (see Abe and Noguchi, 1983).

\section{JANUARY $31,1922(M=7.3)$}

The intensity pattern of the large earthquake of January 31, 1922, is generally similar to that of the 1899 event. This event was well recorded throughout the world.
JANUARY 22, $1923(M=7.2)$

The earthquake of January 22, 1923, strongly shook the Cape Mendocino region and toppled many chimneys in the area. This earthquake was probably associated with the Mendocino Fracture Zone.

DECEMBER $21,1954(M=6.6)$

The strong earthquake of December 21, 1954, apparently was located in the crust of the North American plate above the descending Gorda plate. The relocation of this event by Smith and Knapp (1980) suggests a possible association with the active Mad River fault zone. One fatality is attributed to the earthquake.

\section{NOVEMBER $8,1980(M=7.2)$}

The Eureka earthquake of November 8, 1980, resulted from $100-\mathrm{km}$-long, left-lateral strike-slip rupture of the Gorda plate along a northeast-striking fault (see fig. 5.5). Aftershocks of the earthquake extended from within 30 $\mathrm{km}$ of the coastline southwestward to the Mendocino Fracture Zone. The focal mechanism of the earthquake is thus conjugate to the San Andreas, with its tension axis aligned in the downdip direction. This event argues for high rates of internal deformation within the subducting oceanic lithosphere and against the extension of San Andreas-style faulting northward of the triple junction.

\section{DISCUSSION}

The spatial distribution of large earthquakes during the past 2 centuries defines the San Andreas fault system as a 100 - to $300-\mathrm{km}$-wide zone containing numerous active faults in addition to the San Andreas fault proper (fig. 6.1). Except for the two largest events, the great 1857 and 1906 earthquakes that together ruptured two-thirds of the total length of the San Andreas fault, large earthquakes are conspicuously absent along the master fault itself. Although these two great earthquakes account for half of the seismic-strain release since 1769 , most of the rest occurs on other, smaller elements of the fault system. Major historical events on these secondary faults, such as the 1927 Lompoc and 1952 Kern County earthquakes, serve to define the boundaries of the San Andreas system. Their mechanisms differ significantly from right-lateral strike slip parallel to the plate-motion vector and illustrate the diversity and complexity of seismic-strain release within the plate-boundary zone.

Over the timespan of the historical catalog, the most enduring characteristic of the earthquake distribution may be the spatial clustering of activity at specific localities along the plate boundary. Notable hotspots 
include the Cerro Prieto, Imperial, San Jacinto, and Calaveras faults, all of which are major branches of the San Andreas fault, and the Parkfield segment of the San Andreas fault in the transition zone between the 1857 rupture and the $150-\mathrm{km}$-long central, creeping segment of the fault. In each of these areas, the seismic activity coincides with these high-slip-rate faults $(1-3.5 \mathrm{~cm} / \mathrm{yr})$, and in some places it clearly represents recurrent rupture of the same segment of the fault. At greater distances from the San Andreas fault, the historical events (or sequences) tend to represent isolated occurrences on slower moving faults. Thus, although the overall seismicity spans the broad plate-boundary zone, seismic-strain release over the past 2 centuries correlates with the local rate of fault movement.

In general, the locations of historical earthquakes resemble the overall distribution of microearthquake activity, despite more than six orders of magnitude difference in average seismic moment (fig. 6.13; see chap. 5). One important difference between the distribution of large and small earthquakes is the virtual absence of smaller events along the San Andreas fault segments that ruptured in 1857 and 1906. Similarly, seismic activity is distinctly absent on the potentially dangerous segment between the 1857 break and the Imperial Valley. Except for the central, creeping segment, where numerous small events occur, the San Andreas fault is almost completely aseismic during the long intervals between its rupture in major earthquakes (see figs. 5.6, 5.9).

This inverse correlation between the source regions of large earthquakes and the distribution of smaller events can also be observed for smaller main shocks. Recent studies of the rupture dynamics of $M=6$ events occurring within seismically active regions indicate that the rupture zones of these events are similarly aseismic, with smaller events occurring predominantly outside the slip surface, even during the aftershock sequence (Reasenberg and Ellsworth, 1982; Hartzell and Heaton, 1986; Mendoza and Hartzell, 1988). Thus, the sites of future large earthquakes cannot be identified on the basis of minor seismicity alone.

FIGURE 6.13.-Distribution of large and small earthquakes along the San Andreas fault system. In general, modern instrumental data $(C$; see chap. 5) portray same pattern of activity seen in large earthquakes from preinstrumental $(A)$ and instrumental $(B)$ eras. Some areas characterized by high levels of microearthquakes, such as well-defined faults east of northern section of the San Andreas fault (red line), have not produced significant earthquakes in historical time and so are considered probable sites of future activity.
A.

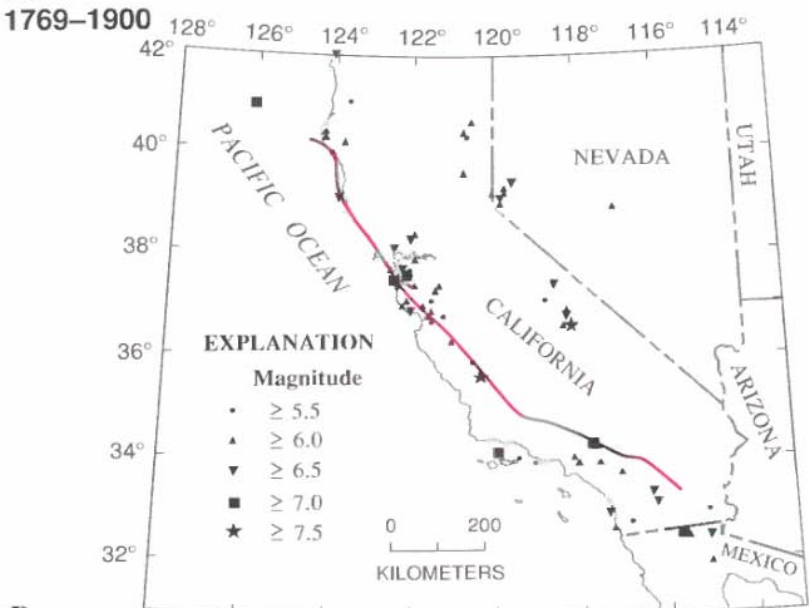

B.

1901-1987 $128^{\circ} 126^{\circ}-124^{\circ}-122^{\circ}-120^{\circ} 118^{\circ} 116^{\circ} 114^{\circ}$

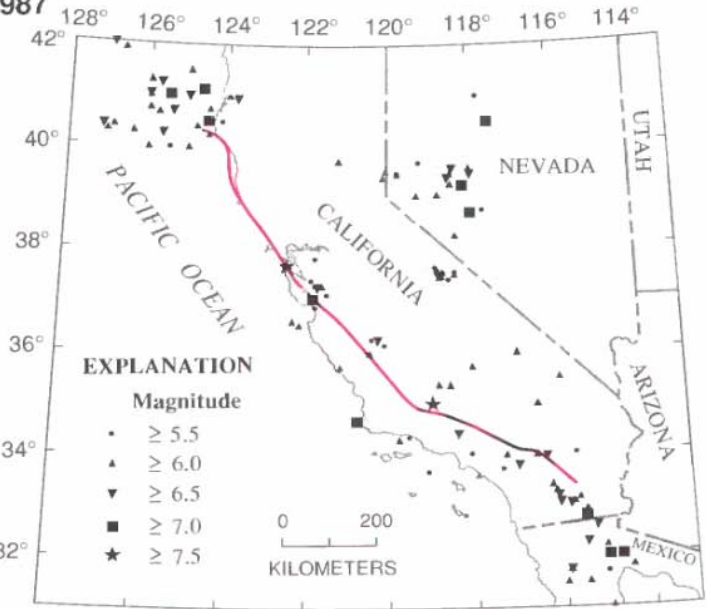

C. 1980-1986

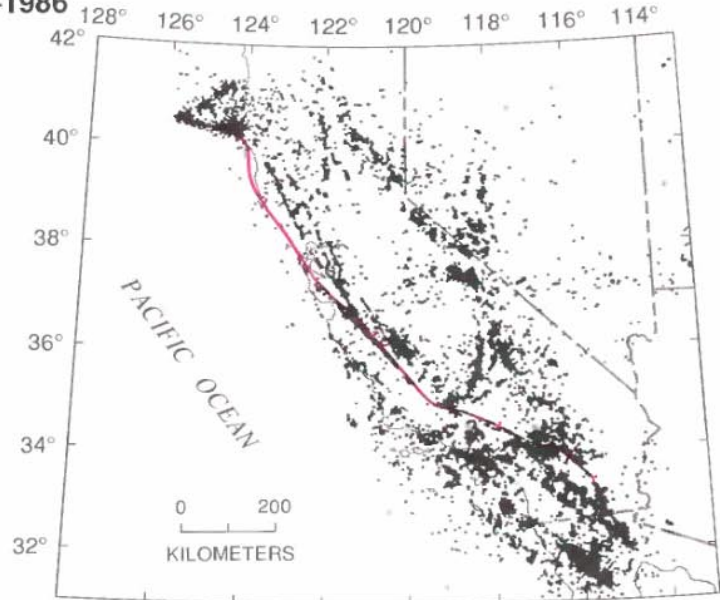




\section{RATE OF SEISMICITY}

The average rate of earthquake activity within the San Andreas system can be estimated from the GutenbergRichter frequency-magnitude relation $\log N=a-b M$, where $N$ is the cumulative number of events of magnitude equal to or greater than $M$ during a given time period. For the 77 events along the fault system with summary magnitudes $M \geq 6$ since 1852 , this relation well describes the population with $a=53 / 4$ and $b=1$ (fig. 6.14). Comparable results are obtained for subsets of $M=6$ events, such as the instrumental period (1898-1989).

It is useful to compare these results from the historical record with the frequency-magnitude relation determined from systematic microearthquake observations. If the historical rate of activity applies today and the frequency-magnitude relation for microearthquakes $(M \geq 3)$ is described by the same relation, then about 5,600 $M \geq 2$ events should be observed each year. This prediction exceeds the number of events observed during the interval $1980-87$ by about a factor of 2 (see chap. 5) and suggests that a somewhat smaller value of $b=0.93$ may be more appropriate for the extended magnitude range.

For the catalog as a whole, the rate of earthquake occurrence is well described by a Poisson process, in which the probability of finding one or more events in any

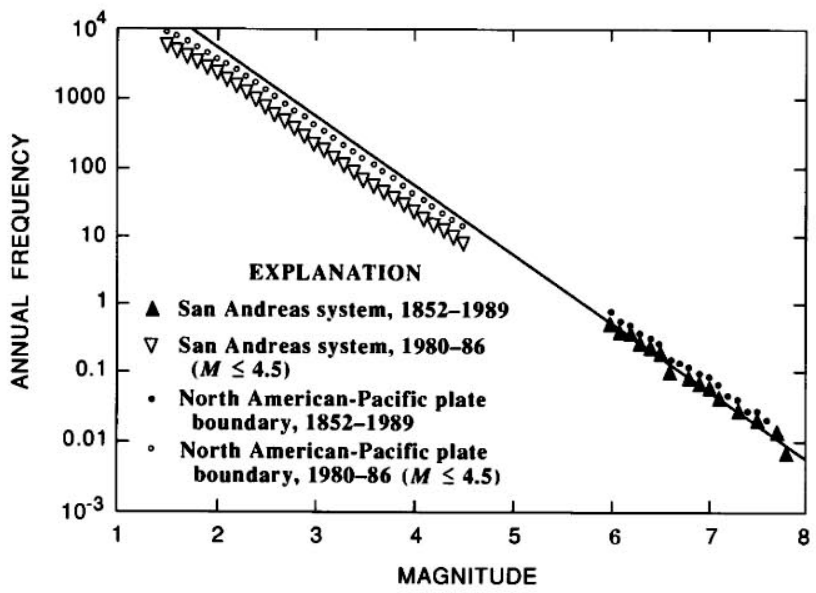

FIGURE 6.14. - Annual frequency of earthquakes of magnitude $\geq M$ as derived from historical and modern instrumental catalogs. Gutenberg-Richter frequency-magnitude relation, $\log N=a-b M$ with $a=5 \% / 4 \mathrm{yr}$ and $b=1$, describes observed distribution of earthquakes of $M \geq 6$ within the San Andreas fault system during 138-yr interval from 1852 to 1989 . Also shown are annual frequency of $M \geq 6$ events from the broader Pacific-North American plate boundary, including the San Andreas fault system and the western Basin and Range province, and of $M=2-4.5$ events in both regions during 1980-86. interval of $t$ years is $P=1-e^{-\lambda} t$, where $\lambda$ is the average rate of earthquake occurrence. It follows from the observed frequency-magnitude relation that the odds of having at least one $M \geq 6$ event per year are 0.43 . There is also an even chance of at least one $M \geq 6$ event within any 15 -month interval, one $M \geq 7$ within any $12 \frac{1}{2}$-year interval, or one $M \geq 8$ within any 125 -year interval.

The rate of earthquake activity along the plate boundary can also be usefully compared with plate-motion estimates derived from plate-tectonic theory. Current estimates of the relative velocity across the North American-Pacific plate boundary, determined from the spreading rate in the Gulf of California of $5 \mathrm{~cm} / \mathrm{yr}$ (DeMets and others, 1987), imply an annual seismicmoment rate of $2 \times 10^{26}$ dyne-cm/yr for a $10-\mathrm{km}$-thick brittle crust, equivalent to a single $\mathbf{M}=6.8$ earthquake. Earthquakes of this size occur far less often, and the principal seismic contribution to the plate motion comes from infrequent large events. The erroneous notion that the smaller events substantially contribute to the total is demonstrably false, as shown by summing the contributions of all the earthquakes below some magnitude. The innumerable events of $\mathbf{M} \leq \mathbf{6}$ occurring each year contribute less than 10 percent to the total seismic-strain release.

Within the San Andreas fault system, the total seismicmoment release since 1852 corresponds to 70 percent of the total North American-Pacific plate motion predicted by plate-tectonic models. This proportion is somewhat inflated because not all of the earthquakes act to transmit slip along the plate boundary; for example, the $1952 \mathrm{Kern}$ County earthquake, the third largest in historic time, directly accommodated little plate-parallel motion. Although aseismic displacements account for some of the deficit, notably along the central, creeping section of the San Andreas fault, deformation occurring elsewhere, notably within the Basin and Range, contributes substantially to the relative motion between the North American and Pacific plates.

\section{PARADOX OF THE MISSING PLATE MOTION}

The discrepancy between plate-tectonic estimates of relative motion across the North American-Pacific plate boundary and seismic estimates also holds for geologic and geodetic estimates of motion along the San Andreas fault system. The explanation of this apparent paradox is thought to include deformation within the Basin and Range province in western Nevada and eastern California (Atwater, 1970), which has been the locus of major seismic activity in historical time, including the third 
largest event, in 1872 , and 3 of the $11 M \approx 7$ events in the 20 th century.

It has long been recognized that the Basin and Range province has undergone substantial extension during the Cenozoic and is presently opening in a N. $60^{\circ} \mathrm{W}$. direction (Zoback and Zoback, 1980). Historical seismicity partly agrees with this geologically derived pattern; however, it also indicates a significant component of dextral shear in nearly every well-studied historical event (Shawe, 1965; Doser, 1986). Because the geologic expression of strikeslip displacement is much more difficult to recognize and quantify than vertical slip, a major question is raised about the significance of the historic seismicity for the total strain within the western Basin and Range.

Since the 1872 earthquake, the net seismic strain within the Basin and Range province can be estimated by summing the contributions of individual events. The net shear strain thus determined indicates nearly equal components of extensional strain in a N. $60^{\circ} \mathrm{W}$. direction and dextral shear trending $\mathrm{N} .10^{\circ} \mathrm{W}$. The resulting average-motion vector nearly coincides with the orientation of the San Andreas fault, and the lateral slip largely balances the coastward expansion of the province that results from extension alone. If both the rate and style of historical faulting accurately portray the long-term deformation within the region, they diminish the discrepancy between the predicted and observed rates of motion across the North American-Pacific plate boundary.

\section{EARTHQUAKE RECURRENCE AND CHARACTERISTIC EARTHQUAKES}

Over geologic time, the net displacement across a fault accumulates through the action of countless individual slip events. Measured over many displacement cycles, the average interval between events must equal the average event displacement divided by the remote slip rate. First principles, however, provide little guidance as to the properties of the recurrence, which might range from a totally random distribution of events in both space and time to identical earthquakes repeating at fixed intervals. If recurrence is essentially random, then long-term seismic hazard is described by the Poisson rate of activity, as discussed above. Greater regularities and systematics in recurrence imply that useful time-dependent forecasts of future activity can be derived from knowledge of the past behavior of the fault system.

Results for San Andreas earthquakes have played a central role in establishing the existence of broad regularities in the recurrence process. At Parkfield, the San Andreas fault has ruptured six times since 1857 in $M \approx 6$ events with highly repeatable characteristics every $22 \pm 6$ years. The latest three events, in 1922, 1934, and 1966, for which instrumental records exist, are virtually iden- tical (fig. 6.15; Bakun and McEvilly, 1984). Amplitude data from Milne seismographs uncovered in the preparation of table 6.1 show that the 1901 and 1922 events produced the same surface-wave amplitudes on common stations, strengthening earlier speculations that all the 20th-century events are similar. Intensity data for the 1881 event (Toppozada and others, 1981) and for foreshocks to the great 1857 earthquake (Sieh, 1978b) place them along the Parkfield segment as well. These regularities in the size, location, and timing of all known events at Parkfield led Bakun and Lindh (1985) to propose a specific recurrence model for Parkfield earthquakes. On the basis of this model, the next in the series of characteristic events is anticipated before 1993, and its forecast represents the first formally endorsed earthquake prediction in the United States.

Geodetic analysis of the strain released in the 1966 earthquake and its subsequent reaccumulation led Segall and Harris (1987; see Harris and Segall, 1987) to identify the zone where strain accumulates and is released, the

\section{DBN-EW}

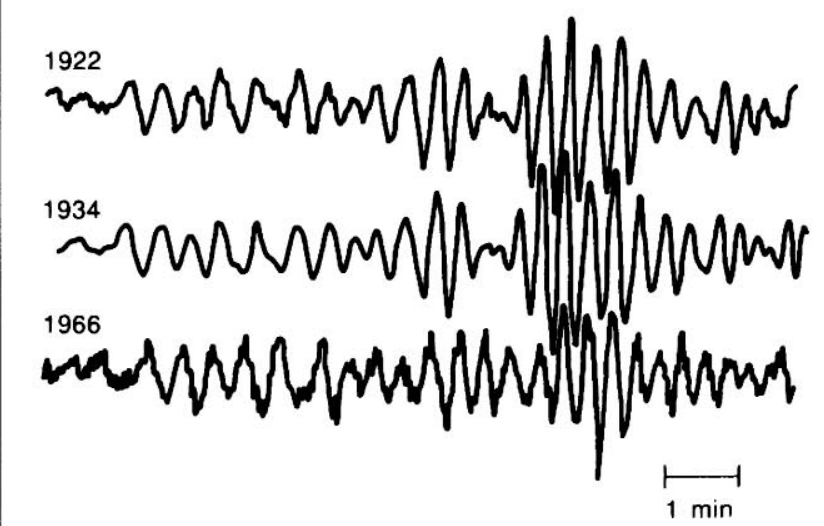

DBN-NS

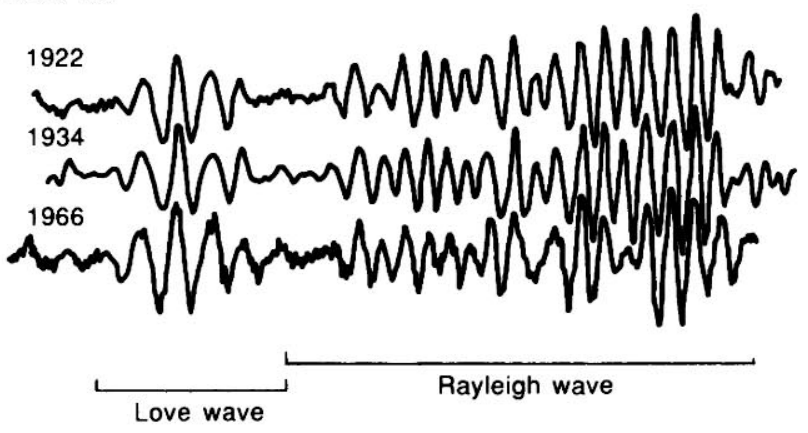

FIGURE 6.15. - Surface waves of 1922, 1934, and 1966 Parkfield, Calif., earthquakes as recorded on same seismograph in DeBilt, The Netherlands (DBN; EW, east-west; NS, north-south). These nearly identical waveforms and amplitudes led Bakun and McEvilly (1984) to propose recurrent rupture of same segment of the San Andreas fault as mechanism of Parkfield earthquakes. 
"Parkfield asperity," as the center of the 1966 rupture zone. This zone of strain accumulation appears to be effectively locked during the interseismic period and corresponds to the center of the 1966 aftershock zone (Eaton and others, 1970) between about 4- and 10-km depth. The significantly fewer events in this part of the aftershock zone than in its periphery suggests that Parkfield earthquakes occur when this locked zone suddenly releases. Aftershocks appear to result from transfer of stress to the perimeter of the asperity.

This same pattern of concentrated coseismic slip occupying a quiet region within the overall aftershock distribution characterizes several recent, well-studied events (Mendoza and Hartzell, 1988), three of which, the Coyote Lake earthquake (Aug. 6, 1979), the Imperial Valley earthquake (Oct. 15, 1979), and the Morgan Hill earthquake (Apr. 24, 1984), all have probable antecedents within the historical record. Reasenberg and Ellsworth (1982) identified the June 20, 1897, earthquake as a predecessor to the 1979 event and noted that the 82-year interval between events equaled the $1.2 \mathrm{~m}$ of coseismic slip determined by Liu and Helmberger (1983) divided by the long-term slip rate of $1.5 \mathrm{~cm} / \mathrm{yr}$ for the Calaveras fault. Similarly, the 73-year interval between the July 11, 1911, event and the 1984 Morgan Hill earthquake (Bakun and others, 1984) well predicts the 0.8 to $1.0 \mathrm{~m}$ of maximum coseismic slip determined by Hartzell and Heaton (1986). The 1979 Imperial Valley earthquake is more complex because it reruptured only the northern 30 $\mathrm{km}$ of the May 19, 1940, fault break. Again, both the time interval between events and the fault-slip rate compare favorably with the fault slip at depth, as determined from seismograms (Hartzell and Heaton, 1983; Archuleta, 1984). Earlier ruptures of this or other segments of the Imperial fault may well be in the historical record, possibly including the April 19, 1906, event, which occurred the afternoon of the great 1906 earthquake in northern California.

Similar observations of recurrent faulting in events with characteristic magnitudes and locations from around the world (Nishenko and Buland, 1987) suggest a simple, first-order model for seismic potential. In this model, the future behavior of a specific segment of a fault can be forecast from knowledge of the size of past earthquakes, the timing and amount of slip in the latest event, and the long-term rate of fault movement (Lindh, 1983; Sykes and Nishenko, 1984). Accordingly, the probability of an event on a recently ruptured fault segment is low until the elastic strain rebuilds, which may be estimated from the geologic slip rate. As the strain rebuilds, the probability of another earthquake increases. Empirically, the time intervals between successive ruptures of a specific fault segment define a bell-shaped distribution that may be used to estimate the odds of the next event within some future time interval, given that it has not yet occurred.

Probabilities for large earthquakes along the major branches of the San Andreas fault derived from this methodology differ markedly from Poisson estimates (Working Group on California Earthquake Probabilities, 1988). For example, the chance of a repetition of the great 1906 earthquake within the next 30 years (1988-2018) is less than 0.1. In contrast, the chance of an $M=71 / 2-8$ earthquake on the southern section of the San Andreas fault is 0.6. When the Working Group's report was written, the southernmost part of the 1906 fault break was assigned the highest chance of failure of any segment of the north half of the San Andreas fault. Now that it has ruptured in the October 18, 1989, Loma Prieta earthquake, the probability of another rupture will be small for several decades. A clearer understanding of past seismicity can only help to improve and refine estimates of future seismicity.

\section{THE SEISMIC CYCLE}

An important implication of the characteristic-earthquake model is the existence of a repetitive cycle of strain accumulation and release (Fedotov, 1968). Mogi (1981) suggested the existence of definite stages in the cycle, including a low level of seismicity in the first part of the cycle once aftershock of the latest event subside, a rise in regional activity as strain accumulates, and ultimately the occurrence of another earthquake with its attendant foreshocks and aftershocks, which initiates the next cycle.

The long-term seismicity within the San Andreas fault system displays these characteristics along the rupture zone of the great 1906 earthquake (figs. 6.16, 6.17; Ellsworth and others, 1981). Activity was relatively high during the 19th century, as becomes particularly apparent after 1850, when the record is virtually complete. After the great 1906 earthquake, the level of seismicity changed drastically, and moderate events essentially ceased for 50 years. Since the mid-1950's, the activity level has increased and begun to approach the 19thcentury level (Tocher, 1959). This change in activity associated with the 1906 earthquake has been noted many times (for example, Gutenberg and Richter, 1954), and it is an open question whether it represents a premonitory increase (Toppozada and others, 1988) or whether the long quiescent period since 1906 is the essential feature (Ellsworth and others, 1981).

Comparable variations in seismicity appear to be present in southern California, although the historical record there is less reliable until about 1890 . Along the rupture zone of the great 1857 earthquake, the available data suggest a similar period of low activity for several 
decades after the event (fig. 6.17). Farther south, along the section of the fault that has not ruptured in 3 centuries, the activity level since at least the 1880 's is reminiscent of the activity in the San Francisco Bay region before the 1906 earthquake (fig. 6.18). As a potential long-term indicator of high seismic potential, the seismicity surrounding the dormant southern section of the San Andreas fault agrees with independent estimates of long-term potential derived from paleoseismology.

\section{FUTURE USES OF EARTHQUAKE HISTORY}

At this stage in our understanding of the San Andreas fault system, seismicity is still best described as a random

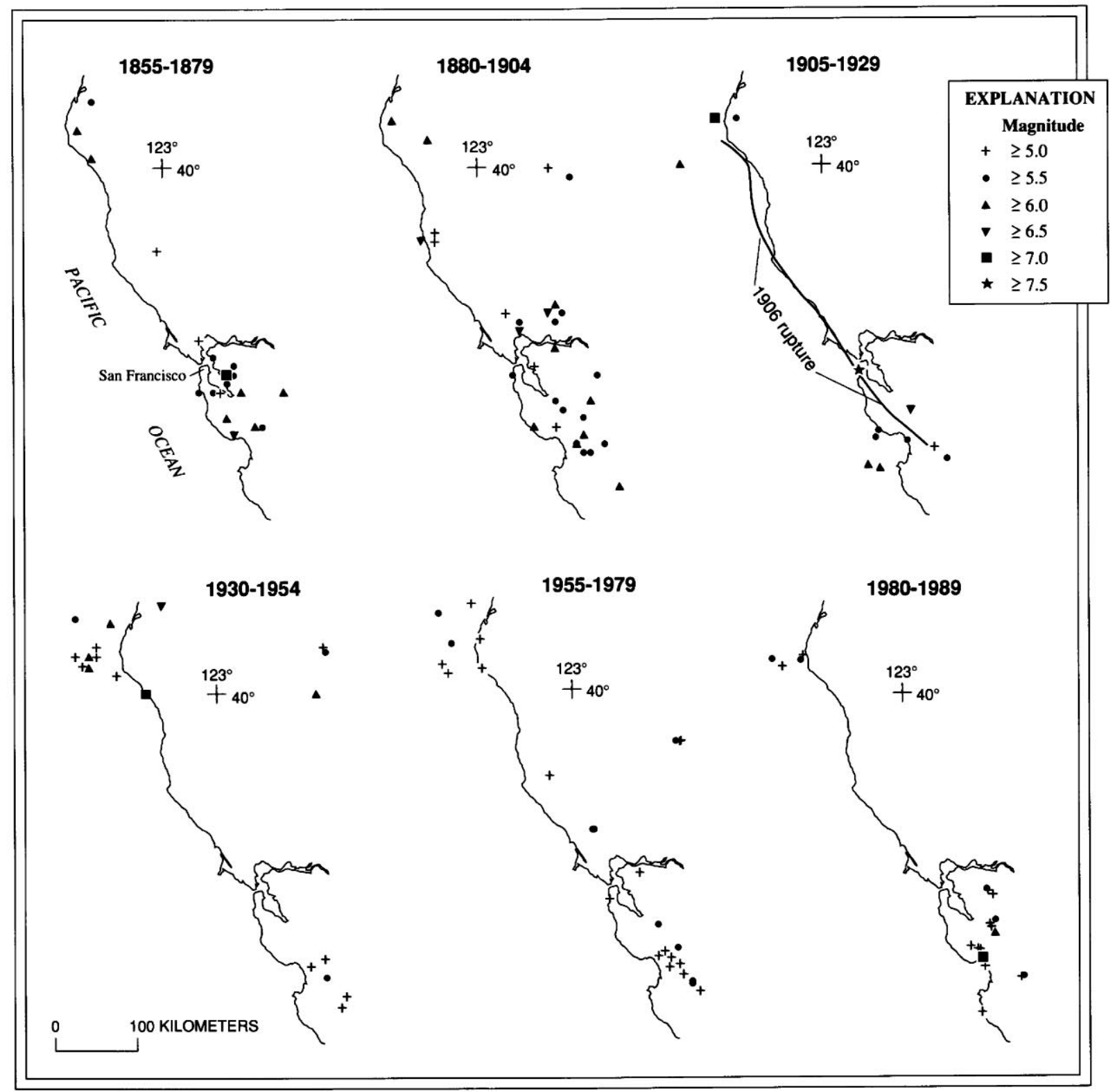

FIGURE 6.16. - Seismicity of the San Francisco Bay region in quartercentury epochs. Activity was high in the region during at least a half-century before 1906 earthquake and drastically declined afterward for the next half-century. Since the mid-1950's, activity has

begun to approach levels last seen in the 19th century. However, both geologic and geodetic evidence suggest that the next great earthquake will not occur for a century or more. 
process over time, with a highly clustered spatial distribution. There are, however, tantalizing hints of underlying regularities, such as those in the characteristic earthquakes at Parkfield, or in the striking changes in seismicity associated with the 1906 earthquake. The next generation of refinements to this history will assuredly make comparable contributions by reducing the uncertainty in earthquake locations and magnitudes. Modern seismologic methods for extracting new information on the mechanisms of earthquakes have already proved practical for many events from the early instrumental period. Systematic treatment of the full instrumental catalog with these methods will provide a new basis for understanding the tectonics of the plate boundary and the mechanics of earthquakes.

\section{CATALOG OF MAJOR EARTHQUAKES, 1769-1989}

\section{CATALOG COMPILATION}

The publication of Edward S. Holden's catalog of Pacific coast earthquakes in 1898 represented the first systematic scientific inquiry into the seismic history of California and surrounding regions. This catalog, and its extension by McAdie (1907), formed the primary basis for the monumental catalog of Townley and Allen (1939) covering the years 1769-1928. These catalogs provide detailed descriptive accounts of virtually all the earth- quakes that are now known from this period, and all subsequent analyses of seismicity up to the modern instrumental period build on these foundations.

Recent studies of preinstrumental seismicity have focused on quantification of the historical record. The catalog presented here relies heavily on the research of Tousson Toppozada and his associates (Toppozada and others, 1981; Toppozada and Parke, 1982), who developed extensive new information on seismic intensities from newspaper accounts and other original sources, and determined locations and magnitudes from the resulting isoseismal maps. In addition, several special studies of important events by other workers have contributed to the catalog.

The development of practical seismographic instrumentation around the turn of the 20th century led to the rapid growth of seismologic data, particularly for those events large enough to register at teleseismic distances on the early instruments. The publication of the Circulars of the Seismological Committee of the British Association for the Advancement of Science (1899-1912) and their continuation as the International Seismological Summary from 1913 on indicate a detection threshold of about $M \approx 6$ for the Western United States as early as 1898. Data from these and other sources enabled Gutenberg and Richter (1954) to systematically catalog seismicity from 1904 onward.

Modern seismographic instrumentation first installed in California in 1910 ushered in the era of earthquake

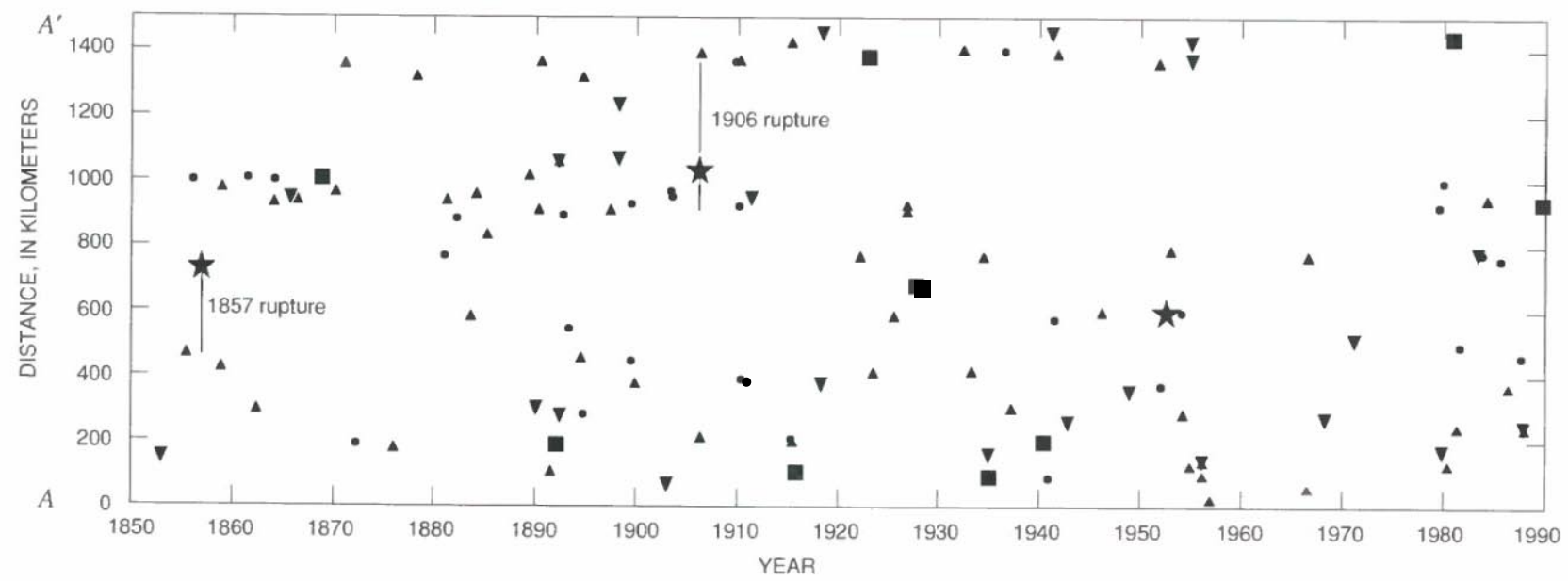

FIGURE 6.17.-Space-time diagram of seismicity since 1850 along the San Andreas fault system between head of the Gulf of California $(A)$ and Punta Gorda $\left(A^{\prime}\right)$. Change in seismicity rate along northern section of the San Andreas fault associated with 1906 earthquake (fig. 6.13) may also be tentatively identified along 1857 earthquake rupture. Persistent activity characterizes south third of the plate boundary since 1890 , spanning the entire interval of reliable earthquake reporting in this region. 
observation at regional distances. The Bulletins of the Seismographic Stations of the University of California,
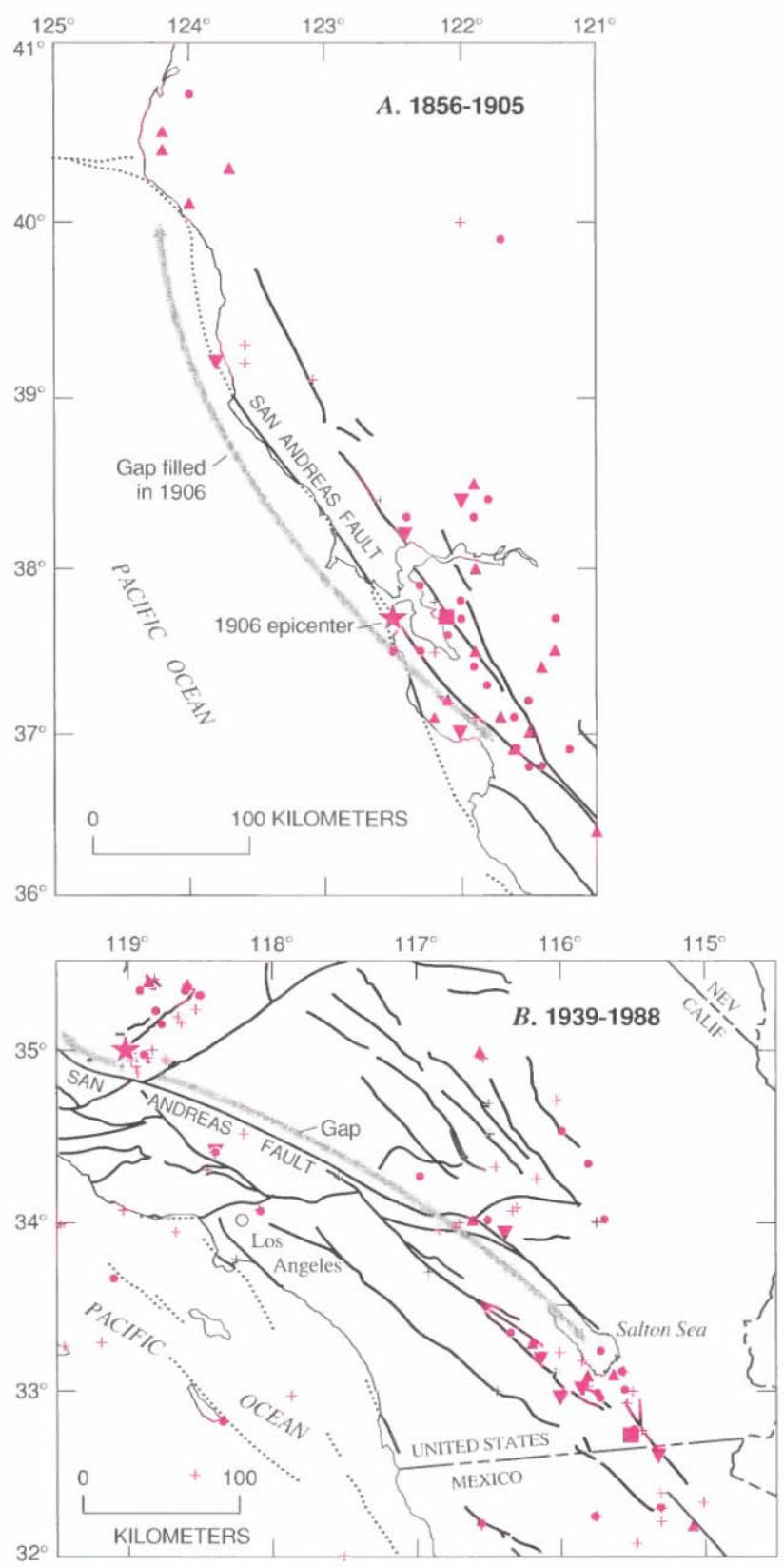

EXPLANATION

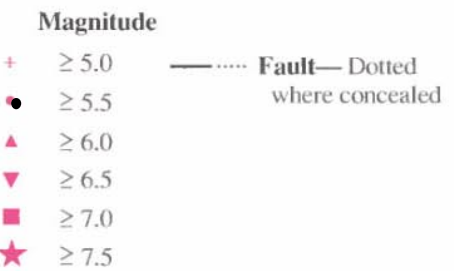

Berkeley, from 1910 to the present form the principal source for events in northern California and adjoining areas. Routine epicentral determinations and magnitude assignments for earthquakes in the southern California region date from 1932 and are taken from the catalog of the Seismological Laboratory of the California Institute of Technology, Pasadena. Additional instrumental results come from various other sources, chiefly the U.S. Geological Survey and the University of Nevada, Reno.

The resulting catalog of major earthquakes in California, western Nevada, and northernmost Baja California from 1769 to 1989 (table 6.1) contains 206 entries. This catalog omits several earthquakes listed in earlier catalogs where this or other recent studies have failed to corroborate previous interpretation as significant events or even, in some cases, their occurrence.

\section{QUANTIFICATION OF EARTHQUAKES AND MAGNITUDE SCALES}

Physical measures of the complex mechanical event producing the earthquake take many forms, including the dimensions of the faulted region, the amount of slip, and the strength of the radiated elastic waves. To relate the characteristics of one event to another, the observed quantities must generally be summarized through the use of either an empirical relation, such as magnitude, or a quantity derived from a physical model, such as seismic moment. Both procedures have their place, and the choice of one metric over another depends principally on the purposes of the comparison and the availability of common data.

Because no single procedure for determining magnitude can be applied to the entire historical record, the catalog must be quantified by using various magnitude scales. Each scale is briefly described below to define its origin and to clarify its relation to the other scales. I emphasize that each scale has a particular range of validity and that different magnitude scales will, in general, yield slightly different values for the same event. Such differences in magnitude seem to provide a never-ending source of interest and controversy for the news media, who commonly lump all scales together under the heading of "Richter scale." To the seismologist,

FigURE 6.18.- Where will the next great earthquake strike along the San Andreas fault system? Numerous lines of evidence point to its long-dormant southernmost segment $(B)$ as having the highest potential. Large earthquake activity in this region shares many similarities with activity in the San Francisco Bay region before 1906 earthquake $(A)$. In both cases, absence of activity directly on the San Andreas fault is pronounced, and a high regional level of activity is concentrated along other major branches of the fault system. 
such differences are neither surprising nor controversial and can, in fact, provide information on the underlying physical processes of the earthquake source.

I also emphasize that intensity scales characterize the effects of the earthquake at a particular location and are not magnitude scales. Strictly speaking, intensity values (or, for that matter, instrumentally measured values of ground-motion parameters) describe the vibratory motions that are the actual earthquake as observed at a particular location, whereas magnitude values describe the faulting event that generates the earthquake.

\section{THE RICHTER SCALE $\left(M_{L}\right)$}

The original magnitude scale of Richter (1935) was introduced for the purpose of providing an objective measure of the energy of each earthquake in the initial listing of earthquakes in the southern California region compiled by the Seismological Laboratory in Pasadena. Rather than attempting to measure the energy of the earthquake source directly, he chose to construct an empirical scale derived from a simple measure of the complex seismic waveform. Using only the maximum excursion of the seismogram as measured on a single type of instrument, the Wood-Anderson seismograph, he defined the local magnitude of an earthquake as

$$
M_{L}=\log _{10} A-\log _{10} A_{0}(\Delta),
$$

where the empirical function $A_{0}$ depends only on the epicentral distance of the station, $\Delta$. The zero point was arbitrarily set by Richter to avoid negative magnitudes in the course of routine work. Use of common logarithms means that two earthquakes located at the same distance from a station and having peak amplitudes differing by a factor of 10 will differ by 1 magnitude unit. In practice, readings from all observing stations are averaged after adjustment with station-specific corrections to obtain the $M_{L}$ value. Although Richter (1935) predicted that the local-magnitude scale "cannot hold to any high accuracy," history has proved it to be a powerful quantitative tool for ordering the relative sizes of earthquakes.

Several points about $M_{L}$ should be emphasized. First, it is strictly defined only for the southern California region, although its applicability to coastal central and northern California has since been shown. Recent studies of the $A_{0}$ curve suggest that it will require revision and regionalization. Second, because $M_{L}$ has no actual physical units associated with it, other empirical magnitude scales may be freely adjusted to coincide with it. The local-magnitude scale has, in fact, been used as the basis for establishing essentially all other magnitude scales. Finally, because $M_{L}$ is derived from measurements taken from a single, band-limited seismograph, $M_{L}$ values saturate once an earthquake becomes large enough. Thus, the "correct" Richter magnitude $M_{L}=6.9$ for the great 1906 earthquake obtained by Jennings and Kanamori (1979) reflects the amplitude of seismic waves at periods near $1 \mathrm{~s}$ but not the total energy of this earthquake. Uniformly valid characterization of the "size" of an earthquake requires use of magnitude scales based on longer-period measures of the event.

\section{SURFACE-WAVE MAGNITUDE $\left(M_{S}\right)$ AND BODY-WAVE MAGNITUDE $\left(m_{b}\right)$}

The successful development of the local-magnitude scale encouraged Gutenberg and Richter to develop magnitude scales based on teleseismic observations of earthquakes. Two scales were developed, one based on surface waves, $M_{S}$, and one on body waves, $m_{b}$.

Surface waves with a period near $20 \mathrm{~s}$ generally produce the largest amplitudes on a standard long-period seismograph, and so the amplitude of these waves is used to determine $M_{S}$, using an equation similar to that used for $M_{L}$.

The body-wave magnitude, $m_{b}$, which was developed specifically to treat deep-focus earthquakes, presents yet another alternative scale for magnitude determination. Although it presently is the most commonly reported teleseismic magnitude, current practice in its determination differs from that employed by Gutenberg, and so it is omitted from table 6.1. As a short-period magnitude, modern $m_{b}$ values measure the same part of the earthquake energy spectrum as $M_{L}$.

The magnitudes listed by Gutenberg and Richter (1954) that appear in table 6.1 as $M_{G-R}$ are essentially $M_{S}$ according to Geller and Kanamori (1977); magnitudes attributed to Richter (1958) are based on $M_{L}$ or $M_{S}$.

Useful estimates of $M_{S}$ can be obtained from many different types of long-period seismographs, including the undamped instruments deployed by Milne beginning in 1897. Abe and Noguchi (1983) constructed estimates of $M_{S}$ from Milne seismograms to resolve a longstanding controversy concerning an apparent peak in global seismicity between 1904 and 1912. Abe (1988) later used the Milne data to determine magnitudes for smaller earthquakes in California between 1898 and 1912. His procedures have been used to compute $M_{S}$ for additional California events occurring between 1898 and 1934, which are listed in table 6.1.

\section{SEISMIC INTENSITY AND EARTHQUAKE MAGNITUDE $\left(M_{I}\right)$}

Before the development of seismographs in the late 19th century, descriptions of the effects of earthquakes provided the only means for assessing earthquake size in all but the rare cases where surface faulting was well 
described. A robust method for relating the area undergoing shaking of a given intensity or greater to $M_{L}$ was developed by Toppozada (1975) for California and western Nevada. Using these relations, Toppozada and others (1981, 1982) successfully assigned an intensity magnitude, $M_{I}$, to many earthquakes. The isoseismal maps developed in the course of their research also generally provide our best estimates of epicentral locations. New $M_{I}$ values have been determined for several events, using the same procedures as part of this study.

\section{SEISMIC MOMENT $\left(M_{0}\right)$, RADIATED ENERGY, AND MOMENT MAGNITUDE (M)}

Magnitude scales based on finite-bandwidth seismographs approach a maximum near which events of clearly different size or energy are indistinguishable. Saturation of $M_{L}$ is apparent for both the 1906 and 1952 earthquakes listed in table 6.1. Recent work by Hutton and Boore (1987) suggests that the local-magnitude scale may begin to saturate at about $M_{L}=6$. Such saturation, which is understood to arise from the scaling law of the seismic spectrum (Aki, 1967), occurs when the peak of the energy spectrum lies below the frequency range of the WoodAnderson seismograph.

By using the well-known properties of the seismic spectrum, magnitude scales can be constructed with uniform validity. One such scale, $M_{w}$, proposed by Kanamori (1977) is based on the seismic energy radiated in the form of elastic waves by the source. Another nearly equivalent magnitude scale, $\mathbf{M}$, the moment magnitude, is based on the seismic moment, $M_{0}=\mu A u$ (Aki, 1966), where $A$ is the area of the earthquake rupture surface, $u$ is the average fault displacement, and $\mu$ is the shear modulus of the crustal volume containing the fault. Hanks and Kanamori (1979) took advantage of the nearly identical relations between $M_{0}$ and both $M_{L}$ and $M_{S}$ to define $\mathbf{M}=2 / 3 \log _{10} M_{0}-10.7$, where $M_{0}$ is measured in dyne-centimeters.

These two magnitude scales, though closely related, are not identical. Singh and Havskov (1980) showed that $M_{w}=2 / 3\left(\log _{10} \quad \mathrm{M}_{0}+\log _{10} \Delta \sigma / \mu-12.1\right)$, where $\Delta \sigma$ is the stress drop. Earthquake stress drops generally fall in a narrow range over the entire magnitude spectrum, and so with $\Delta \sigma / \mu \approx 10^{-4}$ (Kanamori, 1977), $M_{w}=$ M. One advantage to $\mathbf{M}$ for the purpose at hand is its dependence on only the static fault offset and rupture area, which can be determined for the 1857 and 1872 earthquakes.

\section{SUMMARY MAGNITUDE $(M)$}

To construct a single, summary-magnitude scale, $M$, to characterize the relative size of all the events listed in table 6.1, I use each of the scales described above, being careful to consider such factors as the historical period and event location, as well as the quality of individual determinations. Where choices between several magnitude estimates are possible, the summary magnitude, $M$, is weighted toward long-period estimates of magnitude. Specifically, $M_{S}$ and $M_{G-R}$ are selected when judged reliable (110 events). Many local magnitudes have thus been superseded by surface-wave magnitudes; this effect is most noticeable for the largest events, where saturation of $M_{L}$ becomes important. $M_{L}$ is the principal contributor to 20 summary magnitudes, half of which also have reported $\mathbf{M}$ values that agree well. For all but two events before 1898 (1857 and 1872) and for two 20thcentury events, $M$ is based on $M_{I}$. In effect, the summary magnitude is an intensity magnitude before 1898 and a teleseismic surface-wave magnitude thereafter.

If $M$ is to be uniformly validity across the entire timespan of the catalog, $M_{I}$ must be an unbiased estimator of $M_{S}$ or $M_{G-R}$. To test this absence of bias, the correlation between $M_{I}$ and the two surface-wave magnitudes has been examined for 23 events with reliable $M_{S}$ or $M_{G-R}$ estimates, and an $M_{I}$ value determined from the isoseismal maps of Toppozada and others (1981) and Toppozada and Parke (1982). This comparison shows that although the two magnitude scales are well correlated, $M_{I}$ systematically underestimates $M_{S}$ and $M_{G-R}$ by $0.3 \pm 0.3$ units. If the sample is restricted to $M_{S} \leq 6.5$ $(n=18)$, the bias is $0.2 \pm 0.3$ units. To further investigate this apparent bias, $M_{L}$ was compared with $M_{I}$ for 10 common events, for which the bias was $0.25 \pm 0.2$ units. As a final check, the difference between $M_{S}$ or $M_{G-R}$ and $M_{I}$ for the 12 events listed in table 6.1 also used by Toppozada (1975) to develop $M_{I}$ relations was found to be $0.10 \pm 0.19$ units.

On the basis of these results, the summary magnitudes from $M_{I}$ values of Toppozada and others (1981) have been adjusted upward by 0.15 units and then rounded to the nearest quarter magnitude unit. Thus, events of $M_{I}=5.7$ become $M=53 / 4$, and those of $M_{I}=5.8$ become $M=6$. No magnitude adjustment exceeded a quarter unit. $M_{I}$ values from other sources have simply been rounded to the nearest quarter unit, because they average 0.2 units higher than the values of Toppozada and others (1981) and Toppozada and Parke (1982), where comparisons can be made. Summary magnitudes for events before 1850 have not been adjusted upward, owing to the imprecision of the original estimates.

\section{REFERENCES CITED}

Abe, Katsuyuki, 1988, Magnitudes and origin times from Milne seismograph data: Earthquakes in China and California, 1898-1912, in Lee, W.H.K., Meyers, Herbert, and Shimazaki, Kunihiko, eds., Historical seismograms and earthquakes of the 
world: San Diego, Calif., Academic Press, p. 37-50.

Abe, Katsuyuki, and Noguchi, Shin'ichi, 1983, Revision of magnitudes of large shallow earthquakes, 1897-1912: Physics of the Earth and Planetary Interiors, v. 33, no. 1, p. 1-11.

Agnew, D.C., 1985, Evidence on large Southern California earthquakes from historical records, in Shearer, C.F., Minutes of the National Earthquake Prediction Evaluation Council, March 29-30, 1985, Pasadena, California: U.S. Geological Survey Open-File Report 85-507, p. 77-90.

Agnew, D.C., and Sieh, K.E., 1978, A documentary study of the felt effects of the great California earthquake of 1857: Seismological Society of America Bulletin, v. 68, no. 6, p. 1717-1729.

Aki, Keiiti, 1965, Maximum likelihood estimate of $b$ in the formula log $N=a-b M$ and its confidence limits: University of Tokyo, Earthquake Research Institute Bulletin, v. 43, pt. 2, p. 237-239.

- 1966, Generation and propagation of $G$ waves from the Niigata earthquake of June 16, 1964. Part 2. Estimation of earthquake moment, release of energy, and stress-strain drop from $G$ wave spectrum: University of Tokyo, Earthquake Research Institute Bulletin, v. 44, pt. 1, p. 73-88.

- 1967, Scaling law of seismic spectrum: Journal of Geophysical Research, v. 72, no. 4, p. 1217-1231.

Archuleta, R.J., 1984, A faulting model for the 1979 Imperial Valley earthquake: Journal of Geophysical Research, v. 89, no. B6, p. 4559-4585.

Atwater, Tanya, 1970, Implications of plate tectonics for the Cenozoic tectonic evolution of western North America: Geological Society of America Bulletin, v. 81 , no. 12 , p. 3513-3535.

Bakun, W.H., and McEvilly, T.V., 1984, Recurrence models and Parkfield, California, earthquakes: Journal of Geophysical Research, v. 89, no. B5, p. 3051-3058.

Bakun, W.H., Clark, M.M, Cockerham, R.S., Ellsworth, W.L., Lindh, A.G., Prescott, W.H., Shakal, A.F., and Spudich, Paul, 1984, The 1984 Morgan Hill, California, earthquake: Science, v. 225, no. 4659 , p. 288-291.

Bakun, W.H., and Lindh, A. G., 1985, The Parkfield, California, earthquake prediction experiment: Science, v. 229, no. 4714, p. 619-624.

Beanland, Sarah, and Clark, M.M., in press, The Owens Valley fault zone, eastern California, and surface rupture associated with the 1872 earthquake: U.S. Geological Survey Bulletin.

Bolt, B.A., 1968, The focus of the 1906 California earthquake: Seismological Society of America Bulletin, v. 58, no. 1, p. 457-471.

Bolton, H.E., 1927, Fray Juan Crespi, missionary explorer on the Pacific coast, 1769-1774: Berkeley, University of California Press, $402 \mathrm{p}$.

Boore, D.M., 1977, Strong-motion recordings of the California earthquake of April 18, 1906: Seismological Society of America Bulletin, v. 67 , no. 3 , p. $561-577$.

Borcherdt, R.D., ed., 1975, Studies for seismic zonation of the San Francisco Bay region: U.S. Geological Survey Professional Paper 941-A, p. A1-A102.

Coffman, J.L., von Hake, C.A., and Stover, C.W., eds., 1982 Earthquake history of the United States: Boulder, Colo., U.S. Department of Commerce, National Oceanic and Atmospheric Administration Publication 41-1, 208 p.

DeMets, Charles, Gordon, R.G., Stein, Seth, and Argus, D.F., 1987, A revised estimate of Pacific-North America motion and implications for western North America plate boundary zone tectonics: Geophysical Research Letters, v. 14, no. 9, p. 911-914.

Doser, D.I., 1986, Earthquake processes in the Rainbow MountainFairview Peak-Dixie Valley, Nevada, region 1954-1959: Journal of Geophysical Research, v. 91, no. B12, p. 12572-12586.

Eaton, J.P., O'Neill, M.E., and Murdock, J.N., 1970, Aftershocks of the 1966 Parkfield-Cholame, California, earthquake: A detailed study: Seismological Society of America Bulletin, v. 60, no. 4, p. 1151-1197.

Ellsworth, W.L., Lindh, A.G., Prescott, W.H., and Herd, D.G., 1981, The 1906 San Francisco earthquake and the seismic cycle, in Simpson, D.W., and Richards, P.G., eds., Earthquake prediction: An international review (Maurice Ewing Series 4): Washington, American Geophysical Union, p. 126-140.

Engdahl, E.R., and Rinehart, W.A., 1988, Seismicity map of North America: Boulder, Geological Society of America.

Evernden, J.F., and Thompson, J.M., 1985, Predicting seismic intensities, in Ziony, J.I., ed., Evaluating earthquake hazards in the Los Angeles region-an earth-science perspective: U.S. Geological Survey Professional Paper 1360, p. 151-202.

Fedotov, S.A., 1968, The seismic cycle, quantitative seismic zoning, and long-term seismic forecasting, in Medvedev, S.V., ed., Seismic zoning of the USSR: Jerusalem, Israel Program for Scientific Translations, p. 133-164.

Gawthrop, W.H., 1978, The 1927 Lompoc, California, earthquake: Seismological Society of America Bulletin, v. 68, no. 6, p. 1705-1716.

- 1981, Comments on "The Lompoc, California, earthquake (November $4,1927, M=7.3$ ) and its aftershocks," by Thomas C. Hanks: Seismological Society of America Bulletin, v. 71, no. 2, p. $557-560$.

Geller, R.J. and Kanamori, Hiroo, 1977, Magnitudes of great shallow earthquakes from 1904 to 1952: Seismological Society of America Bulletin, v. 67, no. 3, p. 587-598.

Gianella, V.P., 1957, Earthquake and faulting, Fort Sage Mountains, California, December, 1950: Seismological Society of America Bulletin, v. 47, no. 3, p. 173-177.

Gianella, V.P., and Callaghan, Eugene, 1934, The Cedar Mountain, Nevada, earthquake of December 20, 1932: Seismological Society of America Bulletin, v. 24, no. 4, p. 345-384.

Gilbert, G.K., 1884, A theory of the earthquakes of the Great Basin, with a practical application: American Journal of Science, ser. 3, v. 27 , no. 157 , p. $49-53$.

Goter, S.K., compiler, 1988, Seismicity map of California: U.S. Geological Survey Open-File Report 88-286, scale 1:1,000,000.

Gutenberg, Beno, and Richter, C.F., 1954, Seismicity of the earth and associated phenomena (2d ed.): Princeton, N.J., Princeton University Press, $310 \mathrm{p}$.

- 1956, Earthquake magnitude, intensity, energy and acceleration: Seismological Society of America Bulletin, v. 46, no. 2, p. 105-145.

Hanks, T.C., 1979, The Lompoc, California, earthquake (November 4, 1927, $M=7.3$ ) and its aftershocks: Seismological Society of America Bulletin, v. 69, no. 2, p. 451-462.

- 1981, Reply to W. Gawthrop's comments on"The Lompoc, California, earthquake (November 4, 1927, $M=7.3$ ) and its aftershocks": Seismological Society of America Bulletin, v. 71, no. 2, p. 561-565.

Hanks, T.C., and Kanamori, Hiroo, 1979, A moment magnitude scale: Journal of Geophysical Research, v. 84, no. B5, p. 2348-2350.

Hanks, T.C., and Allen, C.R., 1989, The Elmore Ranch and Superstition Hills earthquakes of 24 November 1987: Introduction to the special issue: Seismological Society of America Bulletin, v. 79, no. 2, p. 231-238.

Harley, R.B., 1988, Rev. Juan Caballeria: Historian or storyteller? Rethinking the 1810 Dumetz expedition: Redlands, Calif., San Bernardino County Museum Association Quarterly, v. 35, p. 42.

Harris, R.A., and Segall, Paul, 1987, Detection of a locked zone at depth on the Parkfield, California, segment of the San Andreas fault: Journal of Geophysical Research, v. 92, no. B8, p. 7945-7962.

Hartzell, S.H., and Heaton, T.H., 1983, Inversion of strong ground motion and teleseismic waveform data for the fault rupture history of the 1979 Imperial Valley, California, earthquake: Seismological 
Society of America Bulletin, v. 73, no. 6, pt. A, p. 1553-1583. 1986, Rupture history of the 1984 Morgan Hill, California earthquake from the inversion of strong motion records: Seismological Society of America Bulletin, v. 76, no. 3, p. 649-674.

Heaton, T.H., 1982, The 1971 San Fernando earthquake: A double event?: Seismological Society of America Bulletin, v. 72, no. 6, p. 2037-2062.

Hill, D.P., Wallace, R.E., and Cockerham, R.S., 1985, Review of evidence on the potential for major earthquakes and volcanism in the Long Valley-Mono Craters-White Mountains regions of eastern California: Earthquake Prediction Research, v. 3, no. 3-4, p. 571-594.

Hutton, K.L., and Boore, D.M., 1987, The $M_{L}$ scale in southern California: Seismological Society of America Bulletin, v. 77, no. 6, p. 2074-2094.

Jacoby, G.C., Sheppard, P.R., and Sieh, K.E., 1988, Irregular recurrence of large earthquakes along the San Andreas fault: Evidence from trees: Science, v. 241, no. 4862, p. 196-199.

Jennings, C.W., compiler, 1975, Fault map of California with locations of volcanoes, thermal springs, and thermal wells: California Division of Mines and Geology Geologic Data Map 1, scale 1:750,000.

Jennings, P.C., and Kanamori, Hiroo, 1979, Determination of local magnitude $M_{L}$, from seismoscope records: Seismological Society of America Bulletin, v. 69 , no. 4, p. 1267-1288.

Kanamori, Hiroo, 1977, The energy release in great earthquakes: Journal of Geophysical Research, v. 82, no. 20, p. 2981-2987.

Kovach, R.L., Allen, C.R., and Press, Frank, 1962, Geophysical investigations in the Colorado Delta region: Journal of Geophysical Research, v. 67 , no. 7, p. 2845-2871.

Langston, C.A., 1978, The February 9, 1971 San Fernando earthquake: A study of source finiteness in teleseismic body waves: Seismological Society of America, v. 68 , no. 1, p. 1-29.

Lawson, A.C., chairman, 1908, The California Earthquake of April 18, 1906: Report of the State Earthquake Investigation Commission: Carnegie Institution of Washington Publication 87, $2 \mathrm{v}$.

Lienkaemper, J.J., 1984, Comparison of two surface-wave magnitude scales: $M$ of Gutenberg and Richter (1954) and $M_{S}$ of "Preliminary Determination of Epicenters": Seismological Society of America Bulletin, v. 74, no. 6, p. 2357-2378.

Lienkaemper, J.J., Pezzopane, S.K., Clark, M.M., and Rymer, M.J., 1987, Fault fractures formed in association with the 1986 Chalfant Valley, California, earthquake sequence: Preliminary report: Seismological Society of America Bulletin, v. 77, no. 1, p. 297-305.

Lindh, A.G., 1983, Preliminary assessment of long-term probabilities for large earthquakes along selected fault segments of the San Andreas fault system in California: U.S. Geological Survey Open-File Report 83-63, $14 \mathrm{p}$.

Liu, H.-L., and Helmberger, D.V., 1983, The near-source ground motion of the 6 August 1979 Coyote Lake, California, earthquake: Seismological Society of America Bulletin, v. 73, no. 1, p. 201-218.

Louderback, G.D., 1947, Central California earthquakes of the 1830's: Seismological Society of America Bulletin, v. 37, no. 1, p. 33-74.

McAdie, A.G., 1907, Catalogue of earthquakes on the Pacific coast, 1897-1906: Smithsonian Institution of Washington Miscellaneous Collections, v. 49, art. $5,64 \mathrm{p}$.

McCulloch, D.S., 1985, Evaluating tsunami potential, in Ziony, J.I., ed., Evaluating earthquake hazards in the Los Angeles region-an earth-science perspective: U.S. Geological Survey Professional Paper 1360, p. $375-413$.

Mendoza, Carlos, and Hartzell, S.H., 1988, Aftershock patterns and main shock faulting: Seismological Society of America Bulletin, v. 78 , no. 4 , p. $1438-1449$.
Milne, John, 1901, Analyses of large earthquakes recorded in 1899: British Association for the Advancement of Science Meeting, 70th, Dover, 1900, Report, p. 60-104.

Mogi, Kiyoo, 1981, Seismicity in western Japan and long-term earthquake forecasting: in Simpson, D.W., and Richards, P.G., eds., Earthquake prediction: An international review (Maurice Ewing Series 4): Washington, American Geophysical Union, p. 43-51.

Mount, V.S., and Suppe, John, 1987, State of stress near the San Andreas fault: Implications for wrench tectonics: Geology, v. 15, no. 12 , p. $1143-1146$.

Nishenko, S.P., and Buland, Ray, 1987, A generic recurrence interval distribution for earthquake forecasting: Seismological Society of America Bulletin, v. 77, no. 4, p. 1382-1399.

Oakeshott, G.B., ed., 1955, Earthquakes in Kern County, California during 1952: California Division of Mines Bulletin 171, $283 \mathrm{p}$.

Plafker, George, and Galloway, J.P. eds., 1989, Lessons learned from the Loma Prieta, California, earthquake of October 17, 1989: U.S. Geological Survey Circular 1045, 48 p.

Reasenberg, P.A., and Ellsworth, W.L., 1982, Aftershocks of the Coyote Lake, California earthquake of August 6, 1979: A detailed study: Journal of Geophysical Research, v. 87 , no. B13, p. 10637-10655.

Reid, H.F., 1910, The mechanics of the earthquake, v. 2 of The California earthquake of April 18, 1906: Report of the State Earthquake Investigation Commission: Carnegie Institution of Washington Publication 87, $192 \mathrm{p}$.

Richter, C.F., 1935, An instrumental earthquake scale: Seismological Society of America Bulletin, v. 25, no. 1, p. 1-32.

1958, Elementary seismology: San Francisco, W.H. Freeman and Co., $768 \mathrm{p}$.

- 1973, Historical seismicity of San Fernando earthquake area, in Benfer, N.A., Coffman, J.L., and Bernick, J.R., eds., San Fernando, California, earthquake of February 9, 1971: Washington, U.S. Department of Commerce, National Oceanic and Atmospheric Administration, Environmental Research Laboratories, v. 3 , p. 5-11.

Rymer, M.J., and Ellsworth, W.L., eds., 1990, The Coalinga, California, earthquake of May 2, 1983: U.S. Geological Survey Professional Paper 1487, $417 \mathrm{p}$.

Sanders, C.O., and Slemmons, D.B., 1979, Recent crustal movements in the central Sierra Nevada-Walker Lane region of CaliforniaNevada: Part III, The Olinghouse fault zone: Tectonophysies, v. 52 , no. $1-4$, p. 585-597.

Savage, J.C., and Cockerham, R.S., 1987, Quasi-periodic occurrence of earthquakes in the 1978-1986 Bishop-Mammoth Lakes sequence, eastern California: Seismological Society of America Bulletin, v. 77, no. 4, p. 1347-1358.

Segall, Paul, and Harris, R.A., 1987, Earthquake deformation cycle on the San Andreas fault near Parkfield, California: Journal of Geophysical Research, v. 92, no. B10, p. 10511-10525.

Seismological Society of America Bulletin, 1916, The earthquake at Volcano Lake, Mexico, November 20, 1915: v. 6, no. 2-3, p. 181-184.

Sharp, R.V., 1982, Comparison of 1979 surface faulting with earlier displacements in the Imperial Valley, in The Imperial Valley, California earthquake of October 15, 1979: U.S. Geological Survey Professional Paper 1254, p. 213-221.

Shawe, D.R., 1965, Strike-slip control of Basin-Range structure indicated by historical faults in western Nevada: Geological Society of America Bulletin, v. 76, no. 12, p. 1361-1378.

Shor, G.G., Jr., and Roberts, Ellis, 1958, San Miguel, Baja California Norte, earthquakes of February, 1956: A field report: Seismological Society of America Bulletin, v. 48, no. 2, p. 101-116. 
Sieh, K.E., 1978a, Central California foreshocks of the great 1857 earthquake: Seismological Society of America Bulletin, v. 68, no. 6, p. 1731-1749.

- 1978b, Slip along the San Andreas fault associated with the great 1857 earthquake: Seismological Society of America Bulletin, v. 68, no. 5, p. 1421-1448.

Sieh, K.E., Stuiver, Minze, and Brillinger, David, 1989, A more precise chronology of earthquakes produced by the San Andreas fault in southern California: Journal of Geophysical Research, v. 94, no. B1, p. 603-623.

Singh, S.K,. and Havskov, Jens, 1980, On moment-magnitude scale: Seismological Society of America Bulletin, v. 70, no. 1, p. 379-383.

Slemmons, D.B., Steinbrugge, K.V., Tocher, Don, Oakeshott, G.B., and Gianella, V.P., 1959, Wonder, Nevada, earthquake of 1903 Seismological Society of America Bulletin, v. 49, no. 3, p. 251-265.

Smith, S.W., and Knapp, J.S., 1980, The northern termination of the San Andreas fault, in Streitz, Robert, and Sherburne, R.W., eds., Studies of the San Andreas fault zone in northern California: California Division of Mines and Geology Special Report 140, p. 153-164.

Stein, R.S., and King, G.C.P., 1984, Seismic potential revealed by surface folding: 1983 Coalinga, California, earthquake: Science, v. 224 , no. 4651 , p. 869-871.

Strand, C.L., 1980, Pre-1900 earthquakes of Baja California and San Diego County: San Diego, Calif., San Diego State University, 320 p.

Sykes, L.R., and Nishenko, S.P., 1984, Probabilities of occurrence of large plate rupturing earthquakes for the San Andreas, San Jacinto, and Imperial faults, California, 1983-2003: Journal of Geophysical Research, v. 89, no. B7, p. 5905-5927.

Thatcher, Wayne, 1975, Strain accumulation and release mechanism of the 1906 San Francisco earthquake: Journal of Geophysical Research, v. 80 , no. 35 , p. $4862-4872$.

Thatcher, Wayne, and Lisowski, Michael, 1987, 1906 earthquake slip on the San Andreas fault in offshore northwestern California [abs.]: Eos (American Geophysical Union Transactions), v. 68, no. 44, p. 1507.

Tocher, Don, 1956, Movement on the Rainbow Mountain fault: Seismological Society of America Bulletin, v. 46, no. 1, p. 10-14.

- 1959, Seismic history of the San Francisco region, in San Francisco earthquakes of March 1957: California Division of Mines Special Report 57, p. 39-48.

Toppozada, T.R., 1975, Earthquake magnitude as a function of intensity data in California and western Nevada: Seismological Society of America Bulletin, v. 65, no. 5, p. 1223-1238.

Toppozada, T.R., and Parke, D.L., 1982, Areas damaged by California earthquakes, 1900-1949: California Division of Mines and Geology
Open-File Report 82-17 SAC, $65 \mathrm{p}$.

Toppozada, T.R., Real, C.R., and Parke, D.L., 1981, Preparation of isoseismal maps and summaries of reported effects for pre-1900 California earthquakes: California Division of Mines and Geology Open-File Report 81-11 SAC, 182 p.

— 1988, Earthquake history of California, in Lee, W.H.K., Meyers, Herbert, and Shimazaki, Kunihiko, eds., Historical seismograms and earthquakes of the world: San Diego, Calif., Academic Press, p. 267-275.

Townley, S.D., and Allen, M.W., 1939, Descriptive catalog of earthquakes of the Pacific coast of the United States 1769 to 1928: Seismological Society of America Bulletin, v. 29, no. 1, p. 1-297.

Trifunac, M.D., and Brune, J.N., 1970, Complexity of energy release during the Imperial Valley, California, earthquake of 1940: Seismological Society of America Bulletin, v. 60, no. 1, p. 137-160.

U.S. Geological Survey, 1971, The San Fernando, California, earthquake of February 9, 1971: Professional Paper 733, $254 \mathrm{p}$.

— 1972, The Borrego Mountain earthquake of April 9, 1968: Professional Paper 787, 207 p.

- 1982, The Imperial Valley, California, earthquake of October 15, 1979: Professional Paper 1254, 451 p.

Wallace, R.E., 1984, Fault scarps formed during the earthquakes of October 2, 1915, in Pleasant Valley, Nevada, and some tectonic implications: U.S. Geological Survey Professional Paper 1274-A, p. A1-A33.

Walter, S.R., 1986, Intermediate-focus earthquakes associated with Gorda plate subduction in northern California: Seismological Society of America Bulletin, v. 76, no. 2, p. 583-588.

Wong, I.G., Ely, R.W., and Kollmann, A.C., 1988, Contemporary seismicity and tectonies of the northern and central Coast RangesSierran block boundary zone, California: Journal of Geophysical Research, v. 93, no. B7, p. 7813-7833.

Working Group on California Earthquake Probabilities, 1988, Probabilities of large earthquakes occurring in California on the San Andreas fault: U. S. Geological Survey Open File Report 88-398, $62 \mathrm{p}$.

Ziony, J.I., ed., 1985, Evaluating earthquake hazards in the Los Angeles region-an earth-science perspective: U.S. Geological Survey Professional Paper 1360, 505 p.

Zoback, M.D., Zoback, M.L., Mount, V.S., Suppe, John, Eaton, J.P., Healy, J.H., Oppenheimer, D.H., Reasenberg, P.A., Jones, L.M., Raleigh, C.B., Wong, I.G., Seotti, Oona, and Wentworth, C.M., 1987, New evidence on the state of stress of the San Andreas fault system: Science, v. 238, no. 4830 , p. 1105-1111.

Zoback, M.L., and Zoback, M.D., 1980, Faulting patterns in northcentral Nevada and strength of the crust: Journal of Geophysical Research, v. 85, no. B1, p. 275-284. 



\section{TABLE 6.1}

Earthquake origin times, magnitudes, and locations before 1990 principally derived from interpretations of felt reports by Toppozada and others (1981); after 1900, data principally derived from Gutenberg and Richter (1954) and bulletins of the California Institute of Technology, University of California, Berkeley, University of Nevada, Reno, and U.S. Geological Survey. See text for discussion of summary magnitude $M$. Other magnitude scales are $M_{L}$, local-magnitude scale of Richter (1935); $M_{G-R}$, magnitudes from Gutenberg and Richter (1954), generally based on 20 -s surface waves; $M_{S}, 20$-s surface-wave magnitude; $M_{l}$, magnitude estimated from felt area at various intensity levels; and $\mathbf{M}$, moment magnitude, defined as $\mathbf{M}=2 / 3 \log _{10} M_{0}-10.7$, where $M_{0}$ is in dyne-centimeters-parenthetical values based on seismogram envelope. $M_{S}$ values before 1935 generally derived from undamped Milne seismographs, using the formula of Abe (1988) - parenthetical values based on one or two amplitudes; $M_{S}$ values since 1968 measured from vertical seismograms. Absence of reported amplitudes on Milne seismographs (*) suggests $M_{S}<6$. 
TABLE 6.1.-Major California and Nevada earthquakes, 1769-1989

\begin{tabular}{|c|c|c|c|c|c|c|c|c|c|c|}
\hline \multicolumn{2}{|c|}{$\begin{array}{c}\text { Date and origin } \\
\text { time (GMT) }\end{array}$} & \multirow{2}{*}{$\begin{array}{l}M \\
6 ?\end{array}$} & \multicolumn{2}{|c|}{ Lat $\mathrm{N}$. and Long W. } & \multirow{2}{*}{$\begin{array}{l}\text { Locality } \\
\text { Los Angeles Basin-- }\end{array}$} & \multirow{2}{*}{$\begin{array}{l}M_{L} \\
-\end{array}$} & \multirow{2}{*}{$\frac{M_{G-R}}{-}$} & \multirow{2}{*}{$\begin{array}{l}M_{s} \\
-\end{array}$} & \multirow{2}{*}{$\begin{array}{ll}M \\
6\end{array}$} & \multirow{2}{*}{ M } \\
\hline $1769 / 07 / 28$ & & & $34^{\circ}$ & $118^{\circ}$ & & & & & & \\
\hline $1800 / 11 / 22$ & 21:30 & $61 / 2 ?$ & $33^{\circ}$ & $117^{\circ} 18^{\circ}$ & San Diego region- & - & - & - & $\geq 61 / 2$ & - \\
\hline $1808 / 06 / 21$ & & $6 ?$ & $37^{\circ} 48^{\circ}$ & $122^{\circ} 30^{\circ}$ & San Francisco region-...... & - & - & - & 6 & - \\
\hline $1812 / 12 / 08$ & 15:00 & 7 & $34^{\circ} 22^{\circ}$ & $117^{\circ} 39^{\circ}$ & 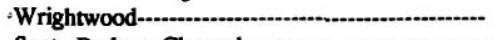 & - & - & - & 6.9 & - \\
\hline $1812 / 12 / 21$ & 19:00 & 7 & $34^{\circ} 12^{\circ}$ & $119^{\circ} 54^{\circ}$ & Santa Barbara Channel- & - & - & - & 7.1 & - \\
\hline $1827 / 09 / 24$ & 04:00 & $51 / 2 ?$ & $34^{\circ}$ & $119^{\circ}$ & Los Angeles region- & - & - & - & $51 / 2$ to 6 & - \\
\hline $1836 / 06 / 10$ & $15: 30$ & $63 / 4$ & $37^{\circ} 48^{\circ}$ & $122^{\circ} 12^{\circ}$ & Hayward fault-.- & - & - & - & 6.8 & - \\
\hline $1838 / 06 / ?$ & p.m. & 7 & $37^{\circ} 36^{\circ}$ & $122^{\circ} 24^{\circ}$ & San Francisco Peninsula- & - & - & - & $\geq 7.0$ & - \\
\hline $1852 / 11 / 29$ & $20: 00$ & $61 / 2$ & $32^{\circ} 30^{\circ}$ & $115^{\circ}$ & Volcano Lake, B.C. & - & - & - & 6 to 7 & - \\
\hline $1855 / 07 / 11$ & $04: 15$ & $6 ?$ & $34^{\circ} 6^{\circ}$ & $118^{\circ} 6^{\circ}$ & Los Angeles region & - & - & - & 6 & - \\
\hline $1856 / 02 / 15$ & $13: 25$ & $53 / 4$ & $37^{\circ} 30^{\circ}$ & $122^{\circ} 18^{\circ}$ & San Francisco Peninsula & - & - & - & 5.5 & - \\
\hline $1857 / 01 / 09$ & $16: 00$ & $81 / 4$ & $35^{\circ} 42^{\circ}$ & $120^{\circ} 18^{\circ}$ & Great Fort Tejon earthquake- & - & - & - & 7.6 & 7.8 \\
\hline $1857 / 09 / 03$ & 03:05 & $61 / 4$ & $39^{\circ} 18^{\circ}$ & $120^{\circ}$ & Westem Nevada or eastern Sierra Nevada--.--- & - & - & - & 6.0 & - \\
\hline $1858 / 11 / 26$ & 08:35 & $61 / 4$ & $37^{\circ} 30^{\circ}$ & $121^{\circ} 54^{\circ}$ & San Jose region- & - & - & - & 6.1 & - \\
\hline $1858 / 12 / 16$ & $10: 00$ & 6 & $34^{\circ}$ & $117^{\circ} 30^{\circ}$ & San Bernadino region-- & - & - & - & 6 & 一 \\
\hline $1860 / 03 / 15$ & 19:00 & $61 / 2$ & $39^{\circ} 30^{\circ}$ & $119^{\circ} 30^{\circ}$ & Carson City, Nev. region- & - & - & - & 6.3 & - \\
\hline $1861 / 07 / 04$ & 00:11 & $53 / 4$ & $37^{\circ} 48^{\circ}$ & $122^{\circ} 0^{\circ}$ & San Ramon Valley-y. & - & - & - & 5.6 & - \\
\hline $1862 / 05 / 27$ & $20: 00$ & 6 & $32^{\circ} 42^{\circ}$ & $117^{\circ} 12^{\prime}$ & San Diego region- & - & - & - & 5.9 & - \\
\hline $1864 / 02 / 26$ & $13: 47$ & 6 & $37^{\circ} 6^{\circ}$ & $121^{\circ} 42^{\circ}$ & Southern Santa Cruz Mountains & - & - & - & 5.9 & - \\
\hline $1864 / 03 / 05$ & $16: 49$ & $53 / 4$ & $37^{\circ} 42^{\circ}$ & $122^{\circ}$ & 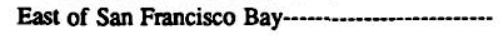 & - & - & - & 5.7 & 一 \\
\hline $1865 / 10 / 08$ & $20: 46$ & $61 / 2$ & $37^{\circ} 0^{\circ}$ & $122^{\circ} 0^{\circ}$ & Southern Santa Cruz Mountains-...- & - & - & - & 6.3 & - \\
\hline $1866 / 07 / 15$ & 06:30 & 6 & $37^{\circ} 30^{\circ}$ & $121^{\circ} 18^{\circ}$ & Western San Joaquin Valley- & - & - & - & 5.8 & - \\
\hline $1868 / 05 / 30$ & 05:10 & 6 & $39^{\circ} 18^{\circ}$ & $119^{\circ} 42^{\circ}$ & Virginia City, Nev. & - & - & - & $5.8,6$ & - \\
\hline $1868 / 10 / 21$ & $15: 53$ & 7 & $37^{\circ} 42^{\circ}$ & $122^{\circ} 6^{\circ}$ & Hayward fault-- & - & - & - & 6.8 & - \\
\hline $1869 / 12 / 27$ & $01: 55$ & $61 / 4$ & $39^{\circ} 24^{\prime}$ & $119^{\circ} 42^{\circ}$ & Olinghouse fault, Nev. (?)- & - & - & - & 6.1 & - \\
\hline $1869 / 12 / 27$ & $10: 00$ & 6 & $39^{\circ} 6^{\circ}$ & $119^{\circ} 48^{\circ}$ & Carson City, Nev. region-........ & - & - & - & 5.9 & - \\
\hline $1870 / 02 / 17$ & $20: 12$ & 6 & $37^{\circ} 12^{\circ}$ & $122^{\circ} 6^{\circ}$ & Los Gatos- & - & - & - & 5.8 & - \\
\hline $1871 / 03 / 02$ & 21:05 & 6 & $40^{\circ} 24^{\circ}$ & $124^{\circ} 12^{\circ}$ & Cape Mendocino- & - & - & - & 5.9 & - \\
\hline $1872 / 03 / 26$ & $10: 30$ & 7.6 & $36^{\circ} 42^{\circ}$ & $118^{\circ} 6^{\circ}$ & Owens Valley-- & - & - & - & 7.3 & 7.6 \\
\hline $1872 / 03 / 26$ & $14: 06$ & $63 / 4$ & $36^{\circ} 54^{\circ}$ & $118^{\circ} 12^{\circ}$ & 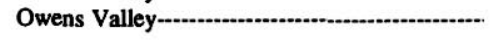 & - & - & - & 6.5 & - \\
\hline $1872 / 04 / 03$ & $12: 15$ & $61 / 4$ & $37^{\circ}$ & $118^{\circ} 12^{\circ}$ & Owens Valley-..-..... & - & - & - & 6.1 & - \\
\hline $1872 / 04 / 11$ & 19:00 & $63 / 4$ & $37^{\circ} 30^{\circ}$ & $118^{\circ} 30^{\circ}$ & Owens Valley-1.-- & - & - & - & 6.6 & - \\
\hline $1872 / 05 / 03$ & 01:00 & $53 / 4$ & $33^{\circ}$ & $115^{\circ}$ & Imperial Valley (?) & - & - & - & $\geq 5.5$ & - \\
\hline $1872 / 11 / 12$ & 00:00 & 6 & $39^{\circ} ?$ & $117^{\circ} ?$ & Austin, Nev. region (?) & - & - & - & 6 & - \\
\hline $1873 / 11 / 23$ & 05:00 & $63 / 4$ & $42^{\circ}$ & $124^{\circ}$ & Crescent City- & - & - & - & 6.7 & - \\
\hline $1875 / 01 / 24$ & $12: 00$ & 6 & $40^{\circ} 12^{\circ}$ & $120^{\circ} 30^{\circ}$ & 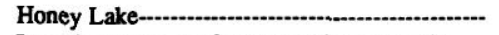 & - & - & - & 5.8 & - \\
\hline $1875 / 11 / 15$ & $22: 30$ & $61 / 4$ & $32^{\circ} 30^{\circ}$ & $115^{\circ} 30^{\circ}$ & Imperial Valley to Colorado River delta (?)---- & - & - & - & 6.2 & - \\
\hline $1878 / 05 / 09$ & $04: 25$ & 6 & $40^{\circ} 6^{\circ}$ & $124^{\circ}$ & Punta Gorda region- & - & - & - & 5.8 & - \\
\hline $1881 / 02 / 02$ & $00: 11$ & $53 / 4$ & $36^{\circ} 0^{\circ}$ & $120^{\circ} 30^{\circ}$ & Parkfield-............. & - & - & - & 5.6 & - \\
\hline $1881 / 04 / 10$ & $10: 00$ & 6 & $37^{\circ} 24^{\circ}$ & $121^{\circ} 24^{\circ}$ & Western San Joaquin Valley-..._... & - & - & - & 5.9 & - \\
\hline $1882 / 03 / 06$ & $21: 45$ & $53 / 4$ & $36^{\circ} 54^{\circ}$ & $121^{\circ} 12^{\circ}$ & Hollister--..- & - & - & - & 5.7 & - \\
\hline $1883 / 09 / 05$ & $12: 30$ & $61 / 4$ & $34^{\circ} 12^{\prime}$ & $119^{\circ} 54^{\circ}$ & Santa Barbara Channel-o- & - & - & - & 6.0 & - \\
\hline $1884 / 01 / 28$ & 07:30 & $53 / 4$ & $41^{\circ} 6^{\circ}$ & $123^{\circ} 36^{\circ}$ & Klamath Mountains-1. & - & - & - & 5.7 & - \\
\hline $1884 / 03 / 26$ & $00: 40$ & 6 & $37^{\circ} 6^{\circ}$ & $122^{\circ} 12^{\circ}$ & 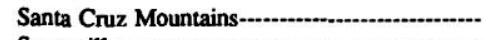 & - & - & - & 5.9 & - \\
\hline $1885 / 01 / 31$ & 05:45 & $53 / 4$ & $40^{\circ} 24^{\circ}$ & $120^{\circ} 36^{\circ}$ & 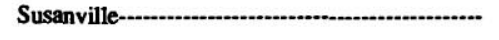 & - & - & - & 5.7 & - \\
\hline $1885 / 04 / 12$ & 04:05 & $61 / 4$ & $36^{\circ} 24^{\circ}$ & $121^{\circ}$ & Southern Diablo Range- & - & - & - & 6.2 & - \\
\hline $1887 / 06 / 03$ & $10: 48$ & $61 / 2$ & $39^{\circ} 12^{\circ}$ & $119^{\circ} 48^{\circ}$ & Carson City, Nev. region & - & - & - & 6.3 & - \\
\hline $1888 / 04 / 29$ & $04: 48$ & 6 & $39^{\circ} 42^{\circ}$ & $120^{\circ} 42^{\circ}$ & Mohawk Valley-........... & - & - & - & 5.9 & - \\
\hline $1889 / 05 / 19$ & 11:10 & $61 / 4$ & $38^{\circ} 0^{\circ}$ & $121^{\circ} 54^{\circ}$ & Antioch--- & - & - & - & 6.0 & - \\
\hline $1889 / 06 / 20$ & $06: 00$ & 6 & $40^{\circ} 30^{\circ}$ & $120^{\circ} 42^{\circ}$ & Susanville------- & - & - & - & 5.9 & - \\
\hline $1889 / 09 / 30$ & 05:20 & $53 / 4$ & $37^{\circ} 12^{\circ}$ & $118^{\circ} 42^{\circ}$ & Bishop region-............. & - & - & - & 5.6 & - \\
\hline $1890 / 02 / 09$ & $12: 06$ & $6 \frac{1}{2}$ & $33^{\circ} 24^{\circ}$ & $116^{\circ} 18^{\circ}$ & San Jacinto or Elsinore fault region (?)-........ & - & - & - & 6.3 & - \\
\hline $1890 / 04 / 24$ & $11: 36$ & $61 / 4$ & $36^{\circ} 54^{\circ}$ & $121^{\circ} 36^{\circ}$ & Pajaro Gap- & - & - & - & 6.0 & - \\
\hline $1890 / 07 / 26$ & 09:40 & $6 \frac{1}{4}$ & $40^{\circ} 30^{\circ}$ & $124^{\circ} 12^{\circ}$ & Cape Mendocino- & - & - & - & 6.0 & - \\
\hline $1891 / 07 / 30$ & $14: 10$ & 6 & $32^{\circ}$ & $115^{\circ}$ & Colorado River delta region--................... & - & - & - & 6.0 & - \\
\hline
\end{tabular}


TABLE 6.1.-Major California and Nevada earthquakes, 1979-1989-Continued

\begin{tabular}{|c|c|c|c|c|c|c|c|c|c|c|}
\hline \multicolumn{2}{|c|}{$\begin{array}{c}\text { Date and origin } \\
\text { time (GMT) }\end{array}$} & \multirow{2}{*}{$M$} & \multicolumn{2}{|c|}{ Lat $\mathrm{N}$. and Long W. } & \multirow{2}{*}{$\begin{array}{l}\text { Locality } \\
\text { Laguna Salada, B.C............ }\end{array}$} & \multirow{2}{*}{$\begin{array}{l}M_{L} \\
-\end{array}$} & \multirow{2}{*}{$\frac{M_{G-R}}{-}$} & \multirow{2}{*}{$\begin{array}{l}M_{s} \\
-\end{array}$} & \multirow{2}{*}{$\begin{array}{c}M_{I} \\
6.7,7.2\end{array}$} & \multirow{2}{*}{$\begin{array}{l}\mathbf{M} \\
-\end{array}$} \\
\hline $1892 / 02 / 24$ & $07: 20$ & & $32^{\circ} 33^{\circ}$ & $115^{\circ} 38^{\circ}$ & & & & & & \\
\hline $1892 / 04 / 19$ & $10: 50$ & $61 / 2$ & $38^{\circ} 24^{\circ}$ & $122^{\circ} 0^{\prime}$ & 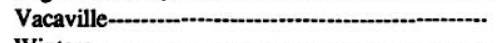 & - & - & - & 6.4 & - \\
\hline $1892 / 04 / 21$ & $17: 43$ & $61 / 4$ & $38^{\circ} 30^{\circ}$ & $121^{\circ} 54^{\prime}$ & Winters- & - & - & - & 6.2 & - \\
\hline $1892 / 05 / 28$ & $11: 15$ & $61 / 2$ & $33^{\circ} 12^{\circ}$ & $116^{\circ} 12^{\prime}$ & San Jacinto or Elsinore fault region (?)-.......- & - & - & - & 6.3 & - \\
\hline $1892 / 11 / 13$ & $12: 45$ & $53 / 4$ & $36^{\circ} 48^{\circ}$ & $121^{\circ} 30^{\prime}$ & Hollister-1-_._- & - & - & - & 5.6 & - \\
\hline $1893 / 05 / 19$ & $00: 35$ & $53 / 4$ & $34^{\circ} 6^{\circ}$ & $119^{\circ} 24^{\prime}$ & Pico Canyon-.. & - & - & - & $5.5,5.9$ & - \\
\hline $1894 / 07 / 30$ & 05:12 & 6 & $34^{\circ} 18^{\circ}$ & $117^{\circ} 36^{\prime}$ & Lytle Creek region- & - & - & - & $5.9,6.0$ & - \\
\hline $1894 / 09 / 30$ & $17: 36$ & 6 & $40^{\circ} 18^{\circ}$ & $123^{\circ} 42^{\prime}$ & Cape Mendocino region-- & - & - & - & 5.8 & - \\
\hline $1894 / 10 / 23$ & 23:03 & $53 / 4$ & $32^{\circ} 48^{\circ}$ & $116^{\circ} 48^{\prime}$ & East of San Diego- & - & - & - & 5.7 & - \\
\hline $1896 / 08 / 17$ & $11: 30$ & 6 & $36^{\circ} 42^{\circ}$ & $118^{\circ} 18^{\prime}$ & Southeastern Sierra Nevada- & - & - & - & 5.9 & - \\
\hline $1897 / 06 / 20$ & 20:14 & $61 / 4$ & $37^{\circ} 0^{\circ}$ & $121^{\circ} 30^{\prime}$ & Gilroy-........ & - & - & - & 6.2 & - \\
\hline $1898 / 03 / 31$ & $07: 43$ & $6^{1 / 2}$ & $38^{\circ} 12^{\prime}$ & $122^{\circ} 24^{\prime}$ & Mare Island-.... & - & - & (6.5) & 6.2 & - \\
\hline $1898 / 04 / 15$ & 07:07 & $61 / 2$ & $39^{\circ} 12^{\prime}$ & $123^{\circ} 48^{\circ}$ & Mendocino- & - & - & (6.7) & 6.4 & - \\
\hline $1899 / 04 / 16$ & $13: 40$ & 7 & $41^{\circ}$ ? & $126^{\circ}$ ? & West of Eureka-- & - & - & 7.0 & 5.7 & - \\
\hline $1899 / 07 / 06$ & $20: 10$ & $53 / 4$ & $37^{\circ} 12^{\circ}$ & $121^{\circ} 30^{\prime}$ & Morgan Hill-....-..-. & - & - & $(4.7)$ & 5.8 & - \\
\hline 1899/07/22 & $20: 32$ & $53 / 4$ & $34^{\circ} 18^{\circ}$ & $117^{\circ} 30^{\circ}$ & Lytle Creek region & - & - & (5.6) & $6.5,6.4$ & - \\
\hline $1899 / 12 / 25$ & $12: 25$ & 6.4 & $33^{\circ} 48^{\circ}$ & $117^{\circ} 0^{\prime}$ & 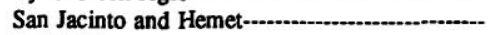 & - & - & 6.4 & $6.6,6.7$ & - \\
\hline $1901 / 03 / 03$ & $07: 45$ & 6.4 & $36^{\circ} 0^{\circ}$ & $120^{\circ} 30^{\circ}$ & Parkfield-1- & - & - & 6.4 & 5.8 & - \\
\hline $1903 / 01 / 24$ & 05:27 & 6.6 & $31^{\circ} 30^{\circ}$ & $115^{\circ}$ & Colorado River delta region- & - & $7+$ & 6.6 & - & - \\
\hline $1903 / 06 / 11$ & $13: 12$ & $5^{1 / 2}$ & $37^{\circ} 24^{\circ}$ & $121^{\circ} 54^{\circ}$ & 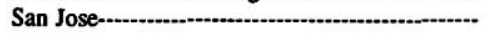 & - & - & $(5.4)$ & 5.8 & - \\
\hline 1903/08/03 & 06:49 & $5^{1 / 2}$ & $37^{\circ} 18^{\prime}$ & $121^{\circ} 48^{\circ}$ & San Jose--.-- & - & - & (5.3) & 5.8 & - \\
\hline $1906 / 04 / 18$ & 13:12 & $81 / 4$ & $37^{\circ} 42^{\circ}$ & $122^{\circ} 30^{\circ}$ & Great 1906 earthquake & 6.9 & $81 / 4,8.3$ & $7.8,8.3$ & 7.8 & 7.7 \\
\hline 1906/04/19 & 00:30 & 6.2 & $32^{\circ} 54^{\circ}$ & $115^{\circ} 30^{\prime}$ & Imperial Valley- & - & $6+$ & 6.2 & 5.8 & - \\
\hline $1906 / 04 / 23$ & 09:10 & 6.4 & $41^{\circ}$ & $124^{\circ}$ & Arcata- & - & - & 6.4 & - & - \\
\hline $1907 / 09 / 20$ & 01:54 & 5.3 & $34^{\circ} 12^{\prime} ?$ & $117^{\circ} 6 \%$ & 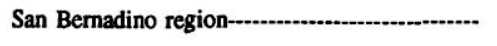 & - & 6 & $*$ & 5.3 & - \\
\hline $1908 / 11 / 04$ & 08:37 & $6 ?$ & $36^{\circ}$ ? & $117^{\circ}$ ? & Death Valley region--... & - & $61 / 2$ & * & - & - \\
\hline 1909/10/29 & $06: 45$ & 5.8 & $40^{\circ} 30^{\circ}$ & $124^{\circ} 12^{\circ}$ & Cape Mendocino---..-. & - & $6+$ & $5.8,(5.1)$ & 6.4 & - \\
\hline 1910/03/11 & 06:52 & 5.8 & $36^{\circ} 54^{\circ}$ & $121^{\circ} 48^{\circ}$ & Watsonville-- & - & - & 5.8 & 5.5 & - \\
\hline 1910/03/19 & 00:11 & 6.0 & $40^{\circ} ?$ & $125^{\circ}$ ? & West of Cape Mendocino-... & - & - & 6.0 & 6.2 & - \\
\hline $1910 / 05 / 15$ & $15: 47$ & $51 / 2$ & $33^{\circ} 42^{\circ}$ & $117^{\circ} 24^{\prime}$ & 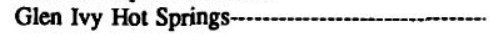 & - & - & (5.5) & $6.0,5.3$ & - \\
\hline 1910/08/05 & 01:31 & 6.6 & $42^{\circ}$ & $127^{\circ}$ & West of Crescent City & - & 6.8 & 6.6 & - & - \\
\hline 1911/07/01 & $22: 00$ & 6.5 & $37^{\circ} 15^{\circ}$ & $121^{\circ} 45^{\circ}$ & Calaveras fault-.. & - & 6.6 & 6.5 & 6.2 & - \\
\hline $1914 / 02 / 18$ & $18: 17$ & $5 / 2$ ? & $39^{\circ} 30^{\circ}$ & $119^{\circ} 48^{\circ}$ & Truckee region-1. & - & - & * & 6 & - \\
\hline $1914 / 04 / 24$ & 08:34 & 6 & $39^{\circ} 30^{\circ}$ & $119^{\circ} 48^{\circ}$ & Truckee region--:- & - & - & (5.5), (5.6) & 6.4 & - \\
\hline $1915 / 05 / 06$ & $12: 09$ & 6.2 & $40^{\circ}$ & $126^{\circ}$ & West of Cape Mendocino & - & $63 / 4$ & $6.2,(6.0)$ & - & - \\
\hline $1915 / 06 / 23$ & 03:59 & 6.0 & $32^{\circ} 48^{\circ}$ & $115^{\circ} 30^{\circ}$ & Imperial Valley-..- & - & $61 / 4$ & $6.0,(5.6)$ & $5.6,5.5$ & - \\
\hline $1915 / 06 / 23$ & 04:56 & 5.9 & $32^{\circ} 48^{\circ}$ & $115^{\circ} 30^{\circ}$ & Imperial Valley-......... & - & $61 / 4$ & 5.9 & $5.6,5.5$ & - \\
\hline $1915 / 10 / 03$ & 06:52 & 7.3 & $40^{\circ} 30^{\circ}$ & $117^{\circ} 30^{\circ}$ & Pleasant Valley, Nev. & - & $73 / 4$ & $7.6,7.4,7.3$ & - & 7.2 \\
\hline $1915 / 11 / 21$ & $00: 13$ & 7.1 & $32^{\circ}$ & $115^{\circ}$ & Volcano Lake, B.C. & - & 7.1 & $7.1,6.8$ & - & - \\
\hline $1915 / 12 / 31$ & $12: 20$ & 6.5 & $41^{\circ}$ & $126^{\circ}$ & West of Eureka-- & - & $61 / 2$ & $6.5,(6.4)$ & - & - \\
\hline $1916 / 02 / 03$ & 05:03 & 5.9 & $41^{\circ}$ & $117^{\circ} 48^{\circ}$ & North of Pleasant Valley, Nev.-............. & - & - & (5.1) & 5.9 & - \\
\hline $1916 / 10 / 23$ & $02: 44$ & 5.3 & $34^{\circ} 54^{\circ}$ & $118^{\circ} 54^{\circ}$ & Tejon Pass region--...... & - & $5^{1 / 2 \pm}$ & 6 & $5.2,5.3$ & (5.3) \\
\hline $1916 / 11 / 10$ & 09:11 & 6.1 & $35^{\circ} 30^{\circ}$ & $116^{\circ} 0^{\circ}$ & South of Death Valley-..- & - & 6.1 & $(5.7,5.9)$ & - & - \\
\hline $1918 / 04 / 21$ & $22: 32$ & 6.9 & $33^{\circ} 48^{\circ}$ & $117^{\circ} 0^{\circ}$ & San Jacinto--.- & - & 6.8 & $7.2,6.9$ & 6.6 & (6.8) \\
\hline $1918 / 07 / 15$ & $00: 23$ & 6.5 & $41^{\circ}$ & $125^{\circ}$ & 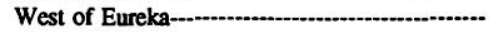 & - & $61 / 2$ & 6.5 & 5.9 & - \\
\hline 1922/01/26 & 09:31 & 6.0 & $41^{\circ}$ & $126^{\circ}$ & 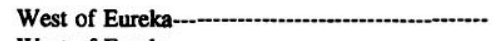 & - & 6 & (6.1) & - & - \\
\hline $1922 / 01 / 31$ & $13: 17$ & 7.3 & $41^{\circ}$ & $125^{\circ} 30^{\circ}$ & 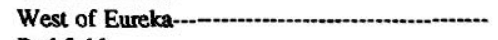 & - & 7.3 & 7.4 & - & - \\
\hline $1922 / 03 / 10$ & 11:21 & 6.3 & $36^{\circ} 0^{\circ}$ & $120^{\circ} 30^{\circ}$ & Parkfield---_e & - & $61 / 2$ & 6.3 & 6.3 & 6.1 \\
\hline 1923/01/22 & 09:04 & 7.2 & $40^{\circ} 30^{\circ}$ & $124^{\circ} 30^{\circ}$ & Cape Mendocino- & - & 7.2 & 7.3 & $6.5,6.8$ & - \\
\hline $1923 / 07 / 23$ & $07: 30$ & 6.0 & $34^{\circ} 0^{\circ}$ & $117^{\circ} 18^{\circ}$ & San Bermadino region--- & - & $61 / 4$ & - & 6.0 & 6.0 \\
\hline 1925/06/04 & 12:02 & 6 & $41^{\circ} 30^{\circ}$ & $125^{\circ}$ & West of Eureka--. & - & 6 & (5.8) & - & - \\
\hline $1925 / 06 / 29$ & $14: 42$ & 6.3 & $34^{\circ} 18^{\circ}$ & $119^{\circ} 48^{\circ}$ & Santa Barbara--1. & - & $61 / 4$ & - & 6.3 & (6.9) \\
\hline $1926 / 10 / 22$ & $12: 35$ & 6.1 & $36^{\circ} 37^{\circ}$ & $122^{\circ} 21^{\prime}$ & Monterey Bay-1. & - & 6.1 & - & 6.1 & - \\
\hline 1926/10/22 & 13:35 & 6.1 & $36^{\circ} 33^{\circ}$ & $122^{\circ} 11^{\circ}$ & Monterey Bay- & - & 6.1 & - & - & - \\
\hline $1926 / 12 / 10$ & 08:38 & 6.0 & $40^{\circ} 45^{\circ}$ & $126^{\circ}$ & 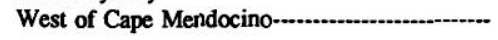 & - & 6.0 & (6.2) & - & - \\
\hline
\end{tabular}


TABLE 6.1. -Major California and Nevada earthquakes, 1979-1989-Continued

\begin{tabular}{|c|c|c|c|c|c|c|c|c|c|c|}
\hline \multicolumn{2}{|c|}{$\begin{array}{c}\text { Date and origin } \\
\text { time (GMT) }\end{array}$} & \multirow{2}{*}{\begin{tabular}{l|}
$M$ \\
6
\end{tabular}} & \multicolumn{2}{|c|}{ Lat $\mathrm{N}$. and Long $\mathrm{W}$. } & \multirow{2}{*}{ 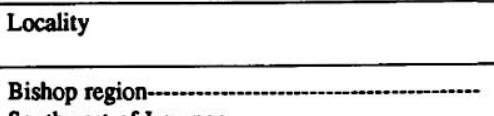 } & \multirow{2}{*}{$\frac{M_{\boldsymbol{L}}}{-}$} & \multirow{3}{*}{$\frac{M_{G-R}}{6.3,7.5}$} & \multirow{3}{*}{$\begin{array}{c}M_{S} \\
\overline{(7.2)}\end{array}$} & \multirow{3}{*}{$\begin{array}{l}M_{I} \\
5.5 \\
6.2\end{array}$} & \multirow{2}{*}{$\bar{M}$} \\
\hline $1927 / 09 / 18$ & 02:07 & & $37^{\circ} 30^{\circ}$ & $118^{\circ} 45^{\circ}$ & & & & & & \\
\hline $1927 / 11 / 04$ & 13:50 & 7.3 & $34^{\circ} 42^{\prime}$ & $120^{\circ} 48^{\circ}$ & Southwest of Lompoc-................................... & & & & & (7.3) \\
\hline 1932/06/06 & 08:44 & 6.4 & $40^{\circ} 45^{\circ}$ & $124^{\circ} 30^{\circ}$ & Eureka-1........................ & - & 6.4 & (6.4) & 5.9 & - \\
\hline $1932 / 12 / 21$ & 06:10 & 7.2 & $38^{\circ} 45^{\circ}$ & $118^{\circ}$ & 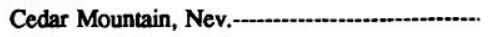 & - & 7.2 & (7.4) & - & - \\
\hline 1933/01/05 & 06:51 & 5.9 & $38^{\circ} 46^{\circ}$ & $117^{\circ} 44^{\circ}$ & Cedar Mountain, Nev........................... & 5.7 & 5.9 & - & - & - \\
\hline 1933/03/11 & 01:54 & 6.3 & $33^{\circ} 37^{\circ}$ & $117^{\circ} 58^{\circ}$ & Long Beach-...-. & 6.3 & $61 / 4$ & (6.5) & 6.2 & 6.2 \\
\hline $1933 / 06 / 25$ & 20:45 & 6.1 & $39^{\circ} 4^{\prime}$ & $119^{\circ} 20^{\circ}$ & Yerington, Nev...- & - & 6.1 & - & - & - \\
\hline $1934 / 01 / 30$ & 20:16 & 6.3 & $38^{\circ} 18^{\circ}$ & $118^{\circ} 24^{\circ}$ & Excelsior Mountain, Nev.----:- & - & $6.3,6.3$ & (6.4) & - & - \\
\hline 1934/06/08 & 04:47 & 6.0 & $36^{\circ} 0^{\circ}$ & $120^{\circ} 30^{\prime}$ & Parkfield-...-. & $2,6.0,6.1$ & 6.0 & - & 5.6 & 6.1 \\
\hline 1934/07/06 & $22: 48$ & 6.5 & $41^{\circ} 15^{\circ}$ & $125^{\circ} 45^{\circ}$ & 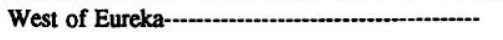 & - & 6.5 & - & - & - \\
\hline $1934 / 12 / 30$ & $13: 52$ & 6.5 & $32^{\circ} 15^{\circ}$ & $115^{\circ} 30^{\circ}$ & Laguna Salada, B.C. & 6.5 & 6.5 & - & - & (6.4) \\
\hline $1934 / 12 / 31$ & $18: 45$ & 7.0 & $32^{\circ}$ & $114^{\circ} 45^{\circ}$ & Colorado River delta- & 7.1 & 7.0 & - & - & (7.1) \\
\hline $1935 / 02 / 24$ & $01: 45$ & 5.3 & $31^{\circ} 59^{\circ}$ & $115^{\circ} 12^{\circ}$ & 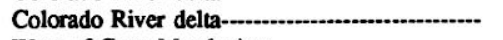 & 6.0 & $51 / 4$ & - & - & $(\leq 5.3)$ \\
\hline $1936 / 06 / 03$ & 09:15 & 5.9 & $40^{\circ}$ & $125^{\circ} 30^{\circ}$ & West of Cape Mendocino & - & 5.9 & - & - & - \\
\hline $1937 / 03 / 25$ & $16: 49$ & 6.0 & $33^{\circ} 28^{\circ}$ & $116^{\circ} 25^{\circ}$ & Buck Ridge--o.s. & $6.0,5.9$ & 6.0 & - & 5.9 & - \\
\hline 1940/02/08 & 08:05 & 6 & $39^{\circ} 45^{\circ}$ & $121^{\circ} 15^{\circ}$ & (n) & 5.7 & 6 & - & - & - \\
\hline 1940/05/19 & 04:36 & 7.1 & $32^{\circ} 44^{\circ}$ & $115^{\circ} 30^{\circ}$ & Imperial Valley-........ & 6.2 & $6.7,7.1$ & 7.2 & $6.4,6.6$ & $6.9 \cdot 7.1$ \\
\hline 1940/12/07 & 22:16 & $51 / 2$ & $31^{\circ} 40^{\circ}$ & $115^{\circ} 5^{\circ}$ & Colorado River delta--..--...- & 6.0 & $53 / 4$ & - & - & $(\leq 5.3)$ \\
\hline $1941 / 02 / 09$ & 09:44 & 6.6 & $40^{\circ} 42^{\circ}$ & $125^{\circ} 24^{\circ}$ & West of Cape Mendocino & 6.4 & 6.6 & - & - & - \\
\hline $1941 / 04 / 09$ & 17:08 & 5.3 & $31^{\circ}$ & $114^{\circ}$ & Gulf of California- & 6.0 & $51 / 4$ & - & - & - \\
\hline $1941 / 05 / 13$ & $16: 01$ & 6.0 & $40^{\circ} 18^{\circ}$ & $126^{\circ} 24^{\circ}$ & West of Cape Mendocino------. & 6.0 & 6 & - & - & - \\
\hline 1941/07/01 & 07:50 & 5.9 & $34^{\circ} 22^{\circ}$ & $119^{\circ} 35^{\circ}$ & Carpenteria- & 5.9 & 5.9 & - & $5.5,6.0$ & (6.0) \\
\hline 1941/09/14 & $16: 43$ & 5.8 & $37^{\circ} 34^{\circ}$ & $118^{\circ} 44^{\circ}$ & Tom's Place-.... & $5.8,6.0$ & 5.8 & - & 5.6 & \\
\hline 1941/09/14 & $18: 39$ & 6.0 & $37^{\circ} 34^{\circ}$ & $118^{\circ} 44^{\circ}$ & Tom's Place--....... & 6.0 & 6.0 & - & 5.6 & (5.5) \\
\hline $1941 / 10 / 03$ & $16: 13$ & 6.4 & $40^{\circ} 24^{\circ}$ & $124^{\circ} 48^{\circ}$ & West of Cape Mendocino--.-.. & 6.4 & 6.4 & - & - & - \\
\hline $1942 / 10 / 21$ & $16: 22$ & 6.5 & $33^{\circ} 3^{\prime}$ & $116^{\circ} 5^{\circ}$ & Fish Creek Mountains---..--..- & 6.5 & $61 / 2$ & - & $6.0,6.3$ & 6.6 \\
\hline $1942 / 12 / 03$ & 09:44 & 5.9 & $39^{\circ} 42^{\circ}$ & $119^{\circ} 18^{\prime}$ & North of Wadsworth, Nev........... & 5.5 & 5.9 & - & - & - \\
\hline 1945/05/19 & 15:07 & 6.2 & $40^{\circ} 24^{\circ}$ & $126^{\circ} 54^{\circ}$ & West of Cape Mendocino-....... & 6.0 & 6.2 & - & - & - \\
\hline 1945/09/28 & $22: 24$ & 6.0 & $41^{\circ} 54^{\circ}$ & $126^{\circ} 42^{\circ}$ & West of Crescent City-- & 6.0 & 6.0 & - & - & - \\
\hline 1946/03/15 & 13:49 & 6.3 & $35^{\circ} 44^{\circ}$ & $118^{\circ} 3^{\circ}$ & Walker Pass---.-.. & 6.3 & $61 / 4$ & - & 6.1 & 6.0 \\
\hline $1947 / 04 / 10$ & $15: 58$ & 6.4 & $34^{\circ} 59^{\circ}$ & $116^{\circ} 33^{\circ}$ & Manix- & 6.2 & 6.4 & - & $6.3,6.4$ & 6.6 \\
\hline $1948 / 12 / 04$ & $23: 43$ & 6.5 & $33^{\circ} 56^{\circ}$ & $116^{\circ} 23^{\circ}$ & Desert Hot Springs- & 6.5 & $6.5 \pm$ & - & $6.2,6.5$ & 6.0 \\
\hline $1948 / 12 / 29$ & $12: 53$ & 6.0 & $39^{\circ} 33^{\circ}$ & $120^{\circ} 5^{\circ}$ & 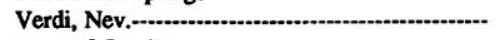 & 6.0 & 6.0 & - & 5.7 & - \\
\hline 1949/03/24 & 20:56 & 6.2 & $41^{\circ} 18^{\circ}$ & $126^{\circ}$ & West of Eureka-- & 5.9 & 6.2 & - & - & - \\
\hline 1949/05/02 & $11: 25$ & 5.9 & $34^{\circ} 1^{\circ}$ & $115^{\circ} 41^{\circ}$ & 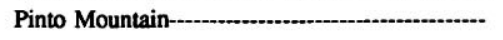 & 5.9 & 5.9 & - & - & - \\
\hline 1951/10/08 & $04: 10$ & 6 & $40^{\circ} 15^{\circ}$ & $124^{\circ} 30^{\circ}$ & West of Cape Mendocino- & 5.8 & 6 & - & - & - \\
\hline $1951 / 12 / 26$ & 00:46 & 5.9 & $32^{\circ} 48^{\circ}$ & $118^{\circ} 18^{\circ}$ & San Clemente Island-...................... & 5.9 & 5.9 & - & - & - \\
\hline $1952 / 07 / 21$ & $11: 52$ & 7.7 & $35^{\circ} 0^{\circ}$ & $119^{\circ} 1^{\circ}$ & Kern County earthquake-1. & 7.2 & 7.7 & 7.8 & 7.0 & $7.5,7.3$ \\
\hline $1952 / 07 / 21$ & $12: 05$ & 6.4 & $35^{\circ} 0^{\circ}$ & $119^{\circ} 0^{\circ}$ & Kern County-.. & 6.4 & - & - & - & - \\
\hline $1952 / 07 / 23$ & $00: 38$ & 6.1 & $35^{\circ} 22^{\circ}$ & $118^{\circ} 35^{\circ}$ & 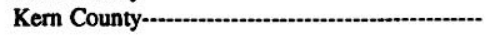 & 6.1 & - & - & - & 5.7 \\
\hline 1952/07/29 & 07:03 & 6.1 & $35^{\circ} 23^{\circ}$ & $118^{\circ} 51^{\circ}$ & ............ & 6.1 & - & - & - & 6.3 \\
\hline $1952 / 11 / 22$ & $07: 46$ & 6.0 & $35^{\circ} 44^{\circ}$ & $121^{\circ} 12^{\prime}$ & & 6.0 & $6 \pm$ & - & - & - \\
\hline $1954 / 01 / 12$ & 23:33 & 5.9 & $35^{\circ} 0^{\circ}$ & $119^{\circ} 1^{\prime}$ & West of Wheeler Ridge & 5.9 & - & - & - & 5.7 \\
\hline 1954/03/19 & 09:54 & 6.2 & $33^{\circ} 17^{\circ}$ & $116^{\circ} 11^{\circ}$ & Arroyo Salada- & $6.2,6.2$ & - & - & 6.2 & 6.4 \\
\hline $1954 / 07 / 06$ & 11:13 & 6.6 & $39^{\circ} 25^{\circ}$ & $118^{\circ} 32^{\prime}$ & Rainbow Mountain, Nev, & 6.8 & 6.6 & 6.3 & - & 6.2 \\
\hline 1954/07/06 & 22:07 & 6.4 & $39^{\circ} 18^{\circ}$ & $118^{\circ} 30^{\circ}$ & Mountain, Nev.---.. & 6.0 & 6.4 & - & - & 6.1 \\
\hline $1954 / 08 / 24$ & 05:51 & 6.8 & $39^{\circ} 35^{\circ}$ & $118^{\circ} 27^{\circ}$ & Stillwater, Nev, & 6.8 & 6.8 & 6.9 & - & 6.6 \\
\hline $1954 / 08 / 31$ & 22:20 & 6.3 & $39^{\circ} 30^{\circ}$ & $118^{\circ} 30^{\circ}$ & Stillwater, Nev.-1 & 5.8 & 6.3 & - & - & 5.8 \\
\hline $1954 / 10 / 24$ & 09:44 & 6.0 & $31^{\circ} 30^{\circ}$ & $116^{\circ}$ & East of Santo Tomas, B.C. & 6.0 & - & - & - & 6.0 \\
\hline $1954 / 11 / 12$ & $12: 26$ & 6.3 & $31^{\circ} 30^{\prime}$ & $116^{\circ}$ & 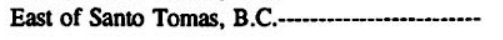 & 6.3 & - & - & - & 6.3 \\
\hline $1954 / 11 / 25$ & $11: 16$ & 6.5 & $40^{\circ} 16^{\circ}$ & $125^{\circ} 38^{\circ}$ & 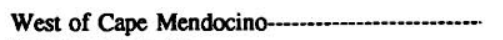 & 6.1 & 6.5 & 7.2 & - & - \\
\hline 1954/12/16 & 11:07 & 7.1 & $39^{\circ} 19^{\circ}$ & $118^{\circ} 12^{\circ}$ & 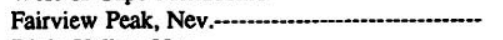 & 7.2 & 7.1 & - & - & 7.2 \\
\hline $1954 / 12 / 16$ & $11: 11$ & 6.8 & $39^{\circ} 30^{\circ}$ & $118^{\circ} 0^{\circ}$ & Dixie Valley, Nev.-. & 7.1 & 6.8 & - & - & 7.0 \\
\hline $1954 / 12 / 21$ & 19:56 & 6.6 & $40^{\circ} 56^{\circ}$ & $123^{\circ} 47^{\circ}$ & East of Arcata---:- & 6.5 & 6.6 & - & - & - \\
\hline $1956 / 02 / 09$ & $14: 32$ & 6.8 & $31^{\circ} 45^{\circ}$ & $115^{\circ} 55^{\circ}$ & San Miguel, B.C.-. & 6.8 & - & - & 6.3 & 6.5 \\
\hline
\end{tabular}


TABLE 6.1.-Major California and Nevada earthquakes, 1979-1989-Continued

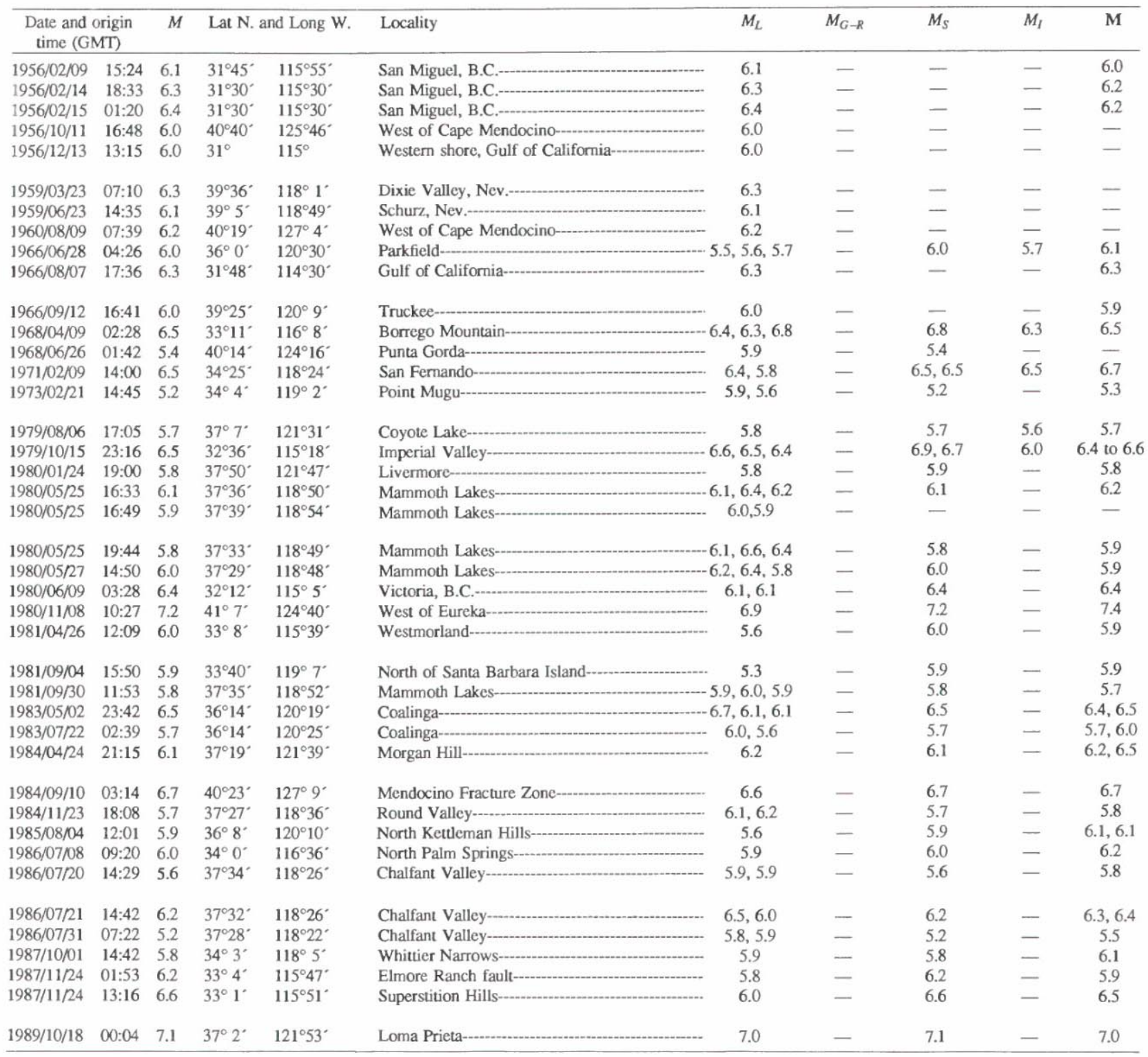




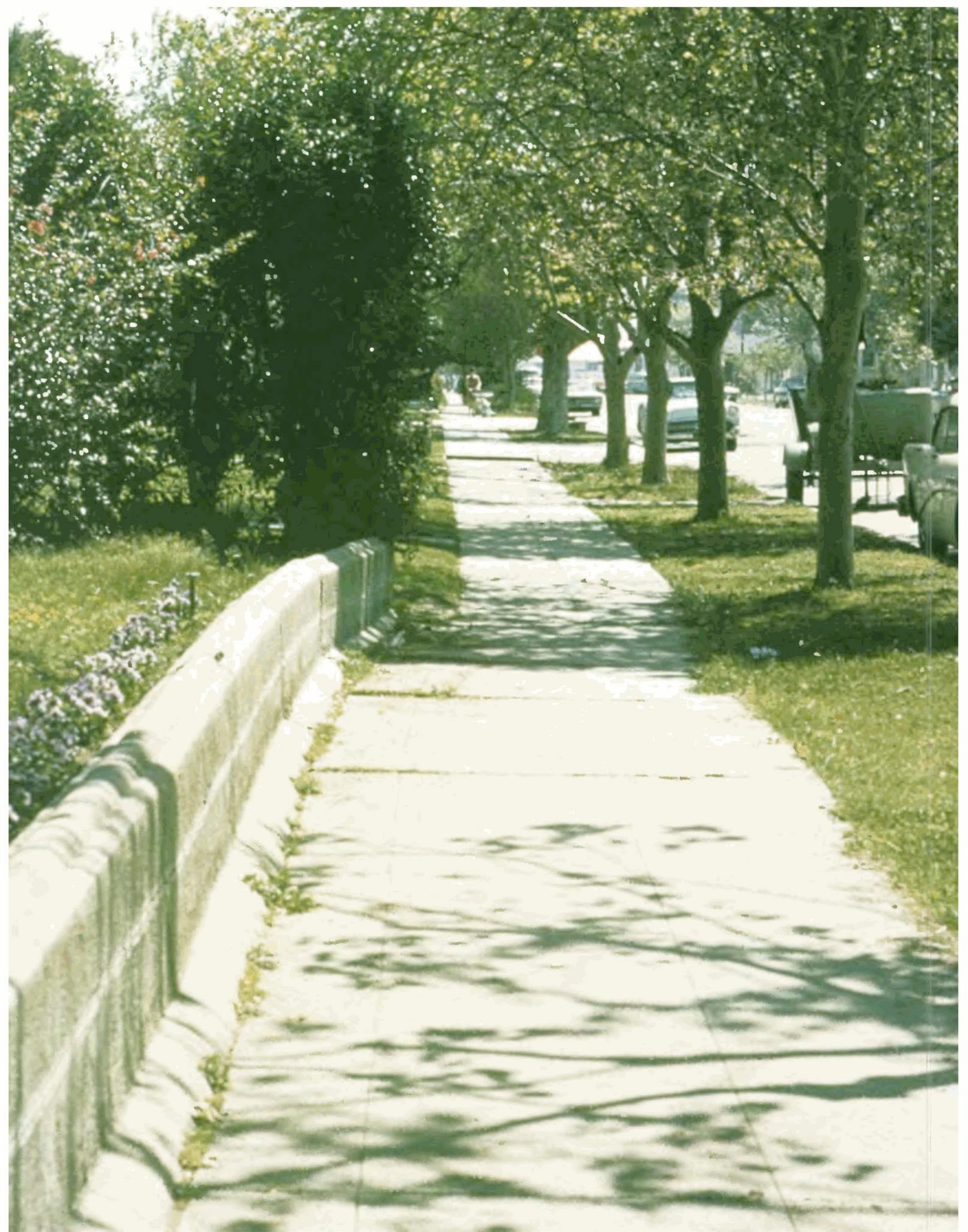


earthquakes have been documented, some on the same fault strand, and the entire zone of plate-boundary deformation is exceptionally broad. Major changes in fault strike also play a role in redistributing plateboundary deformation and diffusing it over a wider zone. Compressional bends introduce uplift, crustal thickening, and subsidiary reverse faulting, such as in the Transverse Ranges of southern California. Extensional bends are characterized by subsidence, basin filling, and, possibly, volcanism, as occurs in the Imperial Valley. Extensional and compressional features are more localized at the smaller-scale discontinuities and changes in fault strike that occur throughout the San Andreas system.

Crustal movements observed at the surface reflect deformation processes occurring at depth in the lithosphere. Both laboratory rock-mechanics experiments and studies of exhumed fault zones define the nature of these processes, which, in turn, constrain the classes of largescale faulting models consistent with surface measurements. In the cool and brittle seismically active parts of the crust, elastic processes are dominant, the frictional strength of active faults increases linearly with depth, and faulting is controlled by Coulomb failure. The transition from brittle seismic behavior to ductile aseismic deformation occurs in the midcrust. Although it is generally agreed that this transition occurs as a result of increasing temperature, its precise mechanism is uncertain. If deformation in the midcrust is concentrated within a narrow vertical shear zone lying beneath the seismically active fault plane, then the brittle/ductile transition may reflect either the increasing importance of ductile or cataclastic flow at depth (Sibson, 1982) or a thermally controlled transition from unstable to stable frictional sliding (Brace and Byerlee, 1966; Tse and Rice, 1986). However, if ductile deformation is broadly distributed in the midcrust, then the cyclic buildup and relief of stresses in the brittle seismogenic crust is controlled by the stress transfer between the elastic lithosphere and ductile "asthenosphere" and the flow properties of the latter.

Both the steady, aseismic movements within the San Andreas plate-boundary zone and the coseismic strain release in large earthquakes are well within the range of detectability of repeated geodetic-survey measurements. The purpose of this chapter is to summarize the salient features of these observations, demonstrating the constraints they place on the amount of present-day plate motion occurring across the San Andreas plate-boundary zone and showing how measurements shed light on the mechanics of the cycle of strain accumulation and release. The emphasis is necessarily on movements close to the main strands of the San Andreas fault system, where observations are most numerous, although some networks extend as far as $100 \mathrm{~km}$ from the major faults. The measurements include triangulation, repeated observations of the angular separation of permanent survey markers, for which useful data date back to about 1850 , when gold was first discovered in California; trilateration, repeated line-length measurements made by laser ranging since about 1970; and local measurements of aseismic fault slip made periodically or recorded continuously over apertures of about 10 to $100 \mathrm{~m}$ since about 1960 .

\section{OBSERVATIONS OF CRUSTAL DEFORMATION}

The focus here is on the spatial and temporal patterns of interearthquake horizontal crustal movements in California that owe their origins to relative motion between the Pacific and North American plates, movements that supply the strain energy which is stored in crustal rocks and ultimately released in large shallow-focus earthquakes. Observations of purely coseismic crustal deformation are not explicitly considered in this chapter; such movements are now well-understood consequences of slip on approximately the upper 10 to $15 \mathrm{~km}$ of vertical strike-slip faults. These models and their predicted deformation patterns are discussed within the context of the entire earthquake deformation cycle in the next section. Readers interested in the coseismic movements observed for specific San Andreas earthquakes are referred to the reports by Lawson (1908) and Thatcher (1975) (1906 San Francisco earthquake), Zhang and others (1988) (1940 El Centro earthquake), and Segall and Harris (1987) (1966 Parkfield earthquake).

Vertical crustal movements can locally be substantial, at least when averaged over recent geologic time (see Yeats, 1977; Lajoie, 1986). Deformation from reversefaulting earthquakes has also been well documented in several events (for example, 1952 Kern County earthquake by Stein and Thatcher, 1981; 1971 San Fernando earthquake by Castle and others, 1975; 1983 Coalinga earthquake by Stein, 1983). Nonetheless, vertical movements are second-order features along most of the San Andreas fault system, and so they are not considered further in this chapter.

Furthermore, in this chapter there is no review of measurement techniques, methods of analyzing and reducing data, or the mathematical and computational tools used in modeling deformation processes. Interested readers are referred to the reports by Bomford (1980) and Savage and Prescott (1973) for descriptions of horizontaldeformation-surveying methods and their precision, to those by Prescott (1976, 1981), Thatcher (1979), and Segall and Harris (1987) for discussions of data-analysis methods, and to the references cited below in the section entitled "Mechanics of Deformation" for details of the mathematical techniques used in model formulation. 
Contemporary crustal movements in California are concentrated within a plate-boundary deformation zone that is typically 50 to $200 \mathrm{~km}$ wide, centered approximately on the San Andreas fault. Observations of coseismic, postseismic, and interseismic movements define the earthquake deformation cycle and constrain models of strain accumulation and release for strike-slip plate boundaries.

\title{
7. PRESENT-DAY CRUSTAL MOVEMENTS AND THE MECHANICS OF CYCLIC DEFORMATION
}

\author{
By WAYNe Thatcher
}

\section{CONTENTS}

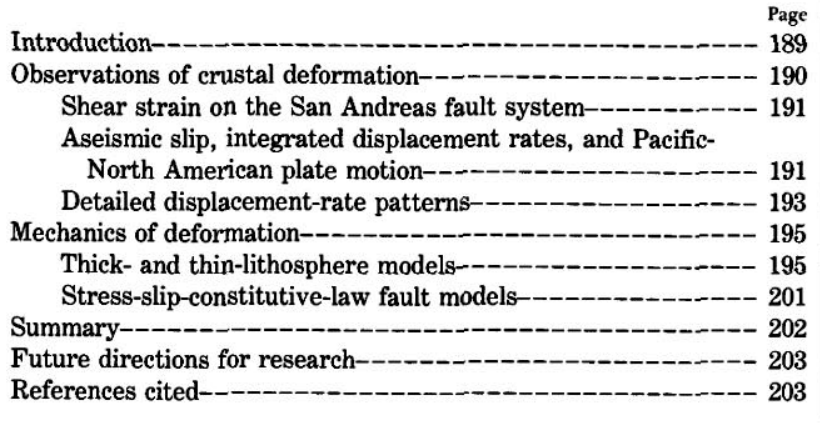

\section{INTRODUCTION}

Crustal movements measured in California today sample deformation processes that have continued through at least the past $5 \mathrm{Ma}$ of Pliocene, Pleistocene, and Holocene time. During this interval, several hundred kilometers of right-lateral offset has accumulated across the San Andreas fault system, and many thousands of great earthquakes similar to the historical events of 1857 and 1906 have undoubtedly occurred. The observed deformation results from relative right-lateral translation of the Pacific and North American plates far from the main plate-boundary faults, which are either freely slipping and without major seismic activity, or are in locked frictional contact and slip episodically in repeated great earthquakes. Aseismic fault slip (creep), as occurs across the San Andreas fault in central California (fig. 7.1), causes no crustal deformation beyond a growing offset across the fault, although this offset may be distributed across a zone as broad as a few tens or hundreds of meters. Where the plate-boundary fault is alternately locked aseismically in its upper $10 \mathrm{~km}$ or so and abruptly slipping in great earthquakes, deformation extends several tens of kilometers into the plate interiors. Between large events, elastic strains build up in this zone and are episodically released every few hundred years. Subsequent postearthquake recovery processes redistribute the strains aseismically for years to decades after a major shock, and this deformation gradually merges into the steady accumulation of elastic-strain energy that persists until the frictional strength of the fault is again exceeded. This sequence of interearthquake strain accumulation, coseismic strain release, and postseismic readjustment is thus a recurring process, here referred to inclusively as the earthquake deformation cycle.

Several fault-zone features result in measurable deformation spread over an extremely broad plate-boundary zone. This deformation occurs where the San Andreas fault system comprises several subparallel splays, as in both the San Francisco Bay region and southern California. There, both aseismic slip and major strike-slip

Figure 7.1. - A wall and sidewalk in Hollister, Calif., are bent and offset by creep on the Calaveras fault. A slip rate of 5 to $6 \mathrm{~mm} / \mathrm{yr}$ characterizes much of the Calaveras fault. View eastward along north side of Sixth Street. Photograph by R.E. Wallace, U.S. Geological Survey. 
Horizontal interearthquake deformation is summarized below in rates of both displacement and shear strain. For both of these parameters, the components parallel to major active faults are the most significant and best illustrate the dominant pattern of present-day tectonic movements, and so in this chapter these components are commonly shown exclusively. For example, although three independent tensor components are needed to completely characterize the horizontal-deformation field, in California the only significantly nonzero strainrate component is commonly the shear strain parallel to the local trend of faults in the San Andreas system. Here, I consider only the component of maximum horizontal shear-strain rate, which, within observational uncertainty, almost invariably parallels the San Andreas fault or one of its major strands.

\section{SHEAR STRAIN ON THE SAN ANDREAS FAULT SYSTEM}

Rates of contemporary shear strain are displayed in several complementary ways in figures 7.2 through 7.4; details of each rate determination are summarized in table 7.1. Although only the magnitude of the maximum shear-strain rate is shown in each figure, the orientation of the maximum-horizontal-contraction axis is listed in table 7.1. Note that for each of the strain rates shown in figures 7.2 through 7.4, aseismic fault slip contributes only negligibly, if at all, to the measured deformation. Further details on each strain field determination can be found in the references cited in table 7.1.

Shear-strain rates peak at 0.4 to $0.6 \mu \mathrm{rad} / \mathrm{yr}$ (fig. 7.2) across the currently locked northern and southern sections of the San Andreas fault. Significant but slightly lower strain rates of 0.3 to $0.4 \mu \mathrm{rad} / \mathrm{yr}$ are observed across right-lateral strike-slip faults in the northern California Coast Ranges (north of lat $38^{\circ} \mathrm{N}$.) east of the San Andreas fault, as well as across the San Jacinto fault in southern California. Shear-strain rates resolvably greater than zero are observed as far as about $80 \mathrm{~km}$ from the San Andreas fault itself.

In addition, significant deformation is occurring across active faults in east-central California. In the White Mountains, along the southern California-Nevada State line, small but resolvable strain rates $(0.06 \pm 0.02 \mu \mathrm{rad} /$ $\mathrm{yr}$ ) have been measured, and the orientation of the strain field indicates crustal extension perpendicular to northsouth-striking normal faults in the area. Somewhat higher deformation rates are observed farther south, where right-lateral strain is occurring parallel to the Owens Valley fault, site of the $M \simeq 8$ earthquake of 1872 (see chap. 6).

Shear-strain rate is plotted as a function of perpendicular distance from the San Andreas fault in figure 7.3. Deformation rates peak at the fault and decrease to half their maximums at a distance of about $30 \mathrm{~km}$ from the fault. Most of the deformation is encompassed within a zone about $100 \mathrm{~km}$ wide centered on the fault ("San Andreas boundary deformation zone"), as discussed below. However, the reader may confirm that this total lies in the range of about $30-40 \mathrm{~mm} / \mathrm{yr}$ by drawing a smooth curve through the data plotted in figure 7.3 and integrating this curve (that is, measuring and summing the total area underneath the curve) from -60 to $+60 \mathrm{~km}$.

Maximum shear-strain rates at the San Andreas fault tend to be higher across the 1906 earthquake rupture in northern California (approx $0.6 \mu \mathrm{rad} / \mathrm{yr}$ ) than in southern California (0.4 $\mu \mathrm{rad} / \mathrm{yr})$, although the Carrizo Plain data violate this generalization. Rather high deformation rates are also observed 20 to $60 \mathrm{~km}$ east of the San Andreas fault in the northern California Coast Ranges.

Shear-strain rates at various locations on the two currently locked sections of the San Andreas fault are plotted versus time since the most recent great earthquake at each locality in figure 7.4. Most of these data are derived from triangulation measurements, many of which were first made in the late 19th or early 20 th century. Thus, these determinations are much less precise than those listed in table 7.1 and plotted in figures 7.2 and 7.3, most of which are from the post-1970 period. Nonetheless, it is clear from figure 7.4 that deformation rates on the fault are much higher in the years to tens of years immediately after a great earthquake than they are later. Although it may be questionable to lump values from northern and southern California together on a single plot, the temporal decline in shear-strain rate shown in figure 7.4 depends only on about the first 70 years of data plotted, all of which come from the 1906 rupture on the northern section of the San Andreas fault.

\section{ASEISMIC SLIP, INTEGRATED DISPLACEMENT RATES, AND PACIFIC-NORTH AMERICAN PLATE MOTION}

Rates of surface aseismic slip (fault creep) at representative points on the San Andreas fault system are listed in table 7.2 and plotted in figure 7.5. All fault segments displaying measurable aseismic slip are represented, but the detailed distribution along each segment is not shown; interested readers are referred to the references cited in table $\mathbf{7 . 2}$ for more details. Figure 7.5 also displays the rates of relative right-lateral displacement integrated across geodetic networks of 50- to 140-km aperture that span the San Andreas and related faults in seven areas of California, for several of which the detailed displacement-rate pattern is shown in figures 7.6 and 7.7.

With the notable exception of the central, creeping section of the San Andreas fault, aseismic slip at the surface represents only a very small proportion of the 
total right-lateral displacement across the San Andreas fault system. On the $160-\mathrm{km}$-long central section of the San Andreas fault, maximum fault-creep rates average $30 \mathrm{~mm} / \mathrm{yr}$, close to the geodetically derived displacement rate of $33 \pm 1 \mathrm{~mm} / \mathrm{yr}$ obtained over a $60-\mathrm{km}$ aperture that spans the fault and the California Coast Ranges to the southwest. These data are the strongest evidence that no significant strain is accumulating in the crustal blocks adjacent to the fault in this region, and so all the relative plate motion taken up by the San Andreas system is here being accommodated by rigid-block translation across the fault. Just north of this segment, on the southern section of the Calaveras fault, a significant amount of rightlateral slip at a rate of about $13 \mathrm{~mm} / \mathrm{yr}$, occurs as fault creep. Elsewhere in California, however, measured aseismic-slip rates range from 2 to $6 \mathrm{~mm} / \mathrm{yr}$, and creep

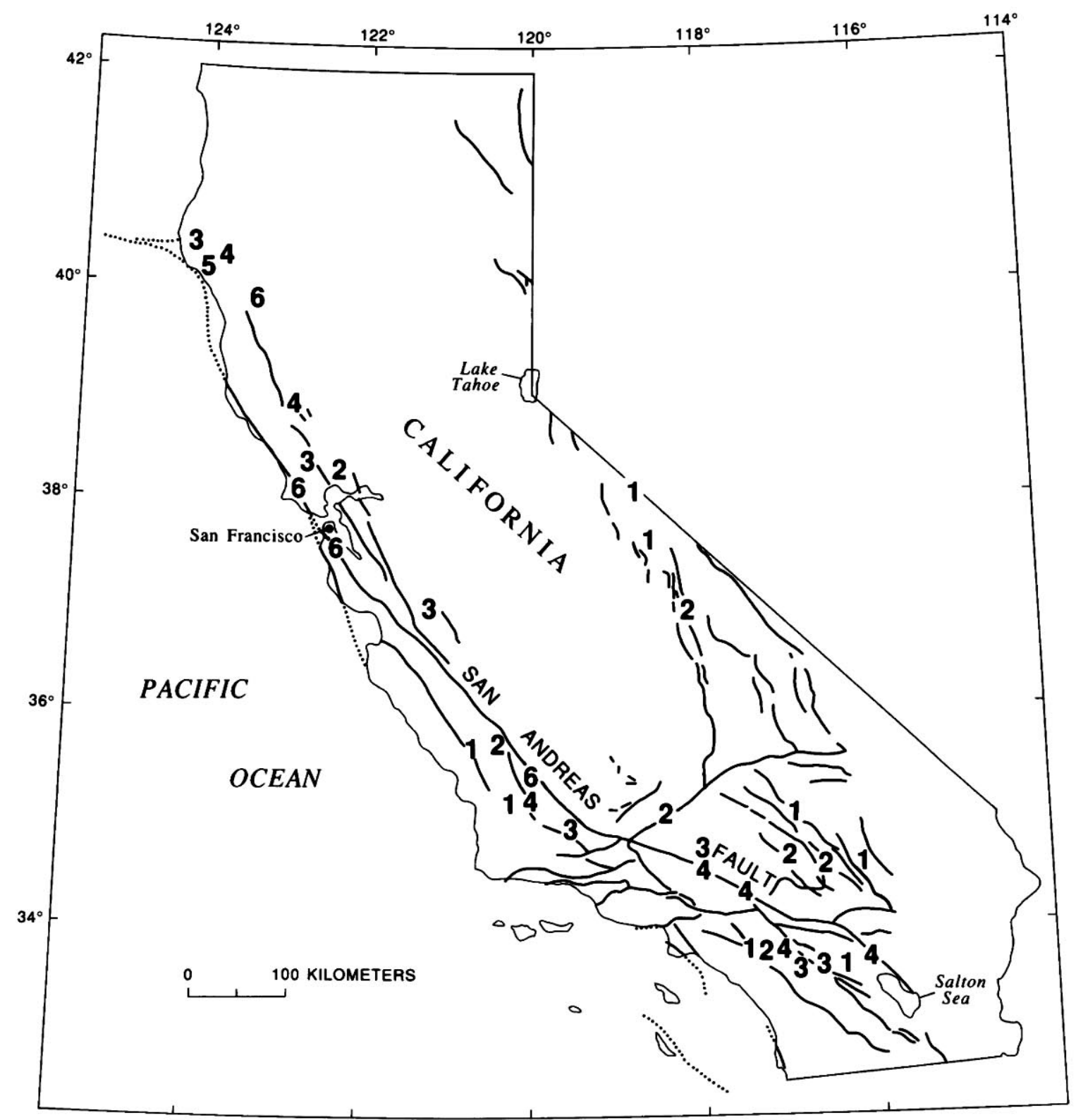

FIGURE 7.2. - Shear-strain rates (in $10^{-7} \mathrm{rad} / \mathrm{yr}$ ) and major active Quaternary faults of California; faults dotted where concealed. See table 7.1 for details. 
commonly occurs only on restricted segments of otherwise-locked faults (for example, the Garlock and San Jacinto faults).

The integrated right-lateral displacement rates shown in figure $\mathbf{7 . 5}$ firmly constrain the proportion of PacificNorth American relative plate motion accommodated across the San Andreas fault system in California. In northern, central, and southern California, maximum rates range from 33 to $37 \mathrm{~mm} / \mathrm{yr}$. Global reconstructions of the motions of the major tectonic plates over the past $3 \mathrm{Ma}$, as well as analyses of magnetic-anomaly lineations at the mouth of the Gulf of California, point to a relative Pacific-North American plate-motion rate of $49 \pm 3 \mathrm{~mm} / \mathrm{yr}$ (DeMets and others, 1987). The San Andreas fault system thus accounts for 70 to 80 percent of the relative plate motion, although the San Andreas fault itself does not everywhere take up all of this motion, and deformation is typically distributed across a boundary zone about $100 \mathrm{~km}$ wide.

Precisely how much additional relative plate motion is accommodated across other faults in California is uncertain, although the amount is probably very little. According to Minster and Jordan (1987), very long baseline interferometric (VLBI) surveying results indicate that oblique extension of the Basin and Range province, directly east of California, is occurring at a rate of $10 \pm 2$ $\mathrm{mm} / \mathrm{yr}$ with an orientation of N. $56^{\circ} \pm 10^{\circ} \mathrm{W}$. Depending

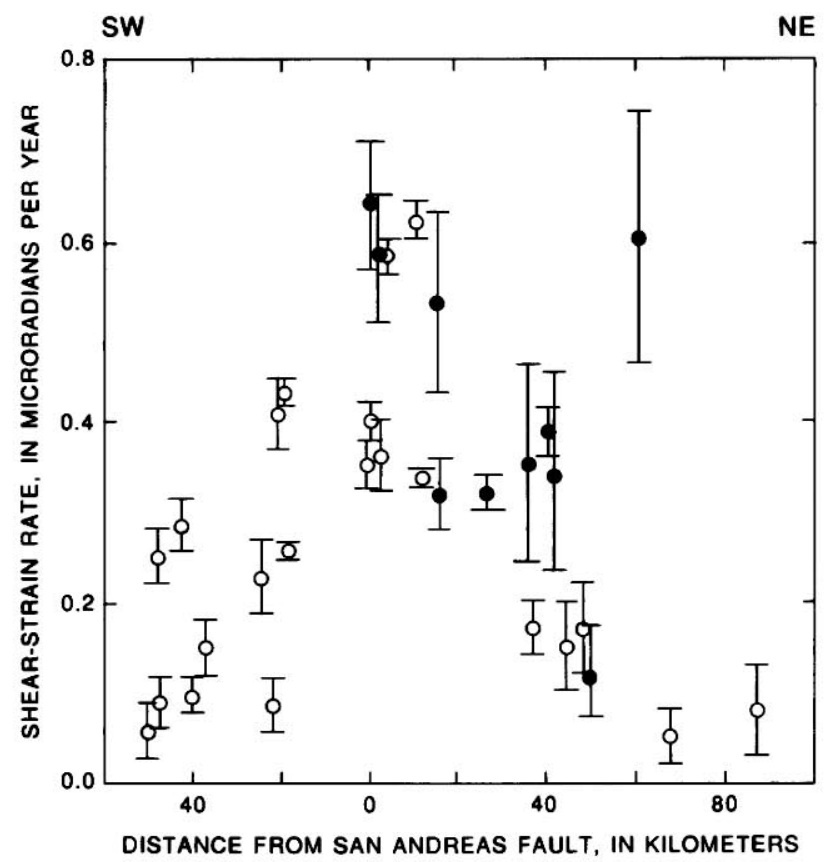

FIGURE 7.3. -Shear-strain rate versus perpendicular distance from the San Andreas fault. Dot, determination from northern California; circle, determination from southern California. 1- $\sigma$ error bars shown for reference. on the exact rate and orientation of this extension, as well as on the precise direction of relative Pacific-North American plate motion, the residual "missing" plate motion being accommodated in California on faults other than those of the San Andreas system ranges from negligibly small to possibly as much as $10 \mathrm{~mm} / \mathrm{yr}$. Thus, although the geodetic coverage in California is far from complete (see figs. 7.2, 7.5), all or most of the zone of significant plate-boundary deformation apparently has been encompassed.

\section{DETAILED DISPLACEMENT-RATE PATTERNS}

Considerable detail on the distribution of deformation in the San Andreas boundary zone is provided by the rather complete geodetic coverage available in the San Francisco Bay region and southern California. In the method used to reduce these data, geodetic-line-length changes are used to determine station-displacement rates relative to a point at the center of gravity of the network. Fault-normal displacements are permitted by this method, but their values are minimized in the inversion

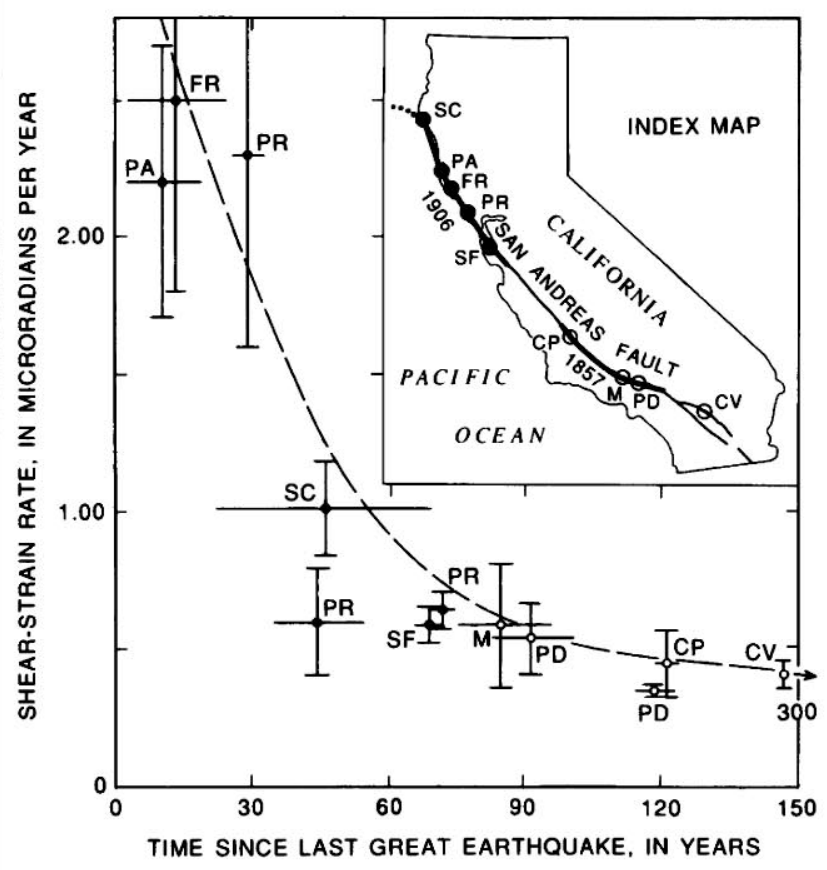

FIGURE 7.4. - Shear-strain rate versus time since last great earthquake (years 1906 and 1857 in inset; heavy line indicates extent of fault rupture) on the San Andreas fault. CP, Carrizo Plain; CV, Coachella Valley; FR, Fort Ross; M, Mojave; PA, Point Arena; PD, Palmdale; PR, Point Reyes; SC, Shelter Cove; SF, San Francisco. Locations of data points are keyed to index map. For each data point, vertical bar is $1 \sigma$, and horizontal line indicates time interval between surveys. Data points are plotted at middle of intervals. Dots, determinations from northern California; circles, determinations from southern California; dashed curve, approximate fit to data (Thatcher, 1983). 
TABLE 7.1.-Shear-strain rates in California

[Maximum compression measured from north, with clockwise direction positive]

\begin{tabular}{|c|c|c|c|c|c|c|}
\hline \multirow{2}{*}{ Area } & \multicolumn{2}{|c|}{ Location } & \multirow{2}{*}{$\begin{array}{c}\text { Rate } \\
(\mathrm{ppm} / \mathrm{yr})\end{array}$} & \multirow{2}{*}{$\begin{array}{c}\text { Maximum } \\
\text { compression } \\
\text { direction* }\left(^{\circ}\right)\end{array}$} & \multirow{2}{*}{ Interval } & \multirow{2}{*}{ Reference } \\
\hline & Lat N. & Long W. & & & & \\
\hline Mendocino ................................ & $\begin{array}{l}40.1^{\circ} \\
40.1^{\circ} \\
40.2^{\circ}\end{array}$ & $\begin{array}{l}124.0^{\circ} \\
123.7^{\circ} \\
124.1^{\circ}\end{array}$ & $\begin{array}{r}0.53 \pm 0.10 \\
.35 \pm 0.11 \\
.34 \pm 0.11\end{array}$ & $\begin{array}{r}3 \pm 4 \\
11 \pm 6 \\
21 \pm 9\end{array}$ & $\begin{array}{c}1981-84 \\
--\end{array}$ & Breen and others (1987). \\
\hline Round Valley ............................ & $39.9^{\circ}$ & $123.3^{\circ}$ & $.60 \pm 0.14$ & $-11 \pm 5$ & $1942-64$ & Prescott (1985). \\
\hline Point Reyes ........................... & $38.1^{\circ}$ & $122.8^{\circ}$ & $.64 \pm 0.07$ & $2 \pm 2$ & $1972-82$ & Prescott and Yu (1986). \\
\hline $\begin{array}{l}\text { Santa Rosa (Rodgers Creek } \\
\text { fault). }\end{array}$ & $38.4^{\circ}$ & $122.8^{\circ}$ & $.32 \pm 0.02$ & $12 \pm 2$ & -- & -- \\
\hline The Geysers (Maacama fault). & $38.8^{\circ}$ & $122.9^{\circ}$ & $.39 \pm 0.03$ & $11 \pm 3$ & -- & -- \\
\hline Napa (West Napa fault) ............. & $38.3^{\circ}$ & $122.3^{\circ}$ & $.17 \pm 0.05$ & $20 \pm 9$ & -- & -- \\
\hline San Francisco peninsula .............. & $38.5^{\circ}$ & $122.4^{\circ}$ & $.58 \pm 0.07$ & $-2 \pm 9$ & $1970-80$ & Prescott and others (1981). \\
\hline White Mountains ........................ & $\begin{array}{l}37.9^{\circ} \\
37.5^{\circ}\end{array}$ & $\begin{array}{l}118.6^{\circ} \\
118.5^{\circ}\end{array}$ & $\begin{array}{l}.06 \pm 0.02 \\
.06 \pm 0.02\end{array}$ & $\begin{array}{r}-13 \pm 12 \\
-8 \pm 14\end{array}$ & $1972-79$ & Savage and Lisowski (1984). \\
\hline Owens Valley ............................ & $36.9^{\circ}$ & $118.1^{\circ}$ & $.16 \pm 0.06$ & $28 \pm 12$ & $1974-79$ & Savage and Lisowski (1980). \\
\hline $\begin{array}{l}\text { Hollister (E. of Calaveras } \\
\text { fault). }\end{array}$ & $36.9^{\circ}$ & $121.3^{\circ}$ & $.32 \pm 0.04$ & $-16 \pm 3$ & $1971-78$ & Savage and others (1979). \\
\hline \multicolumn{7}{|l|}{ San Luis network: } \\
\hline Central ............. & $35.5^{\circ}$ & $120.4^{\circ}$ & $.23 \pm 0.04$ & $-23 \pm 3$ & $1977-83$ & $\begin{array}{l}\text { N.E. King (unpub. data, } \\
\text { 1988). }\end{array}$ \\
\hline $\begin{array}{l}\text { West.................................. } \\
\text { Carrizo network: }\end{array}$ & $35.4^{\circ}$ & $120.7^{\circ}$ & $.09 \pm 0.03$ & $-18 \pm 10$ & -- & -- \\
\hline $\mathrm{A}$ & $35.4^{\circ}$ & $119.8^{\circ}$ & $.62 \pm 0.02$ & -- & $1977-83$ & $\begin{array}{l}\text { N.E. King (unpub. data, } \\
\text { 1983). }\end{array}$ \\
\hline B. & $35.3^{\circ}$ & $119.8^{\circ}$ & $.58 \pm 0.02$ & -- & -- & -- \\
\hline ....................... & $35.1^{\circ}$ & $119.9^{\circ}$ & $.43 \pm 0.02$ & -- & -- & -- \\
\hline 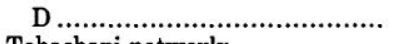 & $35.1^{\circ}$ & $120.2^{\circ}$ & $.10 \pm 0.02$ & -- & -- & -- \\
\hline \multicolumn{7}{|l|}{ Tehachapi network: } \\
\hline Garlock fault ....................... & $34.9^{\circ}$ & $118.5^{\circ}$ & $.17 \pm .03$ & $4 \pm 3$ & $1973-83$ & King and Savage (1984). \\
\hline San Andreas fault ..................... & $34.6^{\circ}$ & $118.0^{\circ}$ & $.34 \pm .01$ & $-17 \pm 1$ & -- & -- \\
\hline Cajon network......................... & $34.3^{\circ}$ & $117.5^{\circ}$ & $.36 \pm .04$ & $-16 \pm 2$ & $1974-84$ & Savage and others (1986). \\
\hline Los Padres network................... & $34.8^{\circ}$ & $119.5^{\circ}$ & $.26 \pm .01$ & $-1 \pm 1$ & -- & \\
\hline Barstow ............................... & $35.0^{\circ}$ & $116.9^{\circ}$ & $.08 \pm .05$ & $24 \pm 17$ & $1979-84$ & King (1985). \\
\hline Palmdale ................................ & $34.4^{\circ}$ & $118.2^{\circ}$ & $.35 \pm .03$ & $-19 \pm 4$ & $1971-80$ & Savage and others (1981). \\
\hline \multicolumn{7}{|l|}{ Mojave network: } \\
\hline W1 $1 . . . . . . . . . . . . .$. & $34.6^{\circ}$ & $117.0^{\circ}$ & $.17 \pm .05$ & $4 \pm 11$ & $1934-82$ & Sauber and others (1986). \\
\hline 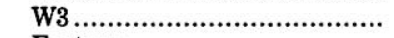 & $34.4^{\circ}$ & $116.6^{\circ}$ & $.15 \pm .05$ & $5 \pm 8$ & -- & -- \\
\hline Eastern.............................. & $34.5^{\circ}$ & $116.1^{\circ}$ & $.05 \pm .03$ & -- & -- & -- \\
\hline \multicolumn{7}{|l|}{ Anza network: } \\
\hline 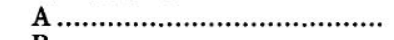 & $33.8^{\circ}$ & $117.4^{\circ}$ & $.06 \pm .03$ & -- & $1973-81$ & King and Savage (1983). \\
\hline 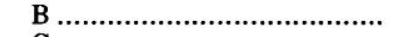 & $33.8^{\circ}$ & $117.1^{\circ}$ & $.15 \pm .03$ & $30 \pm 13$ & -- & -- \\
\hline C & $33.8^{\circ}$ & $117.0^{\circ}$ & $.41 \pm .04$ & $21 \pm 5$ & -- & -- \\
\hline 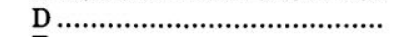 & $33.5^{\circ}$ & $116.8^{\circ}$ & $.25 \pm .03$ & $30 \pm 8$ & -- & -- \\
\hline 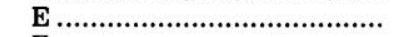 & $33.5^{\circ}$ & $116.7^{\circ}$ & $.29 \pm .03$ & $1 \pm 5$ & -- & -- \\
\hline 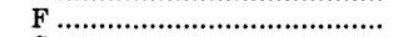 & $33.6^{\circ}$ & $116.4^{\circ}$ & $.09 \pm .03$ & -- & -- & -- \\
\hline 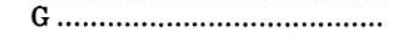 & $33.7^{\circ}$ & $116.1^{\circ}$ & $.40 \pm .02$ & $8 \pm 2$ & -- & -- \\
\hline
\end{tabular}

process (see Prescott, 1981). Gross departures from this constraint would be revealed by notable disagreements between observed and predicted line-length changes, but no such discrepancies were found for the results presented here. Because the fault-normal displacement rates are small and show no consistent trends, they are not plotted on the profiles presented here.

Displacement rates in the San Francisco Bay region are plotted in figure 7.6. The distribution of deformation varies considerably across the San Andreas boundary zone from north to south of the San Francisco Bay. In the north bay, the integrated right-lateral-displacement rate across the network of $27 \pm 3 \mathrm{~mm} / \mathrm{yr}$ (fig. $7.6 B$ ) indicates that not all of the boundary zone has been captured within its $110-\mathrm{km}$ aperture. Within about $5 \mathrm{~km}$ of the San Andreas fault, rapid change in the gradient of deformation rate indicates that interearthquake strain is concentrated close to the fault. Outside this near-fault region, deformation southwest of the fault appears to be negligible. Northeast of the fault, however, the persistence of significant movements right to the edge of the profile suggests that the 5 - to $10-\mathrm{mm} / \mathrm{yr}$ deficit in boundary-zone deformation across this profile is being accommodated to the east of the Green Valley fault. Across the central and south bay (fig. 7.6C), movements are more evenly distributed through the network, and the integrated 
TABLE 7.2.-Representative aseismic-slip rates on faults of the San Andreas system

\begin{tabular}{|c|c|c|c|c|c|c|}
\hline Fault & Site & Lat N. & Long W. & $\begin{array}{c}\text { Rate } \\
(\mathrm{mm} / \mathrm{yr})\end{array}$ & Reference & \\
\hline Hayward ................ & Hayward network ................... & $37.6^{\circ}$ & $122.1^{\circ}$ & 6 & Prescott and Lisowski & (1983). \\
\hline $\begin{array}{l}\text { Northern section } \\
\text { of the Calaveras. }\end{array}$ & 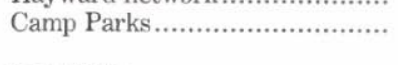 & $37.7^{\circ}$ & $121.9^{\circ}$ & 3 & Do. & \\
\hline $\begin{array}{l}\text { Southern section } \\
\text { of the Calaveras. }\end{array}$ & San Felipe ............................. & $37.0^{\circ}$ & $121.5^{\circ}$ & 13 & Lisowski and Prescott & (1981). \\
\hline San Andreas ............................ & Cienega Winery.......................... & $36.7^{\circ}$ & $121.5^{\circ}$ & 13 & Schulz and others (1982). & \\
\hline Do....................................... & Eade Ranch .......................... & $36.4^{\circ}$ & $121.0^{\circ}$ & 30 & Buford and Harsh (1980). & \\
\hline 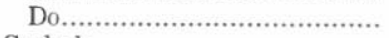 & Parkfield (Durham Ranch).......... & $35.9^{\circ}$ & $120.4^{\circ}$ & 13 & Do. & \\
\hline 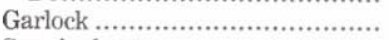 & Cameron ....................................... & $35.1^{\circ}$ & $118.3^{\circ}$ & 4 & Louie and others (1985). & \\
\hline San Andreas ........................... & Indio Hills .................................. & $33.7^{\circ}$ & $116.2^{\circ}$ & 2 & Do. & \\
\hline $\begin{array}{l}\text { San Jacinto } \\
\text { (Coyote Creek strand). }\end{array}$ & Bailey's Well ............................. & $33.0^{\circ}$ & $116.0^{\circ}$ & 5 & Do. & \\
\hline Imperial ................................ & Interstate Highway $80 \ldots \ldots \ldots \ldots \ldots$ & $32.8^{\circ}$ & $115.5^{\circ}$ & 5 & Do. & \\
\hline
\end{tabular}

displacement rate of $37 \pm 3 \mathrm{~mm} / \mathrm{yr}$ across the south bay suggests that the entire boundary zone has been spanned. Closer examination of the profile, however, reveals several zones of locally high deformation gradient, one across the San Andreas fault, where it resembles that observed near the fault in the north bay. In addition, rapid changes in the profile across the Hayward and Calaveras faults reflect aseismic slip at rates of 3 to 6 $\mathrm{mm} / \mathrm{yr}$ on these faults (see fig. 7.5).

In southern California (fig. 7.7), deformation across the San Andreas boundary zone notably broadens from the Salton Sea, in the south, northwestward to the Big Bend region of the San Andreas fault north of Los Angeles (see fig. 7.5). At the south end of the Salton Sea, all of the boundary-zone deformation, $35 \pm 1 \mathrm{~mm} / \mathrm{yr}$, occurs within an area about $50 \mathrm{~km}$ wide (profile $\mathrm{S}$, fig. $7.7 \mathrm{C}$ ) that rapidly broadens to more than $100 \mathrm{~km}$ wide north and west of the Salton Sea (profile N, fig. 7.7C) and, possibly, broader still by about $50 \mathrm{~km}$ farther northwest (fig. $7.7 B$ ). North and west of Los Angeles, networks of $100-\mathrm{km}$ aperture capture only $18 \pm 2 \mathrm{~mm} / \mathrm{yr}$ of the total right-lateral-displacement rate (fig. 7.5). The profiles in figures $7.7 B$ and $7.7 C$ also show that in contrast with the northern section of the San Andreas fault, deformation gradients across the fault are smoother, and deformation is not so closely concentrated near the fault.

\section{MECHANICS OF DEFORMATION}

The observations described in the previous section point to a range of mechanical behavior for the faults comprised by the San Andreas system, from freely sliding with only minor accompanying seismicity, to completely locked from the surface to seismogenic depths except for abrupt slip during infrequent great earthquakes.
On the 160-km-long central section of the San Andreas fault, virtually all fault slip occurs aseismically. Slip rates measured at or near the fault are close to the average rate for the entire San Andreas boundary zone (fig. 7.5), no strain is detectable in the crustal blocks adjacent to the fault, and historical earthquakes of $M \geq 5^{1 / 2}$ have not occurred. Abundant minor seismicity (see fig. 4.10) contributes only negligibly to the slip budget, and except for a few small patches of fault surface that are in frictional contact between these small earthquakes, the first-order steady-state model for this segment involves rigid translation of adjacent fault blocks across the freely sliding plane of the San Andreas.

A transitional behavior applies to those fault segments where steady-state fault creep is observed at the surface but historical or prehistoric earthquakes of $M \geq 6$ have been documented. Examples include the Parkfield and Coachella Valley segments of the San Andreas fault, the Hayward fault, and the Imperial fault. On these segments, during the interseismic phase of the earthquake cycle, the fault is inferred to be freely slipping in its upper few kilometers, in locked frictional contact at seismogenic depths (approx 3-10 km), and once again freely slipping at greater depths (fig. 7.8A). The result of this slip distribution is interseismic creep at the surface fault trace and elastic-strain accumulation in the adjacent blocks (figs. $7.8 B, 7.8 C$ ).

\section{THICK- AND THIN-LITHOSPHERE MODELS}

The most extreme features of locked fault behavior are currently observed on the two San Andreas fault segments where great earthquakes have occurred in historical time, in 1857 and 1906 (see fig. 5.11 for locations and coseismic-slip distributions). On these segments, no aseismic slip is observed at the Earth's surface, the two faces of the fault are in locked frictional contact to depths 
of 10 to $15 \mathrm{~km}$, and interearthquake slip is either extremely small or absent. At greater depths, the mechanics of fault movement is uncertain, but two models bound the range of expected behavior (fig. 7.9). In the first, the thick-lithosphere model, the depth $D$ of coseismic faulting is much less than the thickness $H$ of elastically strong lithosphere. Interearthquake deforma- tion then predominantly results from episodic or steady aseismic slip on the downward extension of the seismogenic fault zone, and any effects of the underlying weak asthenosphere can be safely neglected. In the second, the thin-lithosphere model (fig. 7.9), coseismic faulting depth is comparable to elastic-plate thickness. In this model, transient postseismic and steady interseismic flow in the

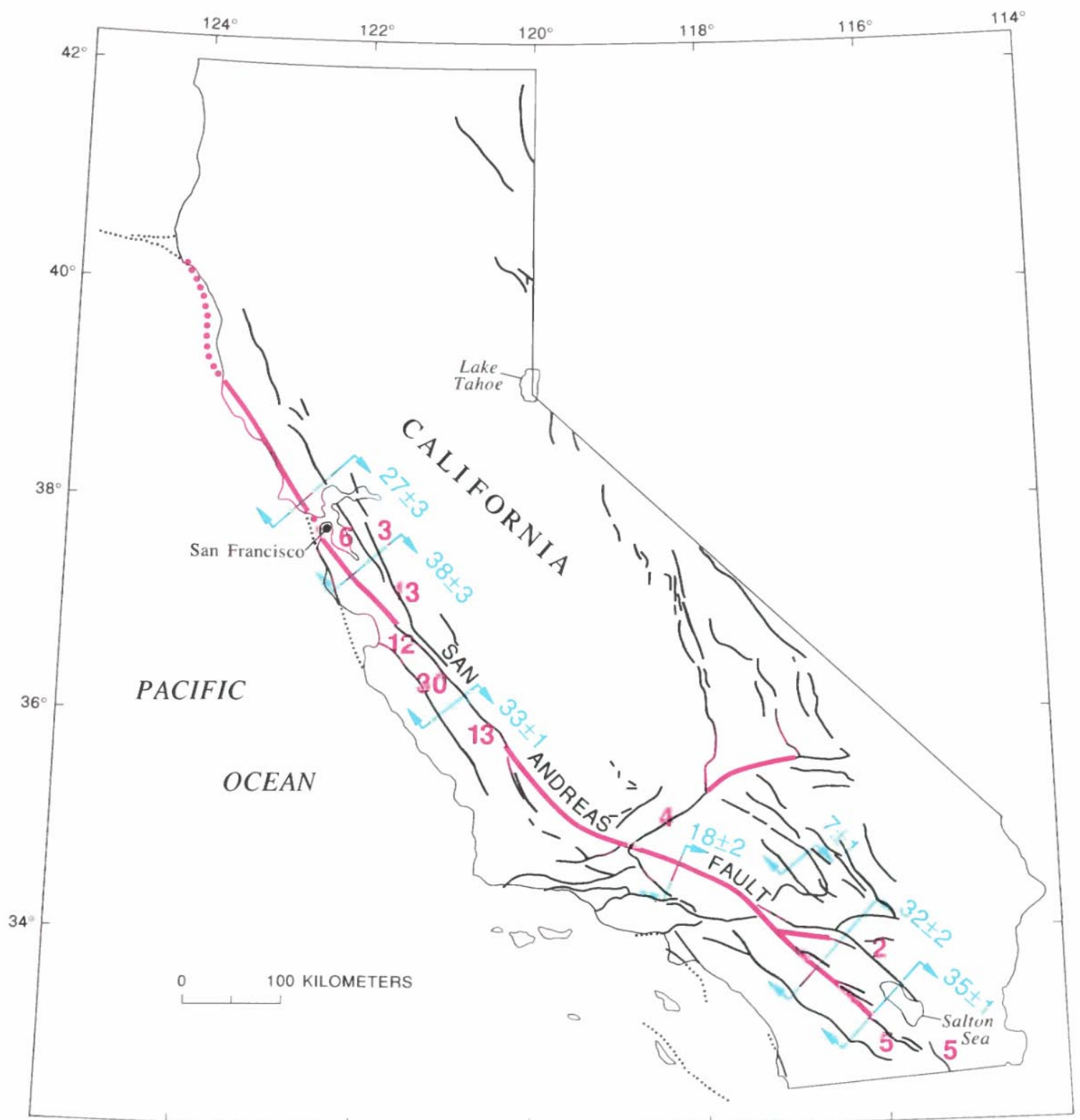

FIGURE 7.5.-Sketch map of California, showing rates (red numbers) of aseismic slip (fault creep) and relative rightlateral-displacement rates (blue numbers) near arrows, which indicate direction of relative movement along major active strands of the San Andreas fault system. Values in millimeters per year. Locked (no surface slip) segment of major fault, red line; other Quaternary fault, black line; faults dotted where concealed. See table 7.2 for details. 

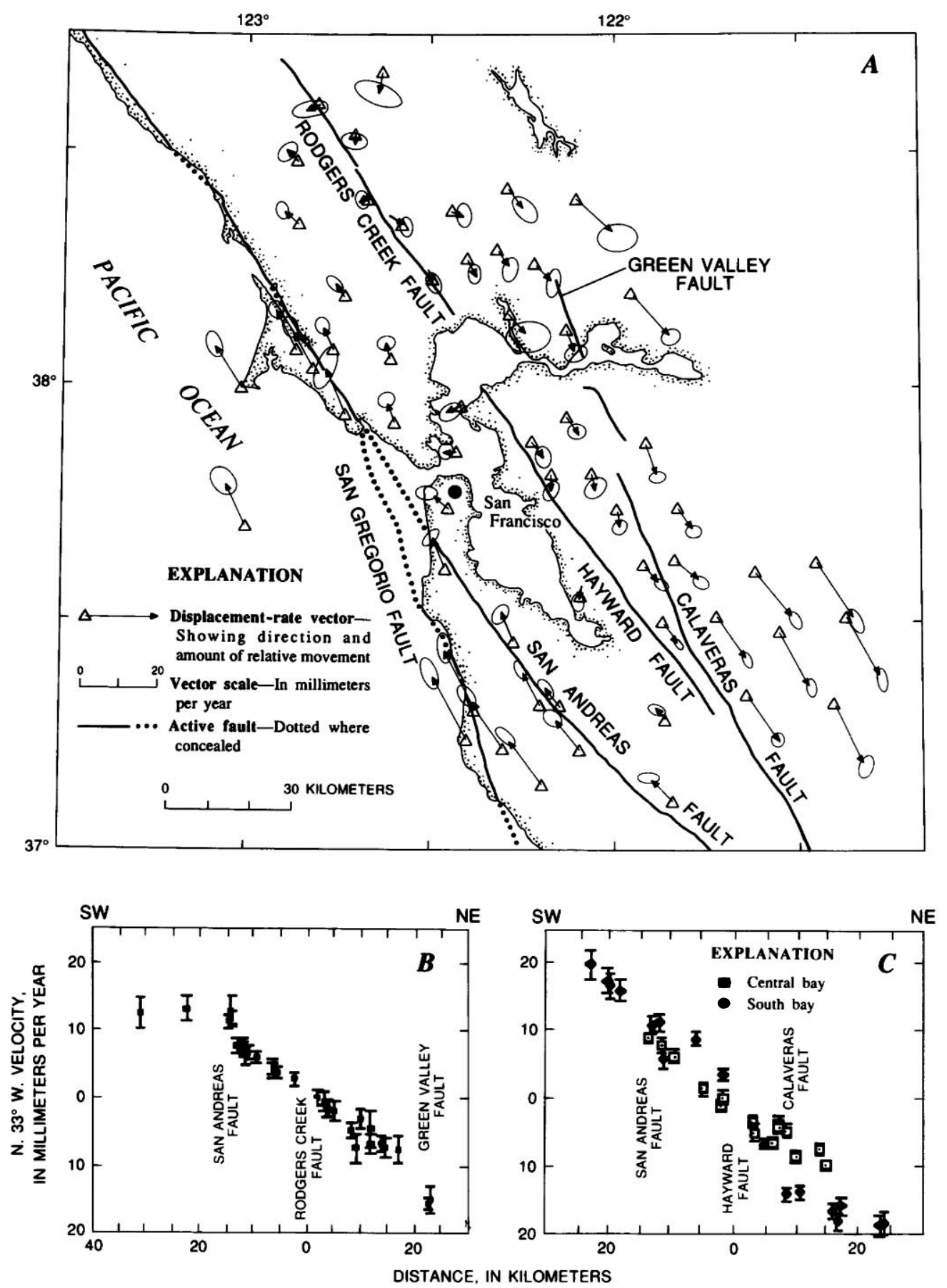

FIGURE 7.6. - Displacement rates across the San Francisco Bay region. $A$, Relative right-lateral displacement rates determined from repeated geodetic surveys made during 1971-87. Error ellipses show 95-percent-confidence limits for each determination (Prescott and others, 1987). B. Relative station velocities parallel to approximate trend of the San Andreas fault (N. $33^{\circ}$ W.) plotted against distance perpendicular to this trend for north bay. $1-\sigma$ bars are indicated. Perpendicular velocity component is negligible and omitted here. $C$, Same as figure 7.6B for central and south bay. 


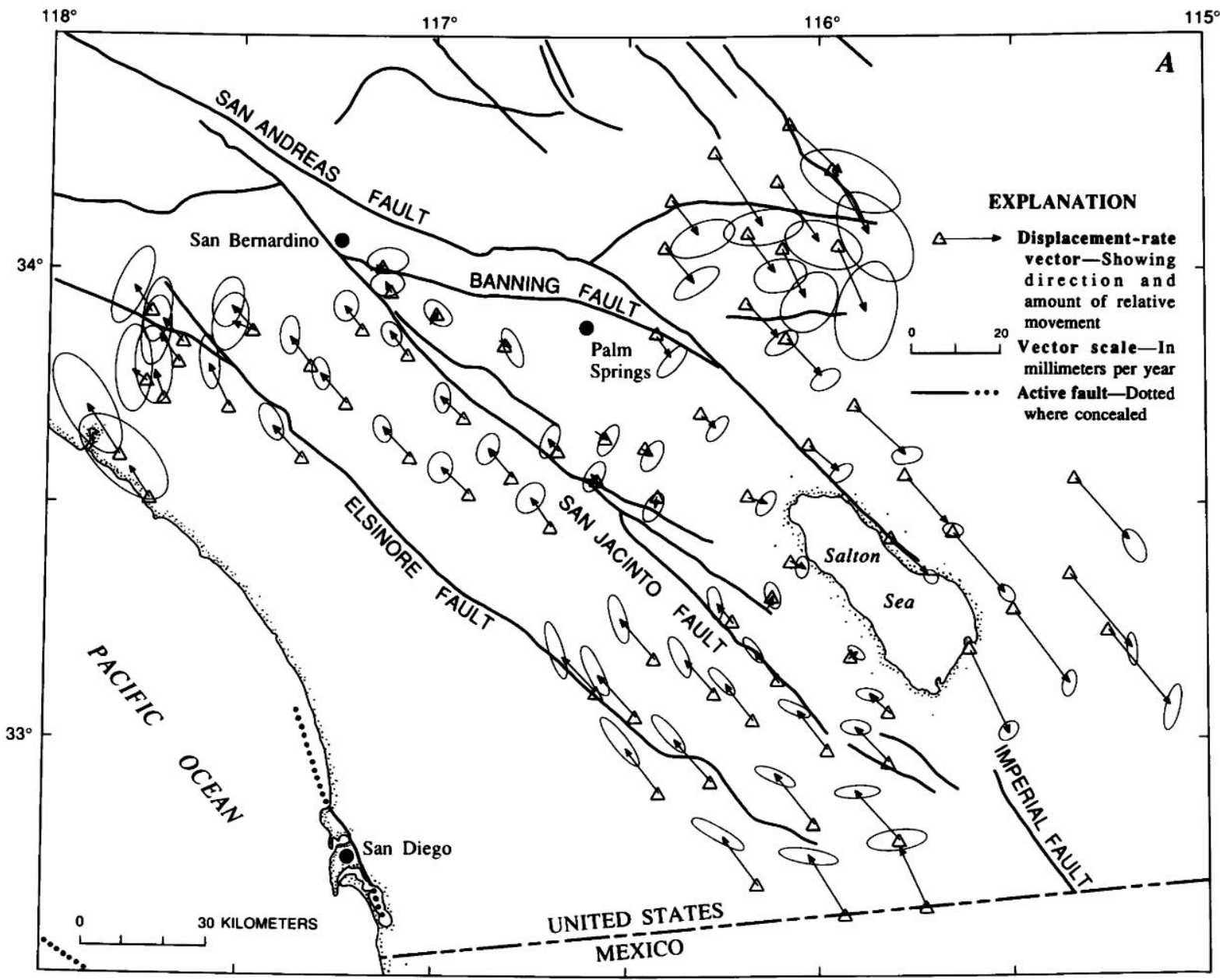

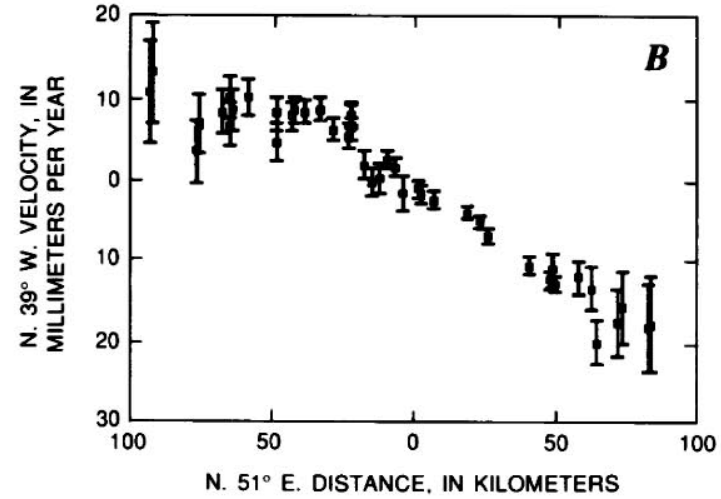

FIGURE 7.7.-Displacement rates in southern California. $A$, Relative right-lateral displacement rates determined from repeated geodetic-survey measurements during 1973-87. Error ellipses show 95-percent-confidence limits for each determination (Prescott and others, 1987). $B$, Relative station velocities parallel to approximate trend of the San Andreas fault (N. $39^{\circ} \mathrm{W}$.) plotted

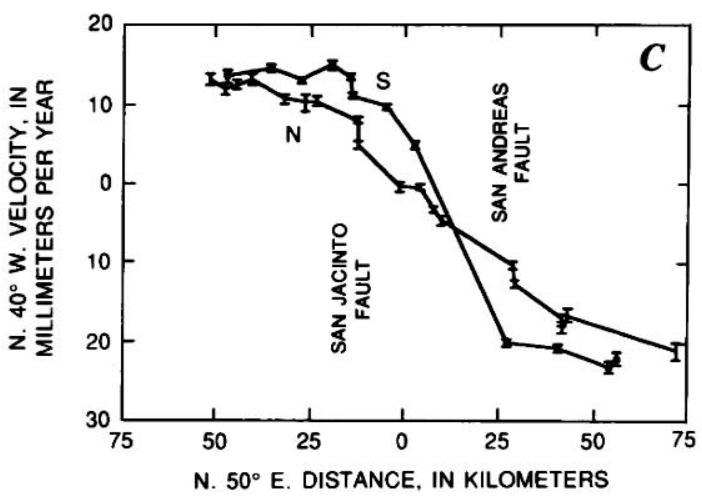

against distance perpendicular to this trend, for stations in northern part of map in figure 7.7A. 1- $\sigma$ error bars are indicated. Perpendicular velocity component is negligible and is not plotted here. $C$, Same as figure $7.7 B$ for stations largely to north $(\mathrm{N})$ and south (S) of the Salton Sea. 
asthenosphere provide the dominant mechanism for interearthquake strain accumulation.

Note that in the context of these two models, the terms "lithosphere" and "asthenosphere" are linked to mechanical properties of the Earth's crust and upper mantle: The lithosphere is the strong elastic layer near the Earth's surface, and the asthenosphere is the region of ductile flow that lies beneath. Their boundary may thus lie well above the thermal boundary layer that separates the moving plates from the convecting mantle. If so, then at least the upper part of the "asthenosphere" forms part of the tectonic plate and moves with it.
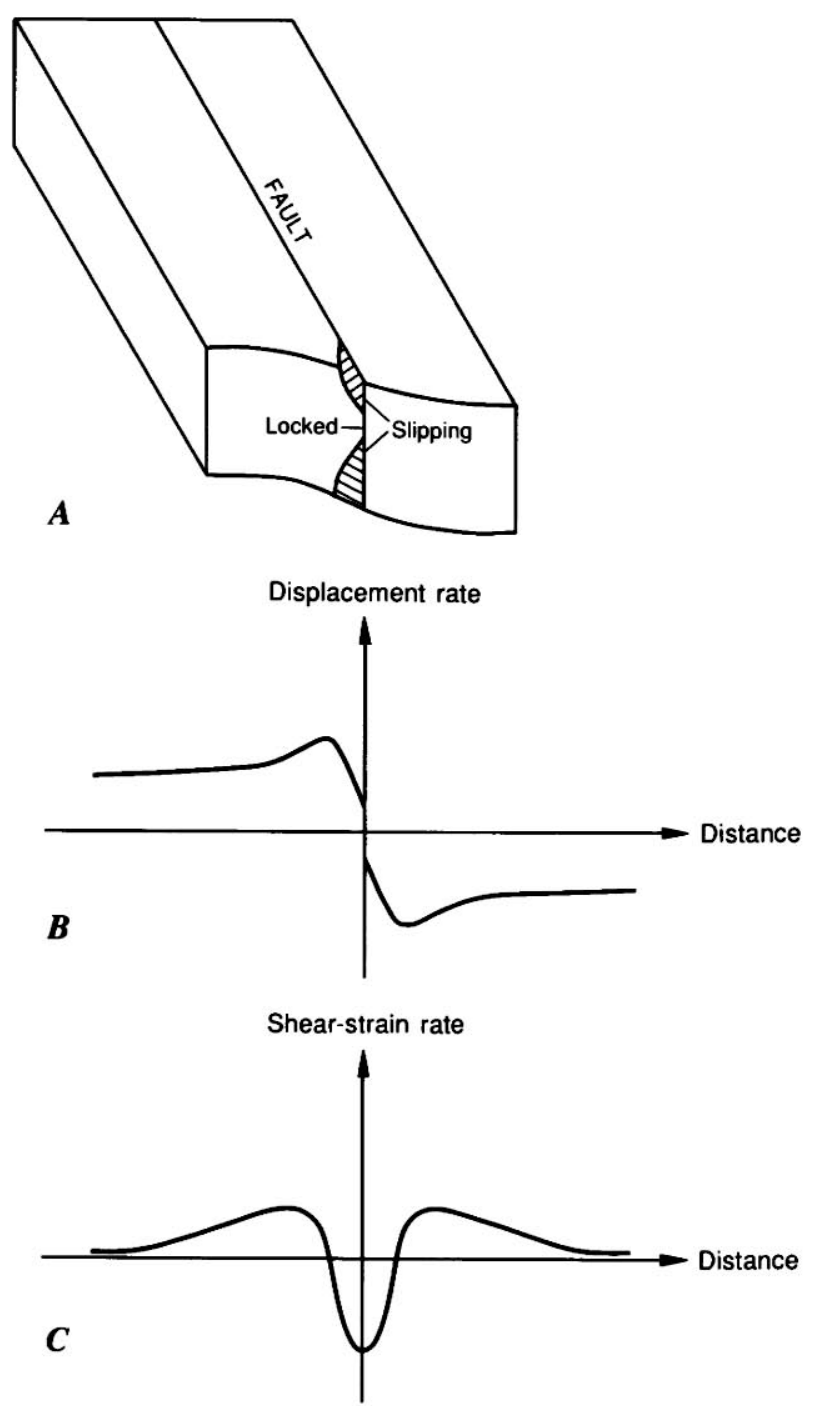

FIGURE 7.8. - Elastic-half-space model showing fault creep at surface, locked (nonslipping) fault at depth, and freely sliding zone at great depth $(A)$. Displacement rate $(B)$ and strain rate $(C)$ are plotted against distance from fault.
Thus considered, the boundary between "lithosphere" and "asthenosphere" defines the zone of decoupling between surface tectonic processes and those that occur in the ductile region beneath. The location of this boundary is thus of central importance to the broad-scale tectonics of the San Andreas fault, the nature of the earthquake-generation process and its thermomechanical implications (see chap. 9), and the relation between shallow structural features and those inferred at depth (see chap. 8). I explore below the influence of this boundary location on cyclic earthquake-related deformation at the currently locked transform fault zones in the San Andreas, illustrating the contrasting mechanical behavior of the thick- and thin-lithosphere models.

All of the models considered here are two dimensional, and so neither slip nor mechanical properties vary along fault strike. Each model consists of only a single planar, vertical strike-slip fault. However, because the medium properties are linear elastic and (or) viscoelastic, the effects of multistranded fault zones can be obtained by simply superposing the deformation due to slip on individual fault segments. Furthermore, all of the twodimensional models discussed here have also been considered in three dimensions, and so complexities arising from changes in fault strike, variations in slip along strike, and the finite extent of faulting can be incorporated straightforwardly as necessary. Similarly, except for the transition from elastic lithosphere to viscoelastic asthenosphere, depth variations in material properties are not considered, although, again, solutions have been obtained for faulting in plane-layered elastic

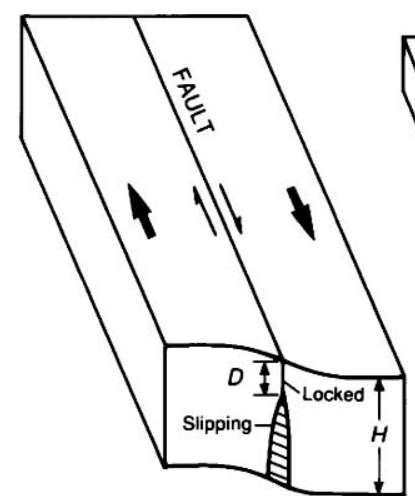

THICK-

LITHOSPHERE MODEL

$D / H \ll 1$

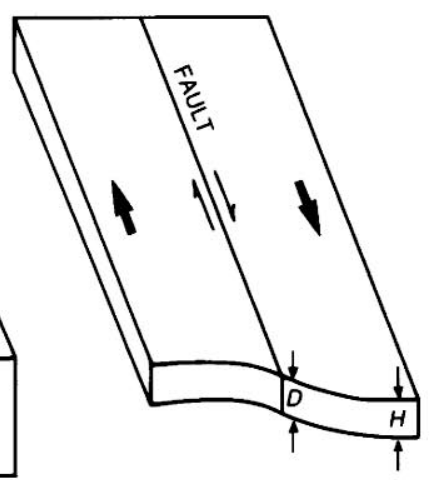

THINLITHOSPHERE MODEL $D / H=1$
FIGURE 7.9. - Thick- and thin-lithosphere models. $D$, depth of coseismic faulting; $H$, thickness of elastically strong lithosphere. Small arrows along fault and larger arrows indicate direction of relative movement of fault and tectonic plates, respectively. 
and viscoelastic media. Although fault end effects and changes in slip and geometry along fault strike can be locally important, these effects, as well as those due to depth-varying material properties, are generally second order relative to the deformation features described here. More important are the effects of the several subparallel strands that compose much of the San Andreas fault system along its two currently locked sections. In these sections, the interseismic deformation due to each major fault strand contributes significantly to the observed displacement pattern, and as a rule the effects of faults lying off the San Andreas proper cannot be safely ignored in matching models to data across the entire San Andreas boundary zone.

The simplest form of the thick lithosphere model, first proposed by Savage and Burford (1970), is illustrated in figure 7.10. In this idealized model, interearthquake strains accumulate uniformly throughout the deformation cycle and have precisely the same spatial pattern as coseismic strains, except that the sense of movement is reversed. The cycle consists of coseismic slip $\Delta u$ extending from the surface to depth $D$ and steady interearthquake aseismic slip at a constant rate $\dot{u}(=\Delta u / T$, where $T$ is the earthquake recurrence interval) beginning at $z=D$ and extending to great depth. For this model of interearthquake deformation, simple expressions relate

COSEISMIC STRAIN RELEASE
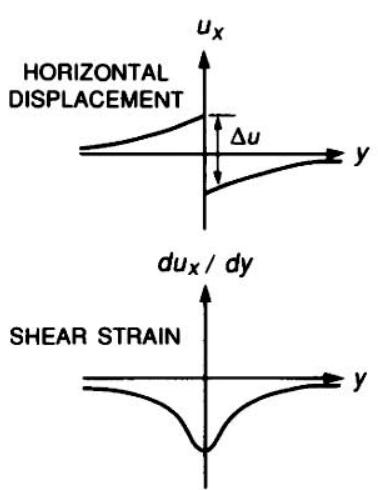

DISLOCATION MODEL
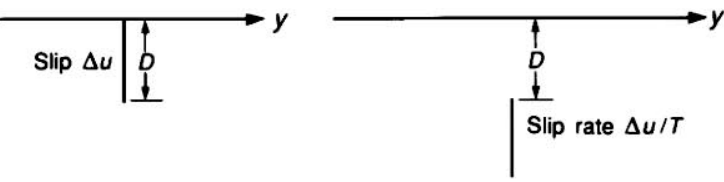

FIGURE 7.10.-Elastic-half-space model for earthquake cycle. $\Delta u$, coseismic slip; $D$, depth of coseismic slip; $T$, earthquake recurrence interval; $u_{x}$, horizontal displacement parallel to fault; $d u_{x} / d y$, shearstrain component parallel to fault; $y$, distance from fault. surface-displacement rates $\dot{u}_{x}(y)$ and shear-strain rates $\dot{e}_{x y}(y)$ to the fault parameters $\dot{u}$ and $D$ and the distance $y$ from the fault trace:

$$
\begin{gathered}
\frac{d u_{x}(y)}{d t}=\dot{u}_{x}(y)=\frac{\dot{u}}{\pi} \tan ^{-1}\left(\frac{y}{D}\right) \\
\dot{e}_{x y}(y)=\frac{d}{d y}\left[\dot{u}_{x}(y)\right]=\frac{\dot{u}}{\pi D}\left[\frac{1}{1+\left(\frac{y}{D}\right)^{2}}\right]
\end{gathered}
$$

A principal utility of this model is the ease with which approximate values of displacement and strain rate can be computed, commonly as a preliminary step to more detailed computations that employ complex models which nonetheless show many of the same general features. For example, using typical San Andreas values of $\Delta u=4 \mathrm{~m}$, $T=200 \mathrm{yr}$, and $D=15 \mathrm{~km}$, then $\dot{u}=20 \mathrm{~mm} / \mathrm{yr}$, and the engineering shear-strain rate (twice the tensor strain rate $\left.\dot{e}_{x y}\right)$ at the fault trace $(y=0)$ is about $0.8 \mu \mathrm{rad} / \mathrm{yr}$, a value close to some of the peak strain rates plotted in figures 7.2 and 7.3. Furthermore, the bell-shaped distribution of secular strain across the model fault (middle right, fig. 7.10) generally accords with observations (fig. 7.3), and the width of the profile is a direct measure of the fault-locking depth $D$. (Note, however, that the observations summarized in figure 7.3 include strain rates determined from multistranded segments of the San Andreas fault system, and so they are not directly comparable to the model calculations for a single fault strand illustrated in fig. 7.10.) Recalling the observations discussed in the section above entitled "Observations of Crustal Deformation," the wider zone of secular strain across the southern section of the San Andreas can be rationalized if the depth of seismic slip and, thus, the locking depth of the fault are simply greater in southern than in northern California. As it stands, this model has no transient effects and so is too simple to explain the postearthquake strain changes plotted in figure 7.4. However, introducing a rather straightforward modification remedies this defect while accounting for the observed difference in strain-rate profiles between northern and southern California. Surprisingly, these same features are, for different reasons, natural consequences of the thin-lithosphere model.

The two models are illustrated in figure 7.11. In the thick-lithosphere model, postseismic effects are introduced by specifying transient postearthquake slip on a segment of the fault immediately beneath the coseismic rupture. Its time history is constrained by an exponentially decreasing slip rate (time constant $\alpha$ ), and its magnitude by the requirement that the cumulative slip sum to the coseismic offset $\Delta u$ by the end of the cycle. In the thin-lithosphere model, the transient deformation 
results from flow in the asthenosphere due to stress relaxation after seismic faulting in the lithosphere. Its time scale is controlled by the asthenosphere-relaxation time $\tau=2 \eta / \mu$, when $\eta$ is the effective viscosity of the asthenosphere and $\mu$ is the average shear modulus of lithosphere and asthenosphere, here taken to be equal. In both models, the transient motions are superimposed on a steady component of deformation that is due to relative plate motion.

Detailed computations show that the two models produce surface deformations that with suitable choices of model parameters are observationally indistinguishable (see Thatcher, 1983). Here, the discussion is restricted to qualitative features, as summarized in figure 7.12. Near the fault, shear-strain rates monotonically decrease over time and gradually approach a constant (fig. 7.12B), while the deformation profile broadens and strains diffuse into the interiors of the adjacent plates as the cycle progresses (fig. 7.12A). It is easy to match the observed temporal decline in strain rate with either model; the particular parameter combinations are themselves not unique, and a range of choices can provide equally good agreement. All satisfactory thin-lithosphere models, however, require an elastic plate only 10 to $15 \mathrm{~km}$ thick, the maximum depth of coseismic slip in the 1906 earthquake (Thatcher, 1975). Both models predict a broadening of the zone of deformation that depends on the time interval since the latest great earthquake, and so the greater width of the strain-rate profile in southern California can be accounted for. For example, data from the northern, locked section of the San Andreas fault may correspond to times $t_{1}$ to $t_{3}$ in figure 7.12, whereas those from the southern section may correspond to times $t_{4}$ and $t_{5}$.

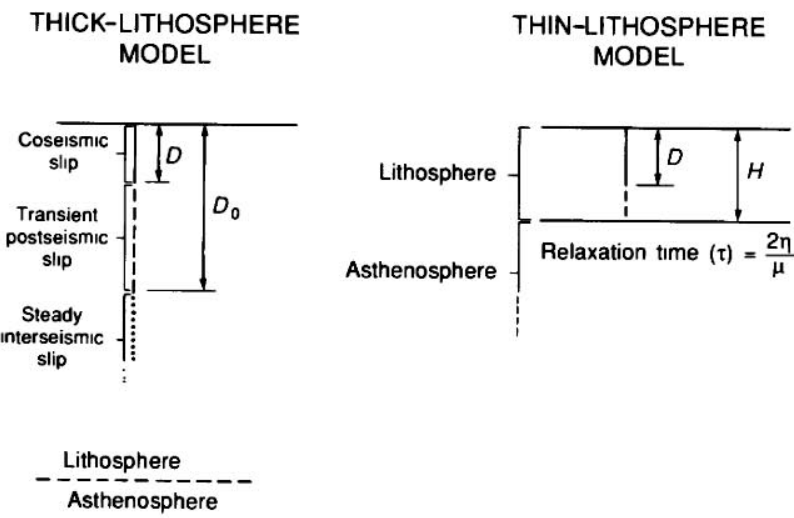

FIGURE 7.11.-Specific features of thick- and thin-lithosphere models. $D$, depth of coseismic slip; $D_{0}$, depth to bottom of zone of transient postseismic slip; $H$, thickness of elastically strong lithosphere; $\eta$, effective viscosity of asthenosphere; $\mu$, average shear modulus of lithosphere and asthenosphere.
More complex models that combine features of both the thick- and thin-lithosphere models are also consistent with available data (for example, Li and Rice, 1987). Furthermore, coseismic and interearthquake fault slip undoubtedly vary as a function of depth, rather than abruptly terminating at some specified fault depth. Although this gradationality of the slip distribution modifies the detailed patterns of surface strain and displacement from those illustrated in figure 7.10, for example, the same qualitative features are preserved, and it will be difficult to distinguish between differing slip-depth distributions on the basis of surface-deformation measurements alone.

In summary, at transform plate boundaries, available data are consistent with both thick- and thin-lithosphere models but do not strongly constrain either. The most geophysically interesting feature of both models is the predicted postearthquake diffusion-like spread of strain from the plate-bounding fault into the interiors of the adjacent plates. Postearthquake surveys, however, are sufficiently infrequent and areal coverage sufficiently limited that these effects, if they indeed occur, have not been directly observed. Details of the temporal decline in deformation rate near the fault are also absent.

\section{STRESS-SLIP-CONSTITUTIVE-LAW FAULT MODELS}

A completely different class of large-scale-faulting models are now being developed to more realistically incorporate the fault-failure process into the earthquake deformation cycle (for example, Stuart, 1979; Tse and Rice, 1986). Instead of specifying slip on the platebounding fault, these models extrapolate from laboratory

$\boldsymbol{A}$

$\boldsymbol{B}$
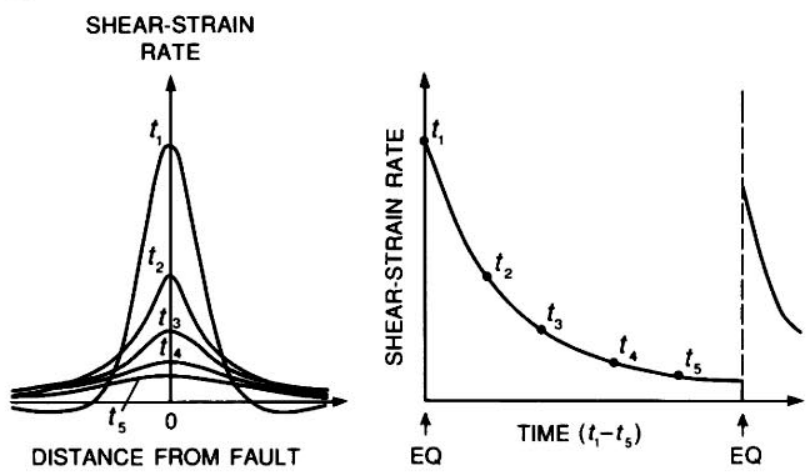

FIGURE 7.12. - Complete earthquake-cycle model predictions for thickand thin-lithosphere models. $A$, Shear-strain rate versus distance from fault and its temporal evolution through deformation cycle. $B$, Shear-strain rate on fault versus time for one complete cycle. EQ, earthquake. 
observations of the time-dependent frictional properties of rocks (for example, Dieterich, 1979; Tullis, 1988) to assign slip-stress-constitutive laws to the fault surface. As remotely applied stresses increase, each segment of the fault slips at a rate that depends on both the previous slip history and the current applied stress, and so the cycle of elastic-strain accumulation and release can be simulated. By specifying the depth dependence of fault frictional properties, a slip behavior nearly identical to that of the thick-lithosphere model (fig. 7.11A) follows naturally. A sample calculation of this type (Tse and Rice, 1986) illustrates the method and shows typical results (fig. 7.13). After a large coseismic slip event in approximately the upper $10 \mathrm{~km}$ of the model fault, transient postseismic slip occurs on both the coseismic fault plane and its downdip extension. As slip rates decline to near zero on the shallow segments of the fault, interseismic slip at greater depths approaches nearly steady-state values. Finally, near the end of the cycle, the constitutive model predicts an increase in slip rate on the shallow coseismic fault segment before the next large slip instability ("earthquake").

Although the appropriateness of this extrapolation of laboratory results to large-scale faulting is a matter of current debate and the scaling of laboratory parameters to the field is uncertain, Tse and Rice's calculations clearly demonstrate that the principal observed features of the earthquake deformation cycle on the San Andreas fault can be reproduced by such models. Ongoing laboratory studies should refine and modify the stressslip-constitutive laws, and geodetic and continuous strain-monitoring observations of preearthquake and postearthquake crustal deformation can test the applicability of these postulates to large-scale faulting processes.

\section{SUMMARY}

Contemporary crustal movements in California are concentrated within a plate-boundary-deformation zone that is typically 50 to $200 \mathrm{~km}$ wide, approximately centered on the San Andreas fault. Integrated rightlateral displacement rates across this zone range from 33 to $37 \mathrm{~mm} / \mathrm{yr}$, representing about 75 percent of the Pacific-North American relative plate motion. Most or all of the rest may be taken up east of the San Andreas fault system in the Basin and Range province. Although aseismic fault slip (creep) is a locally important component of this relative plate motion, most of the geodetically measured deformation represents elastic strain on the crustal blocks adjacent to faults of the San Andreas system. Rates of secular (interseismic) shear strain are a maximum on the two currently locked segments of the San Andreas fault, sites of the great 1857 and 1906

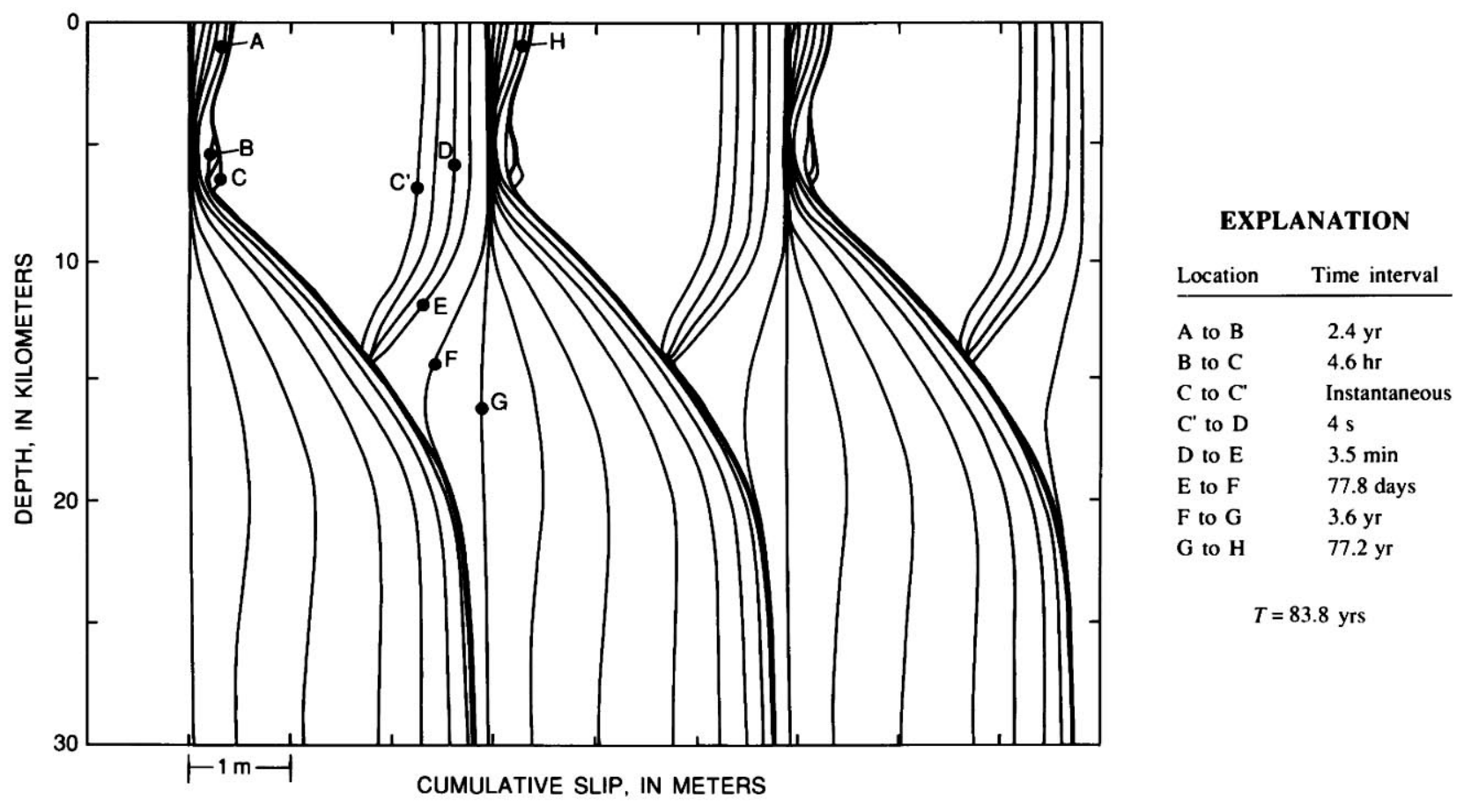

FIGURE 7.13. - Cumulative slip versus depth for selected time intervals through deformation cycle in quasi-static fault-instability model modified from Tse and Rice (1986). $T$, recurrence interval. 
earthquakes. Values range from 0.4 to 0.6 parts per million per year (ppm/yr) at the fault to $0.1 \mathrm{ppm} / \mathrm{yr} 30$ to $80 \mathrm{~km}$ from it. Deformation occurring at the times of large strike-slip earthquakes (coseismic strain) is concentrated within a few tens of kilometers of the surface fault rupture, indicating that earthquake fault slip is largely confined to the upper 10 to $15 \mathrm{~km}$ of the crust. After major events, postseismic shear strain occurs at transiently high rates (more than $2 \mathrm{ppm} / \mathrm{yr}$ ) that decay to background interseismic rates over a time scale of years to tens of years.

Observations of coseismic, postseismic, and interseismic movements define the earthquake deformation cycle and constrain models of strain accumulation and release for strike-slip plate boundaries. Observations are fitted equally well by two contrasting models. In the first model, the depth of coseismic faulting is much less than the thickness of the elastically strong lithosphere, and postseismic and interseismic deformation result from transient and steady aseismic slip on the downward extension of the earthquake fault plane. At the other extreme, if earthquake slippage extends through most or all of the elastic lithosphere, interearthquake deformation is due to transient or steady flow in the underlying weak substrate ("asthenosphere").

\section{FUTURE DIRECTIONS FOR RESEARCH}

Although the broad outlines of current movement across the San Andreas boundary zone are now known and the main features of the cyclic deformation expected from great strike-slip earthquakes have been delineated, many issues still remain to be explored. Although all of the relative Pacific-North American plate motion occurring across California may have been measured geodetically, this determination is not yet definitive, and as much as $10 \mathrm{~mm} / \mathrm{yr}$ of motion may be accommodated east or west of the approximately $100-\mathrm{km}$-wide zone defined by current measurements. Furthermore, the thickness of the elastically strong crust is uncertain by at least a factor of 3, and so major alternative models of the earthquake deformation cycle cannot be distinguished (fig. 7.9). Because surface-deformation observations cannot themselves resolve this ambiguity, other data, possibly gravity-field observations and lithosphericdeflection models (for example, McNutt, 1980), are needed.

Few details exist on the preseismic and postseismic movements related to large plate-boundary earthquakes. Whether detectably anomalous crustal movements precede large earthquakes is uncertain. Theoretical models and fragmentary observations suggest that precursory slip may occur on or beneath the eventual coseismic rupture plane. However, except for the observation that premonitory deformations must be small relative to coseismic movements (for example, Johnston and others, 1987), precursory slip is otherwise unconstrained. Existing data are sufficient to demonstrate that postseismic movements, at least those from great earthquakes, are large-commonly, 10 to 30 percent of the coseismic deformation (Thatcher, 1984)-but the time scale and spatial distribution of these motions are not well determined at strike-slip plate boundaries. Laboratory experiments on lower-crustal rock types suggest that their ductile behavior is not approximated well by linear viscoelasticity, as assumed in the thin-lithosphere model, but postseismic observations are not yet sufficiently detailed to confirm this expectation.

Furthermore, vertical crustal movements in California are not well understood. Though not dominant in California's largely strike-slip-faulting environment, vertical movements can nonetheless be locally important in such regions as the Los Angeles and Ventura Basins, the Transverse Ranges of southern California, and the Cape Mendocino area of northern California. Current and future work that integrates geologic and geodetic information in these regions should begin to shed light on long-term, secular vertical-movement patterns and their origins.

Within complex, multistranded fault zones and, possibly, in simpler regions, permanent inelastic deformation of upper-crustal rocks may contribute significantly to the current movement pattern. For example, at subduction boundaries, geologic and geodetic observations indicate a substantial imbalance between cumulative interearthquake strain and coseismic strain release, commonly reflected in long-term uplift or subsidence of coastal and inland regions. However, at such predominantly transcurrent boundaries as the San Andreas, the observable effects of inelastic strain are more subtle. The thermal consequences of such deformation may be the most direct evidence for inelastic strain (see chap. 9). However, for California at least, the available data are either contradictory or ambiguous, and the extent to which measured interearthquake movements release elastically stored strain is currently unresolved.

\section{REFERENCES CITED}

Bomford, Guy, 1980, Geodesy (4th ed.): London, Oxford University Press, $731 \mathrm{p}$.

Brace, W.F., and Byerlee, J.D., 1966, Stick-slip as a mechanism for earthquakes: Science, v. 153 , no. 3739, p. 990-992.

Breen, N.A., Lisowski, Michael, and Prescott, W.H., 1987, Spatially varying patterns of crustal strain near the Mendocino triple junction, California [abs.]: Eos (American Geophysical Union Transactions), v. 68 , no. 44, p. 1240.

Burford, R.O., and Harsh, P.W., 1980, Slip on the San Andreas fault in central California from alinement array surveys: Seismological 
Society of America Bulletin, v. 70, no. 4, p. 1223-1261.

Castle, R.O., Church, J.P., Elliott, M.R., and Morrison, N.L., 1975, Vertical crustal movements preceding and accompanying the San Fernando earthquake of February 9, 1971: A summary: Tectonophysics, v. 29, p. 127-140.

DeMets, Charles, Gordon, R.G., Stein, Seth, and Argus, D.F., 1987, A revised estimate of Pacific-North America motion and implications for western North America plate boundary zone tectonics: Geophysical Research Letters, v. 14, no. 9, p. 911-914.

Dieterich, J.H., 1979, Modelling of rock friction, 1, Experimental results and constitutive equations: Journal of Geophysical Research, v. 84, no. B5, p. 2161-2168.

Johnston, M.J.S., Linde, A.T., Gladwin, M.T., and Borcherdt, R.D., 1987, Fault failure with moderate earthquakes: Tectonophysics, v. 144, no. 1-3, p. 189-206.

King, N.E., 1985, Horizontal deformation in the Mojave Desert near Barstow, California, 1979-1983: Journal of Geophysical Research, v. 90 , no. B6, p. $4491-4494$.

King, N.E., and Savage, J.C., 1983, Strain-rate profile across the Elsinore, San Jacinto and the San Andreas faults near Palm Springs, California, 1973-81: Geophysical Research Letters, v. 10, no. 1 , p. $55-57$.

- 1984, Regional deformation near Palmdale, California, 1973-1983: Journal of Geophysical Research, v. 89, no. B4, p. 2471-2477.

Lajoie, K.R., 1986, Coastal tectonics, in Active tectonics: Washington, National Academy Press, p. 95-124.

Lawson, A.C., chairman, 1908, The California earthquake of April 18, 1906: Report of the State Earthquake Investigation Commission: Carnegie Institution of Washington Publication 87, $2 \mathrm{v}$.

Li, V.C., and Rice, J.R., 1987, Crustal deformation in great California earthquake cycles: Journal of Geophysical Research, v. 92, no. B11, p. 11533-11551.

Lisowski, Michael, and Prescott, W.H., 1981, Short-range distance measurements along the San Andreas fault system in central California, 1975 to 1979: Seismological Society of America Bulletin, v. 71 , no. 5 , p. $1607-1624$.

Louie, J.N., Allen, C.R., Johnson, D.C., Haase, P.C., and Cohn, S.N., 1985, Fault slip in southern California: Seismological Society of America Bulletin, v. 75 , no. 3, p. 811-833.

McNutt, Marcia, 1980, Implications of regional gravity for state of stress in the earth's crust and upper mantle: Journal of Geophysical Research, v. 85, no. B11, p. 6377-6396.

Minster, J.B., and Jordan, T.H., 1987, Vector constraints on Western U.S. deformation from space geodesy, neotectonics, and plate motions: Journal of Geophysical Research, v. 92, no. B6, p. 4798-4804.

Prescott, W.H., 1976, An extension of Frank's method for obtaining crustal shear strains from survey data: Seismological Society of America Bulletin, v. 66, no. 6, p. 1847-1853.

- 1981, The determination of displacement files from geodetic data along a strike slip fault: Journal of Geophysical REsearch, v. 86, no. B7, p. 6067-6072.

- 1985, An overview of the distribution of relative plate motion along the San Andreas fault system from Hollister, California, to the Mendocino triple junction, in Shearer, C.F., Minutes of the National Earthquake Prediction Evaluation Council, July 26-27, 1985, Menlo Park, California: U.S. Geological Survey Open-File Report 85-754, p. 232-246.

Prescott, W.H., and Lisowski, Michael, 1983, Strain accumulation along the San Andreas fault system east of San Francisco Bay, California: Tectonophysics, v. 97, no. 1-4, p. 41-56.

Prescott, W.H., Lisowski, Michael, and Savage, J.C., 1981, Geodetic measurement of crustal deformation on the San Andreas, Hayward, and Calaveras faults near San Francisco, California: Journal of Geophysical Research, v. 86, no. B11, p. 10853-10869.

1987, Velocity field along the San Andreas fault in southern California [abs.]: Eos (American Geophysical Union Transactions), v. 68 , no. 44 , p. 1506 .

Prescott, W.H., and Yu, S.-B., 1986, Geodetic measurements of horizontal deformation in the northern San Francisco Bay region, California: Journal of Geophysical Research, v. 91, no. B7, p. 7475-7484.

Sauber, Jeanne, Thatcher, Wayne, and Solomon, S.C., 1986, Geodetic measurement of deformation in the central Mojave Desert, California: Journal of Geophysical Research, v. 91, no. B12, p. 12683-12693.

Savage, J.C., and Burford, R.O., 1970, Accumulation of tectonic strain in California: Seismological Society of America Bulletin, v. 60, no. 6 , p. $1877-1896$.

Savage, J.C., and Lisowski, Michael, 1980, Deformation in Owens Valley, California: Seismological Society of America Bulletin, v. 70 , no. 4 , p. $1225-1232$.

- 1984, Deformation in the White Mountain seismic gap, CaliforniaNevada, 1972-1982: Journal of Geophysical Research, v. 89, no. B9, p. 7671-7687.

Savage, J.C., and Prescott, W.H., 1973, Precision of geodolite distance measurements for determining fault movements: Journal of Geophysical Research, v. 78, v. 26, p. 6001-6008.

Savage, J.C., Prescott, W.H., and Gu, Guohua, 1986, Strain accumulation in southern California 1973-1984: Journal of Geophysical Research, v. 91, no. B7, p. 7455-7473.

Savage, J.C., Prescott, W.H., Lisowski, Michael, and King, N.E., 1979, Geodolite measurements of deformation near Hollister, California, 1971-1978: Journal of Geophysical Research, v. 84, no. B13, p. 7599-7615.

- 1981, Strain accumulation in southern California, 1973-1980: Journal of Geophysical Research, v. 86, no. B8, p. 6991-7001.

Schulz, S.S., Mavko, G.M., Burford, R.O., and Stuart, W.D., 1982, Long-term fault creep observations in central California: Journal of Geophysical Research, v. 87, no. B8, p. 6977-6982.

Segall, Paul, and Harris, R.A., 1987, Earthquake deformation cycle on the San Andreas fault near Parkfield, California: Journal of Geophysical Research, v. 92, no. B10, p. 10511-10525.

Sibson, R.H., 1982, Fault zone models, heat flow, and the depth distribution of earthquakes in the continental crust of the United States: Seismological Society of America Bulletin, v. 72, no. 1, p. 151-163.

Stein, R.S., 1983, Reverse slip on a buried fault during the 2 May 1983 Coalinga earthquake: Evidence from geodetic elevation changes, in Bennett, J.H., and Sherburne, R.W., eds., The 1983 Coalinga, California earthquakes: California Division of Mines and Geology Special Publication 66, p. 151-163.

Stein, R.S., and Thatcher, Wayne, 1981, Seismic and aseismic deformation associated with the 1952 Kern County, California, earthquake and relationship to the Quaternary history of the White Wolf fault: Journal of Geophysical Research, v. 86, no. B6, p. 4913-4928.

Stuart, W.D., 1979, Strain softening prior to two-dimensional strike slip earthquakes: Journal of Geophysical Research, v. 84, no. B3, p. 1063-1070.

Thatcher, Wayne, 1975, Strain accumulation and release mechanism of the 1906 San Francisco earthquake: Journal of Geophysical Research, v. 80 , no. 35 , p. $4862-4872$.

1979, Systematic inversion of geodetic data in central California: Journal of Geophysical Research, v. 84, no. B5, p. 2283-2295. 1983, Nonlinear strain buildup and the earthquake cycle on the San Andreas fault: Journal of Geophysical Research, v. 88, no. B7, p. 5893-5902.

Tse, S.T., and Rice, J.R., 1986, Crustal earthquake instability in 
relation to the depth variation of frictional slip properties: Journal of Geophysical Research, v. 91, no. B9, p. 9452-9472.

Tullis, T.E., 1988, Rock friction constitutive behavior from laboratory experiments and its implications for an earthquake prediction field monitoring program: Pure and Applied Geophysics, v. 126, no. $2-4$, p. $555-588$.
Yeats, R.S., 1977, High rates of vertical crustal movement near Ventura, California: Science, v. 196, no. 4287, p. 295-298.

Zhang, Y., Thatcher, Wayne, and Snay, R.A., 1988, Coseismic slip in the 1940 and 1979 Imperial Valley earthquakes and its implications [abs.]: Eos (American Geophysical Union Transactions), v. 69, p. 1433. 


\section{EXPLANATION}

Pre-late Miocene crystalline basement

$\therefore \quad$ Late Miocene and younger metasedimentary basement

- 1 Subbasement (basaltic intrusions)

,$- \cdots \quad$ Inferred intrusions or fractures underlying geothermal areas

* BZ Brawley seismic zone

$\rightleftharpoons$ Fault - Arrows indicate direction of relative movement

Principal stress direction

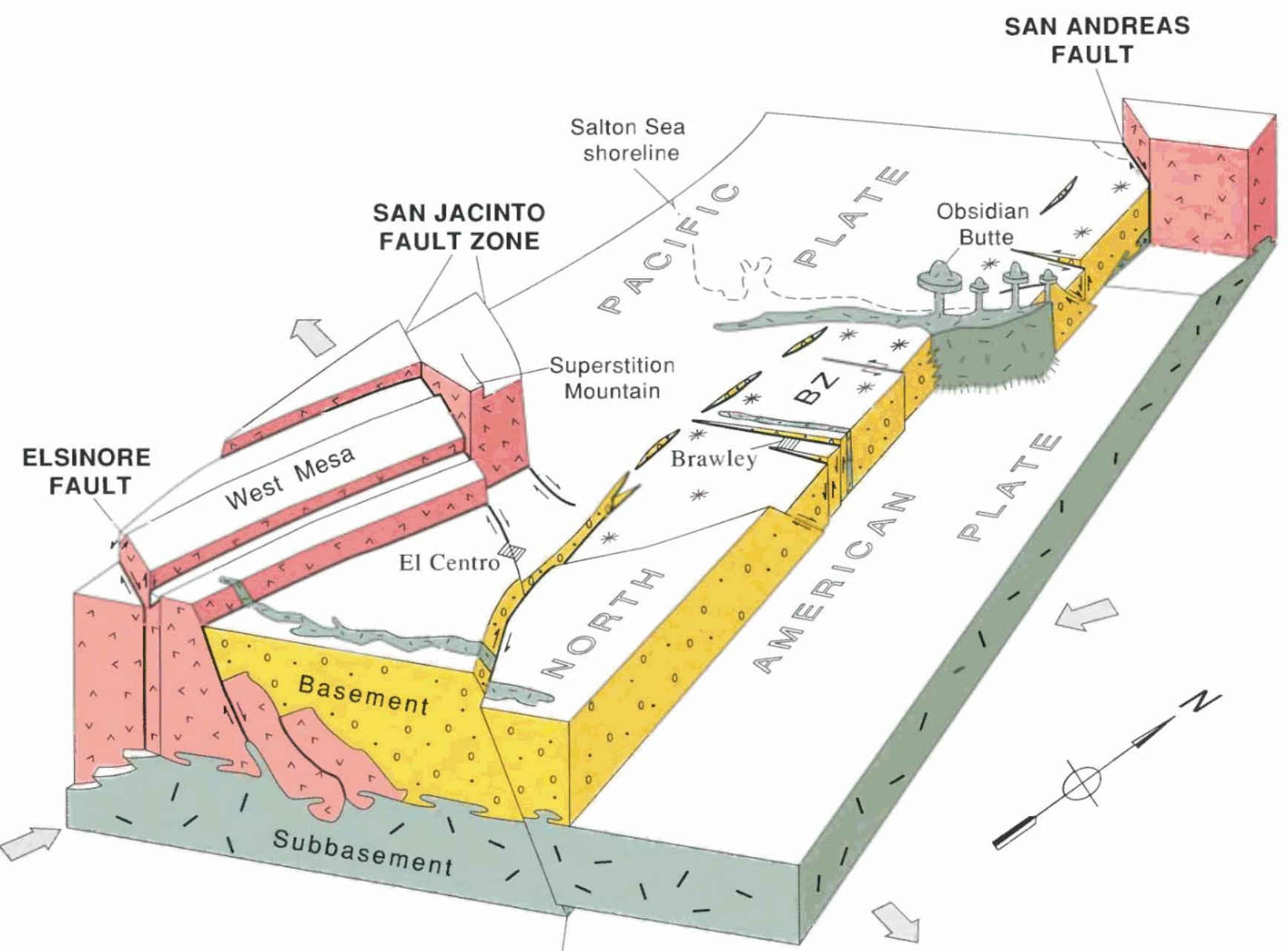

IMPERIAL FAULT 
7 he crust of much of California was formed at an Andean-type 1 continental margin during the Mesozoic and early Cenozoic, and was modified by large strike-slip offsets along the San Andreas fault system during the late Cenozoic. Decoupling within the crust, as implied by present upper-crustal tectonic wedging in central California, and decoupling between the crust and mantle, as implied by "subduction" of lithospheric mantle in southern California, indicates that the San Andreas fault system must change with depth in its location and (or) style of deformation.

\title{
8. LITHOSPHERIC STRUCTURE AND TECTONICS FROM SEISMIC-REFRACTION AND OTHER DATA
}

\author{
By Gary S. Fuis and Walter D. Mooney
}

\section{CONTENTS}

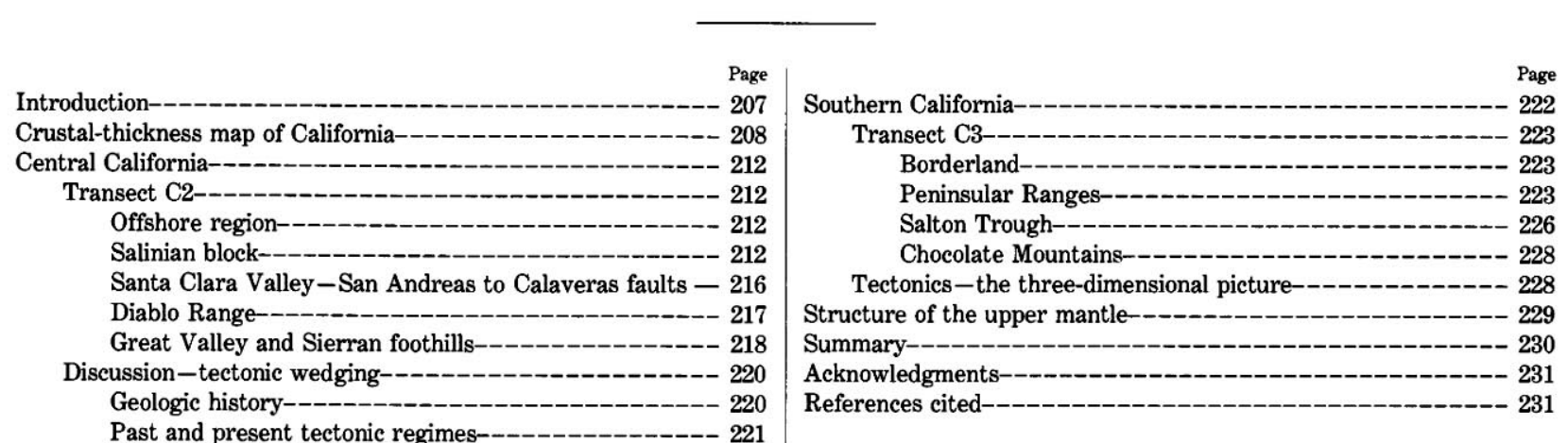

\section{INTRODUCTION}

Studies of the crustal and upper-mantle structure of California along the San Andreas fault system have been underway for more than half a century, beginning with the early studies by Byerly and Wilson (1935) and Byerly (1946) in northern California and by Gutenberg (1943) in southern California. Crustal profiling along and
FIGURE 8.1. - Schematic block diagram of Imperial Valley region of the Salton Trough, with unmetamorphosed sedimentary rocks removed and seismic basement cut away along line approximately parallel to the Brawley seismic zone (BZ; see fig. 8.7). Seismic basement consists of rocks with $P$-wave velocities of 5.5 to $6.5 \mathrm{~km} / \mathrm{s}$. In this region, there are two types of seismic basement: one type, on flanks of the Salton Trough, consists of pre-late Miocene igneous and metamorphic rocks; other type, in central part of trough, consists of late Miocene and younger metasedimentary rocks (similar in age and provenance to sedimentary rocks stripped off in this diagram). Pacific and North American plates are separating across the Brawley seismic zone, an inferred onshore spreading center of the East Pacific Rise. North and south of the Brawley seismic zone, these two plates are separated from each other by transform faults, the San Andreas and Imperial faults, respectively. As the plates pull apart, subsidence occurs within the Brawley seismic zone, sediment is deposited to fill rift from above, and mafic intrusions (basalt, diabase, and gabbro) enter rift from below, metamorphosing sedimentary rocks below a certain depth (generally approx $5 \mathrm{~km}$ in central part of rift). This process is repeated until central part of rift consists entirely of young crust. Geographic locations projected downward onto seismic basement for reference. 
near the San Andreas fault was first accomplished in the early 1960's by Eaton (1963), Healy (1963), and Roller and Healy (1963). Research accelerated after the 1966 $M=6.0$ Parkfield, Calif., earthquake to include both detailed crustal profiling and installation of dense seismic networks for the study of earthquakes (see chap. 5; Eaton and others, 1970). Since 1970, a wide variety of seismologic methods have been used to investigate crustal and upper-mantle structure in the vicinity of the San Andreas fault system. In this chapter, we summarize the main features of this structure and relate the structure to broad-scale tectonic processes.

Seismologic studies of crustal and upper-mantle structure in California make use of three primary data sources: (1) traveltimes of local earthquakes as measured by permanent and temporary seismic arrays, (2) seismicrefraction and reflection profiles, and (3) teleseismic delay times measured by seismic arrays. Traveltimes of local earthquakes, in addition to containing the information needed to locate earthquakes, contain a wealth of information regarding the seismic-velocity structure of the crust and upper mantle. Velocity structure can be determined from these traveltimes by iteratively adjusting an initial velocity model and associated hypocentral parameters, using inversion methods (for example, Crosson, 1976; Eberhart-Phillips and Oppenheimer, 1984). The resolution of velocity structure from local earthquake data is a function of the interstation spacing of the network and the abundance and distribution of seismicity.

Seismic refraction and reflection profiles together form a complementary set of seismic measurements. Seismicrefraction profiles provide the highest resolution of seismic $P$-wave velocities in the crust and upper mantle. The seismic-refraction method, however, generally does not provide the sharpest picture of lithologic interfaces, from which geologic structure is inferred; such a picture is better provided by seismic-reflection profiling.

Teleseismic delay-time studies offer the most effective means of determining the structure of the subcrustal lithosphere. The method is based on interpreting relative arrival times of compressional waves throughout a seismic array in terms of velocity variations at depth beneath the array. The Earth structure in the volume beneath the array generally is described by a series of blocks, and velocity deviations are derived for each block from the observed delay times (Aki and others, 1977; Thurber and Aki, 1987). The California seismic array is ideally suited for such investigations because of its large areal extent and the length of time it has been in operation (see chap. 5).

The primary product of the seismologic methods described above is a model of the seismic $P$-wave-velocity distribution in the crust and upper mantle. However, the interpretation of seismic $P$-wave velocities in terms of rock type is highly nonunique because laboratory velocity data indicate that numerous rock types can have similar velocities (for example, Birch, 1960). This interpretation is further complicated by the fact that, in rocks at pressures of less than 2 kbars (depths above $8 \mathrm{~km}$ ), seismic velocities are strongly affected by the presence of cracks (on all scales) and porosity. In addition, rock velocities are affected by temperature and the presence of water. Thus, the interpretation of $P$-wave velocities in terms of rock types must involve other data sets, including laboratory velocity measurements on rocks at different pressures, temperatures, and water saturations, surface geologic data, well data, and other geophysical data, including gravity and magnetic data. Fortunately, abundant laboratory velocity data (for example, Stewart and Peselnick, 1977; Lin and Wang, 1980), geologic data (see chaps. 1,3), and geophysical data (see chap. 9) are available for California, making the lithosphere of this region one of the best studied in the world.

In this chapter, we summarize the lithospheric structure and tectonics along the San Andreas fault system of California (fig. 8.2) with maps of crustal thickness and upper-mantle seismic-velocity anomalies, and with crustal cross sections for central and southern California. Structure changes more rapidly parallel to the San Andreas fault in southern California than in central California, and so we supplement the cross section for southern California with a map showing crustal-block motions and a diagram illustrating the different motion of the lithospheric mantle below. Seismic and other data currently are still not dense enough to construct a cross section along the San Andreas fault system itself.

Construction of the crustal cross section for central California led us to a new interpretation of upper-crustal tectonic wedging, the mechanism whereby the Franciscan assemblage was emplaced in the Coast Ranges during the late Mesozoic(?) and Cenozoic. This interpretation extends that of Wentworth and others (1984) to include a two-part history whereby the observed structures atop the wedge, which include both extensional and compressional faults, were created. We further speculate that similar tectonic wedging occurred in southern California from the Mojave Desert to the Chocolate Mountains to emplace the Rand schist and the Pelona-Orocopia schist of Haxel and Dillon (1978) into rocks east of the San Andreas fault.

\section{CRUSTAL-THICKNESS MAP OF CALIFORNIA}

A contour map of crustal thicknesses in California (fig. $8.3 A$ ) provides an overview of the geophysical setting of the San Andreas fault system. The seismic and gravity 
data used in compiling this map (fig. 8.3B) were discussed by Mooney and Weaver (1989).

Crustal thickness along the San Andreas fault increases from $16-24 \mathrm{~km}$ in northern California to $28-32 \mathrm{~km}$ in southern California. Thus, the crust along the San Andreas fault system is everywhere thinner than the 36-km average for the conterminous United States (Braile and others, 1989), and in northern California it is

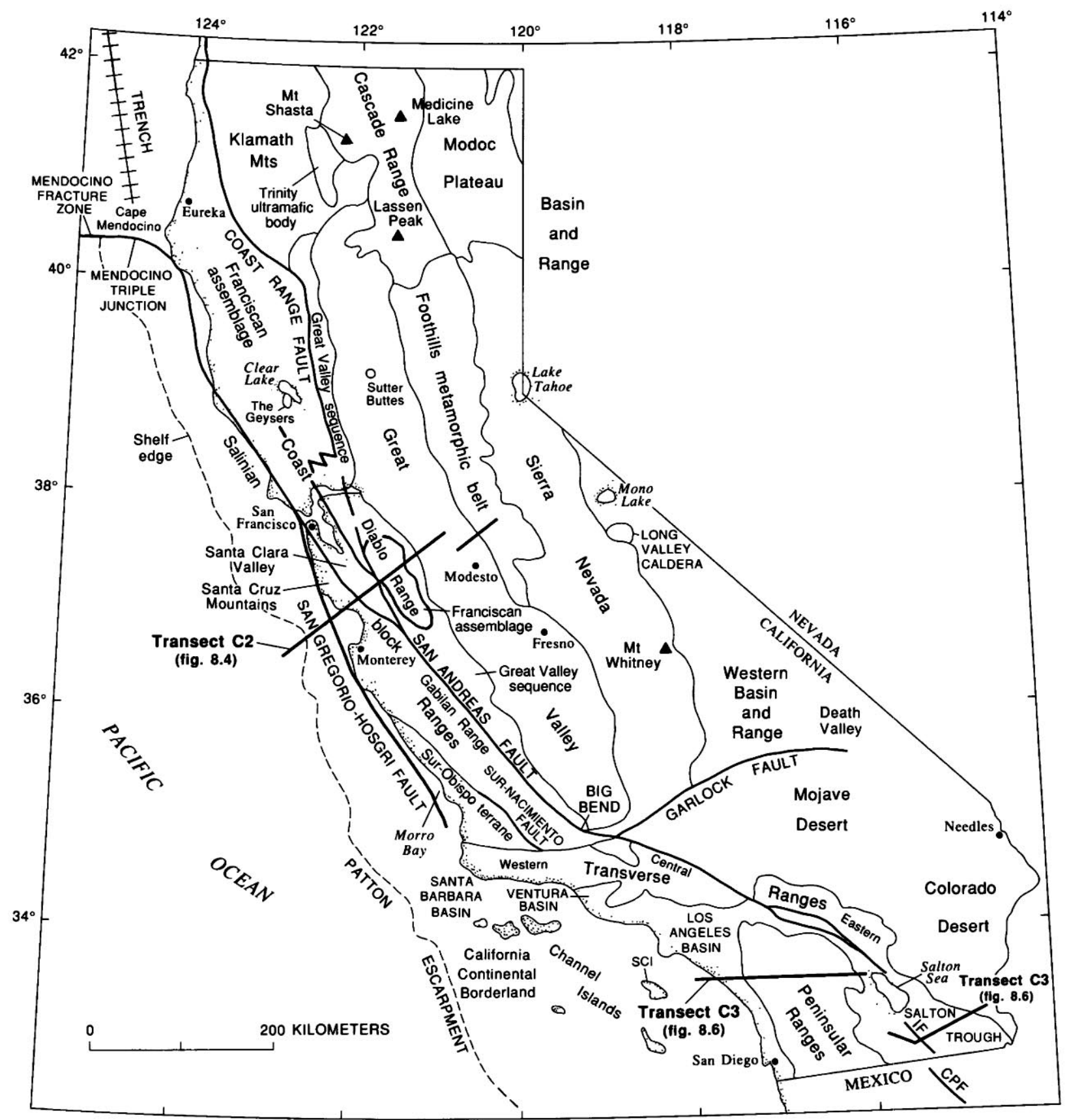

FIGURE 8.2. - California, showing place names, geologic provinces, selected geologic units, and locations of crustal transects shown in figures 8.4 and 8.6. The San Andreas fault extends from the Salton Trough to triple junction at Cape Mendocino. CPF, Cerro Prieto fault; IF, Imperial fault; SCI, Santa Catalina Island. Fault with crosslining is trench, offshore northern California. 
substantially thinner than this average. To a first-order approximation, crustal thickness resembles the topography (see Jachens and Griscom, 1983, fig. 13).

Cape Mendocino in northern California marks the change from the strike-slip regime of the San Andreas fault to the subduction regime of the Cascade Range.
North of Cape Mendocino, the crust thickens eastward from about $16 \mathrm{~km}$ at the coast to about $38 \mathrm{~km}$ in the southern Cascade Range (fig. 8.3A). Near the coast, this thickness includes both the North American plate and the subducting Gorda plate. Estimates of crustal thickness in the northern Coast Ranges at Cape Mendocino lack

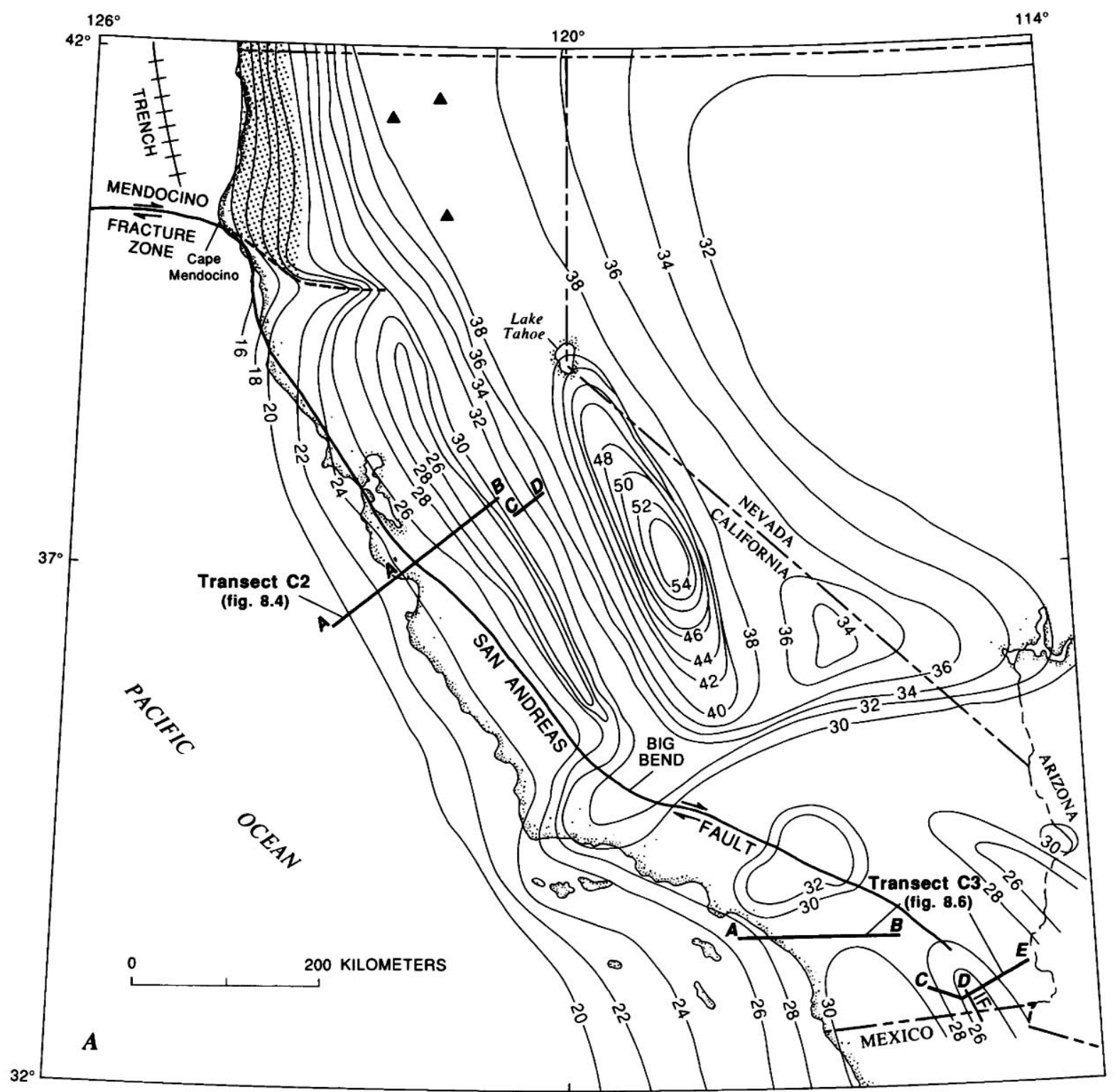

FIGURE 8.3.-Crustal thickness $(A)$ for California and adjacent regions, modified from Mooney and Weaver (1989), with data sources $(B)$. Contour interval, $2 \mathrm{~km}$. Northeast of the San Andreas fault in central California, thin crust (within enclosed 28-km contour) corresponds to Mesozoic/early Cenozoic forearc basin (Great Valley; see fig. 8.2 for place names), and thick crust

(within enclosed 40-km contour) corresponds to magmatic arc of same age (Sierra Nevada). Southwest of the San Andreas fault in central California, this Andean-marginal sequence is repeated but shortened; crust is relatively thin there. In southern California, crustal thickness is relatively uniform (about $30 \mathrm{~km}$ ), despite considerable tectonic activity throughout most of geologic time, 
seismic refraction or reflection control, but detailed gravity models, heat-flow observations, and teleseismic data indicate an abrupt decrease in both crustal and lithospheric thickness southward of the landward projec- tion of the Mendocino Fracture Zone (see chaps. 9, 10; Zandt and Furlong, 1982; Jachens and Griscom, 1983).

In central California, the crust thickens eastward from about $25 \mathrm{~km}$ near the coast to as much as $55 \mathrm{~km}$ in the

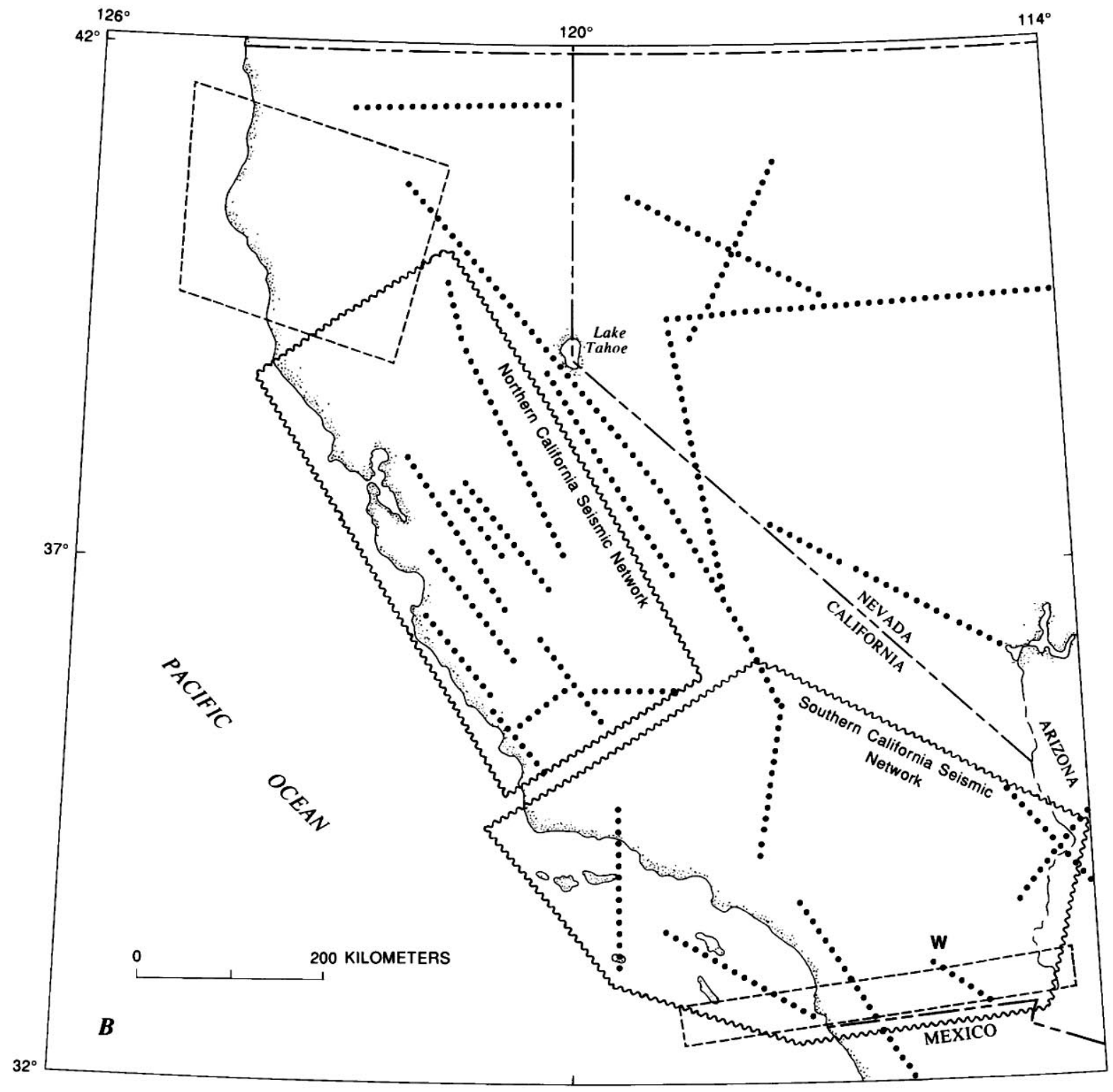

including present subduction of lithospheric mantle (see below). Estimated error in figure $8.3 A$ is 10 percent, or 1 to $1 / 2$ contour intervals. Heavy lines, faults-dashed where the Mendocino Fracture Zone extends onshore (and beneath North American plate); arrows indicate direction of relative movement; crosslined along trench, offshore northern California. Triangles, volcanoes of
Cascade Range continental arc. Dot pattern, area of contours on Gorda-plate Moho. IF, Imperial fault. Data sources in $8.3 B$ include seismic-refraction profiles (dotted lines), earthquake networks (wavy outlines), and gravity (dashed outlines). "W" associated with seismic-refraction profile in the Salton Trough indicates that only wide-angle reflections are available to constrain Moho depth. 
Sierra Nevada, but this general landward thickening is interrupted by thin crust $(25 \mathrm{~km})$ beneath the Great Valley (fig. 8.3A; compare Oppenheimer and Eaton, 1984). The crust of central California represents a Mesozoic and early Cenozoic Andean-type continental margin (see chap. 3; Hamilton, 1969) that has been modified by late Cenozoic strike-slip faulting along the San Andreas fault system and by uplift of the Sierra Nevada. Andean features include a subduction complex (eastern Coast Ranges), a forearc basin (Great Valley), and a magmatic arc (Sierra Nevada). Cenozoic strike-slip faulting along the San Andreas fault system has moved a shortened Andean-marginal sequence outboard of this sequence. Southwest of the San Andreas fault, the batholithic Salinian block (western Coast Ranges) is juxtaposed, across other right/oblique-slip faults of the San Andreas fault system, against an inactive accretionary prism, or subduction complex (western Coast Ranges and offshore California).

In southern California, the crust thickens eastward from about $20 \mathrm{~km}$ at the western margin of the California Continental Borderland to about $32 \mathrm{~km}$ in the eastern Transverse Ranges (fig. 8.3A). Over most of onshore southern California, crustal thickness is $30 \pm 2 \mathrm{~km}$. Considering the complex tectonic history of this region, including the present subduction of lithospheric mantle (see below), this uniformity in crustal thickness is remarkable.

\section{CENTRAL CALIFORNIA}

Crustal structure in central California is grossly two dimensional, as can be readily inferred from the crustalthickness map (fig. 8.3A). There are five blocks or provinces with subparallel fault boundaries: an accretionary prism, which is partly off shore; the Salinian block, which underlies the western Coast Ranges, including the Santa Cruz Mountains and Gabilan Range; a complex block between the San Andreas and Calaveras faults, underlying the Santa Clara Valley; the Diablo block, beneath the Diablo Range; and the Great Valley/Sierran block (fig. 8.2). To illustrate the crustal structure of central California, we have modified and reinterpreted the part of Centennial Continent-Ocean Transect C2 (Saleeby, 1986) that extends from offshore California at Monterey Bay to the Sierran foothills near Modesto (figs. $8.2,8.4)$. Seismic control, which is exceptionally good along this transect, has been augmented since Saleeby's (1986) study primarily by analysis of seismic-refraction profiles in the Great Valley (fig. 8.4A). The reader is referred to Hill (1978) for an earlier treatment of deep structure along approximately this same transect.
TRANSECT C2

\section{OFFSHORE REGION}

The offshore region of transect $\mathrm{C} 2$ is underlain by an inactive, early Tertiary accretionary prism overlapped by uppermost Oligocene to Holocene sedimentary rocks (see Saleeby, 1986). The San Simeon terrane, consisting of Late Cretaceous Franciscan rocks (disrupted marine sedimentary rocks; see chap. 3), is imbricated in this prism along with poorly known, lower Tertiary sedimentary rocks. The prism is underlain by oceanic crust with an inferred age of about 26 to $20 \mathrm{Ma}$ (Atwater and Menard, 1970; Atwater, 1989). The accretionary prism is juxtaposed against granitic rocks of the Salinian block across the (inactive) Nacimiento fault, which is overlapped by upper Tertiary sedimentary rocks. This fault, in turn, is offset by the (active) right/oblique-slip San Gregorio-Hosgri fault. The Moho is $10 \mathrm{~km}$ below sea level near the west end of the transect (Shor and others, 1971) and deepens to 24- to 26-km depth beneath the Gabilan Range and Santa Cruz Mountains (Walter and Mooney, 1982).

We follow D.S. McCulloch (in Saleeby, 1986) in showing steep northeastward dips on both the Nacimiento and San Gregorio-Hosgri faults (fig. 8.4A) that are based on marine reflection data. Focal mechanisms for earthquakes on the San Gregorio-Hosgri fault at this latitude indicate nearly pure strike slip on vertical planes; however, farther south, they indicate chiefly reverse faulting on northeast- or southwest-dipping planes (see chap. 5).

\section{SALINIAN BLOCK}

The area between the Nacimiento and San Andreas faults is underlain by a batholithic terrane that has been transported northwestward by the San Andreas (and other?) fault(s) by amounts estimated to range from 550 $\mathrm{km}$ (see Ross, 1978) to $2,500 \mathrm{~km}$ (Champion and others, 1984). Plutonic rocks include tonalite, granodiorite, and quartz monzonite of mostly Late Cretaceous age (Ross, 1978; Mattinson, 1982). Metamorphic pendants and screens include mostly quartz-rich clastic rocks of amphibolite facies. Ross and McCulloch (1979) postulated that these upper-crustal plutonic and metamorphic rocks are not rooted to the lower crust but are in fault contact with a buried terrane, possibly consisting of Franciscan rocks.

The velocity structure derived by Walter and Mooney (1982) from Stewart's (1968) seismic-refraction measurements in the Gabilan Range and Santa Cruz Mountains can be subdivided into four separate crustal layers with velocities of $2.1-4.6 \mathrm{~km} / \mathrm{s}$ (layer 1), $5.3-5.6 \mathrm{~km} / \mathrm{s}$ (layer 2), 


\section{EXPLANATION FOR FIGURES 8.4A AND 8.6A}

3.6/4.6 $P$-wave velocity in kilometers per second at top/base of layer-Velocities in parentheses are projected

$\boldsymbol{P}$-wave velocity boundary-Heavy tick where profile perpendicular to page; light line where profile in plane of page; short dashed where change in gradient only: long dashed in figure $8.4 \mathrm{~A}$ for model of Dean Whitman and others (unpub. data, 1985). Boundaries are determined by refraction profiling except for offshore central California (fig. 8.4A) where they are determined by reflection profiling

\section{$\approx \sim \sim$ Reflector from reflection profiling-Queried where} uncertain

- -0 - Density and magnetic boundary

? Inferred region in which midcrustal and Moho discontinuities may exist-Queried where uncertain

LVZ, / Possible low-velocity zone

Fault

EXPLANATION FOR FIGURES 8.4B AND 8.6B LITHOLOGIC SYMBOLS FOR TECTONIC ENVIRONMENT

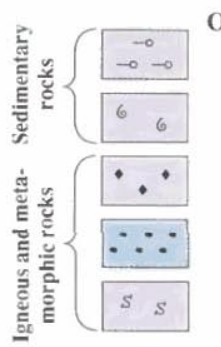

Oceanic

Basin floor and trench turbidites

Pelagic sedimentary rocks

Seamounts

Ophiolite, or top of ophiolite where undivided mafic crust is shown below

Serpentine

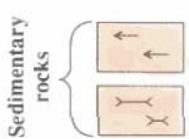

Magmatic arc

Forearc rocks

Intra-are rocks

Volcanic $\square \quad \nabla$ rocks 4

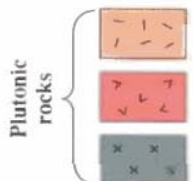

Rocks of mixed and (or) intermediate composition

Granite and quartz monzonite

Granodiorite and tonalite

Gabbro

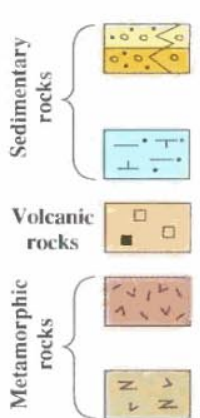

Continental and continental rift

Nonmarine clastic rocks-Circles, conglomerate: circles and dots, conglomerate and sandstone; darker color, metamorphosed

Marine clastic rocks-Strike-and-dip symbol, carbonate bearing

Rocks of mixed felsic to mafic composition

Middle crust - Inferred to be gneiss and schist developed at 10 - to $20-\mathrm{km}$ depth at greenschist to amphibolite facies

Lower crust- Inferred to be gneiss developed below $20-k m$ depth at amphibolite to granulite facies

Mafic crust, undivided-Denser pattern: higher velocity

Mantle-Closely spaced ticks, top of lithospheric mantle; widely spaced ticks, top of asthenospheric mantle or lithospheric mantle with partial melt

\section{OTHER SYMBOLS}

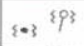

Melange-Symbols enclosed by zigzag lines indicate block type

$\alpha \beta \gamma \quad$ Metamorphic facies-Amphibolite, blueschist ( \pm eclogite), greenschist

\section{$z=\quad$ Shear zone}

Lithologic contact

Normal or strike-slip fault-Sense of motion shown: arrows indicate direction of relative movement: $A$, away from observer; $T$, toward observer

Mesozoic thrust fault-Sawteeth on upper plate

Mesozoic or Cenozoic thrust fault-Teeth on upper plate; arrow indicates inferred motion of upper plate; dotted where inferred to have formerly existed

$\longrightarrow$ Cenozoic thrust fault - Teeth on upper plate; arrow indicates inferred motion of upper plate

-11 Mesozoic or Cenozoic detachment fault-Ticks on upper plate

ـ Cenozoic detachment fault-Ticks on upper plate

In figure 8.6, Chocolate Mountains: Mesozoic or Cenozoic thrust or detachment fault ("Chocolate Mountains thrust fault"; see text

NOTE: Lithologic contacts and faults-Long dashed where not constrained by figures $8.4 \mathrm{~A}$ and $8.6 \mathrm{~A}$ or by earthquakes of chapter 5 ; short dashed where gradational (lithologic contact only) or projected above surface; queried where existence uncertain

? $~ T o p$ of brittle-ductile transition zone inferred from earthquakes (see text)—Queried where uncertain

Explanation for figures 8.4 and 8.6. 

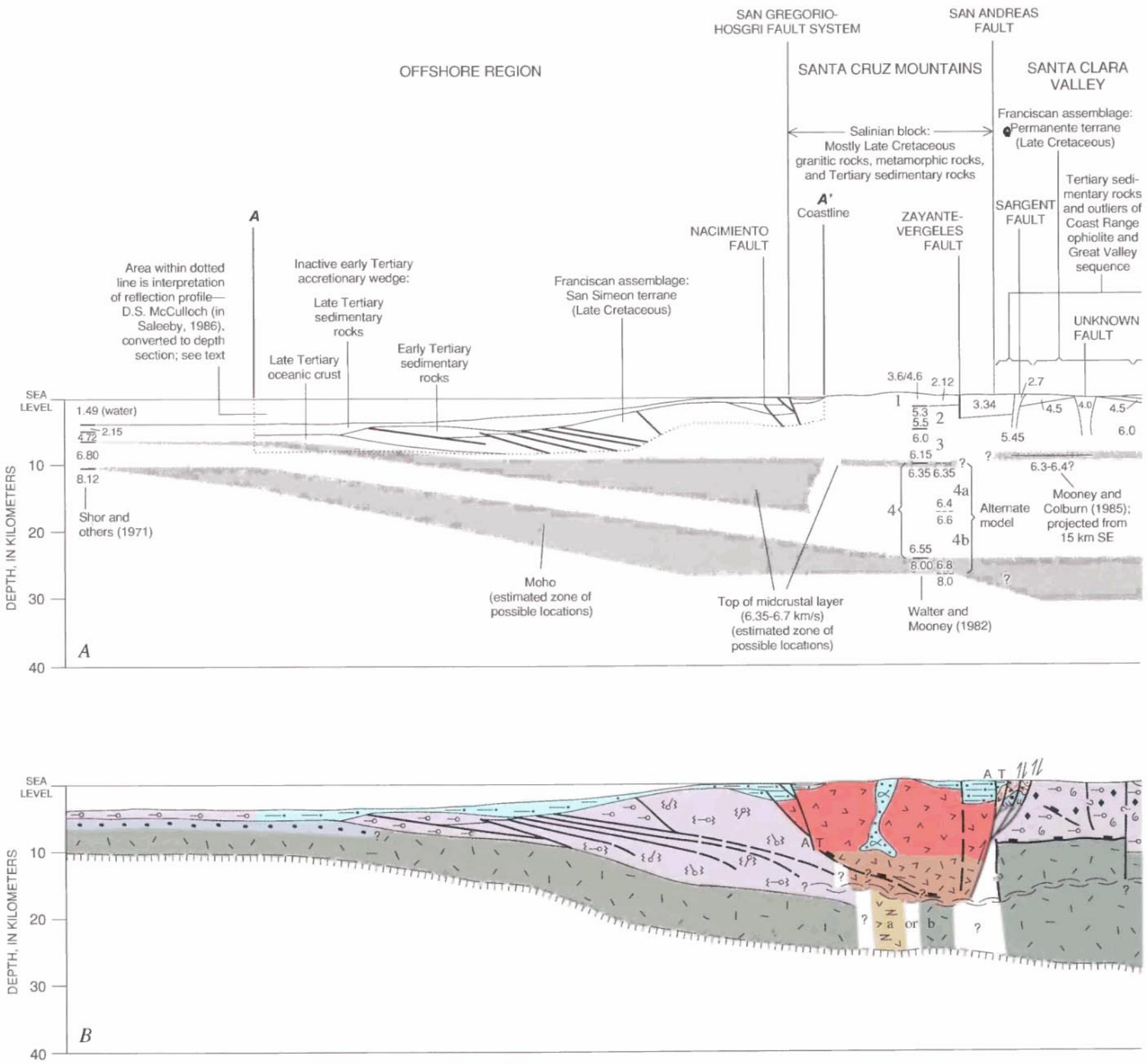

FIGURE 8.4.-Crustal structure of central California. A, Surface geology, depth-converted seismic-reflection data, and models of seismic-refraction, gravity, and magnetic data along western part of Centennial ContinentOcean Transect C2 (see Saleeby, 1986). B, Reinterpretation of Transect C2. Major features in figure $8.4 B$ include, from west to east, (1) offshore, inactive, early Tertiary accretionary wedge; (2) batholithic Salinian block of the Santa Cruz Mountains, positioned between the active oblique-slip San Gregorio-Hosgri and San Andreas faults; (3) Franciscan terranes of the Santa Clara Valley and Diablo Range, interpreted to compose a tectonic wedge; (4) Mesozoic and Cenozoic sedimentary rocks of the Great Valley; and (5) rocks of the Sierran foothills, including Jurassic and older volcanic, plutonic, and related sedimentary rocks accumulated or emplaced in an island-are setting and Cretaceous plutonic rocks. Tectonic wedge in feature 3 is interpreted to have moved during the late Mesozoic(?) and Cenozoic, possibly in several episodes, largely along contact between Mesozoic crystalline rocks and overlying Mesozoic sedimentary rocks. In the eastern Great Valley, these sedimentary rocks are still rooted to (or depositionally overlie) this basement. Movement of 

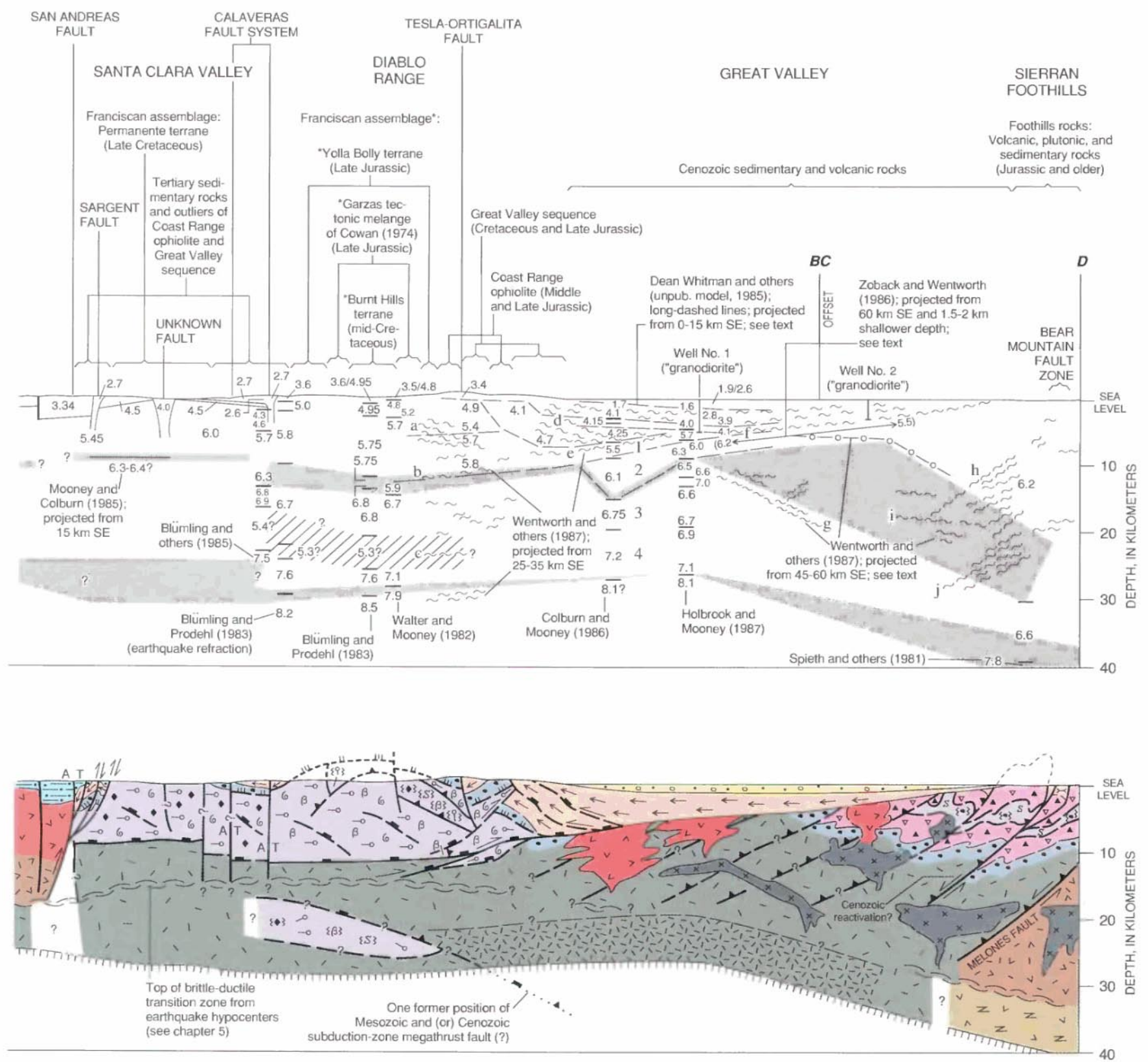

wedge during present San Andreas transform-faulting regime may be along one or more thrust faults that merge with postulated decollement in brittle-ductile transition zone in the erust. This reinterpretation differs from Saleeby's (1986) in eliminating inferred east-dipping subduction zone or thrust fault beneath the western Great Valley. Off shore, interpretation of unmigrated reflection section by D.S. McCulloch (in Saleeby, 1986) has been converted to depth section, using assumed velocities for each inferred geologic unit. In the Santa Cruz Mountains, velocity model consisting of layers 1 through 4 is shown (fig. 8.4A; see fig. $8.5 A$ ), along with alternative model in which layer 4 is subdivided into layers $4 \mathrm{a}$ and $4 \mathrm{~b}$. First model gives rise to interpretation a, and alternative model to interpretation b (fig. 8.4B). a-j, reflectors in the eastern Diablo Range, Great Valley, and Sierran foothills; $1-4$, seismic-velocity layers in the Great Valley (fig. 8.4A) discussed in text. See figures 8.2 and 8.3 for location of Transect C2. No vertical exaggeration. 
$6.0-6.15 \mathrm{~km} / \mathrm{s}$ (layer 3), and 6.35-6.55 km/s (layer 4). Layer 4, middle and lower crust, can alternatively be modeled as two layers of velocities $6.3 \mathrm{~km} / \mathrm{s}$ (layer 4a) and $6.6-6.8 \mathrm{~km} / \mathrm{s}$ (layer $4 \mathrm{~b}$ ). These layer velocities can be correlated to rock type using surface geologic data and laboratory velocity data. Layer 1 corresponds to outcrops of Cenozoic sedimentary rocks along the transect. Basement outcrops along or near the transect include abundant quartz monzonite (Ross, 1972). Lin and Wang (1980) studied the velocity behavior of a sample of quartz monzonite from this region as a function of pressure and temperature, and constructed a velocity-depth curve for this rock appropriate for the Coast Ranges. On their curve (fig. 8.5A), the rock is slightly faster than layers 2 and 3 and slower than layer 4. Walter and Mooney (1982) interpreted layers 2 and 3 as granitic rocks similar to this

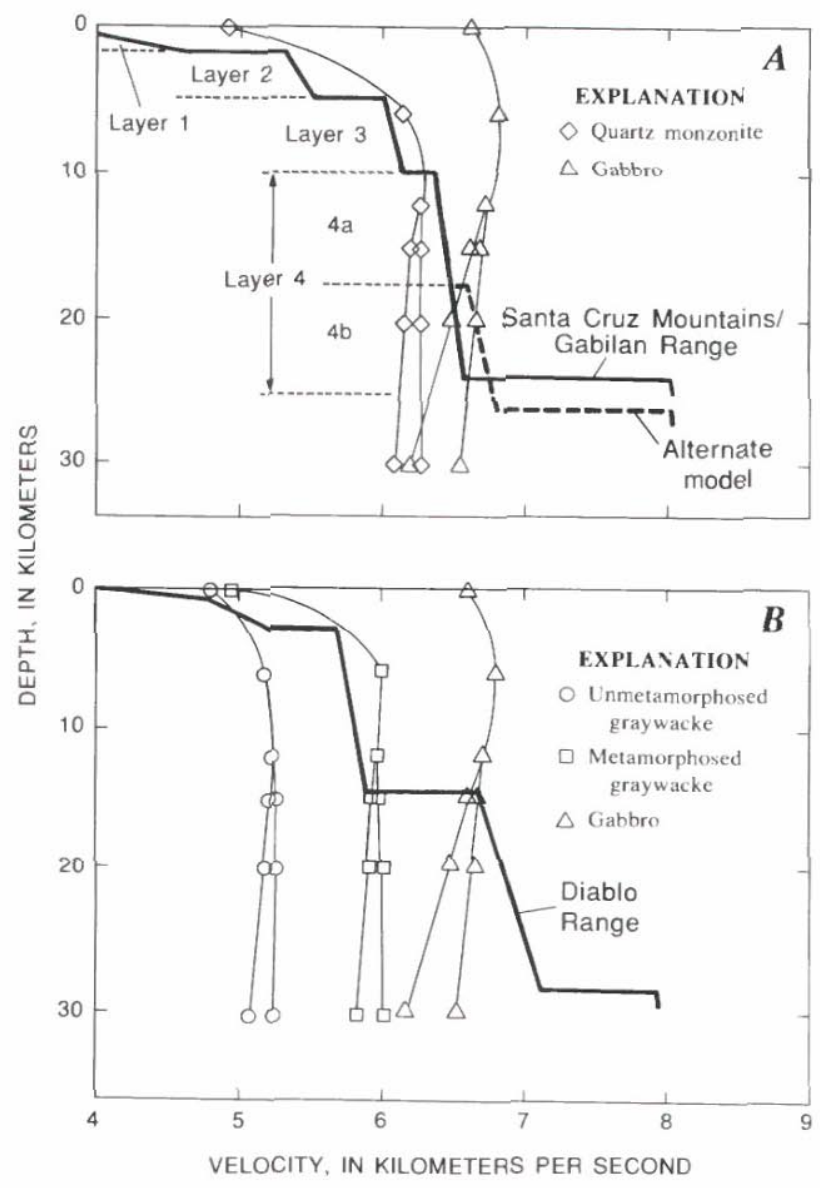

Figure 8.5.-Velocity-depth curves. A, Santa Cruz Mountains and Gabilan Range (Salinian block). B, Diablo Range. Heavy curves from seismic results (Walter and Mooney, 1982); light curves from laboratory velocity measurements and heat-flow modeling (two different geotherms assumed below about 10-km depth; Lin and Wang, 1980). See text for discussion of layers shown in figure $8.5 \mathrm{~A}$. quartz monzonite. The somewhat lower velocity of these two layers in comparison with the laboratory sample may be interpreted to result from (1) megascopic fractures in the Earth, not present in the laboratory sample; (2) a slightly lower content of mafic minerals (which have high seismic velocity) in the granitic rocks beneath the transect in comparison with the laboratory sample; or (3) both. Layer 4 is intermediate in velocity between the quartz monzonite sample and gabbro samples (hornblende gabbro and olivine gabbro) from the Coast Ranges. Walter and Mooney (1982) interpreted this layer to correspond to gneiss of intermediate composition, on the basis of a comparison of layer 4 with other laboratory data. In an alternative model, however, where middle and lower crust are separated as layers $4 \mathrm{a}$ and $4 \mathrm{~b}$, layer 4b may be reasonably interpreted as gabbro (fig. 8.5A).

Alternative interpretations of these several crustal layers are also possible, given the fact that different rock types may have similar velocities. Stewart and Peselnick (1977) and Lin and Wang (1980) studied the velocity behavior of Franciscan rocks, also common in the Coast Ranges (Jennings and Strand, 1958). Two lithologic components of the Franciscan assemblage, unmetamorphosed and metamorphosed graywacke, produce velocity-depth curves (fig. $8.5 \mathrm{~B}$ ) that bracket those for most other components of the Franciscan assemblage (including basalt). On the basis of velocity data alone, layers 2 and 3 might be interpreted as Franciscan rocks, but surface geologic data lead us to reject this interpretation. On the basis of velocity data alone, however, layer 4 is most likely not Franciscan rocks. Thus, if the middle and lower crust of the Salinian block represents a different terrane from the upper crust, as postulated by Ross and McCulloch (1979), that terrane is most likely not Franciscan assemblage.

In our cross section (fig. $8.4 B$ ), we show alternative interpretations of layer 4 , given the alternative velocity models discussed above. In one interpretation (a, fig. $8.4 B$ ), layer 4 is entirely gneiss of intermediate composition. In a second interpretation (b, fig. 8.4B), layer 4a is intermediate gneiss, and layer $4 \mathrm{~b}$ is gabbro. In interpretation a, no buried terranes are present; in interpretation b, the lower-crustal gabbro may be a buried terrane (oceanic crust) or magmatically underplated gabbro.

\section{SANTA CLARA VALLEY-SAN ANDREAS TO CALAVERAS FAULTS}

In the Santa Clara Valley, between the San Andreas and Calaveras faults, Franciscan assemblage (Permanente terrane; Blake and others, 1982) is overlain by outliers of Late Jurassic Coast Range ophiolite and Upper Cretaceous Great Valley sequence (McLaughlin 
and others, 1988a). The Franciscan assemblage includes melange, volcanogenic sandstone, pillow basalt, serpentine, chert, and limestone. The Franciscan sedimentary rocks were deposited in equatorial waters and presumably transported thousands(?) of kilometers northward before accretion to the North American Continent (Blake and others, 1982).

Along transect C2, the San Andreas fault juxtaposes a thick section of Tertiary marine sedimentary rocks on the southwest against slivers of Coast Range ophiolite, Great Valley sequence, and other Tertiary marine rocks on the northeast that have been imbricated along the southwest-dipping Sargent fault and related thrust faults (McLaughlin and others, 1988a). Presumably, the granitic rocks of the Salinian block and Franciscan assemblage are juxtaposed at depth. In contrast, similar rocks are juxtaposed on either side of the Calaveras fault, including Coast Range ophiolite, Great Valley sequence, and, at depth, presumably the Franciscan assemblage.

Aftershocks of the $M=7.1$ Loma Prieta earthquake of 1989 indicate a steep southwestward dip (approx $70^{\circ}$ ) on the San Andreas/Sargent fault zone, and the main shock produced subequal components of strike- and reverse-slip motion (Plafker and Galloway, 1989). Relatively low elevations in this region, however, indicated that the motion along this fault zone in the past has been chiefly strike slip, and seismicity before the Loma Prieta earthquake (Olsen and Lindh, 1985; Olsen, 1986) indicates a complex fault zone that may include both vertical and southwest-dipping fault strands (see fig. 8.4B).

Although a steep $\left(80^{\circ}-85^{\circ}\right)$ eastward dip on the Calaveras fault is indicated by earthquakes (see cross sec. $D-D^{\prime}$, fig. 5.7B; Reasenberg and Ellsworth, 1982; Oppenheimer and others, 1988), such an attitude is not resolvably different from a vertical dip (shown in fig. $8.4 B$ ), given errors in earthquake locations.

A seismic-refraction profile across the Santa Cruz Mountains and Santa Clara Valley reveals a heterogeneous upper crust (Mooney and Colburn, 1985). Layer offsets and velocity changes are visible in the model for this profile at the Zayante-Vergeles, Sargent, and Calaveras faults but, surprisingly, not at the San Andreas fault. An additional discontinuity is visible at an inferred buried fault in the central Santa Clara Valley (fig. 8.4A). Vertical zones of low velocity, 1 to $2 \mathrm{~km}$ wide, extending to a depth of as much as 3 to $5 \mathrm{~km}$, are visible at a few of these faults (Mayer-Rosa, 1973; Blümling and others, 1985; Mooney and Colburn, 1985). The surficial layer $(2.1-4.5 \mathrm{~km} / \mathrm{s})$ corresponds to different rocks in different places (fig. 8.4B). The "basement" layer has a velocity $(5.4-6.0 \mathrm{~km} / \mathrm{s})$ appropriate for either granitic or Franciscan rocks at shallow crustal levels (Mooney and Colburn, 1985; see discussion above and fig. 8.5); presumably, it represents Franciscan rocks except west of the San Andreas fault. The higher-velocity basement (6.0 $\mathrm{km} / \mathrm{s}$ ) in the eastern Santa Clara Valley may represent metamorphosed Franciscan rocks. A strong reflector is visible at 8- to $9-\mathrm{km}$ depth beneath the Santa Clara Valley, but the seismic velocity below it is unknown. By analogy with the strong midcrustal reflector in the Diablo Range (see below), we infer this reflector to be the top of accreted island-arc and (or) oceanic crust.

Moho depth beneath the Santa Clara Valley is not known accurately enough to resolve whether the Moho steps downward to the east at the San Andreas and Calaveras faults or dips smoothly eastward between control points in the Santa Cruz Mountains/Gabilan Range (24- to 26-km depth) and the Diablo Range (29- to 30-km depth). McEvilly and Clymer (1975) conducted a seismic-reflection survey across the San Andreas fault south of its junction with the Calaveras and found a crustal thickness of $24 \mathrm{~km}$ with no change in thickness across the fault. Peake and Healy (1977), however, indicated a change in crustal thickness at the fault in this area.

\section{DIABLO RANGE}

The Diablo Range, the east-central Coast Ranges between the Calaveras fault and the Great Valley, is underlain chiefly by Franciscan assemblage. These rocks constitute at least three thrust sheets or nappes that are folded into an antiform (fig. 8.4; Blake, 1981; Saleeby, 1986). The youngest thrust sheet, the Burnt Hills terrane (Blake and others, 1982; Saleeby, 1986), consists of mid-Cretaceous blueschist-facies graywacke, arkose, conglomerate, argillite, and chert, approximately equivalent in age and provenance to mid-Cretaceous forearc sedimentary rocks of the Great Valley sequence. The Burnt Hills terrane is exposed in the core of the antiform. The oldest thrust sheets are the Upper Jurassic (informal) Garzas tectonic melange (Cowan, 1974) and the Yolla Bolly terrane (Blake and others, 1982). The Garzas tectonic melange consists of mafic blueschist-amphibolite, greenstone, serpentinized peridotite, and metagraywacke; it contains fragments of Upper Jurassic rocks (Coleman and Lanphere, 1971; Suppe and Armstrong, 1972) similar to those accreted in the Sierran foothills during the Nevadan orogeny (see below). The Yolla Bolly terrane lithologically resembles the Burnt Hills terrane, although there are some important differences. Both the Garzas tectonic melange and Yolla Bolly terrane crop out on the flanks of the antiform. The Coast Range ophiolite and Great Valley sequence lie above the Franciscan rocks on the low-angle Coast Range fault, which is complexly offset by the steeply dipping Cenozoic Tesla-Ortigalita fault on the northeast flank of the Diablo Range (fig. 8.4). (We follow Jayko and others, 1987, in referring to the 
"Coast Range thrust fault" as simply the "Coast Range fault"-see below.)

The velocity structure of the Diablo Range derived by Walter and Mooney (1982) from seismic-refraction data collected by Stewart (1968) includes, beneath a 3.5- to $5.3-\mathrm{km} / \mathrm{s}$ near-surface layer, a $5.7-$ to $5.9-\mathrm{km} / \mathrm{s}$ layer beginning at 3-km depth, a $6.7-$ to $7.1-\mathrm{km} / \mathrm{s}$ layer beginning at 15-km depth, and the Moho at 29-km depth (fig. 8.4A). Importantly, a strong reflection is observed from the layer boundary at $15 \mathrm{~km}$, indicating a strong velocity contrast between upper and lower crust. Blümling and Prodehl (1983) reanalyzed the same data and derived a similar velocity structure, except that they interpreted more phases in the data and added a lower-crustal low-velocity layer $(5.3 ? \mathrm{~km} / \mathrm{s})$, with its base at about 26-km depth.

Seismic-reflection data have been collected in the eastern Diablo Range (Zoback and Wentworth, 1986) and compiled with other seismic data (Wentworth and others, 1987). These reflection data include a band of strong reflectors in the upper crust that dips shallowly east (reflectors a, fig. 8.4A), a weak reflector in the middle crust that dips shallowly west (reflector b), and a weak reflector at about $30-\mathrm{km}$ depth (reflector c). The shallowly west-dipping reflector $b$, appears to link the top of the Great Valley basement with the top of the 6.7- to 7.1-km/s layer (Wentworth and Zoback, 1989).

Between 3- and 15-km depth, seismic velocities in the Diablo Range are well bracketed by velocity-depth curves predicted for end-member rocks of the Franciscan assemblage (fig. 8.5B; Steward and Peselnick, 1977; Lin and Wang, 1980). Within this depth range, the observed velocities also are slightly lower than those predicted for most granitic rocks (see fig. 8.5A). Between 15- and $20-\mathrm{km}$ depth, the observed velocities agree well with those predicted for gabbro (fig. 8.5B; Lin and Wang, 1980 ) or, possibly, high-grade metamorphic rocks (Birch, 1960; Christensen and Fountain, 1975).

The 6.7- to $7.1-\mathrm{km} / \mathrm{s}$ layer in the Diablo Range may represent the middle and lower crust of an island arc or several imbricated island arcs. If so, this layer might include mixed intermediate and mafic plutonic rocks, including compositions from granodiorite to gabbro, as well as metamorphic rocks (see description of the Coast Range ophiolite by Evarts, 1977). Its relatively high velocity indicates that rocks of mafic composition must dominate or that the rocks are of amphibolite to granulite facies. This "island arc" interpretation is consistent with linking this layer to rocks beneath the Great Valley and thence to rocks of the Sierran foothills, which represent the middle and upper crust of island $\operatorname{arc}(\mathrm{s})$ (Saleeby, 1986). The 6.7- to $7.1-\mathrm{km} / \mathrm{s}$ layer, however, may also represent middle and lower oceanic crust, or diabase and gabbro, similar to the lowest layer of oceanic crust at the west end of transect C2 (fig. 8.4A). The 6.7- to $7.1-\mathrm{km} / \mathrm{s}$ layer is too thick, however, to represent a single layer of oceanic crust. It consists of either several slices of tectonically underplated oceanic crust or of oceanic crust that has been augmented by mafic intrusions after underplating. If the low-velocity zone of Blümling and Prodehl (1983) is present, the 6.7- to 7.1-km/s layer may include oceanic sedimentary rocks tectonically underplated along with the oceanic crust.

We show a fault contact between the Franciscan assemblage and the 6.7- to $7.1-\mathrm{km} / \mathrm{s}$ layer in the Diablo Range to reflect the eastward transport of a wedge of Franciscan rocks (fig. 8.4B), similar to that discussed by Wentworth and others (1984). This interpretation departs from that of Saleeby (1986), who linked the shallowly east-dipping reflectors in the eastern Diablo Range (a, fig. 8.4A) with a hypothetical subduction zone or thrust fault beneath the Great Valley and Sierran foothills (see section below entitled "Discussion-Tectonic Wedging").

\section{GREAT VALLEY AND SIERRAN FOOTHILLS}

Rocks of the Great Valley are known from exposures in an upturned section on the east side of the Diablo Range and from wells. The upturned section rests structurally above the Franciscan assemblage on the low-angle Coast Range fault, although in many places this relation is obscured by younger high-angle faults. This upturned section includes, from oldest to youngest, Middle and Late Jurassic Coast Range ophiolite and a related tuffaceous unit; Upper Jurassic and Cretaceous Great Valley sequence, which is chiefly forearc flysch; lower Cenozoic postarc marine and terrestrial sedimentary rocks; and upper Cenozoic continental-arc sedimentary rocks (Maddock, 1964; Evarts, 1977; Bartow and others, 1985).

At the latitude of transect C2, the Coast Range ophiolite is interpreted to be a (rifted) island-arc assemblage because it contains abundant silicic volcanic and intrusive rocks (Bailey and Blake, 1974; Evarts, 1977; Hopson and others, 1981; McLaughlin and others, 1988b). Its contact with the overlying sedimentary rocks, though faulted in most places, is believed to be fundamentally depositional (Bailey and others, 1970); on transect C2 it is demonstrably depositional (Evarts, 1977).

The Great Valley sequence and younger rocks exposed in the upturned section in the eastern Diablo Range appear to be nearly twice as thick as the section of sedimentary rocks penetrated in wells farther east in the Great Valley (fig. 8.4). Some of this apparent westward thickening results from the stratigraphic addition of older rocks to the basal part of the section in the west; some may be caused by imbrication along thrust faults (Wentworth and others, 1984). Similar apparent thickening 
west of the synclinal axis of the Great Valley has been documented in other localities as well. In the southern Great Valley, Wentworth and others (1984) indicated an apparent doubling of thickness west of the axis, and in the northern Great Valley, an apparent trebling of thickness.

Most of the basement rocks that have been penetrated by wells in the Great Valley have been identified as granitic rocks (Saleeby, 1986). Rocks exposed in the Sierran foothills, east of the Great Valley, may be related to basement rocks beneath the Great Valley, but they are not so dense or magnetic (see below; fig. 8.4A).

Deep structure along transect C2 in the Great Valley has been elaborated in some detail by Colburn and Mooney (1986), Holbrook and Mooney (1987), and Dean Whitman and others (unpub. data, 1985) from seismicrefraction data, and by Wentworth and others (1987) primarily from seismic-reflection data. Seismic velocities in the sedimentary section range from 1.6 to $4.1 \mathrm{~km} / \mathrm{s}$ where these velocities can be clearly ascribed to sedimentary rocks, such as near well No. 1 (fig. $8.4 A$ ). In the eastern Diablo Range, velocities as high as $4.7 \mathrm{~km} / \mathrm{s}$ may also be due to sedimentary rocks (fig. 8.4A). East of the synclinal axis in the Great Valley, reflections within the sedimentary section are subparallel to the top of basement, which is marked by the disappearance of reflections (f, fig. 8.4A). West of the synclinal axis, these reflections (d, fig. $8.4 A$ ) diverge slightly from the inferred top of basement (e, fig. 8.4A).

Beneath the sedimentary rocks of the Great Valley are several layers of increasing seismic velocity: a 5.5- to $5.7-\mathrm{km} / \mathrm{s}$ layer, 1.5 to $2 \mathrm{~km}$ thick (layer 1 ), a 6.0 - to $6.3-\mathrm{km} / \mathrm{s}$ layer, 2.5 to $6 \mathrm{~km}$ thick (layer 2); a 6.6 - to $6.75-\mathrm{km} / \mathrm{s}$ layer, 4 to $7 \mathrm{~km}$ thick (layer 3 ); and a 6.9 - to 7.2 $\mathrm{km} / \mathrm{s}$ layer, about $7 \mathrm{~km}$ thick (layer 4) (fig. 8.4A). In addition, there is a thin, laterally discontinuous $7.0-\mathrm{km} / \mathrm{s}$ layer embedded in the top of layer 3. Well No. 1 indicates that layer 1 is granitic rocks. Farther west, however, this layer may be interpretable either as granitic rocks or as Franciscan assemblage, which have similar velocities at this depth (fig. 8.5). In the original data of Colburn and Mooney (1986) and Holbrook and Mooney (1987), there is no perceptible reflection from an interface between layers 1 and 2 (as there is, for example, between layer 1 and the overlying sedimentary rocks), and so these two layers may, in fact, grade into one another. Layer 2 could then also be granitic rocks, and layers 1 and 2 together would constitute a velocity-depth section similar, for example, to upper crust of the batholithic Salinian block (figs. 8.4A, 8.5). Layers 3 and $4(6.6-7.2 \mathrm{~km} / \mathrm{s})$, which are analogous to the lower-crustal layer in the Diablo Range $(6.7-7.1 \mathrm{~km} / \mathrm{s})$, may represent the middle and lower crust of accreted island $\operatorname{arc}(\mathrm{s})$ and (or) oceanic crust. The Moho is well documented at about $27-\mathrm{km}$ depth. Deep reflection data beneath the Great Valley (Wentworth and others, 1987) indicate a conspicuous east-dipping band of reflections (g, fig. 8.4A) and less conspicuous subhorizontal and west-dipping reflectors.

Rocks of the Sierran foothills consist of Lower to Upper Jurassic mafic to felsic volcanic and plutonic rocks and related sedimentary rocks (argillite, chert, and flysch) that were accumulated or emplaced in an islandarc setting (Clark, 1964; Schweickert and Cowan, 1975; Saleeby, 1982; Schweickert and Bogen, 1983). The basement and metamorphic wallrocks for the intrusive rocks are tectonically disrupted and polymetamorphosed Paleozoic ophiolitic rocks (approx $300 \mathrm{Ma}$; Saleeby, 1982).

The island $\operatorname{arc}(\mathrm{s})$ in which the Jurassic rocks of the Sierran foothills were formed collapsed against the margin of the North American Continent during the Late Jurassic Nevadan orogeny (Jones and others, 1976). How this collapse occurred is problematic. Steeply east-dipping faults and upright antiforms are seen in the Sierran foothills, but a study by Moores and Day (1984) of surface relations $300 \mathrm{~km}$ north of transect $\mathrm{C} 2$ indicates obduction of the $\operatorname{arc}(\mathrm{s})$ on west-dipping thrust faults. These rocks were intruded during the Early Cretaceous by mafic to intermediate plutons belonging to the western phase of Sierra Nevada plutonism (Evernden and Kistler, 1970).

The deep structure of the Sierran foothills is known from the reconnaissance seismic-refraction experiment of Spieth and others (1981), the reflection profiling of Zoback and Wentworth (1986), and the compilation of reflection, refraction, and potential-field results by Wentworth and others (1987). The refraction data can be modeled with a $6.2-\mathrm{km} / \mathrm{s}$ basement from near the surface to about 30-km depth, a 6.6-km/s lower crust, and a Moho at 39-km depth. Other models are possible, however, and the Moho may be as shallow as $30 \mathrm{~km}$ (Spieth and others, 1981). We have projected the seismic-reflection results and gravity/magnetic boundary of Wentworth and others (1987) from 45 to $60 \mathrm{~km}$ southward onto transect C2. Two conspicuous west-dipping sets of reflections are visible, as well as a few subhorizontal reflectors. The gravity/ magnetic boundary, however, has a moderate eastward dip.

Our projection of the results of Wentworth and others (1987) is uncertain not only because of the distances involved but also because their profile terminates on the east in an area that is anomalous both geologically and geophysically. In this area, batholithic rocks (trondhjemite) engulf most accreted rocks of the Sierran foothills (Jennings, 1977) and are associated with a gravity low (Oliver and others, 1980). Our projection, however, may be defensible as follows. (1) The batholithic rocks responsible for the gravity low probably do not extend below 10-km depth (R.C. Jachens, oral commun., 1988); most of the reflectors that we have projected are largely below 
that depth. (2) The modeled gravity/magnetic boundary is approximately similar in shape throughout the length of the Great Valley (Andrew Griscom, oral commun., 1988); in our projection, we have attempted to correct for the difference in azimuth between transect $\mathrm{C} 2$ and the profile of Wentworth and others (1987) by assuming a strike parallel to the Great Valley.

Given the geologic and seismic constraints discussed above, we have interpreted the cross section through the Great Valley and Sierran foothills (fig. 8.4B), using some of the ideas of Wentworth and others $(1984,1987)$ for the configuration of an inferred tectonic wedge of Franciscan rocks, and some of the ideas of Saleeby (1986) for structure within crystalline rocks. The uppermost part of our cross section (to approx 2-km depth) on the east flank of the Diablo Range (fig. 8.4A) was supplied by R.C. Evarts (written commun., 1989). Below this area, we have added a hypothetical west-dipping thrust fault to bring the Great Valley sequence beneath the easternmost block of the Coast Range ophiolite and to grossly satisfy the velocity constraints of Dean Whitman and others (unpub. data, 1985; fig. 8.4A). East of the Coast Range ophiolite, we postulate thrust faults that largely follow bedding planes in the upturned section of the Great Valley sequence, similar to those postulated by Wentworth and others (1984) for the northern Great Valley. These "backthrust" faults are required for emplacement of the wedge and help explain the thickening of the Great Valley sequence in the western limb of the syncline (see section below entitled "Discussion-Tectonic Wedging"). From the easternmost backthrust fault in the Great Valley to the San Andreas fault, we have modeled the discontinuity between variably reflective rocks of lower velocity (Franciscan assemblage, Coast Range ophiolite, and Great Valley sequence; $1.7-5.8 \mathrm{~km} / \mathrm{s}$ ) and poorly reflective rocks of higher velocity (mafic rocks of the Diablo Range and crystalline basement of the Great Valley; $5.5-6.8 \mathrm{~km} / \mathrm{s}$ ) as the floor thrust fault of the wedge. Wentworth (1987) presented a similar interpretation.

The details of composition and structure in the crystalline rocks beneath the Great Valley and Sierran foothills are speculative. Saleeby (1986) interpreted these rocks to consist fundamentally of slabs or nappes of island-arc and oceanic rocks obducted along west-dipping Nevadan thrust faults intruded by chiefly Early Cretaceous Sierran granitic plutons. We have adopted this basic scheme and added some details, interpreting layers 1 and 2 in the basement beneath the Great Valley (5.5-6.3 $\mathrm{km} / \mathrm{s}$; see above) as post-Nevadan felsic plutonic rocks, although, as noted above, the western part of layer 1 (5.5 $\mathrm{km} / \mathrm{s}$ ) may be Franciscan assemblage. We interpret the east-dipping gravity/magnetic boundary of Wentworth and others (1987) as the average top of mafic crust
(pre-Nevadan gabbro, diabase, or basalt) in the inferred obducted sequence. Alternatively, this boundary may be the average top of mafic, magnetic intrusions in the crust (post-Nevadan gabbro) or the average base of felsic, nonmagnetic intrusions (post-Nevadan granitic rocks). At the location where this boundary was actually modeled, it may be the average base of a large trondhjemite intrusion. We associate the east-dipping reflections beneath the central Great Valley (g, fig. 8.4A) with the thin, discontinuous 7.0-km/s layer of Holbrook and Mooney (1987), although the depth correspondence is imperfect, and we interpret this feature as a gabbroic dike. Alternatively, these east-dipping reflections may represent an east-dipping fault zone. Following Saleeby (1986), we correlate the upper and lower west-dipping bands of reflections in the eastern Great Valley and Sierran foothills $(\mathrm{h}$, j, fig. 8.4A) with the Bear Mountain and Melones fault zones, which may represent Cenozoic reactivations of inferred west-dipping Nevadan thrust faults.

\section{DISCUSSION-TECTONIC WEDGING}

\section{GEOLOGIC HISTORY}

Wentworth and others (1984) interpreted the juxtaposition of Franciscan assemblage and a coeval section consisting of Coast Range ophiolite and Great Valley sequence as having occurred during landward movement of the Franciscan assemblage as a tectonic wedge. They reinterpreted the "Coast Range thrust fault" of Bailey and others (1970), a subduction megathrust between the Coast Range ophiolite and the Franciscan assemblage, as the roof thrust of the wedge. More recently, the thrust nature of the "Coast Range thrust fault" has been reevaluated. Jayko and others (1987), testing an hypothesis by Platt (1986), produced abundant evidence that the contact between Franciscan assemblage and Coast Range ophiolite is a detachment surface along which the upper plate was extended during uplift of the Franciscan assemblage. Their evidence is the consistent attenuation, as opposed to repetition, of geologic section across this discontinuity and associated faults above it. They proposed the term "Coast Range fault" for this discontinuity, which we adopt here. Evidence of attenuation is present even on transect $\mathrm{C} 2$, in that the two outcrops of the Coast Range ophiolite in the eastern Diablo Range (fig. 8.4A) represent an abridged section of ophiolite: The western outcrop is partially serpentinized ultramafic rock of the basal part of an ophiolite, whereas the eastern outcrop is the sill complex and volcanic flows of the upper part of an ophiolite. These two parts of the ophiolite are now juxtaposed across the crooked, steeply dipping Tesla-Ortigalita fault. Although this fault now offsets the 
Coast Range fault, it may represent reactivation of a normal fault that originally soled into the Coast Range fault (compare Raymond, 1973).

The extensional nature of the Coast Range fault poses several problems for emplacement of the Franciscan assemblage as a tectonic wedge. Where is the roof thrust fault of the wedge? How did the Franciscan assemblage reach its current position with an extended overlying section of the Coast Range ophiolite and Great Valley sequence? Was the Franciscan assemblage uplifted from beneath the western Great Valley? The apparent continuity between the Great Valley basement and the 6.7- to $7.1-\mathrm{km} / \mathrm{s}$ layer in the Diablo Range indicates a negative answer to the last question.

These problems can be solved if the extensional event was separated in time and space from the compressional event, or tectonic wedging. Jayko and others (1987) reviewed the published evidence regarding the geologic history of extensional faulting. In one place, the Coast Range fault and associated faults are overlapped by sedimentary rocks of Oligocene and younger age, and in another place by sedimentary rocks of Paleocene and younger age. The occurrence of detritus derived from the Franciscan assemblage in Paleocene and Eocene strata of the Coast Ranges (Dickinson, 1966; Berkland, 1973) indicates that the lower plate was exposed by the early Tertiary. Jayko and others (1987) inferred that uplift of the Franciscan assemblage and associated extensional faulting in the upper plate occurred during the Late Cretaceous and (or) early Tertiary.

The history of compressional tectonics in the Coast Ranges is sparse and varies from place to place. In the northern Coast Ranges, thrust faulting and folding began during the early Tertiary (Blake and others, 1987; M. C. Blake, Jr., oral commun., 1989), and compressional deformation is continuing today in rocks of the northern Great Valley (Harwood and Helley, 1987). In the southern Coast Ranges, at least four Cenozoic deformations or uplifts, indicated by unconformities or eastward-migrating depocenters, have ages of late Paleocene, late Eocene to early Miocene, late Miocene, and late Pliocene (Namson and Davis, 1988; Namson and others, 1990; Rentschler and Bloch, 1988). Modern thrust faulting and folding still is occurring, as indicated by the 1983 Coalinga earthquake (see chap. 5; Eaton, 1990).

Landward movement of the Franciscan assemblage as a wedge may have even begun in the Mesozoic. In the northern Coast Ranges, several northwest-striking faults (Paskenta, Elder Creek, and Cold Fork faults) offset rocks structurally above the Franciscan assemblage (but not the Franciscan assemblage itself) and represent major discontinuities in the depositional environment of the Great Valley sequence (Jones and Irwin, 1971). These faults, which have displacements of tens of kilometers to as much as $100 \mathrm{~km}$, are interpreted to have moved primarily during the Cretaceous (Jones and Irwin, 1971), although the latest limit on the time of movement is about $3.4 \mathrm{Ma}$ (Hardwood and Helley, 1987; M.C. Blake, Jr., oral commun., 1989). Wentworth and others (1984) and Jayko and others (1987) interpreted these faults as tear faults in the plate structurally above a wedge of Franciscan assemblage.

In light of the above data and interpretations, we postulate (1) that uplift of the Franciscan assemblage and extension of the upper plate, consisting of Coast Range ophiolite and Great Valley sequence, occurred during the Cretaceous (or, at the latest, during the early Tertiary, if Cretaceous movement on the Paskenta-Cold Fork fault system is not linked to landward wedge transport) well west of the present Diablo Range; and (2) that a tectonic wedge of Franciscan assemblage was subsequently driven landward, with the extended upper plate riding passively atop it. This wedge is interpreted to have moved along a floor thrust fault aligned with the contact between the Great Valley sequence and its crystalline basement. To the west of the present Diablo Range, where movement initiated, the basement was an outboard part of the Coast Range ophiolite. Beneath the Great Valley, where the movement is presently occurring, the basement is similar to the Coast Range ophiolite but contains numerous younger plutons. A roof thrust fault apparently developed only near the east tip of the wedge (fig. 8.4B); presumably, erosion kept pace with uplift near the tip. Differential vertical or horizontal movements of the wedge may have produced tear faults, such as the Paskenta, Elder Creek, and Cold Fork faults, and may have reactivated extensional faults to produce complex faults, such as the Tesla-Ortigalita fault.

\section{PAST AND PRESENT TECTONIC REGIMES}

The Mendocino triple junction has moved northward through offshore central California during approximately the past $20 \mathrm{Ma}$, and subduction of the Farallon plate (or its derivative) was replaced by transform motion of the Pacific plate past North America (see chap. 3; Atwater, $1970,1989)$. If tectonic wedging occurred during the late Mesozoic and Cenozoic, in association with all of the episodes of tear faulting or compression outlined above, then clearly it was driven during both subduction and transform regimes. At present, it is being driven by a transform regime. At least two additional arguments can be made that wedge motion-indeed, probably a major fraction of wedge motion-occurred during the subduction regime. The first argument is simply based on geometry: The east boundary of the Coast Ranges, inferred to coincide approximately with the buried tip of the wedge, largely parallels Mesozoic structures in the 
Sierran foothills and the Great Valley rather than the late Cenozoic San Andreas fault (Wentworth and Zoback, 1989; C.M. Wentworth, oral commun., 1990). The second argument, developed below, is based on the total apparent displacement of the wedge.

If the inferred tectonic wedge of Franciscan assemblage extends to the San Andreas fault, as we have shown (fig. 8.4B), then a minimum shortening of about 70 $\mathrm{km}$ has occurred along faults at the top and bottom of the wedge in the Diablo Range. Likewise, in the northern Coast Ranges, the inferred tear faults in the plate above the wedge have a total displacement-and, thus, shortening-of many tens of kilometers (Wentworth and others, 1984), possibly as much as $100 \mathrm{~km}$ (Jones and Irwin, 1971).

Although a transform regime has replaced a subduction regime in central California over approximately the past $20 \mathrm{Ma}$, plate-margin compression, necessary to drive the wedge, has persisted for only approximately the past $5 \mathrm{Ma}$ (Page and Engebretson, 1984). At about 5.5-4.5 Ma, transform motion was also transferred from offshore faults to the modern San Andreas fault system (see chap. 3; Atwater, 1989; Humphreys and Weldon, in press). Present plate-margin compression is understandable from (1) the slight misalignment of the direction of relative plate motion $\left(\mathrm{N} .35^{\circ}\right.$ W.; Minster and Jordan, 1978) and the strike of the San Andreas fault (N. $40^{\circ} \mathrm{W}$.), and (2) the opening of the Basin and Range province. Crouch and others (1984) calculated from these two effects a rate of shortening across the Coast Ranges that, integrated over the past $5.5 \mathrm{Ma}$, predicted a total shortening of 28 to $72 \mathrm{~km}$. Most of this shortening could be accounted for in small fault displacements and folds distributed throughout the Coast Ranges (Crouch and others, 1984). Thus, the minimum shortening of 70 to 100 $\mathrm{km}$ represented by the tectonic wedge, as discussed above, would appear to equal or exceed the maximum shortening calculated for the transform regime, a result suggesting that some, if not most, of the wedge motion occurred during the subduction regime.

Shear coupling between the subducting plate and overlying accretionary prism (Franciscan assemblage) could conceivably drive the wedge during the subduction regime. Such a mechanism has been postulated for southern Alaska by Fuis and Plafker (in press). To drive the wedge during a transform regime appears to require a less obvious mechanism, such as plate-margin compression combined with differing deformation in the upper and lower crust. Such a mechanism is developed below.

Sibson (1982) pointed out, on the basis of strength considerations, that ductile flow could be expected in the middle crust, below the maximum depth of earthquake hypocenters. Several workers (Crouch and others, 1984; Namson and Davis, 1988; Eaton and Rymer, in press) have postulated a decollement near the base of the seismicity in the Coast Ranges (avg 15-km depth; see chap. 5; Wesson and others, 1973) into which thrust and oblique-slip faults on both sides of the Coast Ranges sole. They envision differential movement between upper and lower crust caused by differing alignment of the transform faults in these two layers, or by shortening of the lower crust by ductile thickening.

We have incorporated the idea of a Coast Range-wide detachment in our cross section (fig. 8.4B). In the Diablo Range, we show a young thrust fault at the base of the inferred tectonic wedge soling into the brittle-ductile transition zone, which in this area is, coincidentally, near the interface between Franciscan rocks and mafic crust. Although we also indicate soling of the San GregorioHosgri fault into such a zone and underthrusting of the Salinian block by the early Tertiary accretionary prism, focal mechanisms in this region indicate pure strike slip on the San Gregorio-Hosgri fault (see chap. 5) and argue against this interpretation. Such an interpretation of a Coast Ranges-wide midcrustal detachment requires that the deformational style and (or) location of the San Andreas fault system change from the upper to the lower crust.

If we have correctly inferred the geologic history of wedge movement, it is remarkable that such movement has apparently occurred in two quite different tectonic regimes, a subduction regime and a transform regime.

\section{SOUTHERN CALIFORNIA}

The crustal structure of southern California is complicated by the Big Bend in the San Andreas fault, situated between the Coast Ranges and Transverse Ranges, and by onshore spreading centers of the East Pacific Rise, situated in the Salton Trough (figs. 8.2, 8.3). The Big Bend is thought to result from westward movement of the Sierra Nevada relative to the Mojave Desert, along the Garlock fault (Hill and Dibblee, 1953). The San Andreas fault crosses the Transverse Ranges, between the Big Bend and Salton Trough, at an angle oblique to relative plate motion, while somehow remaining a largely vertical, strike-slip fault.

The onshore spreading centers in the Salton Trough are situated at echelon offsets between the San Andreas, Imperial, and Cerro Prieto faults (see fig. 3.8; Lomnitz and others, 1970). These three faults are interpreted as transform faults; the San Andreas links the northernmost spreading center in the Salton Trough with the Mendocino triple junction. A progressive decrease in spreading rate northward along the East Pacific Rise is inferred to give rise to movement on the San Jacinto, Elsinore, San Miguel/Newport-Inglewood, and other faults in southern 
California and Mexico (Lomnitz and others, 1970; Elders and others, 1972).

First, we discuss a transect across southern California, Centennial Continental-Ocean Transect C3 (Howell and others, 1985). Second, because of the three-dimensionality of the geology and tectonics in southern California, we include a discussion of block motions, largely from Weldon and Humphreys (1986).

\section{TRANSECT C3}

We modify and reinterpret the section of Centennial Continent-Ocean Transect C3 (Howell and others, 1985) that extends from Santa Catalina Island to the Colorado Desert (fig. 8.2). This section of the transect crosses four blocks or provinces, the California Continental Borderland (hereafter referred to simply as the "borderland"), Peninsular Ranges, Salton Trough, and Chocolate Mountains (fig. 8.6). The transect crosses the NewportInglewood, Elsinore, San Jacinto, and Imperial strikeslip faults. Constraints for the transect include surface geology, isotopic studies, seismic-refraction profiling (which is sparse, except in the Salton Trough), tomographic studies, and potential-field studies.

\section{BORDERLAND}

The borderland is broken up by right-slip faults into several northwest-trending blocks. Our cross section (fig. 8.6) begins on the easternmost block, the "Catalina terrane" (Howell and others, 1985), bounded on the east by the Newport-Inglewood fault. The Catalina terrane is underlain, beneath patches of Tertiary volcanic rocks, by Franciscan assemblage, on the basis of outcrops on Santa Catalina Island (Platt, 1975, 1976; Jones and others, 1976) and submarine dredge and core samples (Vedder and others, 1974). The block west of the Catalina terrane, the "San Nicholas terrane" (Howell and others, 1985), is inferred to be underlain, beneath Cenozoic marine sedimentary rocks, by rocks similar to the Great Valley sequence and Coast Range ophiolite of central California, possibly in fault contact with Franciscan assemblage at depth (Vedder and others, 1974).

A reversed seismic-refraction profile just west of Santa Catalina Island indicates $P$-wave velocities of $5.8 \mathrm{~km} / \mathrm{s}$ to $6-\mathrm{km}$ depth and of $6.7 \mathrm{~km} / \mathrm{s}$ to the Moho at about $24-\mathrm{km}$ depth (fig. 8.6A, Shor and Raitt, 1958). This velocitydepth section is similar to that for the Diablo Range of central California (see above), where Franciscan rocks are equated with the $5.8-\mathrm{km} / \mathrm{s}$ interval, and middle and lower crust of island $\operatorname{arc}(\mathrm{s})$ and (or) oceanic crust are equated with the $6.7-\mathrm{km} / \mathrm{s}$ interval. In this region, there is no clear evidence of landward movement of the Franciscan assemblage as a tectonic wedge, although such evidence may surface during future investigations. As in the Diablo Range, the lower crust must have been brought to its present $18-\mathrm{km}$ thickness by (1) imbrication of slices of island-arc crust, (2) tectonic underplating of several thicknesses of oceanic crust, and (or) (3) magmatic underplating. Subduction continued beneath the borderland until sometime between 30 and $20 \mathrm{Ma}$ (see Atwater, 1970), depending on the latitude to which the borderland is palinspastically restored.

\section{PENINSLI AR RANGES}

The Peninsular Ranges are underlain in the west by supracrustal rocks, including, from top to bottom, Cenozoic marine sedimentary rocks, Cretaceous forearc sedimentary rocks, Lower(?) Cretaceous and Upper Jurassic andesite (Santiago Peak Volcanics), and Middle Jurassic flysch (Bedford Canyon Formation) that was disrupted and overturned before the Late Jurassic (Larsen, 1948; Jennings, 1977; Criscione and others, 1978). These rocks are intruded by Early Cretaceous plutons of the Peninsular Ranges batholith that include chiefly tonalite and gabbro and show no special age trends (static magmatic arc; Silver and others, 1979). About $80 \mathrm{~km}$ east of the coastline, both prebatholithic and batholithic rocks change (fig. $8.6 A$ ): To the east, the prebatholithic rocks are dominantly metamorphosed clastic rocks of amphibolite grade, and the batholithic rocks are chiefly tonalite and granodiorite whose ages decrease progressively eastward (from 105 to 80-90 Ma; migrating magmatic are; Silver and others, 1979). Major-element chemistry and oxygen isotopes indicate that deep crustal rocks in the west half of the batholith are dominantly primitive and tholeiitic but, in the east, more aluminous and oxidized (fig. 8.6A). Older crust that was once at the Earth's surface is inferred at depth in the east (Silver and others, 1979).

Seismic constraints for the deep structure of the Peninsular Ranges are sparse. Using blasts at the Corona Quarry in the northernmost Peninsular Ranges, Gutenberg (1951) and Shor (1954) obtained an unreversed refraction profile, extending southward to the United States-Mexican border, along with a reflection record at the blast site. Interpretation of these data by Shor and Raitt (1958) indicated velocities of $5.9 \mathrm{~km} / \mathrm{s}$ to $8-\mathrm{km}$ depth, $6.8 \mathrm{~km} / \mathrm{s}$ to $26-\mathrm{km}$ depth (with a possible lowvelocity zone in this interval), and $7.0 \mathrm{~km} / \mathrm{s}$ to the Moho at 30 - to $32-\mathrm{km}$ depth (fig. $8.6 A$ ). In contrast, a study by Nava and Brune (1982) using a blast at the same quarry, reversed by an earthquake in Baja, Mexico, indicated a Moho depth of $42 \mathrm{~km}$. Hearn and Clayton (1986a, b) used as many as 600,000 arrivals from local earthquakes in southern California to map the velocity of the crust and upper mantle, using tomography. Their map indicates 
that the west half of the Peninsular Ranges has a higher average upper-crustal velocity and a lower average mantle velocity in comparison with the east half. Their map of $P_{n}$ delays for the Peninsular Ranges suggests no crustal root and an average crustal thickness of nearly 30 $\mathrm{km}$. Gravity modeling of the Peninsular Ranges (Fuis and others, 1984) and isostatic calculations also indicate a maximum crustal thickness of 30 to $33 \mathrm{~km}$. In our cross section (fig. 8.6B), we adopt a maximum crustal thickness of $33 \mathrm{~km}$.

W
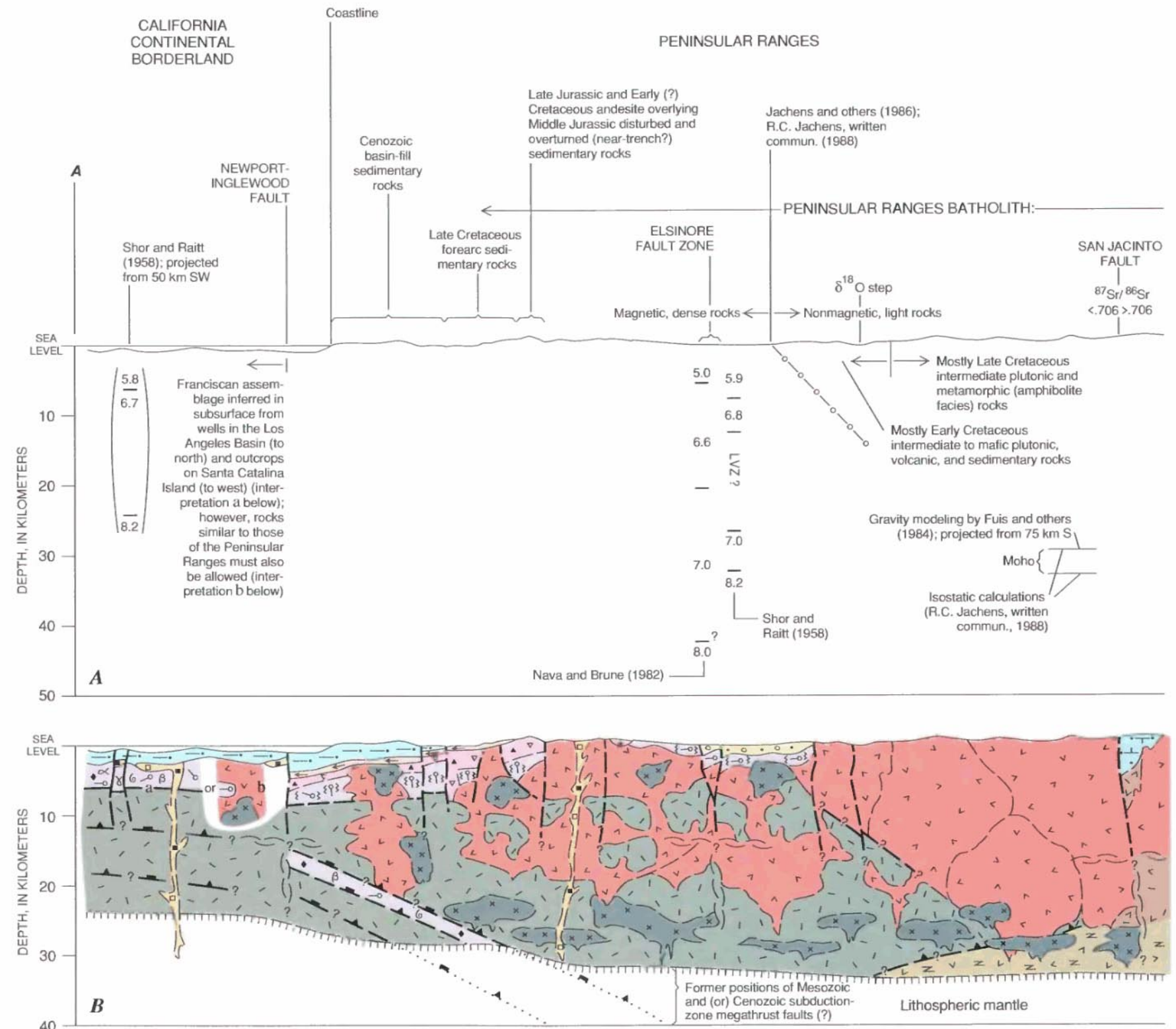

Figure 8.6.-Crustal structure of southern California. A, Surface geology, isotope data, and models of seismic-refraction, gravity, and magnetic data for part of Centennial Continent-Ocean Transect C3 (see Howell and others, 1985). $B$, Reinterpretation of Transect C3. Major features in figure $8.6 B$ include, from west to east, (1) Franciscan assemblage overlying mafic crust in the borderland; (2) Peninsular Ranges batholithic block, consisting of west half inferred to be underlain at depth by mafic (island arc or oceanic) crust and east half inferred to be underlain at depth by intermediate continental Precambrian(?) rocks; (3) late Cenozoic rift, the Salton Trough, whose central part is inferred to be underlain by entirely new crust that includes, from top to bottom, sedimentary rocks, thermally metamorphosed sedimentary rocks, and gabbro generated at onshore 
An additional constraint on crustal structure is the modeling by Jachens and others (1986; R.C. Jachens, written commun., 1988) of strong magnetic and gravity steps (500 nT and $40 \mathrm{mGal}$, respectively) in the central Peninsular Ranges: A moderately east dipping boundary is modeled between more magnetic, dense rocks on the west and less magnetic, lighter rocks on the east. This boundary is poorly defined at the latitude of our transect; it correlates approximately (within $15 \mathrm{~km}$ or so) with the boundary between the east and west halves of the
SALTON TROUGH

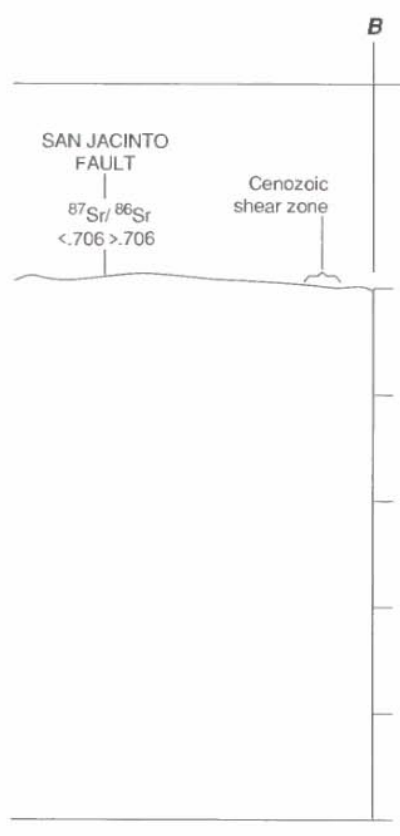

CHOCOLATE MOUNTAINS

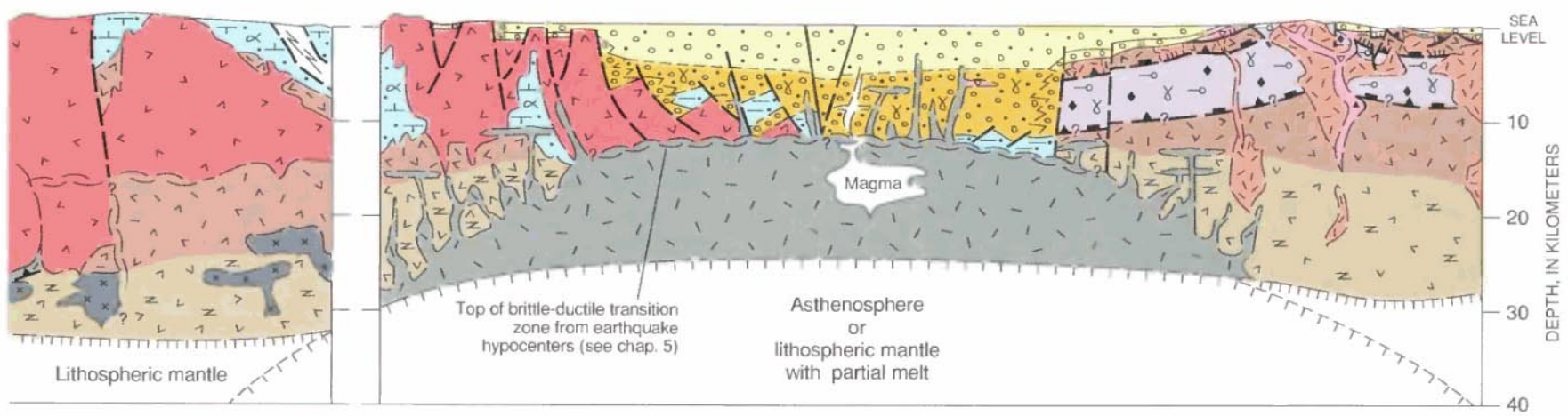

spreading center; and (4) Pelona-Orocopia schist of Haxel and Dillon (1978) (similar to the Franciscan assemblage), interpreted to compose tectonic wedge. Tectonic wedge in feature 4 is postulated to have been obducted onto continental crust (see text); its tip would lie well east of east end of cross section. This reinterpretation differs from Howell and others' (1985) primarily in interpreting mafic crust at shallower depths beneath the borderland and western Peninsular Ranges ( $5-8 \mathrm{~km}$ versus $11-15 \mathrm{~km}$ ) to better match seismic and potential-field results. See figures 8.2 and 8.3 for location of Transect C3; see figure 8.4 for explanation. No vertical exaggeration. 
Peninsular Ranges batholith, as discussed above (fig. $8.6 A$ ). In the cross section (fig. $8.6 B$ ), we interpret an eastward deepening of mafic rocks, including prebatholithic and (or) batholithic mafic rocks (gabbro, diabase, and metamorphic rocks), along this magnetic/gravity boundary. R.C. Jachens (oral commun., 1989) indicated that, in some places, this boundary is so planar as to be interpretable as a fault. As beneath the borderland, the mafic rocks beneath the Peninsular Ranges may have reached their current thickness by thrust imbrication, tectonic underplating, or magmatic underplating. We speculatively show some tectonic underplating on the west side.

\section{SALTON TROUGH}

The Salton Trough is the landward extension of a ridge/transform-fault system, the East Pacific Rise, of the Gulf of California (see fig. 3.13). This system became well established during the late Cenozoic (approx $5 \mathrm{Ma}$ ) as the plate boundary jumped inland from offshore Baja California (Atwater, 1970, 1989; Humphreys and Weldon, in press).

The Salton Trough is underlain by upper Cenozoic sedimentary rocks and minor amounts of volcanic rocks, which are exposed chiefly around its edge and are penetrated in wells. Onset of rifting and major subsidence in the Salton Trough was followed by marine incursion during the latest Miocene to late(?) Pliocene, as indicated by the Imperial Formation (Dibblee, 1954; Powell, 1984). The thick Cenozoic sedimentary section is offset by Quaternary faults, both exposed and buried, and is intruded by Quaternary volcanic rocks, both silicic rocks that form volcanoes at the two inferred onshore spreading centers (fig. 8.7) and mafic rocks that are penetrated in geothermal wells (Elders and others, 1972; Robinson and others, 1976). Faulting in the Salton Trough occurs primarily on conjugate northwest- and northeast-striking faults and is largely strike slip (Johnson and Hadley, 1976; Johnson, 1979; Fuis and others, 1982). North-south-striking faults, however, such as the north end of the Imperial fault, the Brawley fault, and north-south-striking seismicity lineaments (that outline inferred spreading centers; figs. 8.1, 8.7), have normal components and lead to the subsidence that ultimately created the Salton Trough. Earthquake hypocentral depths indicate that brittle fault motion extends to about 12-km depth in the Imperial Valley but deeper in the adjacent Peninsular Ranges along the San Jacinto fault (Doser and Kanamori, 1986).

Detachment faulting on the east flank of the Salton Trough, in the Chocolate Mountains and other ranges, preceded the Pliocene and later basin-forming tectonics in the Salton Trough (Dillon, 1975; Berg and others, 1982;
Frost and others, 1982). Similar faulting on the west flank of the Salton Trough, however, may have both preceded and overlapped in time the tectonics in the Salton Trough (Wallace and English, 1982; Schultejahn, 1984; Isaac and others, 1986).

Biehler and others (1964) and Fuis and others (1982, 1984) demonstrated from seismic surveys that the sedimentary rocks $(1.8-5.5 \mathrm{~km} / \mathrm{s})$ in the central Salton Trough are as much as $5 \mathrm{~km}$ thick (fig. 8.6A). Below 5-km depth, a low-velocity $(5.6 \mathrm{~km} / \mathrm{s})$ "basement," which is not separated from the overlying sedimentary rocks by a velocity discontinuity, is inferred to be metamorphosed (greenschist facies) sedimentary rocks (Fuis and others, 1982, 1984); this "basement" layer extends to $12-\mathrm{km}$ depth. High heat flow in the Salton Trough (see Lachenbruch and others, 1985) is inferred to cause the metamorphism of the sedimentary rocks. Thus, the entire section of inferred upper Cenozoic sedimentary rocks, metamorphosed and unmetamorphosed, is as much as 12 $\mathrm{km}$ thick.

Below 12- to 14-km depth in the Salton Trough, a high-velocity $(7.1-7.2 \mathrm{~km} / \mathrm{s})$ "subbasement" that is indicated by seismic-refraction data (fig. 8.6A) is inferred to be gabbro generated at one of the nearby spreading centers (Fuis and others, 1982, 1984). Modeling of seismic-refraction and gravity data indicate that the Moho in the central Salton Trough is 23 to $28 \mathrm{~km}$ deep (Fuis and others, 1982, 1984). The central Salton Trough is interpreted to be underlain entirely by late Cenozoic crust (fig. 8.6B).

Buried scarps separating old crust (plutonic and metamorphic rocks; $5.9-6.0 \mathrm{~km} / \mathrm{s}$ ) from new crust (sedimentary and basaltic rocks; $1.8-7.2 \mathrm{~km} / \mathrm{s}$ ) are visible by seismic methods on both sides of the Salton Trough (Fuis and others, 1982; Fuis and Kohler, 1984). On the west side of the rift, where the new-crust/old-crust boundary is ragged in outline (fig. 8.7), we interpret normal faults

FIGURE 8.7.-Tectonic block motion in southern California (modified from Weldon and Humphreys, 1986, and Humphreys and Weldon, in press). Various blocks (italicized names near motion vectors) move through region where the San Andreas fault trends obliquely to plate motion, between the Big Bend and the Salton Trough, without major convergence with each other. Through this region they move counterclockwise, following nearly concentric arcs (arcs and radii, thin red lines). New crust, which is forming in wake of the Salton and Perris blocks in the Salton Trough, is created by sedimentary-basin fill and gabbroic intrusions at onshore spreading centers, outlined by seismicity lineaments. High-velocity mantle beneath the Transverse Ranges is interpreted as cold, sinking lithospheric mantle, and low-velocity mantle beneath the Salton Trough as hot upwelling asthenosphere or lithospheric mantle containing partial melt (Humphreys and others, 1984; Humphreys and Clayton, in press). Motion vectors for the Mojave Desert and Sierra Nevada modified to incorporate results of Sauber and others (1986). 
(fig. 8.6B); on the east side, where this boundary is linear, we interpret a strike-slip fault. In our cross section, faults on the west side of the Salton Trough are inferred to have originated by pullaway from the Cerro Prieto spreading center to the southeast; the fault on the east side is inferred to be a largely passive suture (figs.

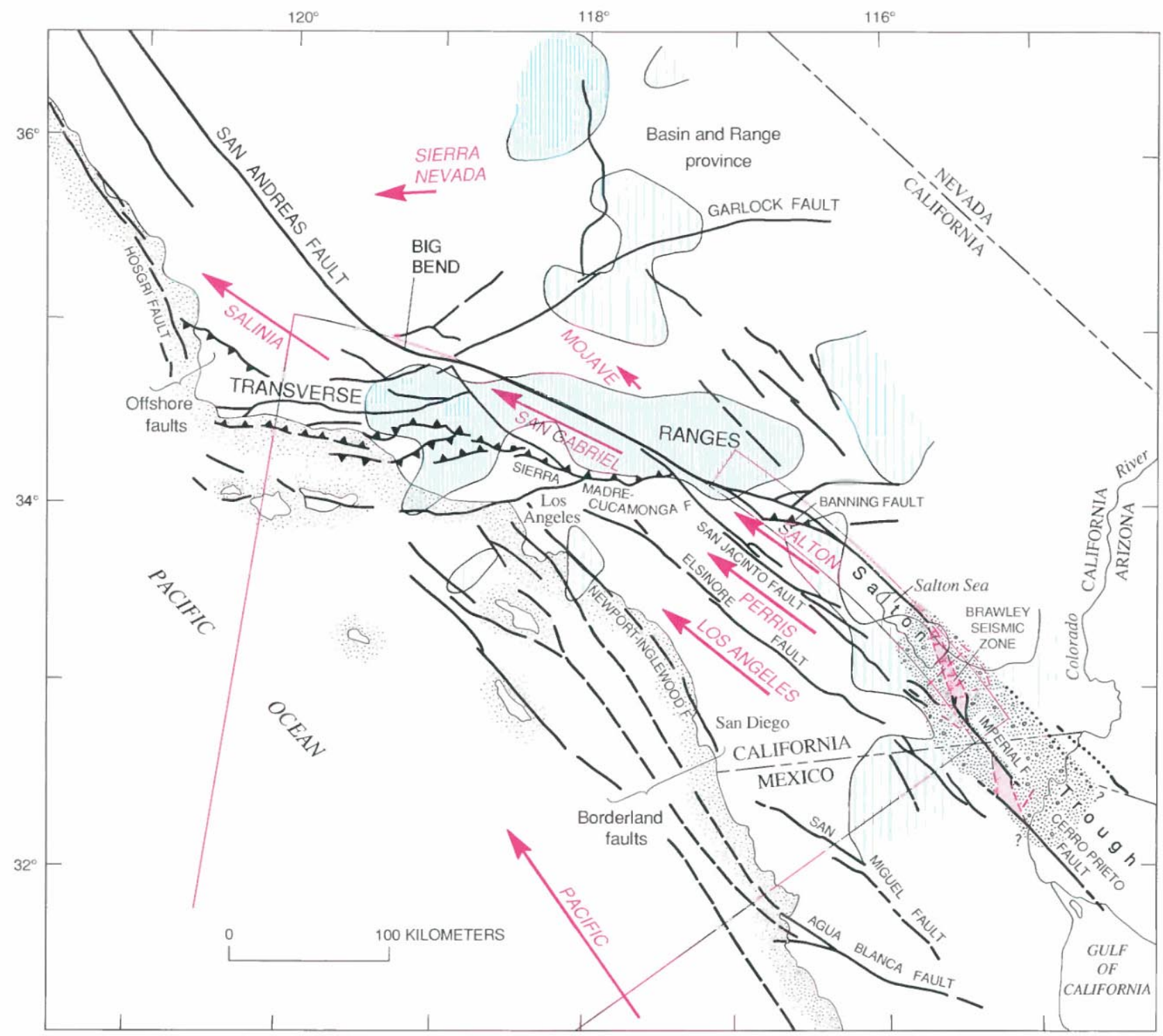

EXPLANATION

\begin{tabular}{|c|c|}
\hline$<$ & Motion vector of tectonic block- \\
\hline $\begin{array}{l}\text { Vector scale } \\
20 \mathrm{~mm} / \mathrm{yr}\end{array}$ & Relative to North America \\
\hline 60 & New crust (late Cenozoic) \\
\hline & Onshore spreading center \\
\hline & High-velocity mantle \\
\hline
\end{tabular}

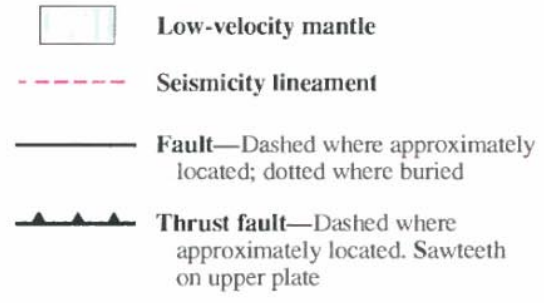

Low-velocity mantle

Seismicity lineament

ault-Dashed where approximately

hrust fault-Dashed where on upper plate 
8.6B, 8.7; Fuis and others, 1982). A similar rift configuration is seen, for example, in the Gulf of Elat (Gulf of Aqaba, Red Sea; Ben-Avraham, 1985).

\section{CHOCOLATE MOLNTAINS}

Rocks on the east flank of the Salton Trough are igneous and metamorphic rocks that compose two or more fault-bounded packages, or tectonostratigraphic terranes (see Howell and others, 1985). A complex of metasedimentary and mafic metaigneous rocks described by Dillon (1975) may include two Precambrian terranes, the Joshua Tree and San Gabriel terranes, described farther north by Powell (1981). This complex is intruded by intermediate to felsic Mesozoic plutons and rests on the low-angle Chocolate Mountains thrust fault above the (informal) Pelona-Orocopia schist of Haxel and Dillon (1978; see also Haxel, 1977). The Pelona-Orocopia schist consists chiefly of metagraywacke and lesser metapelite, metabasite, metachert, marble, and serpentinite (albiteepidote-amphibolite facies) of uncertain but probable late Mesozoic or early Tertiary age (Conrad and Davis, 1977; Miller and Morton 1977, 1980). It resembled the Franciscan assemblage but lacks melange.

Many workers have speculated on the depositional environment and origin of the Pelona-Orocopia schist. Haxel and Dillon (1978) postulated formation in an ensimatic rift basin with continent on both sides-not unlike the current Salton Trough. Powell (1981) favored an origin as a parautochthonous continental-marginal deposit. In any case, from its quartz content, the Pelona-Orocopia schist clearly originated near a continent and incorporated continental detritus. It was thrust beneath the continental metasedimentary-metaigneous complex some time after Mesozoic plutonism (80 Ma; Powell, 1981) and before Oligocene volcanism (35 Ma; Crowe 1978; Crowe and others, 1979). The thrust fault may have been reactivated one or more times as a low-angle normal, or detachment, fault (Frost and others, 1982).

Evidence from refraction profiling in the western Mojave Desert across the Rand schist, which has been correlated with the Pelona-Orocopia schist (Ehlig, 1968), indicates relatively low-velocity crust beneath this body ( $\max 6.4 \mathrm{~km} / \mathrm{s}$; Fuis and others, 1986) that we infer to be continental crust. We speculate that the Pelona-Orocopia schist also rests on continental crust and that the Rand and Pelona-Orocopia schists were emplaced as a tectonic wedge into continental crust in a manner similar to the Franciscan assemblage of central and northern California. We hypothesize that the metasedimentary-metaigneous complex structurally above the schist is analogous to either (1) rocks of the Coast Range ophiolite/Great Valley sequence which rode passively atop the wedge in central and northern California after being extended during uplift of the Franciscan assemblage, or (2) rocks of the Great Valley sequence which were peeled up along backthrust faults during landward movement of the wedge. In southern California, tectonic wedging clearly occurred before the present transform regime, presumably during subduction of the Farallon plate (or its derivative). The geologic data discussed above indicate that the Salton Trough has undergone extension, rather than compression, for approximately the past $5 \mathrm{Ma}$ (probably even longer; see Humphreys and Weldon, in press).

Crustal thickness is unknown in the Chocolate Mountains; however, the Colorado Desert, to the east and north, has a generally thin (26-28 km) crust (fig. 8.3$)$ and a local root (32 km deep) under the Whipple Mountains metamorphic-core complex (Fuis, 1981; Jill McCarthy, written commun., 1988).

\section{TECTONICS - THE THREE-DIMENSIONAL PICTURE}

The geology and, presumably, the deep structure of southern California illustrated along transect C3 (fig. 8.6) is grossly two dimensional as far north as the Transverse Ranges. In the Transverse Ranges, the rocks on the southwest side of the San Andreas fault are similar to those in the Chocolate Mountains. These rocks are bounded on the south and west by older, deformed strands of the San Andreas fault system (fig. 8.7; Powell, 1981). The tectonics also changes in the Transverse Ranges: Crustal-block motion swings to the west to follow the trend of the San Andreas fault, as discussed below.

Using Quaternary geologic and geodetic evidence, Weldon and Humphreys (1986) documented complex motion of crustal blocks in southern California that is not simply predictable from the motion vectors of the Pacific and North American plates. These motion vectors predict a large component of convergence across the San Andreas fault in the Transverse Ranges between the Big Bend and the Salton Trough (fig. 8.7). For a total offset on the San Andreas fault system of about $300 \mathrm{~km}$ (Hill and Dibblee, 1953; Crowell, 1962, 1981; Powell, 1981), a maximum of $45 \mathrm{~km}$ of uplift in the Transverse Ranges would be expected (Weldon and Humphreys, 1986). However, the preservation in the Transverse Ranges of upper Cenozoic sedimentary rocks and of offset bedrock features on either side of the San Andreas fault argues against such major uplift and associated consumption of crust, as does the relatively minor crustal root in the Transverse Ranges (fig. 8.3). Weldon and Humphreys (1986) constructed a kinematic model in which crustal blocks between the San Andreas fault and a system of borderland and other offshore faults rotate counterclock- 
wise, parallel to the San Andreas fault, between the Salton Trough and the Big Bend (fig. 8.7). Approximately two-thirds of the relative northwestward motion of the Pacific plate past the North American plate is taken up by the San Andreas fault system, including the San Jacinto fault; approximately one-third of it is taken up by the Elsinore fault, a system of borderland faults, and offshore faults in central California, including the San Gregorio-Hosgri fault (fig. 8.7); and only a minor fraction of it is taken up within the blocks (see Humphreys and Weldon, in press).

A marked advance in the $P$-wave traveltimes of teleseismic arrivals in southern California is associated with the Transverse Ranges and extends across the San Andreas fault (Hadley and Kanamori, 1977; Raikes, 1980). Tomographic analysis of this anomaly indicates that it results from a vertical slablike region of relatively high velocity in the mantle which extends downward as far as $250 \mathrm{~km}$ (Humphreys and others, 1984; Humphreys, 1985; Humphreys and Clayton, in press). The amount of velocity increase, a maximum of 3 percent, is most reasonably explained by a thermal difference in the mantle. This velocity increase, coupled with a velocity decrease in the upper $90 \mathrm{~km}$ or so of mantle beneath the Salton Trough, led Humphreys and Hager (1984 and in press) to infer small-scale mantle convection between the Salton Trough and the Transverse Ranges. This convection involves passive rising of asthenosphere beneath the Salton Trough and cooling and sinking of lithosphere beneath the Transverse Ranges. The vertical extent of the inferred lithospheric slab beneath the Transverse Ranges, $250 \mathrm{~km}$, is similar to the $300-\mathrm{km}$ estimate of total offset along the San Andreas fault system. However, because the cooled mantle slab extends across the San Andreas fault, most of the mantle seems to be moving independently of the crust (fig. 8.8; Hadley and Kanamori, 1977; Humphreys and others, 1984; Humphreys, 1985; Humphreys and Hager, in press). The horizon of decoupling is apparently at or below the Moho because crustal material is not entrained in the slablike feature. Additional decoupling may be occurring in the crust, similar to that postulated for central California (Yeats, 1981; Webb and Kanamori, 1985). Decoupling at the Moho requires that the deformational style and (or) location of the San Andreas fault system change from the crust to the mantle (fig 8.8 ). We note that mantle drag on the crust is required to maintain the Big Bend in the San Andreas fault because plate-edge forces alone would tend to "short-circuit" the San Andreas fault south of the Big Bend and cause most plate motion to be taken up on the San Jacinto, Elsinore, or more westerly faults (Kosloff, 1978; Humphreys, 1985).

To summarize, block motions in the region between the Big Bend and the Salton Trough result in only minor interblock convergence in the crust. In contrast, major convergence in the lithospheric mantle is indicated by the presence of an inferred, sinking lithospheric slab.

\section{STRUCTURE OF THE UPPER MANTLE}

In addition to the Transverse Ranges and Salton Trough, other regions in California show mantle velocity anomalies that imply structure within the lithospheric mantle and even the asthenosphere. The seismic networks in California (see chap. 5) provide an abundant source of regional earthquake and teleseismic arrivals that have been used to determine this upper-mantle structure.

A detailed study of the compressional-wave velocity of the uppermost mantle in central California reveals a normal velocity of about $8.0 \mathrm{~km} / \mathrm{s}$ and no evidence for

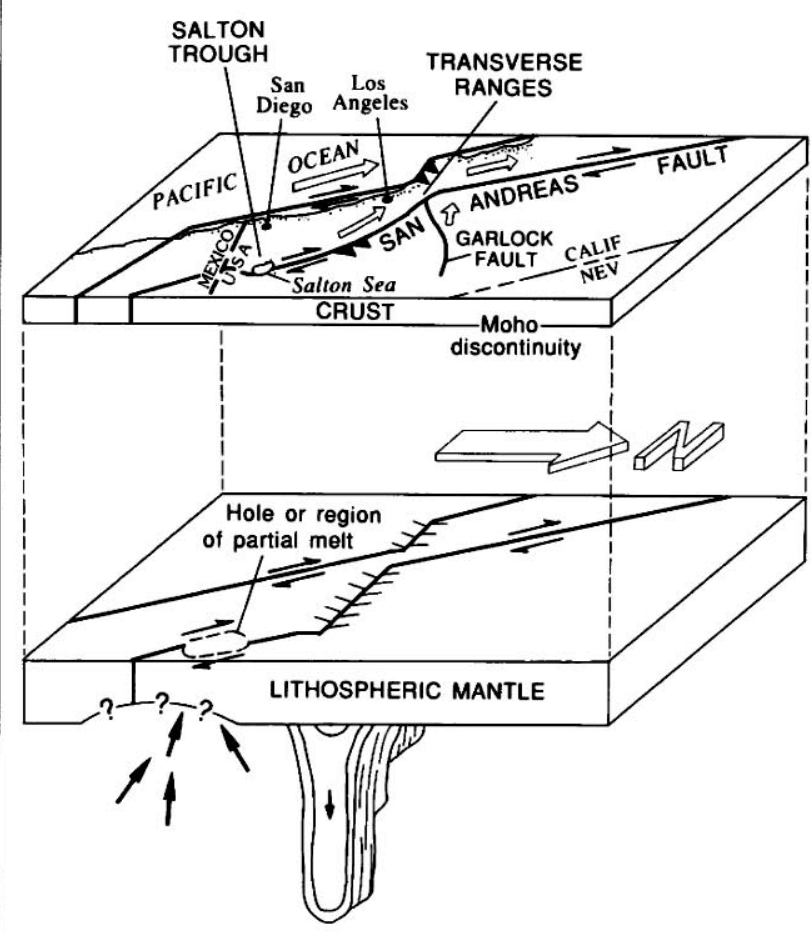

FIGURE 8.8.-Motion of crustal blocks in southern California (open arrows; see fig. 8.7) and somewhat different motion of lithospheric mantle below (solid arrows) (modified from Humphreys, 1985, and Humphreys and Hager, in press). Mantle convection cell is envisioned between the Salton Trough and the Transverse Ranges. Crust and lithospheric mantle appear to be moving independently of one another, as the San Andreas fault trends obliquely across region of inferred, sinking lithospheric mantle beneath the Transverse Ranges (see fig. 8.7). Small arrows, relative fault motion; sawteeth, upper plates of crustal thrust faults; crosslines, subduction zones in lithospheric mantle. 
velocity anisotropy (Oppenheimer and Eaton, 1984). A similar study in southern California finds nearly the same average velocity, $7.95 \mathrm{~km} / \mathrm{s}$, with evidence for 2-percent velocity anisotropy (Vetter and Minster, 1981; Hearn, 1984). The fast direction is $\mathrm{N}$. $75^{\circ} \mathrm{W}$., approximately parallel to the San Andreas fault in southern California. Seismic-velocity anisotropy in the upper mantle has been reported elsewhere, notably in oceanic crust, and is commonly attributed to alignment of olivine in the mantle along a shear-stress direction (Bamford and others, 1979). In southern California, this shear would presumably be that associated with the motion of crustal blocks above the lithospheric mantle.

Lithospheric thickness along the San Andreas fault has been investigated by using delay times of teleseismic arrivals and thermal models (Zandt and Furlong, 1982). These studies indicate a lithospheric thickness of only 30 to $60 \mathrm{~km}$ for much of western California, and as little as $20 \mathrm{~km}$ for northern California just south of Cape Mendocino. These lithospheric thicknesses contrast with averages of 60 to $80 \mathrm{~km}$ for the Western United States and 120 to $170 \mathrm{~km}$ for the Central and Eastern United States (Iyer and Hitchcock, 1989). The thinness of the lithosphere in northern California south of Cape Mendocino is due to the creation of the San Andreas fault system itself: The transform fault is lengthening as the Mendocino triple junction migrates northward. As this junction migrates northward, the west edge of North America is sliding off the edge of the northward-moving, subducting Gorda plate, thereby creating a "window" where no subducting lithospheric slab is present (Dickinson and Synder, 1979). In this slabless window, the North American crust is initially in direct contact with the asthenosphere that has welled upward to fill the hole left by the Gorda plate (Zandt and Furlong, 1982). This geometry produces the thinnest lithosphere in California and, probably, in North America. In contrast, the lithosphere is abnormally thick $(250 \mathrm{~km})$ in the Transverse Ranges, where "subduction" of lithospheric mantle is occurring, as discussed above.

Velocity anomalies appear to extend even into the asthenosphere beneath western California. Aki (1982) summarized the results of Cockerham and Ellsworth (1979) and Raikes (1980) in a combined velocity-anomaly model for a depth range of about $100-225 \mathrm{~km}$ in the mantle (fig. 8.9). Aki suggested that the low-velocity region in central California is hot, mobile material associated with the slabless window. Such an association appears likely for the northwest-trending prong of this anomaly, as refined by the recent work of Benz and others (1990); however, the center of the anomaly, located near Long Valley caldera (figs. 8.2, 8.9), apparently has a different origin. Low-velocity regions are also associated with the Salton Trough, where asthenospheric upwelling is inferred, and the eastern Mojave Desert, where crustal extension has occurred. The high-velocity region that crosses the San Andreas fault in southern California is similar to the one discussed above (fig. 8.7).

\section{SUMMARY}

The crust along the San Andreas fault system thickens from about $16 \mathrm{~km}$ at Cape Mendocino, in northern California, to about $30 \mathrm{~km}$ in southern California and thus is significantly thinner than the average thickness ( 36 $\mathrm{km}$ ) for the conterminous United States. Lithospheric thickness $(20-60 \mathrm{~km})$ is also substantially less along most of the San Andreas fault system than is typical for continental areas $(60-170 \mathrm{~km})$. The lithosphere is thinnest at both ends of the fault system, at the Mendocino triple junction on the north, where the North American plate is sliding off the edge of the Gorda plate as it moves northward, and in the Salton Trough on the south, where

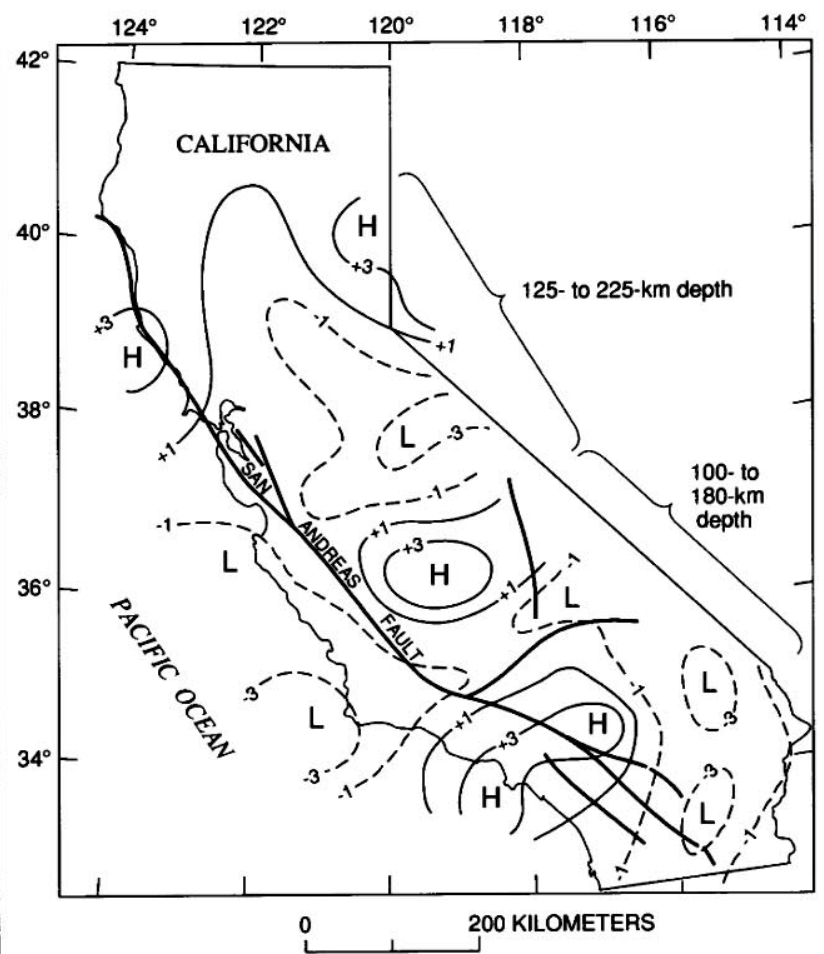

FIGURE 8.9. - Seismic-velocity anomalies in upper mantle (chiefly asthenosphere), derived from teleseismic delay-time data (Aki, 1982), for depth ranges 125-225 km (central California; Cockerham and Ellsworth, 1979) and 100-180 km (southern California; Raikes, 1980). H, high velocities (contours solid); L, low velocities (contours dashed). Contour interval, 2 percent. High seismic velocities that cross the San Andreas fault in southern California are similar in pattern to those shown in figure 8.7. Heavy lines, major faults. 
onshore spreading centers of the East Pacific Rise are generating new crust in a rift between the North American and Pacific plates. In contrast, the lithosphere is abnormally thick $(250 \mathrm{~km})$ in the Tranverse Ranges, where "subduction" of lithospheric mantle is occurring.

The crust of central California was formed at an Andean-type continental margin and has been modified by large offsets along strike-slip faults of the San Andreas fault system. East of the San Andreas fault, the Andean-marginal sequence includes a subduction complex (Franciscan rocks), a forearc basin (Great Valley sequence), and a magmatic arc (plutons of the Sierra Nevada). The subduction complex appears to have been emplaced as a tectonic wedge beneath sedimentary rocks of the forearc basin. West of the fault, displaced blocks constitute an Andean-marginal sequence that has been shortened by strike-slip faulting.

The tectonic wedge of Franciscan rocks east of the fault is reinterpreted to extend from its tip beneath the Great Valley all the way to the San Andreas fault. This interpretation is motivated by the apparent continuity between crystalline basement rocks beneath the Great Valley and mafic rocks at midcrustal depths in the Diablo Range, beneath the Franciscan rocks. The presence of extended crust atop the tectonic wedge (outliers of Coast Range ophiolite and Great Valley sequence) has led us to propose the following tectonic evolution for the wedge. (1) Franciscan rocks were uplifted and upper-plate rocks (those above the subduction zone) were extended during the Cretaceous (or, possibly, early Tertiary) well west of their current position in the Coast Ranges. (2) The Franciscan rocks and overlying extended crust were subsequently forced landward during one or more episodes in the form of a wedge that largely followed the contact between Great Valley basement and the Great Valley sequence. (3) Wedge movement began during the subduction of the Farallon plate (or its derivative) beneath central California; however, it apparently is also occurring at present, in the San Andreas transform regime. Present movement is interpreted to result from compression across the San Andreas fault system coupled with differential motion between the upper and lower crust; this differential motion is interpreted to occur on thrust fault(s) at the base of the wedge that sole into the brittle-ductile transition zone.

The crustal structure in southern California shares several features in common with central California, including, west of the fault, an Andean-marginal sequence that has been shortened or, at least, shuffled by strike-slip faulting, and, east of the fault, subductioncomplex rocks that are inferred to have moved landward as a tectonic wedge into the continental rocks. However, major differences are apparent in southern California. First, east of the San Andreas fault, the Andean- marginal sequence is incomplete: A forearc basin is absent, and the magmatic arc is diffuse. Second, new continental crust has formed in the Salton Trough, an active crustal pullapart basin, by a combination of rapid sedimentation, metamorphism, and magmatic intrusion at the onshore spreading centers. In addition, the motions of the crust and lithospheric mantle differ in southern California: The crust is moving as a collage of blocks, with only minor interblock convergence, whereas the lithospheric mantle is converging and "subducting" beneath the Transverse Ranges.

The interpretations of (1) a midcrustal detachment in the brittle-ductile transition zone in central California and (2) a crust-mantle detachment in the Transverse Ranges of southern California would appear to require that the deformational style and (or) location of the San Andreas fault system change with depth in these regions.

The properties of the lithosphere along the San Andreas fault are not at all typical of continental areas, and further characterization of these properties presents a significant scientific challenge.

\section{ACKNOWLEDGMENTS}

Stimulating discussions with C.M. Wentworth and M.C. Blake, Jr., led to some of our ideas concerning the configuration and emplacement history of the inferred wedge of Franciscan rocks in central and northern California. A. Griscom and R.C. Jachens provided insightful discussions regarding interpretation of potentialfield models, and R.C. Evarts assisted us in drawing a cross section through the uppermost crust in the northeastern Diablo Range. We are also indebted to E.D. Humphreys for providing preprints of manuscripts on lithospheric motion in southern California.

\section{REFERENGES CITED}

Aki, Keiiti, 1982, Three-dimensional seismic inhomogeneities in the lithosphere and asthenosphere: Evidence for decoupling in the lithosphere and flow in the asthenosphere: Reviews of Geophysics and Space Physics, v. 20, p. 161-170.

Aki, Keiiti, Christoffersson, Anders, and Husebye, E.S., 1977, Determination of the three-dimensional seismic structure of the lithosphere: Journal of Geophysical Research, v. 82, no. 2, p. 277-296.

Atwater, Tanya, 1970, Implications of plate tectonics for the Cenozoic tectonic evolution of western North America: Geological Society of America Bulletin, v. 81, no. 12, p. 3513-3535.

1989, Plate tectonic history of the northeast Pacific and western North America, chap. 4 of Winterer, E.L., Hussong, D.M., and Decker, R.W., eds., The eastern Pacific Ocean and Hawaii, v. N of The geology of North America: Boulder, Colo., Geological Society of America, p. 21-72.

Atwater, Tanya, and Menard, H.W., 1970, Magnetic lineations in the northeast Pacific: Earth and Planetary Science Letters, v. 7, no. 5, p. $445-450$. 
Bailey, E.H., and Blake, M.C., Jr., 1974, Major chemical characteristics of Mesozoic Coast Range ophiolite in California: U.S. Geological Survey Journal of Research, v. 2, no. 6, p. 637-656.

Bailey, E.H., Blake, M.C., Jr., and Jones, D.L., 1970, On-land Mesozoic oceanic crust in California Coast Ranges, in Geological Survey research, 1970: U.S. Geological Survey Professional Paper 700-C, p. C70-C81.

Bamford, David, Jentsch, Martin, and Prodehl, Claus, 1979, $P_{n}$ anisotropy studies in northern Britain and the eastern and western United States: Royal Astronomical Society Geophysical Journal, v. 57 , no. 2 , p. $397-429$.

Bartow, J.A., Lettis, W.R., Sonneman, H.S., and Switzer, J.R., Jr., 1985, Geologic map of the east flank of the Diablo Range from Hospital Creek to Poverty Flat, San Joaquin, Stanislaus, and Merced Counties, California: U.S. Geological Survey Miscellaneous Investigations Series Map I-1656, scale 1:62,500.

Ben-Avraham, Zvi, 1985, Structural framework of the Gulf of Elat (Aqaba), northern Red Sea: Journal of Geophysical Research, v. 90 , no. B1, p. 703-726.

Benz, H.M., Zandt, George, and Oppenheimer, D.H., 1990, Seismic imaging of the subducting plate and the slabless window beneath northern California [abs.]: Seismological Research Letters, v. 61, no. 1, p. 32.

Berg, L., Leveille, G., and Geis, P., 1982, Mid-Tertiary detachment faulting and manganese mineralization in the Midway Mountains, Imperial County, California, in Mesozoic-Cenozoic tectonic evolution of the Colorado River region, California, Arizona, and Nevada: San Diego, Calif., Cordilleran Publishers, p. 298-312.

Berkland, J.O., 1973, Rice Valley outlier-new sequence of CretaceousPaleocene strata in northern Coast Ranges, California: Geological Society of America Bulletin, v. 84, no. 7, p. 2389-2405.

Biehler, Shawn, Kovach, R.L., and Allen, C.R., 1964, Geophysical framework of the northern gulf province, in van Andel, T.H., and Shor, G.G., Jr., eds., Marine geology of the Gulf of California: American Association of Petroleum Geologists Memoir 3, p. 126-143.

Birch, A.F., 1960, The velocity of compressional waves in rocks to 10 kilobars, part 1: Journal of Geophysical Research, v. 65, no. 4, p. 1083-1102.

Blake, M.C., Jr., 1981, Geologic transect of the northern Diablo Range, California, in Frizzell, V.A., Jr., ed., Upper Mesozoic Franciscan rocks and Great Valley sequence, central Coast Ranges, California: Pacific Section, Society of Economic Paleontologists and Mineralogists, Pacific Section field trip guidebook, p. 35-43.

Blake, M.C., Jr., Howell, D.G., and Jones, D.L., 1982, Preliminary tectonostratigraphic terrane map of California: U.S. Geological Survey Open-File Report 82-593, 10 p., scales 1:750,000, 3 sheets.

Blake, M.C., Jr., Jayko, A.S., and Murchey, B.L., 1987, Structure, age, and tectonic significance of the Coast Range ophiolite and related rocks near Paskenta, California [abs.]: Geological Society of America Abstracts with Programs, v. 19, no. 7, p. 590.

Blümling, Peter, Mooney, W.D., and Lee, W.H.K., 1985, Crustal structure the southern Calaveras fault zone, central California, from seismic refraction investigations: Seismological Society of America Bulletin, v. 75, no. 1, p. 193-209.

Blümling, Peter, and Prodehl, Claus, 1983, Crustal structure beneath the eastern part of the Coast Ranges (Diablo Range) of central California from explosion seismic and near earthquake data: Physics of the Earth and Planetary Interiors, v. 31, no. 4, p. 313-326.

Braile, L.W., Hinze, W.J., von Frese, R.R.B., and Keller, G.R., 1989, Seismic properties of the crust and uppermost mantle of the conterminous United States and adjacent Canada, chap. 28 of Pakiser, L.C., and Mooney, W.D., eds., Geophysical framework of the continental United States: Geological Society of America Memoir 172, p. 655-680.

Byerly, Perry, 1946, The seismic waves from the Port Chicago [California] explosion: Seismological Society of America Bulletin, v. 36 , no. 4 , p. $331-348$.

Byerly, Perry, and Wilson, J.T., 1935, The Richmond quarry blast of August 16, 1934: Seismological Society of America Bulletin, v. 25, p. $259-268$.

Champion, D.E., Howell, D.G., and Grommé, C.S., 1984, Paleomagnetic and geologic data indicating $2500 \mathrm{~km}$ of northward displacement for the Salinian and related terranes: Journal of Geophysical Research, v. 89, no. B9, p. 7736-7752.

Christensen, N.I., and Fountain, D.M., 1975, Constitution of the lower continental crust based on experimental studies of seismic velocities in granulite: Geological Society of America Bulletin, v. 86, no. 2, p. 229-236.

Clark, L. D., 1964, Stratigraphy and structure of part of the western Sierra Nevada metamorphic belt, California: U.S. Geological Survey Professional Paper 410, $70 \mathrm{p}$.

Cockerham, R.S., and Ellsworth, W.L., 1979, Three-dimensional large-scale mantle structure in central California [abs]: Eos (American Geophysical Union Transactions), v. 60, no. 45, p. 875.

Colburn, R.H., and Mooney, W.D., 1986, Two-dimensional velocity structure along the synclinal axis of the Great Valley, California: Seismological Society of America Bulletin, v. 76, no. 5, p. 1305-1322.

Coleman, R.G., and Lanphere, M.A., 1971, Distribution and age of high-grade blueschists, associated eclogites, and amphibolites from Oregon and California: Geological Society of America Bulletin, v. 82 , no. 9 , p. $2397-2412$.

Conrad, R.L., and Davis, T.E., 1977, Rb/Sr geochronology of cataclastic rocks of the Vincent thrust, San Gabriel Mountains, southern California [abs.]: Geological Society of America Abstracts with Programs, v. 9, no. 4, p. 403-404.

Cowan, D.S., 1974, Deformation and metamorphism of the Franciscan subduction zone complex northwest of Pacheco Pass, California: Geological Society of America Bulletin, v. 85, no. 10, p. 1623-1634.

Criscione, J.J., Davis, T.E., and Ehlig, P.L., 1978, The age and sedimentation/diagenesis for the Bedford Canyon and the Santa Monica Formation in southern California-a $\mathrm{Rb} / \mathrm{Sr}$ evaluation, in Howell, D.G., and McDougall, K.A., eds., Mesozoic paleogeography of the Western United States: Pacific Coast Paleogeography Symposium 2: Los Angeles, Society of Economic Paleontologists and Mineralogists, Pacific Section, p. 385-396.

Crosson, R.S., 1976, Crustal structure modeling of earthquake data 1. Simultaneous least squares estimation of hypocenter and velocity parameters: Journal of Geophysical Research, v. 81, no. 17, p. 3036-3046.

Crouch, J.K., Bachman, S.B., and Shay, J.T., 1984, Post-Miocene compressional tectonics along the central California margin, in Crouch, J.K., and Bachman, S.B., eds., Tectonics and sedimentation along the California margin (volume 38): Society of Economic Paleontologists and Mineralogists, Pacific Section Annual Meeting, San Diego, Calif., 1984, Papers, p. 37-54.

Crowe, B.M., 1978, Cenozoic volcanic geology and probable age of inception of basin-range faulting in the southeasternmost Chocolate Mountains, California: Geological Society of America Bulletin, v. 89 , no. 2, p. 251-264.

Crowe, B.M., Crowell, J.C., and Krummenacher, Daniel, 1979, Regional stratigraphy, $\mathrm{K}-\mathrm{Ar}$ ages, and tectonic implications of Cenozoic volcanic rocks, southeastern California: American Journal of Science, v. 279, no. 2, p. 186-216.

Crowell, J.C., 1962, Displacement along the San Andreas fault, California: Geological Society of America Special Paper 71, 61 p. 
- 1981, An outline of the tectonic history of southeastern California, in Ernst, W.G., ed., The geotectonic development of California (Rubey volume 1) Englewood Cliffs, N.J., PrenticeHall, p. 583-600.

Dibblee, T.W., Jr., 1954, Geology of the Imperial Valley region, California, in Geology of the natural provinces, chap. 2 of Jahns, R.H., ed., Geology of southern California: California Division of Mines Bulletin, 170, v. 1, p. 21-28.

Dickinson, W.R., 1966, Table Mountain serpentinite extrusion in California Coast Ranges: Geological Society of America Bulletin, v. 77 , no. 5 , p. $451-471$

Dickinson, W.R., and Snyder, W.S., 1979, Geometry of subducted slabs related to San Andreas transform: Journal of Geology, v. 87, no. 6 , p. 609-627.

Dillon, J.T., 1975, Geology of the Chocolate and Cargo Muchacho Mountains, southeasternmost California: Santa Barbara, University of California, Ph.D. thesis, $405 \mathrm{p}$.

Doser, D.I., and Kanamori, Hiroo, 1986, Depth of seismicity in the Imperial Valley region (1977-1983) and its relationship to heat flow, crustal structure, and the October 15, 1979, earthquake: Journal of Geophysical Research, v. 91, no. B1, p. 675-688.

Eaton, J.P., 1963, Crustal structure from San Francisco, California, to Eureka, Nevada, from seismic-refraction measurements: Journal of Geophysical Research, v. 68 , no. 20 , p. 5789-5806.

1990 , The earthquake and its aftershocks from May 2 through September 30, 1983, chap. 8 of Rymer, M.J., and Ellsworth, W.L., eds., The Coalinga, California, earthquake of May 2, 1983: U.S. Geological Survey Professional Paper 1487, p. 113-170.

Eaton, J.P., O'Neill, M.E., and Murdock, J.N., 1970, Aftershocks of the 1966 Parkfield-Cholame, California, earthquake: A detailed study: Seismological Society of America Bulletin, v. 60, no. 4, p. 1151-1197.

Eaton, J.P., and Rymer, M.J., 1990, Regional seismotectonic model for the southern Coast Ranges, chap. 7 of Rymer, M.J., and Ellsworth, W.L., eds., The Coalinga, California, earthquake of May 2, 1983: U.S. Geological Survey Professional Paper 1487, p. 97-111.

Eberhart-Phillips, Donna, and Oppenheimer, D.H., 1984, Induced seismicity in the Geysers geothermal area, California: Journal of Geophysical Research, v. 89, no. B2, p. 1191-1207.

Ehlig, P.L., 1968, Causes of distribution of Pelona, Rand, and Orocopia schists along the San Andreas and Garlock fault, in Dickinson, W.R., and Grantz, Arthur, eds., Proceedings of conference on geologic problems of San Andreas fault system: Stanford, Calif., Stanford University Publications on Geological Sciences, v. 11, p. 294-305.

Elders, W.A., Rex, R.W., Meidav, Tsvi, Robinson, P.T., and Biehler, Shawn, 1972, Crustal spreading in southern California: The Imperial Valley and the Gulf of California formed by the rifting apart of a continental plate: Science, v. 178, no. 4056, p. 15-24.

Evarts, R.C., 1977, The geology and petrology of Del Puerto ophiolite, Diablo Range, central California Coast Ranges, in Coleman, R.G., and Irwin, W.P., eds., North American ophiolites: Oregon Department of Geology and Mineral Industries Bulletin 95, p. 121-139.

Evernden, J.F., and Kistler, R.W., 1970, Chronology of emplacement of Mesozoic batholithic complexes in California and western Nevada: U.S. Geological Survey Professional Paper 623, $67 \mathrm{p}$

Frost, E.G., Martin, D.L., and Krummenacher, Daniel, 1982, MidTertiary detachment faulting in southwestern Arizona and southeastern California and its overprint on the Vincent-Orocopia thrust system [abs.]: Geological Society of America Abstracts with Programs, v. 14, no. 4, p. 164.

Fuis, G.S., 1981, Crustal structure of the Mojave Desert, California, in
Howard, K.A., Carr, M.D., and Miller, D.M., eds., Tectonic framework of the Mojave and Sonoran Deserts, California and Arizona: U.S. Geological Survey Open-File Report 81-503, p. 36-38.

Fuis, G.S., and Kohler, W.M., 1984, Crustal structure and tectonics of the Imperial Valley region, California, in Rigsby, C.A., ed., The Imperial Basin-tectonics, sedimentation, and thermal aspects (volume 40): Society of Economic Paleontologists and Mineralogists, Pacific Section Annual Convention, San Diego, Calif., 1984, Papers, p. 1-13.

Fuis, G.S., Mooney, W.D., Healy, J. H., McMechan, G.A., and Lutter, W.J., 1982, Crustal structure of the Imperial Valley region, in The Imperial Valley, California, earthquake of October 15, 1979: U.S. Geological Survey Professional Paper 1254, p. 25-49.

1984, A seismic refraction survey of the Imperial Valley region, California: Journal of Geophysical Research, v. 89, no. B2, p. 1165-1189.

Fuis, G.S., and Plafker, George, in press, Evolution of deep structure along the Trans-Alaska Crustal Transect, Chugach Mountains and Copper River basin, southern Alaska: Journal of Geophysical Research.

Fuis, G.S., Walter, A.W., Mooney, W.D., and McCarthy, Jill, 1986 , Crustal velocity structure of the Salton Trough, western Mojave Desert, and Colorado Desert, from seismic refraction [abs.]: Geological Society of America Abstracts with Programs, v. 18, no. 2, p. 107.

Gutenberg, Beno, 1943, Earthquakes and structure in southern California: Geological Society of America Bulletin, v. 54, no. 4, p. 499-526.

- 1951, Travel times from blasts in southern California: Seismological Society of America Bulletin, v. 41, no. 1, p. 5-12.

Hadley, D.M., and Kanamori, Hiroo, 1977, Seismic structure of the Transverse Ranges, California: Geological Society of America Bulletin, v. 88 , no. 10, p. $1469-1478$.

Hamilton, Warren, 1969, Mesozoic California and the underflow of Pacific mantle: Geological Society of America Bulletin, v. 80, no. 12 , p. 2409-2429.

Harwood, D.S., and Helley, E.J., 1987, Late Cenozoic tectonism of the Sacramento Valley, California: U.S. Geological Survey Professional Paper 1359, $46 \mathrm{p}$.

Haxel, G.B., 1977, The Orocopia schist and the Chocolate Mountain Thrust, Picacho-Peter Kane Mountains area, southeasternmost California: Santa Barbara, University of California, Ph.D. thesis, $277 \mathrm{p}$.

Haxel, G.B., and Dillon, J.T., 1978, The Pelona-Orocopia schist and Vincent-Chocolate Mountain thrust system, southern California, in Howell, D.G., and McDougall, K.A., eds., Mesozoic paleogeography of the Western United States: Pacific Coast Paleogeography Symposium 2: Los Angeles, Society of Economic Paleontologists and Mineralogists, Pacific Section, p. 453-469.

Healy, J.H., 1963, Crustal structure along the coast of California from seismic refraction measurements: Journal of Geophysical Research, v. 68 , no. 20 , p. $5777-5787$.

Hearn, T.M., 1984, $P_{n}$ travel times in southern California: Journal of Geophysical Research, v. 89, no. B3, p. 1843-1855.

Hearn, T.M., and Clayton, R.W., 1986a, Lateral velocity variations in southern California: 1. Results for the upper crust from $P_{g}$-waves: Seismological Society of America Bulletin, v. 76, no. 2, p. 495-509. 1986b, Lateral velocity variations in southern California: 2 . Results for the lower crust from $\boldsymbol{P}_{n}$-waves: Seismological Society of America Bulletin, v. 76, no. 2, p. 511-520.

Hill, D.P., 1978, Seismic evidence for the structure and Cenozoic tectonics of the Pacific Coast states, in Smith, R.B., and Eaton, G.P., eds., Cenozoic tectonies and regional geophysics of the 
western Cordillera: Geological Society of America Memoir 152, p. 145-174.

Hill, M.L., and Dibblee, T.W., Jr., 1953, San Andreas, Garlock, and Big Pine faults, California - a study of the character, history, and tectonic significance of their displacement: Geological Society of America Bulletin, v. 64, no. 4, p. 443-458.

Holbrook, W.S., and Mooney, W.D., 1987, The crustal structure of the axis of the Great Valley, California, from seismic refraction measurements: Tectonophysics, v. 140, no. 1, p. 49-63.

Hopson, C.A., Mattinson, J.M., and Pessagno, E.A., 1981, Coast Range ophiolite, western California, in Ernst, W.G., ed., Geotectonic development of California (Rubey volume 1): Englewood Cliffs, N.J., Prentice-Hall, p. 418-510.

Howell, D.G., Gibson, J.D., Fuis, G.S., Knapp, J.H., Haxel, G.B., Keller, B.R., Silver, L.T., and Vedder, J.G., 1985, C-3: Pacific abyssal plain to the Rio Grande rift: Boulder, Colo., Geological Society of America, Centennial Continent/Ocean Transect 5, 23 p., scale 1:500,000, 3 sheets.

Humphreys, E.D., 1985, Studies of the crust-mantle system beneath southern California: Pasadena, California Institute of Technology, Ph.D thesis, 189 p.

Humphreys, E.D., and Clayton, R.W., in press, Tomographic image of the southern California mantle: Journal of Geophysical Research.

Humphreys, E.D., Clayton, R.W., and Hager, B.H., 1984, A tomographic image of mantle structure beneath southern California: Geophysical Research Letters, v. 11, no. 7, p. 625-627.

Humphreys, E.D., and Hager, B.H., 1984, Small-scale convection beneath the Tranverse Ranges, southern California [abs.]: Eos (American Geophysical Union Transactions), v. 65, no. 16, p. 195.

in press, A kinematic model for the recent development of southern California crust and upper mantle: Journal of Geophysical Research.

Humphreys, E.D., and Weldon, R.J., II, in press, Kinematic constraints on the rifting of Baja California, in Daupin, J.P., and Simoneit, B.R.T., eds., The Gulf and Peninsular provinces of the Californias: American Association of Petroleum Geologists Memoir 47.

Isaac, Sharon, Rockwell, T.K., and Gastil, Gordon, 1986, Plio-Pleistocene detachment faulting, Yuha Desert region, western Salton Trough, northern Baja California [abs.]: Geological Society of America Abstracts with Programs, v. 18, no. 2, p. 120.

Iyer, H.M., and Hitchcock, Tim, 1989, Upper-mantle velocity structure in continental U.S. and Canada, chap. 29 of Pakiser, L.C., and Mooney, W.D., eds., Geophysical framework of the continental United States: Geological Society of America Memoir. 172, p. 681-710.

Jachens, R.C., and Griscom, Andrew, 1983, Three-dimensional geometry of the Gorda plate beneath northern California: Journal of Geophysical Research, v. 88, no. B11, p. 9375-9392.

Jachens, R.C., Simpson, R.W., Griscom, Andrew, and Mariano, John, 1986, Plutonic belts in southern California defined by gravity and magnetic anomalies [abs.]: Geological Society of America Abstracts with Programs, v. 18, no. 2, p. 120.

Jayko, A.S., Blake, M.C., Jr., and Harms, T.A., 1987, Attenuation of the Coast Range Ophiolite by extensional faulting, and nature of the Coast Range "thrust," California: Tectonics, v. 6, no. 4, p. 475-488.

Jennings, C.W., compiler, 1977, Geologic map of California: California Division of Mines and Geology Geologic Data Map 2, scale $1: 750,000$.

Jennings, C.W., and Strand, R.G., compilers, 1958, Santa Cruz sheet of Geologic map of California: Sacramento, California Division of Mines, scale 1:250,000.

Johnson, C.E., 1979, CEDAR-an approach to the computer automation of short-period local seismic networks; seismotectonics of the
Imperial Valley of southern California: Pasadena, California Institute of Technology, Ph.D. thesis, $343 \mathrm{p}$.

Johnson, C.E., and Hadley, D.M., 1976, Tectonic implications of the Brawley earthquake swarm, Imperial Valley, California, January 1975: Seismological Society of America Bulletin, v. 66, no. 4, p. 1133-1144.

Jones, D.L., Blake, M.C., Jr., and Rangin, C., 1976, The four Jurassic belts of northern California and their significance to the geology of the southern California borderland, in Howell, D.G., ed., Aspects of the geologic history of the California Continental Borderland: American Association of Petroleum Geologists, Pacific Section Miscellaneous Publication 24, p. 343-362.

Jones, D.L., and Irwin, W.P., 1971, Structural implications of an offset Early Cretaceous shoreline in northern California: Geological Society of America Bulletin, v. 82, no. 4, p. 815-822.

Kosloff, D.D., 1978, Numerical models of crustal deformation: Pasadena, California Institute of Technology, Ph.D. thesis, $187 \mathrm{p}$.

Lachenbruch, A.H., Sass, J.H., and Galanis, S.P., Jr., 1985, Heat flow in southernmost California and the origin of the Salton Trough: Journal of Geophysical Research, v. 90, no. B8, p. 6709-6736.

Larson, E.S., Jr., 1948, Batholith and associated rocks of Corona, Elsinore, and San Luis Rey quadrangles, southern California: Geological Society of America Memoir 29, $182 \mathrm{p}$.

Lin, Wunan, and Wang, C.-Y., 1980, $P$-wave velocity in rocks at high pressure and temperature and the constitution of the central California crust: Royal Astronomical Society Geophysical Journal, v. 61 , no. 2 , p. $379-400$.

Lomnitz, Cinna, Mosser, Federico, Allen, C.R., Brune, J.N., and Thatcher, Wayne, 1970, Seismicity and tectonics of the northern Gulf of California region, Mexico. Preliminary results: Geofisica Internacional, v. 10, no. 2, p. 27-48.

Maddock, M.E., 1964, Geology of the Mt. Boarman Quadrangle, Stanislaus County, California: California Division of Mines and Geology Map Sheet 3, scale 1:62,500.

Mattinson, J.M., 1982, Granitic rocks of the Gabilan Range, California: $\mathrm{U}-\mathrm{Pb}$ isotopic systematics and implications for age and origin [abs.]: Geological Society of America Abstracts with Programs, v. 14 , no. 4 , p. 184.

Mayer-Rosa, Dieter, 1973, Travel-time anomalies and distribution of earthquakes along the Calaveras fault zone, California: Seismological Society of America Bulletin, v. 63, no. 2, p. 713-729.

McEvilly, T.V., and Clymer, R.W., 1975, A deep crustal reflection survey on the San Aindreas fault [abs.]: Eos (American Geophysical Union Transactions), v. 56, no. 12, p. 1021.

McLaughlin, R.J., Clark, J.C., and Brabb, E.E., 1988a, Geologic map and structure sections of the Loma Prieta $7 \frac{1}{1} 2^{\prime}$ quadrangle, Santa Clara and Santa Cruz Counties, California: U.S. Geological Survey Open-File Report 88-752, 31 p., scale 1:24,000, 2 sheets.

McLaughlin, R.J., Blake, M.C., Jr., Griscom, Andrew, Blome, C.D., and Murchey, B.L, 1988b, Tectonics of formation, translation, and dispersal of the Coast Range ophiolite of California: Tectonics, $v$. 7 , no. 5, p. 1033-1056.

Miller, F.K., and Morton, D.M., 1977, Comparison of granitic intrusions in the Pelona and Orocopia Schists, southern California: U.S. Geological Survey Journal of Research, v. 5, no. 5, p. 643-649.

Miller, F.K., and Morton, D.M., 1980, K-Ar geochronology of the eastern Transverse Ranges and southern Mojave Desert, southern California: U.S. Survey Professional Paper 1152, 30 p.

Minster, J.B., and Jordan, T.H., 1978, Present-day plate motions: Journal of Geophysical Research, v. 83, no. B11, p. 5331-5354.

Mooney, W.D., and Colburn, R.H., 1985, A seismic-refraction profile across the San Andreas, Sargent, and Calaveras faults, westcentral California: Seismological Society of America Bulletin, v. 75, no. 1, p. 175-191.

Mooney, W.D., and Weaver, C.S., 1989, Regional crustal structure and 
tectonics of the Pacific Coastal States: California, Oregon, and Washington, chap. 9 of Pakiser, L.C., and Mooney, W.D., eds., Geophysical framework of the continental United States: Geological Society of America Memoir 172, p. 129-161.

Moores, E.M., and Day, H.W., 1984, Overthrust model for the Sierra Nevada: Geology, v. 12, no. 7, p. 416-419.

Namson, J.S., and Davis, T.L., 1988, Seismically active fold and thrust belt in the San Joaquin Valley, central California: Geological Society of America of Bulletin, v. 100, no. 2, p. 257-273.

Namson, J.S., Davis, T.L., and Lagoe, M.B., 1990, Tectonic history and thrust-fold deformation style of seismically active structures near Coalinga, chap. 6 of Rymer, M.J., and Ellsworth, W.L., eds., The Coalinga, California, earthquake of May 2, 1983: U.S. Geological Survey Professional Paper 1487, p. 79-96.

Nava, F.A., and Brune, J.N., 1982, An earthquake-explosion reversed refraction line in the Peninsular Ranges of southern California and Baja California Norte: Seismological Society of America Bulletin, v. 72, no. 4 , p. $1195-1206$.

Oliver, H.W., Chapman, R.H., Biehler, Shawn, Robbins, S.L., Hanna, W.F., Griscom, Andrew, Beyer, L.A., and Silver, E.A., 1980, Gravity map of California and its continental margin: California Division of Mines and Geology Geologic Data Map 3, scale $1: 750,000,2$ sheets.

Olsen, J.A., 1986, Seismicity of the San Andreas fault zone in the San Francisco Peninsula area, California: Royal Society of New Zealand Bulletin 24, p. 87-97.

Olsen, J.A., and Lindh, A.G., 1985, Seismicity of the San Andreas Fault from Cienega Winery to the Golden Gate, in Shearer, C.F., Minutes of the National Earthquake Prediction Evaluation Council, July 26-27, 1985, Menlo Park, California: U.S. Geological Survey Open-File Report 85-754, p. 316-324.

Oppenheimer, D.H., and Eaton, J.P., 1984, Moho orientation beneath central California from regional earthquake traveltimes: Journal Geophysical Research, v. 89, no. 12, p. 10267-10282.

Oppenheimer, D.H., Reasenberg, P.A., and Simpson, R.W., 1988, Fault-plane solutions for the 1984 Morgan Hill, California, earthquake sequence: Evidence for the state of stress on the Calaveras fault: Journal of Geophysical Research, v. 93, no. B8, p. 9007-9026.

Page, B.M., and Engebretson, D.C., 1984, Correlation between the geologic record and computed plate motions for central California: Tectonics, v. 3, no. 2, p. 133-155.

Peake, L.G., and Healy, J.H., 1977, A method for determination of the lower crustal structure along the San Andreas fault system in central California: Seismological Society of America Bulletin, v. 67 , no. 3, p. 793-807.

Plafker, George, and Galloway, J.P., eds., 1989, Lessons learned from the Loma Prieta, California, earthquake of October 17, 1989: U.S. Geological Survey Circular 1045, 48 p.

Platt, J.P., 1975, Metamorphic and deformational processes in the Franciscan Complex, California: Some insights from the Catalina Schist terrane: Geological Society of America Bulletin, v. 86, no. 10 , p. 1337-1347.

- 1976, The significance of the Catalina schist and the history of the southern California Borderland, in Howell, D.G., ed., Aspects of the geologic history of the California Continental Borderland: American Association Petroleum Geologists, Pacific Section Miscellaneous Publication 24, p. 47-52.

- 1986, Dynamics of orogenic wedges and the uplift of highpressure metamorphic rocks: Geological Society of America Bulletin, v. 97 , no. 9, p. 1037-1053.

Powell, C.L., II, 1984, Bivalve molluscan paleoecology of the marine Neogene Imperial Formation in Riverside County, California [abs.]: Western Society of Malacologists Annual Report 17, p. 29-32.

Powell, R.E., 1981, Geology of the crystalline basement complex, eastern Transverse Ranges, southern California; constraints on regional tectonic interpretation: Pasadena, California Institute of Technology, Ph.D. thesis, $441 \mathrm{p}$.

Raikes, S.A., 1980, Regional variations in upper mantle structure beneath southern California: Royal Astronomical Society Geophysical Journal, v. 63, no. 1, p. 187-216.

Raymond, L.A., 1973, Tesla-Ortigalita fault, Coast Range thrust fault, and Franciscan metamorphism, northeastern Diablo Range, California: Geological Society of America Bulletin, v. 84, no. 11, p. 3547-3562.

Reasenberg, P.A., and Ellsworth, W.L., 1982, Aftershocks of the Coyote Lake, California, earthquake of August 6, 1979: A detailed study: Journal of Geophysical Research, v. 87, no. B13, p. 10637-10655.

Rentschler, M.S., and Bloch, R.B., 1988, Flexural subsidence modeling of the San Joaquin basin, California, in Graham, S.A., and Olson, H.C., eds., Studies of the geology of the San Joaquin basin (volume 60): Society of Economic Paleontologists and Mineralogists, Pacific Section Field Trip Guidebook, p. 29-57.

Robinson, P.T., Elders, W.A., and Muffler, L.J.P., 1976, Quaternary volcanism in the Salton Sea geothermal field, Imperial Valley, California: Geological Society of America Bulletin, v. 87, no. 3, p. 347-360.

Roller, J.C., and Healy, J.H., 1963, Seismic-refraction measurements of crustal structure between Santa Monica Bay and Lake Mead: Journal of Geophysical Research, v. 68, no. 20, p. 5837-5849.

Ross, D.C., 1972, Petrographic and chemical reconnaissance study of some granitic and gneissic rocks near the San Andreas fault from Bodega Head to Cajon Pass, California: U.S. Geological Survey Professional Paper 698, $92 \mathrm{p}$.

1978, The Salinian block: A Mesozoic granitic orphan in the California Coast Ranges, in Howell, D.G., and McDougall, K.A., eds., Mesozoic paleogeography of the Western United States: Pacific Coast Paleogeography Symposium 2: Los Angeles, Society of Economic Paleontologists and Mineralogists, Pacific Section, p. 509-522.

Ross, D.C., and McCulloch, D.S., 1979, Cross section of the southern Coast Ranges and San Joaquin Valley from offshore Point Sur to Madera, California: Geological Society of America Map and Chart Series, no. MC-28H, scale 1:250,000.

Saleeby, J.B., 1982, Polygenetic ophiolite belt of the California Sierra Nevada: Geochronological and tectonostratigraphic development: Journal of Geophysical Research, v. 87, no. 3, p. 1803-1824. 1986, C-2: Central California offshore to Colorado Plateau: Geological Society of America, Centennial Continent/Ocean Transect 10, 63 p., scale 1:500,000, 2 sheets.

Sauber, Jeanne, Thatcher, Wayne, and Solomon, S.C., 1986, Geodetic measurement of deformation in the central Mojave Desert, California: Journal of Geophysical Research, v. 91, no. B12, p. 12683-12693.

Schultejahn, P.A., 1984, The Yaqui Ridge antiform and detachment fault: Mid-Cenozoic extensional terrane west of the San Andreas fault: Tectonics, v. 3, no. 6 , p. $677-691$.

Schweickert, R.A., and Bogen, N.L., 1983, Tectonic transect of Sierran Paleozoic through Jurassic accreted belts: Society of Economic Paleontologists and Mineralogists, Pacific Section Field Trip Guidebook, 22 p.

Schweickert, R.A., and Cowan, D.S., 1975, Early Mesozoic tectonic evolution of the western Sierra Nevada, California: Geological Society of America Bulletin, v. 86, no. 10, p. 1329-1336.

Shor, G.G., Jr., 1954, Crustal structure and reflections from the Mohorovicic discontinuity: Pasadena, California Institute of Technology, Ph.D. thesis, $158 \mathrm{p}$.

Shor, G.G., Jr., Menard, H.W., and Raitt, R.W., 1971, Structure of the Pacific basin, in Maxwell, A.E., ed., The sea: Ideas and observa- 
tions on progress in the study of the seas: New York, John Wiley \& Sons, v. 4, pt. 2, p. 3-27.

Shor, G.G., Jr., and Raitt, R.W., 1958, Seismic studies in the southern California Continental Borderland, in International Geological Congress, 20th, Mexico City, 1956, Proceedings, sec. 9, v. 2, p. 243-259.

Sibson, R.H., 1982, Fault zone models, heat flow, and the depth distribution of earthquakes in the continental crust of the United States: Seismological Society of America Bulletin, v. 72, no. 1, p. 151-163.

Silver, L.T., Taylor, H.P., and Chappell, B., 1979, Some petrological, geochemical, and geochronological observations of the Peninsular Ranges batholith near the international border of the U.S.A. and Mexico, in Abbott, P.L., and Todd, V.R., eds., Mesozoic crystalline rocks: Peninsular Ranges batholith and pegmatites, Point Sal Ophiolite: San Diego, Calif., San Diego State University, Department of Geological Sciences, p. 83-110.

Spieth, M.A., Hill, D.P., and Geller, R.J., 1981, Crustal structure in the northwestern foothills of the Sierra Nevada from seismic refraction experiments: Seismological Society of America Bulletin, v. 71 , no. 4 , p. $1073-1085$.

Stewart, R.M., and Peselnick, Louis, 1977, Velocity of compressional waves in dry Franciscan rocks to $8 \mathrm{kbar}$ and $300^{\circ} \mathrm{C}$ : Journal of Geophysical Research, v. 82, no. 14, p. 2027-2039.

Stewart, S.W., 1968, Preliminary comparison of seismic traveltimes and inferred crustal structure adjacent to the San Andreas fault in the Diablo and Gabilan Ranges of central Calif., in Dickinson, W.R., and Grantz, Arthur, eds., Proceeding of the conference on geologic problems of the San Andreas fault system: Stanford, Calif., Stanford University Publications in the Geological Sciences, v. 11, p. 218-230.

Suppe, John, and Armstrong, R.L., 1972, Potassium-argon dating of Franciscan metamorphic rocks: American Journal of Science, v. 272 , no. 3, p. 217-233.

Thurber, C.H., and Aki, Keiiti, 1987, Three-dimensional seismic imaging: Annual Reviews of Earth and Planetary Sciences, v. 15, p. 115-139.

Vedder, J.G., Beyer, L.A., Junger, Arne, Moore, G.W., Roberts, A.E., Taylor, J.C., and Wagner, H.C., 1974, Preliminary report on the geology of the continental borderland of southern California: U. S. Geological Survey Miscellaneous Field Studies Map MF-624, 34 p., scales 1:500,000, 1:1,000,000, 9 sheets.

Vetter, Ute, and Minster, J.-B., 1981, $P_{n}$ velocity anisotropy in southern California: Seismological Society of America Bulletin, v. 71 , no. 5 , p. $1511-1530$.

Wallace, R.D., and English, D.J., 1982, Evaluation of possible detachment faulting west of the San Andreas, southern Santa Rosa
Mountains, California, in Frost, E.G., and Martin, D.L., eds., Mesozoic-Cenozoic tectonic evolution of the Colorado River region, California, Arizona, and Nevada: San Diego, Calif., Cordilleran Publishers, p. 502-510.

Walter, A.W., and Mooney, W.D., 1982, Crustal structure of the Diablo and Gabilan Ranges, central California: A reinterpretation of existing data: Seismological Society of America Bulletin, v. 72, no. 5, p. 1567-1590.

Webb, T.H., and Kanamori, Hiroo, 1985, Earthquake focal mechanisms in the eastern Transverse Ranges and San Emigdio Mountains, southern California and evidence for a regional decollement: Seismological Society of America Bulletin, v. 75, no. 3, p. 737-757.

Weldon, R.J., and Humphreys, E.D., 1986, A kinematic model of southern California: Tectonics, v. 5, no. 1, p. 33-48.

Wentworth, C.M., 1987, Implications for crustal structure in the western Coast Ranges, California, from studies along their eastern margin [abs.]: Eos (American Geophysical Union Transactions), v. 68 , no. 44 , p. 1366.

Wentworth, C.M., Blake, M.C., Jr., Jones, D.L., and Walter, A.W., 1984, Tectonic wedging associated with emplacement of the Franciscan assemblage, California Coast Ranges, in Blake, M.C., Jr., ed., Franciscan geology of northern California (volume 43): Society of Economic Paleontologists and Mineralogists, Pacific Section Field Trip Guidebook, p. 163-173.

Wentworth, C.M., and Zoback, M.D., 1989, The style of late Cenozoic deformation at the eastern front of the California Coast Ranges: Tectonics, v. 8, no. 2, p. 237-246.

Wentworth, C.M., Zoback, M.D., Griscom, Andrew, Jachens, R.C., and Mooney, W.D., 1987, A transect across the Mesozoic accretionary margin of central California: Royal Astronomical Society Geophysical Journal, v. 89, no. 1, p. 105-110.

Wesson, R.L., Burford, R.O., and Ellsworth, W.L., 1973, Relationship between seismicity, fault creep, and crustal loading along the central San Andreas fault, in Kovach, R.L., and Nur, Amos, eds., Proceedings of the conference on tectonic problems of the San Andreas fault system: Stanford, Calif., Stanford University Publications in the Geological Sciences, v. 13, p. 303-321.

Yeats, R.S., 1981, Quaternary flake tectonics of the California Transverse Ranges: Geology, v. 9, no. 1, p. 16-20.

Zandt, George, and Furlong, K.P., 1982, Evolution and thickness of the lithosphere beneath coastal California: Geology, v. 10, no. 7, p. 376-381.

Zoback, M.D., and Wentworth, C.M., 1986, Crustal studies in central California using an 800-channel seismic reflection recording system, in Barazangi, Muawia, and Brown, Larry, eds., Reflection seismology: A global perspective (Geodynamics Series, v. 13): Washington, American Geophysical Union, p. 183-196. 



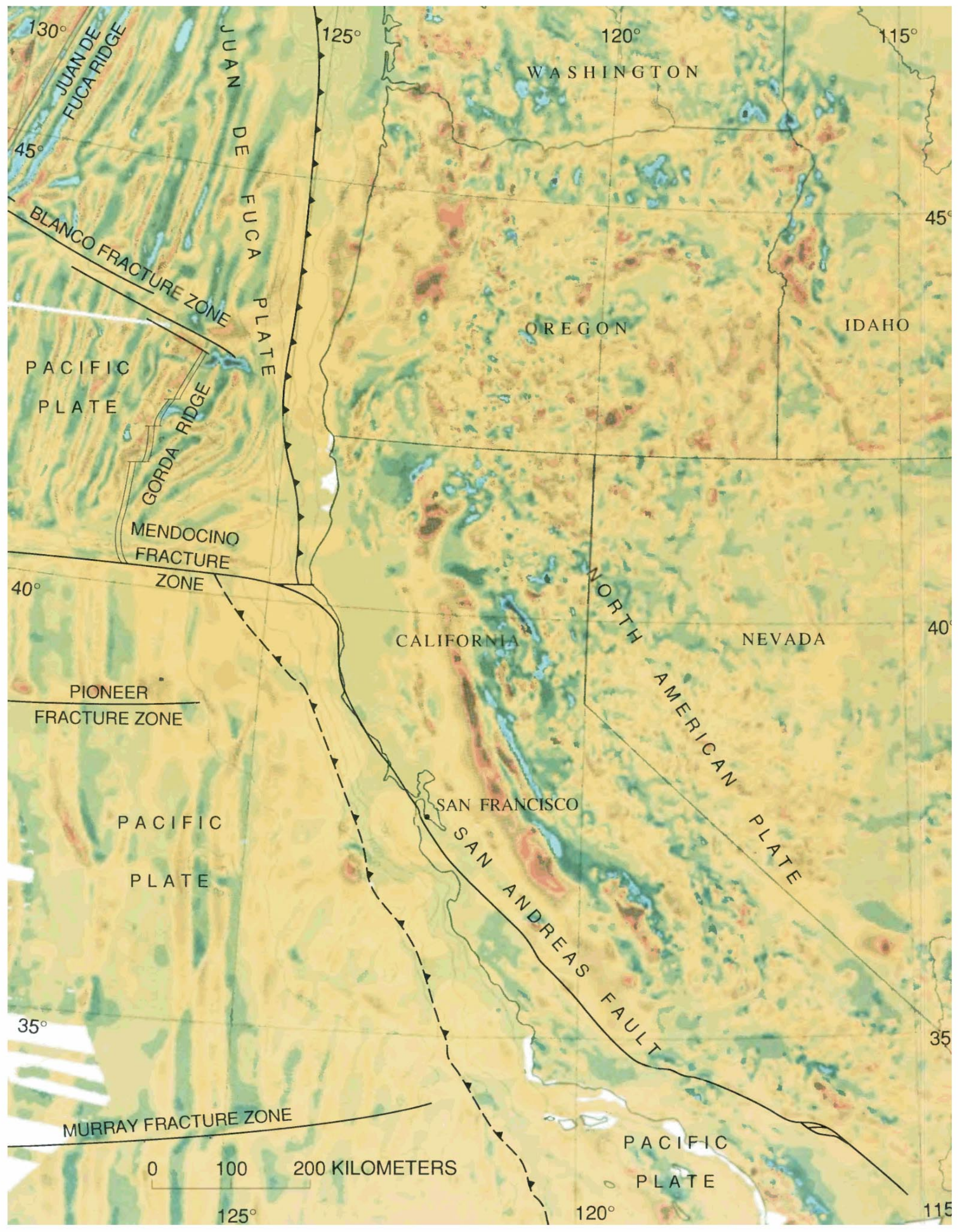


S tudies on the gravity and magnetic fields of the San Andreas $\mathcal{N}$ fault system span more than 30 years, but only recently have the fundamental data sets become adequate to provide a general view of the entire system. Modeling these new data defines the three-dimensional geometries of the faults and helps unravel the tectonic history of the system by "seeing through" the relatively thin cover of young sedimentary deposits and water to the older rocks below.

\title{
9. CRUSTAL AND LITHOSPHERIC STRUCTURE FROM GRAVITY AND MAGNETIC STUDIES
}

\author{
By ANDrew Griscom and Robert C. Jachens
}

\section{CONTENTS}

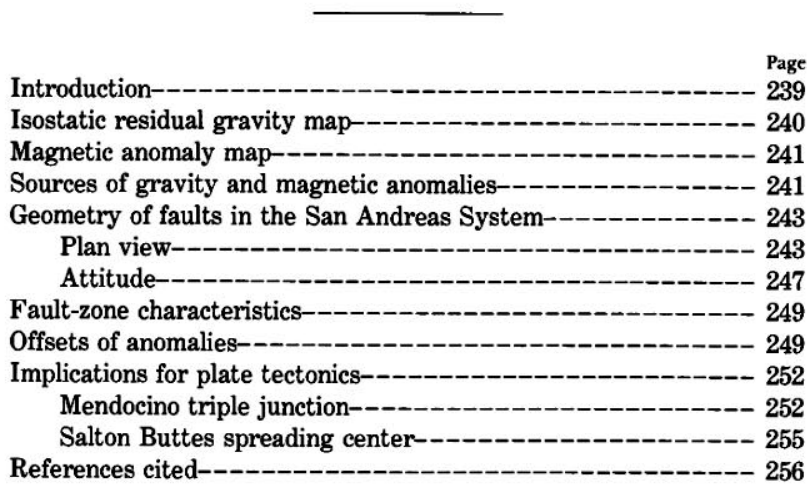

\section{INTRODUCTION}

Studies of the San Andreas fault system using the Earth's gravity and magnetic fields began before 1960 but received their main impetus during the 1970's, when work on the possibility of predicting earthquakes on this system began in earnest. Early investigations focused mainly on short segments of the faults because only limited data were available. More extensive potentialfield data sets that have been published in recent years now permit the gravity and magnetic expression of the entire fault system to be viewed in a regional context (fig. 9.1).

Gravity and magnetic data reflect, respectively, the density and magnetization of the rocks beneath the surface; and, in many situations, these properties can be closely correlated with the rock types seen in outcrop. Anomalies in the Earth's gravity and magnetic fieldsfor example, local deviations of the measured fields from those predicted on the basis of simplified Earth modelsprimarily reflect lateral variations in density and magnetization that generally are not included in such simple models. These anomalies can be interpreted qualitatively to infer the general spatial distribution of rock types in the subsurface, and quantitatively, through the use of efficient computer-based modeling techniques (Saltus and Blakely, 1983; Chuchel, 1985; Blakely and Simpson, 1986), to determine the geometries and specific locations of concealed rock bodies. Although all such interpretations are nonunique, both because many different distributions of density and magnetization can give rise to identical anomalies and because density and magnetiza-
Figure 9.1.-Magnetic map of the Western United States and eastern Pacific Ocean, showing locations of major plate boundaries: solid line, present boundary; dashed line, former boundary; double line, spreading ridge; single line, transform fault; toothed line, subduction-zone fault or transpressional fault (sawteeth on upper plate). From
Geological Society of America (1987); used with permission. Plate boundaries from King (1969), McCulloch (1987), and Wilson (1989). Each color band represents 100 nanoteslas; values range from low (blue) to high (red); white area, no data. Bathymetric contours in meters. 
tion do not uniquely define a specific rock type, the combined use of gravity and magnetic data with geologic, geochemical, and other geophysical data can be especially effective in limiting the number of acceptable interpretations.

In the sections below, we first present regional gravity and magnetic maps covering the San Andreas fault system and briefly discuss the sources, compilation methods, and limitations of the data from which they were produced and, in general terms, the sources of the anomalies shown on them. We then summarize the results of individual studies of sections of the major faults in the system and attempt to synthesize these results in terms of the geometries of the faults, the structures and rock types in the surrounding areas that are related to the faults, and the properties of the fault zones. Next, we focus on studies that relate to movement on the faults, including constraints on total displacements. Finally, we discuss the plate-tectonic implications of potential-field investigations of the fault system.

\section{ISOSTATIC RESIDUAL GRAVITY MAP}

An isostatic residual gravity map of the region surrounding the San Andreas fault system is shown in figure 9.2. We have chosen to present the gravity data in this form rather than in terms of the more common Bouguer or free-air gravity because of the generally closer correlation between isostatic residual gravity and mapped geology (Jachens and Griscom, 1985; Simpson and others, 1986). Most long-wavelength anomalies (longer than approx $250 \mathrm{~km}$ ) on a Bouguer gravity map are caused by deep-seated density distributions that buoyantly support the topography in a manner consistent with the principle of isostasy (Simpson and others, 1986). Bouguer gravity anomalies related to isostasy are prevalent in California because of the extreme topographic relief in the State (Oliver, 1980; Jachens and Griscom, 1985), and they are particularly strong near the coast, where an eastward to northeastward decrease in gravity reflects the transition from thin oceanic crust to thicker continental crust. In such areas as California, the Bouguer gravity anomalies associated with isostatic support of topography are so strong that they tend to distort or even mask the lower-amplitude anomalies caused by density distributions in the middle to upper crust, those anomalies most easily correlatable with rocks exposed at the surface (Jachens and Griscom, 1985). Our isostatic residual gravity map has these long-wavelength isostatic effects removed, at least to first order. We emphasize that the anomalies remaining on our map are predominantly caused by lateral density variations in the middle to upper crust and, as such, do not represent areas that are out of isostatic balance (Jachens and Griscom, 1985).

Our isostatic residual gravity map (fig. 9.2) is based on the new isostatic residual gravity map of the conterminous United States by Simpson and others (1986), who presented a detailed discussion of the data sets and procedures used to generate this map. The basic gravitydata set was compiled for the "Gravity Anomaly Map of the United States" (Society of Exploration Geophysicists, 1982) and includes 1 million on shore and 0.8 million offshore gravity observations. These data were sampled on a rectangular grid with a grid spacing of $4 \mathrm{~km}$, containing Bouguer gravity values onshore and free-air gravity values at sea (Godson, 1985). To produce our isostatic residual gravity map, the offshore free-air gravity values were converted to Bouguer gravity values. The gravitational effects of the deep density distributions that support the topography within $166.7 \mathrm{~km}$ of each grid intersection were computed according to the Airy-Heiskanen model of isostasy (Heiskanen and Moritz, 1967) using a 5- by 5-minute topographic-bathymetric data grid and model parameters as follows: topographic density, $2.67 \mathrm{~g} / \mathrm{cm}^{3}$; crustal thickness at sea level, $30 \mathrm{~km}$; and density contrast across the base of the model crust, $0.35 \mathrm{~g} / \mathrm{cm}^{3}$. Combined isostatic and topographic effects for the region from $166.7 \mathrm{~km}$ to the antipode of each grid intersection were obtained from the maps by Karki and others (1961). This model gravity field was subtracted from each Bouguer gravity grid value to yield a grid of isostatic residual gravity values; the resulting grid was contoured by computer and displayed in color-band intervals of $10 \mathrm{mGal}$ to produce figure 9.2 .

Limitations on the use of this map stem both from uncertainties in the point data from which the grid was constructed and from characteristics generated by the gridding process. For onshore data, uncertainties in the point data values resulting from errors in observed gravity, elevation, terrain corrections, and isostatic reductions are estimated to be less than 2 to $3 \mathrm{mGal}$ for most stations, possibly larger in areas of extreme topographic relief (Simpson and others, 1986). In offshore areas, the greatest uncertainty results from conversion of the original free-air gravity data to Bouguer gravity values, using the 5 - by 5 -minute average bathymetry. Where the sea-bottom topography is relatively gentle, this conversion probably results in uncertainties of about $5 \mathrm{mGal}$, but in such areas as parts of the California Continental Borderland (south of lat $34^{\circ} \mathrm{N}$.) and over the edge of the Continental Shelf, where water depths change rapidly, errors of several tens of milligals are possible. These conversion errors generally appear as high-amplitude, nearly circular anomalies with diameters of as much as $40 \mathrm{~km}$. 
Although gravity coverage along most of the San Andreas fault system is quite dense when viewed at the scale of figure 9.2 , sampling of these data on a $4-\mathrm{km}$ grid means that anomalies with characteristic dimensions less than several times the grid spacing are not faithfully portrayed. Our isostatic residual gravity map (fig. 9.2) is sufficient for qualitative and quantitative interpretation at the scale shown, but for more detailed interpretations, especially quantitative modeling, the reader is referred to the original data sources, such as Oliver and others (1980), Roberts and others (1981), Snyder and others (1982), and the other reports cited throughout this chapter.

\section{MAGNETIC ANOMALY MAP}

A magnetic anomaly map of the region surrounding the San Andreas fault system is shown in figure 9.3. This map is based on the magnetic anomaly map of the Western United States by Bond and Zietz (1987), which was compiled from hundreds of magnetic surveys with widely differing flight heights, flightline spacings, and sensor types.

In contrast to the lengthy series of reduction steps that were required to convert the gravity observations to the form shown in figure 9.2, very little was done to the observed magnetic data to prepare them for compilation. Although the original data were collected at many different heights, no analytic procedures were used to continue them to a common elevation. Instead, the various surveys were referenced to the International Geomagnetic Reference Field (IGRF) adjusted for the date of the survey and an arbitrary zero datum, and then combined manually by inspection. Long profiles of magnetic data collected under the National Uranium Resource Evaluation (NURE) program of the U.S. Department of Energy and by the U.S. Naval Oceanographic Office (NOO) served as guides for determining the zero datum for the various surveys. The resulting data are presented at a color contour interval of $100 \mathrm{nT}$ (gammas) in figure 9.3 .

Our magnetic anomaly map (fig. 9.3) is the most complete compilation available for the San Andreas fault system and is useful for qualitatively determining the location, shape, and regional setting of large magnetic bodies. However, because of the compilation methods used to construct this map and because the contour interval is relatively coarse $(100 \mathrm{nT})$, it will not, in general, be adequate for detailed qualitative or quantitative examination of individual anomalies. Where detailed information is required, the reader is referred to the original sources from which our map was compiled; a comprehensive listing of these sources is given by Bond and Zietz (1987).
A particularly valuable source of aeromagnetic data over the San Andreas fault system is the profile data collected under the NURE program. In general, these data were collected along long profiles oriented east-west at a nominal height of $120 \mathrm{~m}$ above terrain and spaced about $5 \mathrm{~km}$ apart. The wide flightline spacing and low altitude of the survey lines preclude constructing realistic contour maps from these data in most places, but the long profiles are well suited for quantitative modeling. These data are available in the form of atlas folios or digital tapes for individual $1^{\circ}$ by $2^{\circ}$ quadrangles from the U.S. Department of Energy, Grand Junction, Colo.

When interpreting magnetic data, the inclination of the Earth's magnetic field must be taken into account because the magnetization induced in the magnetic source rocks by this field will have a similar inclination. Along the San Andreas fault, this inclination ranges from $58^{\circ}$ to $64^{\circ}$ downward toward magnetic north. Contoured magnetic anomalies over inductively magnetized or normally magnetized sources at these field inclinations will commonly display a dipole response, namely, magnetic lows associated with the north sides of magnetic highs. Inspection of our magnetic-anomaly map (fig. 9.3) indeed identifies numerous such magnetic lows on the north or northeast sides of major magnetic highs. In general, each magnetic low is located directly beyond the north or northeast contact of the causative magnetic mass.

\section{SOURCES OF GRAVITY AND MAGNETIC ANOMALIES}

Conspicuous features of the gravity field over the San Andreas fault system are linear highs and lows that trend subparallel to the major faults in the system. Highs $(\geq 10$ mGal) generally occur over exposed crystalline rocks of the Salinian block southwest of the San Andreas fault, over mafic granitic and metamorphic rocks of the Sierra Nevada and the Mojave Desert, and over Mesozoic and Tertiary layered rocks of the Franciscan assemblage, particularly in areas containing large amounts of mafic volcanic rocks (generally part of an ophiolite belt) or high-pressure metamorphic-mineral facies. Most of the deepest lows are caused by thick accumulations of low-density Cenozoic sedimentary rocks that fill tectonic basins adjacent to the faults and in the surrounding areas. Shallower lows occur over certain large serpentinite bodies within the Franciscan assemblage, over felsic plutons in the granitic terranes of California, and over a young concealed granitic pluton associated with the Geysers geothermal area at lat $39^{\circ} \mathrm{N}$., long $122^{\circ} 45^{\prime}$ W. (Chapman, 1975; Isherwood, 1976).

Magnetic anomalies in the vicinity of the San Andreas fault system typically are caused by any one of three 


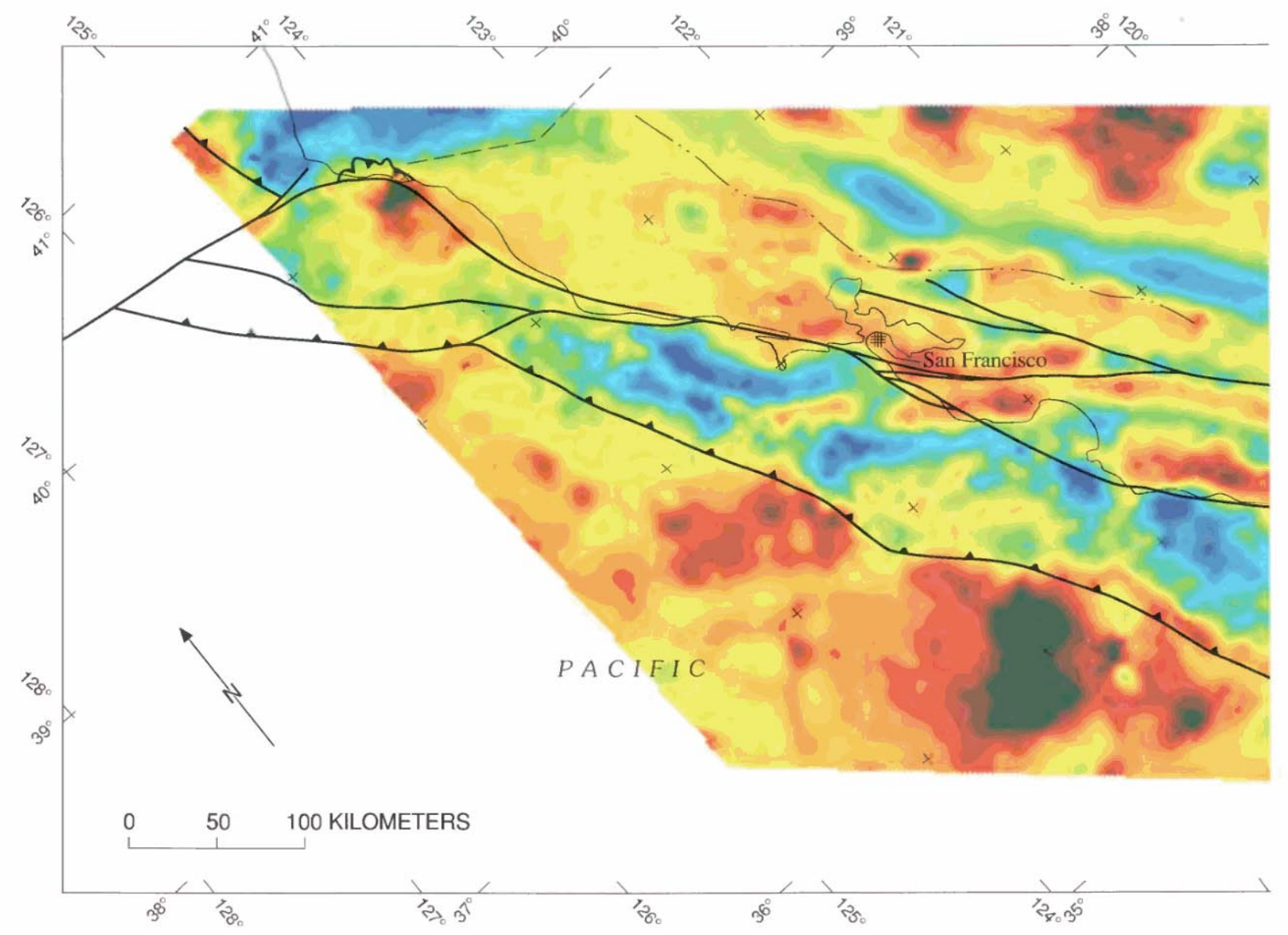

EXPLANATION

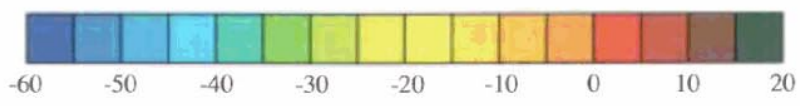

ISOSTATIC RESIDUAL GRAVITY VALUES, IN MILLIGALS

FIGURE 9.2.-Isostatic residual gravity map of the San Andreas fault system. Contour interval, 5 mGal. Faults simplified from Jennings and others (1977), McCulloch (1987), and Vedder (1987). Fault names and explanation in figure 9.4.

different rock types. The strongest anomalies generally reflect tabular bodies of serpentinite associated with the Franciscan assemblage and may also reflect the ophiolitic rocks, especially serpentinite, that locally lie above it. Mafic plutonic rocks, such as those exposed in the western Peninsular Ranges and along the west edge of the southern Sierra Nevada, can produce moderate to strong magnetic anomalies. Plutonic sources, not necessarily mafic only, probably account for most of the anomalies in the Salinian block, southwest of the San Andreas fault. Although younger volcanic rocks, in particular the mafic varieties, commonly are highly magnetic, such rocks do not cause significant magnetic features near the San Andreas fault as shown on our magnetic anomaly map (fig. 9.3) because magnetic volcanic rocks are volumetrically unimportant at the scale of this map.

In most areas, sedimentary rocks are considered nonmagnetic because they fail to cause aeromagnetic anomalies. Along the San Andreas fault system, however, several sedimentary-rock units cause magnetic anomalies as large as $150 \mathrm{nT}$. These units include rocks of Mesozoic and Tertiary age; other units composed primarily of detrital serpentinite also produce anomalies of this 


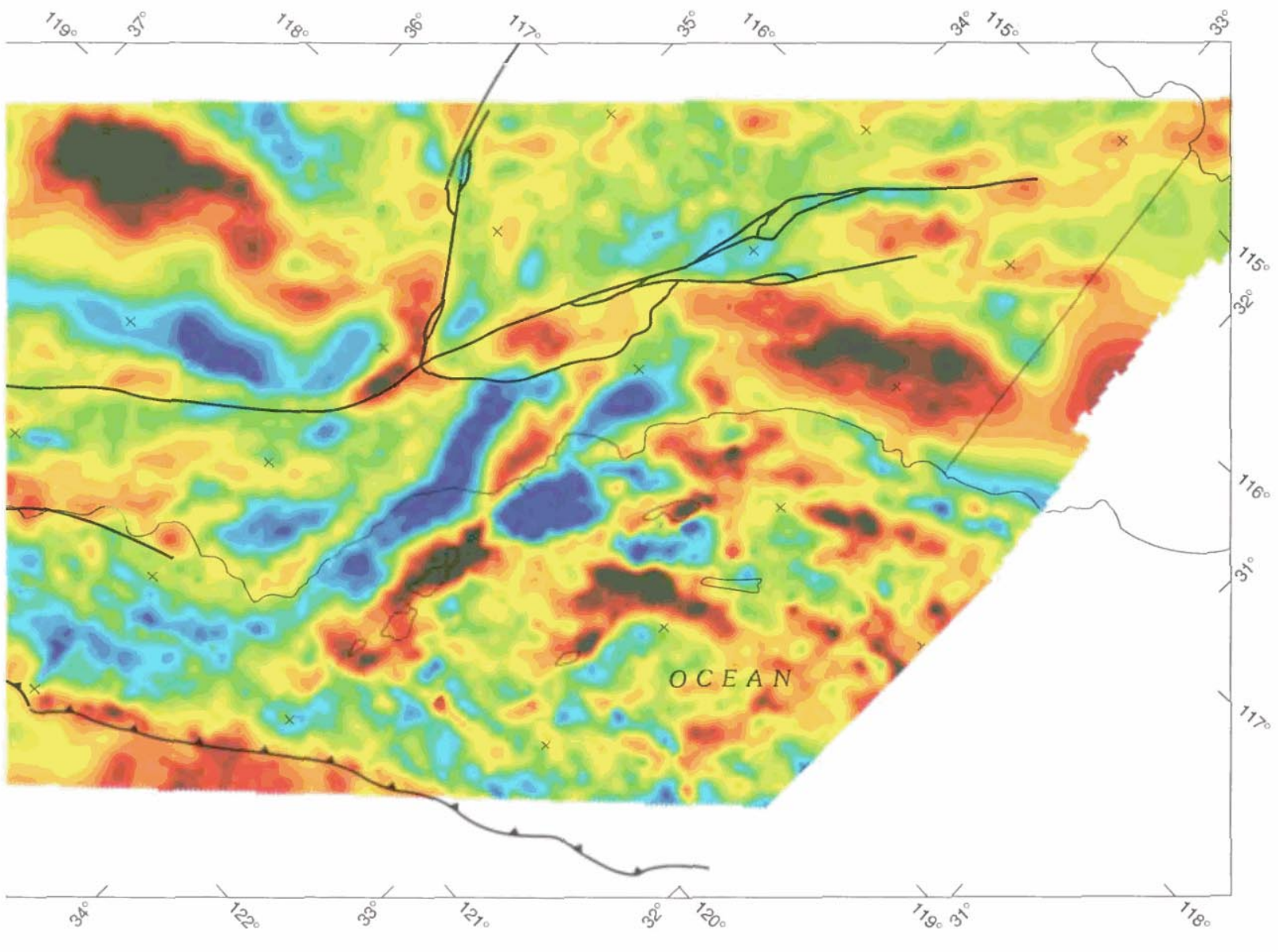

Figure 9.2.-Continued.

magnitude. None of these sedimentary units are areally large enough to produce magnetic anomalies visible at the scale of our magnetic anomaly map (fig. 9.3).

Near the north end of the San Andreas fault, several magnetic anomalies project landward from the linear pattern of anomalies that characterizes the oceanic crust. These anomalies reflect remanent magnetization in the oceanic crust; the source rocks are primarily basaltic volcanic rocks.

\section{GEOMETRY OF FAULTS IN THE SAN ANDREAS SYSTEM}

\section{PLAN VIEW}

The usefulness of potential-field data along the San Andreas fault system is maximized where rock masses with differing physical properties are juxtaposed. Under these conditions, geophysical anomalies arise from which the location and attitude of the fault may be calculated
(Blakely and Simpson, 1986). In general, the fault is expected to be situated at or near the steepest gradient of the anomaly. These sites are particularly helpful in areas where the fault trace or zone is concealed by young sedimentary deposits or by the Pacific Ocean. In addition, we have found that some of these data are useful in identifying the main strand of the fault zone where the presently active fault trace may not, in fact, be the original plate boundary. Some areas where the potentialfield data define the locations of faults are shown on figure 9.4 and are discussed below.

Although the location of the San Andreas fault between Point Arena and Cape Mendocino is concealed by the Pacific Ocean, the aeromagnetic data show a linear magnetic anomaly, striking northwest within the Pacific plate, that is inferred to be obliquely cut off by the fault about $20 \mathrm{~km}$ northwest of Point Arena. Farther north, the fault trace just south of Cape Mendocino has proved particularly difficult to locate because it may be too close to shore to be resolved by marine geophysical surveys. A 


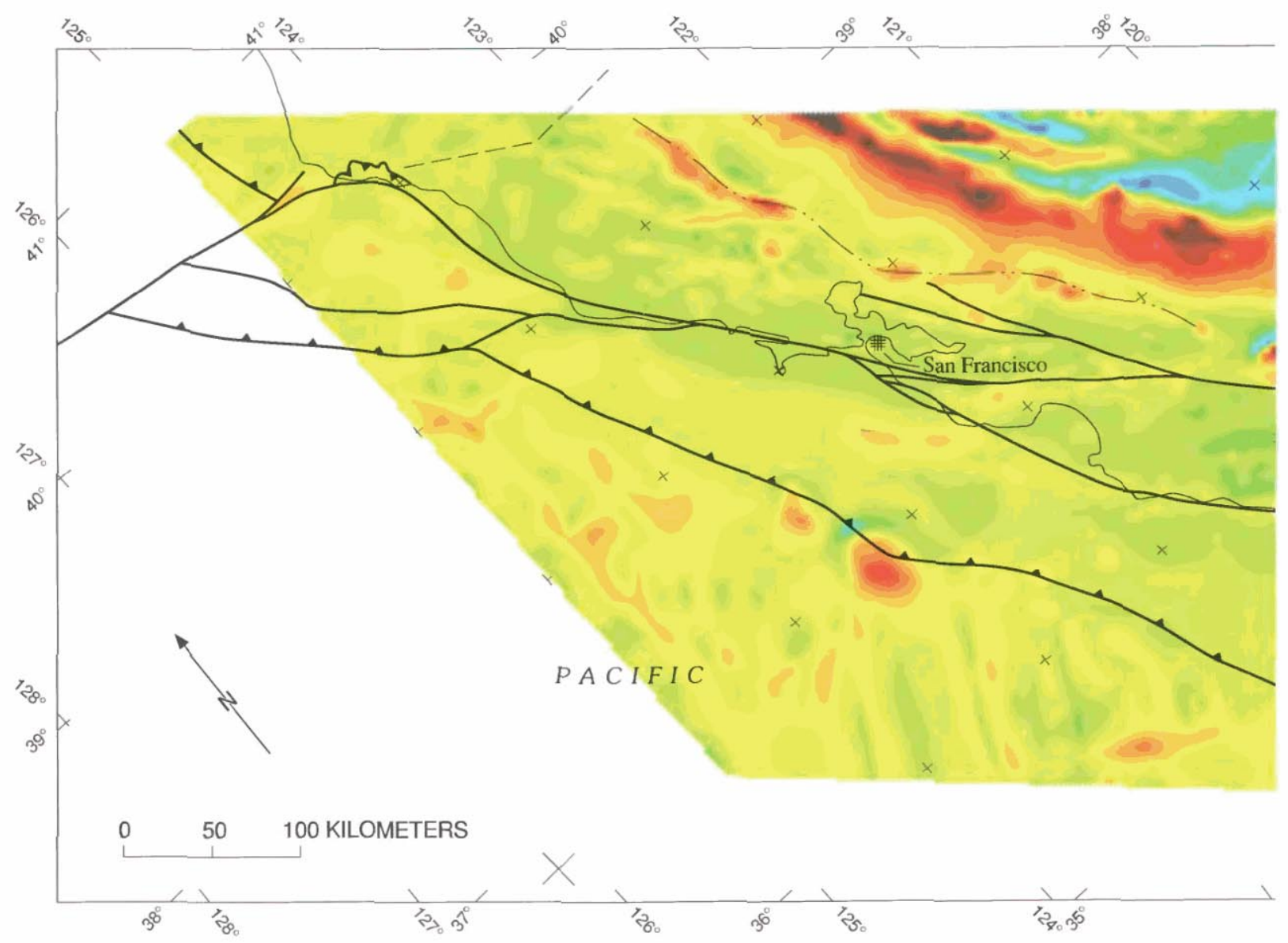

EXPLANATION

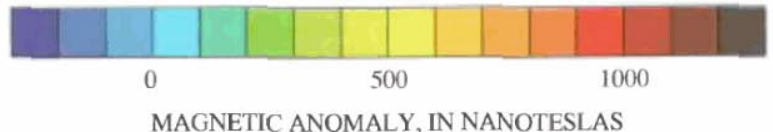

Figure 9.3,-Magnetic map of the San Andreas fault system (from Bond and Zietz, 1987). Contour interval, 100 nT. Faults simplified from Jennings and others (1977), McCulloch (1987), and Vedder (1987). Same symbols as in figure 9.4.

recent aeromagnetic map of this problematic area has, indeed, displayed a magnetic boundary trending close to and along the shore, thus representing the likely location of the San Andreas fault (Griscom, 1980a).

Aeromagnetic surveys over the Pacific Ocean at the entrance to the San Francisco Bay (Brabb and Hanna, 1981) show that the offshore extension of the Pilarcitos fault (an inactive fault branching westward from the San Andreas fault) is cut off by the offshore northward extension of the San Gregorio fault. The San Gregorio fault can be traced northward by using a detailed aeromagnetic map to the point where it intersects the
San Andreas fault at Bolinas Lagoon, about $20 \mathrm{~km}$ northwest of the bay mouth (see McCulloch, 1987, fig. 15).

From San Francisco southward to lat $35^{\circ} 15^{\prime}$ N., the detailed gravity and magnetic data indicate that, in general, the westernmost strand of the main San Andreas fault zone is the major plate boundary. The layered Franciscan assemblage to the east may be less competent than the granitic basement of the Salinian block to the west, and new strands may be more likely to appear in the less competent rocks. An exception to this generalization is found at lat $36^{\circ} \mathrm{N}$., where a thin fault sliver of 


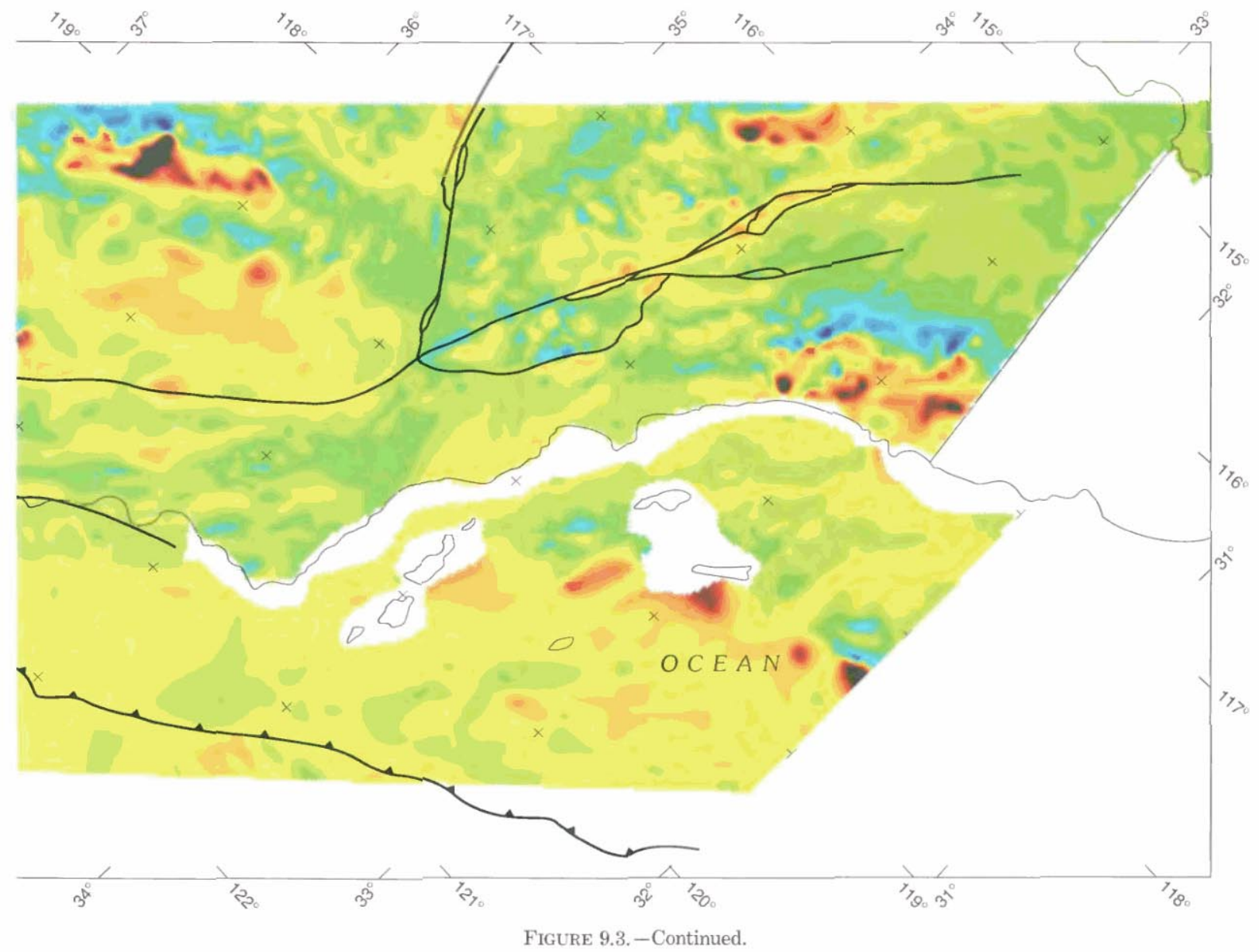

hornblende-quartz gabbro occurs at Gold Hill (Ross, 1970) that has been used to estimate offset on the San Andreas fault. The magnetic anomaly associated with this gabbro body indicates that it is at most $10 \mathrm{~km}$ long by $2 \mathrm{~km}$ wide (U.S. Geological Survey, 1987).

Farther south along the San Andreas fault, a linear magnetic high extends along the fault approximately between long $116^{\circ}$ and $118^{\circ} \mathrm{W}$. (fig. 9.3). On the basis of local model studies of this anomaly, Simpson and others (in press) show that this feature probably reflects the edge of an extensive block of magnetic rocks on the northeast side of the San Andreas fault, where the magnetic material is Precambrian igneous and metamorphic rocks, as well as Mesozoic plutonic rocks. Using detailed magnetic data (U.S. Geological Survey, 1979), the south border or magnetic boundary of this magnetic block (fig. 9.4) can be traced from west to east along a series of fault segments; from long $117^{\circ} 15^{\prime} \mathrm{W}$., the boundary follows the southern fault trace to long $116^{\circ} 15^{\prime}$ W., then crosses over to the northern trace along the short, east-west-trending fault segment, and finally continues eastward along the northern trace. These faults thus may represent the original fault boundary (now somewhat kinked) between the two plates. The geologic observation that rocks on the north side of these fault segments are native to the San Bernardino Mountains and contrast with compositionally different rocks on the south side (Matti and others, 1985) agrees with the magnetic interpretation. The magnetic boundary continues southeastward along the San Andreas fault in Coachella Valley to long $116^{\circ} 08^{\prime}$ W. A possible farther continuation of this linear magnetic high extends southeastward at a lower amplitude and diverges eastward from the present San Andreas fault, generally following and lying northeast of the Clemens Wells fault, a possible earlier strand of the San Andreas fault.

In Coachella Valley, the San Andreas fault (North Branch or Coachella segment) is situated along the northeast side of a substantial linear gravity low caused by at least $4.7 \mathrm{~km}$ of low-density sedimentary rocks 


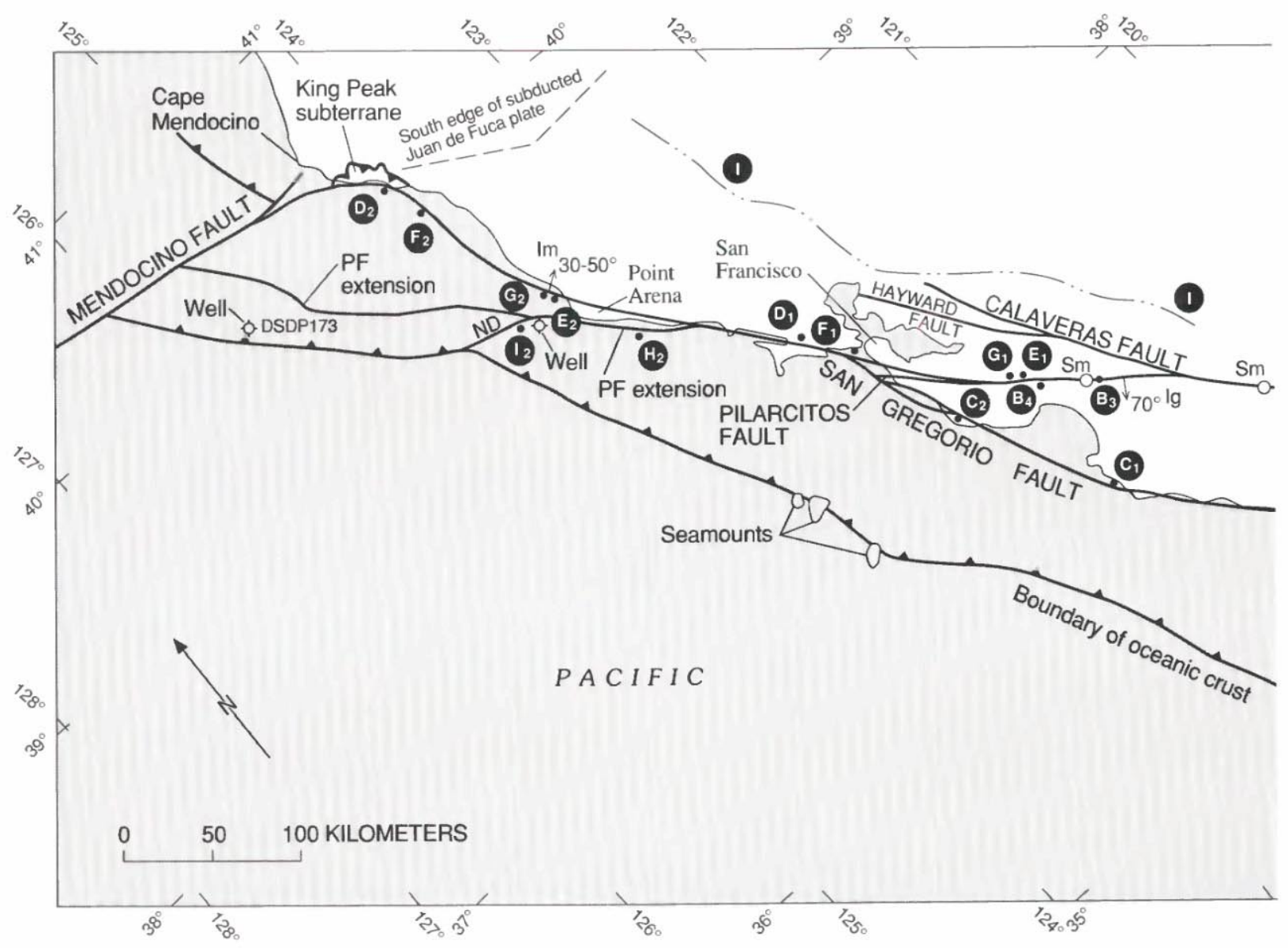

\section{EXPLANATION}

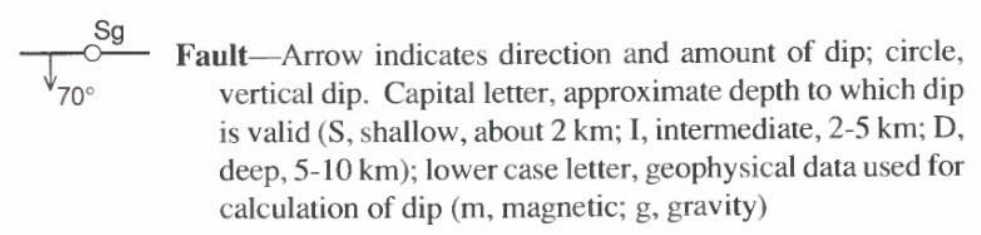

_ـ_ Thrust fault-Sawteeth on upper plate

(1) Crest of magnetic anomaly

. B1 Location of offset geophysical anomaly

.... Magnetic boundary $\left(\mathrm{J}_{1}\right.$ and $\left.\mathrm{J}_{2}\right)$ discussed in text

Q. Well

FIGURE 9.4.-San Andreas fault system, showing fault dips calculated from gravity and magnetic data, locations of offset geophysical anomalies, and south border of the subducted Juan de Fuca plate. Note wells at lat $39^{\circ}$ and $40^{\circ} \mathrm{N}$. ND, Navarro discontinuity; PF, Pilarcitos fault. 


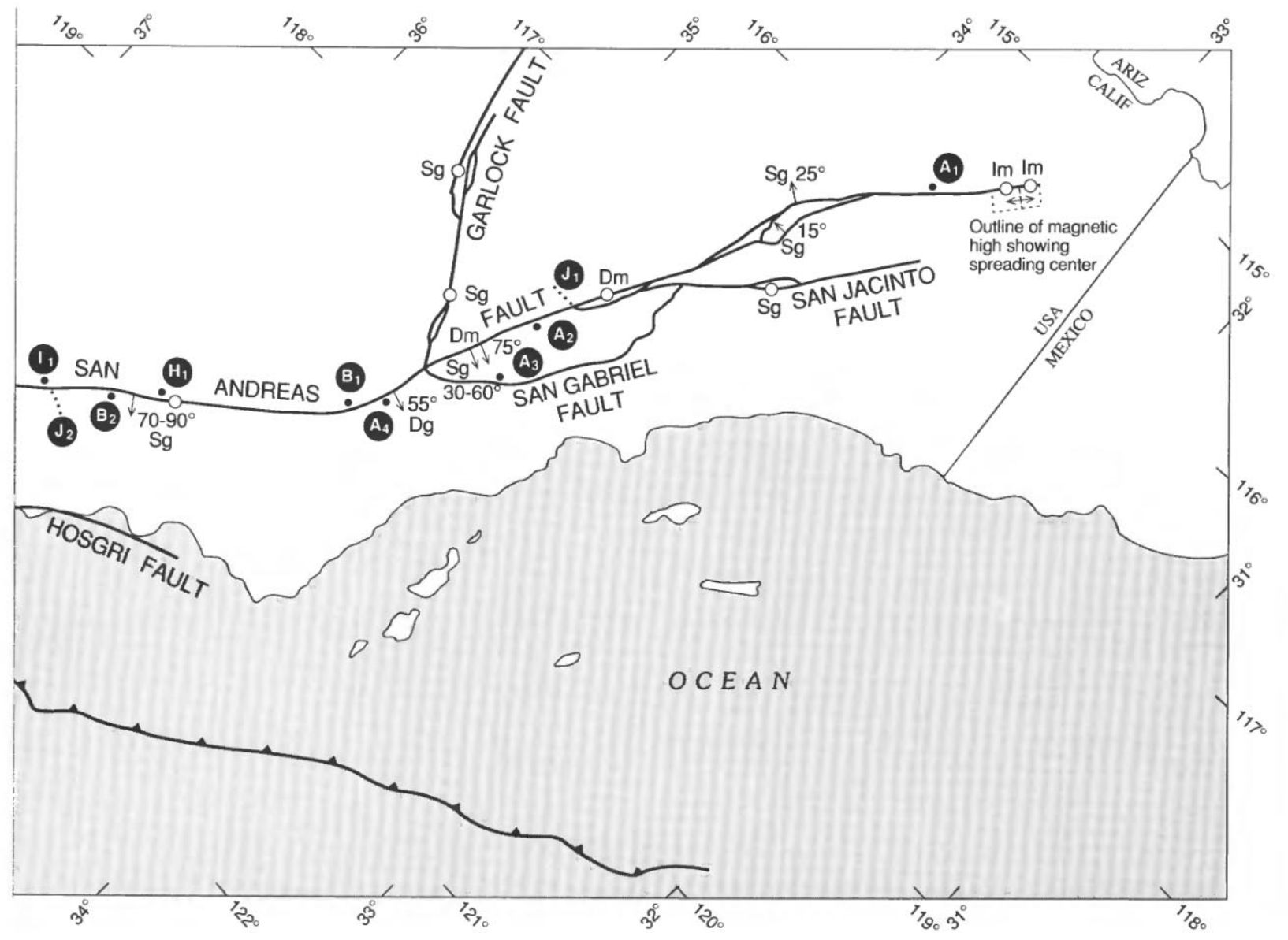

FIGURE 9.4.-Continued.

(Biehler, 1964) filling the valley. Gradient studies on the relatively detailed gravity data in this valley by one of us (Griscom) identify numerous fault strands, including the northern and southern branches of the San Andreas fault (the latter, the Banning fault), as well as several possible fault segments on the southwest side of the valley.

The Garlock fault at long $118^{\circ} \mathrm{W}$. changes direction and forms a zone as much as $8 \mathrm{~km}$ wide. Models of both the magnetic and gravity fields calculated normal to the fault indicate that here the main lithologic boundary is the most northerly fault (fig. 9.4); the granitic rocks farther north are more magnetic and less dense than those to the south.

\section{ATTITUDE}

At several sites along the San Andreas fault, the juxtaposition of large masses with contrasting densities and (or) magnetizations causes characteristic potential- field anomalies that reflect the attitude of the fault. Information on the dip of the fault most commonly is obtained through quantitative modeling of these anomalies, but in some cases, the anomalies are so diagnostic that qualitative interpretations suffice to indicate the direction and approximate attitude of the fault plane.

The results of such interpretations at 16 sites primarily along the main trace of the San Andreas fault are shown in figure 9.4. The dip and depth-extent of the density or magnetization interfaces that are assumed to define the fault plane at these sites are somewhat uncertain because of the inherent ambiguity of gravity and magnetic interpretations, particularly those based on magnetic data, because rock magnetizations can have anomalous directions associated with their remanent components and because magnetic susceptibilities seldom are known with sufficient accuracy to serve as effective independent constraints. Thus, where the magnetic anomalies can be compatible with a vertical fault, we show the dip as vertical. The reader should be aware, however, that a 
dipping interface extending to shallower depth would also be compatible with the data in some places.

Although major strike-slip faults probably are vertical over much of their reach, some have inferred dips of less than $90^{\circ}$, as indicated by many of the attitudes shown in figure 9.4. Just north of Point Arena, a buried magnetic body truncated on the east by the San Andreas fault has an east boundary that dips east beneath the trace of the fault (fig. 9.5A); its precise dip is uncertain but probably falls in the range $30^{\circ}-50^{\circ}$. To the south, near the junction of the San Andreas and Calaveras faults, gravity modeling (Pavoni, 1973) suggests that the fault dips $70^{\circ} \mathrm{SW}$. to a depth of about $6 \mathrm{~km}$. A detailed study of seismicity along this section of the fault (Spieth, 1981) shows that hypocenters define a plane dipping $70^{\circ} \mathrm{SW}$., thus strongly supporting the interpretation by Pavoni (1973). Robbins (1982) also found a southwest-dipping density interface at this site but argued that the fault plane was vertical, on the basis of a magnetic anomaly that he believed reflected a magnetic body, extending from 3- to $5-\mathrm{km}$ depth, with a southwest edge directly beneath the surface trace of the fault. More recent, detailed magnetic measurements indicate that this magnetic body is much shallower (probably cropping out) than modeled by Robbins (1982) and thus weaken the argument for a vertical dip.

Near the intersection of the San Andreas and Garlock faults, gravity modeling by Andrew Griscom and K.G. Freeman (Griscom and Oliver, 1980) suggests that the fault dips $55^{\circ} \mathrm{SW}$. to a depth of $6 \mathrm{~km}$ and thence vertically to a depth of at least $10 \mathrm{~km}$ (fig. $9.5 B$ ). About $60 \mathrm{~km}$ farther southeast, gravity data also indicate a southwesterly dip for the fault, but the angle of dip $\left(30^{\circ}-60^{\circ}\right)$ is uncertain, owing to difficulty in interpreting the complex gravity field that results from large lateral density variations in the region southwest of the fault. Farther southeast, where the San Andreas fault splits into numerous branches (long $116^{\circ} 00^{\prime}$ W.), gravity data on two branches indicate that both faults dip northeast, with Precambrian crystalline rocks in the upper plate overlying young sedimentary rocks and alluvium. The gravity models suggest dips of $15^{\circ}-25^{\circ} \mathrm{NE}$. to depths of 1.5 to 2.5 $\mathrm{km}$ but do not resolve the fault attitude at greater depth

Figure 9.5.-Magnetic and gravity models across the San Andreas fault. $m$, magnetization; $\rho$, density. A, Magnetic model just north of Point Arena (long $123^{\circ} 40^{\prime}$ W.). $B$, Gravity model near junction of the San Andreas and Garlock faults (long $119^{\circ} 07^{\prime}$ N.). A, Mesozoic and Precambrian crystalline basement mantled by older Tertiary sedimentary rocks to south; B, mafic igneous rocks of the southern Sierra Nevada batholith; C, Tertiary and Quaternary sedimentary rocks of the Great Valley. $C$, Gravity model across southern branch at long $116^{\circ} 40^{\prime}$ W. A, Mesozoic and Precambrian crystalline basement; B, Tertiary and Quaternary sedimentary rocks of Coachella Valley. (fig. 9.5C). Geologic mapping, which shows part of the southern branch of the San Andreas fault as a northdipping thrust fault (Matti and others, 1985), and a study of recent earthquakes in this area, which yielded faultplane solutions of predominantly oblique-slip motion and
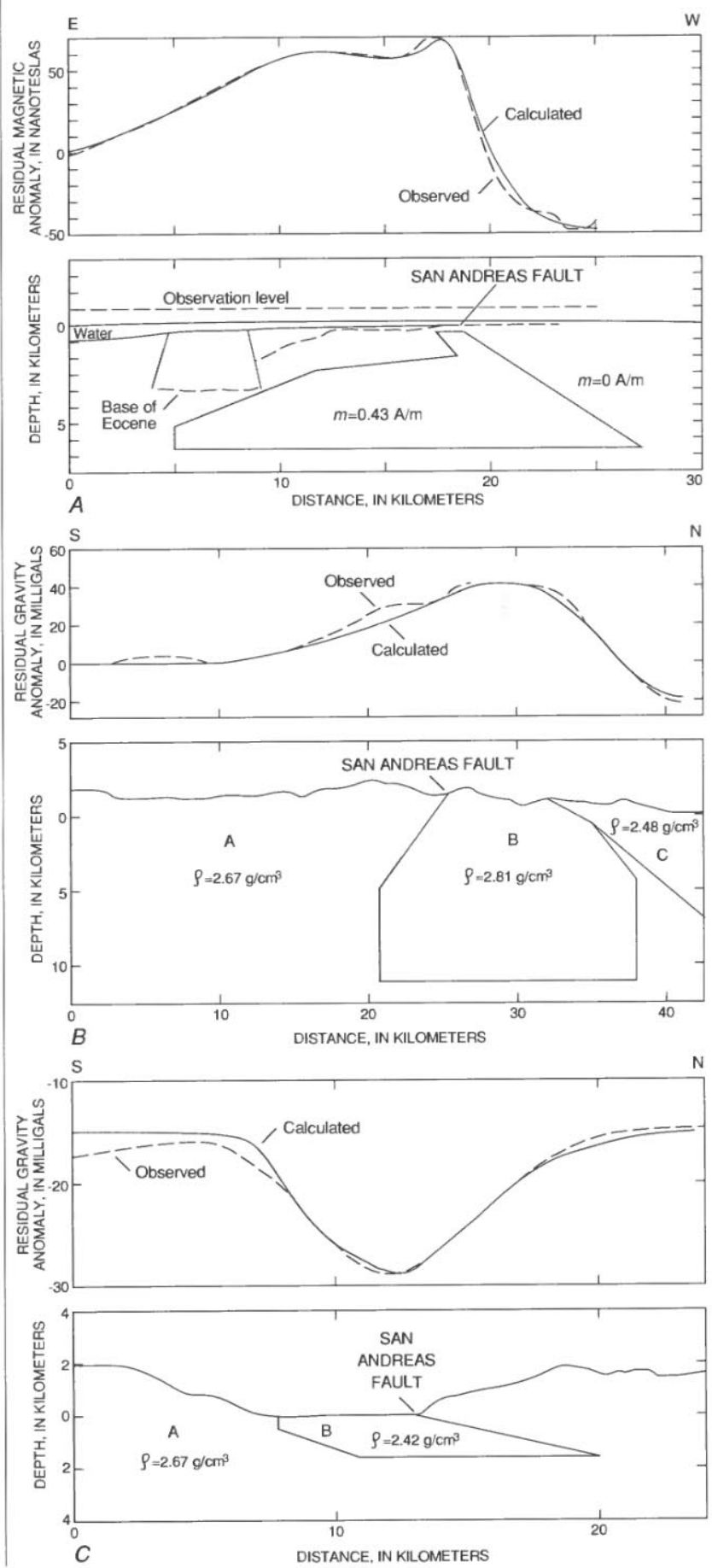
including low-angle thrust solutions dipping $30^{\circ} \mathrm{N}$. (Nicholson and others, 1986), both support the gravity interpretation of northeast-dipping faults in this area.

The inferred fault attitudes shown in figure 9.4 suggest a relation between attitude and plan-view geometry. Faults tend to be vertical except where they undergo abrupt changes of strike. The sinistral bends in the San Andreas fault near its junction with the Calaveras fault and in the Big Bend region southeast of its junction with the Garlock fault create regions likely to be subject to compression due to relative southward movement of the North American plate with respect to the Pacific plate. The dipping fault planes in these regions may reflect a thrust component of fault movement that accommodated the compression. Similarly, the region around the broad dextral bend in the San Andreas fault north of Point Arena may have a component of extension parallel to the direction of relative plate motion, and the low- angle eastward dip of fault plane there may reflect accommodation of the extension by low-angle normal faulting.

The number of examples on which the above speculations are based is quite limited, and further detailed investigations at critical sites along the San Andreas fault system are needed to test the relation between fault attitude, change of strike, and relative plate-motion direction.

\section{FAULT-ZONE CHARACTERISTICS}

Millions of years of strike-slip movement along faults of the San Andreas system have produced, in many places, a narrow fault zone in which physical properties differ from those in the surrounding rock masses. These differences are due to the presence within the fault zone of fractured or pulverized rock, exotic rock slivers that have been transported along the fault from other places, and such mobile materials as fluids and serpentinite that have migrated along the fault zone. A few investigators have used gravity and magnetic data to study the properties of this zone.

Although Stierman (1984) and Wang and others (1986) sought to explain gravity lows along the fault as the result of a substantial increase in porosity by fracturing, gravity lows not directly associated with basins filled by Cenozoic sedimentary rocks along the faults are very uncommon. These rare lows amount, with few exceptions (such as the 10-12-mGal low studied by Stierman, 1984), to amplitudes of only a few milligals. Feng and McEvilly (1983) and Trehu and Wheeler (1987) inferred from seismic data that zones of low seismic velocity 5 to $10 \mathrm{~km}$ wide and more than $10 \mathrm{~km}$ deep are associated with the San Andreas fault zone and, presumably, with fractured rocks. The low-velocity zone of Trehu and Wheeler (1987), however, has no associated gravity low, even though calculations by Andrew Griscom indicate that this zone might be expected to produce a gravity anomaly of about $-25 \mathrm{mGal}$ and more than 10 wide, using the standard velocity-density relations of Hill (1978). An explanation for this unexpected result can be found in the borehole gravity and seismic-velocity results (Schmoker, 1977; Stierman and Kovach, 1979) from a 600-m-deep borehole in diorite located $1.2 \mathrm{~km}$ from the San Andreas fault. For the lower half of this borehole, the seismic velocity averages only $3.1 \mathrm{~km} / \mathrm{s}$ (although saturated core samples measured $6.6 \mathrm{~km} / \mathrm{s}$ in the laboratory), and the average computed rock densities are as follows: bulk density from cores, $2.72 \mathrm{~g} / \mathrm{cm}^{3}$; borehole density from gravity measurements, $2.60 \mathrm{~g} / \mathrm{cm}^{3}$; and computed density from borehole velocities (density-velocity relations of Hill, 1978), $2.36 \mathrm{~g} / \mathrm{cm}^{3}$. Correcting for a nearby lowdensity sedimentary section that causes a gravity gradient along the hole raises the borehole density (from gravity measurements) closer to the bulk density. The results described above indicate that macrofractures can cause large decreases in seismic velocity but much smaller decreases in density than those predicted from standard velocity-density relations.

Allen (1968) pointed out a possible relation between the style of fault movement and the presence of serpentinite within fault zones of the San Andreas, Calaveras, and Hayward faults. He noted that serpentine is common within the fault zone along the creeping section of the San Andreas fault between Hollister and Cholame, whereas it is absent along the locked segments to the north and south. Irwin and Barnes (1975) noted the same relation between serpentinite and fault creep and discussed the possible role of metamorphic fluids on the seismic behavior of fault segments. Hanna and others (1972) studied aeromagnetic data along the San Andreas fault between San Francisco and San Bernardino and found that the creeping segment of the fault is characterized by broad aeromagnetic anomalies, which they interpreted as reflecting large concealed masses of serpentinite. Linear magnetic anomalies that most likely reflect serpentinite also are present along the creeping section of the Hayward fault east of the San Francisco Bay (fig. 9.3). These magnetic data support the speculation that appreciable amounts of serpentinite contained within a fault zone can influence the style of movement on the fault.

\section{OFFSETS OF ANOMALIES}

Strike-slip movement on the faults of the San Andreas system has produced offsets in formerly continuous geophysical anomalies. As might be expected, on those faults where the geologic offset is at most a few tens of kilometers, it is generally easy to identify corresponding magnetic or gravity features that are offset by similar 
distances. Examples of such faults are the Elsinore fault and the rectilinear system of minor strike-slip faults in the Mojave Desert block northeast of the San Andreas fault. In figure 9.4, the two or more piercing points of an offset geophysical anomaly are labeled with the same letter, and the specific points being described are designated with subscripts, numbered consecutively from northeast to southwest across the fault system.

Offset along the San Andreas fault system in southern California is believed to be approximately $300 \mathrm{~km}$ in a right-lateral sense, based on offset of the Pelona-Orocopia schist belts, together with associated characteristic Precambrian and Triassic rock assemblages of the thrust plate overlying the schist belts (Crowell, 1962; Clarke and Nilsen, 1973; summarized in Hamilton, 1978). Isostatic gravity highs are associated with the Orocopia Schist (point $A_{1}$ at lat $33^{\circ} 35^{\prime}$ N., northeast side of fault), with the Pelona Schist of the Sierra Pelona/Soledad area (points $\mathrm{A}_{2}, \mathrm{~A}_{3}$ at lat $34^{\circ} 35^{\prime} \mathrm{N}$., between the San Andreas and San Gabriel faults), and adjacent to the south side of the Pelona Schist of the Tejon/Garlock area (point $\mathrm{A}_{4}$ at lat $34^{\circ} 50^{\prime}$ N., south of the San Andreas fault and west of the San Gabriel fault). Point $\mathrm{A}_{4}$ is not well determined. The offsets of the gravity highs are, respectively, $240 \mathrm{~km}$ along the San Andreas between the first two highs $\left(A_{1}\right.$ and $\mathrm{A}_{2}$ ) and $60 \mathrm{~km}$ along the San Gabriel between the second two highs $\left(A_{3}\right.$ and $\left.A_{4}\right)$, for a total of $300 \mathrm{~km}$ along the San Andreas fault system, in agreement with Crowell (1962). The source of the gravity highs is not obvious and may not be any of the rocks exposed at the surface (Griscom, 1980b), both because the density of the schist coring the antiforms is probably similar to or slightly lower than that of the surrounding Precambrian crystalline rocks and because other large areas of Pelona/ Orocopia schist do not display associated gravity highs. The schist is marine in origin, predominantly metagraywacke of low metamorphic grade (Haxel and Dillon, 1978), and may be underlain by subducted oceanic crust. The gravity highs may indicate relatively uplifted oceanic crust beneath these specific antiformal exposures of the schist, or else the proportion of greenstone interbedded with schist may increase here with depth.

As mentioned above in the subsection entitled "Plan View," a linear magnetic high that extends along the San Andreas fault from long $116^{\circ}$ to $118^{\circ} \mathrm{W}$., a distance of about $200 \mathrm{~km}$, indicates that a large area north of the fault in this region is composed of magnetic rocks, predominantly Mesozoic granitic plutons; the northwest limit of this magnetic area $\left(J_{1}\right)$ is shown in figure 9.4. A similar large area of magnetic basement, also predominantly Mesozoic granitic rocks, that extends along the southwest side of the San Andreas fault is displaced from the former area right-laterally approximately $300 \mathrm{~km}$; the northwest limit of this correlative area $\left(J_{2}\right)$ is also shown in figure 9.4. This second area of magnetic rocks does not produce a significant magnetic high directly at the fault because the fault is on the northeast side of the magnetic mass and a magnetic low should occur for this geometry.

Several significant geophysical anomalies are found along the central section of the San Andreas fault north of its junction with the Garlock fault. A pronounced gravity high is located on the northeast side of the fault at lat $34^{\circ} 55^{\prime}$ N., where the southern "tail" of the Sierra Nevada is exposed. The associated rocks are hornblendequartz gabbro and anorthositic gabbro (Ross, 1970, 1984) that also produce a substantial aeromagnetic high (point $B_{1}$, fig. 9.4). Similar rocks (Ross, 1970) are found within the San Andreas fault zone at Gold Hill (point $\mathrm{B}_{2}$ at lat $35^{\circ} 50^{\prime}$ N., too small to show at this scale) and at Logan (point $\mathrm{B}_{3}$ at lat $36^{\circ} 52^{\prime} \mathrm{N}$.), where magnetic anomalies (U.S. Department of Energy, 1981; U.S. Geological Survey, 1987) indicate that the gabbro bodies are thin slivers within the fault zone. The Logan outcrops are offset about $290 \mathrm{~km}$ from the gabbro of the Sierran "tail." A major northwest-trending magnetic anomaly extends northwestward of Logan near the coast (from point $\mathrm{B}_{4}$ at lat $37^{\circ} 08^{\prime} \mathrm{N}$.). The source rocks for this magnetic anomaly are interpreted to be gabbro, similar to that exposed near Logan (Hanna and others, 1972a), because the anomaly requires a source body several kilometers thick. These corresponding offset geophysical anomalies support the geologic correlations implying about 300 to $320 \mathrm{~km}$ of offset.

The additional $100 \mathrm{~km}$ of granitic rocks extending northward from Logan to Montara Mountain (lat 37 $35^{\prime}$ N.) along the southwest side of the San Andreas fault does not have any correlative rocks exposed on the northeast side of the fault north of the gabbro of Sierran "tail," but the concealed crystalline basement rocks beneath the sedimentary rocks of the Great Valley may be correlative. Indeed, recent work on the Tertiary sedimentary rocks that overlie this additional $100 \mathrm{~km}$ of granitic rocks on the San Francisco peninsula suggests a lithologic and paleogeographic correlation with similar sedimentary rocks of the Great Valley (San Joaquin Basin) that are relatively offset 320 to $330 \mathrm{~km}$ to the southeast (see fig. 3.4; Stanley, 1987).

Movement on the San Andreas fault north of San Francisco (Griscom and Jachens, 1989) is complicated by right-lateral displacement added by the presently active San Gregorio-Hosgri fault, which intersects the San Andreas fault at San Francisco and provides an additional $115 \mathrm{~km}$ (Graham and Dickinson, 1978) or $150 \mathrm{~km}$ (Clark and others, 1984; Ross, 1984) of offset. The total offset on the San Andreas fault system here is further complicated by movement on branch faults to the east (Calaveras and Hayward fault systems of unknown offset) and, more importantly, by past movement along the Pilarcitos fault, 
the presently inactive fault strand branching westward from the San Andreas fault on the San Francisco peninsula. Probably most of the 300 to $320 \mathrm{~km}$ of displacement on the San Andreas fault has taken place along this strand because the presently active strand of the San Andreas fault that lies directly east of the Pilarcitos fault demonstrates only about $26 \mathrm{~km}$ of offset of a characteristic limestone belt within the Permanente terrane of the Franciscan assemblage (Bailey and others, 1964, p. 69; M.C. Blake, Jr., oral commun., 1987). The Pilarcitos fault (now truncated to the northwest by the San Gregorio fault) may have its former extension on the ocean side of the San Gregorio-San Andreas fault at about lat $38^{\circ} 30^{\prime} \mathrm{N}$. (see fig. 9.4), as proposed by Graham and Dickinson (1978). This proposed extension may have granitic rocks on the southwest side (more than the additional $100 \mathrm{~km}$ already discussed) that have no correlatives northeast of the San Andreas fault, unless the total offset on the San Andreas system substantially exceeds $300 \mathrm{~km}$ or unless granitic rocks underlie thrust blocks of Franciscan assemblage near the south end of the Great Valley (see preceding paragraph). There may be other, unidentified faults within the Salinian block that allow for this additional offset.

Offsets of geophysical anomalies along the San Gregorio-Hosgri fault support a total right-lateral movement of about 100 to $130 \mathrm{~km}$ that has been added to the total offset on the San Andreas fault system north of its junction with the San Gregorio fault. An offset gravity high (Silver, 1974) is located on the northeast side near Point Sur (point $\mathrm{C}_{1}$ at lat $36^{\circ} 30^{\prime} \mathrm{N}$.) and on the southwest side at Año Nuevo (point $C_{2}$ at lat $37^{\circ} 15^{\prime} \mathrm{N}$.), with an offset of 105 to $130 \mathrm{~km}$ as remeasured by Graham and Dickinson (1978). We prefer an offset of $105 \mathrm{~km}(\max 115 \mathrm{~km})$ because any larger displacement will place the offset extension of the Pilarcitos fault on land north of lat $38^{\circ} 30^{\prime}$ N., where no such fault is known.

Displacements along the San Andreas fault north of lat $38^{\circ} 30^{\prime} \mathrm{N}$. have proved difficult to measure, both because the rocks exposed southwest of the fault near Point Arena have no obvious correlatives on the opposite side of the fault and because most of the fault trace is concealed beneath the Pacific Ocean (Griscom and Jachens, 1989). The rocks cropping out southwest of the fault near Point Arena are Upper Cretaceous and Tertiary marine sedimentary rocks, together with some older spilitic volcanic rocks that may be part of the Franciscan assemblage (Wentworth, 1968). Little basement information from rock samples is available in the shelf areas west of the San Andreas fault between Point Arena and the Mendocino fault. An important well $20 \mathrm{~km}$ west of Point Arena (fig. 9.4) recovered quartz-mica schist and slate basement cuttings (Hoskins and Griffiths, 1971) at a depth of about $1.43 \mathrm{~km}$. This description resembles rocks either from the eastern metamorphosed Franciscan assemblage south of San Francisco or from roof pendants in the Salinian block, implying that a major strike-slip fault is located between the well and Point Arena. The proposed Pilarcitos fault extension is thus interpreted to lie here between the well and the coastline on a major fault shown by McCulloch (1987). Location of this proposed Pilarcitos fault extension farther northwest than Point Arena is uncertain, although the fault presumably continues to the former triple junction. McCulloch (1986; 1987, fig. 2b) described a boundary, termed the "Navarro discontinuity," trending east-west from the Point Arena area to the lower continental slope, on the basis of regional differences in magnetic pattern and physiography; this boundary may be the fault extension or an earlier strike-slip fault of this system. Griscom and Jachens (1989) also hypothesized a more northwestward extension, approximately colinear with the fault segment south of Point Arena, following a fault trace interpreted from seismic-reflection profiles (McCulloch, 1987, fig. 14).

Distinctive gravity and magnetic anomalies characterize the poorly known shelf area lying north of Point Arena and between the San Andreas fault and the proposed Pilarcitos extension (figs. 9.2, 9.3). The sources of these anomalies lie in the basement, with their upper surfaces at the basement interface below Tertiary sedimentary rocks, according to geophysical models and basementdepth calculations. A major gravity high $(+20 \mathrm{mGal})$ is located near lat $40^{\circ} \mathrm{N}$. (point $\mathrm{D}_{2}$, fig. 9.4). We believe that the high-density basement rocks which cause this high extend southward along the west side of the San Andreas fault at least as far as at Point Arena ( $E_{2}$, fig. 9.4), even though the gravity values on the map fall below $0 \mathrm{mGal}$ along the southern part of this reach. The basement along the postulated southern part of the high is mantled by 1 to $3 \mathrm{~km}$ of Tertiary sedimentary rocks (Hoskins and Griffiths, 1971), which probably cause gravity lows (-15 to $-30 \mathrm{mGal}$ ) that here mask the gravity high caused by the basement. Two magnetic anomalies on the shelf are truncated by the San Andreas fault at point $\mathrm{F}_{2}$ and at a place a few kilometers south of point $\mathrm{G}_{2}$ (fig. 9.4), which is located where the steepest gradient on the northeast side of the second anomaly is truncated by the fault (see McCulloch, 1987, fig. 17).

Our search for geophysical anomalies or features matching points $\mathrm{D}_{2}, \mathrm{E}_{2}, \mathrm{~F}_{2}$, and $\mathrm{G}_{2}$ on the opposite (northeast) side of the San Andreas fault (see Griscom and Jachens, 1989) began with the observation that gravity highs are not characteristic of much of the Franciscan assemblage and are observed only extending along the San Andreas fault between approximately lat $37^{\circ}$ and $38^{\circ} \mathrm{N}$. (fig. 9.2). We have selected points $D_{1}$ and $\mathrm{E}_{1}$ (fig. 9.4) as the approximate limits of the gravity highs 
on the northeast side and propose to correlate these points and their connecting strip of high gravity with the corresponding points $\mathrm{D}_{2}$ and $\mathrm{E}_{2}$ and associated gravity high discussed in the previous paragraph. The positions of these points ( $D$ and $E$ ) along the fault vary in reliability but are probably no more accurate than $\pm 20 \mathrm{~km}$; point $\mathrm{E}_{2}$ is the most uncertain. The total offset of the gravity high by the San Andreas fault is thus about $250 \pm 40 \mathrm{~km}$. We have used the gravity results to explore our magneticanomaly map (fig. 9.3) for additional correlations. Only one correlation was found within an offset range of 200-300 km. We suggest that point $\mathrm{F}_{1}$, marking the end of a truncated magnetic high passing through San Francisco, correlates with point $\mathrm{F}_{2}$ and that point $\mathrm{G}_{1}$, the truncated end of a magnetic gradient more than $50 \mathrm{~km}$ long, correlates with the other truncated gradient at point $\mathrm{G}_{2}$. The locations of points $\mathrm{F}_{1}, \mathrm{~F}_{2}$, and $\mathrm{G}_{2}$ along the fault are accurate to within about $\pm 5 \mathrm{~km}$. Point $\mathrm{G}_{1}$ is located a few kilometers too far to the southeast because a short northwestward extension of the feature was recently cut off by the young segment of the San Andreas fault in the San Francisco peninsula area and now lies between the San Andreas and Pilarcitos faults. The offset of points $F_{1}$ and $F_{2}$ is $250 \mathrm{~km}$; the offset of points $G_{1}$ and $\mathrm{G}_{2}$ is $263 \mathrm{~km}$. The magnetic anomalies truncated at points $\mathrm{F}_{1}$ and $\mathrm{G}_{1}$ are associated with northwest-striking belts of mafic and ultramafic rocks within the Franciscan assemblage and are best shown on the more detailed maps by Brabb and Hanna (1981) and Griscom and Jachens (1989).

We conclude that the total offset of the pairs of corresponding magnetic features is approximately $250 \pm 10 \mathrm{~km}$. Of this offset, about $105 \mathrm{~km}$ is attributable to the San Gregorio-Hosgri fault, leaving only $145 \mathrm{~km}$ for the San Andreas fault south of its junction with the San Gregorio fault. Because the total San Andreas offset south of the San Francisco peninsula is considered to be much larger, namely, about $300 \mathrm{~km}$, we suggest that the missing $155 \mathrm{~km}$ is predominantly accounted for by former movement on the Pilarcitos fault and its proposed northwestward extension, which is thought to intersect the San Andreas at about lat $38^{\circ} 30^{\prime}$ N., as described above. This early Pilarcitos fault was thus formerly the main strand of an earlier San Andreas fault system that lay to the west of both magnetic features $\mathrm{F}$ and $\mathrm{G}$ (that is, before they were offset by faulting). Note that this interpreted fault-movement history and the subsequent plate-tectonic analysis all depend on the correctness of the correlation between the pairs of offset magnetic and gravity anomalies on the San Francisco peninsula and northwest of Point Arena. The magnetic and gravity anomalies northwest of Point Arena and west of the San Andreas fault are such conspicuous features and so obviously truncated by the San Andreas fault that we would expect to find their counterparts somewhere on the opposite side of the fault. Although we can find no alternative correlations for these anomalies other than those indicated in figure 9.4, we are aware that they may not correlate with any anomalies on the opposite side of the fault, although we consider this noncorrelation to be unlikely.

Additional information on offset along the proposed Pilarcitos fault extension is provided by interpretation of two strong magnetic anomalies on the northeast side of the San Andreas fault in central California $\left(\mathrm{H}_{1}\right.$ at lat $35^{\circ} 30^{\prime}-35^{\circ} 40^{\prime} \mathrm{N}$. and lat $36^{\circ} 00^{\prime}-36^{\circ} 15^{\prime}$ N., respectively). The source bodies for both anomalies appear to be truncated by the fault, and interpretations of the gravity and magnetic fields over both bodies suggest that they are composed of serpentinite (Hanna and others, 1972; Griscom and Jachens, in press). The most likely candidates for corresponding magnetic features on the southwest side of the fault system are the poorly defined anomalies at points $\mathrm{H}_{2}$ and $\mathrm{I}_{2}$ west of Point Arena. The magnetic field is poorly known in this area, and so anomaly locations and shapes may not be accurate, but the offset is approximately $435 \mathrm{~km}$ from points $\mathrm{H}_{1}$ and $\mathrm{I}_{1}$. This distance can be obtained by summing an assumed $320 \mathrm{~km}$ for offset on the San Andreas fault south of San Francisco plus $115 \mathrm{~km}$ offset on the San Gregorio-Hosgri fault. The location of point $\mathrm{I}_{2}$ supports the Navarro discontinuity as a possible continuation of the proposed Pilarcitos fault extension, or some earlier continuation. We suggest that the large magnetic-high area bounded by the $500-n T$ contour and located $25 \mathrm{~km}$ south of point $\mathrm{I}_{2}$ (fig. 9.3) may represent a southerly extension of anomaly I, which north of point $I_{1}$ extends for $400 \mathrm{~km}$ along the east side of the Coast Ranges. There appear to be no satisfactory alternative anomalies for correlation with points $\mathrm{H}_{1}$ and $\mathrm{I}_{1}$ along the southwest side of the present San Andreas fault near Point Arena.

\section{IMPLICATIONS FOR PLATE TECTONICS}

In the previous sections, we have discussed how potential-field data provide information on the threedimensional configuration of the San Andreas fault and on the various offsets along member faults of the San Andreas system in relation to plate tectonics. Here, we interpret the potential-field expression of the two ends of the San Andreas fault system in relation to plate tectonics and lithospheric thickness.

\section{MENDOCINO TRIPLE JUNCTION}

At the north end of the San Andreas fault off Cape Mendocino, three lithospheric plates (the Juan de Fuca, 
Pacific, and North American) meet at the Mendocino triple junction, where a trench meets two transform faults, the San Andreas and Mendocino faults. Along this trench to the north, the Juan de Fuca plate is subducting eastward beneath the North American plate. The geometry of this subducted plate has important implications (Jachens and Griscom, 1983) for an understanding of the Mendocino triple junction and its effects on the tectonics of California. During approximately the past $29 \mathrm{Ma}$, this triple junction has been migrating relatively northwestward along the coast of California from a latitude near Los Angeles (see fig. 3.11; Atwater, 1970; Atwater and Molnar, 1973). As this incipient San Andreas transform fault lengthened over time, eastward subduction continued to the north of the migrating triple junction.

During 29-23 Ma, the major fault of the San Andreas system was probably situated near the base of the continental slope, where an accreted wedge of Miocene(?) sedimentary rocks (McCulloch, 1987) accumulated between lat $35^{\circ}$ and $40^{\circ} \mathrm{N}$., presumably because of oblique subduction from transpressive forces between the plates. This now-inactive fault forms a contact between oceanic and continental crusts (fig. 9.4) that have major differences in magnetic properties (fig. 9.3). The oceanic crust displays the typical oceanic lineated or striped magnetic pattern striking north-south and northeast, with interruptions striking east-west or southeast that are caused by transform faults. The continental crust adjacent to this inactive fault is magnetically rather smooth and featureless. The magnetic boundary between oceanic and continental crust west of the San Andreas fault is very abrupt in comparison with active subduction zones (compare the magnetic expression of the Cascadia subduction zone off Oregon in Bond and Zietz, 1987); the oceanic stripes terminate at the base of the continental slope, even though reflection profiles show oceanic crust continuing farther east beneath the slope (McCulloch, 1987). The low convergence rate of oblique subduction and the time available since the fault became inactive may have allowed the concealed or subducted oceanic crust to heat up sufficiently beneath the continental margin to destroy the remanent magnetization that causes the stripes.

During early Miocene time (23 Ma), the motion along the transform must have been essentially strike slip and was substantially transferred to the present San Andreas fault system in central California. Without subduction east of the elongating transform, an ever-enlarging triangular hole or window (Dickinson and Snyder, 1979) developed in the slab of lithosphere subducted beneath the continent. This window model is also applicable to the time interval (29-23 Ma) but needs modification to include effects of transpression along the earlier San Andreas fault. The north boundary of this window is the subducted south edge of the Juan de Fuca plate, and hot upwelling asthenospheric material presumably occupies the window. The south edge of the Juan de Fuca plate lies beneath the North American plate at the shore about 20 $\mathrm{km}$ south of Cape Mendocino and can be identified by an east-west magnetic anomaly (Griscom, 1980a), as well as by the distribution of seismicity (Hutchings and others, 1981). This position coincides with a steep gravity gradient (here called the Cape Mendocino gravity anomaly) that slopes downward into a large gravity low ( $-50 \mathrm{mGal})$ to the north and east. The spatial coincidence between the position of the Cape Mendocino gravity anomaly at the coast and the place where the south edge of the Juan de Fuca plate passes beneath the coastline strongly suggests that this gravity anomaly reflects the south edge of the subducted plate (fig. 9.4). At least three other characteristics (Jachens and Griscom, 1983) of the anomaly support this interpretation. (1) The southeastward trend of the gravity anomaly and then its change to easterly are consistent with the directions of present and past relative motions between the Juan de Fuca and Pacific plates (Nishimura and others, 1981; Wilson, 1986). (2) The gravity anomaly broadens and is less steep toward the southeast, suggesting that its source progressively deepens in this direction; calculated depths along the anomaly to the end of the southeast-trending segment define a line plunging approximately $9^{\circ} \mathrm{SE}$. with a depth of only $6 \mathrm{~km}$ at the coastline corresponding well to the $8-\mathrm{km}$ depth estimated from aeromagnetic data (Griscom, 1980a). (3) A cross section across this anomaly, using the above depths together with reasonable densities and thicknesses for the subducted Juan de Fuca plate and the asthenospheric window fill to the southwest, produces a calculated gravity model (Jachens and Griscom, 1983) in good agreement with the observed gravity field. We draw the following conclusions from the gravity data (Jachens and Griscom, 1983).

1. Above the south edge of the Juan de Fuca plate, the North American plate must have the shape of a thin lip that gradually thickens eastward, attaining a thickness of possibly only about $30 \mathrm{~km}$ at the Coast Range fault; this fault marks the east limit of the Franciscan assemblage about $130 \mathrm{~km}$ inland from Cape Mendocino (see chap. 3). Just south of the Juan de Fuca plate, asthenospheric material that filled the slab window should lie beneath the North American plate at a depth comparable to that of the upper surface of the Juan de Fuca plate. Because the North American plate has been moving relatively southward across this boundary for many millions of years, the top of the asthenosphere probably is shallow beneath much of the Coast Ranges in central California, and the thin west lip of the North American plate may be decoupled from much of the mantle, although some underplating by mantle material is likely. 
2. For reasons similar to conclusion 1, the lithosphere of southern California near the San Andreas fault system is thin and may be decoupled from much of the mantle.

3. Relatively thin, decoupled lithosphere may explain why deformation along the boundary between the Pacific and North American plates takes place over a zone 50 to $100 \mathrm{~km}$ wide rather than being restricted to the San Andreas fault, and why the plate boundary has been able to migrate eastward from the base of the continental slope to its present position at the San Andreas fault. It may also explain both why certain structural blocks southwest of the fault in southern California have been able to rotate clockwise by as much as $70^{\circ}-90^{\circ}$ during and after the Miocene (Luyendyk and others, 1985; Hornafius and others, 1986) and how extensional basins formed between these blocks. Furthermore, it can help explain why the seismicity of the San Andreas fault generally does not extend below 12-km depth.

4. Thin, relatively cool lithosphere of the southwardmoving North American plate has been continuously placed on hot upwelling asthenosphere when crossing the Juan de Fuca plate boundary. As pointed out by Lachenbruch and Sass (1980), this process can explain the heat-flow anomaly in the North American plate that peaks in the Coast Ranges about $300 \mathrm{~km}$ south of the latitude of Cape Mendocino (Lachenbruch and Sass, 1973). Calculations by Lachenbruch and Sass (1980) show that, given a velocity of $5 \mathrm{~cm} / \mathrm{yr}$ for movement of the Pacific plate relative to the North American plate, the heat flow should increase by a factor of 2 approximately $200 \mathrm{~km}$ south of the edge of the Juan de Fuca plate because $4 \mathrm{Ma}$ is required for the heat anomaly to reach the surface from $20-\mathrm{km}$ depth. These various parameters agree with the observed heat-flow anomaly. For a heat source as deep as $20 \mathrm{~km}$, the model requires the hot asthenosphere to accrete to the bottom of the North American plate and to be conveyed off southward, so that a continuous supply of vertically moving, hot asthenosphere be supplied to the bottom near the Juan de Fuca plate boundary. This hypothesized coupling involves a rather thin layer of accreting upper mantle that, in turn, is probably decoupled from underlying asthenosphere. The gravitationally predicted depth to the base of the North American plate is within the limits required by Lachenbruch and Sass, (1980) model, at least within $70 \mathrm{~km}$ of the San Andreas fault. Interpretation of geologic and geophysical data for the San Andreas fault system north of San Francisco (Griscom and Jachens, 1989) suggests that eastward migration of the plate boundary from its presumed original position at the base of the continental slope to its present position at the San Andreas transform fault may have occurred by means of a series of eastward jumps of the Mendocino triple junction covering a total distance of about $150 \mathrm{~km}$ during the past $29 \mathrm{Ma}$. Our general model for the history of this triple junction is one of successive eastward jumps, with sustained periods at each position while significant strike-slip motion occurred on the various transform fault systems, including the San Andreas fault. We are aware, however, that the picture in detail may have been far more complex. The present position of the San Andreas fault north of San Francisco is thus interpreted to be relatively youthful. The triple junction was initially situated near the base of the continental slope at the northwest end of the Miocene(?) accreted wedge (but far to the south of its present latitude); the basal fault (McCulloch, 1987) below the subduction complex is shown as a toothed line in figure 9.4 because of the thrust component in this transform fault. The triple junction is interpreted to have been subsequently situated at the north end of the proposed Pilarcitos fault extension and then to have jumped eastward a minimum of about $100 \mathrm{~km}$ to the present San Andreas fault trace at what is now approximately lat $38^{\circ} 20^{\prime} \mathrm{N}$. on the North American plate. When this jump occurred, the three faults that formed the junction all had to readjust; the simplest scenario is as follows: (1) The Mendocino fault was extended on strike farther eastward, for the distance of the jump, about $100 \mathrm{~km}$; (2) a new segment of the San Andreas fault broke obliquely through the Franciscan assemblage to the northwest (severing the correlated geophysical anomalies described above) and extended from the new triple junction to the junction of the newly formed (or soon to be formed) San Gregorio fault with the Pilarcitos fault, a distance of about $250 \mathrm{~km}$; and (3) the surface trace of the subduction zone north of the triple junction also jumped eastward $100 \mathrm{~km}$, thus abruptly isolating a thin triangular slab of Franciscan assemblage (probably less than $15 \mathrm{~km}$ thick) from the North American plate. This postulated triangular slab of rocks is now gone, most likely subducted away. Further complexity is provided by the King Peak subterrane of the King Range terrane (McLaughlin and others, 1982), which is an elongate mass of turbidites, about $45 \mathrm{~km}$ long, just south of Cape Mendocino (fig. 9.4) that is believed to have been obductively accreted from the west during the early Pleistocene (McLaughlin and others, 1986). The King Peak subterrane may have been detached and transported northwestward from the San Francisco area (just south of lat $38^{\circ} 20^{\prime}$ N.) as part of the Pacific plate and then reattached to the North American plate by a very recent local jump of the triple junction westward less than $35 \mathrm{~km}$ (McLaughlin and others, 1982); this explanation may account for the anomalously higher thermal metamorphism of this subterrane relative to the terranes that are now adjacent to it. Recent work suggests that the triple 
junction may be on shore at Cape Mendocino (Clarke, 1988; McLaughlin and others, 1988); if so, the King Peak subterrane may still be essentially part of the Pacific plate. The tectonic interpretation detailed above also requires that the San Gregorio-Hosgri fault first began moving and joined the present San Andreas fault at approximately the same time as or shortly after the eastward jump of the triple junction, and thus cut off the proposed northward extension of the Pilarcitos fault, after which the extension became inactive.

The proposed $150-\mathrm{km}$ eastward movement of the triple junction can also explain the submarine topography near Cape Mendocino, where the Continental Shelf south of the Mendocino fault extends about $130 \mathrm{~km}$ farther west than that directly north of the fault.

The timing of the jump can be estimated from the horizontal offset of the paired geophysical anomalies, about $250 \mathrm{~km}$, which translates to an age of about $5 \mathrm{Ma}$, assuming combined strike-slip rates of $4.8 \mathrm{~cm} / \mathrm{yr}$ (DeMets and others, 1987; Minster and Jordan, 1978) for the San Andreas and San Gregorio faults. This age estimate is crude because it assumes that no other faults were absorbing the relative motion between the two plates. For example, simultaneous movement on the HaywardCalaveras fault system will cause the computed age of offset to be too young. The eastward jump of the triple junction appears to be associated with a change in stress orientations in this region. The north end of the San Gregorio-Hosgri fault trends about $20^{\circ}$ clockwise relative to the older fault traces. In addition, the northwardmigrating triple junction subsequently traced out a major right-lateral bend, as shown by the present position of the San Andreas fault north of Point Arena. The central section of this bend is about $100 \mathrm{~km}$ long and trends $20^{\circ}$ clockwise to the older trace. This change may correlate with the gradual change in absolute motion of the Pacific plate that occurred between 5 and $3.2 \mathrm{Ma}$ (Cox and Engebretson, 1985; Pollitz, 1986), producing a change from strike slip to transpression in this region and a clockwise rotation of $20^{\circ}$ (Harbert and Cox, 1986) in the relative-velocity vector for the plate pair, the same angle as the anomalous change in direction for both the San Gregorio fault and the right-lateral bend in the San Andreas fault north of Point Arena. This change in relative motion probably correlates with a change in strike direction of the subducting south edge of the Juan de Fuca plate, as deduced from gravity data (Jachens and Griscom, 1983). Before the jump, this strike was eastwest, thus permitting eastward extension of the Mendocino transform fault without interference; after the jump, the strike of the subducting plate edge changed to S. $60^{\circ}$ E., making later eastward fault extension more difficult.

Stratigraphic evidence for the postulated eastward jump of the triple junction about 5 Ma may be sought in the late Miocene and Pliocene stratigraphy of Deep Sea Drilling Project (DSDP) Site 173 (fig. 9.4). Depositional hiatuses occur at 5 and 4.3-3.2 Ma (Barron, 1989), whereas a study of both micropaleontology and tephra beds indicates a hiatus from about 4.4 to 2.8-Ma (SarnaWojcicki and others, 1987). McCulloch (1987, fig. 25) believed that the middle Pliocene deformation and minor erosion interpreted from reflection profiles correlate with this 4.4-2.8-Ma hiatus at Site 173. We suggest that the eastward jump of the triple junction about $5 \mathrm{Ma}$ was shortly followed by the middle Pliocene deformation and by the hiatus at Site 173. These two correlative events were thus caused both by the jump and by the simultaneous change in the direction of relative plate motion.

\section{SALTON BUTTES SPREADING CENTER}

The San Andreas fault terminates to the southeast in a buried spreading center at the south end of the Salton Sea, where a row of five small siliceous volcanic domes ("buttes") protrude above recent sedimentary deposits of the Salton Trough. These domes, in addition to being associated with a local northeast-striking magnetic high, are situated on the crest of a larger, northwest-trending magnetic high (outlined on fig. 9.4) that is interpreted (Griscom and Muffler, 1971) to be caused by a magnetic mass, $30 \mathrm{~km}$ long, 3 to $12 \mathrm{~km}$ wide, and about $4 \mathrm{~km}$ thick, with its top buried more than $2 \mathrm{~km}$ below the surface. This magnetic high is associated with a similarly shaped gravity high (Biehler and Rotstein, 1979), the source of which may partly be the magnetic mass but may also be the relatively high density metamorphosed sedimentary rocks associated with the geothermal area (Elders and others, 1972). The Salton Buttes spreading center probably strikes northeast because the row of domes, the local aeromagnetic and gravity anomalies, and the geothermal area all coincide and strike northeast; (2) this proposed position for the center bisects the larger northwesttrending magnetic high into approximately equal parts interpreted to be new "oceanic" crust; and (3), ideally, a spreading center should trend approximately normal to an associated transform fault. In apparent contradiction, the Brawley seismic zone strikes S. $20^{\circ} \mathrm{E}$. from the Salton Sea (Johnson and Hill, 1982) and consists of shallow earthquakes (Severson and McEvilly, 1987) located mostly within the valley fill; this seemingly anomalous direction may be due to accommodation of these overlying, partly decoupled materials to a series of short northeast-trending spreading centers between the Salton Sea and Cerro Prieto, Mexico (see fig. 3.6), on strike S. $20^{\circ} \mathrm{E}$. and $100 \mathrm{~km}$ distant (Fuis and Kohler, 1984; Sibson, 1987). The large, northwest-trending magnetic mass is interpreted to reflect about $30 \mathrm{~km}$ of northwestward spreading along its long axis, in which the spreading was 
associated with intrusive activity that built up a 30 $\mathrm{km}$-long strip of magnetic mafic rocks and new crust in the lower section of and below the sedimentary fill. This magnetic feature may not be directly comparable to oceanic-crustal anomalies because slow cooling beneath the fill probably results in weak remanent magnetization, unlike the situation for oceanic crust. This anomaly thus may be predominantly caused by induced magnetization.

The gravity field of the Salton Trough, which is filled with great thicknesses of Cenozoic sedimentary rocks, varies systematically from north to south. An elongate gravity low of -30 to $-40 \mathrm{mGal}$ is associated with the sedimentary rocks northwest of the Salton Sea (beyond lat $33^{\circ} 20^{\prime}$ N.). Southward along the axis of the trough, the gravity field increases rapidly until the south end of the Salton Sea, where maximum values of $0 \mathrm{mGal}$ are obtained over the presumed spreading center described above. Farther southeast, to the United States-Mexico border, gravity values range from only -10 to $-20 \mathrm{mGal}$, an initially surprising observation because the $3.5 \mathrm{~km}$ or more of young, unmetamorphosed sedimentary deposits in this area might be expected to produce anomalies lower than $-40 \mathrm{mGal}$ (Biehler, 1964; Griscom, 1980c, p. 20 ), similar to the gravity expression northwest of the Salton Sea. Biehler (1964) offered two explanations for the missing low: thinner crust or local high-density basement beneath the trough. Seismic-refraction studies (Fuis and others, 1982, fig. 17A) confirm the second explanation and show a deep "subbasement" (density, 3.1 $\mathrm{g} / \mathrm{cm}^{3}$ ) in the trough that extends below about $12-\mathrm{km}$ depth. Using this refraction model as a constraint, a gravity model (Fuis and others, 1982, fig. 20) indicates that the crust beneath the trough is no thinner than that of the bordering mountains a few kilometers to the northeast.

\section{REFERENCES CITED}

Allen, C.R., 1968, The tectonic environments of seismically active areas along the San Andreas fault system, in Dickinson, W.R., and Grantz, Arthur, eds., Proceedings of conference on geologic problems of San Andreas fault system: Stanford, Calif., Stanford University Publications in the Geological Sciences, v. 11, p. 70-82.

Atwater, Tanya, 1970, Implications of plate tectonics for the Cenozoic tectonic evolution of western North America: Geological Society of America Bulletin, v. 81, no. 12, p. 3513-3635.

Atwater, Tanya, and Molnar, Peter, 1973, Relative motion of the Pacific and North American plates deduced from sea-floor spreading in the Atlantic, Indian, and South Pacific Oceans, in Kovach, R.L., and Nur, Amos, eds., Proceedings of the conference on tectonic problems of the San Andreas fault system: Stanford, Calif., Stanford University Publications in the Geological Sciences, v. 13 , p. 136-148.

Bailey, E.H., Irwin, W.P., and Jones, D.L., 1964, Franciscan and related rocks, and their significance in the geology of western California: California Division of Mines and Geology Bulletin 183, $177 \mathrm{p}$.
Barron, J.A., 1989, The late Cenozoic stratigraphic record and hiatuses of the northeast Pacific: Results from the Deep Sea Drilling Project, in Winterer, E.L., Hussong, D.M., and Decker, R.W., eds., The eastern Pacific Ocean and Hawaii (DNAG Associated Volume GSMV-N): Boulder, Colo., Geological Society of America.

Biehler, Shawn, 1964, Geophysical study of the Salton trough of southern California: Pasadena, Calif., California Institute of Technology, Ph.D. thesis, 139 p.

Biehler, Shawn, and Rotstein, Yair, compilers, 1979, Salton Sea sheet of Bouguer gravity map of California: Sacramento, California Division of Mines and Geology, scale 1:250,000.

Blakely, R.J., and Simpson, R.W., 1986, Approximating edges of source bodies from magnetic or gravity anomalies: Geophysics, v. 51, no. 7, p. 1494-1498.

Bond, K.R., and Zietz, Isadore, 1987, Composite magnetic-anomaly map of the conterminous United States west of $96^{\circ}$ longitude: U.S. Geological Survey Geophysical Investigations Map GP-977, scale $1: 2,500,000$.

Brabb, E.E., and Hanna, W.F., 1981, Maps showing aeromagnetic anomalies, faults, earthquake epicenters, and igneous rocks in the southern San Francisco Bay region, California: U.S. Geological Survey Geophysical Investigations Map GP-932, scale 1:125,000.

Chapman, R.H., 1975, Geophysical study of the Clear Lake region, California; California Division of Mines and Geology Special Report 116, 23 p.

Chuchel, B.A., 1985, POLYGON-an interactive program for constructing and editing the geometries of polygons using a color graphics terminal: U.S. Geological Survey Open-File Report 85-233, 38 p.

Clark, J.C., Brabb, E.E., Greene, H.G., and Ross, D.C., 1984, Geology of Point Reyes peninsula and implications for San Gregorio fault history, in Crouch, J.K., and Bachman, S.B., eds., Tectonics and sedimentation along the California margin: Los Angeles, Society of Economic Paleontologists and Mineralogists, Pacific Section, p. 67-86.

Clarke, S.H., Jr., 1988, Late Cenozoic deformation of the California continental margin north of Cape Mendocino: Implications for Mendocino triple junction location [abs.]: Geological Society of America Abstracts with Programs, v. 20, no. 7, p. A382.

Clarke, S.H., Jr., and Nilsen, T.H., 1973, Displacement of Eocene strata and implications for the history of offset along the San Andreas fault, central and northern California, in Kovach, R.L., and Nur, Amos, eds., Proceedings of the conference on tectonic problems of the San Andreas fault system: Stanford, Calif., Stanford University Publications in the Geological Sciences, v. 13, p. 358-367.

Cox, Allan, and Engebretson, D.C., 1985, Change in motion of Pacific plate at 5 Myr Bp: Nature, v. 313, no. 6002 , p. $472-474$.

Crowell, J.C., 1962, Displacement along the San Andreas fault, California: Geological Society of America Special Paper 71, 61 p.

DeMets, Charles, Gordon, R.G., Stein, Seth, and Argus, D.F., 1987, A revised estimate of Pacific-North America motion and implications for western North America plate boundary zone tectonics: Geophysical Research Letters, v. 14, no. 9, p. 911-914.

Dickinson, W.R., and Snyder, W.S., 1979, Geometry of subducted slabs related to San Andreas transform: Journal of Geology, v. 87, no. 6, p. 609-627.

Elders, W.A., Rex, R.W., Meidav, Tsvi, Robinson, P.T., and Biehler, Shawn, 1972, Crustal spreading in southern California: The Imperial Valley and the Gulf of California formed by the rifting apart of a continental plate: Science, v. 178, no. 4056, p. 15-24.

Feng, Rui, and McEvilly, T.V., 1983, Interpretation of seismic reflection profiling data for the structure of the San Andreas fault zone: Seismological Society of America Bulletin, v. 73, no. 6, p. $1701-1720$. 
Fuis, G.S., and Kohler, W.M., 1984, Crustal structure and tectonics of the Imperial Valley region, California, in Rigsby, C.A., ed., The Imperial Basin-tectonics, sedimentation, and thermal aspects (Volume 40): Society of Economic Paleontologists and Mineralogists, Pacific Section Annual Convention, San Diego, Calif., 1984, Papers, p. 1-13.

Fuis, G.S., Mooney, W.D., Healey, J.H., McMechan, G.A., and Lutter, W.J., 1982, Crustal structure in the Imperial Valley region, in The Imperial Valley, California, earthquake of October 15, 1979: U.S. Geological Survey Professional Paper 1254, p. 25-49.

Geological Society of America, 1987, Magnetic anomaly map of North America: Boulder, Colo., scale 1:5,000,000, 4 sheets.

Godson, R.H., 1985, Preparation of a digital grid of gravity anomaly values of the conterminous United States, in Hinze, W.J., ed., The utility of regional gravity and magnetic anomaly maps: Tulsa, Okla., Society of Exploration Geophysicists, p. 38-45.

Graham, S.A., and Dickinson, W.R., 1978, Apparent offsets of on-land geologic features across the San Gregorio-Hosgri fault trend: California Division of Mines and Geology Special Report 137, p. 13-23.

Griscom, Andrew, 1980a, Aeromagnetic interpretation of the Mendocino triple junction, in Streitz, Robert, and Sherburne, R.W., eds., Studies of the San Andreas fault zone in northern California: California Division of Mines and Geology Special Report 140, p. 121-127.

- 1980b, Aeromagnetic map and interpretation maps of the King Range and Chemise Mountain instant study areas, northern California: U.S. Geological Survey Miscellaneous Field Studies Map MF-1196-B, scale 1:62,500, 2 sheets.

— 1980c, Salton Trough, in Oliver, H.W., ed., Interpretation of the gravity map of California and its continental margin: California Division of Mines and Geology Bulletin 205, p. 20-21.

Griscom, Andrew, and Jachens, R.C., 1989, Tectonic history of the north portion of the San Andreas fault system, California, inferred from gravity and magnetic anomalies: Journal of Geophysical Research, v. 93, no. B4, p. 3089-3099.

Griscom, Andrew, and Jachens, R.C., in press, Tectonic implications of gravity and magnetic models along east-west seismic profiles across the Great Valley near Coalinga, chap. 5 of Rymer, M.J., and Ellsworth, W.L., eds., The Coalinga, California, earthquake of May 2, 1983: U.S. Geological Survey Professional Paper 1487, p. 69-78.

Griscom, Andrew, and Muffler, L.J.P., 1971, Aeromagnetic map and interpretation of the Salton Sea geothermal area, California: U.S. Geological Survey Geophysical Investigations Map GP-754, scale $1: 62,500$.

Griscom, Andrew, and Oliver, H.W., 1980, Isostatic gravity highs along the west side of the Sierra Nevada and the Peninsular Ranges batholiths, California [abs.]: Eos (American Geophysical Union Transactions), v. 61 , no. 46, p. 1126.

Hamilton, Warren, 1978, Mesozoic tectonics of the western United States, in Howell, D.G., and McDougall, K.A., eds., Mesozoic paleogeography of the western United States: Pacific Coast Paleogeography Symposium 2: Los Angeles, Society of Economic Paleontologists and Mineralogists, Pacific Section, p. 33-70.

Hanna, W.F., Brown, R.D., Ross, D.C., and Griscom, Andrew, 1972a, Aeromagnetic reconnaissance along the San Andreas fault between San Francisco and San Bernardino, California: U.S. Geological Survey Geophysical Investigations Map GP-815, scale $1: 250,000$.

Hanna, W.F., Burch, S.H., and Dibblee, T.W., Jr., 1972b, Gravity, magnetics, and geology of the San Andreas fault area near Cholame, California: U.S. Geological Survey Professional Paper 646-C, p. C1-C29.

Harbert, William, and Cox, Allan, 1986, Late Neogene motion of the
Pacific plate [abs.]: Eos (American Geophysical Union Transactions), v. 67 , no. 44 , p. 1225.

Haxel, G.B., and Dillon, J.T., 1978, The Pelona-Orocopia schist and Vincent- Chocolate Mountain thrust system, southern California, in Howell, D.G., and McDougall, K.A., eds., Mesozoic paleogeography of the western United States: Pacific Coast Paleogeography Symposium 2: Los Angeles, Society of Economic Paleontologists and Mineralogists, Pacific Section, p. 453-469.

Heiskanen, W.A., and Moritz, Helmut, 1967, Physical geodesy: San Francisco, W.H. Freeman, 364 p.

Hill, D.P., 1978, Seismic evidence for the structure and Cenozoic tectonics of the Pacific Coast states, in Smith, R.B., and Eaton, G.P., eds., Cenozoic tectonics and regional geophysics of the western Cordillera: Geological Society of America Memoir 152, p. $145-174$.

Hornafius, J.S., Luyendyk, B.P., Terres, R.R., and Kamerling, M.J., 1986, Timing and extent of Neogene tectonic rotation in the western Transverse Ranges, California: Geological Society of America Bulletin, v. 97 , no. 12 , p. 1476-1487.

Hoskins, E.G., and Griffiths, J.R., 1971, Hydrocarbon potential of northern and central California offshore, in Cram, I.H., ed., Future petroleum provinces of the United States-their geology and potential: American Association of Petroleum Geologists Memoir 15, v. 1, p. 212-228.

Hutchings, L.J., Turcotte, F.T., Schnapp, Madeleine, and McPherson, R.B., 1981, Seismicity of the Mendocino triple junction [abs.]: Earthquake Notes, v. 52, no. 1, p. 42-43.

Irwin, W.P., and Barnes, Ivan, 1975, Effect of geologic structure and metamorphic fluids on seismic behavior of the San Andreas fault system in central and northern California: Geology, v. 3, no. 12, p. 713-716.

Isherwood, W.F., 1976, Gravity and magnetic studies of the GeysersClear Lake geothermal region, California, U.S.A.: United Nations Symposium on the Development and Use of Geothermal Resources, 2d, San Francisco, 1975, Proceedings, v. 2, p. 1065-1074.

Jachens, R.C., and Griscom, Andrew, 1983, Three-dimensional geometry of the Gorda plate beneath northern California: Journal of Geophysical Research, v. 88, no. B11, p. 9375-9392.

- 1985, An isostatic residual gravity map of California-a residual map for interpretation of anomalies from intracrustal sources, in Hinze, W.J., ed., The utility of regional gravity and magnetic anomaly maps: Tulsa, Okla., Society of Exploration Geophysicists, p. $347-360$.

Jennings, C.W., Strand, R.G., and Rogers, T.H., compilers, 1977, Geologic map of California: Sacramento, California Division of Mines and Geology, scale 1:750,000.

Johnson, C.E., and Hill, D.P., 1982, Seismicity of the Imperial Valley, in The Imperial Valley, California, earthquake of October 15, 1979: U.S. Geological Survey Professional Paper 1254, p. 15-24.

Karki, Penti, Kivioja, Lassi, and Heiskanen, W.A., 1961, Topographicisostatic reduction maps for the world for the Hayford Zones 18-1, Airy-Heiskanen system, $\mathrm{T}=30 \mathrm{~km}$ : International Association of Geodesy, Isostatic Institute Publication $35,5 \mathrm{p}$.

King, P.B., compiler, 1969, Tectonic map of North America: Washington, U.S. Geological Survey, scale 1:5,000,000, 2 sheets.

Lachenbruch, A.H., and Sass, J.H., 1973, Thermo-mechanical aspects of the San Andreas fault system, in Kovach, R.L., and Nur, Amos, eds., Proceedings of the conference on tectonic problems of the San Andreas fault system: Stanford, Calif., Stanford University Publications in the Geological Sciences, v. 13, p. 190-205. 1980, Heat flow and energetics of the San Andreas fault zone: Journal of Geophysical Research, v. 85, no. B11, p. 6185-6222.

Luyendyk, B.P., Kamerling, M.J., Terres, R.R., and Hornafius, J.S., 1985, Simple shear of southern California during Neogene time suggested by paleomagnetic declinations: Journal of Geophysical 
Research, v. 90, no. B14, p. 12454-12466.

Matti, J.C., Morton, D.M., and Cox, B.F., 1985, Distribution and geologic relations of fault systems in the vicinity of the central Transverse Ranges, southern California: U.S. Geological Survey Open-File Report 85-365, 27 p., scale 1:250,000, 2 sheets.

McCulloch, D.S., 1986, The Vizcaino block south of the Mendocino triple junction [abs.]: Eos (American Geophysical Union Transactions), v. 67 , no. 44 , p. $1219-1220$.

- 1987, Regional geology and hydrocarbon potential of offshore central California, chap. 16 of Scholl, D.W., Grantz, Arthur, and Vedder, J.G., eds., Geology and resource potential of the continental margin of western North America and adjacent ocean basins--Beaufort Sea to Baja California (Earth Science Series, v. 6): Houston, Tex., Circum-Pacific Council for Energy and Mineral Resources, p. 353-401.

McLaughlin, R.J., Kling, S.A., Poore, R.Z., McDougall, Kristin, and Beutner, E.C., 1982, Post-middle Miocene accretion of Franciscan rocks, northwestern California: Geological Society of America Bulletin, v. 93 , no. 7, p. 595-605.

McLaughlin, R.J., Sliter, W.V., Clarke, S.H., Jr., McCulloch, D.S., Frederiksen, N.O., and Engebretson, D.C., 1988, Implications of onshore and offshore structure for location and Cenozoic evolution of the Mendocino triple junction [abs.], Geological Society of America Abstracts with Programs, v. 20, no. 7, p. A382.

McLaughlin, R.J., Sliter, W.V., and Frederiksen, N.O., 1986, Plate motions recorded by tectonostratigraphic terranes adjacent to the Mendocino triple junction [abs.]: Eos (American Geophysical Union Transactions), v. 67, no. 44, p. 1219.

Minster, J.B., and Jordan, T.H., 1978, Present-day plate motions: Journal of Geophysical Research, v. 83, no. B11, p. 5331-5354.

Nicholson, Craig, Seeber, Leonardo, Williams, Patrick, and Sykes, L.R., 1986, Seismicity and fault kinematics through the eastern Transverse Ranges, California: Block rotation, strike-slip faulting, and low-angle thrusts: Journal of Geophysical Research, v. 91, no. B5, p. 4891-4908.

Nishimura, C., Wilson, D.S., and Hey, R.N., 1981, Present-day subduction of the Juan de Fuca plate [abs.]: Eos (American Geophysical Union Transactions), v. 62, no. 17, p. 404.

Oliver, H. W., ed., 1980, Interpretation of the gravity map of California and its continental margin: California Division of Mines and Geology Bulletin 205, $52 \mathrm{p}$.

Oliver, H.W., Chapman, R.H., Biehler, Shawn, Robbins, S.L., Hanna, W.F., Griscom, Andrew, Beyer, L.A., and Silver, E.A., 1980, Gravity map of California and its continental margin: California Division of Mines and Geology California Geologic Data Map 3, scale 1:750,000, 2 sheets.

Pavoni, Nazario, 1973, A structural model for the San Andreas fault zone along the northeast side of the Gabilan Range, in Kovach, R.L., and Nur, Amos, eds., Proceedings of the conference on tectonic problems of the San Andreas fault system: Stanford, Calif., Stanford University Publications in the Geological Sciences, v. 13 , p. $259-267$.

Pollitz, F.F., 1986, Pliocene change in Pacific plate motion: Nature, v. 320 , no. 6064 , p. $738-741$.

Robbins, S.L., 1982, Complete Bouguer gravity, aeromagnetic, and generalized geologic map of the Hollister 15-minute quadrangle, California: U.S. Geological Survey Geophysical Investigations Map GP-945, scale 1:62,500, 2 sheets.

Roberts, C.W., Jachens, R.C., and Oliver, H.W., 1981, Preliminary isostatic residual gravity map of California: U.S. Geological Survey Open-File Report 81-573, scale 1:750,000, 5 sheets.

Ross, D.C., 1970, Quartz gabbro and anorthositic gabbro: Markers of offset along the San Andreas fault in the California Coast Ranges: Geological Society of America Bulletin, v. 81, no. 12, p. 3647-3661. 1984, Possible correlations of basement rocks across the San
Andreas, San Gregorio-Hosgri, and Rinconada-Reliz-King City faults, California: U.S. Geological Survey Professional Paper 1317, $37 \mathrm{p}$.

Saltus, R.W., and Blakely, R.J., 1983, Hypermag: An interactive, two-dimensional gravity and magnetic modeling program: U.S. Geological Survey Open-File Report 83-241, 91 p.

Sarna-Wojcicki, A.M., Morrison, S.D., Meyer, C.E., and Hillhouse, J.W., 1987, Correlation of upper Cenozoic tephra layers between sediments of the western United States and eastern Pacific Ocean and comparison with biostratigraphic and magnetostratigraphic age data: Geological Society of America Bulletin, v. 98, no. 2, p. 207-223.

Schmoker, J.W., 1977, Density variation in quartz diorite determined from borehole gravity measurements, San Benito County, California: $\log$ Analyst, v. 18 , no. 2, p. 32-38.

Severson, L.K., and McEvilly, T.V., 1987, Analysis of seismic reflection data from the Imperial Valley, California [abs.]: Geological Society of America Abstracts with Programs, v. 19, no. 6, p. 449-450.

Sibson, R.H., 1987, Earthquake rupturing as a mineralizing agent in hydrothermal systems: Geology, v. 15, no. 8, p. 701-703.

Silver, E.A., 1974, Structural interpretation from free-air gravity on the California continental margin, $35^{\circ}$ to $40^{\circ} \mathrm{N}$.: Geological Society of America Abstracts with Programs, v. 6, p. 253.

Simpson, R.W., Jachens, R.C., Blakely, R.J., and Saltus, R.W., 1986, A new isostatic residual gravity map of the conterminous United States with a discussion on the significance of isostatic residual anomalies: Journal of Geophysical Research, v. 91, no. B8, p. 8348-8372.

Simpson, R.W., Kelty, T.K., and Rodriguez, E.A., in press, Aeromagnetic map of the Cucamonga Roadless Areas, San Bernardino County, California: U.S. Geological Survey Miscellaneous Investigations Series Map I-1646-C, scale 1:62,500.

Snyder, D.B., Roberts, C.W., Saltus, R.W., and Sikora, R.F., 1982, A magnetic tape containing the principal facts of 64,026 gravity stations in California: U.S. National Technical Information Service Report PB 82-168287, 34 p.

Society of Exploration Geophysicists, 1982, Gravity anomaly map of the United States exclusive of Alaska and Hawaii: Tulsa, Okla., scale $1: 2,500,000$.

Spieth, M.A., 1981, Two detailed seismic studies in central California. Part I: Earthquake clustering and crustal structure studies of the San Andreas fault near San Juan Bautista. Part II: Seismic velocity structure along the Sierra foothills near Oroville, California: Stanford, Calif., Stanford University, Ph.D. thesis, 174 p.

Stanley, R.G., 1987, New estimates of displacement along the San Andreas fault in central Califormia based on paleobathymetry and paleogeography: Geology, v. 15, no. 2, p. 171-174.

Stierman, D.J., 1984, Geophysical and geological evidence for fracturing, water circulation, and chemical alteration in granitic rocks adjacent to major strike-slip faults: Journal of Geophysical Research, v. 89 , no. B7, p. 5849-5857.

Stierman, D.J., and Kovach, R.L., 1979, An in situ velocity study: The Stone Canyon well: Journal of Geophysical Research, v. 84, no. B2, p. $672-678$.

Trehu, A.M., and Wheeler, W.H., IV, 1987, Possible evidence for subducted sedimentary materials beneath central California: Geology, v. 15 , no. 3 , p. $254-258$.

U.S. Department of Energy, 1981, Airborne gamma-ray spectrometer and magnetometer survey, Santa Cruz quadrangle, California: Open-File Report GJBX 50(81), 2 v

U.S. Geological Survey, 1979, Aeromagnetic map of the southern San Bernardino Mountains area, California: Open-File Report 791448 , scale $1: 62,500$ 1987, Aeromagnetic map of the Hernandez-Parkfield area, south- 


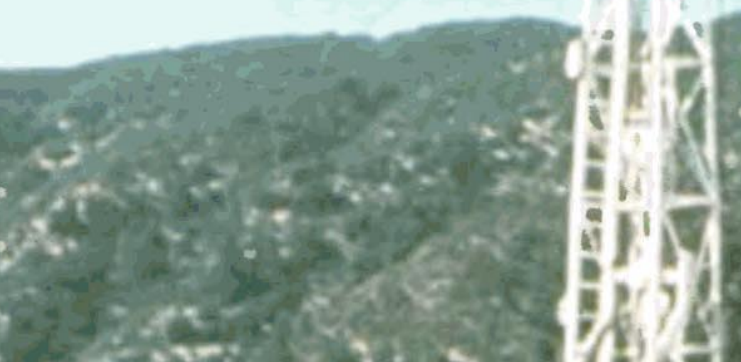

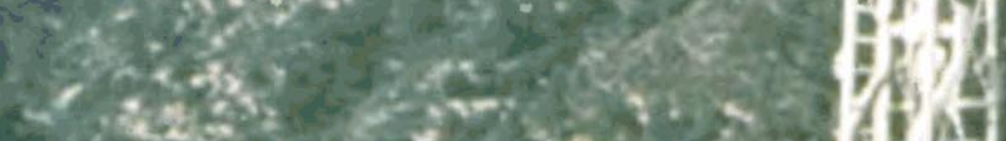

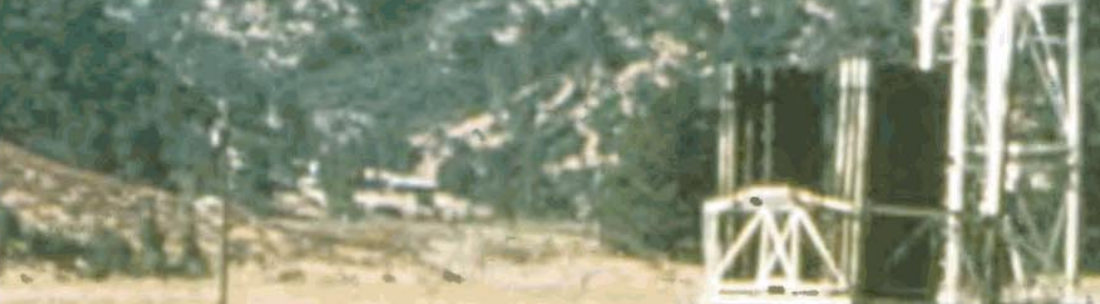

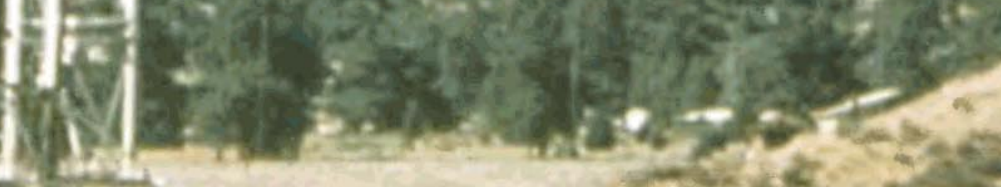

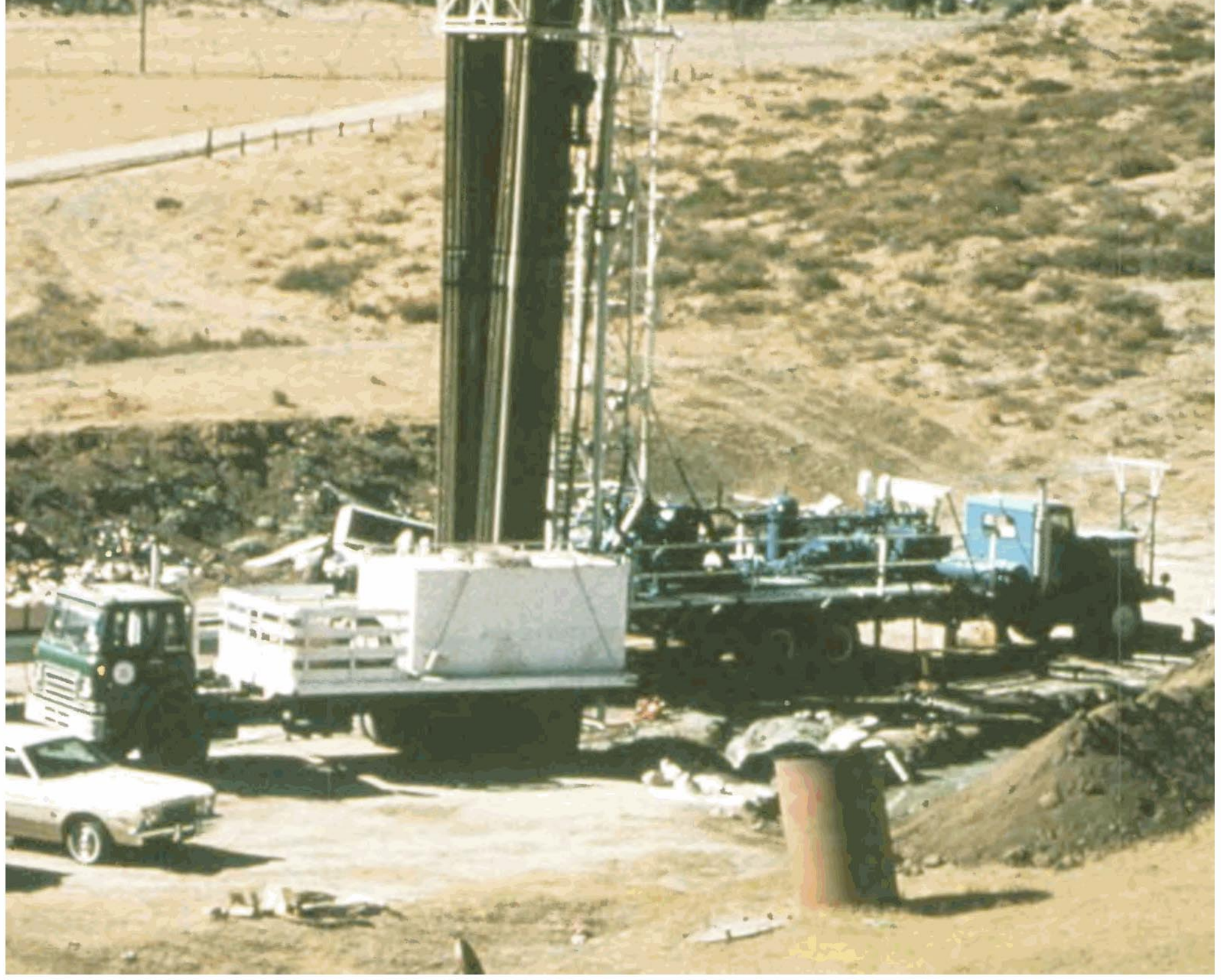


western California: Open-File Report 87-092, scale 1:250,000.

Vedder, J.G., 1987, Regional geology and petroleum potential of the southern California borderland, in Scholl, D.W., Grantz, Arthur, and Vedder, J.G., eds., Geology and resource potential of the continental margin of western North America and adjacent ocean basins-Beaufort Sea to Baja California (Earth Science Series, v. 6): Houston, Tex., Circum-Pacific Council for Energy and Mineral Resources, p. 403-447.

Wang, C.-Y., Feng, Rui, Yao, Zhengsheng, and Shi, Xingjue, 1986, Gravity anomaly and density structure of the San Andreas fault zone: Pure and Applied Geophysics, v. 124, no. 1, p. 127-140.
Wentworth, C.M., 1968, Upper Cretaceous and lower Tertiary strata near Gualala, California, and inferred large right slip on the San Andreas fault, in Dickinson, W.R., and Grantz, Arthur, eds., Proceedings of conference on geologic problems of San Andreas fault system: Stanford, Calif., Stanford University Publications in Geological Sciences, v. 11, p. 130-148.

Wilson, D.S., 1986, A kinematic model for the Gorda deformation zone as a diffuse southern boundary of the Juan de Fuca plate: Journal of Geophysical Research, v. 91, no. B10, p. 10259-10269.

— 1989, Deformation of the so-called Gorda plate: Journal of Geophysical Research, v. 94 , no. B3, p. 3065-3075. 
$A$ s the Pacific plate slides northward past the North American resists plate motion there is overcome to cause earthquakes. However, the frictional heating predicted for the process has never been detected. Thus, in spite of its importance to an understanding of both plate motion and earthquakes, the size of this frictional stress is still uncertain, even in order of magnitude.

\section{STRESS AND HEAT FLOW}

By Arthur H. Lachenbruch and A. McGarr

\section{CONTENTS}

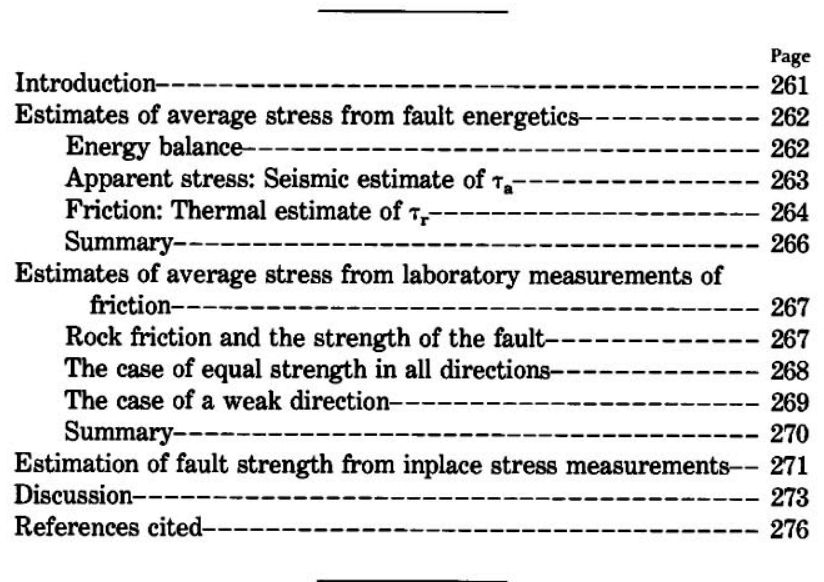

\section{INTRODUCTION}

As one of the best exposed tectonic-plate boundaries in the world, the San Andreas fault provides an excellent opportunity to study the forces causing interplate motion and the associated great earthquakes. Thus, there is considerable motivation, scientific, social, and economic, to understand the thermomechanics of the San Andreas fault system, which has been the subject of intensive studies for the past several decades.
Although substantial progress has been made in unraveling the complex kinematics of the San Andreas fault system (Atwater, 1970; Minster and Jordan, 1984; Weldon and Humphries, 1986), efforts to determine the stresses that give rise to San Andreas fault slip, to date, have not led to anything resembling scientific consensus. The uncertainty results from widespread disagreement over the implications of different methods of assessing the stresses.

The question of how much shear stress acts on the San Andreas fault to cause dextral slip began to acquire definition in 1968, when the first heat-flow data adjacent to the fault zone (fig. 10.1) were gathered and analyzed by Henyey (1968). Because these data did not reveal any anomalous heat flow near the major active faults of the San Andreas system, upper bounds of about 10 to $20 \mathrm{MPa}$ on the average frictional stress resisting fault motion could be calculated (Brune and others, 1969; Henyey and Wasserburg, 1971). These upper bounds were taken as evidence confirming speculation on the low strength of the crust based on earthquake stress drops, almost invariably in the range 0.1-10 $\mathrm{MPa}$ (for example, Chinnery, 1964; Brune and Allen, 1967). At the same time, however, laboratory experiments indicated typical frictional strengths for precut rock samples of about $100 \mathrm{MPa}$ under pressure and temperature conditions thought to obtain in the upper crust (Byerlee and Brace, 1968, 1969; Byerlee, 1970).

FiguRE 10.1. - Heat-flow and stress measurements are taken in wells such as this one being drilled by the U.S. Geological Survey at the Crystallaire site, $4 \mathrm{~km}$ northeast of the San Andreas fault in the western Mojave Desert. Photograph by M.D. Zoback. 
Over the next several years, new heat-flow measurements supported the absence of any local heat-flow anomaly associated with the San Andreas fault (Lachenbruch and Sass, 1973) and thus augmented the position for low frictional fault strength. The recognition of a broad heat-flow high coincident with the Coast Ranges of California led Lachenbruch and Sass (1973) to suggest that partial decoupling at the base of the seismogenic part of the crust might account for both the weak fault (minimum in shear stress at the fault trace) and the broad thermal anomaly.

Additional laboratory experiments on different rock types, and in conditions of higher temperature and confining pressure than had been obtained previously, continued to support high frictional strength in the top 15 to $20 \mathrm{~km}$ of the fault zone (Stesky and Brace, 1973). The experimental results are most simply characterized in terms of a coefficient of friction that varies little with rock type (Byerlee, 1978), slip rate, or slip history (Dieterich, 1979; Ruina, 1983). As emphasized by Brace and Kohlstedt (1980) and Kirby (1980), these results still indicate a high-strength upper crust.

Beginning in the late 1970's, inplace stress measurements have provided another way to assess the stress acting on the San Andreas fault (Zoback and others, 1977), especially with the advent of stress measurements at depths approaching $1 \mathrm{~km}$ only a few kilometers distant from the fault (Zoback and others, 1980). If the observed depth gradient for the component of shear stress thought to act on the San Andreas fault could be extrapolated to the base of the seismogenic zone, as argued by McGarr and others (1982), then the corresponding frictional stress resisting fault motion is a factor of 3 greater than the upper bound from the heat-flow analyses, as presented most recently by Lachenbruch and Sass (1980).

The most recent developments, if accepted at face value, could be construed as additional evidence favoring a low-strength San Andreas fault. Specifically, stressdirection indicators on either side of the fault have been interpreted to mean that there is almost no shear stress resolved on the fault plane, thus implying a very weak fault zone (Mount and Suppe, 1987; Zoback and others, 1987). If so, then the question regarding the strength of the fault would be answered, and the outstanding problem would be the equally vexing one of understanding the nature of a remarkably weak fault zone.

This chapter is largely a review and commentary on the different approaches taken to estimate the tractions acting on the San Andreas fault. We restrict our attention to three main methods: (1) inferring stress from the fault's energy budget (thermal and kinetic), (2) inferring fault strength from laboratory measurements of the stresses needed to slide rocks past one another under pressure, and (3) inferring stress on the fault from observations of the crustal state of stress.

\section{ESTIMATES OF AVERAGE STRESS FROM FAULT ENERGETICS}

\section{ENERGY BALANCE}

In figure 10.2, an earthquake is viewed, according to Reid's (1910) rebound theory, as a strained patch of fault surface of area $A$ that suddenly breaks, permitting points initially in contact to be displaced from one another by an average amount $u$. The breakage is like the sudden failure of an overloaded leaf spring. We are interested in the average shear stress acting parallel to the wall in the failed section of the fault surface. We denote its initial value by $\tau_{1}$ and its final value by $\tau_{2}$. The inclined line in figure 10.3 represents the elastic unloading of the medium as the earthquake displacement increases to its final value $u$. The area under this line, which represents the total elastic energy released by the earthquake per unit area of faulted surface, can be written as

$$
\begin{gathered}
\frac{E}{A}=\bar{\tau} u, \\
\bar{\tau}=\frac{1}{2}\left(\tau_{1}+\tau_{2}\right) .
\end{gathered}
$$

The energy $E$ must supply the work $E_{\text {a }}$ of generating seismic waves and the work $\mathrm{E}_{\mathbf{r}}$, converted to heat in overcoming frictional resisting forces. Thus,

$$
E=E_{\mathrm{a}}+E_{\mathrm{r}}+?,
$$

where the question mark is a reminder (which we shall forget for the moment) that there may be other significant sinks of earthquake energy, such as the surface

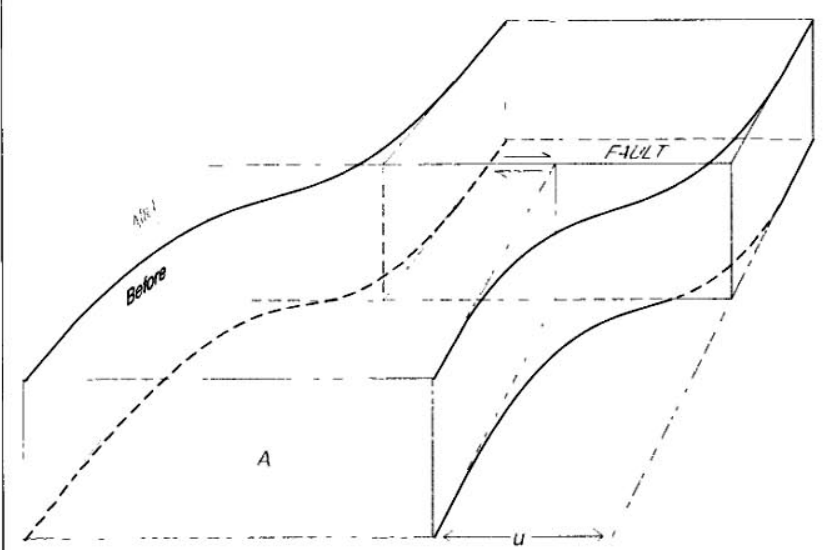

FIGURE 10.2. - Elastic-rebound theory (Reid, 1910), showing displacement near a strike-slip fault segment of area $A$ before and after an earthquake with displacement $u$. Arrows along fault indicate direction of relative movement. 
energy consumed in creating new fractures. We can now write

$$
\begin{aligned}
& \frac{E_{\mathrm{a}}}{A}=\tau_{\mathrm{a}} u \\
& \frac{E_{\mathrm{r}}}{A}=\tau_{\mathrm{r}} u,
\end{aligned}
$$

where $\tau_{\mathrm{a}}$, the "apparent stress" of seismology, is the portion of the earthquake stress $\bar{\tau}$ allocated to the production of seismic waves, and $\tau_{r}$ is the average frictional resisting stress allocated to the production of heat. The individual areas represented by equations 3 and 4 are shown in figure 10.3 by contrasting patterns.

This interpretation of the areas in figure 10.3 is fairly general, as long as we define $\tau_{1}, \tau_{2}$, and $\tau_{r}$, respectively, as the weighted averages of initial stress, final stress, and friction over the faulted surface, the weighting function being the local fault slip (see Savage and Wood,

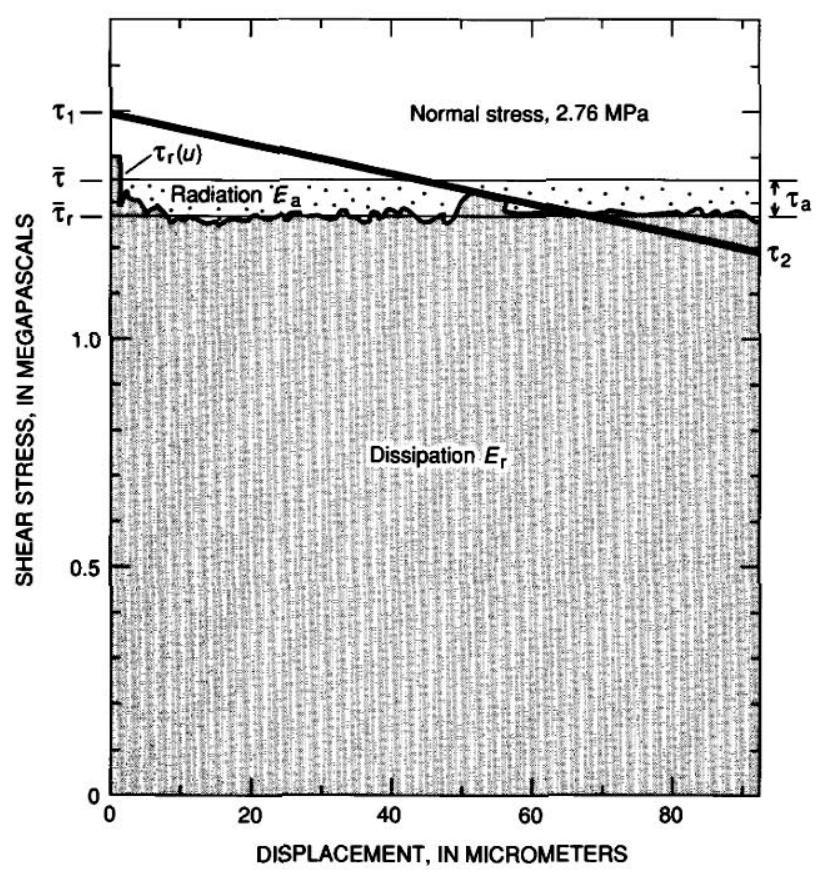

FIGURE 10.3. - Relation between resisting stress and displacement in the unloading elastic medium (inclined line) during an earthquake. As slip $(u)$ increases, stress in the rock diminishes linearly from $\tau_{1}$ to $\tau_{2}$, with average value $\bar{\tau}$. Area under this line is total work expended per unit fault area; area (shaded) below curve of resisting stress $\left(\tau_{\mathrm{r}}(u)\right.$, with average value $\left.\bar{\tau}_{r}\right)$ is energy dissipated per unit fault area $\left(E_{\mathbf{r}}\right)$. Difference between total work expended and dissipated energy is work (done by apparent stress $\tau_{\mathrm{a}}$ ) that is available for seismic radiation $\left(E_{\mathrm{a}}\right.$, stippled area). Modified from a laboratory experiment on a large granite sample by Lockner and Okubo (1983).
1971; Lachenbruch and Sass, 1980). Combining equations 1 through 4 yields

$$
\bar{\tau}=\tau_{\mathrm{a}}+\tau_{\mathrm{r}}+?,
$$

which states that unless the question mark represents something important that we've neglected, the average earthquake stress $\bar{\tau}$ is the sum of the apparent stress $\tau_{a}$, to be estimated from seismic measurements of $E_{\mathrm{a}}$ (eq. 3), and the resisting stress $\tau_{r}$, to be estimated from thermal measurements of frictional heat $E_{\mathrm{r}}$ (eq. 4).

\section{APPARENT STRESS: SEISMIC ESTIMATE OF $\tau_{\star}$}

Seismologists (for example, Wyss and Brune, 1968; Savage and Wood, 1971; Wyss and Molnar, 1972) have defined apparent stress as

$$
\tau_{\mathrm{a}}=\eta \bar{\tau},
$$

where $\eta$ is the seismic efficiency, defined by

$$
\begin{aligned}
\eta & =\frac{E_{\mathrm{a}}}{E} \\
& =\frac{\tau_{\mathrm{a}}}{\bar{\tau}},
\end{aligned}
$$

where equation $7 \mathrm{~b}$ follows from $7 \mathrm{a}$ according to equations 2 through 5; that is, $\eta$ is simply the fraction of the total energy release, or the fraction of the average earthquake stress, allocated to seismic radiation.

To estimate $\tau_{a}$, seismologists first determine the radiated energy $E_{\mathrm{a}}$ and the seismic moment $M_{0}$, defined as

$$
M_{0}=G A u \text {, }
$$

where $u$ is the average slip of an earthquake over a fault-surface area $A$, and $G$ is the modulus of rigidity (Aki, 1966). Equations 1 and 6 through 8 then yield the simple relation

$$
\tau_{\mathrm{a}}=\frac{G E_{\mathrm{a}}}{M_{0}} .
$$

A numerical estimate of $\tau_{\mathrm{a}}$ can be obtained from equation 9 with the following commonly used formulas relating earthquake magnitude $M$ to $E_{\mathrm{a}}$ or $M_{0}$ (Gutenberg and Richter, 1956; Hanks and Kanamori, 1979),

$$
\begin{aligned}
& \log M_{0}=16+1.5 M \\
& \log E_{\mathrm{a}}=11.8+1.5 M,
\end{aligned}
$$


where $M_{0}$ and $E_{\mathrm{a}}$ are in ergs. Substitution of equations 10 in 9 yields

$$
\tau_{\mathrm{a}}=6.3 \times 10^{-5} \mathrm{G} .
$$

With $G=3 \times 10^{4} \mathrm{MPa}$, the value for $\tau_{\mathrm{a}}$ is $2 \mathrm{MPa}$. Almost without exception, estimates of $\tau_{\mathrm{a}}$ fall within the range $0-5 \mathrm{MPa}$, with no indication of any systematic dependence on either earthquake size or tectonic environment (Spottiswoode and McGarr, 1975; Fletcher and others, 1983; Boatwright and Choy, 1986). In short, $5 \mathrm{MPa}$ appears to be a conservative upper bound to $\tau_{\mathrm{a}}$. Thus, the contribution of $\tau_{\mathrm{a}}$ is small, and the average fault stress $\bar{\tau}$ can be large only if the frictional resistance $\tau_{\mathbf{r}}$ is large (eq. 5).

If laboratory "earthquakes" are proper analogs of crustal earthquakes, which may or may not be the case, then data for such events, including those illustrated in figure 10.3, indicate that $\tau_{\mathrm{a}}$ is indeed small, only a tiny fraction of $\tau_{\mathrm{r}}$. By inducing unstable frictional failure (earthquakes) across a 2-m-long fault between slabs of granite $40 \mathrm{~cm}$ thick (Dieterich, 1981), Lockner and Okubo (1983) measured seismic efficiencies $\eta$ for numerous events to conclude that $\eta \approx 0.05$. If this result were true also for natural earthquakes-a big "if"-then for a typical value $\tau_{\mathrm{a}}$ of $2 \mathrm{MPa}$, the corresponding value of $\bar{\tau}$, from equation 6 , would be $40 \mathrm{MPa}$, which, as will be seen, is nearly 3 times higher than the limit inferred from an analysis of heat-flow data (Lachenbruch and Sass, 1980).

\section{FRICTION: THERMAL ESTIMATE OF $\boldsymbol{\tau}_{\mathbf{r}}$}

Unlike the energy of seismic waves, which permits an estimate of apparent stress $\tau_{\mathrm{a}}$ for individual earthquakes from measurements at distant stations, the heat energy of individual earthquakes is not readily analyzable to estimate friction because it causes a measurable temperature rise only within a few meters of the earthquake source, a location inaccessible for measurement. Even for the largest earthquakes, these individual temperature pulses would be indistinguishable from background a few months after the event, and so timely attempts to detect them by drilling would be difficult (McKenzie and Brune, 1972; Lachenbruch, 1986). However, because the frictionally generated heat diffuses quite slowly, it should accumulate in the vicinity of the fault, eventually building up the local thermal gradient until the observable heat loss at the Earth's surface in the fault zone exceeds the normal background heat flow by the rate of heat generation on the fault. Thus, in principle, the measurement of a heat-flow anomaly in the fault zone should permit an estimate of the average frictional contribution $\tau_{\mathbf{r}}$ to the earthquake fault stress $\bar{\tau}$ (eq. 5).
The heat-flow anomaly that we seek does not depend on the amount of heat $E_{\mathrm{r}}$ liberated by a single earthquake in a restricted fault area with a displacement $u$ (eq. 4), but on the long-term average rate of heat generation $(Q)$ and the long-term average slip rate $(v)$ from the cumulative effect of successive events. Although most fault displacement probably occurs within a few tens of seconds during large earthquakes every century or so at slip velocities greater than the average ones by a factor of about $10^{8}$, the long-term buildup of the heat-flow anomaly would be indistinguishable from that caused by uniform slip at an equivalent average velocity because the thermal time constant for the buildup (approx $10^{6} \mathrm{yr}$ ) is large relative to the earthquake-recurrence interval $\left(10^{1}-10^{3}\right.$ yr). Therefore, we view the slip as a uniform continuous process and introduce

$$
\begin{gathered}
Q=\frac{1}{A} \frac{d E_{r}}{d t} \\
v=\frac{d u}{d t} .
\end{gathered}
$$

Differentiation of equation 4 yields

$$
Q=\tau_{\mathbf{r}} v,
$$

where $v$ is the long-term average slip velocity, $\tau_{\mathrm{r}}$ is the (displacement averaged) frictional resistance, and $Q$ is the long-term average rate of frictional heat production per unit area on the fault surface.

Equation 13 refers to the entire seismogenic (brittle) layer (approx 10-15 km thick), not just a patch as in equation 5. Over this depth, it is reasonable to consider the long-term slip velocity $v$ to be independent of depth, but generally the heat-production rate $Q$ will not be. For example, if the friction $\tau_{\mathrm{r}}$ increased linearly with depth (for example, because of increasing gravitational pressure on the fault, as discussed below), the heat production $Q$ on the fault would also increase linearly, as shown in figure 10.4B. According to heat-conduction theory, the temperature in the fault plane would then build up over time, as shown in figure $10.4 C$, and a heat-flow anomaly would develop at the surface over the fault, as shown in figure 10.4A. For such a distribution, a sharp heat-flow anomaly is seen to build up over the fault in about $1 \mathrm{~m} . y$.; after several million years, it approaches a maximum value somewhat greater than half the average frictional heat production $Q$ on the fault surface (fig. 10.4B). This anomaly falls off over a distance from the fault of the same order as the depth of the seismic layer (assumed to be $14 \mathrm{~km}$ in fig. 10.4). Other reasonable distributions of 
frictional sources give similar results (see Henyey, 1968; Brune and others, 1969; Henyey and Wasserburg, 1971; Lachenbruch and Sass, 1973, 1980).

The long-term slip rate $v$, which can be estimated from studies of offset (and dated) geologic features, generally ranges from 2 to $4 \mathrm{~cm} / \mathrm{yr}$ for motion on the main trace of the San Andreas fault over the past several million years throughout California (see chap. 7; Grantz and Dickinson, 1968). As a useful rule of thumb, if the fault in figure 10.4 were slipping at an average rate $(v)$ of $3 \mathrm{~cm} / \mathrm{yr}$ and
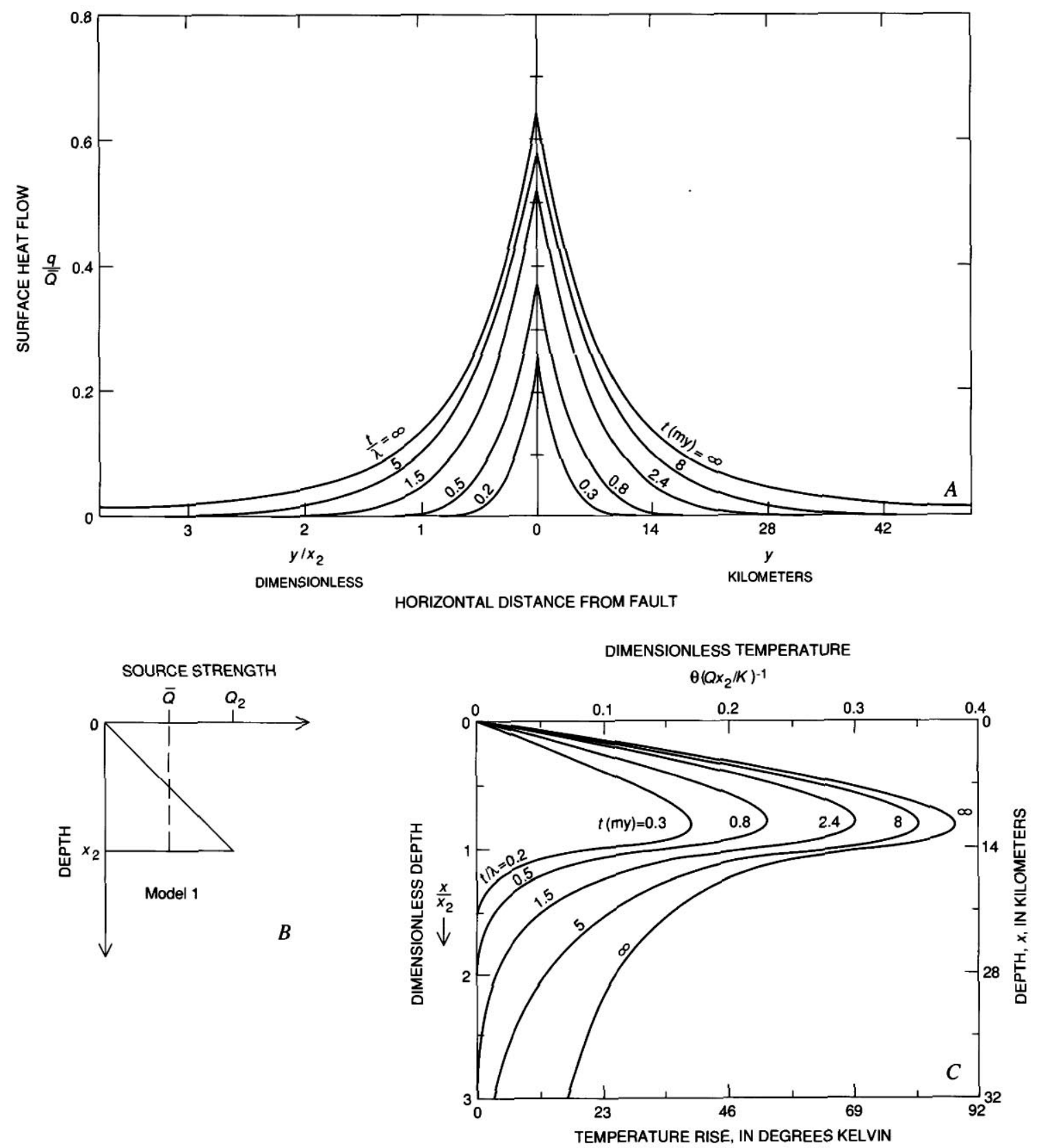

FIGURE 10.4. - Surface heat flow $q(A)$ and fault-plane temperature $\Theta(C)$ for a linear increase in source strength from zero at the surface to $Q_{2}$ at depth $x_{2}(B) . t$, time since initiation of faulting; $\lambda$, dimensionless time; $Q$, average rate of frictional heat generation on fault; $K$, thermal conductivity. Dimensional results are for $x_{2}=14 \mathrm{~km}, K=2.5 \mathrm{~W} / \mathrm{mK}$, and $Q=42 \mathrm{~mW} / \mathrm{m}^{2}$ (equivalent to $2 v \simeq 25 \mathrm{~mm} / \mathrm{yr}, \tau_{\mathrm{r}} \approx 50 \mathrm{MPa}$ ) (Lachenbruch and Sass, 1980). 
resisted by an average frictional stress $\tau_{\mathrm{r}}$ of $100 \mathrm{MPa}$, then the average rate of frictional heat production $Q$ (figure $10.4 B$ ) would be about $0.1 \mathrm{~W} / \mathrm{m}^{2}$; that is,

$$
0.1 \mathrm{~W} / \mathrm{m}^{2}=100 \mathrm{MPa} \times 3 \mathrm{~cm} / \mathrm{yr} .
$$

This quantity is about twice the stable continental heat flow, and so, according to figure $10.4 \mathrm{~A}$, the corresponding heat-flow anomaly over the fault would be about 100 percent of background after 2 or $3 \mathrm{~m} . \mathrm{y}$. of fault slip, whereas if the mean frictional resistance were only 10 $\mathrm{MPa}$, the corresponding heat-flow anomaly would be only about 10 percent of background, close to the limit of detection. Accordingly, if no heat-flow anomaly could be detected over the fault, the mean frictional resistance would be no more than about $10 \mathrm{MPa}$; if the mean frictional resistance were about $100 \mathrm{MPa}$, a very conspicuous anomaly should be observed.

An example of heat-flow measurements near the San Andreas fault is shown in figure $\mathbf{1 0 . 5}$ for the Mojave Desert region of southern California (region 7, fig. 10.6). The pattern of anomaly curves from the model in figure
10.4 is scaled for the estimated local slip velocity (25 $\mathrm{mm} / \mathrm{yr}$; Weldon and Sieh, 1985) and for a mean frictional resistance of $50 \mathrm{MPa}$. Clearly, the data are incompatible with such an anomaly; in fact, the average heat flows near the fault and far from the fault ("within $10 \mathrm{~km}$ " and "beyond $10 \mathrm{~km}$," figs. $10.7 C, 10.7 D$ ) are statistically indistinguishable. Figures $10.7 A$ and $10.7 B$ show that the same condition prevails in the Coast Ranges of central California (regions 3-6, fig. 10.6). In fact, no local heat-flow anomaly has been confirmed anywhere on the main trace of the San Andreas fault (for possible exceptions, see Lee, 1983; Lachenbruch and Sass, 1988), and so, according to the foregoing simple considerations, the average friction on the fault, $\tau_{r}$, probably does not exceed $10 \mathrm{MPa}$.

\section{SUMMARY}

In summary, we note that analysis of the kinetic energy of seismic waves suggests that the associated apparent stresses $\left(\tau_{\mathrm{a}}\right)$ do not exceed $5 \mathrm{MPa}$. Similarly, analysis of long-term frictional heating and the predicted and observed effects on heat flow from conduction theory

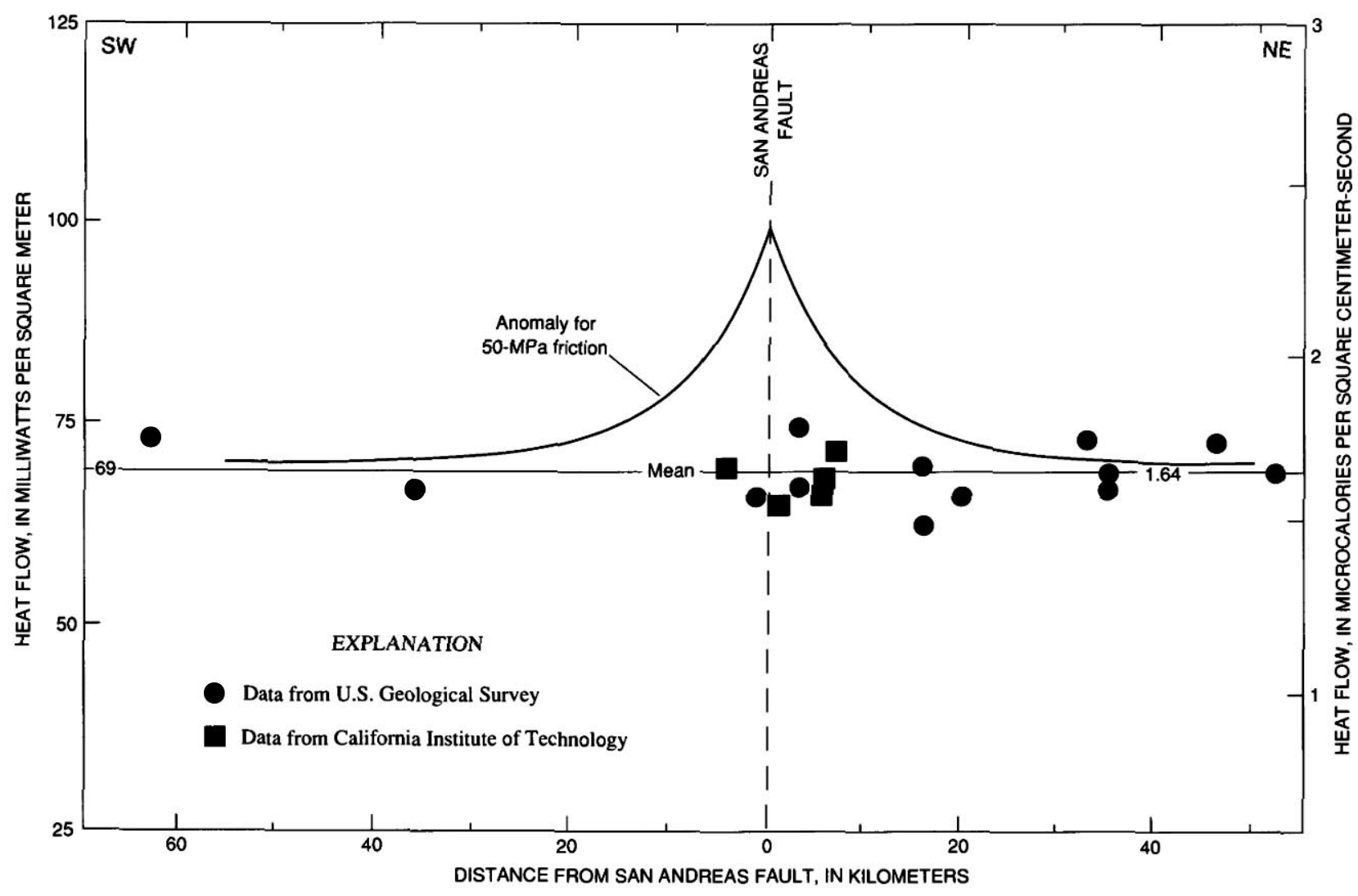

FIGURE 10.5. - Heat flow as a function of distance from the San Andreas fault in the Mojave segment (region 7, fig. 10.6). Theoretical anomaly is for a slip velocity of $25 \mathrm{~mm} / \mathrm{yr}$ and average friction of $50 \mathrm{MPa}$ (Lachenbruch and Sass, 1988). 
suggest that the average frictional resistance $\tau_{\mathrm{r}}$ does not exceed about $10 \mathrm{MPa}$. Thus, according to equation 5 , the long-term average combined earthquake stress $\bar{\tau}$ probably does not exceed about $15 \mathrm{MPa}$, and, of course, it could be much less. The initial stress $\tau_{1}$, or "fault strength," would be greater by half the stress drop (fig. 10.2; Lachenbruch and Sass, 1980, eq. 41a), no more than another $5 \mathrm{MPa}$, for an upper limit of $20 \mathrm{MPa}$. The major assumptions in this analysis are (1) that heat transfer is exclusively by conduction - that is, no significant heat is transferred by moving ground water; (2) that the fault geometry can be represented by the usual simple conventions (see figs. 10.2, 10.3, and 10.4); and (3) that an earthquake's energy is converted exclusively to seismic waves and heat-that is, no appreciable energy is consumed by creating new surfaces, phases, or chemical combinations (Lachenbruch and Sass, 1973, 1980). We shall discuss these points later.

\section{ESTIMATES OF AVERAGE STRESS FROM LABORATORY MEASUREMENTS OF FRICTION}

\section{ROCK FRICTION AND THE STRENGTH OF THE FAULT}

We have seen that the average shear stress $\bar{\tau}$ on an earthquake fault can be viewed as the sum of a dynamic part $\tau_{\mathrm{a}}$ and a frictional part $\tau_{\mathrm{r}}$. The dynamic part is shown

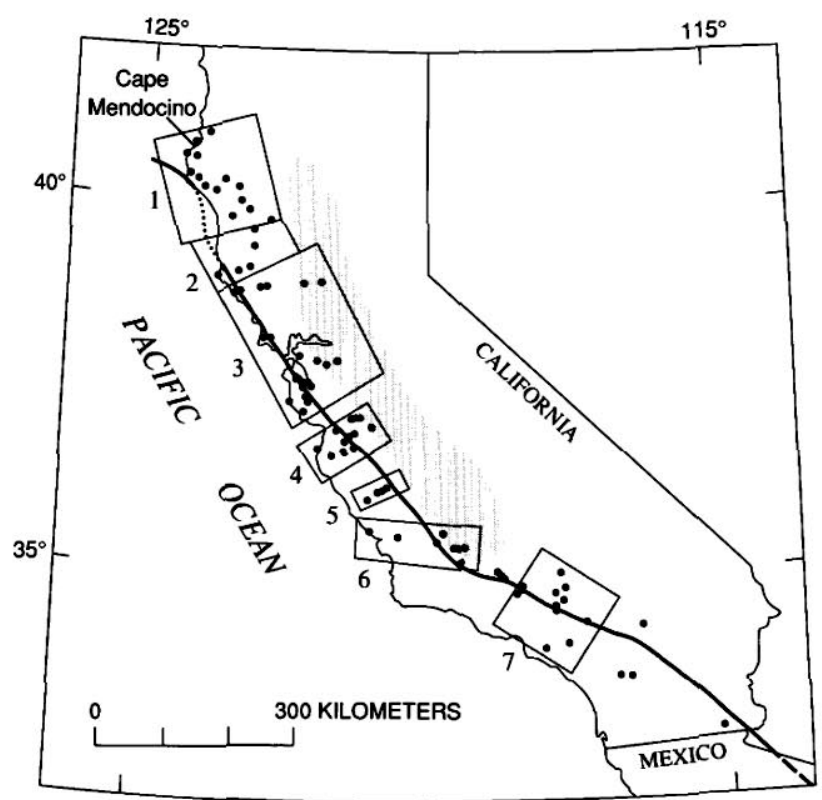

FIGURE 10.6.-Locations of heat-flow measurements near the San Andreas fault and of numbered regions referred to in figure 10.7 (Lachenbruch and Sass, 1980). Heavy line, San Andreas fault, dashed where approximately located, dotted where concealed; stippled area, Great Valley. to be small from seismic evidence, and so the earthquake stress must be large or small according to the size of $\tau_{r}$. We have also seen that $\tau_{\mathrm{r}}$ is small according to geothermal evidence. We now consider a second line of evidence from laboratory measurement of friction which suggests to many that, contrary to the geothermal evidence, $\tau_{\mathbf{r}}$ must be large.

According to these results, rock surfaces will slide when the shear stress on their surface of contact exceeds the static frictional strength $\tau_{\mathrm{f}}$, given by

$$
\tau_{\mathrm{f}}=\mu \sigma_{\mathrm{n}}^{\prime},
$$

where

$$
\sigma_{\mathrm{n}}^{\prime}=\sigma_{\mathrm{n}}-P
$$

$\sigma_{n}$ is the normal pressure pushing the surfaces together, and $P$ is the fluid pressure in the pores and cracks tending to hold the surfaces apart; $\sigma_{n}^{\prime}$ is called the "effective" normal stress (we generally denote such effective stresses by a prime, “'”). The proportionality constant $\mu$ in equation 15a is the coefficient of static friction; extensive laboratory experiments show that its value is generally in the range $0.6-0.9$ for a remarkably large variety of rock types and surface conditions (Byerlee, 1978), although some studies (for example, Wang and others, 1980), reported substantially lower friction coefficients for some geologic materials, including certain types of fault gouge.

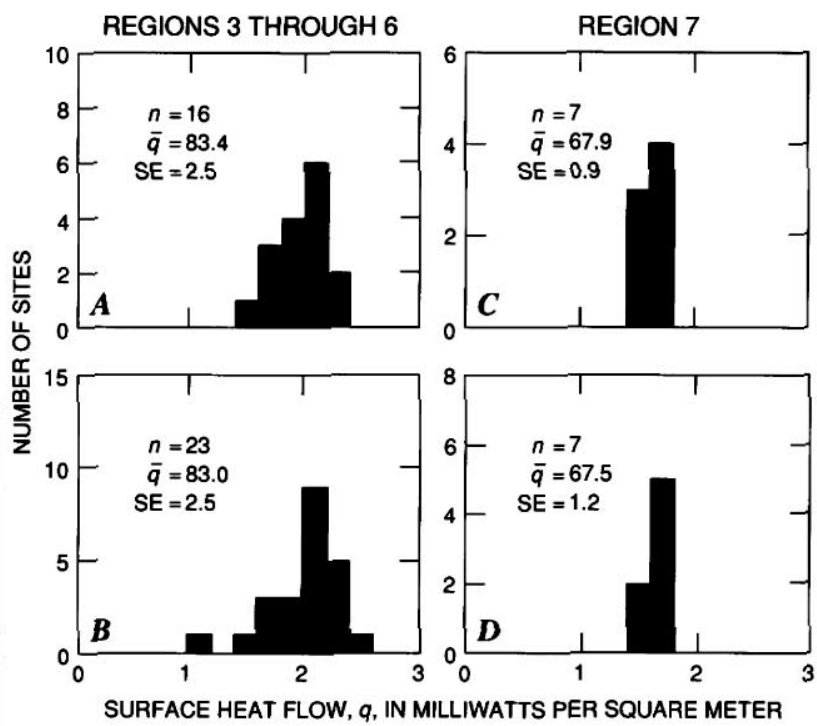

FIGURE 10.7. - Comparison of heat flow within $10 \mathrm{~km}$ of main trace of the San Andreas fault $(A, C)$ and beyond $10 \mathrm{~km}(B, D)$ for regions 3-6 $(A, B)$ and region $7(C, D)$ (see fig. 10.6 for locations); transitional regions 1 and 2 are not represented. Modified from Lachenbruch and Sass (1980). $n$, number of samples; $\bar{q}$, mean heat flow; SE, standard error. 
We presume that a fault is a fracture with little cohesive strength that remains inactive until the natural shear stress $\tau$ resolved along it exceeds its frictional strength $\tau_{f}$ given by equation 15 . This shear stress, which depends on the magnitudes of the principal stresses and on the angular relation between the fault plane and the principal stress directions (fig. 10.8), is given by (Jaeger, 1956, p. 8)

$$
\tau=\frac{1}{2}\left(\sigma_{1}-\sigma_{3}\right) \sin 2 \theta,
$$

where it is assumed for convenience that the intermediate-principal-stress direction $\left(\sigma_{2}\right)$ lies in the fault plane (true if $\mu$ is independent of the orientation of this plane). In figure 10.8, $\sigma_{2}$ is vertical, and $\sigma_{1}$ and $\sigma_{3}$ are the maximum and minimum horizontal principal stresses. $\theta$ is the angle formed by the fault normal and the direction of least compression $\left(\sigma_{3}\right)$; it is also the angle between the fault trace and the direction of greatest compression $\left(\sigma_{1}\right)$. To express the failure criterion (eq. 15) in terms of the stress field and fault orientation, we note that the effective normal stress, $\sigma_{n}^{\prime}$, in equation 15 can be written as (Jaeger, 1956, p. 8)

$$
\sigma_{n}^{\prime}=\frac{1}{2}\left(\sigma_{1}^{\prime}+\sigma_{3}^{\prime}\right)-\frac{1}{2}\left(\sigma_{1}^{\prime}-\sigma_{3}^{\prime}\right) \cos 2 \Theta .
$$

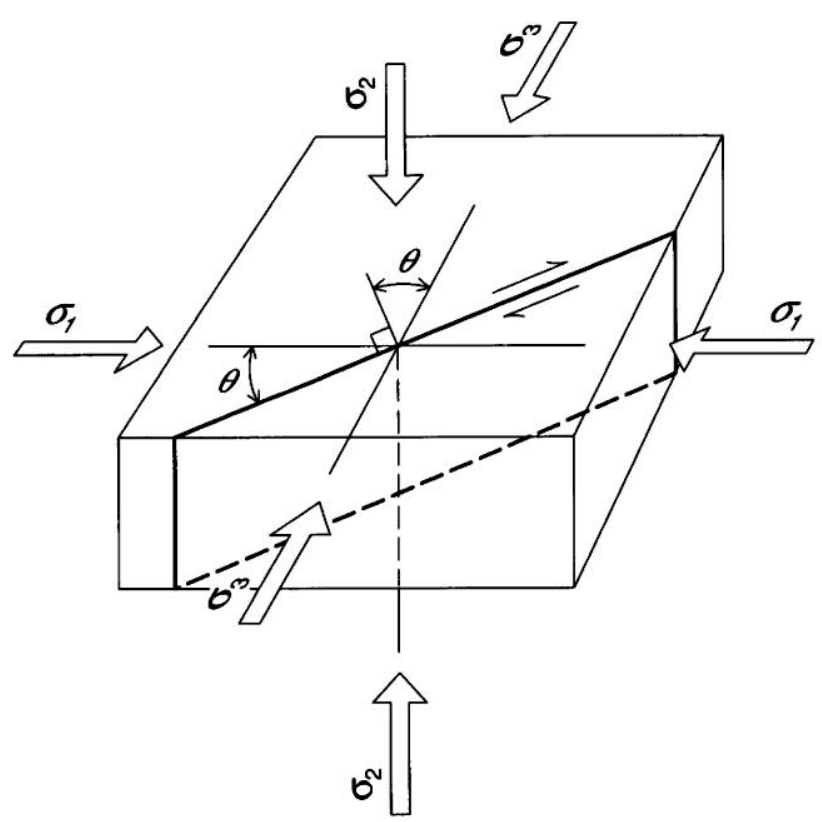

FigURE 10.8. - Conventions for discussing orientation of fault relative to direction of principal stresses: $\sigma_{1}>\sigma_{2}>\sigma_{3}$. Arrows indicate direction of relative movement along fault.
With equations 15 through 17 , the friction stress $\tau_{\mathrm{f}}$ that must be exceeded on a fault for it to slip can be determined if we know (1) the maximum and minimum principal stresses $\sigma_{1}$ and $\sigma_{3}$, (2) the fluid pressure $P$, (3) the coefficient of friction $\mu$, and (4) the angle $\Theta$ describing the orientation of the fault relative to the principal-stress axes.

As we increase the stress difference, in what direction $(\Theta)$ will the Earth ultimately break, and what will be the stress on the failure plane? Clearly, the answer could be influenced by the existence of planes of weakness (McKenzie, 1969); for example, major preexisting faults or foliated country rock might result in directions with anomalously low $\mu$.

\section{THE CASE OF EQUAL STRENGTH IN ALL DIRECTIONS}

We first assume that no such directional strength variation exists, that the rock is fractured in all directions, and that all potential shear surfaces have the same coefficient of friction $\mu$. In this case, the foregoing equations show that the trace of the favored fault plane will depart from the direction of maximum compression by an angle $\Theta_{0}$, dependent only on the coefficient of friction, as follows:

$$
\Theta_{0}=45^{\circ}-\frac{1}{2} \tan ^{-1} \mu
$$

Note that generally $\Theta_{0}<45^{\circ}$ (the direction of the surface of maximum resolved elastic shear stress, eq. 16) because of the effects of normal stress on friction (Jaeger, 1956). With this additional relation (eq. 18), we can express the frictional strength $\tau_{f}$ of a plane of orientation $\theta$ in terms of the coefficient of friction and the effective-principalstress components as follows:

$$
\begin{array}{rlr}
\frac{\tau_{f}}{\sigma_{1}^{\prime}} & =\frac{\mu}{1+\mu \cot \theta} \\
& =\frac{\mu}{1+\mu^{2}}\left(1+\frac{\mu}{\sqrt{1+\mu^{2}}}\right)^{-1}, \quad \theta=\theta_{0} \\
\frac{\tau_{f}}{\sigma_{3}^{\prime}} & =\frac{\mu}{1-\mu \tan \theta} \\
& =\frac{\mu}{1+\mu^{2}}\left(1+\frac{\mu}{\sqrt{1+\mu^{2}}}\right)^{-1}, \quad \theta=\theta_{0}
\end{array}
$$




$$
\begin{aligned}
\frac{\tau_{\mathrm{f}}}{1 / 2\left(\sigma_{1}^{\prime}+\sigma_{3}^{\prime}\right)} & =\frac{\mu}{1+\mu \cot 2 \theta} & \\
& =\frac{\mu}{1+\mu^{2}}, & \theta=\theta_{0}
\end{aligned}
$$

To evaluate the frictional strength, the vertical stress is generally assumed to be a principal stress (reasonable because the Earth's surface supports no traction) equal to the rock column's weight, $\rho g z$, an assumption supported by inplace stress measurements (McGarr and Gay, 1978). In this case, the vertical effective stress $\sigma_{\mathbf{v}}^{\prime}$ will be

$$
\sigma_{\mathrm{v}}^{\prime}=\rho g z-P,
$$

where $\rho$ is the rock density, and the fluid pressure $P$ is given by

$$
P=\lambda \rho g z
$$

The value $\lambda=0$ represents conditions in dry rock. For a typical open ("hydrostatic") hydrologic system, we have $\lambda \sim 0.37\left(=\rho_{\mathrm{w}} / \rho_{\text {rock }}\right.$, where $\rho_{\mathrm{w}}$ is the density of water). As $\lambda \rightarrow 1$, the fluid pressure approaches the weight of overburden, and the vertical effective stress $\sigma_{v}^{\prime}$ vanishes (as discussed below, this limit probably occurs only in the thrusting regime, where $\sigma_{3}$ is vertical).

The curves in figure 10.9 (referred to ordinate scale at left margin) give the frictional strength normalized by the effective vertical principal stress for those cases in which the vertical stress is the maximum (dashed curve), average (solid curve), or minimum (dotted curve) principal stress, respectively. The first right-hand ordinate scale gives the increase in frictional strength with depth $\left(\tau_{\mathrm{f}} / z\right)$ for the usual assumption of hydrostatic fluid pressure $\left(P=\rho_{\mathrm{w}} g z\right)$. For typical values of $\mu$ from Byerlee's results (for example, $0.6-0.9$ ), the frictional strength for normal and thrust faults increases with depth at rates of about 5 and $20 \mathrm{MPa} / \mathrm{km}$, respectively (fig. 10.9). The rate of increase for strike-slip faults lies between these limits; a commonly used value, $8 \mathrm{MPa} / \mathrm{km}$, is shown by the solid curve in figure 10.9. For an upper-crustal fault extending to $14 \mathrm{~km}$ depth, these increases would result in average friction (the value at a 7-km depth) of 35,56 , and $140 \mathrm{MPa}$ for normal, strike-slip, and thrust faults, respectively (see second ordinate scale on right, fig. 10.9). Such calculations provide the basis for the expectation of high fault stress from the analysis of laboratory results: These values are substantially greater than the $20 \mathrm{MPa}$ upper limit for initial stress suggested from the analysis of heat-flow data in strike-slip tectonic regimes (horizontal dashed line, fig. 10.9). Note that the heat-flow limit would require $\mu \leqslant 0.2$ for the assumed conditions.

\section{THE CASE OF A WEAK DIRECTION}

The estimates of large friction from the fault model of figure 10.9 depend on three principal assumptions: (1) that the average coefficient of friction on real faults is comparable to typical laboratory values $(\mu \sim 0.6-0.9)$, (2) that the average fluid pressure throughout the depth of the fault is comparable to the weight of the overlying column of water $(\lambda \sim 0.37$, eq. 20$)$, and (3) that the coefficient of friction $(\mu)$ is the same in all directions, so that the fault direction $\left(\theta_{0}\right)$ is determined by the applied stress (eq. 18) and not by the orientation of a special plane of weakness. Partly in response to recent reports that the maximum horizontal principal stress is oriented nearly perpendicular to the San Andreas fault (Mount and Suppe, 1987; Zoback and others, 1987), we drop the last assumption and suppose that the fault occupies a very weak plane (which is assumed to contain the intermediate principal stress). Because of the anomalous weakness of this plane, the friction along it could be very low, consistent with the heat-flow data, and faulting could persist there irrespective of the ambient stress field.

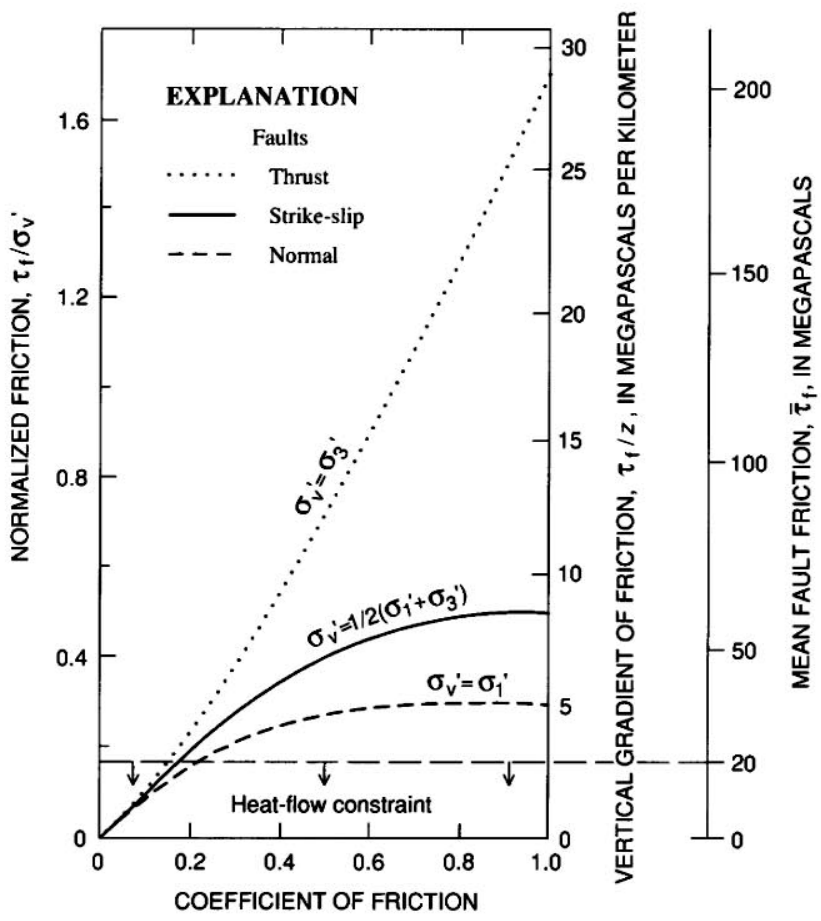

FIGURE 10.9. - Variation of normalized fault friction (left-hand ordinate scale) with coefficient of friction under three conditions for vertical effective stress $\left(\sigma_{v}^{\prime}\right)$ for failure at optimum angle $\theta_{0}$. Increase in fault friction $\tau_{\mathrm{f}}$ with depth $z$ under hydrostatic fluid pressure is given by right-hand ordinate scale, and mean friction $\bar{\tau}_{\mathrm{f}}$ on a fault $14 \mathrm{~km}$ deep by scale on far right. Horizontal dashed line is upper limit of mean friction suggested by heat-flow constraint. $\sigma_{1}^{\prime}$ and $\sigma_{3}^{\prime}$, maximum and minimum horizontal effective principal stress, respectively. 
According to the friction model (eq. 15), the two factors that might weaken the plane are either an abnormally low coefficient of friction or unusually high pore pressure. For now, we assume that each of these conditions can exist regardless of laboratory or hydrologic evidence.

The first question we consider is whether a very weak fault can coexist with stronger faults such that both types are active, as may be the case along the San Andreas fault (for a closely related discussion, see Sibson, 1985). To address this question, it is convenient to express the crustal strength in terms of the ratio $\sigma_{1}^{\prime} / \sigma_{3}^{\prime}$ (Brace and Kohlstedt, 1980). From equations 19a and 19b, the condition at failure (eq. 15a) for a weak plane oriented at an angle $\Theta$ to the direction of $\sigma_{1}$ (fig. 10.8) is

$$
\frac{\sigma_{1}^{\prime}}{\sigma_{3}^{\prime}}=\frac{1+\mu \cot \theta}{1-\mu \tan \theta}
$$

For isotropic strength, failure occurs at $\Theta_{0}$ (eq. 18), the direction in which $\sigma_{1}^{\prime} / \sigma_{3}^{\prime}$ is a minimum for a given $\mu$ :

$$
\frac{\sigma_{1}^{\prime}}{\sigma_{3}^{\prime}}=\left(\sqrt{1+\mu^{2}}+\mu\right)^{2}, \quad \Theta=\theta_{0} .
$$

Faults at angles other than $\Theta_{0}$ support greater deviatoric stresses and the higher values of $\sigma_{1}^{\prime} / \sigma_{3}^{\prime}$ given by equation 21a.

The conditions necessary for the coexistence of active faults with different coefficients of friction are illustrated in figure 10.10, where the ratio of effective principal stresses at the point of failure is plotted as a function of the fault angle for various values of the coefficient of friction (eq. 21a). Suppose, for example, that the coefficient of friction is only 0.1 in the direction of the San Andreas fault, whereas in all other directions it is 0.6. Because $\sigma_{1}^{\prime} / \sigma_{3}^{\prime}$ must be at least 3.1 to cause faulting in the crustal environs, the low-strength San Andreas fault must be oriented at $\Theta \leq 3.5^{\circ}$ or $\Theta \geq 81.5^{\circ}$ (fig. 10.10); otherwise, $\sigma_{1}^{\prime} / \sigma_{3}^{\prime}$ would be too low to cause slip in the stronger directions. In this example, then, the weak fault must be oriented either nearly parallel or nearly perpendicular to the direction of $\sigma_{1}$.

In the context of the notion that the San Andreas fault is nearly perpendicular to the direction of $\sigma_{1}^{\prime}$, or at $\Theta \sim 90^{\circ}$ in figure 10.10, we note that a very low coefficient of fault friction is required. The strength curves for each value of $\mu$ have two asymptotes where $\sigma_{1}^{\prime} / \sigma_{3}^{\prime} \rightarrow \infty$. These asymptotes occur where the denominator of equation 21a vanishes; one asymptote is at $\theta=0$, or $\sigma_{1}$ parallel to the fault, for any value of $\mu$, and the other is at $\theta=2 \theta_{0}$ (eq. 8 ), or $\Theta=90-\tan ^{-1} \mu$. Thus, the normal to any fault that fails in shear must be oriented at an angle of at least $\tan _{-1}$ $\mu$ from the direction of $\sigma_{1}$. For the four curves in figure 10.10 , the right-hand asymptotes are at $\Theta=84.3,73.3$,
59.0 , and 48.0 , respectively, for $\mu=0.1,0.3,0.6$, and 0.9 . Thus, if the fault trace makes an angle greater than $59^{\circ}$, then $\mu$ must be less than 0.6 as long as the fluid pressure is less than the least principal stress.

More generally, enhanced pore pressure alone cannot lead to active faults nearly normal to $\sigma_{1}$ unless $P>\sigma_{3}$, in which case $\sigma_{3}^{\prime}<0$ and failure is likely to manifest itself as hydraulic fracturing rather than fault slip.

\section{SUMMARY}

To recapitulate, the simplest interpretation of earthquakes in terms of the frictional fault model and laboratory measurements of rock friction leads to fault stresses many times larger than the limits suggested from heatflow and fault energetics. This interpretation depends on three assumptions: (1) that the average coefficient of friction on real faults is comparable to typical laboratory values $(\mu \sim 0.6-0.9)$, (2) that the pore-fluid pressure throughout the depth of faulting is comparable to the weight of the overlying column of water, and (3) that the intrinsic resistance of the Earth to sliding is isotropicthat is, no weak directions exist. To reduce the high estimates of friction obtained from rock mechanics to the low ones obtained from heat flow, we must assume either smaller values of the coefficient of friction $\mu$ or larger

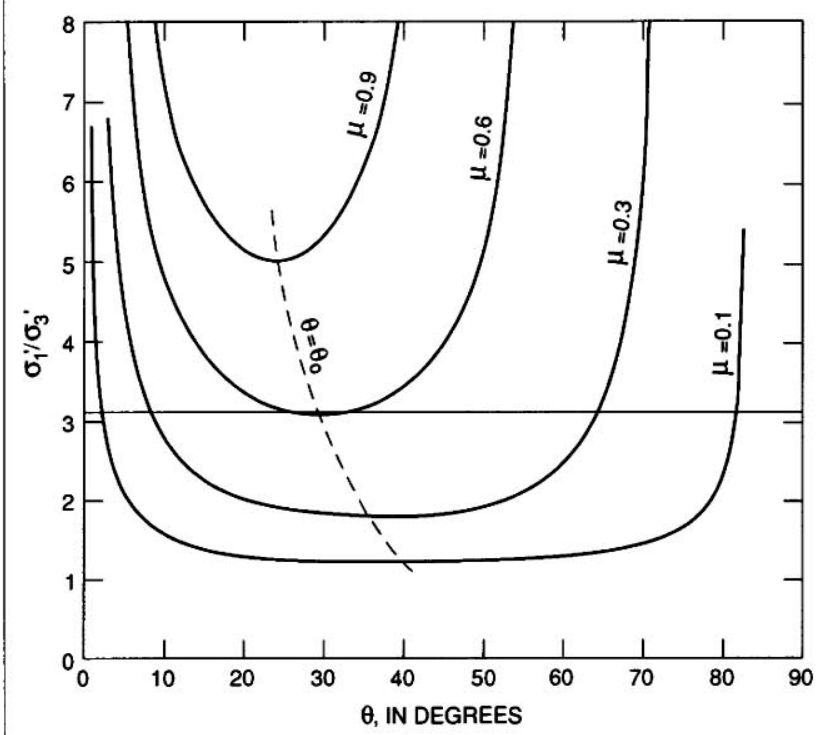

FIGURE 10.10. - Failure criteria for various coefficients of friction as functions of fault angle $\Theta$. For fixed $\sigma_{1}^{\prime}, \sigma_{3}^{\prime}$, and $\mu$, slip will occur for all $\Theta$ between points where horizontal line defined by $\sigma_{1}^{\prime} / \sigma_{3}^{\prime}$ intersects curve defined by $\mu$. For example shown, if $\sigma_{1}^{\prime} / \sigma_{3}^{\prime}=3.1$, then for $\mu=0.1$, slip can occur at all angles between $3^{\circ}$ and $82^{\circ}$ but only at optimum angle $29.5^{\circ}$ if $\mu=0.6$. Dashed curve, optimal failure angle $\Theta_{0}(\mu)$ (eq. 18). $\sigma_{1}^{\prime}$ and $\sigma_{3}^{\prime}$, maximum and minimum horizontal effective principal stress, respectively. 
values of fluid pressure $P$ (see eq. 15). Of particular interest in this connection is reported evidence that the trend of the San Andreas fault in California might occupy an anomalous weak direction. According to Mount and Suppe (1987) and Zoback and others (1987), the fault plane is nearly perpendicular to the direction of maximum compression $(\Theta \sim \pi / 2$, fig. 10.10), a direction in which the resolved shear stress is very small. Such a condition could be consistent with the low friction required by heat flow, while permitting high stresses to accommodate the subsidiary faulting observed on more favorably situated planes. This model, however, raises some basic questions regarding the mechanics of faulting; for the fault to slip, it must have a low shear strength, as well as the low shear stress suggested by its orientation. If conventional friction theory applies, anomalously high fluid pressure along the fault cannot readily account for the required low friction because, unless $\mu$ is unusually low, the fault becomes exceedingly resistant to shear failure as $\Theta$ begins to approach $\pi / 2$ (fig. 10.10).

\section{ESTIMATION OF FAULT STRENGTH FROM INPLACE STRESS MEASUREMENTS}

In principle, measurements of the magnitude and orientation of crustal stress in the vicinity of the San Andreas fault should provide the most direct evidence of the forces acting to cause interplate motion there. However, some essential problems exist with this approach. Because we have little understanding of the mechanics of the system, it is difficult to interpret the data. We are not dealing with a laboratory experiment in which a sample is loaded in a testing machine whose characteristics are well known; in such a situation, it is straightforward to use gages to estimate the magnitude of the load. In contrast to the well-controlled laboratory situation, we have little idea of the nature of the forces applied to the Earth's crust to cause a deviatoric state of stress and, in the case of tectonically active areas, slip across major throughgoing faults. We know neither where the forces are applied nor what is applying them; moreover, there is even debate about what the state of stress would be if only gravity were acting (McGarr, 1988).

In addition to the absence of a conceptual framework, there are numerous experimental difficulties in determining the state of stress, that is, the magnitudes and orientations of the three principal stresses as functions of position within the crust. Data must be obtained from depths below the zone of weathering, in rock that is sufficiently strong to support deviatoric stresses. In granitic rocks, this requirement, in effect, necessitates stress measurements at depths of about $50 \mathrm{~m}$ or more, thus limiting the measurement technique to hydraulic fracturing, the only common procedure that can be used at such depths (Haimson and Fairhurst, 1970).

The hydraulic-fracturing, or "hydrofrac," method involves isolating a section of a borehole and then pressurizing this cylinder by pumping in fluid until a tensile crack forms and propagates into the previously unfractured rock. By monitoring the pressure-time history of the fluid in the isolated section, both the maximum and minimum horizontal stresses can be estimated (Hubbert and Willis, 1957; Zoback and Haimson, 1983). This approach assumes that one of the principal stresses $\sigma_{v}$ is oriented vertically and can be calculated from the weight of overburden (eq. 20 ). The other two principal stresses are the maximum, $\sigma_{\mathrm{H}}$, and minimum, $\sigma_{\mathrm{h}}$, horizontal stresses. In contrast to engineering usage, the convention adopted here is for compressional stresses to be positive because, in the Earth's crust, tensional stresses are rarely encountered, even at the surface.

Although the uppermost crust near the San Andreas fault system has not been sampled as much for stress as for heat flow, enough inplace stresses have been measured to provide an indication of the state of stress there and how it compares with crustal stresses in other tectonic settings. To date, 41 successful hydrofrac measurements have been made in the 12 wells shown in figure 10.11 at depths of as much as $850 \mathrm{~m}$. A total of 29 of these data, in wells along the Mojave reach of the fault (fig. $10.11 C$ ), were analyzed by McGarr and others (1982). Since that study, four stress measurements have been made at Black Butte (BB, fig. 10.11C) in the Mojave Desert (Stock and Healy, 1988), the data from the Hi Vista well have been reanalyzed by Hickman and others (1988), and additional measurements have been made in central California (Zoback and others, 1980). Currently, stress measurements are being made at the Cajon Pass well near the southeast end of the Mojave reach of the San Andreas fault, with some observations at depths below $3 \mathrm{~km}$. Because no clear picture has yet emerged (see Healy and Zoback, 1988), we have not incorporated the Cajon Pass results into this review.

The state of horizontal deviatoric stress can be characterized in terms of two parameters: the maximum horizontal shear stress $\tau_{m}$ given by

$$
\tau_{m}=\frac{1}{2}\left(\sigma_{H}-\sigma_{h}\right),
$$

and the angle $\theta$ between the trace of the fault and the direction of maximum horizontal compressive stress $\sigma_{\mathrm{H}}$. Under favorable conditions, both parameters can be determined by the hydrofrac technique. We have shown that if $\Theta \sim 45^{\circ}$, then $\tau_{m}$ is entirely resolved onto the plane of the fault to produce its slip; as $\Theta$ approaches $0^{\circ}$ or $90^{\circ}$, 
the resolved stress on the fault becomes arbitrarily small irrespective of the magnitude of $\tau_{\mathrm{m}}$ (eq. 16).
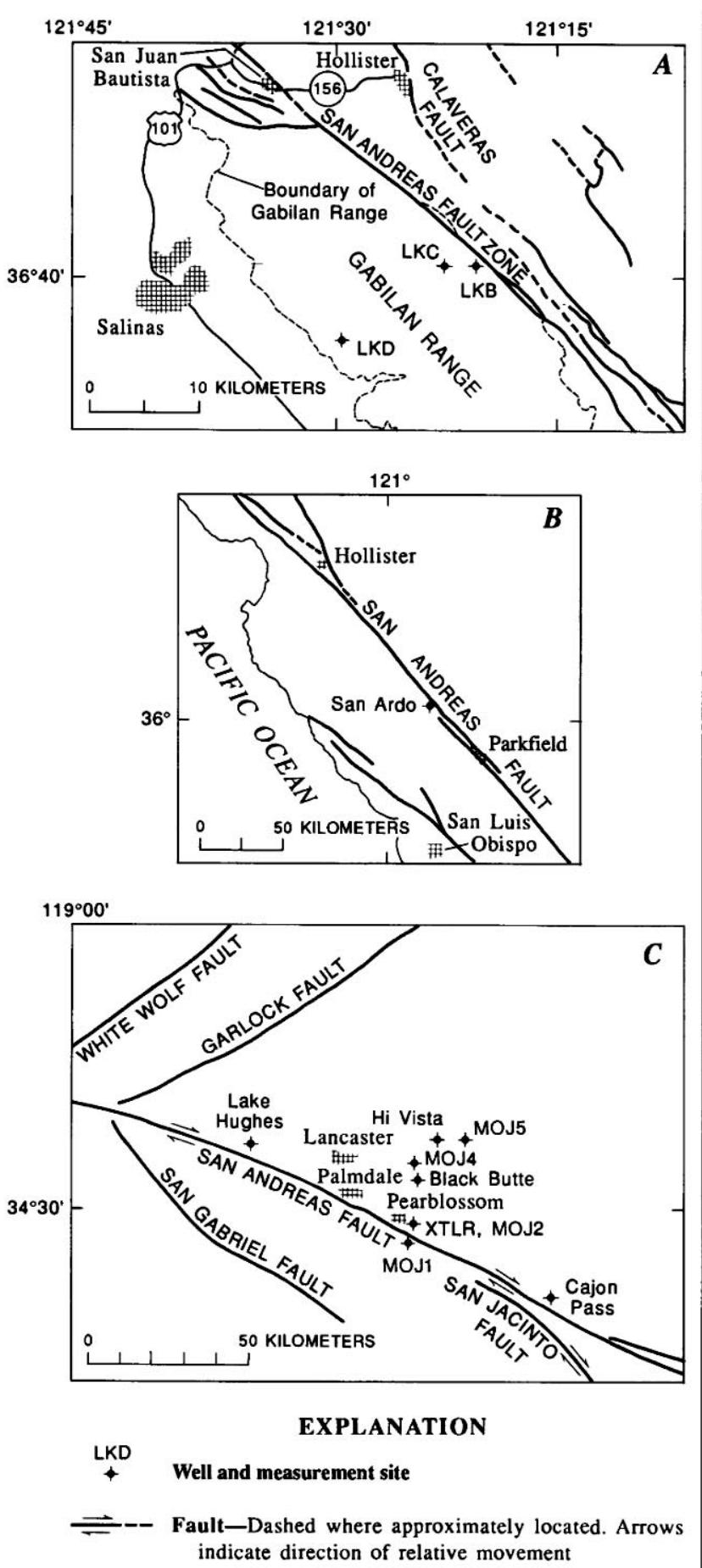

FIGURE 10.11. -Sketch maps of the Gabilan Range $(A)$, central California coast $(B)$, and western Mojave Desert $(C)$, showing locations of wells where stress measurements have been taken along the San Andreas fault using the hydrofracturing technique.
Evidence regarding the actual orientation of $\sigma_{\mathrm{H}}$ relative to the strike of the San Andreas fault is contradictory. Observations favoring $\theta$ distributed about $45^{\circ}$, so as to cause dextral fault slip, were presented by $\mathrm{McNal}$ ley and others (1978), Zoback and others (1980), Zoback and Zoback (1980), and Hickman and others (1988); however, these data, from the Mojave Desert, show considerable scatter. In contrast, Mount and Suppe (1987) and Zoback and others (1987) reviewed a broad set of data, including many borehole breakout orientations, that suggest $\Theta \approx 90^{\circ}$; Oppenheimer and others (1988) came to a similar conclusion. An intermediate result was obtained by Jones (1988), who stated that $\sigma_{H}$ is oriented at $65^{\circ}$ to the local strike of the San Andreas fault in southern California. Thus, currently, we know neither the preferred value of $\theta$ nor whether such a value even exists. For the foregoing values of $\Theta\left(45^{\circ}, 65^{\circ}\right.$, or $\left.90^{\circ}\right)$, the shear stress resolved on the fault (eq. 16) would be $\tau_{m}$, $0.77 \tau_{\mathrm{m}}$, or 0 , respectively. In view of this uncertainty, we leave $\theta$ unspecified and describe what is known of $\tau_{m}$ the upper limit to the shear stress that can be resolved on the fault.

The first-order feature seen in data from the San Andreas fault zone (fig. 10.12) is a marked tendency for $\tau_{m}$ to increase with depth. The solid line, a regression fit to all of the data, indicates a depth gradient of 8.3 $\mathrm{MPa} / \mathrm{km}$, not significantly greater than the gradient of $7.9 \mathrm{MPa} / \mathrm{km}$ reported by $\mathrm{McGarr}$ and others (1982) on the basis of 29 of the 41 data plotted in figure 10.12. We note that the observed depth gradient of $\tau_{\mathrm{m}}$ also agrees well with the curves for strike-slip faults (solid curves, fig. 10.9) for a coefficient of friction of 0.6 or greater. In addition to the general increase in $\tau_{m}$ with depth, considerable variation from one well to another and within individual wells is suggested by figure 10.12 .

Figure 10.13 shows that the departure of the measured values of $\tau_{m}$ from the regression line in figure 10.12 does not vary systematically with distance from the San Andreas fault. The principal conclusion to be drawn from figure 10.13 seems to be that the magnitude of deviatoric stress is not measurably affected by proximity to the San Andreas fault. Thus, whatever effect the fault may have on the magnitude of the shear stress, it is either too subtle, too localized, or too deep to be recognized in the current data set.

We note that there is no detectable difference between the Mojave Desert residuals, measured near a locked section of the San Andreas fault, and those in central California (fig. 10.11A), where the fault is creeping and presumably does not produce great earthquakes. If measurements were made to greater depths, some differences might appear, but at least in the topmost several hundred meters, the magnitude of shear stress seems to be largely independent of position along the strike of the San Andreas fault. 
Having failed to discover any spatial relation between the San Andreas fault and deviatoric-stress magnitudes, we now consider the question of whether or not any detectable differences exist between the stress states measured near the San Andreas fault (fig. 10.12) and those measured elsewhere in different tectonic settings. A review of crustal shear stress by McGarr (1980) considered a large suite of stress data in "hard" rocks measured at depths extending to $3.6 \mathrm{~km}$. The resulting regression line of

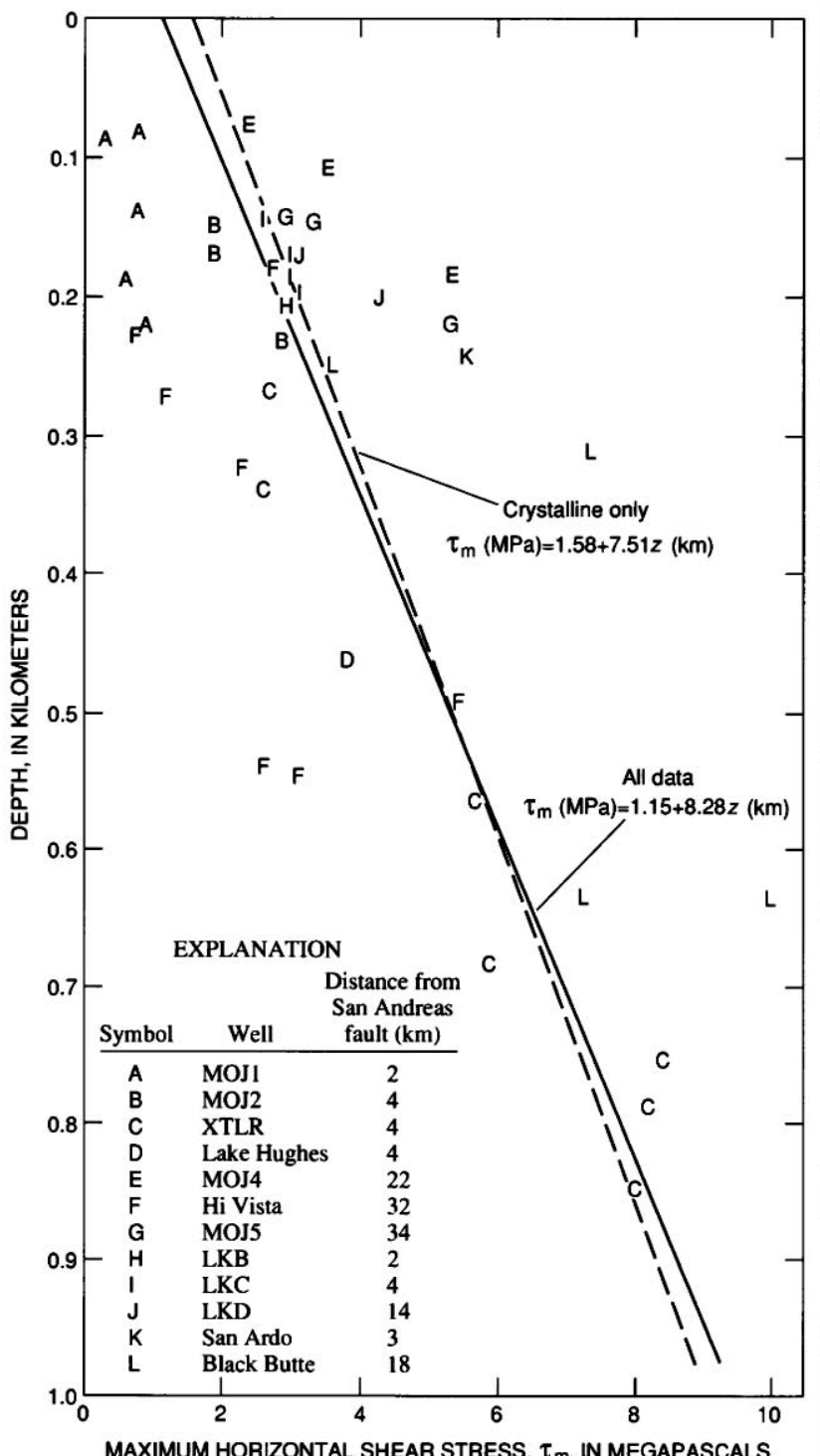

FIGURE 10.12. - Maximum horizontal shear stress as a function of depth $z$. Solid regression line has been fitted to all data, and dashed line to measurements in crystalline rock only. See figure $\mathbf{1 0 . 1 1}$ for locations of wells.

$$
\tau_{\mathrm{m}}(\mathrm{MPa})=5.0+6.59 z(\mathrm{~km})
$$

has a greater surface intercept but a similar depth gradient to the San Andreas regression

$$
\tau_{\mathrm{m}}(\mathrm{MPa})=1.58+7.51 z(\mathrm{~km})
$$

fitted to the crystalline-rock data in figure 10.12. The comparison between equations 23 and 24 is not entirely appropriate because the data used to develop equation 23 represent all three stress states; stresses measured in regions of strike-slip tectonics were not considered separately by McGarr (1980) (see fig. 10.9). More recently, however, data measured in a 2,000-m-deep well in Cornwall, U.K. (Pine and others, 1983), permit quite an interesting comparison. For both the San Andreas and the Cornwall data sets, most of the stress observations are compatible with strike-slip tectonics; that is, $\sigma_{v}$ is the intermediate principal stress. For most of the San Andreas and all of the Cornwall measurements, the rock is granitic. In contrast to the San Andreas system, however, the tectonic setting in Cornwall is presently inactive. The deviatoric stresses at Cornwall are believed to be a consequence of the Alpine orogeny, which apparently has caused the maximum horizontal stress to be oriented northwestward throughout much of Europe (for example, McGarr and Gay, 1978).

The 12 data sets obtained by Pine and others (1983) indicate a stress state (fig. 10.14) surprisingly similar to that of the San Andreas fault (fig. 10.12). For the maximum shear stress, the depth gradient of $7.52 \mathrm{MPa}$ $\mathrm{km}$ is indistinguishable from its counterpart in the crystalline San Andreas crust of $7.46 \mathrm{MPa} / \mathrm{km}$; however, the surface intercept at Cornwall is larger. If the state of deviatoric stress is much the same in Cornwall as along the San Andreas system, then we must conclude that the plate-tectonic motion in California along the San Andreas fault has no expression in the shallow (1-2 km deep) stress field. Accordingly, much of what has been discovered about continental-crustal stress in general may apply to the crust adjacent to the San Andreas fault.

This generalization implies that the applied forces which give rise to $\tau_{m}$ in the vicinity of the San Andreas fault are not specific to the Pacific-North American plate boundary. In terms of observed shear stress, a major active plate-boundary fault would be at least as likely in Cornwall, U.K., as in California from what we currently know of stress magnitudes, at depths down to a few kilometers.

\section{DISCUSSION}

From what we currently know of crustal stress and heat flow, neither is influenced by proximity to the San Andreas fault, the most conspicuous and best studied 
plate-boundary fault on the continents. The measured horizontal shear stress increases rapidly with depth (approx $8 \mathrm{MPa} / \mathrm{km}$ ), essentially as would be predicted from laboratory measurements of friction and the assumption that crustal stress is limited by the frictional resistance of fractures forced together by the weight of overlying rocks. From this consistency of independent observations, two large "if's" lead to what seems to be a physical contradiction: (1) if these vertical stress gradients persist throughout the depth of the seismogenic faulting layer (approx 12-15 km), then the average of the maximum horizontal shear stresses throughout the layer is quite large (approx $50 \mathrm{MPa}$ ); and (2) if the direction of the San Andreas fault is aligned with this maximumhorizontal-shear-stress direction, then the frictional heat generated by such stress during the documented fault motion (tens of kilometers per million years) should cause the background heat flow to double as the fault is approached. In 100 heat-flow measurements over a $1,000-\mathrm{km}$ span of the San Andreas fault, no such heatflow anomaly has been observed.

The contradiction stems from two separate lines of argument: (1) inplace and laboratory measurements of rock stress imply average fault stresses of about $50 \mathrm{MPa}$ or more, and (2) the absence of a local heat-flow anomaly and the energy balance of the fault imply an average fault stress of about $15 \mathrm{MPa}$ or less. At least one of these arguments must be wrong. We have outlined the major factors in each argument, and we shall now point out some possible loopholes and areas for further study.

The energy-balance argument leading to the heat-flow constraint on fault stress could be invalidated if the neglected energy sinks turn out to be important, or if the heat-conduction model is unrealistic or inappropriate. The general energy argument assumes that fault slip produces only seismic radiation and heat. It supposes that the energy consumed by the grinding of rocks into fault gouge (Lachenbruch and Sass, 1980) or the heat absorbed by possible phase changes or chemical reactions is negligible, and that the energy of seismic radiation does not grossly differ from the estimates made by seismologists. The heat-conduction model assumes that the frictional heat production occurs in a near-vertical fault zone (whose width is small relative to its depth) extending throughout the seismogenic layer. Systematic nonconductive removal of frictional heat by circulating ground water could invalidate this model (see O'Neill and Hanks, 1980; Williams and Narasimhan, 1989), as could a grossly different fault geometry-for example, a fault whose lower half was continually being rejuvenated because of migration of the upper half away from it along an upper-crustal detachment surface (Namson and Davis, 1988). All of these effects probably deserve further study.

The mechanical argument leading to large fault stress is based on observations of inplace stress (to maximum depths of approx $1 \mathrm{~km}$ in the San Andreas fault zone and of approx $4 \mathrm{~km}$ elsewhere on the continents), on laboratory measurements of rock friction and the efficiency of simulated earthquakes, and on downward extrapolation of these results through the seismic layer, on the assumption that fluid pressure is normal and frictional properties are uniform and isotropic. The consistency between the most frequently measured friction coefficients and the inplace determinations of the vertical gradient of maximum shear stress is reassuring (solid curves, fig. 10.9; fig. 10.12); however, the downward extrapolation of these results to depths of 10 or $15 \mathrm{~km}$ is an uncertain step, with loopholes that could invalidate the high-fault-stress conclusion.

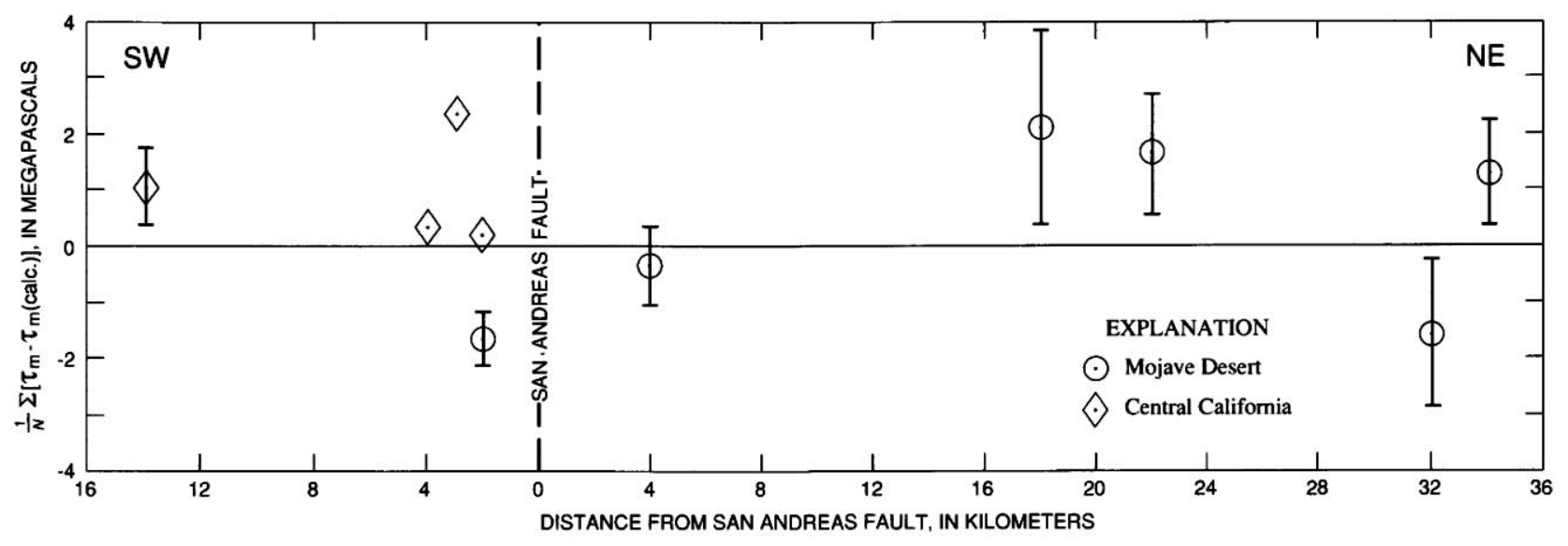

FIGURE 10.13. - Averages of $N$ maximum-shear-stress $\left(\tau_{\mathrm{m}}\right)$ residuals as functions of distance from the San Andreas fault. In calculating residual at a particular distance, effect of depth $z$ is removed by using solid-line regression fit to data of figure $10.12\left[\tau_{\mathrm{m}}(\mathrm{MPa})=1.15+8.28 z(\mathrm{~km})\right]$. Error bars, $1 \sigma$. 
There are at least three such loopholes. First, the fluid pressure might increase with depth, as it is known to do in some sedimentary basins, approaching the minimum principal stress (Berry, 1973). Second, the friction coefficient at depth might be lower than average laboratory values; such lower values have been reported in some studies of gouge and other clay-size aggregates (Wang and others, 1980). Each of these effects could substantially lower the maximum stress at depth. Third, the frictional strength properties might be anisotropic, with the main trace of the fault occupying a weak direction. If so, the maximum stress at depth might be high, as maintained in the mechanical argument, but the shear

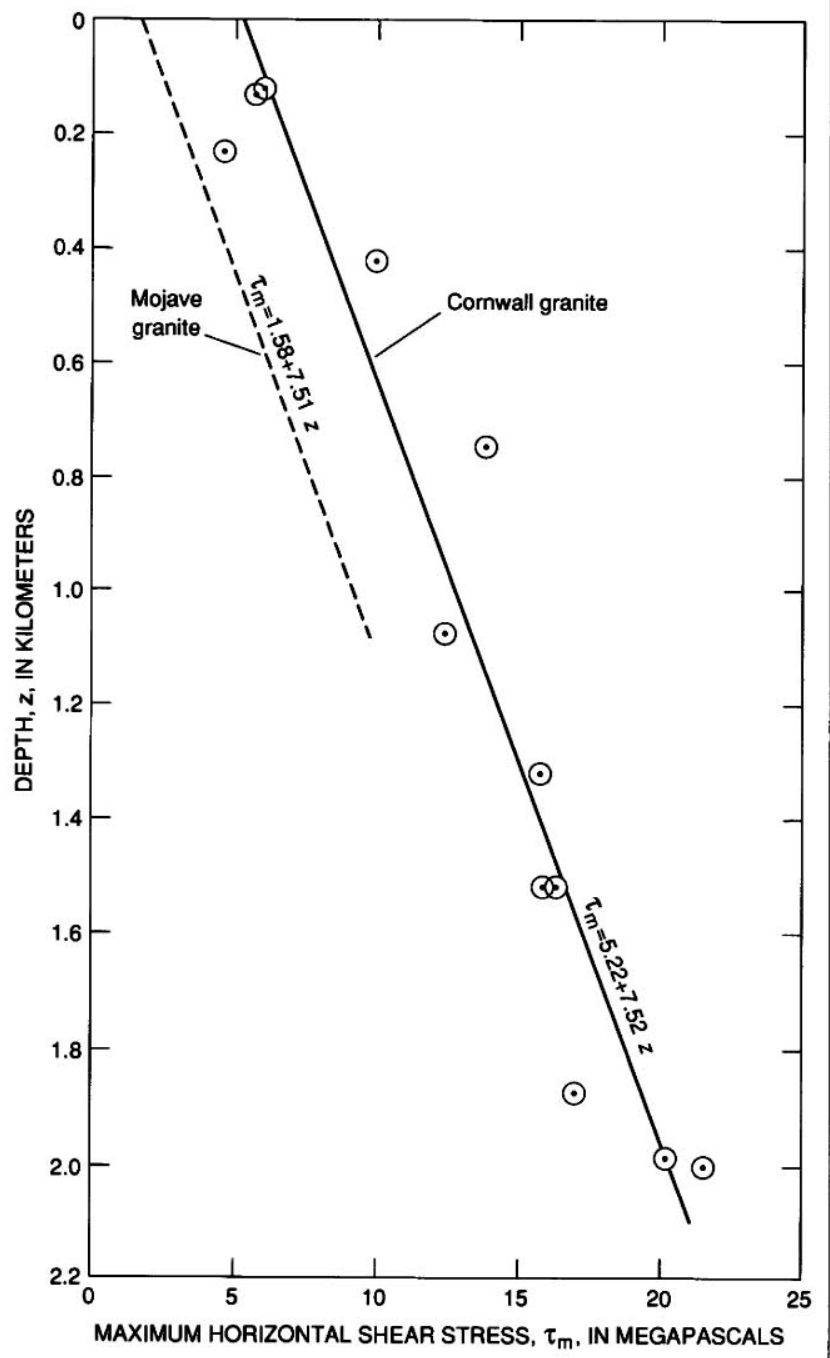

Figure 10.14. - Maximum horizontal shear stress $\tau_{m}$ as a function of depth $z$ in granite near Cornwall, U.K. Data from Pine and others (1983). stress resolved on the fault might be very low, as maintained in the thermal argument. Under these circumstances, the fault must be nearly parallel to a principal axis, as suggested by Mount and Suppe (1987) and Zoback and others (1987). Such a condition could be consistent with the low friction on the main fault required by heat flow, while permitting high stresses to accommodate subsidiary faulting on more favorably situated planes with normal frictional properties.

As mentioned above in the section entitled "Introduction," geothermal studies of the San Andreas fault have provided evidence for a very weak fault for two decades; the meaning of this result depends heavily on the direction of principal stresses in the fault zone and the magnitude of the stress differences there. As we have shown, existing evidence is contradictory, especially in the Mojave Desert region. Many measurements of stress near the San Andreas fault suggest that the fault trace is inclined at an intermediate azimuth (approx $45^{\circ}$ ) to the principal-stress directions, and thereby imply that the fault coincides approximately with the direction of maximum shear stress and that the heat-flow constraint could not be satisfied unless horizontal shear stress (and stress differences) were low everywhere. In this case, both the San Andreas fault and active subsidiary faults with other orientations would have to be weak. If, however, the horizontal-stress differences are large, the weak fault required by heat flow is a "zero shear stress" boundary condition on the adjacent fault blocks that requires the fault to be almost normal to a principal-stress direction. In this case, the heat-flow constraint could be honored on an anomalously weak main trace, whereas subsidiary faults with other orientations and normal strength could also be active.

Thus, the occurrence of a weak direction may reconcile observations of rock mechanics with the longstanding implications of thermomechanical studies. It does, however, raise several questions:

1. Does the maximum-horizontal-principal-stress direction form an intermediate angle with the trace of the San Andreas fault (as was formerly accepted and as is required by isotropic frictional properties), or is the maximum compression nearly fault normal, as suggested by more recent observations (Mount and Suppe, 1987; Zoback and others, 1987)? As we have pointed out, there is conflicting observational evidence on this issue.

2. If the horizontal compressive stress is nearly faultnormal, what is the physical mechanism that permits the fault to slip under the small shear stress resolved on its direction? We have shown that the mechanism commonly invoked to explain a weak fault-namely, locally elevated fluid pressure-is not likely; however, anomalously low coefficients of friction could 
account for slip under near fault-normal compression if the frictional fault model is valid.

3. How would such a weak plate-boundary fault evolve, and would its existence imply that the resistance to relative motion between the Pacific and North American plates is negligible? What is the role of decoupling and basal resistance? Lachenbruch and Sass (1973) pointed out that strong shear stresses in the far field which might drive dextral slip between the plates cannot be balanced by a weak fault without invoking unexpected strength in the lower crust and drag (and possible decoupling or "detachment") beneath the horizontal base of the faulting layers. If the faulted plate boundary should weaken as it evolves, then either such basal drag must develop near the fault,or the far-field stress must diminish to maintain the equilibrium condition. The best way to learn whether such basal tractions exist is to determine whether the shear stress resolved parallel to the fault diminishes as the fault is approached (Lachenbruch and Sass, 1973; McGarr and others, 1982). We have shown here that a transect normal to the San Andreas fault shows no such diminution, although the observations were much shallower (approx $1 \mathrm{~km}$ deep or above) than the depth of earthquakes; direct stress measurements at seismogenic depths (below $5 \mathrm{~km}$ ) are needed. Whether or not such basal decoupling and drag exist near the San Andreas fault is fundamental to our understanding of its earthquakes and of the nature of continental transform plate boundaries and their resistance to plate motion.

\section{REFERENCES CITED}

Aki, Keiiti, 1966, Generation and propagation of $G$ waves from the Niigata earthquake of June 16,1964. Part 2, Estimation of earthquake moment, released energy, and stress-strain drop from the $G$ wave spectrum: University of Tokyo, Earthquake Research Institute Bulletin, v. 44 , pt. 1, p. $73-88$.

Atwater, Tanya, 1970, Implications of plate tectonies for the Cenozoic tectonic evolution of western North America: Geological Society of America Bulletin, v. 81, no. 12, p. 3513-3536.

Berry, F.A.F., 1973, High fluid potentials in California Coast Ranges and their tectonic significance: American Association of Petroleum Geologists Bulletin, v. 57 no. 7, p. 1219-1248.

Boatwright, John, and Choy, G.L., 1986, Teleseismic estimates of the energy radiated by shallow earthquakes: Journal of Geophysical Research, v. 91, no. B2, p. 2095-2112.

Brace, W.F., and Kohlstedt, D.L., 1980, Limits on lithospheric stress imposed by laboratory experiments: Journal of Geophysical Research, v. 85, no. B11, p. 6248-6252.

Brune, J.N., and Allen, C.R., 1967, A low-stress-drop, low-magnitude earthquake with surface faulting: The Imperial, California, earthquake of March 4, 1966: Seismological Society of America Bulletin, v. 57 , no. 3 , p. 501-514.

Brune, J.N., Henyey, T.L., and Roy, R.F., 1969, Heat flow, stress, and rate of slip along the San Andreas fault, California: Journal of Geophysical Research, v. 74, no. 15, p. 3821-3827.
Byerlee, J.D., 1970, Static and kinetic friction of granite at high norma stress: International Journal of Rock Mechanics and Mining Sciences, v. 7, no. 6, p. 577-582.

1978, Friction of rocks: Pure and Applied Geophysics, v. 116, no. 4-5, p. 615-626.

Byerlee, J.D., and Brace, W.F., 1968, Stick-slip, stable sliding, and earthquakes-effect of rock type, pressure, strain rate, and stiffness: Journal of Geophysical Research, v. 73, no. 18, p. 6031-6037.

- 1969, High-pressure mechanical instability in rocks: Science, v. 164 , no. 3880 , p. $713-715$.

Chinnery, M.A., 1964, The strength of the earth's crust under horizontal shear stress: Journal of Geophysical Research, v. 69, no. 10 , p. 2085-2089.

Dieterich, J.H., 1979, Modelling of rock friction, 1. Experimental results and constitutive equations: Journal of Geophysical Research, v. 84, no. B5, p. 2161-2168.

- 1981, Potential for geophysical experiments in large scale tests: Geophysical Research Letters, v. 8, no. 7, p. 653-656.

Fletcher, J.B., Boatwright, John, and Joyner, W.B., 1983, Depth dependence of source parameters at Monticello, South Carolina: Seismological Society of America Bulletin, v. 73, no. 6, pt. A, p. 1735-1751.

Grantz, Arthur, and Dickinson, W.R., 1968, Indicated cumulative offsets along the San Andreas fault in the California Coast Ranges, in Dickinson, W.R., and Grantz, Arthur, eds., Proceedings of conference on geologic problems of San Andreas fault system: Stanford, Calif., Stanford University Publications in the Geological Sciences, v. 11, p. 117-120.

Gutenberg, Beno, and Richter, C.F., 1956, Magnitude and energy of earthquakes: Annali di Geofisica, Rome, v. 9, no. 1, p. 1-15.

Haimson, B.C., and Fairhurst, Charles, 1970, In situ stress determination at great depth by means of hydraulic fracturing, chap. 28 of Somerton, W.H., ed., Rock mechanics, theory and practice: Symposium on Rock Mechanics, 11th, Berkeley, Calif., 1969, Proceedings, p. 559-584.

Hanks, T.C., and Kanamori, Hiroo, 1979, A moment magnitude scale: Journal of Geophysical Research, v. 84, no. B5, 2348-2350.

Healy, J.H., and Zoback, M.D., 1988, Hydraulic fracturing in situ stress measurements to $2.1 \mathrm{~km}$ depth at Cajon Pass, California: Geophysical Research Letters, v. 15, no. 9, p. 1005-1008.

Henyey, T.L., 1968, Heat flow near major strike-slip faults in central and southern California: Pasadena, California Institute of Technology, Ph.D. thesis, $421 \mathrm{p}$.

Henyey, T.L., and Wasserburg, G.J., 1971, Heat flow near major strike-slip faults in California: Journal of Geophysical Research, v. 76, no. 32, p. 7924-7946.

Hickman, S.H., Zoback, M.D., and Healy, J.H., 1988, Continuation of a deep borehole stress measurement profile near the San Andreas fault, 1, Hydraulic fracturing stress measurements at Hi Vista, Mojave Desert, California: Journal of Geophysical Research, v. 93, no. B12, p. $15183-15195$.

Hubbert, M.K., and Willis, D.G., 1957, Mechanics of hydraulic fracturing: Journal of Petroleum Technology, v. 9, no. 6, p. 153-168.

Jaeger, J.C., 1956, Elasticity, fracture, and flow: New York, John Wiley and Sons, $152 \mathrm{p}$.

Jones, L.M., 1988, Focal mechanisms and the state of stress on the San Andreas fault in southern California: Journal of Geophysical Research, v. 93, no. B8, p. 8869-8891.

Kirby, S.H., 1980, Tectonic stresses in the lithosphere: Constraints provided by the experimental deformation of rocks: Journal of Geophysical Research, v. 85, no. B11, p. 6353-6363.

Lachenbruch, A.H., 1986, Simple models for the estimation and measurement of frictional heating by an earthquake: U.S. Geological Survey Open-File Report 86-508, $13 \mathrm{p}$. 
Lachenbruch, A.H., and Sass, J.H., 1973, Thermomechanical aspects of the San Andreas fault system, in Kovach, R.L., and Nur, Amos, eds., Proceedings of the conference on tectonic problems of the San Andreas fault system: Stanford, Calif., Stanford University Publications in the Geological Sciences, v. 13, p. 192-205.

- 1980, Heat flow and energetics of the San Andreas fault zone: Journal of Geophysical Research, v. 85, no. B11, p. 6185-6222.

- 1988, The stress heat-flow paradox and thermal results from Cajon Pass: Geophysical Research Letters, v. 15, no. 9, p. 981-984.

Lee, T.C., 1983, Heat flow through the San Jacinto fault zone, southern California: Royal Astronomical Society Geophysical Journal, v. 72, no. 3, p. 721-731.

Lockner, D.A., and Okubo, P.G., 1983, Measurements of frictional heating in granite: Journal of Geophysical Research, v. 88 , no. B5, p. $4313-4320$.

McGarr, Arthur, 1980, Some constraints on levels of shear stress in the crust from observations and theory: Journal of Geophysical Research, v. 85, no. B11, p. 6231-6238.

- 1988, On the state of lithospheric stress in the absence of applied tectonic forces: Journal of Geophysical Research, v. 93, no. B11, p. 13609-13617.

McGarr, Arthur, and Gay, N.C., 1978, State of stress in the earth's crust: Annual Review of Earth and Planetary Sciences, v. 6, p. 405-436.

McGarr, Arthur, Zoback, M.D., and Hanks, T.C., 1982, Implications of an elastic analysis of in situ stress measurements near the San Andreas fault: Journal of Geophysical Research, v. 87, no. B9, p. 7797-7806.

McKenzie, D.P., 1969, The relation between fault plane solutions for earthquakes and the directions of the principal stresses: Seismological Society of America Bulletin, v. 59, no. 2, p. 591-601 .

McKenzie, D.P. and Brune, J.N., 1972, Melting on fault planes during large earthquakes: Royal Astronomical Society Geophysical Journal, v. 29 , no. 1 , p. $65-78$.

McNally, K.C., Kanamori, Hiroo, Pechmann, J.C., and Fuis, G.S., 1978, Earthquake swarm along the San Andreas fault near Palmdale, southern California, 1976 to 1977: Science, v. 201, no. 4358 , p. 814-817.

Minster, J.B., and Jordan, T.H., 1984, Vector constraints on Quaternary deformation of the western United States east and west of the San Andreas fault, in Crouch, J.K., and Bachman, S.B., eds., Tectonics and sedimentation along the California margin: Society of Economic Paleontologists and Mineralogists, Pacific Section field trip guide, v. 38, p. 1-16.

Mount, V.S., and Suppe, John, 1987, State of stress near the San Andreas fault: Implications for wrench tectonics: Geology, v. 15, no. 12 , p. 1143-1146.

Namson, J.S., and Davis, T.L., 1988, Seismically active fold and thrust belt in the San Joaquin Valley, central California: Geological Society of America Bulletin, v. 100, no. 2, p. 257-273.

O'Neill, J.R., and Hanks, Thomas, 1980, Geochemical evidence for water-rock interaction along the San Andreas and Garlock faults of California: Journal of Geophysical Research, v. 85, no. B11, p. 6286-6292.

Oppenheimer, D.H., Reasenberg, P.A., and Simpson, R.W., 1988, Fault-plane solutions for the 1984 Morgan Hill, California, earthquake sequence: Evidence for the state of stress on the Calaveras fault: Journal of Geophysical Research, v. 93, no. B8, p. 9007-9026.

Pine, R.J., Ledingham, Peter, and Merrifield, C.M., 1983, In-situ stress measurement in the Carnmenellis granite-II. Hydrofracture tests at Rosemanowes Quarry to depths of 2000 m: International Journal of Rock Mechanics and Mining Sciences \& Geomechanical Abstracts, v. 20, no. 2, p. 63-72.
Reid, H.F., 1910, The mechanics of the earthquake, v. 2 of The California earthquake of April 18, 1906: Report of the State Earthquake Investigation Commission: Carnegie Institution of Washington Publication 87, 192 p.

Ruina, A.L., 1983, Slip instability and state variable friction laws: Journal of Geophysical Research, v. 88, no. B12, p. 10359-10370.

Savage, J.C., and Wood, M.D., 1971, The relationship between apparent stress and stress drop: Seismological Society of America Bulletin, v. 61 , no. 5, p. 1381-1388.

Sibson, R.H., 1985, A note on fault reactivation: Journal of Structural Geology, v. 7, no. 6, p.751-754.

Spottiswoode, S.M., and McGarr, Arthur, 1975, Source parameters of tremors in a deep-level gold mine: Seismological Society of America Bulletin, v. 65, no. 1, p. 93-112.

Stesky, R.M., and Brace, W.F., 1973, Estimation of frictional stress on the San Andreas fault from laboratory measurements, in Kovach, R.L., and Nur, Amos, eds., Proceedings of the conference on tectonic problems of the San Andreas fault system: Stanford, Calif., Stanford University Publications in the Geological Sciences, v. 13, p. 206-214.

Stock, J.M., and Healy, J.H., 1988, Continuation of a deep borehole stress measurement profile near the San Andreas fault zone, 2, Hydraulic fracturing stress measurements at Black Butte, Mojave Desert, California: Journal of Geophysical Research, v. 93, no. B12, p. 15196-15206.

Wang, C.-Y., Mao, N.-H., and Wu, F.T., 1980, Mechanical properties of clays at high pressure: Journal of Geophysical Research, v. 85, no. B3, p. 1462-1468.

Weldon, R.J., and Humphries, E.D., 1986, A kinematic model of southern California: Tectonics, v. 5, no. 1, p. 33-48.

Weldon, R.J., and Sieh, K.E., 1985, Holocene rate of slip and tentative recurrence interval for large earthquakes on the San Andreas fault in Cajon Pass, southern California: Geological Society of America Bulletin, v. 96, no. 6, p. 793-812.

Williams, C.F., and Narasimhan, T.N., 1989, Hydrogeologic constraints on heat flow along the San Andreas fault-a testing of hypotheses: Earth and Planetary Science Letters, v. 92, p. $131-143$.

Wyss, Max, and Brune, J.N., 1968, Seismic moment, stress, and source dimensions for earthquakes in the California-Nevada region: Journal of Geophysical Research, v. 73, no. 14, p. 4681-4694.

Wyss, Max, and Molnar, Peter, 1972, Efficiency, stress drop, apparent stress, effective stress, and frictional stress of Denver, Colorado, earthquakes: Journal of Geophysical Research, v. 77, no. 8, p. 1433-1438.

Zoback, M.D., and Haimson, B.C., eds., 1983, Hydraulic fracturing stress measurements: Washington, D.C., National Academy Press, $270 \mathrm{p}$.

Zoback, M.D., Healy, J.H., and Roller, J.C., 1977, Preliminary stress measurements in central California using the hydraulic fracturing technique: Pure and Applied Geophysics, v. 115, p. 135-152

Zoback, M.D., Tsukahara, Hiroaki, and Hickman, S.H., 1980, Stress measurements at depth in the vicinity of the San Andreas fault: Implications for the magnitude of shear stress at depth: Journal of Geophysical Research, v. 85, no. B11, p. 6157-6173.

Zoback, M.D., Zoback, M.L., Mount, V.S., Suppe, John, Eaton, J.P., Healy, J.H., Oppenheimer, D.H., Reasenberg, P.A., Jones, L.M., Raleigh, C.B., Wong, I.G., Scotti, Oona, and Wentworth, C.M., 1987, New evidence on the state of stress of the San Andreas fault system: Science, v. 238 , no. 4830 , p. 1105-1111.

Zoback, M.L., and Zoback, M.D., 1980, State of stress in the conterminous United States: Journal of Geophysical Research, v. 85, no B11, p. 6113-6156. 



\title{
SUPPLEMENT: ADDITIONAL READING AND SOURCE MATERIAL
}

\author{
Robert E. Wallace, Compiler
}

To help the reader find avenues into the voluminous literature about the San Andreas fault system, the following selected references are grouped into four sets: (1) maps, (2) review and reference publications, (3) publications of historical interest, and (4) publications of general interest. Many of these selected references have been included because they themselves have extensive bibliographies. The references in section 3 are limited to those pre-1965, except for Hill's review (1981) on the history of concepts. The references in section 4 are directed especially toward the layman or specialists in disciplines other than earth science. These suggested additional readings should be available in most earthscience libraries or from the publisher; many can also be found in larger public libraries.

\section{MAPS}

Bond, K.R., and Zietz, Isidore, 1987, Composite magnetic anomaly map of the conterminous United States: U.S. Geological Survey Geophysical Investigations Map GP-977, scale 1:2,500,000.

Dibblee, T.W., Jr., 1973, Regional geologic map of San Andreas and related faults in Carrizo Plain, Temblor, Caliente, and La Panza Ranges and vicinity, California: U.S. Geological Survey Miscellaneous Geologic Investigations Map I-757, 9 p., scale 1:125,000.

Drummond, K.J., chairman, 1981, Pacific Basin sheet of Plate-tectonic map of the circum-Pacific region: Tulsa, Okla., American Association of Petroleum Geologists, scale 1:10,000,000.

Engdahl, E.R., and Rinehart, W.A., 1988, Seismicity map of North America: Boulder, Colo., Geological Society of America: scale 1:5,000,000, 4 sheets.

Geological Society of America, 1987, Gravity anomaly map of North America: Boulder, Colo., scale $1: 5,000,000,4$ sheets.

1987, Magnetic anomaly map of North America: Boulder, Colo., scale 1:5,000,000, 4 sheets.

Goter, S.K., 1988, Seismicity of California 1808-1987: U.S. Geological Survey Open-File Report 88-286, scale 1:1,000,000.

Shaded relief map in color with earthquake epicenters in red.

Jennings, C.W., compiler, 1958-66, Geologic atlas of California: Sacramento, California Division of Mines and Geology, scale 1:250,000, 27 sheets.

This atlas contains 27 geologic map sheets that together constitute the "Geologic Map of California" at a scale of 1:250,000. Information sheets accompany each geologic map. As of 1989, the map series is being brought up to date, and the Santa Rosa Regional Geologic map series $2 A$ (1982, 5 sheets) and San Bernardino Regional Geologic map series $3 A$ (1987, 5 sheets) have been completed.

compiler, 1975, Fault map of California with locations of volcanoes, thermal springs, and thermal wells: California Division of Mines and Geology Geologic Data Map 1, scale 1:750,000.

This is the principal map representation of faults in California on a single map sheet. It contains a wealth of information and is indispensable to anyone interested in the San Andreas fault. An updated edition is in preparation.

compiler, 1977, Geologic map of California: California Division of Mines and Geology Geologic Data Map 2 , scale $1: 750,000$.

1985, An explanatory text to accompany the 1:750,000 scale fault and geologic maps of California: California Division of Mines and Geology Bulletin 201, 197 p.

A significant review of data. For example, plate 2 includes four maps: (1) structural provinces of California, (2) parallelism between major Quaternary faults, (3) relation of earthquake epicenters to faults, and (4) earthquake epicenters.

King, P.B., compiler, 1969, Tectonic map of North America: Washington, U.S. Geological Survey, scale 1:5,000,000, 2 sheets.

King, P.B., and Beikman, H.M., compilers, 1974, Geologic map of the United States (exclusive of Alaska and Hawaii): Washington, U.S. Geological Survey, scale 1:2,500,000, 3 sheets.

Real, C.R., Toppozada, T.R., and Parke, D.L., 1978, Earthquake epicenter map of California: California Division of Mines and Geology Map sheet 39, scale $1: 1,000,000$. A map and tabulation of earthquakes of 279 
magnitude 5 and greater, 1900-74.

Simpson, R.W., Hildenbrand, T.G., Godson, R.H., and Kane, M.F., 1987, Digital colored Bouguer gravity, free-air gravity, station location, and terrain maps for the conterminous United States: U.S. Geological Survey Geophysical Investigations Map GP-953-B, scale $1: 7,500,000,2$ sheets.

Simpson, R.W., Jachens, R.C., Saltus, R.W., and Blakely, R.J., 1986, Isostatic residual gravity, topographic, and first-vertical-derivative gravity maps of the conterminous United States: U.S. Geological Survey Geophysical Investigations Map GP-975, scale 1:7,500,000, 2 sheets.

Stover, C.W., 1986, Seismicity map of the conterminous United States and adjacent areas, 1975-1984: U.S. Geological Survey Geophysical Investigations Map GP-984, scale 1:5,000,000.

A standard reference depicting seismicity in the United States.

\section{REVIEW AND REFERENCE PUBLICATIONS}

Atwater, Tanya, 1970, Implications of plate tectonics for the Cenozoic tectonic evolution of western North America: Geological Society of America Bulletin, v. 81, no. 12 , p. $3513-3536$.

Develops the concept of the Pacific system of plates converging with and underriding the North American plate.

Crowell, J.C., ed., 1975, San Andreas fault in southern California: California Division of Mines and Geology Special Report 118, 272 p.

A guidebook containing 29 papers and a useful preliminary fault and geologic map of southern California at a scale of 1:750,000.

Dibblee, T.W., 1967, Areal geology of the western Mojave Desert, California: U.S. Geological Survey Professional Paper 522, $153 \mathrm{p}$.

Documents many of the bedrock features that characterize the San Andreas fault system.

Dickinson, W.R., and Grantz, Arthur, eds., 1968, Proceedings of conference on geologic problems of San Andreas fault system: Stanford, Calif., Stanford University Publications in the Geological Sciences, v. 11, $374 \mathrm{p}$.

An important collection of 47 papers, representing the prevailing state of knowledge about the San Andreas fault system at the time of its publication.

Eaton, J.P., O’Neill, M.E., and Murdock, J.N., 1970, Aftershocks of the 1966 Parkfield-Cholame, California, earthquake: A detailed study: Seismological
Society of America Bulletin, v. 60, no. 4, p. 1151-1197.

Ernst, W.G., ed., 1981, The geotectonic development of California (Rubey volume 1): Englewood Cliffs, N.J., Prentice-Hall, 706 p.

Possibly the best general review in one volume of the geologic and tectonics relations pertinent to the San Andreas fault system. More than 1,300 references listed in the back of the volume provide an invaluable source for further study.

Hart, E.W., Hirschfeld, S.E., and Schulz, S.S., eds., 1982, Conference on Earthquake Hazards in the Eastern San Francisco Bay Area, Hayward, Calif., 1982, Proceedings: California Division of Mines and Geology Special Publication 62, 447 p.

A collection of 61 papers in which the Hayward and Calaveras faults, and other smaller branches of the San Andreas fault system, receive considerable attention.

Hinze, W.J., Kane, M.F., O’Hara, N.W., Redford, M.S., Tanner, James, and Weber, Christian, eds., 1985, The utility of regional gravity and magnetic anomaly maps: Tulsa, Okla., Society of Exploration Geophysicists, $454 \mathrm{p}$.

A set of 34 papers providing information and guidance on the use and interpretation of gravity and magnetic-anomaly data, as well as regional maps.

Kovach, R.L., and Nur, Amos, eds., 1973, Proceedings of the conference on tectonic problems of the San Andreas fault system: Stanford, Calif., Stanford University Publications in the Geological Sciences, v. $13,494 \mathrm{p}$.

An important collection of 58 papers, representing the prevailing state of knowledge about the San Andreas fault system at the time of its publication.

Oliver, H.W., 1980, Interpretation of the gravity map of California and its continental margin: California Division of Mines and Geology Bulletin 205, $52 \mathrm{p}$.

A general reference and bibliographic source of gravity data.

Pakiser, L.C., Jr., and Mooney, W.D., eds., in press, Geophysical framework of the continental United States: Geological Society of America Memoir 172.

A collection of 34 papers covering a broad range of subjects, including stress, tectonics, regional summaries, and methods.

Ross, D.C., 1984, Possible correlations of basement rocks across the San Andreas, San Gregorio-Hosgri and Rinconada-Reliz-King City faults, California: U.S. Geological Survey Professional Paper 1317, 37 p.

An insight into the longer term history of the San Andreas fault system as indicated by the dismuption of older rocks.

Scholl, D.W., Grantz, Arthur, and Vedder, J.G., eds. 
1987, Geology and resource potential of the continental margin of western North America and adjacent ocean basins-Beaufort Sea to Baja California (Earth Science Series, v. 6): Houston, Tex., Circum-Pacific Council for Energy and Mineral Resources.

A major source volume about the continental margin of North America. Includes 33 chapters concerned with topics ranging from tectonic and basin evolution to hydrocarbon and metallicmineral occurrence and potential.

Sharp, R.V., 1967, San Jacinto fault zone in the Peninsular Ranges of southern California: Geological Society of America Bulletin, v. 78, no. 6, p. 705-729.

Stewart, J.H., and Crowell, J.C., in press, Strike-slip tectonics in the Cordilleran region, western United States in Burchfiel, B.C., Libman, P.W., and Zoback, M.L., eds., The Cordilleran orogen: Boulder, Colo., Geological Society of America.

A review of strike-slip faults, including the San Andreas fault, in the Western United States.

Streitz, Robert, and Sherburne, R.W., eds., 1980, Studies of the San Andreas fault zone in northern California: California Division of Mines and Geology Special Report 140, $187 \mathrm{p}$.

A valuable set of 16 papers on subjects including geology, geophysics, seismology, and engineering.

Sylvester, A.G., 1988, Strike-slip faults: Geological Society of America Bulletin, v. 100, no. 11, p. 1666-1703.

An excellent review of the concept, recognition, mechanics, and behavior of strike-slip faults, with numerous references to the San Andreas fault. Includes an extensive bibliography.

Ziony, J.I., ed., 1985, Evaluating earthquake hazards in the Los Angeles region-an earth-science perspective: U.S. Geological Survey Professional Paper 1360, $505 \mathrm{p}$.

A valuable collection of 16 papers that review the state of the art about geologic hazards, ranging from predicting earthquake faulting and ground motion to landslides, tsunamis, and the use of earth-science information.

\section{PUBLICATIONS OF HISTORICAL INTEREST}

Allen, C.R., 1957, San Andreas fault in San Gorgonio Pass, southern California: Geological Society of America Bulletin, v. 68, no. 3, p. 315-349.

Anderson, F.M., 1899, The Geology of Point Reyes peninsula: Berkeley, University of California Publications, Department of Geology Bulletin, v. 2, no. 5, p. 119-153.

Bailey, E.H., Irwin, W.P., and Jones, D.L., 1964,
Franciscan and related rocks, and their significance in the geology of western California: California Division of Mines and Geology Bulletin 183, 177 p.

A classic paper in which the San Andreas fault receives considerable attention and early tectonic models are presented.

Branner, J.C., 1906, An authoritative opinion: Mining and Scientific Press, v. 92, p. 347.

Crowell, J.C., 1952, Probable large lateral displacement on the San Gabriel fault, southern California: American Association of Petroleum Geologists Bulletin, v. 36 , no. 10 , p. $2026-2035$.

1962, Displacement along the San Andreas fault, California: Geological Society of America Special Paper 71, 59 p.

Documents large-scale strike slip on the San Andreas fault system.

Eaton, J.E., 1939, Geology and oil possibilities of Caliente Range, Cuyama Valley and Carrizo Plain, California: California Journal of Mines and Geology, v. 35, no. 3, p. 255-274.

Suggests 25 miles of strike slip on the San Andreas fault.

Gilbert, G.K., 1907, The earthquake as a natural phenomenon, in The San Francisco earthquake and fire of April 18, 1906, and their effects on structures and structural materials: U.S. Geological Survey Bulletin 324, p. 1-13.

This paper provided the first overview of the San Andreas fault in northern California. From Gilbert's field notes, he appears to have been the first to appreciate the true significance of the fault.

Hill, M.L., 1981, San Andreas fault: History of concepts: Geological Society of America Bulletin, pt. 1, v. 92, no. 3, p. 112-131.

A review of the early development of concepts about the significance of the San Andreas fault, especially the amount of strike slip.

Hill, M.L., and Dibblee, T.W., Jr., 1953, San Andreas, Garlock, and Big Pine faults, California: A study of the character, history, and tectonic significance of their displacements: Geological Society of America Bulletin, v. 64 , no. 4 , p. $443-458$.

This classic paper was the first to provide data indicative of hundreds of miles of strike slip on the San Andreas fault.

Hill, R.T., 1928, Southern California geology and Los Angeles earthquakes: Los Angeles, Southern California Academy of Sciences, $232 \mathrm{p}$.

Lawson, A.C., 1895, Sketch of the geology of the San Francisco peninsula: U. S. Geological Survey Annual Report 15, p. 439-473. 
First use of the name "San Andreas fault."

chairman, 1908, The California earthquake of April 18, 1906: Report of the State Earthquake Investigation Commission: Carnegie Institution of Washington Publication 87, $2 \mathrm{v}$.

This treatise on the 1906 earthquake contains an abundance of important data about the San Andreas fault.

Noble, L.F., 1926, The San Andreas rift and some other active faults in the desert region of southeastern California: Carnegie Institution of Washington Year Book 25, p. 415-422..

1933, Excursion to the San Andreas fault and Cajon Pass: International Geological Congress, 16th, Washington, 1933, Guidebook 15, p. 10-21.

1954, The San Andreas fault zone from Soledad Pass to Cajon Pass, California, [pt ] 5 off Structural features, chap. 4 of Jahns, R.H., ed., Geology of southern California: California Division of Mines Bulletin 170, v. 1, p. 37-48.

Oakeshott, G.B., 1959, The San Andreas fault in Marin and San Mateo Counties, in Oakeshott, G.B., ed., San Francisco earthquakes of March 1957: California Division of Mines Special Report 57, 127 p.

Pack, R.W., 1920, The Sunset-Midway oil field, California, part 1, Geology and oil resources: U.S. Geological Survey Professional Paper 116, 179 p.

Pack, R.W., and English, W.A., 1915, Geology and oil prospects of Waltham, Priest, Bitterwater, and Peachtree Valleys, California: U.S. Geological Survey Bulletin 581, p. 119-160.

Reed, R.D., 1933, Geology of California: Tulsa, Okla., American Association of Petroleum Geologists, 355 p.

— 1943, California's record in the geologic history of the world, in Geologic formations and economic development of the oil and gas fields of California: California Division of Mines Bulletin 118, p. 99-118. Does not mention strike slip on the San Andreas fault.

Reed, R.D., and Hollister, J.S., 1936, Structural evolution of southern California: American Association of Petroleum Geologists Bulletin, v. 20, no. 12, p. 1529-1704.

Reid, H.F., 1910, The mechanics of the earthquake, v. 2 of The California earthquake of April 18, 1906:
Report of the State Earthquake Investigation Commission: Carnegie Institution of Washington Publication 87, $192 \mathrm{p}$.

Develops elastic-rebound theory.

Schuyler, J.D., 1896, Reservoirs for irrigation: U.S. Geological Survey Annual Report 18, p. 617-740.

Steinbrugge, K.V., Zacher, E.G., Tocher, Don, Whitten, C.A., and Claire, C.N., 1960, Creep on the San Andreas fault: Seismological Society of America Bulletin, v. 50, no. 3, p. 389-415.

This paper was the first to report slow, continuous slip (creep) on the San Andreas fault.

Taliaferro, N.L., 1938, San Andreas fault in central California [abs.]: Geological Society of America Proceedings, 1937, p. 254-255.

Concludes that horizontal slip on the San Andreas fault is less than a mile.

Vaughan, F.E., 1922, Geology of San Bernardino Mountains north of San Gorgonio Pass: Berkeley, University of California Publications, Department of Geological Sciences Bulletin, v. 13, no. 9, p. 319-411.

Vickery, F.P., 1925, The structural dynamics of the Livermore [California] region: Journal of Geology, v. 33 , no. 6 , p. 608-628.

Wallace, R.E., 1949, Structure of a portion of the San Andreas rift in southern California: Geological Society of America Bulletin, v. 60, no. 4, p. 781-806.

Wilson, J.T., 1965, A new class of faults and their bearing on continental drift: Nature, v. 207, no. 4995, p. 343-347.

Develops the concept of a transform fault.

Wood, H.O., and Buwalda, J.P., 1930, Horizontal displacement along the San Andreas fault in Carrizo Plain, California [abs.] : Pan-American Geologist, v. 54 , no. 1 , p. 75 .

\section{PUBLICATIONS OF GENERAL INTEREST}

Dewey, J.F., 1972, Plate tectonics: Scientific American, v. 226 , no. 5 , p. $56-68$.

A brief introduction to the concepts of plate tectonics, including excellent diagrams of the geometry of the global plates.

Iacopi, Robert, 1971, Earthquake country: Menio Park, Calif., Lane, 160 p.

A review and guidebook about the San Andreas fault, written for the layman, but includes useful maps and photographs of interest 
to the scientist and layman alike.

Jones, D.L., Cox, Allan, Coney, Peter, and Beck, Myrl, 1982, The growth of western North America: Scientific American, v. 247, no. 5, p. 70-84.

Refines the concept of plate tectonics has been refined to include the accretion of smaller blocks to the main continental masses. The San Andreas fault system is involved with the motions of both larger and smaller plates.

Jordan, T.H., and Minster, J.B., 1988, Measuring crustal deformation in the American West: Scientific American, v. 259 , no. 2 , p. $48-58$.
Provides some ideas and data about how western North America is being deformed.

Schulz, S.S., and Wallace, R.E., 1987, The San Andreas fault: Washington, U.S. Geological Survey, 17 p. Pamphlet providing a brief review for the layman.

Wesson, R.L., and Wallace, R.E., 1985, Predicting the next great earthquake in California: Scientific American, v. 252, no. 2, p. 35-43.

The science of earthquake prediction has been evolving, and the San Andreas fault system has been a target of major interest. This paper reviews some progress that has been made. 



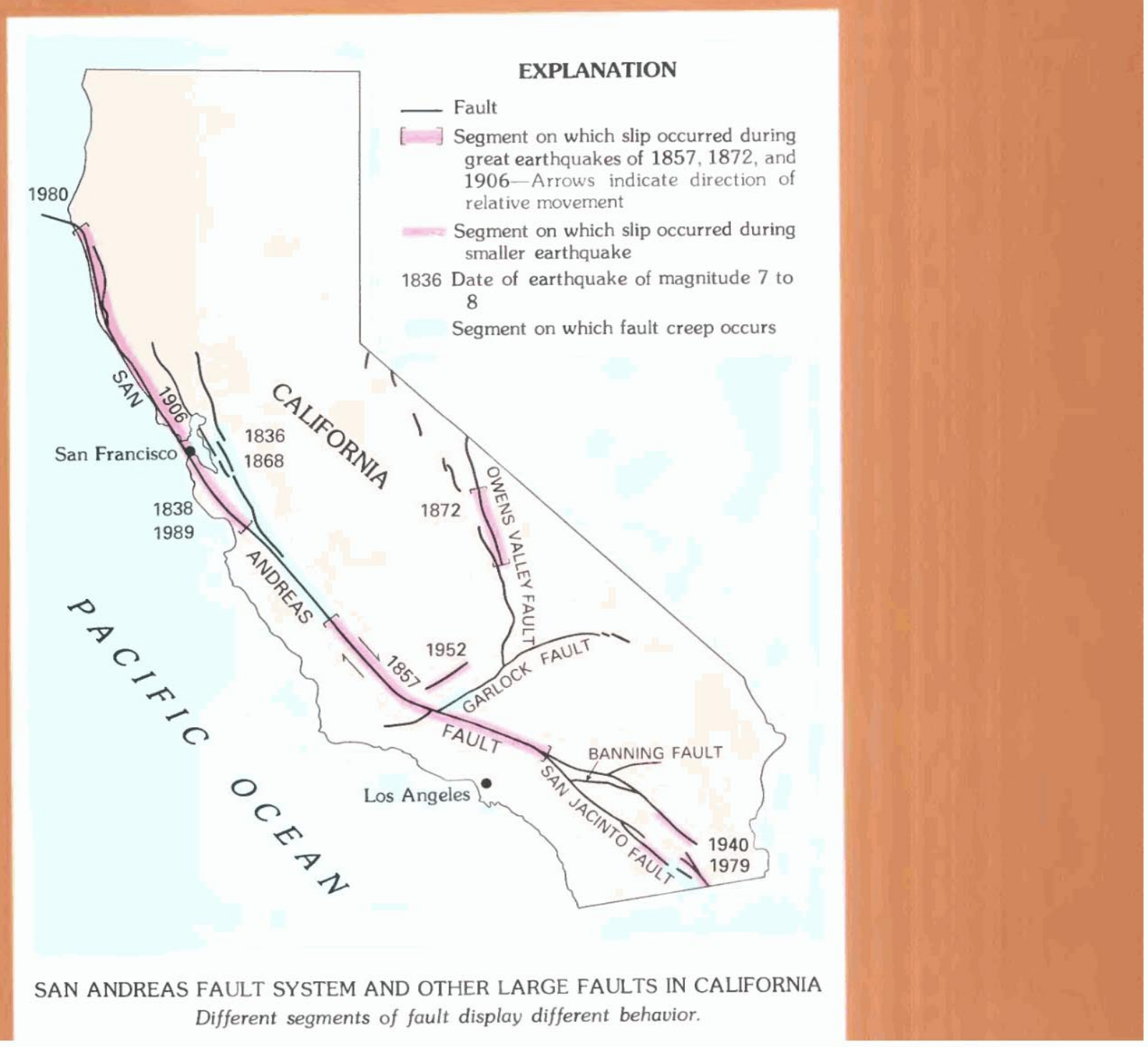




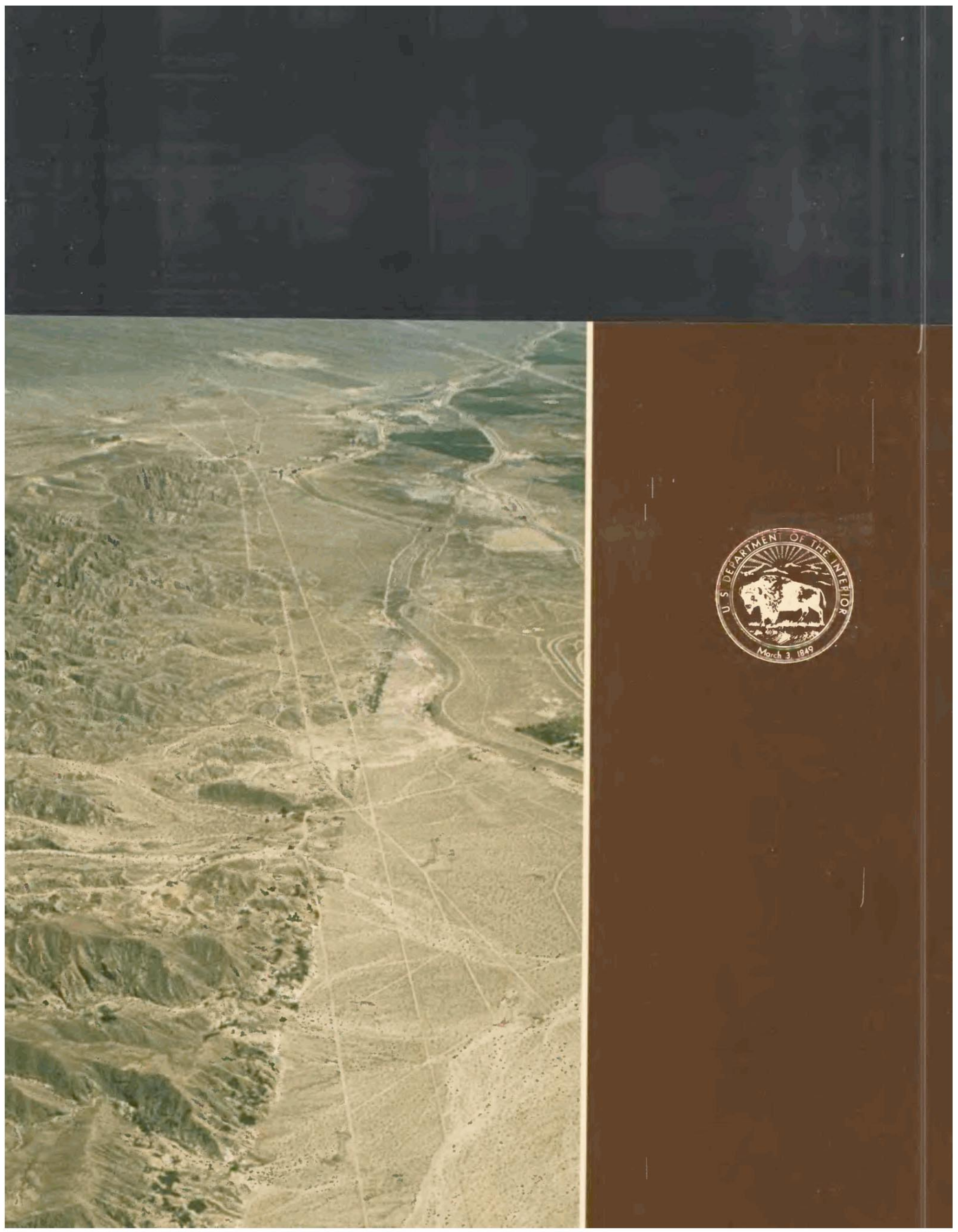

